\section{Pacific Northwest} National Laboratory

Operated by Battelle for the U.S. Department of Energy

\title{
Characterization of Vadose Zone Sediments from C Waste Management Area: Investigation of the C-152 Transfer Line Leak
}
C. F. Brown
K. N. Geiszler
R. J. Serne
C. Iovin
B. N. Bjornstad
E. T. Clayton
M. M. Valenta
I. V. Kutnyakov
D. C. Lanigan
S. R. Baum
T. S. Vickerman
M. J. Lindberg
R. E. Clayton
R. D. Orr

January 2007

Prepared for CH2M HILL Hanford Group, Inc. and the U.S. Department of Energy under Contract DE-AC05-76RL01830 


\title{
DISCLAIMER
}

This report was prepared as an account of work sponsored by an agency of the United States Government. Neither the United States Government nor any agency thereof, nor Battelle Memorial Institute, nor any of their employees, makes any warranty, express or implied, or assumes any legal liability or responsibility for the accuracy, completeness, or usefulness of any information, apparatus, product, or process disclosed, or represents that its use would not infringe privately owned rights. Reference herein to any specific commercial product, process, or service by trade name, trademark, manufacturer, or otherwise does not necessarily constitute or imply its endorsement, recommendation, or favoring by the United States Government or any agency thereof, or Battelle Memorial Institute. The views and opinions of authors expressed herein do not necessarily state or reflect those of the United States Government or any agency thereof.

\author{
PACIFIC NORTHWEST NATIONAL LABORATORY \\ operated by \\ BATTELLE \\ for the \\ UNITED STATES DEPARTMENT OF ENERGY \\ under Contract DE-AC05-76RL01830
}

Printed in the United States of America

Available to DOE and DOE contractors from the

Office of Scientific and Technical Information,

P.O. Box 62, Oak Ridge, TN 37831-0062;

ph: (865) 576-8401

fax: $(865) 576-5728$

email: reports@adonis.osti.gov

\footnotetext{
Available to the public from the National Technical Information Service, U.S. Department of Commerce, 5285 Port Royal Rd., Springfield, VA 22161 ph: (800) 553-6847

fax: (703) 605-6900

email: orders@ntis.fedworld.gov

online ordering: http://www.ntis.gov/ordering.htm
}

This document was printed on recycled paper. 


\section{Characterization of Vadose Zone Sediments from $C$ Waste Management Area: Investigation of the C-152 Transfer Line Leak}
C. F. Brown
K. N. Geiszler
R. J. Serne
C. Iovin
B. N. Bjornstad
E. T. Clayton
M. M. Valenta
I. V. Kutnyakov
D. C. Lanigan
S. R. Baum
T. S. Vickerman
M. J. Lindberg
R. E. Clayton
R. D. Orr

January 2007

Prepared for CH2M HILL Hanford Group, Inc. and the U.S. Department of Energy under Contract DE-AC05-76RL01830

Pacific Northwest National Laboratory

Richland, Washington 99352 


\section{Executive Summary}

The overall goal of the Tank Farm Vadose Zone Project, led by CH2M HILL Hanford Group, Inc., is to define risks from past and future single-shell tank farm activities at Hanford. To meet this goal, CH2M HILL Hanford Group, Inc., tasked scientists from Pacific Northwest National Laboratory to perform detailed analyses on vadose zone sediments from within waste management area (WMA) C. Specifically, this report contains all the geologic, geochemical, and selected physiochemical characterization data compiled on vadose zone sediment recovered from direct-push samples collected around the site of an unplanned release (UPR), UPR-200-E-82, adjacent to the 241-C-152 Diversion Box located in WMA C.

UPR 200-E-82 was a waste-loss event near the 241-C-152 Diversion Box that occurred in December 1969 and involved the loss of approximately 2,600 gallons of cesium-137 recovery process feed solution (Wood et al. 2003). The leak event created a temporary ground-surface puddle measuring 100 gallons in volume, which was quickly covered over with clean gravel. It is estimated that 11,300 Ci of cesium-137, $18.3 \mathrm{~kg}$ of uranium, and $5.01 \mathrm{Ci}$ of technetium-99 were released to the subsurface.

An initial geologic/geochemical investigation in the vicinity of UPR-200-E-82 was performed using pairs of direct-push probe holes. A total of 41 vertical direct pushes extending to approximately $60 \mathrm{ft}$ below ground surface (bgs) were completed between July and September 2005 to characterize vadose zone moisture and the distribution of contaminants. Twenty vadose zone sediment sample sets, containing one or two core samples in stainless-steel liners and one grab sample, were delivered to the laboratory for characterization and analysis. The sediments were collected around the documented location of the C-152 pipeline leak (UPR-200-E-82) and created an approximately 120-ft-diameter circular pattern around the waste site.

A second series of six probe holes were emplaced around the site of the pipeline leak between March and June 2006. Unlike their 2005 vertical counterparts, these probe holes were driven at angles of $30^{\circ}$, $45^{\circ}$, or $60^{\circ}$ from horizontal, and extended to approximately $80 \mathrm{ft} \mathrm{bgs}$. Up to three sets of samples $(1.5 \mathrm{ft}$ of core plus material recovered from the drive shoe) were retrieved from each slant probe hole. The goal of this operation was to collect a sample at depth from directly beneath the projected site of the pipeline leak.

A core log was generated for both sets of samples and a visual geologic evaluation of all liner samples was performed at the time of sample processing. Aliquots of sediment from the liners were analyzed and characterized in the laboratory for the following parameters: moisture content, gammaemitting radionuclides, one-to-one sediment:water extractions (which provided soil $\mathrm{pH}$, electrical conductivity, cation, trace metal, and anion data), total carbon and inorganic carbon content, and 8-M nitric acid leaches (which provided a measure of the total leachable contaminant content in the sediment). Two key radioactive contaminants, technetium-99 and uranium-238, along with other trace metals were determined in acid and water extractions using inductively coupled plasma-mass spectrometry (ICP-MS). All of the parameters were elevated in at least some of the samples analyzed as part of this study. Specifically, soil pH was elevated (up to 9.99) in samples collected northeast and southwest of the $\mathrm{C}-152$ pipeline leak, as well as in samples collected directly beneath the projected leak location (at a depth of $42 \mathrm{ft}$ bgs). Similarly, samples collected from these same direct-push holes contained elevated water-extractable sodium (more than $90 \mu \mathrm{g} / \mathrm{g}$ of dry sediment), uranium (as much as 
$0.766 \mu \mathrm{g} / \mathrm{g}$ of dry sediment), nitrate (up to $30 \mu \mathrm{g} / \mathrm{g}$ of dry sediment), and technetium-99 (up to $28.6 \mathrm{pCi} / \mathrm{g}$ of dry sediment). Most of the samples containing elevated concentrations of water-extractable sodium also had decreased levels of water-extractable calcium and/or magnesium, indicating that tank-related fluids that were high in sodium were present in these sediments.

After evaluating all the characterization and analytical data, there is no question that the vadose zone surrounding the $\mathrm{C}-152$ pipeline leak site has been contaminated by tank-related waste. The two regions that contained the largest amount of contaminants, either in concentration or by occurrence of several key constituents/contaminants of concern, were located 1) between the 241-C-151 and 241-C-152 Diversion Boxes and 2) west of the C-153 Diversion Box. Additionally, the slant push data has shown that mobile constituents associated with the pipeline leak event have migrated to a depth of at least $80 \mathrm{ft}$ bgs at this locale.

Although a distinct waste signature was observed in the sediment surrounding the $\mathrm{C}-152$ pipeline leak site, immobile contaminants were not detected in significant concentrations. The samples collected for this study were retrieved as close as possible to the cap overlying the pipeline leak site, as well as directly beneath the projected leak point. Collectively, the data indicate that the bulk of the activity associated with the leak event (i.e., cesium-137) is constrained shallow in the vadose zone in proximity to the discharge point. However, data from the vertical and slant push samples indicate that more mobile key contaminants of concern (i.e., technetium-99) have migrated much farther laterally (beyond the edge of the cap) and vertically (at least $80 \mathrm{ft}$ bgs) than was initially predicted. 


\section{Acknowledgments}

This work was conducted as part of the Tank Farm Vadose Zone Project led by CH2M HILL Hanford Group, Inc., in support of the U.S. Department of Energy (DOE)'s Office of River Protection. The authors wish to thank John G. Kristofzski, Frank J. Anderson, Fredrick M. Mann, David A. Myers, and Harold A. Sydnor with CH2M HILL Hanford Group, Inc., and Dwayne Crumpler with Columbia Energy and Environmental Services for their planning support, and technical review of this work, and Marcus I. Wood with Fluor Hanford, Inc., and Bill Deutsch and Wooyong Um, both with Pacific Northwest National Laboratory (PNNL), for their technical review of the report. We would also like to express our gratitude to Robert Lober with the DOE Office of River Protection for his support and interest.

We would especially like to thank Kent D. Reynolds, Dave Skoglie, Kelly Olson, and Mark Repko (Duratek Federal Services, Inc.) for their efforts in selecting depths to sample and executing the field work that obtained the samples.

Finally, the authors would also like to thank Theresa L. Gilbride (PNNL) for completing the editorial review and final formatting of this technical report. 


\section{Acronyms and Abbreviations}

$\begin{array}{ll}\text { ASA } & \text { American Society of Agronomy } \\ \text { ASTM } & \text { American Society for Testing and Materials } \\ \text { DOE } & \text { U.S. Department of Energy } \\ \text { EC } & \text { electrical conductivity } \\ \text { EPA } & \text { U.S. Environmental Protection Agency } \\ \text { GEA } & \text { gamma energy analysis } \\ \text { H1 } & \text { Hanford formation - H1 unit } \\ \text { H2 } & \text { Hanford formation - H2 unit } \\ \text { HCl } & \text { hydrochloric acid } \\ \text { HEIS } & \text { Hanford Environmental Information System } \\ \text { HF } & \text { hydrofluoric acid } \\ \text { HNO } & \text { nitric acid } \\ \text { HPGe } & \text { high-purity germanium } \\ \text { IC } & \text { ion chromatography or ion chromatograph } \\ \text { IC-MS } & \text { inductively coupled mass spectrometry } \\ \text { ICP-MS } & \text { inductively coupled plasma-mass spectrometery } \\ \text { ICP-OES } & \text { inductively coupled plasma-optical emission spectroscopy } \\ \text { K } & \text { distribution coefficient, or sorption partition coefficient, in units of } \mathrm{mL} / \mathrm{g} \\ \text { NDIR } & \text { non-dispersive infrared } \\ \text { NIST } & \text { National Institute of Standards and Technology } \\ \text { PNNL } & \text { Pacific Northwest National Laboratory } \\ \text { RCRA } & \text { Resource Conservation and Recovery Act of 1976 } \\ \text { UFA } & \text { unsaturated flow apparatus (ultracentrifuge for squeezing pore water out of sediment) } \\ \text { UPR } & \text { unplanned release } \\ \text { USGS } & \text { U.S. Geological Survey } \\ \text { WMA } & \text { waste management area }\end{array}$




\section{Units of Measure}

\begin{tabular}{ll}
$\%$ & percent \\
$\mathrm{bgs}$ & below ground surface \\
${ }^{\circ} \mathrm{C}$ & temperature in degrees Celsius $\left[\mathrm{T}\left({ }^{\circ} \mathrm{C}\right)=\mathrm{T}(\mathrm{K})-273.15\right)$ \\
$\mathrm{Ci}$ & curie \\
$\mathrm{cm}$ & centimeter \\
$\mathrm{ft}$ & foot \\
$\mathrm{g}$ & gram \\
$\mathrm{g}$ & acceleration due to gravity \\
$\mu$ & micro (prefix, $10-6)$ \\
$\mu \mathrm{Ci}$ & microcurie \\
$\mu \mathrm{eq}$ & microequivalent \\
$\mu \mathrm{g}$ & microgram \\
$\mu \mathrm{m}$ & micrometer \\
$\mathrm{m}$ & meter \\
$\mathrm{M}$ & molarity, mol/L \\
$\mathrm{meq} / \mathrm{L}$ & milli-equivalent per liter \\
$\mathrm{mg}$ & milligram \\
$\mathrm{mL}$ & milliliter \\
$\mathrm{mm}$ & millimeter \\
$\mathrm{mM}$ & millimolar \\
$\mathrm{mN}$ & millinormal \\
$\mathrm{mol}$ & mole \\
$\mathrm{mS}$ & milliSiemen \\
$\mathrm{N}$ & Normal \\
$\mathrm{nCi}$ & nanocurie \\
$\mathrm{ng}$ & nanogram \\
$\mathrm{pCi}$ & picocurie \\
$\mathrm{wt} \%$ & weight percent \\
\hline
\end{tabular}




\section{Contents}

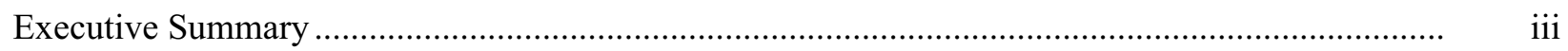

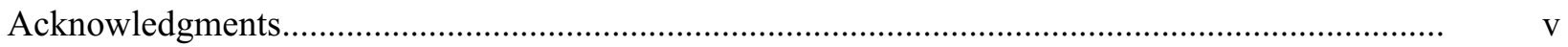

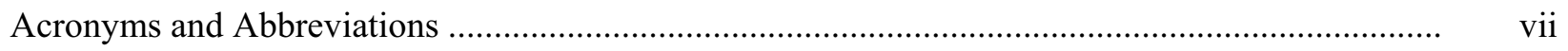

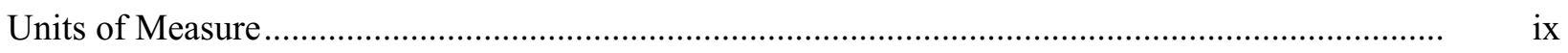

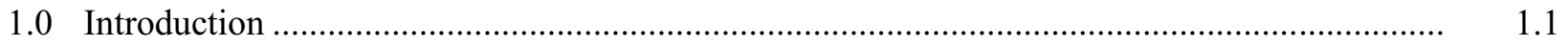

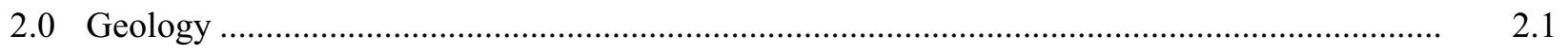

2.1 Characterization and Sampling Methods ................................................................... 2.1

2.1.1 Lithologic (Moisture) Boundaries .................................................................... 2.7

2.2 Interpreted Geology Near the 241-C-152 Diversion Box .............................................. 2.8

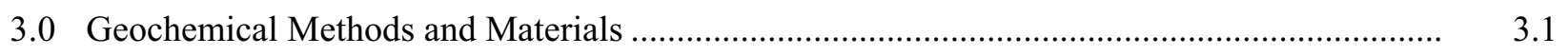

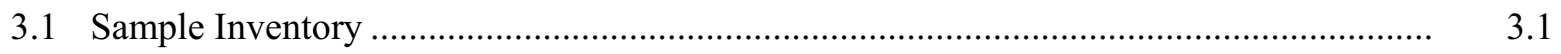

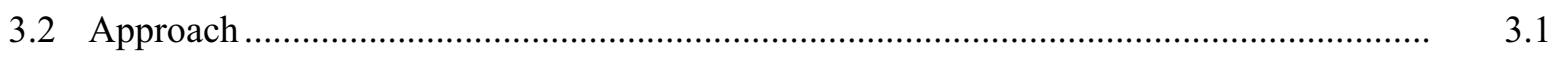

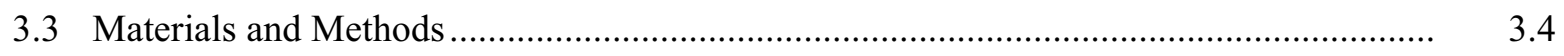

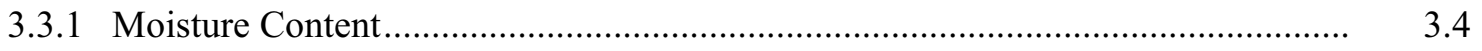

3.3.2 1:1 Sediment:Water Extractions................................................................. 3.4

3.3.3 8-M Nitric Acid Extraction ........................................................................... 3.5

3.3.4 Carbon Content of Sediment .......................................................................... 3.6

3.3.5 Ammonium Acetate Extractions ...................................................................... 3.6

3.3.6 Magnetic Sample Separation and Digestion................................................... 3.7

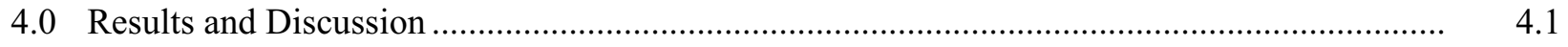

4.1 Vadose Zone Sediment from the Vertical Direct-Push Samples..................................... 4.1

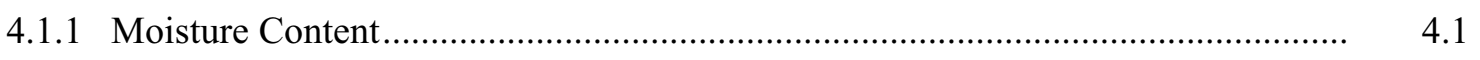

4.1.2 1:1 Sediment:Water Extractions........................................................................

4.1.3 Vadose Zone Pore Water Chemical Composition............................................... 4.15

4.1.4 8-M Nitric Acid-Leachable Amounts of Selected Elements in the C-152 Sediments ............................................................................................... 4.21

4.1.5 Radionuclide Content in Vadose Zone Sediment from the C-152 Direct-

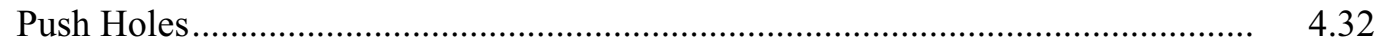

4.1.6 Total Carbon, Calcium Carbonate, and Organic Carbon Content of Vadose
Zone Sediment from the C-152 Vertical Push Samples ....................................... 4.32

4.2 Vadose Zone Sediment from the Slant Probe Hole Direct-Push Samples ........................ 4.32

4.2.1 Moisture Content .......................................................................................... 4.32

4.2.2 1:1 Sediment:Water Extractions....................................................................... 4.39

4.2.3 Vadose Zone Pore Water Chemical Composition................................................ 4.54

4.2.4
C-M Nitric Acid-Leachable Amounts of Selected Elements in the
C-152 Push Sediments ............................................................................ 4.61 
4.2.5 Radionuclide Content in Vadose Zone Sediment from the C-152 Slant Push Holes....................................................................................... 4.68

4.2.6 Total Carbon, Calcium Carbonate, and Organic Carbon Content of Vadose Zone Sediment from the C-152 Slant Push Holes................................... 4.69

4.3 Tier II Sample Investigations ................................................................................ 4.70

4.3.1 Ammonium Acetate Extractions .................................................................. 4.71

4.3.2 Magnetic Separation and Digestion ............................................................ 4.73

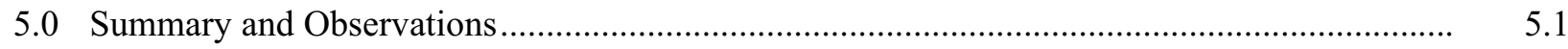

5.1 Sampling Summary near the C-152 Pipeline Leak ..................................................... 5.1

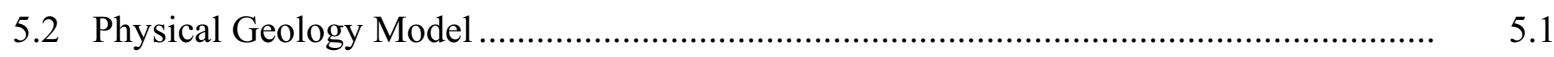

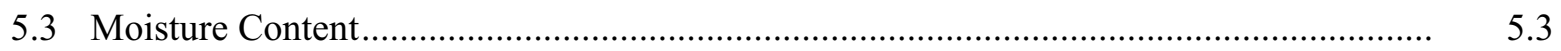

5.4 Contamination Profile around the C-152 Pipeline Leak ............................................... 5.3

5.5 Source of Contamination around the C-152 Waste Site................................................ 5.7

5.6 Detailed Characterization to Elucidate Controlling Geochemical Processes .................... 5.8

5.7 Estimates of Contaminant Sorption-Desorption Values................................................. 5.10

5.8 Other Geochemical Characterization Observations ................................................... 5.12

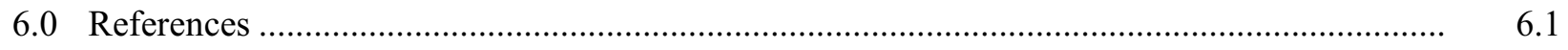

Appendix A1. Photographs of Samples from the C-152 Vertical Probe Holes ............................... A.1

Appendix A2. Photographs of Samples from the C-152 Slant Probe Holes................................... A.14

Appendix B1. Geologic Description of Samples from C-152 Vertical Probe Holes ....................... B. B.1

Appendix B2. Geologic Description of Samples from C-152 Slant Probe Holes........................... B. B.21 


\section{Figures}

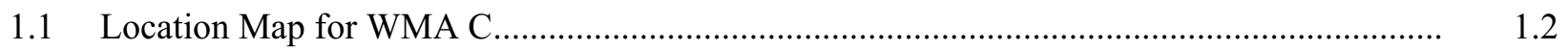

1.2 Selected Probe Hole Location Map for WMA C …............................................................

1.3 Photograph of the Hydraulic Hammer Direct-Push Apparatus.............................................. 1.4

2.1 Hydrogeologic Cross Section through WMA C ................................................................ 2.2

2.2 Cross Sections Showing Four Major Lithologic Boundaries Based on Neutron-Moisture Geophysical Logs in the Vicinity of the 241-C-152 Diversion Box ....................................... 2.3

2.3 Alternating Sand- and Silt-Dominated Beds in Two Adjacent Core Segments....................... 2.7

2.4 Structure Contour Maps on Upper Surfaces of the Four Moisture Boundaries in the Vicinity of the C-152 Diversion Box ............................................................................ 2.14

2.5 Depths Below Ground Surface to Four Moisture Boundaries in the Vicinity of the

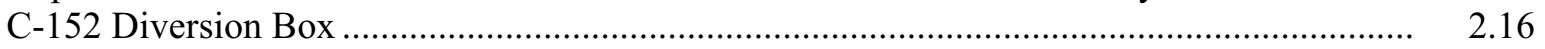

4.1 Water-Extractable Sodium Data for the C-152 Vertical Direct-Push Samples....................... 4.10

4.2 Water-Extractable Technetium-99 Data for the C-152 Vertical Direct-Push Samples............ 4.16

4.3 Water-Extractable Uranium-238 Data for the C-152 Vertical Direct-Push Samples............... 4.17

4.4 Acid-Leachable Technetium-99 Data for the C-152 Vertical Direct-Push Samples ............... 4.30

4.5 Acid-Leachable Uranium-238 Data for the C-152 Vertical Direct-Push Samples ................. 4.31

4.6 Moisture Content Data for the C-152 Slant Direct-Push Samples ......................................... 4.38

4.7 1:1 Sediment:Water Extraction pH Data for the C-152 Slant Direct-Push Samples ............... 4.41

4.8 Water-Extractable Nitrate Data for the C-152 Slant Direct-Push Samples............................. 4.44

4.9 Water-Extractable Calcium Data for the C-152 Slant Direct-Push Samples .......................... 4.47

4.10 Water-Extractable Sodium Data for the C-152 Slant Direct-Push Samples .......................... 4.48

4.11 Water-Extractable Technetium-99 Data for the C-152 Slant Direct-Push Samples ............... 4.53

4.12 Water-Extractable Uranium Data for the C-152 Slant Direct-Push Samples ......................... 4.55

4.13 Pore-Water-Corrected Alkalinity Data for the C-152 Slant Direct-Push Samples ................. 4.58

4.14 Acid-Extractable Technetium-99 Data for the C-152 Slant Direct-Push Samples ................. 4.66

4.15 Acid-Extractable Uranium Data for the C-152 Slant Direct-Push Samples ........................... 4.67

4.16 Extractable Technetium-99 in the C-152 Slant Push Samples................................................ 4.72

5.1 Plot of the C-152 Vertical and Slant Probe Locations ........................................................ 5.2 


\section{Tables}

2.1 Direct-Push Holes Emplaced in the Vicinity of the 241-C-152 Diversion Box ...................... 2.4

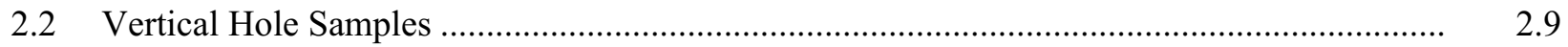

2.3 Slant Hole Samples .............................................................................................. 2.11

2.4 Depths and Elevations for Four Lithologic Boundaries in the Vicinity of the

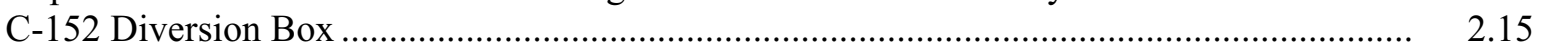

3.1 Sample Inventory from the C-152 Vertical Direct-Push Probe Holes .................................... 3.2

3.2 Sample Inventory from the C-152 Angled Direct-Push Probe Holes .................................... 3.3

4.1 Gravimetric Moisture Content of Samples Obtained from the C-152 Vertical Direct-Push Probe Holes ................................................................................................... 4.2

4.2 $\mathrm{pH}$ for 1:1 Sediment:Water Extractions and Dilution-Corrected EC Values from C-152 Vertical Core and Grab Samples...........................................................................

4.3 Water-Extractable Anions in the C-152 Vertical Core and Grab Samples ............................. 4.6

4.4 Water-Extractable Major Cations in the C-152 Vertical Core and Grab Samples................... 4.8

4.5 Water-Extractable Cations of Aluminum, Iron, Manganese Silicon, and Sulfur in the

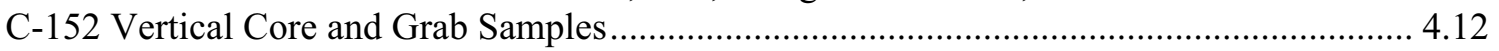

4.6 Water-Extractable Mobile Metals in the C-152 Vertical Core and Grab Samples ................. 4.14

4.7 Calculated Pore Water Anion Concentrations in the C-152 Vertical Core and

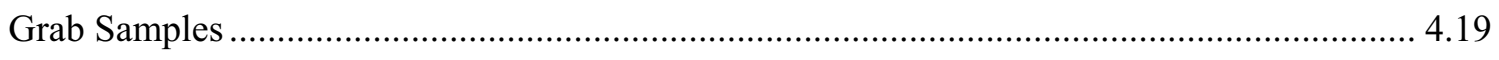

4.8 Calculated Pore Water Cation Concentrations in the C-152 Vertical Core and

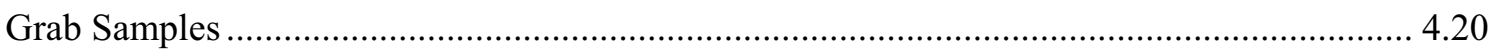

4.9 Calculated Pore Water Metal Concentrations in the C-152 Vertical Core and

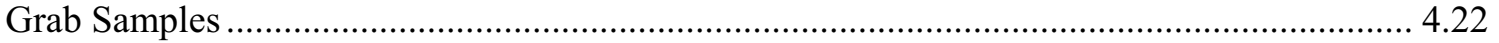

4.10 Calculated Pore Water Mobile Metal Concentrations of Key Contaminants of Concern in the C-152 Vertical Core and Grab Samples...................................................................... 4.24

4.11 Acid-Leachable Cations in the C-152 Vertical Core and Grab Samples ............................... 4.26

4.12 Acid-Leachable Cations in the C-152 Vertical Core and Grab Samples .................................. 4.27

4.13 Acid-Leachable Mobile Metals in the C-152 Vertical Core and Grab Samples ..................... 4.29

4.14 Gamma-Emitting Radionuclides in the C-152 Vertical Vadose Zone Sediments .................. 4.33

4.15 Carbon Content of the C-152 Vertical Vadose Zone Samples............................................. 4.35

4.16 Gravimetric Moisture Content of Samples Obtained from the C-152 Slant Direct-Push

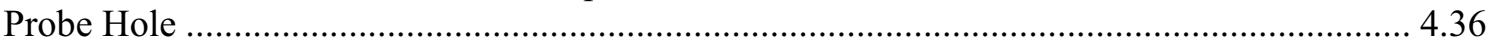

4.17 pH Values for 1:1 Sediment:Water Extractions and Dilution-Corrected EC Values from C-152 Slant Core Samples ...................................................................................... 4.40

4.18 Water-Extractable Anions in the C-152 Slant Probe Hole Core Samples .............................. 4.42

4.19 Water-Extractable Cations in the C-152 Slant Push Samples .............................................. 4.45

4.20 Water-Extractable Cations in the C-152 Slant Push Samples ............................................... 4.50

4.21 Water-Extractable Mobile Metals in the C-152 Slant Core Samples....................................... 4.51

4.22 Water-Extractable Mobile Metals in the C-152 Slant Core Samples..................................... 4.52 
4.23 Calculated Pore Water Anion Concentrations in the C-152 Slant Core Samples.....

4.24 Calculated Pore Water Cation Concentrations in the C-152 Slant Core Samples

4.25 Calculated Pore Water Mobile Metal Concentrations of Key Contaminants of Concern in the C-152 Slant Core and Grab Samples. 4.60

4.26 Acid-Leachable Cations in the C-152 Slant Core and Grab Samples.......................................62

4.27 Acid-Leachable Cations in the C-152 Slant Core and Grab Samples...................................... 4.63

4.28 Acid-Leachable Mobile Metals in the C-152 Slant Core and Grab Samples............................ 4.64

4.29 Gamma-Emitting Radionuclides in the C-152 Slant Push Vadose Zone Sediments ............... 4.68

4.30 Carbon Content of the C-152 Slant Push Vadose Zone Samples .......................................... 4.69

4.31 Exchangeable Technetium-99 in the C-152 Vadose Zone Samples ...................................... 4.71

4.32 Time-Resolved Exchangeable Technetium-99 in the C-152 Slant Push Samples................... 4.72

4.33 Time-Resolved Exchangeable Cations in the C-152 Slant Push Samples ............................... 4.72

4.34 Technetium-99 in Iron-Rich Material from the C-152 Slant Push Samples ........................... 4.73

4.35 Technetium-99 in Acid Leaches and Microwave Digests of the C-152 Slant

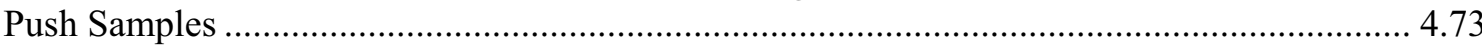

5.1 Maximum Pore Water Concentrations in Sediments from the Hanford Formation Unit ........ 5.9

5.2 Desorption $\mathrm{K}_{\mathrm{d}}$ Values $(\mathrm{mL} / \mathrm{g})$ for Potential Contaminants of Concern in the C-152 Vertical Push Samples

5.3 Desorption $\mathrm{K}_{\mathrm{d}}$ Values $(\mathrm{mL} / \mathrm{g})$ for Potential Contaminants of Concern in the C-152 Slant Push Samples 


\subsection{Introduction}

The overall goals of the Tank Farm Vadose Zone Project, led by CH2M HILL Hanford Group, Inc., are 1) to define risks from past and future single-shell tank farm activities, 2) to identify and evaluate the efficacy of interim measures, and 3) to aid, via collection of geochemical information and data, the future decisions that must be made by the U.S. Department of Energy (DOE) regarding the near-term operations, future waste retrieval, and final closure activities for the single-shell tank waste management areas (WMAs). For a more complete discussion of the goals of the Tank Farm Vadose Zone Project, see the overall work plan, Phase 1 RCRA Facility Investigation/Corrective Measures Study Work Plan for the Single-Shell Tank Waste Management Areas (DOE 1999). Specific details on the rationale for activities performed at WMA C are found in Crumpler (2003). To meet these goals, CH2M HILL Hanford Group, Inc., asked scientists from Pacific Northwest National Laboratory (PNNL) to perform detailed analyses of vadose zone sediment collected within WMA C.

Specifically, this report contains all the geologic, geochemical, and selected physical characterization data collected on vadose zone sediment recovered from 20 vertical and 6 angled direct-push characterization holes emplaced to investigate vadose zone contamination associated with unplanned release (UPR) 200-E-82. UPR-200-E-82 was a pipeline leak (from pipeline V122) consisting of 2,640 gal of cesium-137 recovery process feed solution. The leak occurred in 1969 near the 241-C-152 Diversion Box and resulted in the release of 11,300 Ci of cesium-137 to the soil (Wood et al. 2003). It has been estimated that as much as 100 gal of this waste surfaced as a free-standing puddle. The area of surface contamination was covered with clean gravel in 1969 (Wood et al. 2003). A location map highlighting the area of interest is presented below (Figure 1.1).

Twenty vertical probe holes were emplaced between July and September of 2005 to encircle the UPR-200-E-82 area of interest (red circles in Figure 1.2). The circle was approximately $120 \mathrm{ft}$ in diameter, and probes were driven to depths ranging from 30 to $60 \mathrm{ft}$ below ground surface (bgs) using a hydraulic hammer unit attached to a backhoe (Figure 1.3). The majority of the casing string was composed of 4-ft-long pieces of 2.5-inch (outside diameter) pipe; several 1- to 2-ft pieces were used when necessary. The casing was fitted with a removable drive tip that had a slightly larger diameter than the casing. The hydraulic hammer was mounted on the chain-drive in the mast. The casing was driven into the ground by the impact of the hydraulic hammer and the downward force developed by the chain-drive in the mast. The drilling equipment provided sufficient force to routinely drive the casing to a depth of 60 to $80 \mathrm{ft} \mathrm{bgs}$ and demonstrated the ability to drive the casing to a maximum depth of $128 \mathrm{ft}$ bgs in the sediments within WMA C. The probe holes were logged for moisture, gross gamma, and spectral gamma using calibrated probes (Randall and Price 2005). A zone or depth of interest was identified in each probe hole based on neutron-moisture-logging data; previous drilling and sampling programs have shown that contamination from liquid waste is more likely to be present in zones with elevated moisture content (Brown et al. 2006). Once an appropriate sampling depth was identified, a second hole was pushed as close as possible to the logged hole for collection of $1.5 \mathrm{ft}$ of core material at the depth of interest (blue crosses in Figure 1.1). The vadose zone in the vicinity of this study, the 120-ft-diameter circle encompassing the pipeline leak, contained multiple zones of elevated moisture. Since only one sample could be collected per direct-push sampling, the direct-push holes were "paired" so that two of the high-moisture zones could be sampled at each location. 


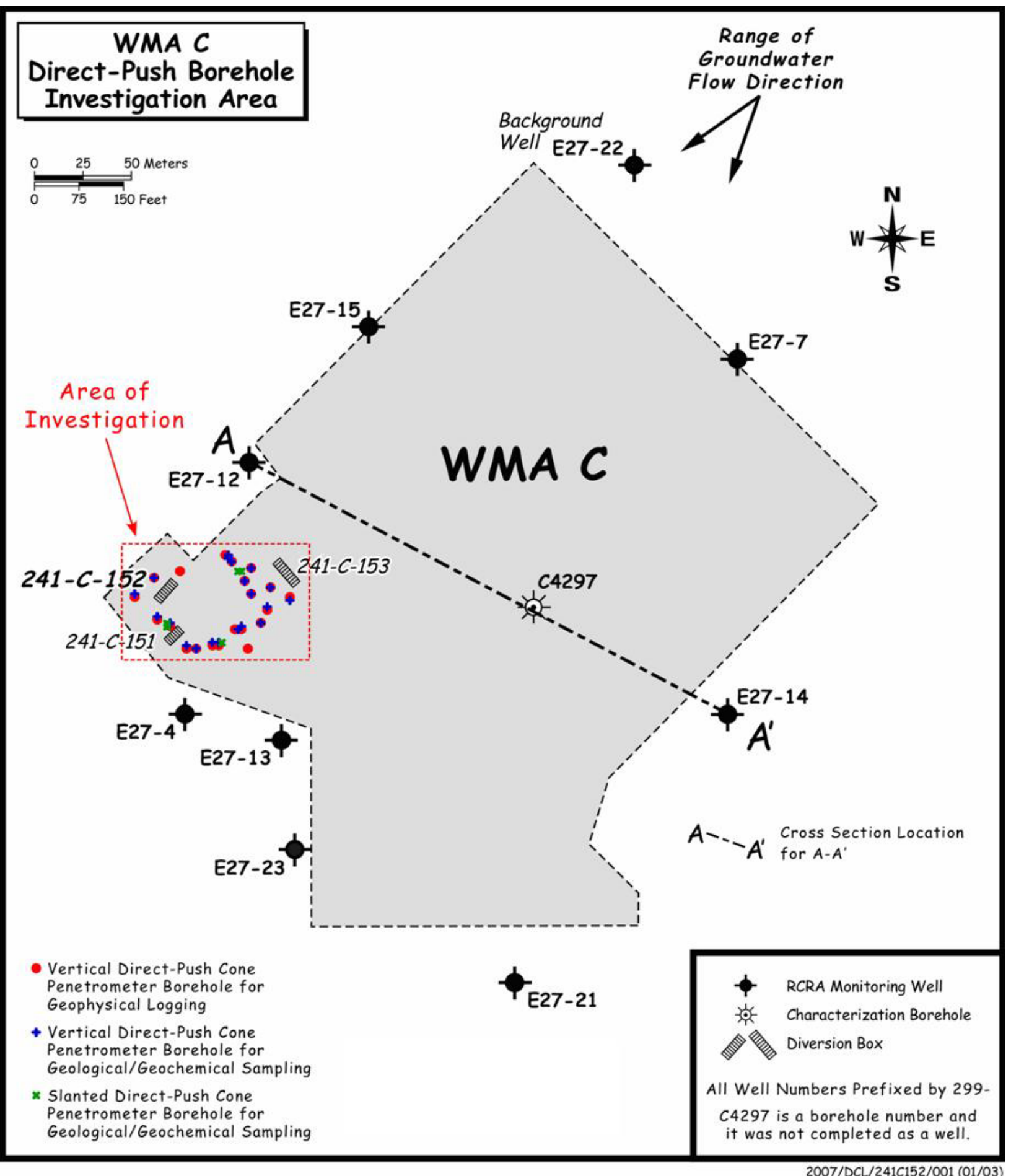

Figure 1.1. Location Map for WMA C 


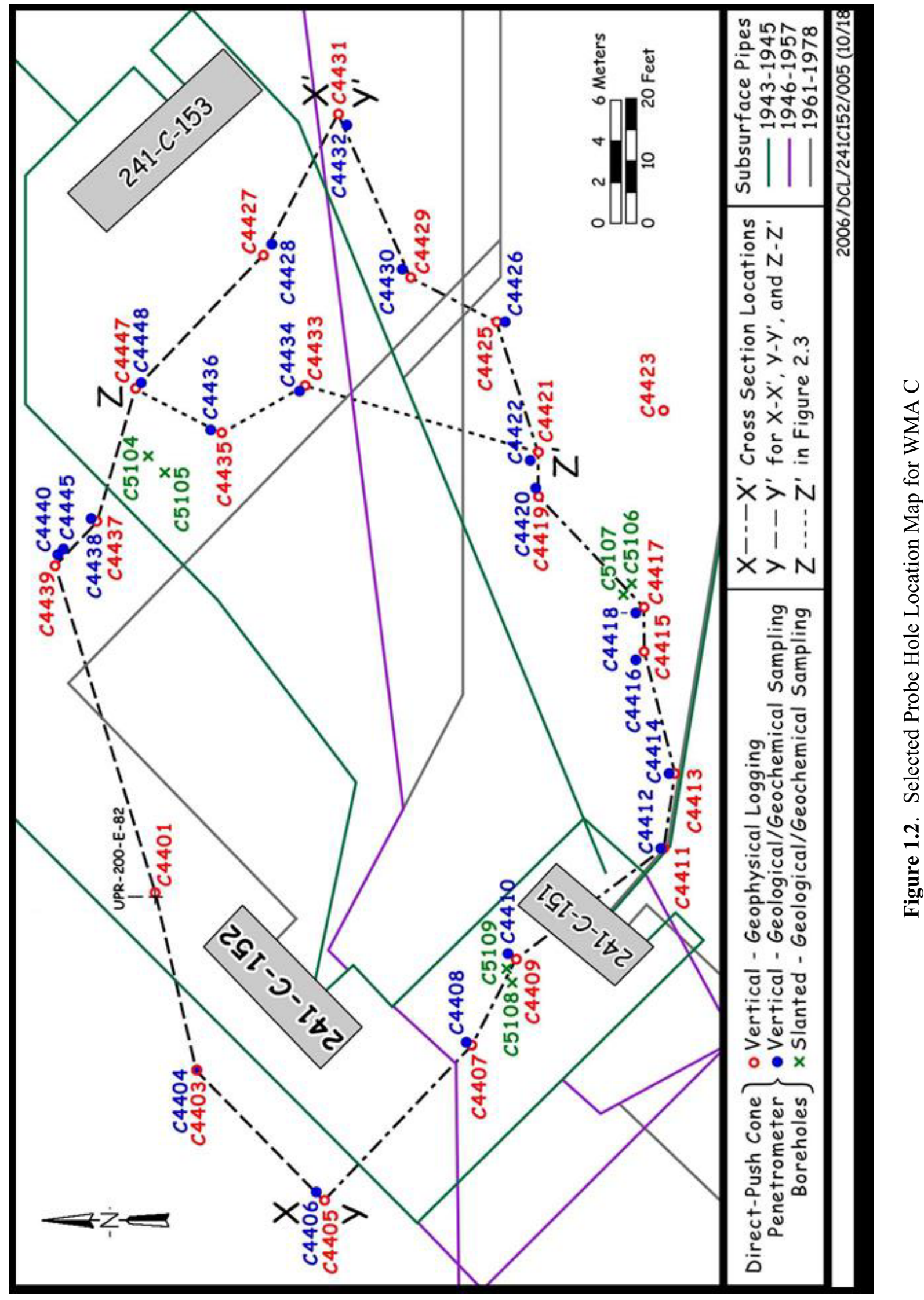




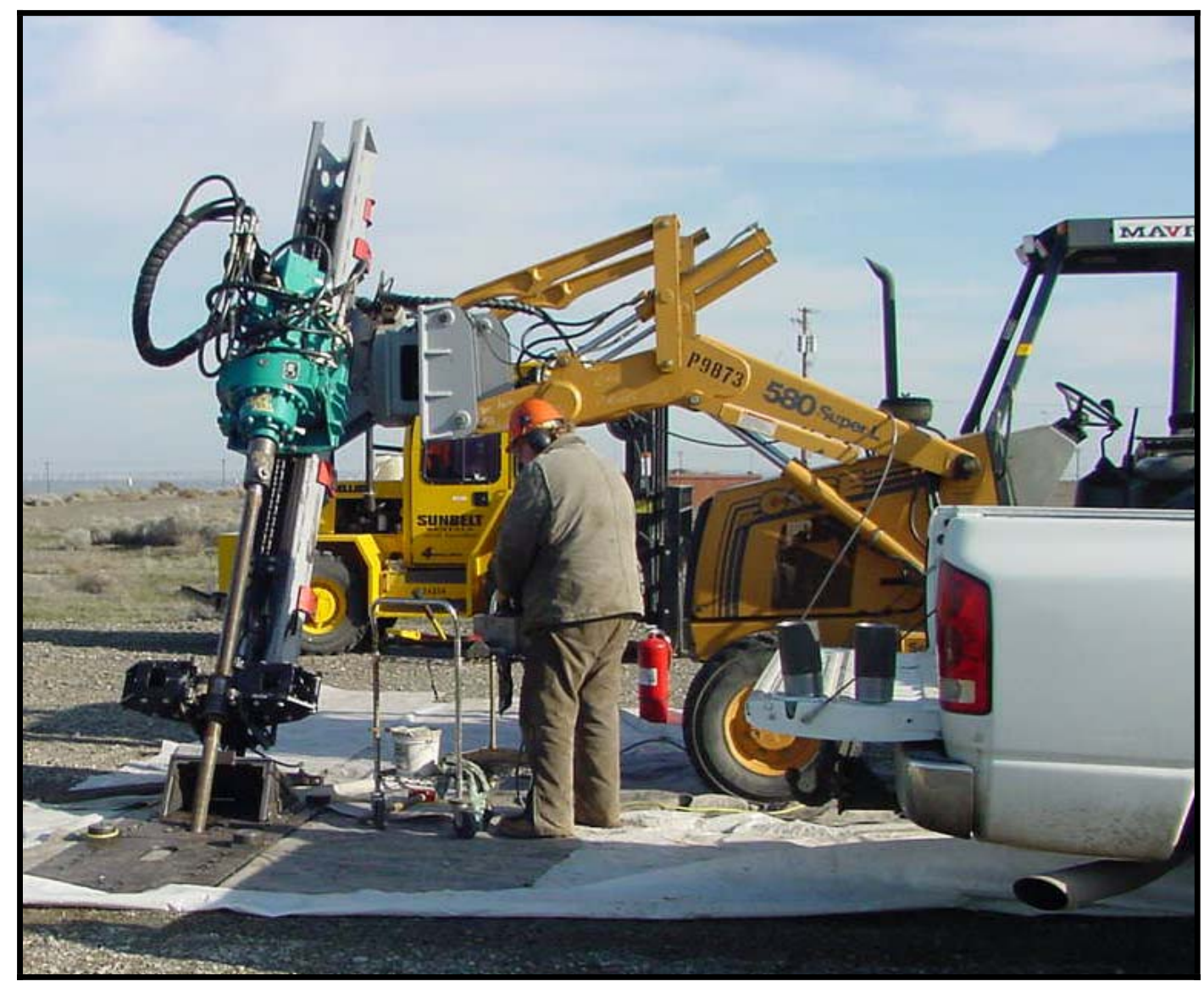

Figure 1.3. Photograph of the Hydraulic Hammer Direct-Push Apparatus

Once data from the 20 vertical probe holes were evaluated (see Section 4.1), a second series of six probe holes were emplaced around the site of the pipeline leak between March and June 2006 (green " $\mathrm{x}$ " symbols in Figure 1.2). Unlike their vertical counterparts, these probe holes were driven at angles of $30^{\circ}$, $45^{\circ}$, or $60^{\circ}$ from horizontal. Up to three sets of samples $(1.5 \mathrm{ft}$ of core plus material recovered from the drive shoe) were retrieved from each probe hole. The intent of this operation was that the final sample set collected from each probe hole was to be retrieved from a different vertical depth directly beneath the projected site of the pipeline leak.

This report is divided into sections that describe the geochemical characterization methods employed and the results of Tier 1 and Tier 2 analysis of the C-152 transfer line direct-push core samples. English units are used in this report for descriptions and discussions of drilling activities and samples because that is the system of units used by drillers to measure and report depths. The metric system is used in this report for all other purposes. To convert feet to meters, multiply by 0.3048 ; to convert inches to centimeters, multiply by 2.54 . 


\subsection{Geology}

The regional geologic setting and site-specific geology in the vicinity of the C Tank Farm has been covered extensively in a number of previous reports (Price and Fecht 1976; Williams et al. 2000; Horton and Narbutovskih 2001; Connelly et al. 1992; Lindsey et al. 1992; DOE/GJO 1998; Wood et al. 2003; Lindsey et al. 2004; Brown et al. 2006). Figure 1.1 shows the location of WMA C and the 241-C-152 Diversion Box (C-152) study area, located southwest of the C Tank Farm. The general geology of WMA C is illustrated in Figure 2.1 along cross section A-A' (shown in Figure 1.1).

In general, the geology beneath the WMA C includes up to $300 \mathrm{ft}$ of mostly unconsolidated cataclysmic flood deposits of the Hanford formation (Figure 2.1). Here, basaltic gravelly sand (H1 unit) overlies a mostly medium- to coarse-grained basaltic sand (H2 unit). Thin layers of finer sand and silt, laid down during waning flood stages, occasionally cap the coarse-grained beds; however, these represent a relatively small fraction of the total. At depth, up to several tens of feet of multi-lithic sands and gravels of either mainstream facies of the Cold Creek unit (DOE 2002) and/or the Ringold Formation lie between the Hanford formation and the top of the basalt bedrock. The top of the water table lies near the base of the Hanford formation at about a $400-\mathrm{ft}$ elevation. Thus, the vadose zone is much thicker $(\sim 250 \mathrm{ft})$ than the unconfined aquifer (few tens of feet) in the study area. WMA C atop the northeast flank of the 12-mile-long Cold Creek Bar, a giant bar that formed as cataclysmic flood sediments of the Hanford formation accumulated and prograded eastward through the central Pasco Basin (DOE 2002; Bjornstad 2006).

\subsection{Characterization and Sampling Methods}

The locations of 45 recent vadose zone, cone-penetrometer probe (direct-push) holes drilled in the vicinity of C-152 are shown in Figure 1.2. Direct-push holes were drilled in three stages. First, 19 directpush holes were advanced up to $60 \mathrm{ft}$ bgs for collection of geophysical logs to identify intervals for core sampling and geological/geochemical characterization. Geophysical logs included both neutron-moisture and gross-gamma geophysical logging techniques (Randall and Price 2005). Two of the holes (C4409 and C4417) were also logged with a spectral gamma probe. Next, core samples were collected from 20 vertical holes located immediately adjacent to the geophysically logged holes, and last, core sampling occurred in six slanted (three pairs) direct-push holes drilled inward toward the center of Figure 2.2. While only a single 2-ft interval was sampled in the vertical holes, up to three intervals were sampled in the slanted, direct-push holes (Table 2.1). The six slanted holes ranged from $30^{\circ}$ to $60^{\circ}$ from horizontal.

From the vertical geological/geochemical sampled holes, a single core was collected from one of the high-moisture zones identified from the initial geophysically logged hole. Total depths of the geological/ geochemical characterization holes were only 5.5 to $25 \mathrm{ft}$ bgs, depending on selected core depth, which was shallower than the geophysically logged holes that penetrated up to $60 \mathrm{ft}$ bgs. Since no significant gamma-emitting zones were identified in the geophysical logs, a single core interval from the geological/ geochemical characterization hole was selected based on one of the spikes in the neutron-moisture log, because potential contaminants are most likely to be associated with elevated moisture zones. 


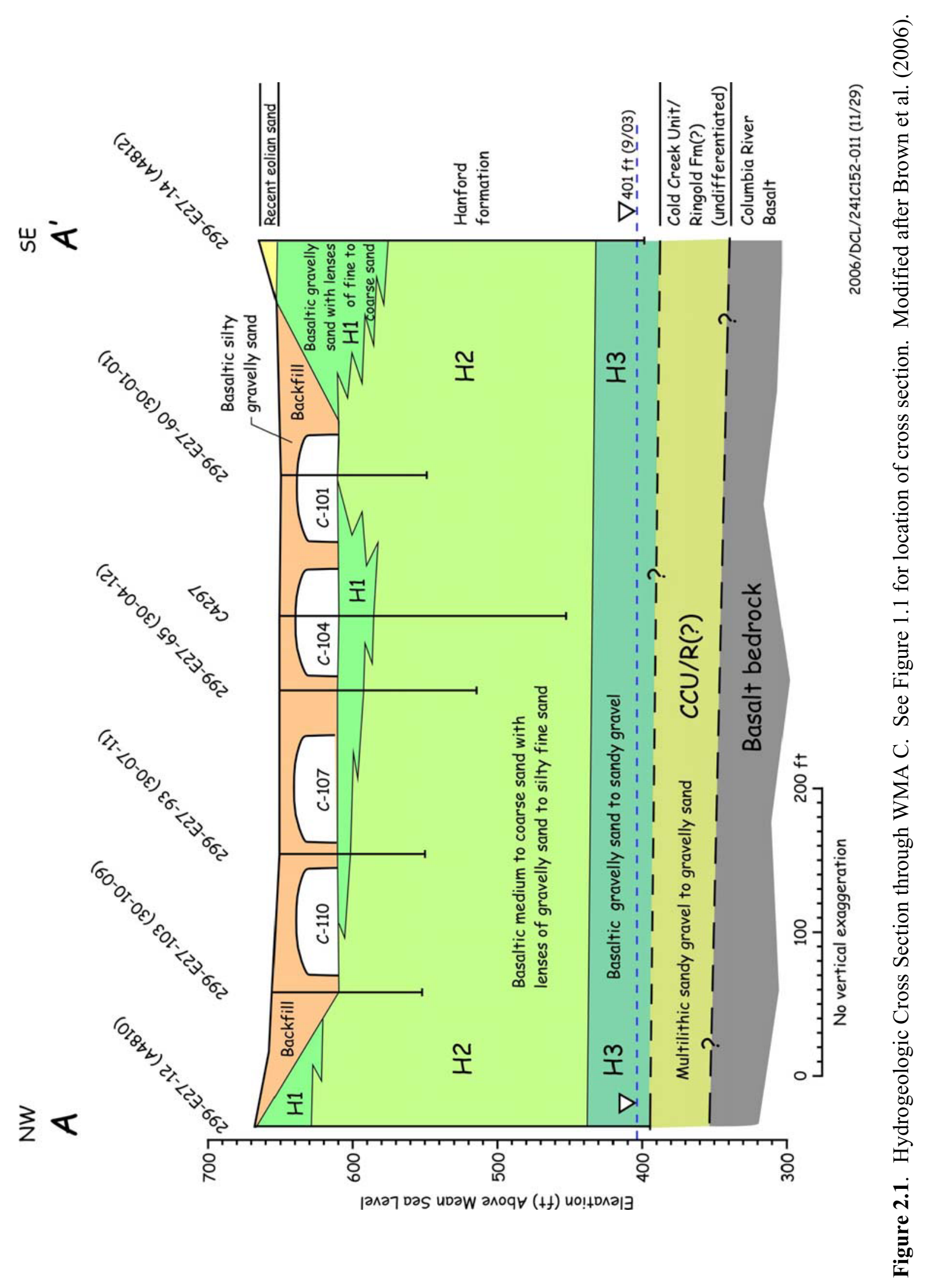




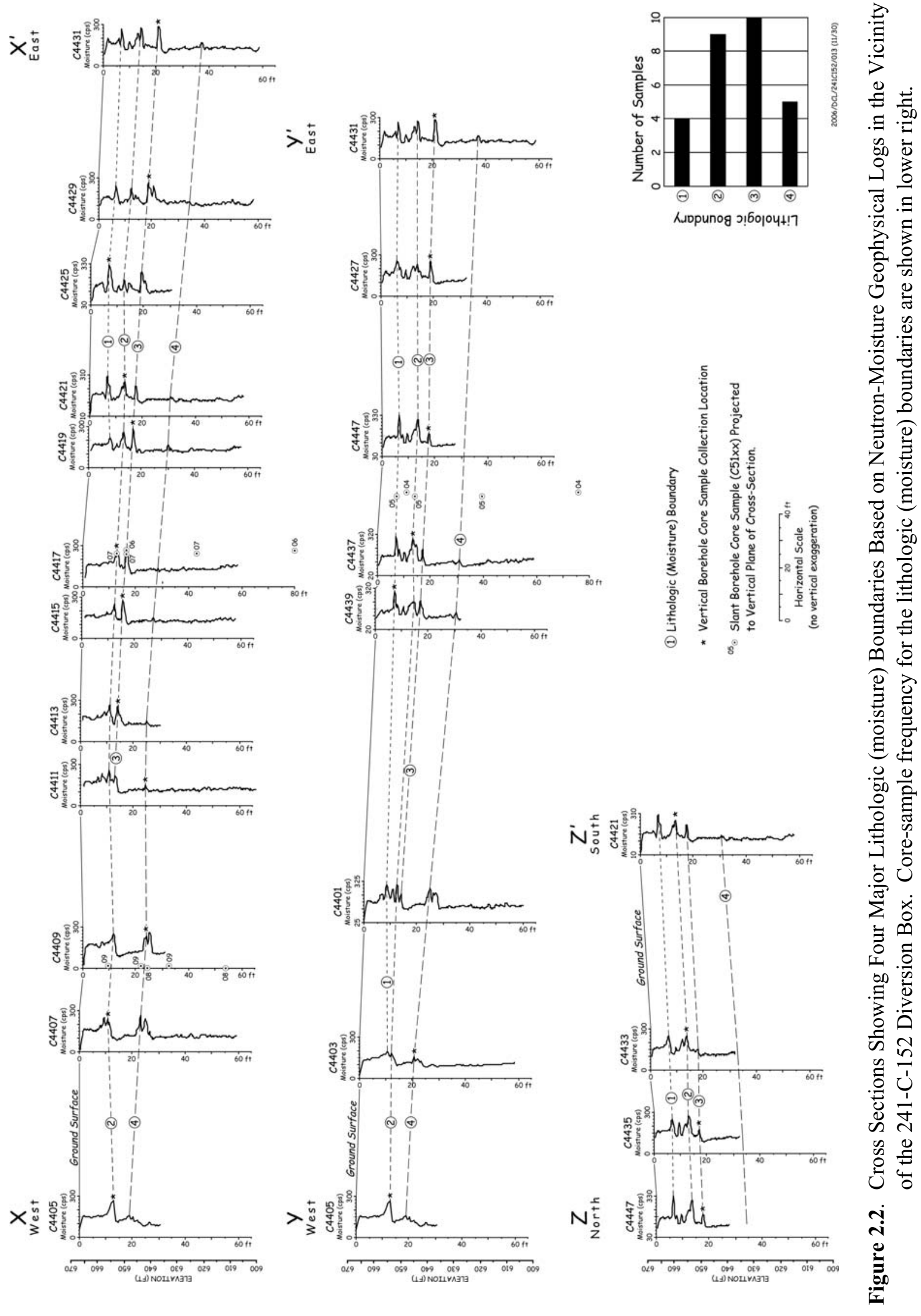




\begin{tabular}{|c|c|c|c|c|c|c|c|c|c|c|c|c|}
\hline 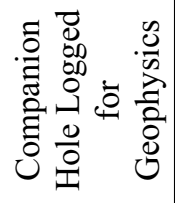 & & 守 & $\stackrel{n}{8}$ & 守 & ঠे & $\underset{J}{\exists}$ & 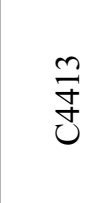 & $\stackrel{n}{g}$ & 竎 & $\underset{\partial}{g}$ & $\overrightarrow{\widetilde{J}}$ & $\stackrel{2}{\stackrel{2}{7}}$ \\
\hline 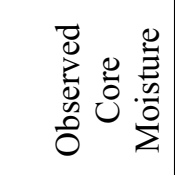 & & $\begin{array}{l}\vec{n} \\
\stackrel{\vec{n}}{0} \\
\vec{\theta} \\
\vec{\theta}\end{array}$ & 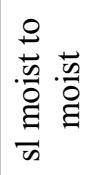 & 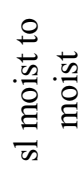 & 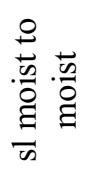 & 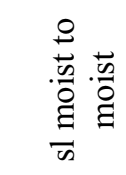 & 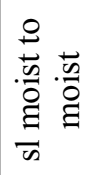 & 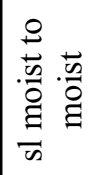 & $\frac{\ddot{n}}{\grave{O}}$ & 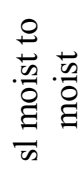 & $\begin{array}{l}. \bar{n} \\
\stackrel{0}{a} \\
\end{array}$ & $\begin{array}{l}\stackrel{2}{*} \\
\stackrel{\vec{A}}{\vec{b}}\end{array}$ \\
\hline 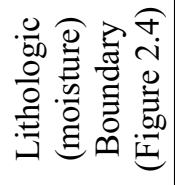 & & $\nabla$ & $N$ & $\sim$ & $\nabla$ & $\nabla$ & $m$ & $n$ & $\sim$ & $m$ & T & - \\
\hline 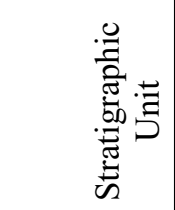 & & 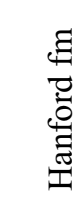 & 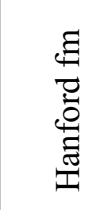 & 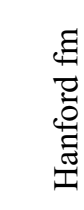 & 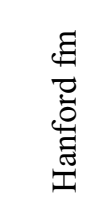 & 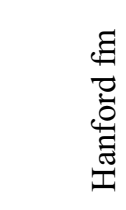 & 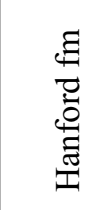 & 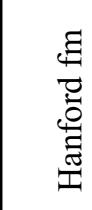 & 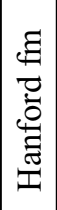 & 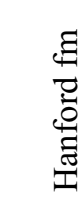 & 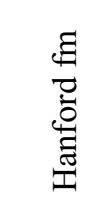 & 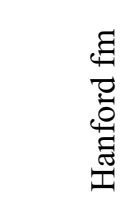 \\
\hline 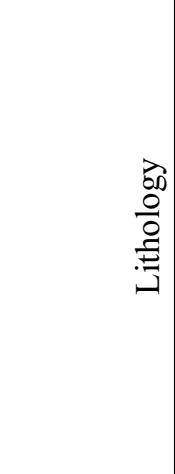 & 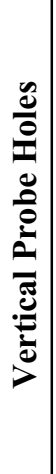 & 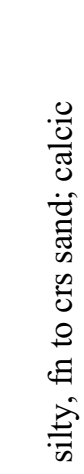 & 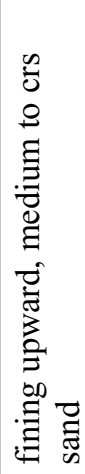 & 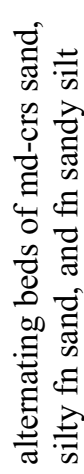 & 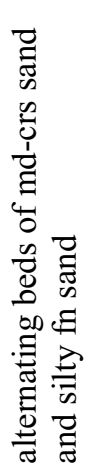 & 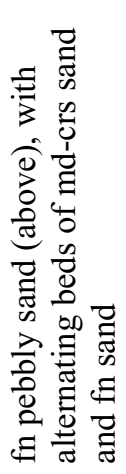 & 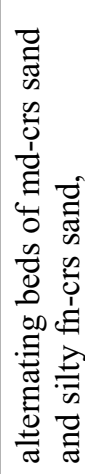 & 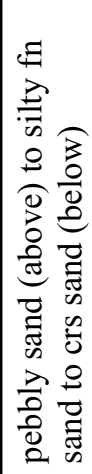 & 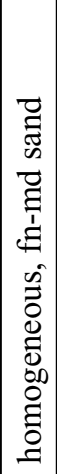 & 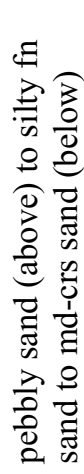 & 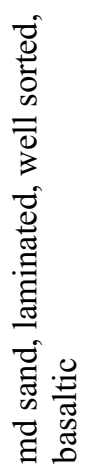 & 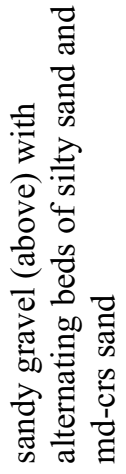 \\
\hline 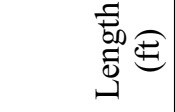 & & $\because$ & $\stackrel{0}{0}$ & $\because$ & $\stackrel{n}{\sim}$ & $\because$ & $\stackrel{n}{\sim}$ & $\stackrel{n}{\longrightarrow}$ & $\because$ & $\cong$ & $\stackrel{n}{\sim}$ & $\stackrel{\circ}{\circ}$ \\
\hline 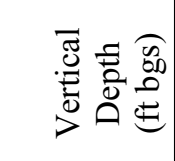 & & 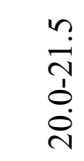 & $\begin{array}{l}\vec{m} \\
\frac{1}{0} \\
\stackrel{d}{J}\end{array}$ & $\begin{array}{l}0 \\
\exists \\
\\
a\end{array}$ & 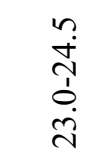 & 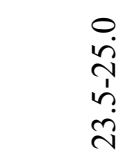 & $\begin{array}{l}\stackrel{0}{n} \\
\stackrel{n}{n} \\
\stackrel{n}{n}\end{array}$ & $\begin{array}{l}\stackrel{0}{0} \\
\dot{1} \\
\stackrel{1}{+}\end{array}$ & $\begin{array}{l}0 \\
\dot{n} \\
\dot{1} \\
\stackrel{n}{=}\end{array}$ & 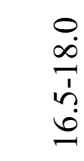 & $\begin{array}{l}\dot{0} \\
\dot{n} \\
\dot{n} \\
=\end{array}$ & $\begin{array}{l}\forall \\
\dot{b} \\
\stackrel{n}{n} \\
i\end{array}$ \\
\hline 疍 & & 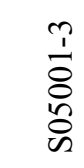 & \begin{tabular}{l}
7 \\
$\frac{1}{8}$ \\
0 \\
$o$ \\
\hdashline
\end{tabular} & $\begin{array}{l}\frac{1}{1} \\
\delta \\
8 \\
0 \\
0 \\
\text { ஸ }\end{array}$ & 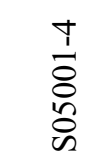 & $\begin{array}{l}0 \\
1 \\
0 \\
8 \\
0 \\
0 \\
i n\end{array}$ & $\begin{array}{l}n \\
\vdots \\
8 \\
0 \\
0 \\
6\end{array}$ & $\begin{array}{l}0 \\
\frac{1}{1} \\
8 \\
8 \\
0 \\
0 \\
\text { n }\end{array}$ & $\begin{array}{l}9 \\
1 \\
8 \\
0 \\
0 \\
0 \\
n\end{array}$ & $\begin{array}{l}\infty \\
1 \\
\\
8 \\
0 \\
0 \\
\text { \& }\end{array}$ & $\begin{array}{l}\frac{1}{1} \\
8 \\
8 \\
8 \\
0\end{array}$ & $\begin{array}{l}\text { } \\
1 \\
8 \\
8 \\
0 \\
0 \\
\text { n }\end{array}$ \\
\hline 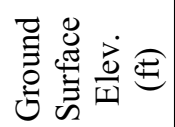 & & 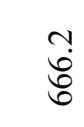 & 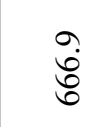 & $\begin{array}{l}\infty \\
\stackrel{0}{0} \\
\stackrel{0}{0}\end{array}$ & न: & $\begin{array}{l}\hat{\delta} \\
\dot{8}\end{array}$ & $\begin{array}{l}\text { : } \\
\stackrel{0}{0}\end{array}$ & 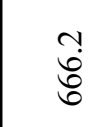 & $\begin{array}{l}-1 \\
8 \\
8\end{array}$ & $\begin{array}{l}\infty \\
\mathbb{d} \\
\dot{0}\end{array}$ & 苞 & 尔 \\
\hline 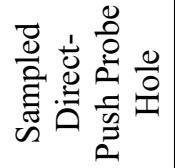 & & $\underset{⿱}{\stackrel{+}{+}}$ & 丞 & 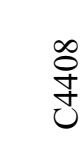 & $\stackrel{0}{\underset{J}{J}}$ & $\underset{J}{\stackrel{J}{J}}$ & $\underset{J}{\stackrel{J}{J}}$ & $\stackrel{0}{\stackrel{8}{J}}$ & $\underset{f}{\stackrel{\infty}{f}}$ & 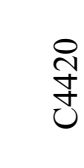 & $\underset{\mathcal{J}}{\mathbb{J}}$ & 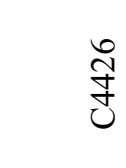 \\
\hline
\end{tabular}




\begin{tabular}{|c|c|c|c|c|c|c|c|c|c|c|c|c|}
\hline 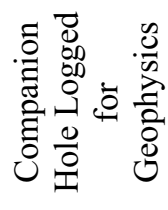 & 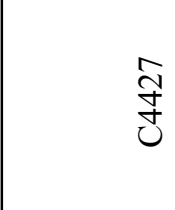 & $\stackrel{\text { ปे }}{J}$ & ঙ্ঠ & 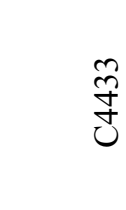 & $\stackrel{n}{\stackrel{n}{8}}$ & 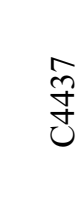 & 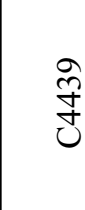 & $\stackrel{\text { Jे }}{\text { Jे }}$ & J & & 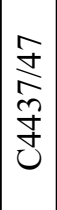 & 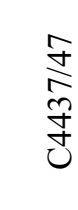 \\
\hline 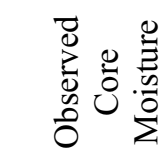 & 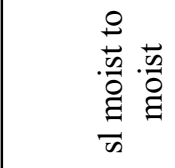 & 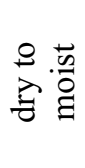 & 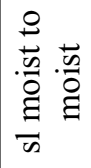 & $\begin{array}{l}\stackrel{0}{0} \\
\vec{y} \\
\vec{\theta}\end{array}$ & 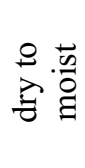 & 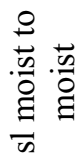 & 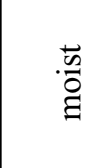 & $\begin{array}{l}\stackrel{\vec{n}}{0} \\
\stackrel{a}{a}\end{array}$ & $\begin{array}{l}\stackrel{0}{0} \cdot \frac{\tilde{2}}{8} \\
\stackrel{2}{\theta}\end{array}$ & & $\begin{array}{l}\overrightarrow{.} \\
\overrightarrow{0} \\
\underline{\Xi} \\
\vec{n}\end{array}$ & 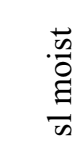 \\
\hline 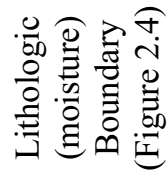 & $m$ & $m$ & $m$ & $N$ & $n$ & $N$ & - & - & $n$ & & * & $*$ \\
\hline 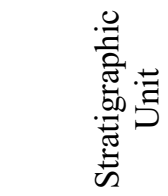 & 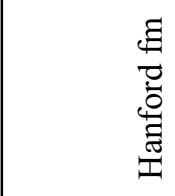 & 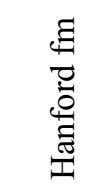 & 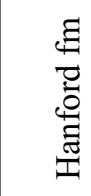 & 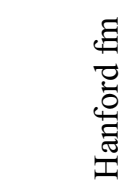 & 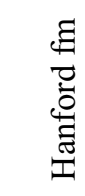 & 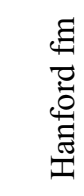 & 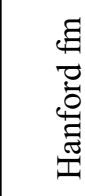 & 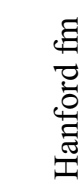 & 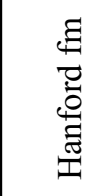 & & 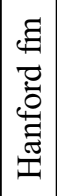 & 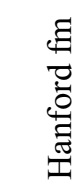 \\
\hline 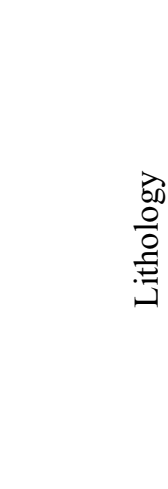 & 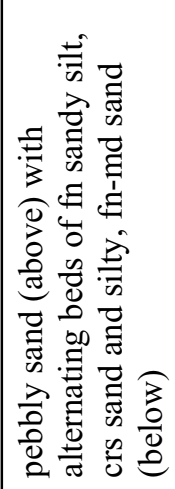 & 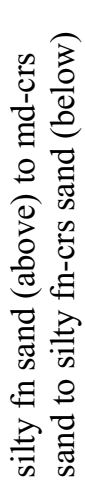 & 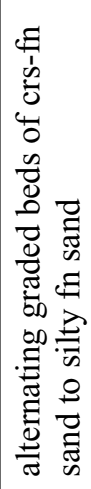 & 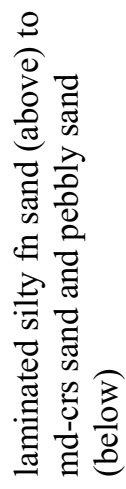 & 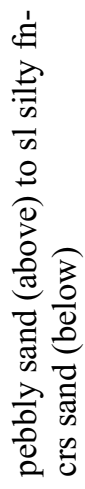 & 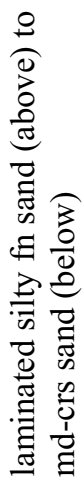 & 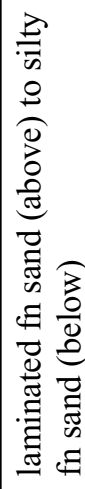 & 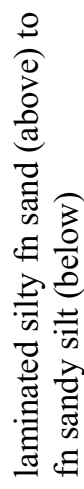 & 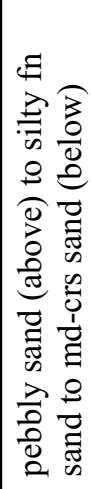 & 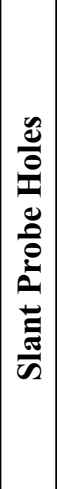 & 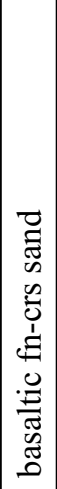 & 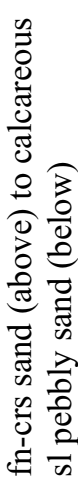 \\
\hline 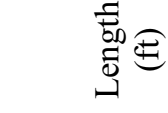 & $\because$ & $\because$ & $\exists$ & $\because$ & $\stackrel{n}{\longrightarrow}$ & $\stackrel{n}{\sim}$ & $\stackrel{\nabla}{0}$ & $\stackrel{\infty}{0}$ & $\stackrel{n}{\sim}$ & & $\stackrel{\circ}{i}$ & $\underset{\sim}{\sim}$ \\
\hline 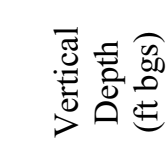 & $\begin{array}{l}n \\
a \\
\vdots \\
\infty \\
\infty\end{array}$ & $\begin{array}{l}0 \\
\stackrel{1}{1} \\
1 \\
\infty \\
\infty\end{array}$ & 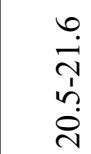 & $\begin{array}{l}0 \\
\stackrel{n}{n} \\
\stackrel{n}{n} \\
\stackrel{n}{n}\end{array}$ & $\frac{n}{5}$ & $\begin{array}{l}0 \\
\frac{n}{n} \\
\dot{n} \\
\dot{n}\end{array}$ & 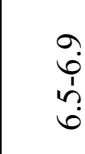 & 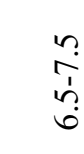 & $\begin{array}{l}n \\
\infty \\
1 \\
0 \\
1\end{array}$ & & $\begin{array}{c}\infty \\
\dot{0} \\
\frac{1}{\grave{r}} \\
a\end{array}$ & $\begin{array}{l}0 \\
\infty \\
\stackrel{1}{a} \\
\stackrel{0}{2}\end{array}$ \\
\hline 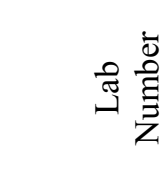 & $\begin{array}{l}\frac{2}{1} \\
\frac{1}{8} \\
8 \\
0 \\
0\end{array}$ & $\begin{array}{l}\overline{1} \\
i \\
\delta \\
0 \\
0 \\
i\end{array}$ & $\begin{array}{l}7 \\
1 \\
\overline{8} \\
8 \\
0 \\
\text { in }\end{array}$ & $\begin{array}{l}\frac{\infty}{1} \\
\frac{1}{8} \\
0 \\
0 \\
0\end{array}$ & $\begin{array}{l}\frac{1}{1} \\
\frac{1}{8} \\
0 \\
0 \\
0 \\
\text { n }\end{array}$ & $\begin{array}{l}\frac{7}{1} \\
\frac{1}{8} \\
8 \\
0 \\
0 \\
\text { in }\end{array}$ & $\begin{array}{l}7 \\
\frac{1}{8} \\
8 \\
0 \\
\text { के }\end{array}$ & $\begin{array}{l}\frac{m}{1} \\
\frac{1}{8} \\
0 \\
0 \\
\text { के }\end{array}$ & $\begin{array}{l}\frac{n}{1} \\
\frac{1}{8} \\
0 \\
0 \\
\text { n }\end{array}$ & & 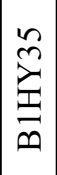 & 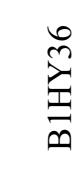 \\
\hline 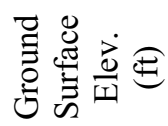 & $\stackrel{+}{\dot{\Xi}}$ & $\begin{array}{l}\infty \\
\text { ర్ర }\end{array}$ & $\frac{\infty}{\dot{0}}$ & त্ & $\frac{9}{8}$ & గ్రి & $\begin{array}{l}0 \\
\text { త్ర }\end{array}$ & $\begin{array}{l}\text { 0 } \\
\text { త్ర }\end{array}$ & $\frac{\sim}{8}$ & & $\frac{9}{8}$ & \\
\hline 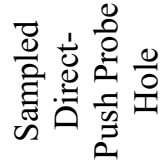 & 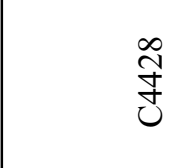 & 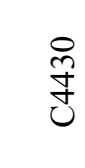 & 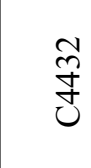 & $\stackrel{\stackrel{+}{+}}{J}$ & 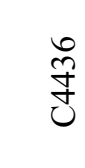 & 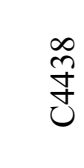 & $\stackrel{?}{\text { f }}$ & $\stackrel{n}{+}$ & $\underset{J}{\stackrel{+}{J}}$ & & $\begin{array}{l}\frac{d}{0} \\
\frac{n}{n}\end{array}$ & $\frac{d}{0}$ \\
\hline
\end{tabular}




\begin{tabular}{|c|c|c|c|c|c|c|c|c|c|c|c|c|c|}
\hline 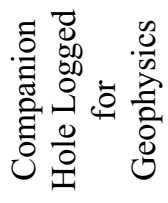 & 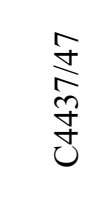 & 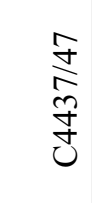 & 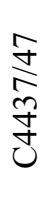 & 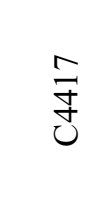 & $\frac{5}{8}$ & 竎 & $\underset{J}{\stackrel{J}{J}}$ & 竎 & 守 & ஓे & 守 & 守 & 守 \\
\hline 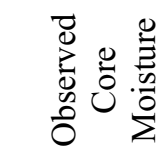 & 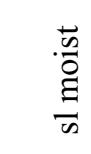 & $\begin{array}{l}\frac{\vec{n}}{\overrightarrow{0}} \\
\frac{\Xi}{\omega}\end{array}$ & $\vec{y}$ & $\begin{array}{l}. \vec{n} \\
\stackrel{\overrightarrow{0}}{\Xi} \\
\frac{\omega}{n}\end{array}$ & 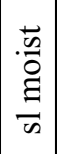 & 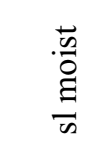 & $\left|\begin{array}{c|}\vec{n} \\
\overrightarrow{0} \\
\vdots \\
\vec{n} \\
\vec{n}\end{array}\right|$ & 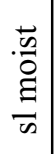 & 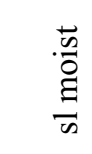 & $\left|\begin{array}{c|}\vec{n} \\
\overrightarrow{0} \\
\vdots \\
\vdots \\
\vec{n}\end{array}\right|$ & 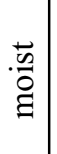 & $\begin{array}{l}\frac{\vec{n}}{0} \\
\stackrel{a}{a} \\
\frac{n}{n}\end{array}$ & 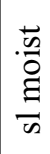 \\
\hline 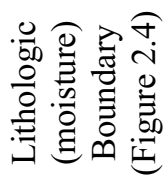 & - & $\sim$ & $*$ & $\sim$ & $*$ & $\sim$ & $m$ & $*$ & $\nabla$ & $*$ & $N$ & $*$ & $*$ \\
\hline 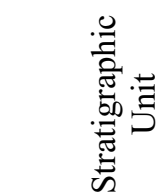 & 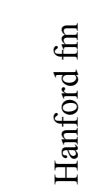 & 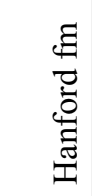 & 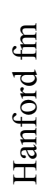 & 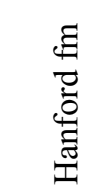 & 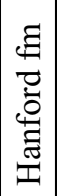 & 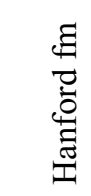 & 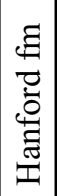 & 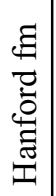 & 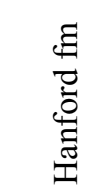 & \begin{tabular}{|l|}
$\Xi$ \\
$\Xi$ \\
0 \\
0 \\
0 \\
$\tilde{\Xi}$ \\
$ت$ \\
$ت$
\end{tabular} & 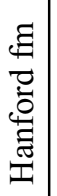 & 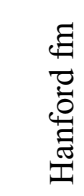 & 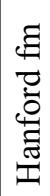 \\
\hline 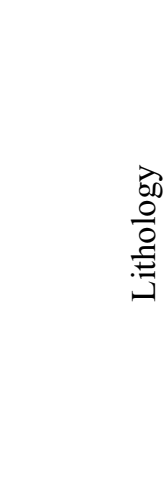 & 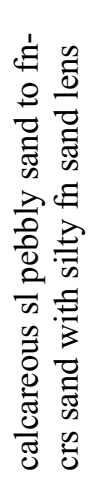 & 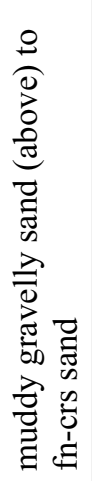 & 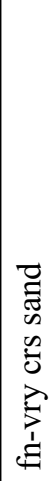 & 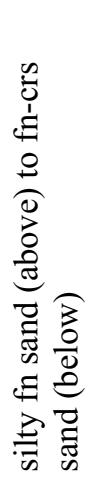 & 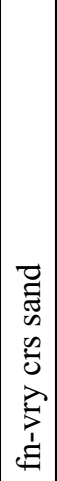 & 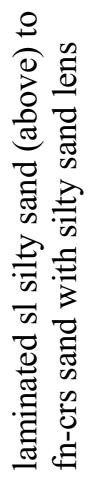 & 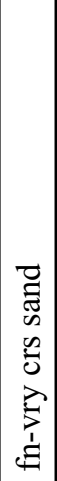 & 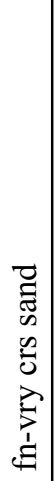 & 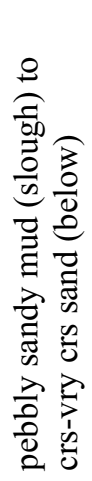 & 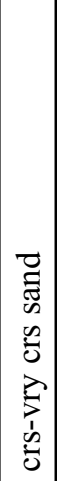 & 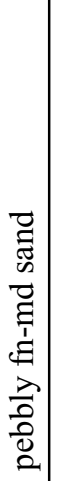 & 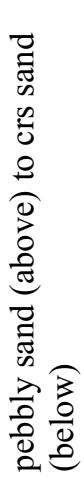 & 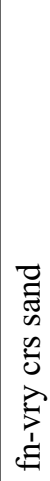 \\
\hline 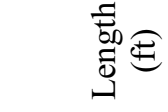 & $\because$ & $\stackrel{\sim}{\mathrm{N}}$ & $\stackrel{\circ}{i}$ & $\stackrel{\circ}{i}$ & $\stackrel{\circ}{i}$ & $\stackrel{\circ}{i}$ & $\stackrel{\circ}{i}$ & $\stackrel{\circ}{i}$ & $\stackrel{\circ}{i}$ & $\stackrel{\circ}{i}$ & $\stackrel{0}{-}$ & $\stackrel{0}{\circ}$ & $\stackrel{\circ}{i}$ \\
\hline 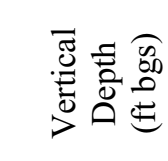 & $\frac{\dot{r}}{\grave{a}}$ & $\begin{array}{l}\stackrel{a}{m} \\
\stackrel{1}{\dot{m}} \\
\dot{m}\end{array}$ & 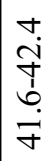 & $\frac{n}{\mathfrak{n}}$ & 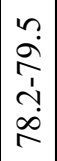 & $\begin{array}{l}m \\
\stackrel{n}{1} \\
\stackrel{1}{d}\end{array}$ & $\begin{array}{l}- \\
\frac{1}{1} \\
\frac{1}{6} \\
-1\end{array}$ & $\begin{array}{c}0 \\
\dot{y} \\
\dot{1} \\
o \\
\dot{v}\end{array}$ & 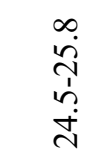 & $\begin{array}{c}r \\
\infty \\
\infty \\
\dot{j} \\
i \\
i n\end{array}$ & $\begin{array}{l}n \\
\exists \\
\infty \\
\infty \\
0 \\
0\end{array}$ & $\begin{array}{l}\stackrel{+}{\pi} \\
\stackrel{\text { İ }}{\Delta}\end{array}$ & $\begin{array}{l}\vec{c} \\
\text { nे } \\
0 \\
\text { iे }\end{array}$ \\
\hline 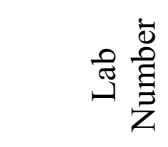 & 空 & 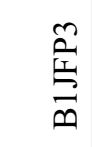 & 壱 & 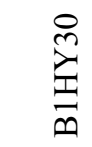 & $\begin{array}{l}\vec{n} \\
\vec{n} \\
\bar{n}\end{array}$ & 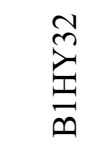 & 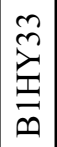 & 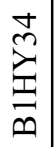 & 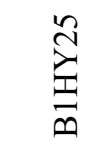 & 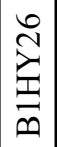 & 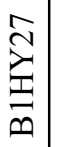 & 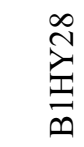 & خે \\
\hline 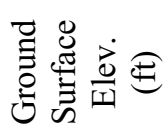 & $\frac{9}{6}$ & & & 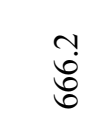 & & 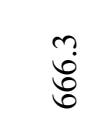 & & & $\begin{array}{l}n \\
8 \\
0 \\
0\end{array}$ & & $\begin{array}{l}0 \\
\dot{0} \\
\dot{0} \\
\end{array}$ & & \\
\hline 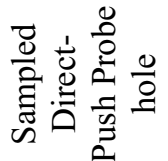 & $\frac{n}{0}$ & $\frac{n}{n}$ & $\frac{n}{0}$ & $\frac{8}{8}$ & $\frac{8}{\frac{8}{3}}$ & $\frac{\hat{0}}{3}$ & $\begin{array}{c}5 \\
0 \\
0 \\
0\end{array}$ & $\frac{5}{0}$ & $\frac{\infty}{0}$ & $\begin{array}{l}\infty \\
0 \\
0 \\
0 \\
0\end{array}$ & $\frac{8}{3}$ & $\frac{8}{8}$ & $\frac{8}{0}$ \\
\hline
\end{tabular}




\subsubsection{Lithologic (Moisture) Boundaries}

Most core intervals recovered from elevated moisture zones from the cone-penetrometer holes at C-152 contained at least one fine-grained (i.e., silty) layer, similar to those shown in Figure 2.3. A few of the increased-moisture zones, however, had no fine-grained layer associated with them. An example is vertical probe hole C4406 (and companion geophysical hole C4405), where elevated moisture occurred within medium sand that overlies a bed of coarse sand (Appendix A). Here, moisture is apparently retained via capillary forces that exist along the contact between these two highly contrasting strata. The highly heterogeneous, complexly bedded nature of cataclysmic flood deposits (Hanford formation) make this stratigraphic unit particularly anisotropic, which leads to significant lateral migration of fluids along bedding interfaces.

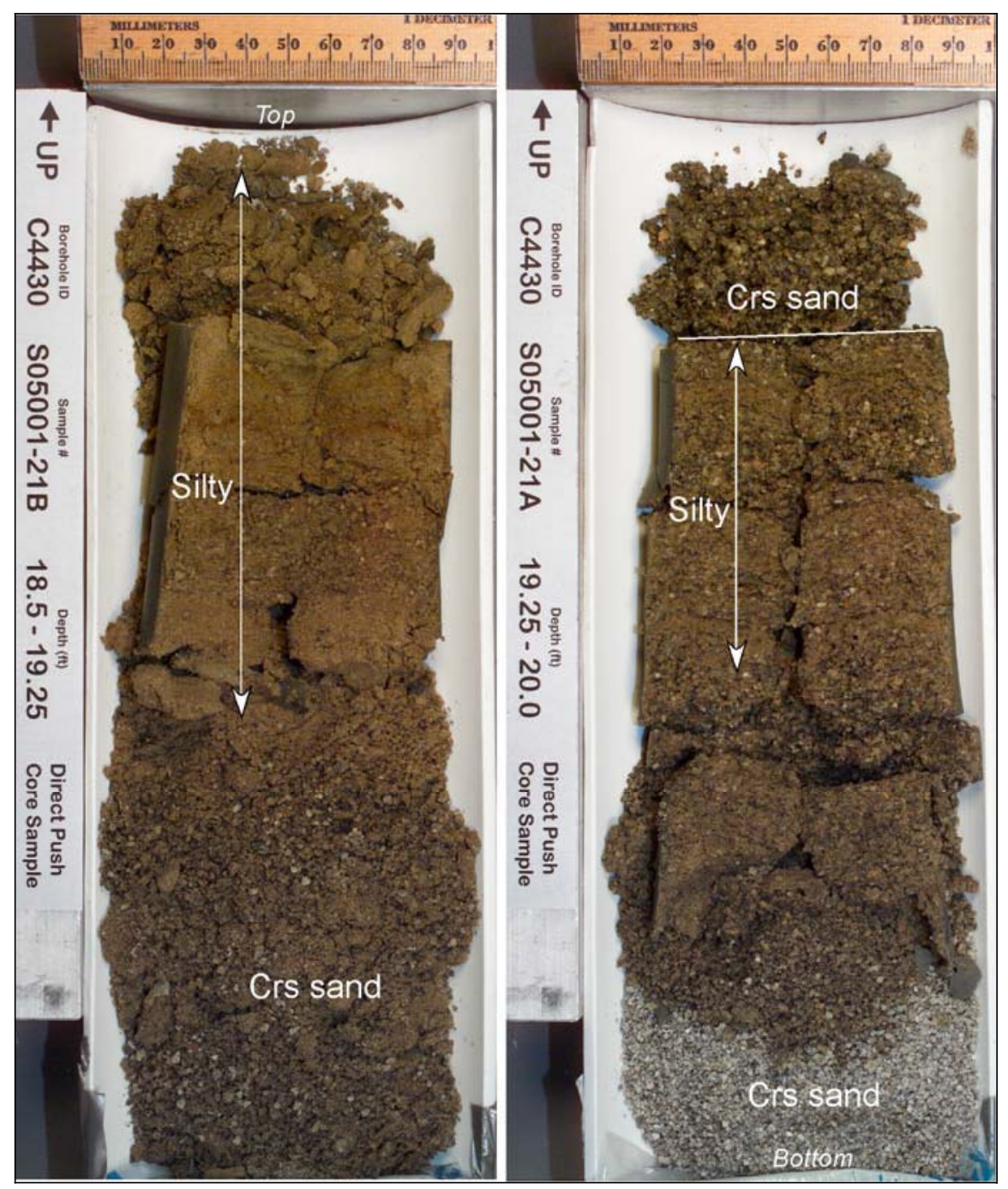

Figure 2.3. Alternating Sand- and Silt-Dominated Beds in Two Adjacent Core Segments. Notice moisture concentrates in area of two silty layers. Below the silty interval is dry coarse sand. Moisture is associated with lithologic boundary \#3 intersected by vertical probe hole $\mathrm{C} 4430$ (see Figure 2.2). 
A single 1.5-ft-long core was collected from each of 20 vertical geological/geochemical characterization probe holes at C-152 (Table 2.1). From each interval, two continuous core segments were collected in 1.5-inch-diameter by 9-inch-long stainless-steel liners (Table 2.2). Conversely, up to three separate, 2-ft-long core intervals were collected from each slant hole. Slant-hole core samples were segmented into four, continuous, 6-inch-long, 1.5-inch-diameter stainless-steel liners (Table 2.3). Occasionally, grab samples were also collected and analyzed from the drive shoe at the base of some core intervals (Tables 2.2 and 2.3). In the laboratory, immediately upon extruding the cores from their liners, moisture samples were collected and high-resolution color photographs were obtained for each 6-inch or 9-inch core segment (Appendix A). Next, standard descriptions of grain size, sorting, color, structure, consolidation, moisture content, mineralogy, and reaction with hydrochloric acid were entered onto geologic core logs (Appendix B). Cores were also sub-sampled for laboratory characterization of physical and chemical properties at that time.

\subsection{Interpreted Geology Near the 241-C-152 Diversion Box}

All 45 new direct-push holes penetrated only cataclysmic flood deposits of the Hanford formation and vadose zone. The deepest cone-penetrometer boring (C4411) was pushed to $66 \mathrm{ft}$ bgs, well above the groundwater table and contact with the pre-Hanford formation deposits (Figure 2.1). Except for scattered core intervals, no direct observations were made available by cone-penetrometer holes. However, some indirect interpretation of lithology can be made based on the neutron-moisture log.

Multiple increased-moisture zones occurred within $40 \mathrm{ft}$ of the surface based on neutron-moisture logs within the borings (Figure 2.2). The neutron-moisture probe was especially effective at identifying the detailed subsurface moisture distribution due to the relatively small hole diameter (2.51 inches). Sudden increases in moisture (up to $25 \%$ of the volume of the formation) occurred along lithologic boundaries by either 1) water within fine-grained layers (e.g., silt and/or fine sand) that, like a sponge, absorb and retain more moisture, or 2) a capillary zone along the interface between two highly contrasting strata (e.g., coarse sand over sandy gravel) (Bjornstad et al. 2003). In the latter case, no fine-grained layer is necessary to create a high-moisture zone.

Based on nearby boreholes and limited core recovered from the cone-penetrometer holes (Appendix B), it appears the deposits beneath C-152 consist predominantly of sand-dominated facies of the Hanford formation (H2 unit). While coarser, gravelly facies of the H1 unit of the Hanford formation occur immediately to the north and east beneath WMA C, these increasingly grade into finer-grained, sand-dominated deposits to the southwest, in the vicinity of C-152. Multiple moisture boundaries (Figure 2.2) and the predominance of sand recovered from cores confirms sand, not gravel, is the dominant sediment type in the vicinity of C-152. However, cores were collected with a bias toward higher moisture zones, which generally occur in the finer-grained sediments. Therefore, sediments between zones of elevated moisture could potentially consist of the coarser sand and/or gravel that are more representative of the $\mathrm{H} 1$ unit.

Based on correlations of the neutron-moisture logs, it appears there are at least four major lithologic boundaries where moisture concentrates within $40 \mathrm{ft}$ of the surface (Figure 2.1). Based on the neutronmoisture logs, no significant moisture boundaries are apparent from $40 \mathrm{ft}$ to $66 \mathrm{ft}$ bgs, the maximum 
Table 2.2. Vertical Hole Samples. Moisture and lithology of each 9-inch core segment were collected from direct-push vertical holes in the vicinity of the 241-C-152 Diversion Box.

\begin{tabular}{|c|c|c|c|c|c|}
\hline Sample Number & $\begin{array}{l}\text { Probe } \\
\text { Hole } \\
\text { Number }\end{array}$ & $\begin{array}{l}\text { Mid- } \\
\text { Depth } \\
\text { (ft bgs) }\end{array}$ & $\begin{array}{l}\text { Lab Moisture } \\
\text { Content }(\%)\end{array}$ & $\begin{array}{l}\text { Observed Core } \\
\text { Moisture }\end{array}$ & Lithology (see Appendix B) \\
\hline S05001-1A & $\mathrm{C} 4406$ & 12.29 & 10.7 & $\begin{array}{l}\text { sl moist to } \\
\text { moist }\end{array}$ & md to crs sand \\
\hline S05001-1 (grab) & C4406 & 12.83 & 3.29 & $\begin{array}{l}\text { sl moist to } \\
\text { moist }\end{array}$ & md to crs sand \\
\hline S05001-2B & C4408 & 9.88 & 10.4 & moist & fn sandy silt to md-crs sand \\
\hline S05001-2A & C4408 & 10.63 & 10.4 & $\begin{array}{l}\text { sl moist to } \\
\text { moist }\end{array}$ & silty fn sand \\
\hline S05001-3B & $\mathrm{C} 4404$ & 20.38 & 2.68 & dry to sl moist & fine to crs sand, calcareous \\
\hline S05001-3A & $\mathrm{C} 4404$ & 21.13 & 4.59 & dry to sl moist & silty fine to crs sand \\
\hline S05001-4B & $\mathrm{C} 4410$ & 21.8 & 4.3 & $\begin{array}{l}\mathrm{sl} \text { moist to } \\
\text { moist }\end{array}$ & $\begin{array}{l}\text { interstratified silty fn sand to } \mathrm{md} \text { - } \\
\text { crs sand }\end{array}$ \\
\hline S05001-4A & $\mathrm{C} 4410$ & 23.38 & 9.27 & moist & $\begin{array}{l}\text { interstratified silty fn sand to md } \\
\text { crs sand }\end{array}$ \\
\hline S05001-5B & $\mathrm{C} 4414$ & 24.13 & 5.77 & $\begin{array}{l}\text { sl moist to } \\
\text { moist }\end{array}$ & $\begin{array}{l}\text { interstratified silty fn sand and } \\
\text { fn-crs sand }\end{array}$ \\
\hline S05001-5A & C4414 & 24.8 & 9.54 & moist & silty fn-crs sand, poorly sorted \\
\hline S05001-6B & $\mathrm{C} 4412$ & 13.88 & 2.71 & sl moist & pebbly sand to md-crs sand \\
\hline S05001-6A-1 & $\mathrm{C} 4412$ & 14.63 & 11.9 & moist & laminated fn sand \\
\hline S05001-6A-2 & $\mathrm{C} 4412$ & 14.63 & 2.81 & sl moist & md-crs sand \\
\hline S05001-7B & $\mathrm{C} 4422$ & 11.88 & 12.1 & moist & $\begin{array}{l}\text { md sand, laminated, vry well } \\
\text { sorted }\end{array}$ \\
\hline S05001-7A & $\mathrm{C} 4422$ & 12.63 & 7.52 & moist & fn-med sand \\
\hline S05001-8B & $\mathrm{C} 4420$ & 13.3 & 12.2 & $\begin{array}{l}\text { sl moist to } \\
\text { moist }\end{array}$ & pebbly sand to silty fn sand \\
\hline S05001-8A & $\mathrm{C} 4420$ & 16.88 & 9.29 & moist & silty fn sand to med-crs sand \\
\hline S05001-9B & $\mathrm{C} 4418$ & 17.63 & 12.6 & moist & fn-md sand, laminated \\
\hline S05001-9A & $\mathrm{C} 4418$ & 18.3 & 7.47 & moist & fn-md sand, laminated \\
\hline S05001-10B & $\mathrm{C} 4416$ & 11.88 & 4.06 & sl moist & pebbly fn-crs sand \\
\hline S05001-10A & $\mathrm{C} 4416$ & 12.63 & 18.3 & moist & silty fn sand \\
\hline S05001-11B & $\mathrm{C} 4432$ & 20.77 & 13.5 & $\begin{array}{l}\text { sl moist to } \\
\text { moist }\end{array}$ & silty fn sand to fn-crs sand \\
\hline S05001-11A & $\mathrm{C} 4432$ & 21.34 & 9.54 & $\begin{array}{l}\text { sl moist to } \\
\text { moist }\end{array}$ & silty fn-crs sand to crs sand \\
\hline S05001-12A & $\mathrm{C} 4440$ & 6.7 & 6.82 & moist & $\begin{array}{l}\text { fn sand over silty fn sand, } \\
\text { laminated, oxidized }\end{array}$ \\
\hline S05001-12 (grab) & $\mathrm{C} 4440$ & 7.1 & 22 & not logged & not logged \\
\hline S05001-13B & $\mathrm{C} 4445$ & 6.63 & 5.65 & moist & silty fn sand, laminated, oxidized \\
\hline S05001-13A-1 & $\mathrm{C} 4445$ & 7.13 & 7.87 & moist & silty fn sand, laminated, oxidized \\
\hline S05001-13A-2 & C4445 & 7.13 & 22.1 & moist & fn sandy silt, laminated, reduced \\
\hline S05001-14B & $\mathrm{C} 4438$ & 13.88 & 11.7 & $\begin{array}{l}\text { sl moist to } \\
\text { moist }\end{array}$ & silty fn sand \\
\hline S05001-14A & $\mathrm{C} 4438$ & 14.63 & 9.81 & sl moist & md-crs sand \\
\hline S05001-14A Dup & C4438 & 14.63 & 8.89 & sl moist & md-crs sand \\
\hline
\end{tabular}


Table 2.2. (contd)

\begin{tabular}{||l|c|c|c|l|l||}
\hline Sample Number & $\begin{array}{c}\text { Probe } \\
\text { Nole }\end{array}$ & $\begin{array}{c}\text { Mid- } \\
\text { Depth } \\
\text { (ft bgs) }\end{array}$ & $\begin{array}{c}\text { Lab Moisture } \\
\text { Content (\%) }\end{array}$ & $\begin{array}{l}\text { Observed Core } \\
\text { Moisture }\end{array}$ & \multicolumn{1}{|c||}{ Lithology (see Appendix B) } \\
\hline \hline S05001-15B & C4448 & 17.38 & 3 & dry to moist & pebbly sand to silty fn sand \\
\hline S05001-15A & C4448 & 18.13 & 8.08 & $\begin{array}{l}\text { sl moist to } \\
\text { moist }\end{array}$ & md-crs sand \\
\hline S05001-17B & C4436 & 16.38 & 2.44 & dry & pebbly sand \\
\hline S05001-17A & C4436 & 17.13 & 9.04 & moist & sl silty fn-crs sand, oxidized \\
\hline S05001-18B & C4434 & 13.88 & 8.47 & $\begin{array}{l}\text { sl moist to } \\
\text { moist }\end{array}$ & silty fn sand to med-crs sand \\
\hline S05001-18A & C4434 & 14.63 & 4.73 & dry to sl moist & $\begin{array}{l}\text { md-crs sand to pebbly sand, } \\
\text { significant color change }\end{array}$ \\
\hline S05001-19B & C4428 & 15.3 & 2.71 & sl moist & pebbly sand \\
\hline S05001-19A & C4428 & 18.38 & 17 & $\begin{array}{l}\text { sl moist to } \\
\text { moist }\end{array}$ & $\begin{array}{l}\text { fn sandy silt, crs sand, and silty } \\
\text { fn-md sand }\end{array}$ \\
\hline S05001-19A Dup & C4428 & 18.38 & 16.7 & $\begin{array}{l}\text { sl moist to } \\
\text { moist }\end{array}$ & $\begin{array}{l}\text { fn sandy silt, crs sand, and silty } \\
\text { fn-md sand }\end{array}$ \\
\hline & & & & & $\begin{array}{l}\text { sandy pebble gravel over } \\
\text { interstratified silty sand and md- } \\
\text { crs sand }\end{array}$ \\
\hline S05001-20A & C4426 & 6.06 & 8.45 & dry to moist \\
\hline S05001-20 (grab) & C4426 & 6.73 & 17.9 & not logged & not logged \\
\hline S05001-21B-1 & C4430 & 6.73 & 10.8 & moist & silty fn sand \\
\hline S05001-21B-2 & C4430 & 18.88 & 8.11 & moist & md-crs sand \\
\hline S05001-21A & C4430 & 18.88 & 6.53 & dry to moist & sl silty fn-crs sand to crs sand \\
\hline
\end{tabular}

depth advanced by the geophysically logged direct-push holes at C-152. This suggests either 1) finegrained layers and/or capillary boundaries are not present, or 2) artificial recharge has yet to migrate beyond the 40-ft depth. Based on what is known about the Hanford formation at other localities, finegrained layers and other capillary boundaries are present throughout the Hanford formation $\mathrm{H} 2$ unit, not just the top. Therefore, it appears artificial recharge fluids at C-152 are being retained in the uppermost layers of the Hanford formation. Between the fine-grained beds, the bulk of the flood deposits are mostly medium to coarse sand or gravelly sands, which do not retain much moisture; these sediment types represent the areas between moisture spikes in Figure 2.2.

While all four of the lithologic (moisture) boundaries were sampled via coring by cone penetrometer, some of these boundaries were sampled more than others (Figure 2.2). Boundary \#3, for example, was sampled 10 times, while Boundaries \#1 and \#4 were only sampled half (or less) as frequently. During downward migration of fluids away from the diversion boxes some contaminants may become attenuated or filtered out as fluids found their way into deeper moisture zones. Therefore, samples collected for pore-water chemistry should be compared and evaluated separately to test for chemical fractionation between the four different zones. 
Table 2.3. Slant Hole Samples. Moisture and lithology of each 6-inch core segment collected from direct-push slant holes in the vicinity of the 241-C-152 Diversion Box.

\begin{tabular}{|c|c|c|c|c|c|c|c|}
\hline $\begin{array}{l}\text { Sample } \\
\text { Number }\end{array}$ & $\begin{array}{l}\text { Probe } \\
\text { Hole } \\
\text { Number }\end{array}$ & $\begin{array}{l}\text { Slant angle } \\
\text { (degrees } \\
\text { from } \\
\text { horiz.) }\end{array}$ & $\begin{array}{l}\text { Slant } \\
\text { Mid- } \\
\text { Depth } \\
\text { (ft bgs) }\end{array}$ & $\begin{array}{l}\text { Corrected } \\
\text { Vertical } \\
\text { Mid Depth } \\
\text { (ft bgs) }\end{array}$ & $\begin{array}{l}\text { Lab } \\
\text { Moisture } \\
\text { Content } \\
(\%)\end{array}$ & $\begin{array}{l}\text { Observed } \\
\text { Core } \\
\text { Moisture }\end{array}$ & $\begin{array}{c}\text { Lithology } \\
\text { (see Appendix B) }\end{array}$ \\
\hline B1HY35C & C5104 & 45 & 13.75 & 9.7 & 6.4 & sl moist & $\begin{array}{l}\text { very basaltic fn to crs sand } \\
\text { to muddy gravelly sand } \\
\text { (slough?) }\end{array}$ \\
\hline B1HY35B & C5104 & 45 & 14.25 & 10.1 & 5.6 & sl moist & fn to crs sand \\
\hline B1HY35A & C5104 & 45 & 14.75 & 10.4 & 6.3 & sl moist & fn to crs sand \\
\hline $\begin{array}{l}\text { B1HY35 } \\
\text { (grab) }\end{array}$ & C5104 & 45 & 15.25 & 10.8 & 5.4 & sl moist & fn to crs sand \\
\hline B1HY36C & C5104 & 45 & 108.75 & 76.9 & 6.9 & sl moist & fn to vry crs sand \\
\hline B1HY36B & C5104 & 45 & 109.25 & 77.2 & 3.4 & sl moist & fn to vry crs sand \\
\hline B1HY36A & C5104 & 45 & 109.75 & 77.6 & 2.7 & sl moist & fn to vry crs sand \\
\hline $\begin{array}{l}\text { B1HY36 } \\
\text { (grab) }\end{array}$ & C5104 & 45 & 110.3 & 78 & 2.8 & sl moist & sl pebbly crs sand \\
\hline B1JFP2B & $\mathrm{C} 5105$ & 30 & 13.75 & 6.9 & 12.4 & sl moist & $\begin{array}{l}\text { sl pebbly fn to md sand, } \\
\text { calcareous }\end{array}$ \\
\hline B1JFP2A & C5105 & 30 & 14.25 & 7.1 & 8.6 & sl moist & fn to crs sand, vry basaltic \\
\hline B1JFP2 & C5105 & 30 & 14.75 & 7.4 & 11.8 & sl moist & $\begin{array}{l}\text { fn to crs sand to silty fn } \\
\text { sand }\end{array}$ \\
\hline B1JFP3C & C5105 & 30 & 26.25 & 13.1 & 5.6 & sl moist & muddy gravelly sand \\
\hline B1JFP3B & C5105 & 30 & 26.75 & 13.4 & 9.4 & sl moist & fn sand, weathered? \\
\hline B1JFP3A & C5105 & 30 & 27.25 & 13.6 & 6.3 & sl moist & fn to vry crs sand \\
\hline $\begin{array}{l}\text { B1JFP3 } \\
\text { (grab) }\end{array}$ & C5105 & 30 & 27.8 & 13.9 & 6.6 & sl moist & fn to vry crs sand \\
\hline B1JFP4C & C5105 & 30 & 83.25 & 41.6 & 3.3 & dry & crs sand \\
\hline B1JFP4B & C5105 & 30 & 83.75 & 41.9 & 2.9 & dry & crs sand \\
\hline B1JFP4A & C5105 & 30 & 84.25 & 42.1 & 2.9 & dry & crs sand \\
\hline $\begin{array}{l}\text { B1JFP4 } \\
\text { (grab) }\end{array}$ & $\mathrm{C} 5105$ & 30 & 84.75 & 42.4 & 2.8 & dry & crs sand \\
\hline B1HY30C & C5106 & 60 & 18.75 & 16.2 & 7.4 & sl moist & $\begin{array}{l}\text { pebbly muddy sand } \\
\text { (slough?) to silty fn sand }\end{array}$ \\
\hline B1HY30B & C5106 & 60 & 19.25 & 16.7 & 7 & sl moist & silty fn sand \\
\hline B1HY30A & C5106 & 60 & 19.75 & 17.1 & 8.3 & sl moist & silty fn sand \\
\hline $\begin{array}{l}\text { B1HY30 } \\
\text { (grab) }\end{array}$ & C5106 & 60 & 20.25 & 17.5 & 7 & sl moist & fn to crs sand \\
\hline B1HY31C & C5106 & 60 & 90.25 & 78.2 & 5.5 & sl moist & $\begin{array}{l}\text { Muddy sand (slough) to crs } \\
\text { sand }\end{array}$ \\
\hline B1HY31B & C5106 & 60 & 90.75 & 78.6 & 3 & sl moist & crs sand \\
\hline B1HY31A & C5106 & 60 & 91.25 & 79 & 2.9 & sl moist & sl pebbly crs sand \\
\hline $\begin{array}{l}\text { B1HY31 } \\
\text { (grab) }\end{array}$ & C5106 & 60 & 91.75 & 79.5 & 1.7 & sl moist & sl pebbly crs sand \\
\hline B1HY32C & C5107 & 45 & 17.25 & 12.2 & 8 & sl moist & sl muddy sand \\
\hline B1HY32B & C5107 & 45 & 17.75 & 12.5 & 9.1 & sl moist & md sand, laminated \\
\hline B1HY32A & C5107 & 45 & 18.25 & 12.9 & 14.3 & sl moist & md sand, laminated \\
\hline $\begin{array}{l}\text { B1HY32 } \\
\text { (grab) }\end{array}$ & C5107 & 45 & 18.75 & 13.3 & 11.4 & sl moist & $\begin{array}{l}\text { md sand, laminated with } \\
\text { silty sand lens }\end{array}$ \\
\hline
\end{tabular}


Table 2.3. (contd)

\begin{tabular}{|c|c|c|c|c|c|c|c|}
\hline $\begin{array}{l}\text { Sample } \\
\text { Number }\end{array}$ & $\begin{array}{c}\text { Probe } \\
\text { Hole } \\
\text { Number }\end{array}$ & $\begin{array}{l}\text { Slant angle } \\
\text { (degrees } \\
\text { from } \\
\text { horiz.) }\end{array}$ & $\begin{array}{c}\text { Slant } \\
\text { Mid- } \\
\text { Depth } \\
\text { (ft bgs) }\end{array}$ & $\begin{array}{l}\text { Corrected } \\
\text { Vertical } \\
\text { Mid Depth } \\
\text { (ft bgs) }\end{array}$ & $\begin{array}{c}\text { Lab } \\
\text { Moisture } \\
\text { Content } \\
(\%)\end{array}$ & $\begin{array}{c}\text { Observed } \\
\text { Core } \\
\text { Moisture }\end{array}$ & $\begin{array}{c}\text { Lithology } \\
\text { (see Appendix B) }\end{array}$ \\
\hline B1HY33C & C5107 & 45 & 22.75 & 16.1 & 6.9 & sl moist & $\begin{array}{l}\text { muddy gravelly sand } \\
\text { (slough?) }\end{array}$ \\
\hline B1HY33B & C5107 & 45 & 23.25 & 16.4 & 5.4 & sl moist & crs sand \\
\hline B1HY33A & C5107 & 45 & 23.75 & 16.8 & 7.3 & sl moist & crs sand \\
\hline $\begin{array}{l}\text { B1HY33 } \\
\text { (grab) }\end{array}$ & C5107 & 45 & 24.25 & 17.1 & 3.8 & sl moist & crs sand \\
\hline B1HY34C & C5107 & 45 & 59.25 & 41.9 & 3.8 & sl moist & sl muddy sand (slough?) \\
\hline B1HY34B & C5107 & 45 & 59.75 & 42.2 & 2.7 & sl moist & crs sand \\
\hline B1HY34A & C5107 & 45 & 60.25 & 42.6 & 2.5 & sl moist & crs sand \\
\hline $\begin{array}{l}\text { B1HY34 } \\
\text { (grab) }\end{array}$ & C5107 & 45 & 60.75 & 43.0 & I.S. & sl moist & crs sand \\
\hline B1HY25C & C5108 & 60 & 28.25 & 24.5 & 5.5 & sl moist & pebbly sandy mud (slough) \\
\hline B1HY25B & C5108 & 60 & 28.75 & 24.9 & 2.5 & sl moist & vry crs sand \\
\hline B1HY25A & C5108 & 60 & 29.25 & 25.3 & 4.8 & sl moist & crs sand \\
\hline $\begin{array}{l}\text { B1HY25 } \\
\text { (grab) }\end{array}$ & C5108 & 60 & 29.75 & 25.8 & 8.3 & sl moist & crs sand \\
\hline B1HY26C & C5108 & 60 & 66.25 & 57.4 & 3.9 & sl moist & crs to vry crs sand, Fe oxide \\
\hline B1HY26B & C5108 & 60 & 66.75 & 57.8 & 2.4 & sl moist & crs to vry crs sand \\
\hline B1HY26A & C5108 & 60 & 67.25 & 58.2 & 2.4 & sl moist & crs to vry crs sand \\
\hline $\begin{array}{l}\text { B1HY26 } \\
\text { (grab) }\end{array}$ & C5108 & 60 & 67.75 & 58.7 & 1.9 & sl moist & crs to vry crs sand \\
\hline B1HY27B & C5109 & 45 & 15.25 & 10.8 & I.S. & Lost core & Lost core \\
\hline B1HY27A & C5109 & 45 & 15.75 & 11.1 & 13.3 & moist & pebbly fn to md sand \\
\hline $\begin{array}{l}\text { B1HY27 } \\
\text { (grab) }\end{array}$ & C5109 & 45 & 16.25 & 11.5 & 17.7 & moist & fn to md sand \\
\hline B1HY28C & C5109 & 45 & 31.25 & 22.1 & 4 & sl moist & pebbly crs sand \\
\hline B1HY28B & C5109 & 45 & 31.75 & 22.4 & 2.4 & sl moist & crs to vry crs sand \\
\hline B1HY29C & C5109 & 45 & 45.25 & 32 & 4.6 & sl moist & crs sand \\
\hline B1HY29B & C5109 & 45 & 45.75 & 32.3 & 2.7 & sl moist & crs sand \\
\hline B1HY29A & C5109 & 45 & 46.25 & 32.7 & 2.7 & sl moist & crs sand \\
\hline $\begin{array}{l}\text { B1HY29 } \\
\text { (grab) }\end{array}$ & C5109 & 45 & 46.75 & 33.1 & 2.5 & sl moist & crs to vry crs sand \\
\hline
\end{tabular}

Based on the attitude of the lithologic (moisture) boundaries shown in Figure 2.2 and on structure contour maps in Figure 2.4, it appears that most of these bedding surfaces have a pronounced dip to the east-northeast. Depths and elevations for each of the four major lithologic (moisture) boundaries are presented in Table 2.4. The attitude of the bedding generally reflects the topographic surface of the Cold Creek flood bar, which dips in the same direction. Therefore, the moisture boundaries appear to be associated with thin, fine-grained, slackwater beds laid down at the end of flood cycles (DOE 2002; Bjornstad 2006). Thus, any fluids moving laterally along these surfaces may preferentially migrate down the dip slope toward the northeast beneath the WMA C. Figure 2.5 shows the depth below ground surface for each of the four lithologic (moisture) boundaries. Similar to structure contour maps 
(Figure 2.4), these maps indicate depths to each of the lithologic boundaries increases to the east, which is consistent with their pronounced eastward dip.

The structural relief on the upper surfaces of these boundaries appears to increase with depth. For example, only a few feet of relief exists on Boundary \#1, while up to $25 \mathrm{ft}$ exists on Boundary \#4. This type of relief is consistent with delta-like sediment accumulation occurring along the front of the Cold Creek flood bar as it migrates eastward with each subsequent flood.

Bedding continuity is another factor that affects the downward percolation and migration of fluids in the vadose zone beneath C-152. Of the four major lithologic boundaries in the upper $40 \mathrm{ft}$, two of these (\#2 and \#4) appear to correlate across the entire study area; the other two (\#1 and \#3) appear to pinch out or merge together within the western portion of C-152 (Figures 2.4 and 2.5). Therefore, near-surface moisture retention and lateral migration may be more effective over the eastern portion of the study area. To the west, fewer lithologic boundaries are present to interfere with vertical flow. 


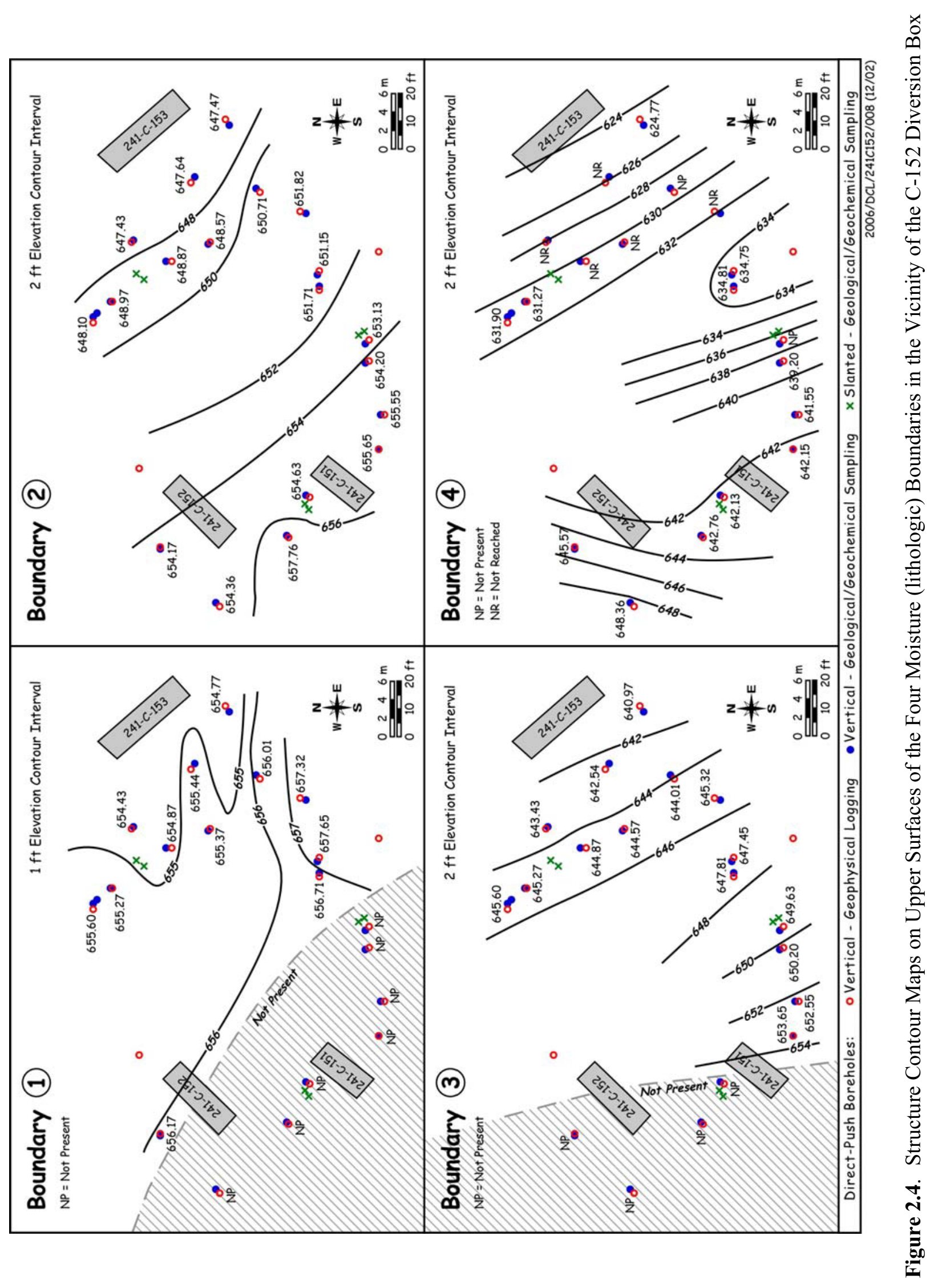




\begin{tabular}{|c|c|c|c|c|c|c|c|c|c|c|c|c|c|c|c|c|c|c|c|c|}
\hline 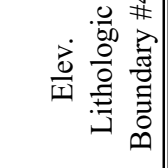 & $\begin{array}{l}\tilde{n} \\
n \\
\dot{b}\end{array}$ & 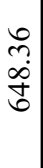 & 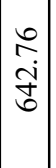 & 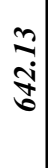 & $\mid \begin{array}{c}2 \\
\vec{z} \\
\vec{v}\end{array}$ & $\mid \begin{array}{c}n \\
n \\
\dot{t} \\
\end{array}$ & ๙ิ่ & $\mathrm{z}$ & $\begin{array}{l}\vec{\infty} \\
\dot{0} \\
\vec{b}\end{array}$ & 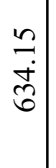 & $\frac{r}{z}$ & 孚 & $\bar{z}$ & 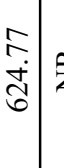 & & & $\frac{1}{6} \frac{9}{3}$ & $\begin{array}{l}\vec{c} \\
\vec{b}\end{array}$ & 学 & \\
\hline 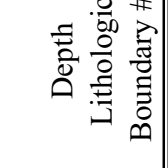 & $\begin{array}{l}0 \\
\dot{\sim} \\
\dot{\sim}\end{array}$ & $\begin{array}{l}n \\
\infty \\
\infty\end{array}$ & $\stackrel{\sim}{\sim}$ & 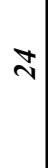 & 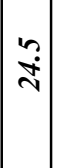 & $\approx$ & $\hat{\sim}$ & $\hat{z}$ & in & $\begin{array}{l}n \\
\tilde{e} \\
n\end{array}$ & 足 & 占 & $\hat{z}$ & $\hat{n}$ & $\mathfrak{z} \mid$ & $\frac{c}{z} \bar{z}$ & $\vec{n}$ & $\begin{array}{l}n \\
0 \\
0\end{array}$ & 孚 & \\
\hline 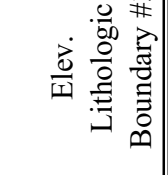 & $\mathrm{z}$ & $\mathbf{z}$ & $\hat{z}$ & 宗 & $\left|\begin{array}{c}n \\
0 \\
\tilde{2} \\
\tilde{6}\end{array}\right|$ & $\mid \begin{array}{c}0 \\
\hat{2} \\
\hat{2} \\
\hat{b}\end{array}$ & 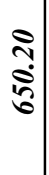 & $\begin{array}{l}\hat{b} \\
\dot{q} \\
\dot{b}\end{array}$ & $\begin{array}{l}\bar{d} \\
\stackrel{a}{0} \\
\vec{b}\end{array}$ & \begin{tabular}{l}
$f$ \\
\multirow{2}{*}{} \\
$f$ \\
d
\end{tabular} & $\begin{array}{c}n \\
\tilde{b} \\
\tilde{b}\end{array} \mid$ & 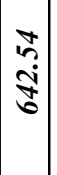 & $\mid \begin{array}{l}a \\
\dot{z} \\
\mathbf{d}\end{array}$ & $\begin{array}{l}\hat{a} \\
\hat{\vec{t}} \\
\hat{\sigma}\end{array}$ & & 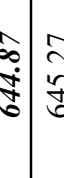 & 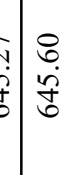 & $\begin{array}{l}\dot{B} \\
\dot{f} \\
\dot{b}\end{array}$ & 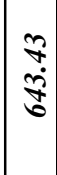 & \\
\hline 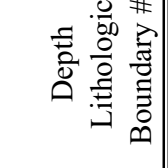 & $\mathbf{z}$ & $\hat{z}$ & $\hat{z}$ & $\hat{z}$ & $\cong$ & \pm & 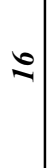 & $\begin{array}{l}n \\
0 \\
0\end{array}$ & $\approx$ & $\stackrel{?}{\beth}$ & 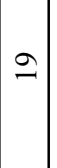 & के & \begin{tabular}{|l|}
$\infty$ \\
$\stackrel{0}{0}$
\end{tabular} & $\begin{array}{ll}\infty \\
\stackrel{\sim}{\mathbf{v}}\end{array}$ & $\stackrel{\infty}{=}$ & $\approx 7$ & $=1$ & $=$ & $\stackrel{\infty}{\stackrel{0}{c}}$ & \\
\hline 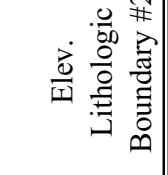 & $\begin{array}{c}7 \\
7 \\
6\end{array}$ & 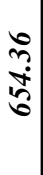 & $\begin{array}{l}2 \\
2 \\
6 \\
6\end{array}$ & $\begin{array}{l}\tilde{b} \\
\dot{v} \\
\sigma\end{array}$ & $\mid \begin{array}{l}0 \\
0 \\
2 \\
6\end{array}$ & 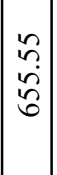 & 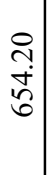 & $\begin{array}{l}2 \\
\tilde{2}\end{array}$ & $\overrightarrow{\vec{c}}$ & $\frac{2}{2}$ & $\begin{array}{c}\tilde{c} \\
\infty \\
\vec{b}\end{array} \mid$ & $\begin{array}{l}\vec{J} \\
\dot{d} \\
\tilde{b}\end{array}$ & $\begin{array}{l}\overrightarrow{1} \\
0 \\
0 \\
0\end{array}$ & 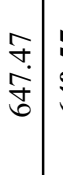 & & $\begin{array}{lll}\infty & 0 \\
0 \\
0 \\
0 \\
0\end{array}$ & $\begin{array}{lll}0 \\
\vdots \\
\vdots \\
\vdots \\
0\end{array}$ & $\begin{array}{l}8 \\
\dot{0} \\
\text { f }\end{array}$ & 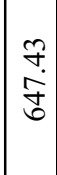 & \\
\hline 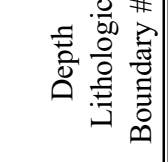 & 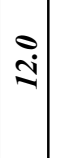 & $\stackrel{n}{\mathfrak{y}}$ & $\stackrel{2}{2}$ & $\stackrel{n}{=}$ & $\stackrel{0}{=}$ & $\stackrel{0}{=}$ & 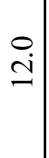 & $\stackrel{2}{2}$ & $\vec{m}$ & $\stackrel{n}{\sim}$ & 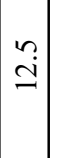 & $\begin{array}{l}\infty \\
\stackrel{\sim}{-}\end{array}$ & $\overrightarrow{\mathrm{i}}$ & $\stackrel{m}{ \pm}$ & & $\begin{array}{lll}0 \\
\vec{c}\end{array}$ & 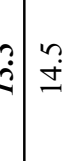 & $\stackrel{i}{i}$ & $\begin{array}{l}\infty \\
\sim \\
\end{array}$ & \\
\hline 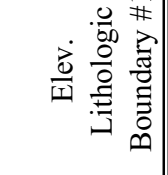 & $\begin{array}{l}= \\
\bar{b} \\
2 \\
0\end{array}$ & 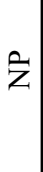 & $\hat{z}$ & $\hat{z}$ & $\hat{z}$ & 文 & $\hat{z}$ & $\hat{\mathbf{z}}$ & $\begin{array}{l}\overrightarrow{\hat{n}} \\
\dot{0} \\
0\end{array}$ & $\begin{array}{l}n \\
6 \\
i \\
0\end{array}$ & $\begin{array}{l}\tilde{n} \\
\frac{3}{6}\end{array}$ & 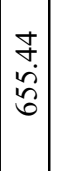 & $\mid \begin{array}{l}0 \\
0 \\
0 \\
b\end{array}$ & 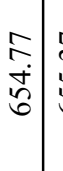 & & 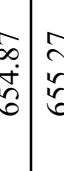 & 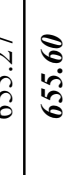 & $\begin{array}{l}8 \\
6 \\
6\end{array}$ & \begin{tabular}{l}
$m$ \\
\multirow{+}{*}{} \\
$\dot{\sim}$ \\
$\dot{b}$
\end{tabular} & \\
\hline 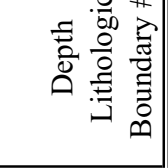 & 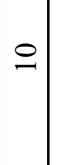 & $\hat{z}$ & $\hat{z}$ & $\hat{z}$ & $\mathbf{z}$ & 文 & $\hat{z}$ & $\hat{z}$ & $\vec{\infty}$ & - & 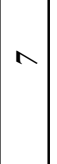 & 0 & $\left|\begin{array}{l}\infty \\
0 \\
0\end{array}\right|$ & $r$ & -7 & $r 7$ & -1 & 6 & $\begin{array}{l}\infty \\
0 \\
0\end{array}$ & 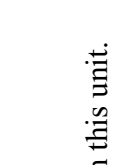 \\
\hline 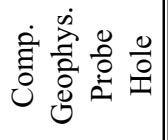 & 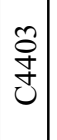 & 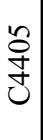 & $\begin{array}{l}\hat{q} \\
\dot{q} \\
\end{array}$ & 字 & $\underset{⿱ 乛 ⿻}{\vec{J}}$ & 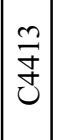 & $\begin{array}{l}\frac{n}{J} \\
J\end{array}$ & $\begin{array}{l}\text { J } \\
\text { J }\end{array}$ & 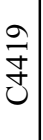 & $\begin{array}{l}\vec{Y} \\
\stackrel{J}{U}\end{array}$ & 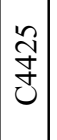 & $\underset{\mathcal{y}}{\tilde{J}}$ & 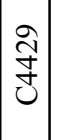 & $\begin{array}{l}\bar{g} \\
\dot{J}\end{array}$ & 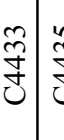 & 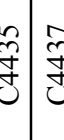 & 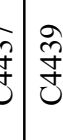 & 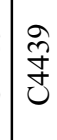 & 导 & 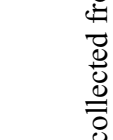 \\
\hline 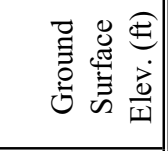 & 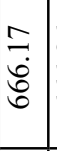 & 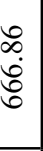 & $\begin{array}{l}0 \\
2 \\
\dot{0} \\
0 \\
0\end{array}$ & $\begin{array}{l}m \\
\stackrel{0}{0} \\
\dot{0} \\
\dot{0}\end{array}$ & $\left|\begin{array}{l}0 \\
0 \\
8 \\
0 \\
0\end{array}\right|$ & $\mid \begin{array}{l}n \\
n \\
8 \\
8 \\
0 \\
0\end{array}$ & 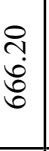 & $\begin{array}{l}m \\
\dot{8} \\
\dot{8} \\
0\end{array}$ & $\begin{array}{l}\vec{\infty} \\
\vec{d} \\
\vec{b}\end{array}$ & $\begin{array}{l}2 \\
0 \\
\dot{b} \\
0\end{array}$ & \begin{tabular}{l}
$\tilde{n}$ \\
$\tilde{J}$ \\
\multirow{0}{0}{}
\end{tabular} & 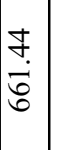 & $\mid \begin{array}{l}\vec{\infty} \\
\stackrel{0}{0} \\
\dot{0}\end{array}$ & $\begin{array}{l}\hat{q} \\
\dot{\vec{b}} \\
\stackrel{b}{0}\end{array}$ & 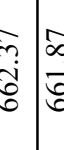 & $\begin{array}{lll}0 \\
\dot{0} \\
\dot{0}\end{array}$ & $\mid \begin{array}{l}8 \\
\text { i } \\
\mathbb{b}\end{array}$ & $\begin{array}{l}8 \\
\dot{0} \\
\dot{b} \\
\text { b }\end{array}$ & 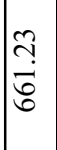 & 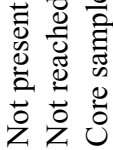 \\
\hline 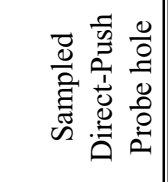 & 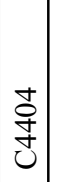 & 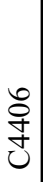 & $\left|\begin{array}{l}\infty \\
0 \\
⿱ \\
⿱ \\
J\end{array}\right|$ & $\begin{array}{l}\stackrel{\ominus}{J} \\
\underset{J}{J}\end{array}$ & 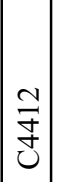 & \begin{tabular}{l} 
\pm \\
\multirow{J}{J}{} \\
\end{tabular} & $\begin{array}{l}0 \\
\vec{J} \\
\vec{J}\end{array}$ & $\begin{array}{l}\infty \\
\stackrel{J}{J}\end{array}$ & 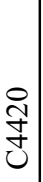 & $\begin{array}{l}\tilde{Z} \\
\tilde{J}\end{array}$ & 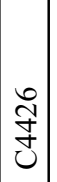 & 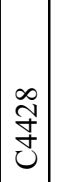 & 竎 & $\begin{array}{l}\tilde{N} \\
\tilde{J} \\
\mathcal{J}\end{array}$ & 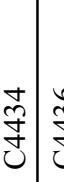 & 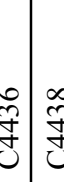 & $\begin{array}{l}0 \\
\substack{f \\
f} \\
\end{array}$ & 封 & \begin{tabular}{l}
$\infty$ \\
\multirow{J}{J}{} \\
$J$
\end{tabular} & 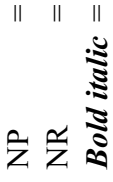 \\
\hline
\end{tabular}




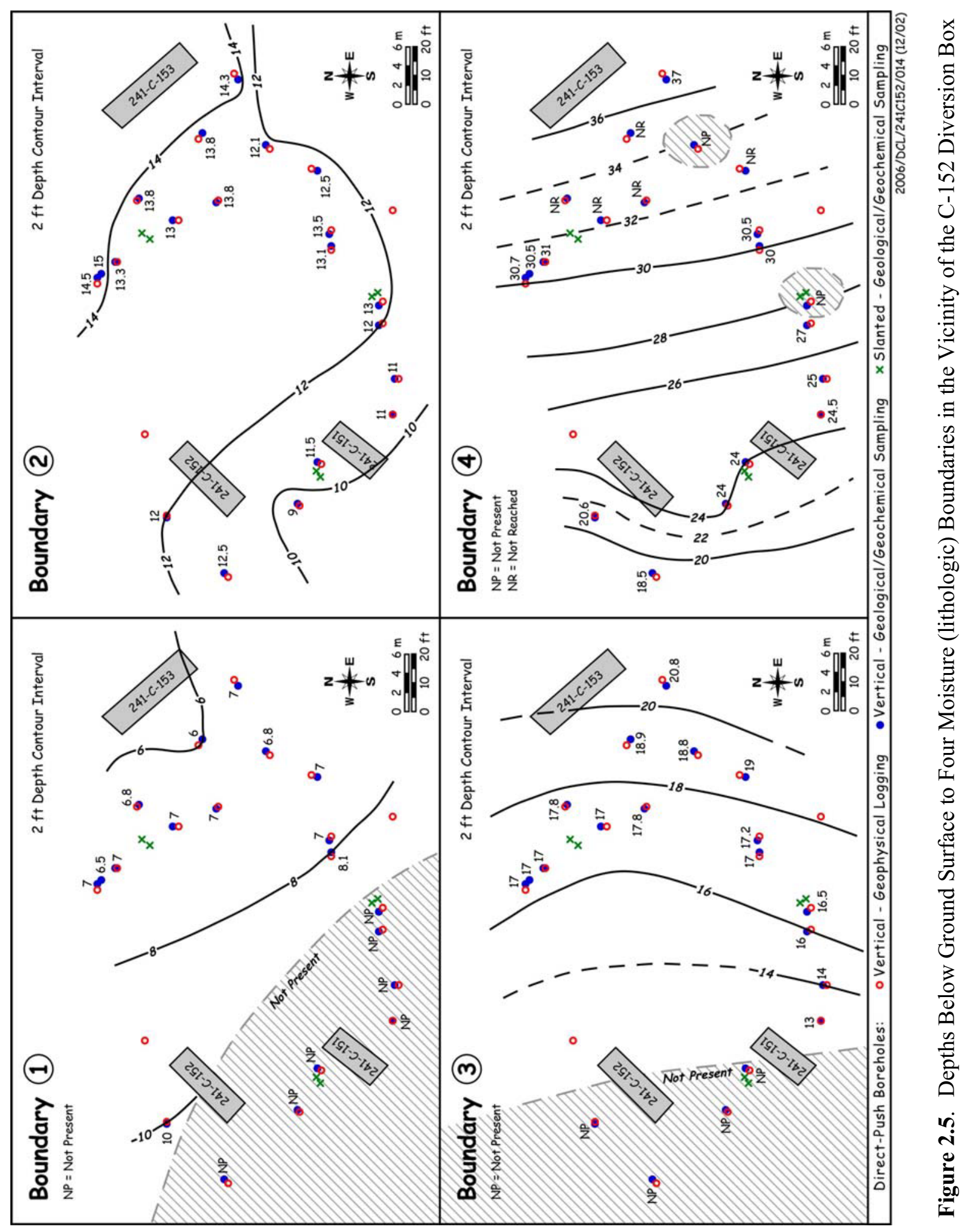




\subsection{Geochemical Methods and Materials}

This chapter discusses the methods and philosophy used to determine which 241-C-152 samples would be characterized, and the parameters that would be measured and analyzed for each sample in the laboratory. It also describes the materials and methods used to conduct analyses of the physical, geochemical, and radio-analytical properties of the sediments.

\subsection{Sample Inventory}

Samples were numbered using a project-specific prefix, in this case S05001 for the vertical probe hole samples, followed by a specific sample identification suffix, such as -1 (Table 3.1). Each directpush-sampling campaign resulted in up to two depth-discrete cores $(3.8 \mathrm{~cm}$ in diameter by approximately $23 \mathrm{~cm}$ long) and one grab sample consisting of the material captured in the drive shoe. The core samples from each direct-push hole were further identified by the letters A or B, where the A Liner was always in the deeper position closest to the drive shoe (i.e., the protective end attached to the bottom of the drive casing). All core samples can be delineated from the grab samples by the additional A or B nomenclature following the sample identification suffix, such as S05001-1A (Table 3.1). Three laboratory duplicate samples were collected during core opening; these are designated by the nomenclature -DUP. Finally, three samples were collected from different locations within a liner based on visually different facies; these are designated by a -1 or -2 , such as S05001-6A-1.

For the angled probe hole samples, a Hanford Environmental Information System (HEIS) sample ID was assigned to each sample at the time of collection; this nomenclature was carried throughout all testing of the sample material (Table 3.2). Each angled push-sampling campaign resulted in up to three sets of samples, with each sample set consisting of up to three depth-discrete cores $(3.8 \mathrm{~cm}$ in diameter by approximately $15 \mathrm{~cm}$ long) and one grab sample containing the material captured in the drive shoe. The core samples from each angled push hole were further identified by the letters A, B, or C, where the A Liner was always in the deeper position closest to the drive shoe (i.e., the protective end attached to the bottom of the drive casing). All core samples can be delineated from the grab samples by the additional $\mathrm{A}, \mathrm{B}$, or C nomenclature following the sample identification suffix, such as B1HY25A (Table 3.2).

\subsection{Approach}

During a past investigation at WMA SX, it was found that changes in sediment type and contaminant concentrations often occurred within a distance of a few inches within a given liner (Serne et al. 2002b). It was concluded that a more methodical scoping approach would be necessary to provide the technical justification for selecting samples for detailed characterization as defined in the data quality objectives process (DOE 1999). Subsequently, a method was developed to select samples that considered depth, geology (e.g., lithology, grain-size composition, and carbonate content, etc.), individual liner contaminant concentration (e.g., radionuclides, nitrate), moisture content, and overall sample quality. Extraction/ leaching procedures were performed and certain key parameters (i.e., moisture content, gamma energy analysis [GEA]) were measured on sediment from each liner. Grab samples were only utilized as part of this study if sufficient sample material for characterization and analysis was not contained in the core samples. 
Table 3.1. Sample Inventory from the C-152 Vertical Direct-Push Probe Holes

\begin{tabular}{|c|c|c|c|c|c|}
\hline $\begin{array}{l}\text { Sample } \\
\text { Number }\end{array}$ & $\begin{array}{l}\text { Probe Hole } \\
\text { Number }\end{array}$ & $\begin{array}{l}\text { Sample } \\
\text { Recovery } \\
(\%)\end{array}$ & $\begin{array}{l}\text { Sample } \\
\text { Number }\end{array}$ & $\begin{array}{l}\text { Probe Hole } \\
\text { Number }\end{array}$ & $\begin{array}{c}\text { Sample } \\
\text { Recovery } \\
(\%)\end{array}$ \\
\hline S05001-1A & C4406 & 77 & S05001-10 & C4416 & 100 \\
\hline S05001-1 & C4406 & 100 & S05001-11B & C4432 & 72 \\
\hline S05001-2B & C4408 & 100 & S05001-11A & C4432 & 80 \\
\hline S05001-2A & C4408 & 100 & S05001-12A & $\mathrm{C} 4440$ & 53 \\
\hline S05001-2 & C4408 & 100 & S05001-12 & C4440 & 80 \\
\hline S05001-3B & C4404 & 100 & S05001-13B & C4445 & 33 \\
\hline S05001-3A & C4404 & 100 & S05001-13A & $\mathrm{C} 4445$ & 100 \\
\hline S05001-3 & C4404 & 100 & S05001-13 & C4445 & 100 \\
\hline S05001-4B & $\mathrm{C} 4410$ & 100 & S05001-14B & C4438 & 100 \\
\hline S05001-4A & $\mathrm{C} 4410$ & 100 & S05001-14A & C4438 & 100 \\
\hline S05001-4 & C4410 & 100 & S05001-14 & C4438 & 67 \\
\hline S05001-5B & C4414 & 100 & S05001-15B & C4448 & 100 \\
\hline S05001-5A & $\mathrm{C} 4414$ & 100 & S05001-15A & C4448 & 100 \\
\hline S05001-5 & C4414 & 100 & S05001-15 & C4448 & 100 \\
\hline S05001-6B & $\mathrm{C} 4412$ & 100 & S05001-17B & C4436 & 100 \\
\hline S05001-6A & C4412 & 100 & S05001-17A & C4436 & 100 \\
\hline S05001-6 & $\mathrm{C} 4412$ & 100 & S05001-18B & C4434 & 100 \\
\hline S05001-7B & $\mathrm{C} 4422$ & 100 & S05001-18A & C4434 & 100 \\
\hline S05001-7A & $\mathrm{C} 4422$ & 100 & S05001-18 & C4434 & 100 \\
\hline S05001-7 & C4422 & 100 & S05001-19B & C4428 & 100 \\
\hline S05001-8B & $\mathrm{C} 4420$ & 100 & S05001-19A & C4428 & 100 \\
\hline S05001-8A & C4420 & 100 & S05001-19 & C4428 & 100 \\
\hline S05001-8 & C4420 & 100 & S05001-20B & $\mathrm{C} 4426$ & 24 \\
\hline S05001-9B & C4418 & 100 & S05001-20A & C4426 & 100 \\
\hline S05001-9A & C4418 & 100 & S05001-20 & C4426 & 100 \\
\hline S05001-9 & C4418 & 100 & S05001-21B & $\mathrm{C} 4430$ & 100 \\
\hline S05001-10B & C4416 & 100 & S05001-21A & $\mathrm{C} 4430$ & 100 \\
\hline S05001-10A & C4416 & 100 & S05001-21 & C4430 & 100 \\
\hline
\end{tabular}


Table 3.2. Sample Inventory from the C-152 Angled Direct-Push Probe Holes

\begin{tabular}{|c|c|c|c|c|c|}
\hline $\begin{array}{l}\text { Sample } \\
\text { Number }\end{array}$ & $\begin{array}{c}\text { Probe Hole } \\
\text { Number }\end{array}$ & $\begin{array}{l}\text { Sample } \\
\text { Recovery } \\
(\%)\end{array}$ & $\begin{array}{l}\text { Sample } \\
\text { Number }\end{array}$ & $\begin{array}{c}\text { Probe Hole } \\
\text { Number }\end{array}$ & $\begin{array}{c}\text { Sample } \\
\text { Recovery } \\
(\%)\end{array}$ \\
\hline B1HY25 & C5108 & 100 & B1HY32C & C5107 & 100 \\
\hline B1HY25A & C5108 & 100 & B1HY33 & C5107 & 100 \\
\hline B1HY25B & C5108 & 100 & B1HY33A & C5107 & 100 \\
\hline B1HY25C & C5108 & 100 & B1HY33B & C5107 & 100 \\
\hline B1HY26 & C5108 & 100 & B1HY33C & C5107 & 100 \\
\hline B1HY26A & C5108 & 100 & B1HY34 & C5107 & 20 \\
\hline B1HY26B & C5108 & 100 & B1HY34A & C5107 & 100 \\
\hline B1HY26C & C5108 & 100 & B1HY34B & C5107 & 100 \\
\hline B1HY27 & C5109 & 100 & B1HY34C & C5107 & 100 \\
\hline B1HY27A & C5109 & 100 & B1HY35 & C5104 & 100 \\
\hline B1HY27B & C5109 & 10 & B1HY35A & C5104 & 100 \\
\hline B1HY28B & C5109 & 100 & B1HY35B & C5104 & 100 \\
\hline B1HY28C & C5109 & 100 & B1HY35C & C5104 & 100 \\
\hline B1HY29 & C5109 & 100 & B1HY36 & C5104 & 100 \\
\hline B1HY29A & C5109 & 100 & B1HY36A & C5104 & 100 \\
\hline B1HY29B & C5109 & 100 & B1HY36B & C5104 & 100 \\
\hline B1HY29C & C5109 & 100 & B1HY36C & C5104 & 100 \\
\hline B1HY30 & C5106 & 100 & B1JFP2 & C5105 & 100 \\
\hline B1HY30A & C5106 & 100 & B1JFP2A & C5105 & 100 \\
\hline B1HY30B & C5106 & 100 & B1JFP2B & C5105 & 100 \\
\hline B1HY30C & C5106 & 100 & B1JFP3 & C5105 & 100 \\
\hline B1HY31 & C5106 & 100 & B1JFP3A & C5105 & 100 \\
\hline B1HY31A & C5106 & 100 & B1JFP3B & C5105 & 100 \\
\hline B1HY31B & C5106 & 100 & B1JFP3C & C5105 & 100 \\
\hline B1HY31C & C5106 & 100 & B1JFP4 & C5105 & 100 \\
\hline B1HY32 & C5107 & 100 & B1JFP4A & C5105 & 100 \\
\hline B1HY32A & C5107 & 100 & B1JFP4B & C5105 & 100 \\
\hline B1HY32B & C5107 & 100 & B1JFP4C & C5105 & 100 \\
\hline
\end{tabular}


During the geologic examination of the core samples, the liner contents were sub-sampled for moisture content, gamma-emission radiocounting, 1:1 water extractions (which provide soil $\mathrm{pH}$, electrical conductivity [EC], and cation and anion data), total carbon and inorganic carbon content, and 8-M nitric acid extractions (which provide a measure of the total leachable sediment content of contaminants). Sampling preference was always biased towards the finer-grained and/or wetter material contained in each liner. The remaining sediment from each liner was then sealed and placed in cold storage.

\subsection{Materials and Methods}

During sub-sampling of each core liner, every effort was made to minimize moisture loss and prevent cross contamination between samples. Depending on the sample matrix, very coarse pebbles and larger material (i.e., $>32 \mathrm{~mm}$ ) were avoided during sub-sampling. Larger substrate was excluded to provide moisture contents representative of GEA and 1:1 sediment:water-extraction samples. Therefore, the results from the sub-sample measurements may contain a possible bias toward higher concentrations for some analytes that would be preferentially associated with the smaller sized sediment fractions.

Procedures ASTM D2488-93 (1993) and PNL-MA-567-DO-1 (PNNL 1990) were followed for visual descriptions and geological descriptions of all direct-push samples. The sediment classification scheme used for geologic identification of the sediment types (used solely for graphing purposes in this report) was based on the modified Folk/Wentworth classification scheme (1968/1922).

\subsubsection{Moisture Content}

Gravimetric water contents of the sediment samples from each liner and shoe grab sample were determined using PNNL procedure PNNL-AGG-WC-001 (PNNL 2005). This procedure is based on the American Society for Testing and Materials procedure "Test Method for Laboratory Determination of Water (Moisture) Content of Soil and Rock by Mass" (ASTM D2216-98 [ASTM 1998]). One representative sub-sample of at least 15 to $70 \mathrm{~g}$ was used. Sediment aliquots were placed in tared containers, weighed, and dried in an oven at $105^{\circ} \mathrm{C}$ until constant weight was achieved, which took at least 24 hours. The containers were removed from the oven, sealed, cooled, and weighed. At least two weighings, each after a 24-hour heating period, were performed to ensure that all moisture was removed. All weighings were performed using a calibrated balance. A calibrated weight set was used to verify balance performance before weighing samples. The gravimetric water content was computed as the percentage change in soil weight before and after oven drying.

\subsubsection{1:1 Sediment:Water Extractions}

The water-soluble inorganic constituents were determined using a 1:1 sediment:deionized-waterextraction method. This method was chosen because the sediment was too dry to easily extract vadose zone pore water. The extractions were prepared by adding an exact weight of deionized water to approximately 60 to $80 \mathrm{~g}$ of sediment sub-sampled from each liner or drive shoe grab sample. The weight of deionized water needed was calculated based on the weight of the field-moist samples and their previously determined moisture contents. The sum of the existing moisture (pore water) and the deionized water was fixed at the mass of the dry sediment. An appropriate amount of deionized water was added to screw cap jars containing the sediment samples. The jars were sealed and briefly shaken by hand, then placed on a mechanical orbital shaker for one hour. The samples were allowed to settle, generally 
overnight, until the supernatant liquid was fairly clear. The supernatant was carefully decanted and separated into unfiltered aliquots for conductivity and $\mathrm{pH}$ determinations, and filtered aliquots (passed through $0.45-\mu \mathrm{m}$ membranes) for anion, cation, alkalinity, and radionuclide analyses. More details can be found in Rhoades (1996) and within Methods of Soils Analysis - Part 3 (ASA 1996).

\subsubsection{1 pH and Conductivity}

Two approximately 3-mL aliquots of the unfiltered 1:1 sediment:water-extraction supernatants were used for $\mathrm{pH}$ and conductivity measurements. The $\mathrm{pH}$ of the extractions was measured with a solid-state $\mathrm{pH}$ electrode and a $\mathrm{pH}$ meter calibrated with buffers 4, 7, and 10. EC was measured and compared to potassium chloride standards with a range of $0.001 \mathrm{M}$ to $1.0 \mathrm{M}$.

\subsubsection{Anions}

The 1:1 sediment:water extractions were analyzed for anions using ion chromatography (IC). Fluoride, chloride, nitrite, bromide, nitrate, carbonate, phosphate, and sulfate were separated on a Dionex AS17 column with a gradient elution of $1 \mathrm{mM}$ to $35 \mathrm{mM}$ sodium hydroxide and measured using a conductivity detector. This methodology is based on U.S. Environmental Protection Agency (EPA) Method 300.0A (EPA 1984) with the exception of using the gradient elution of sodium hydroxide. Water-extraction chromatograms were visually scanned to ensure there were no unidentified peaks caused by other constituents.

\subsubsection{Cations and Trace Metals}

Major cation analysis was performed using an inductively coupled plasma-optical emission spectroscopy (ICP-OES) unit using high-purity calibration standards to generate calibration curves and verify continuing calibration during the analysis run. Dilutions of 100x, 50x, 10x, and 5x were made of each 1:1 water extraction for analysis to investigate and correct for matrix interferences. Details of this method are found in EPA Method 6010B (EPA 2000b). The second instrument used to analyze trace metals, including technetium-99 and uranium-238, was an inductively coupled plasma-mass spectrometer (ICP-MS) using the PNNL-AGG-415 method (PNNL 1998). This method is quite similar to EPA Method 6020 (EPA 2000c).

\subsubsection{Alkalinity}

The alkalinity and inorganic/organic carbon content of several of the 1:1 sediment:water extractions were measured using standard titration with acid and a carbon analyzer, respectively. The alkalinity procedure is equivalent to the U.S. Geological Survey (USGS) National Field Manual (USGS 2001) method.

\subsubsection{8-M Nitric Acid Extraction}

Approximately $20 \mathrm{~g}$ of oven-dried sediment was contacted with 8-M nitric acid at a ratio of approximately five parts acid to one part sediment. The slurries were heated to about $80^{\circ} \mathrm{C}$ for several hours, then the fluid was separated by filtration through $0.2 \mu \mathrm{m}$ membranes. The acid extractions were analyzed for major cations and trace metals using ICP-OES and ICP-MS techniques, respectively. The acid digestion procedure is based on EPA SW-846 Method 3050B (EPA 2000a). 
GEA was performed on sediment from the C-152 direct-push liners. All samples for GEA were analyzed using $60 \%$ efficient intrinsic germanium gamma detectors. All germanium counters were efficiency calibrated for distinct geometries using mixed gamma standards traceable to the National Institute of Standards and Technology (NIST). Field-moist samples were placed in $150-\mathrm{cm}^{3}$ counting containers and analyzed for 100 minutes in a fixed geometry. All spectra were background-subtracted. Spectral analysis was conducted using libraries containing most mixed fission products, activation products, and natural decay products. Control samples were run throughout the analysis to ensure correct operation of the detectors. The controls contained isotopes with photo peaks spanning the full detector range and were monitored for peak position, counting rate, and full-width half-maximum. Details are found in Gamma Energy Analysis, Operation, and Instrument Verification using Genie2000 ${ }^{\mathrm{TM}}$ Support Software (PNNL 1997).

\subsubsection{Carbon Content of Sediment}

The total carbon concentration in aliquots of sediment from the core liners was measured with a Shimadzu TOC-V CSN instrument with a SSM-5000A Total Organic Carbon Analyzer by combustion at approximately $900^{\circ} \mathrm{C}$ based on ASTM Method, Standard Test Methods for Analysis of Metal Bearing Ores and Related Materials by Combustion Infrared Absorption Spectrometry (ASTM E1915-01, 2001). Samples were placed into pre-combusted, tared, ceramic combustion sample holders and weighed on a calibrated balance. After the combustion sample holders were placed into the furnace introduction tube, an approximately 2-minute waiting period was allowed for the ultra-pure oxygen carrier gas to remove any carbon dioxide $\left(\mathrm{CO}_{2}\right)$ introduced to the system from the atmosphere during sample placement. After this sparging process, the sample was moved into the combustion furnace and the combustion was begun. The carrier gas then delivered the sample combustion products to the cell of a non-dispersive infrared (NDIR) gas analyzer where the $\mathrm{CO}_{2}$ was detected and measured. The amount of $\mathrm{CO}_{2}$ measured is proportional to the total carbon content of the sample. Adequate system performance was confirmed by analyzing known quantities of a calcium carbonate standard.

Sediment/solid samples were analyzed for inorganic carbon content by placing a sediment aliquot into a ceramic combustion boat. The combustion boat was placed into the sample introduction tube where it was sparged with ultra-pure oxygen for two minutes to remove atmospheric $\mathrm{CO}_{2}$. A small amount (usually $0.6 \mathrm{~mL}$ ) of $3 \mathrm{M}$ phosphoric acid was then added to the sample in the combustion boat. The boat was moved into the combustion furnace where it was heated to $200^{\circ} \mathrm{C}$. Samples were completely covered by the acid to allow full reaction to occur. Ultra-pure oxygen swept the resulting $\mathrm{CO}_{2}$ through a dehumidifier and scrubber into the cell of a NDIR gas analyzer where the $\mathrm{CO}_{2}$ was detected and measured. The amount of $\mathrm{CO}_{2}$ measured is proportional to the inorganic carbon content of the sample.

Organic carbon content was determined by the difference between the inorganic carbon and total carbon concentration.

\subsubsection{Ammonium Acetate Extractions}

The exchangeable fraction of technetium-99 present in the sediments was determined using a 1-M ammonium acetate extraction. The extractions were prepared by adding approximately $15 \mathrm{~g}$ of sediment to centrifuge tubes containing approximately $35 \mathrm{~mL}$ of $1 \mathrm{M}$ ammonium acetate. The samples were shaken overnight on a mechanical orbital shaker. The effect of time on the release of technetium-99 from the sediment was investigated by sampling several of the centrifuge tubes at time points of 2,6 , and 
24 hours. The remaining centrifuge tubes were only sampled one time (at 24 hours). For each sampling, the tubes were placed in a centrifuge and spun at approximately 2,200 $g$ for 10 minutes. Upon removal from the centrifuge, supernatant was withdrawn using calibrated pipettes and filtered using $0.45-\mu \mathrm{m}$ membranes attached to syringes. Two $\mathrm{mL}$ of sample were removed at the two- and six-hour sampling times, and $10 \mathrm{~mL}$ were collected at the 24 -hour time point. The filtered samples were analyzed for major cations using ICP-OES and for technetium-99 using ICP-MS.

\subsubsection{Magnetic Sample Separation and Digestion}

Aliquots of several of the direct-push sediments were subjected to magnetic separation. Iron-rich material in the samples was separated using a magnet covered with a Kimwipes ${ }^{\circledR}$ wiper (the wiper was changed after each sample to prevent cross-contamination). Once separated, aliquots of the iron-rich materials were digested using microwave-assisted digestion. Using this technique, approximately $300 \mathrm{mg}$ of the magnetic sediment from selected samples was placed in a $100-\mathrm{mL}$ Teflon microwave-digestion vessel. Following this, $10 \mathrm{~mL}$ water, $5 \mathrm{~mL}$ of a 16-M nitric acid $\left(\mathrm{HNO}_{3}\right)$ solution, $2 \mathrm{~mL}$ of a 12-M hydrochloric acid ( $\mathrm{HCl}$ ) solution, and $1 \mathrm{~mL}$ of a 29-M hydrofluoric acid (HF) solution were added, and the vessel was sealed and placed in a MARS5 ${ }^{\mathrm{TM}}$ microwave-assisted digestion system (CEM Corporation, Matthews, NC). The samples were heated at the EPA-recommended temperatures and times. The samples were then allowed to cool, and $0.45 \mathrm{~g}$ of powdered boric acid was added to the digestate and shaken by hand. Boric acid reacts with residual HF in the digestate to form a boron complex, preventing the residual HF from etching the sample introduction glassware in the ICP-MS instrument. Although there were no visible solids in the digestate, samples were filtered through a 0.45 - $\mu \mathrm{m}$-pore-size syringe filter prior to analysis. After filtration, the samples were analyzed for major cations via ICP-OES and technetium-99 using ICP-MS.

An aliquot of each filtered sample was further processed using TEVA® resin (Eichrom, Darien, IL) and reanalyzed for technetium-99 via ICP-MS. This additional step was performed to ensure that any analytical effects resulting from the microwave-digested sample matrix could be removed prior to analysis of the samples. The samples were prepared for processing by diluting $5 \mathrm{~mL}$ of the filtered, microwave-digested sample into $195 \mathrm{~mL}$ of deionized water. All $200 \mathrm{~mL}$ of this solution was added to a column containing $2 \mathrm{~mL}$ of TEVA resin that had been previously cleaned/conditioned using $5 \mathrm{~mL}$ of a $0.1-\mathrm{M} \mathrm{HNO}_{3}$ solution. After addition of the samples, the columns were cleaned by flowing $20 \mathrm{~mL}$ of a $1-\mathrm{M} \mathrm{HNO}_{3}$ solution through each column. The technetium-99 trapped in the columns was eluted using $10 \mathrm{~mL}$ of a $12-\mathrm{M} \mathrm{HNO}_{3}$ solution. The eluted solution containing the technetium-99 was collected in a $20-\mathrm{mL}$ glass liquid scintillation vial and evaporated to dryness under a heat lamp. Once the solution was completely evaporated, $5 \mathrm{~mL}$ of a $2 \% \mathrm{HNO}_{3}$ solution was added to the vials, and the samples were analyzed for technetium-99 via ICP-MS. Recoveries for technetium-99 through this process were evaluated using blank spikes, which consisted of a 4-M $\mathrm{HNO}_{3}$ solution containing $0.3 \mu \mathrm{g} / \mathrm{L}$ technetium-99. Duplicate blank spike samples were processed in the same manner as the digested direct-push samples. Ordinarily, a matrix spike sample would be processed with each data set; however, sufficient sample volume was not available to facilitate this for the microwave digested direct-push samples. 


\subsection{Results and Discussion}

This section presents the geochemical and physical characterization data collected on sediment from the direct-push holes emplaced within WMA C to investigate the extent of contamination associated with the C-152 pipeline leak (UPR-200-E-82). Section 4.1 contains data from the vertical push campaign and Section 4.2 contains data from the slant push campaign.

These characterization activities emphasized tests that provided basic characterization data and were key to determining the distribution of mobile contaminants in the vadose zone sediments. Such information on the direct-push sediments included moisture content and total and inorganic carbon content. Sediment $\mathrm{pH}, \mathrm{EC}$, and major anions were measured via the 1:1 sediment:water extractions. Additionally, measurements of major cations and trace metals (including technetium-99 and uranium-238) were performed on the 1:1 sediment:water and 8-M nitric acid extractions. A GEA of the sediments was also performed to search for any detectable man-made gamma-emitting radionuclides.

\subsection{Vadose Zone Sediment from the Vertical Direct-Push Samples}

\subsubsection{Moisture Content}

The moisture contents of the 42 core liners and three grab samples are shown in Table 4.1. The intent of the vertical sampling effort around the C-152 pipeline leak was to collect vadose zone sediment from zones containing elevated moisture. When practical, the sampling effort attempted to intercept the contact associated with the regions of elevated moisture. The A and B liners from several of the core samples (14 of the 20 sets) contained zones of sediment with appreciably larger moisture contents (greater than a $50 \%$ difference from sediments with low moisture contents), indicating that the contact layer responsible for the zone of increased moisture was captured within the 1.5 - $\mathrm{ft}$ sampling interval. Due to difficulties encountered when extruding sediment from the core liner, the precise location of the contact within each set of cores was not typically determined. Because the friction generated between the sample and the wall of the liner was too great to be overcome by the extruder apparatus, most of the cores required part to most of the sample material to be "dug out" of the liner. Photographs of the sediment removed from each liner are included in Appendix A of this report. The average gravimetric moisture content of all of the vertical push samples measured was 9.2 weight percent (wt $\%$ ), which was considerably higher than the average moisture content in interspersed core samples collected within the Hanford formation $\mathrm{H} 2$ unit (3.1\%) at the nearby C Tank Farm characterization borehole (C4297, near Tank $\mathrm{C}$-105). Therefore, it appears that the $\mathrm{C}-152$ direct-push samples may contain residual moisture from the C-152 pipeline leak; or, alternatively, the samples were moist because of their fine-grained nature, or because there were capillary breaks between two sediment types with large differences in grain size, or because there is residual moisture caused by enhanced infiltration resulting from the gravel placed over the C-152 leak site soon after the leak. 
Table 4.1. Gravimetric Moisture Content of Samples Obtained from the C-152 Vertical Direct-Push Probe Holes

\begin{tabular}{|c|c|c|c|}
\hline $\begin{array}{l}\text { Sample } \\
\text { Number }\end{array}$ & $\begin{array}{c}\text { Probe Hole } \\
\text { Number }\end{array}$ & $\begin{array}{l}\text { Mid-Depth } \\
\text { (ft bgs) }\end{array}$ & $\begin{array}{c}\text { Moisture } \\
\text { Content (\%) }\end{array}$ \\
\hline S05001-1A & $\mathrm{C} 4406$ & 12.29 & 10.7 \\
\hline S05001-1 & C4406 & 12.83 & 3.29 \\
\hline S05001-2B & $\mathrm{C} 4408$ & 9.88 & 10.4 \\
\hline S05001-2A & $\mathrm{C} 4408$ & 10.63 & 10.4 \\
\hline S05001-3B & $\mathrm{C} 4404$ & 20.38 & 2.68 \\
\hline S05001-3A & $\mathrm{C} 4404$ & 21.13 & 4.59 \\
\hline S05001-4B & $\mathrm{C} 4410$ & 21.80 & 4.30 \\
\hline S05001-4A & $\mathrm{C} 4410$ & 23.38 & 9.27 \\
\hline S05001-5B & C4414 & 24.13 & 5.77 \\
\hline S05001-5A & $\mathrm{C} 4414$ & 24.80 & 9.54 \\
\hline S05001-6B & $\mathrm{C} 4412$ & 13.88 & 2.71 \\
\hline S05001-6A-1 & $\mathrm{C} 4412$ & 14.63 & 11.9 \\
\hline S05001-6A-2 & $\mathrm{C} 4412$ & 14.63 & 2.81 \\
\hline S05001-7B & $\mathrm{C} 4422$ & 11.88 & 12.1 \\
\hline S05001-7A & $\mathrm{C} 4422$ & 12.63 & 7.52 \\
\hline S05001-8B & $\mathrm{C} 4420$ & 13.30 & 12.2 \\
\hline S05001-8A & $\mathrm{C} 4420$ & 16.88 & 9.29 \\
\hline S05001-9B & $\mathrm{C} 4418$ & 17.63 & 12.6 \\
\hline S05001-9A & C4418 & 18.30 & 7.47 \\
\hline S05001-10B & $\mathrm{C} 4416$ & 11.88 & 4.06 \\
\hline S05001-10A & $\mathrm{C} 4416$ & 12.63 & 18.3 \\
\hline S05001-11B & $\mathrm{C} 4432$ & 20.77 & 13.5 \\
\hline S05001-11A & $\mathrm{C} 4432$ & 21.34 & 9.54 \\
\hline S05001-12A & $\mathrm{C} 4440$ & 6.70 & 6.82 \\
\hline S05001-12 & $\mathrm{C} 4440$ & 7.10 & 22.0 \\
\hline S05001-13B & $\mathrm{C} 4445$ & 6.63 & 5.65 \\
\hline S05001-13A-1 & $\mathrm{C} 4445$ & 7.13 & 7.87 \\
\hline S05001-13A-2 & $\mathrm{C} 4445$ & 7.13 & 22.1 \\
\hline S05001-14B & $\mathrm{C} 4438$ & 13.88 & 11.7 \\
\hline S05001-14A & $\mathrm{C} 4438$ & 14.63 & 9.81 \\
\hline S05001-14A Dup & $\mathrm{C} 4438$ & 14.63 & 8.89 \\
\hline S05001-15B & C4448 & 17.38 & 3.00 \\
\hline S05001-15A & C4448 & 18.13 & 8.08 \\
\hline S05001-17B & C4436 & 16.38 & 2.44 \\
\hline S05001-17A & $\mathrm{C} 4436$ & 17.13 & 9.04 \\
\hline S05001-18B & $\mathrm{C} 4434$ & 13.88 & 8.47 \\
\hline
\end{tabular}


Table 4.1. (contd)

\begin{tabular}{||l|c|c|c||}
\hline $\begin{array}{c}\text { Sample } \\
\text { Number }\end{array}$ & $\begin{array}{c}\text { Probe Hole } \\
\text { Number }\end{array}$ & $\begin{array}{c}\text { Mid-Depth } \\
\text { (ft bgs) }\end{array}$ & $\begin{array}{c}\text { Moisture } \\
\text { Content (\%) }\end{array}$ \\
\hline \hline S05001-18A & C4434 & 14.63 & 4.73 \\
\hline S05001-19B & C4428 & 15.30 & 2.71 \\
\hline S05001-19A & C4428 & 18.38 & 17.0 \\
\hline S05001-19A Dup & C4428 & 18.38 & 16.7 \\
\hline S05001-20A & C4426 & 6.06 & 8.45 \\
\hline S05001-20 & C4426 & 6.73 & $17.9 \%$ \\
\hline S05001-21B-1 & C4430 & 6.73 & 10.8 \\
\hline S05001-21B-2 & C4430 & 18.88 & 8.11 \\
\hline S05001-21A & C4430 & 18.88 & 6.53 \\
\hline Shaded cells indicate grab samples. \\
\hline
\end{tabular}

\subsubsection{1:1 Sediment:Water Extractions}

A subset of samples from the C-152 cores was characterized by performing 1:1 sediment:water extractions. The following tables present the mass of a given constituent leached per gram of sediment as measured in the water extractions. Other tables show dilution-corrected estimated values that represent concentrations in the vadose zone pore water within the sediment. As discussed in several other Vadose Zone Characterization Project reports, the dilution-corrected 1:1 sediment:water extractions are a reasonable estimate of the actual vadose zone pore water (see Serne et al. 2002a, 2002b, 2002c, 2002e, 2002f).

\subsubsection{1 pH and EC}

The 1:1 sediment:water extraction $\mathrm{pH}$ and $\mathrm{EC}$ data for the $\mathrm{C}-152$ core and grab samples are shown in Table 4.2. The $\mathrm{pH}$ is tabulated as measured in the 1:1 sediment:water extractions, but the EC is corrected for dilution and tabulated as if it was actual pore water. Many of the vertical push samples tested had $\mathrm{pH}$ values in the normal range for Hanford sediments (between 7.5 and 8.0). However, five of the samples (S05001-2A, S05001-4A, S05001-15A, S05001-17A, and S05001-18A) had elevated pH values ranging from 8.68 to 9.99 , and thirteen additional samples had slightly elevated $\mathrm{pH}(8.0-8.5)$. The elevated $\mathrm{pH}$ data indicates the presence of caustic-tank-related waste and can potentially be used to constrain the zone of impact from the C-152 pipeline leak. Previous borehole reports have shown that regions of elevated soil $\mathrm{pH}$ are considered to be good indicators of the location of the original leak event or very near-field to the initial tank waste entry zone (see Serne et al. 2002a, 2002b, 2002c, 2002e, 2002f). The elevated pH sediment samples were collected northeast and southwest of the $\mathrm{C}-152$ pipeline leak.

The pore-water-corrected EC data for all of the samples were dilute, with a range of 1.03 to $6.71 \mathrm{mS} / \mathrm{cm}$. There was no direct correlation between elevated $\mathrm{pH}$ and $\mathrm{EC}$ for the elevated $\mathrm{pH}$ samples collected as part of this sampling campaign. The average pore-water-corrected EC in all 45 samples analyzed as part of this study was $2.87 \mathrm{mS} / \mathrm{cm}$, which was significantly lower than the average calculated pore-water EC $(9.08 \mathrm{mS} / \mathrm{cm})$ in samples from the uncontaminated borehole emplaced north of WMA C 
Table 4.2. $\mathrm{pH}$ for 1:1 Sediment:Water Extractions and Dilution-Corrected EC Values from C-152 Vertical Core and Grab Samples

\begin{tabular}{||l|c|c|c|c||}
\hline $\begin{array}{c}\text { Sample } \\
\text { Number }\end{array}$ & $\begin{array}{c}\text { Probe Hole } \\
\text { Number }\end{array}$ & $\begin{array}{c}\text { Mid-Depth } \\
\text { (ft bgs) }\end{array}$ & $\mathrm{pH}$ & $\begin{array}{c}\text { Conductivity } \\
\text { (mS/cm) }\end{array}$ \\
\hline \hline S05001-1A & C4406 & 12.29 & 7.72 & 1.89 \\
\hline S05001-1 & C4406 & 12.83 & 7.84 & 3.74 \\
\hline S05001-2B & C4408 & 9.88 & $\mathbf{8 . 1 7}$ & 2.54 \\
\hline S05001-2A & C4408 & 10.63 & $\mathbf{8 . 8 5}$ & 6.09 \\
\hline S05001-3B & C4404 & 20.38 & 7.69 & 4.51 \\
\hline S05001-3A & $\mathrm{C} 4404$ & 21.13 & 7.64 & 2.90 \\
\hline S05001-4B & $\mathrm{C} 4410$ & 21.80 & 7.90 & 4.72 \\
\hline S05001-4A & $\mathrm{C} 4410$ & 23.38 & $\mathbf{8 . 6 8}$ & 6.71 \\
\hline S05001-5B & $\mathrm{C} 4414$ & 24.13 & 7.84 & 3.16 \\
\hline S05001-5A & $\mathrm{C} 4414$ & 24.80 & 7.87 & 1.90 \\
\hline S05001-6B & $\mathrm{C} 4412$ & 13.88 & 7.57 & 3.96 \\
\hline S05001-6A-1 & $\mathrm{C} 4412$ & 14.63 & 7.60 & 1.12 \\
\hline S05001-6A-2 & $\mathrm{C} 4412$ & 14.63 & 7.64 & 4.36 \\
\hline S05001-7B & $\mathrm{C} 4422$ & 11.88 & 7.90 & 1.62 \\
\hline S05001-7A & $\mathrm{C} 4422$ & 12.63 & 7.85 & 2.26 \\
\hline S05001-8B & $\mathrm{C} 4420$ & 13.30 & 7.89 & 1.68 \\
\hline S05001-8A & $\mathrm{C} 4420$ & 16.88 & 7.89 & 2.03 \\
\hline S05001-9B & $\mathrm{C} 4418$ & 17.63 & $\mathbf{8 . 0 7}$ & 1.66 \\
\hline S05001-9A & $\mathrm{C} 4418$ & 18.30 & $\mathbf{8 . 0 4}$ & 2.70 \\
\hline S05001-10B & $\mathrm{C} 4416$ & 11.88 & $\mathbf{8 . 0 8}$ & 3.97 \\
\hline S05001-10A & $\mathrm{C} 4416$ & 12.63 & $\mathbf{8 . 0 8}$ & 1.37 \\
\hline S05001-11B & $\mathrm{C} 4432$ & 20.77 & $\mathbf{8 . 0 7}$ & 1.54 \\
\hline S05001-11A & $\mathrm{C} 4432$ & 21.34 & 7.80 & 2.69 \\
\hline S05001-12A & $\mathrm{C} 4440$ & 6.70 & 7.89 & 2.60 \\
\hline S05001-12 & $\mathrm{C} 4440$ & 7.10 & 7.95 & 1.16 \\
\hline S05001-13B & $\mathrm{C} 4445$ & 6.63 & 7.51 & 2.62 \\
\hline S05001-13A-1 & $\mathrm{C} 4445$ & 7.13 & 7.64 & 1.98 \\
\hline S05001-13A-2 & $\mathrm{C} 4445$ & 7.13 & 7.94 & 1.03 \\
\hline S05001-14B & $\mathrm{C} 4438$ & 13.88 & 7.95 & 1.61 \\
\hline S05001-14A & $\mathrm{C} 4438$ & 14.63 & $\mathbf{8 . 0 5}$ & 2.00 \\
\hline S05001-14A Dup & $\mathrm{C} 4438$ & 14.63 & $\mathbf{8 . 3 3}$ & 3.43 \\
\hline S05001-15B & $\mathrm{C} 4448$ & 17.38 & 7.81 & 3.93 \\
\hline S05001-15A & $\mathrm{C} 4448$ & 18.13 & $\mathbf{9 . 0 4}$ & 2.56 \\
\hline
\end{tabular}


Table 4.2. (contd)

\begin{tabular}{||l|c|c|c|c||}
\hline $\begin{array}{c}\text { Sample } \\
\text { Number }\end{array}$ & $\begin{array}{c}\text { Probe Hole } \\
\text { Number }\end{array}$ & $\begin{array}{c}\text { Mid-Depth } \\
(\mathrm{ft} \text { bgs })\end{array}$ & $\mathrm{pH}$ & $\begin{array}{c}\text { Conductivity } \\
(\mathrm{mS} / \mathrm{cm})\end{array}$ \\
\hline \hline S05001-17B & C4436 & 16.38 & 7.99 & 5.42 \\
\hline S05001-17A & C4436 & 17.13 & $\mathbf{9 . 9 9}$ & 4.12 \\
\hline S05001-18B & C4434 & 13.88 & 7.97 & 1.96 \\
\hline S05001-18A & C4434 & 14.63 & $\mathbf{9 . 9 9}$ & 4.48 \\
\hline S05001-19B & C4428 & 15.30 & $\mathbf{8 . 1 4}$ & 4.39 \\
\hline S05001-19A & C4428 & 18.38 & $\mathbf{8 . 4 8}$ & 2.34 \\
\hline S05001-19A Dup & C4428 & 18.38 & $\mathbf{8 . 4 1}$ & 2.36 \\
\hline S05001-20A & C4426 & 6.06 & 7.89 & 4.38 \\
\hline S05001-20 & C4426 & 6.73 & 7.97 & 1.60 \\
\hline S05001-21B-1 & C4430 & 18.88 & $\mathbf{8 . 0 3}$ & 1.81 \\
\hline S05001-21B-2 & C4430 & 18.88 & 7.94 & 2.00 \\
\hline S05001-21A & C4430 & 19.63 & $\mathbf{8 . 0 8}$ & 2.33 \\
\hline $\begin{array}{l}\text { Shaded cells indicate grab samples. } \\
\text { Bold values denote elevated concentrations. } \\
\text { EC values are dilution-corrected and represent pore-water concentrations. }\end{array}$ \\
\hline
\end{tabular}

(299-E27-22) as part of the C4297 characterization effort. However, the sediment samples collected from the 299-E27-22 borehole contained elevated nitrate and were not truly indicative of uncontaminated conditions. Therefore, samples from a study completed near WMA A-AX are being included for reference. Two boreholes emplaced during the construction of groundwater monitoring wells at WMA A-AX, C4665, and C4257 contained average pore-water-corrected conductivities of 1.86 and $2.53 \mathrm{mS} / \mathrm{cm}$, respectively (Brown et al. 2005). Therefore, the pore water in the vertical sediment samples collected around the $\mathrm{C}-152$ pipeline leak appeared to be as dilute with respect to the dissolved salts content as samples collected from uncontaminated boreholes near the A-AX Tank Farm.

\subsubsection{Water Extraction Composition of the 1:1 Sediment:Water Extractions from the Vertical C-152 Core and Grab Samples}

The water-extraction values for the major anions, cations, and several trace constituents are discussed in this section. The anion data are tabulated in Table 4.3 in units of mass per gram of dry sediment. Five of the 1:1 sediment:water extractions contained elevated concentrations of fluoride $(>1.1 \mu \mathrm{g} / \mathrm{g})$ compared to the mean fluoride concentration of all the $1: 1$ sediment:water extractions: $0.60 \mu \mathrm{g} / \mathrm{g}$. These sediment samples came from probe holes C4418, C4422, C4426, and C4434, which were all located at the southern and southeastern end of the $\mathrm{C}-152$ pipeline leak.

Three of the 1:1 sediment:water extractions contained elevated chloride ( $>2 \mu \mathrm{g} / \mathrm{g})$ compared to the mean chloride concentration of all the 1:1 sediment:water extractions: $0.92 \mu \mathrm{g} / \mathrm{g}$. The three sediment samples containing elevated concentrations of chloride were collected from probe holes $\mathrm{C} 4416$ and C4432, which were emplaced at the southern and eastern boundaries of the C-152 sampling campaign, 
Table 4.3. Water-Extractable Anions in the C-152 Vertical Core and Grab Samples ( $\mu \mathrm{g} / \mathrm{g}$ dry sediment)

\begin{tabular}{|c|c|c|c|c|c|c|c|}
\hline $\begin{array}{l}\text { Sample } \\
\text { Number }\end{array}$ & $\begin{array}{l}\text { Probe } \\
\text { Hole } \\
\text { Number }\end{array}$ & $\begin{array}{c}\text { Mid- } \\
\text { Depth } \\
\text { (ft bgs) }\end{array}$ & Fluoride & Chloride & Nitrate & Sulfate & Phosphate \\
\hline S05001-1A & $\mathrm{C} 4406$ & 12.29 & $6.69 \mathrm{E}-01$ & $1.39 \mathrm{E}+00$ & $1.42 \mathrm{E}+01$ & $1.13 \mathrm{E}+01$ & ND \\
\hline S05001-1 & $\mathrm{C} 4406$ & 12.83 & $4.16 \mathrm{E}-01$ & $6.31 \mathrm{E}-01$ & $2.37 \mathrm{E}+00$ & $6.56 \mathrm{E}+00$ & ND \\
\hline S05001-2B & $\mathrm{C} 4408$ & 9.88 & 9.94E-01 & $6.92 \mathrm{E}-01$ & $1.04 \mathrm{E}+01$ & $1.47 \mathrm{E}+01$ & $9.40 \mathrm{E}-01$ \\
\hline S05001-2A & C4408 & 10.63 & $8.96 \mathrm{E}-01$ & $8.66 \mathrm{E}-01$ & $1.38 \mathrm{E}+01$ & $1.24 \mathrm{E}+01$ & $1.32 \mathrm{E}+01$ \\
\hline S05001-3B & $\mathrm{C} 4404$ & 20.38 & $3.60 \mathrm{E}-01$ & $3.21 \mathrm{E}-01$ & $2.37 \mathrm{E}+00$ & $4.30 \mathrm{E}+00$ & ND \\
\hline S05001-3A & $\mathrm{C} 4404$ & 21.13 & 4.57E-01 & $5.27 \mathrm{E}-01$ & $3.96 \mathrm{E}+00$ & $7.92 \mathrm{E}+00$ & ND \\
\hline S05001-4B & $\mathrm{C} 4410$ & 21.80 & $5.46 \mathrm{E}-01$ & $6.95 \mathrm{E}-01$ & $6.36 \mathrm{E}+00$ & $9.42 \mathrm{E}+00$ & ND \\
\hline S05001-4A & $\mathrm{C} 4410$ & 23.38 & 6.44E-01 & $1.16 \mathrm{E}+00$ & $1.28 \mathrm{E}+01$ & $1.82 \mathrm{E}+01$ & $5.69 \mathrm{E}+00$ \\
\hline S05001-5B & C4414 & 24.13 & $6.85 \mathrm{E}-01$ & $9.48 \mathrm{E}-01$ & $8.74 \mathrm{E}+00$ & $1.12 \mathrm{E}+01$ & ND \\
\hline S05001-5A & $\mathrm{C} 4414$ & 24.80 & $6.48 \mathrm{E}-01$ & $1.55 \mathrm{E}+00$ & $6.25 \mathrm{E}+00$ & $1.17 \mathrm{E}+01$ & ND \\
\hline S05001-6B & $\mathrm{C} 4412$ & 13.88 & $2.65 \mathrm{E}-01$ & $2.66 \mathrm{E}-01$ & $2.07 \mathrm{E}+00$ & $7.16 \mathrm{E}+00$ & ND \\
\hline S05001-6A-1 & $\mathrm{C} 4412$ & 14.63 & $3.68 \mathrm{E}-01$ & $5.85 \mathrm{E}-01$ & $3.46 \mathrm{E}+00$ & $1.17 \mathrm{E}+01$ & ND \\
\hline S05001-6A-2 & $\mathrm{C} 4412$ & 14.63 & $3.03 \mathrm{E}-01$ & 4.92E-01 & $2.82 \mathrm{E}+00$ & $1.01 \mathrm{E}+01$ & ND \\
\hline S05001-7B & $\mathrm{C} 4422$ & 11.88 & $1.34 \mathrm{E}+00$ & $3.40 \mathrm{E}-01$ & $2.16 \mathrm{E}+00$ & $1.03 \mathrm{E}+01$ & ND \\
\hline S05001-7A & $\mathrm{C} 4422$ & 12.63 & $8.73 \mathrm{E}-01$ & $5.64 \mathrm{E}-01$ & $3.43 \mathrm{E}+00$ & $9.94 \mathrm{E}+00$ & ND \\
\hline S05001-8B & $\mathrm{C} 4420$ & 13.30 & $5.92 \mathrm{E}-01$ & $1.77 \mathrm{E}+00$ & $1.25 \mathrm{E}+01$ & $1.57 \mathrm{E}+01$ & ND \\
\hline S05001-8A & $\mathrm{C} 4420$ & 16.88 & $6.38 \mathrm{E}-01$ & $1.62 \mathrm{E}+00$ & $6.72 \mathrm{E}+00$ & $1.74 \mathrm{E}+01$ & ND \\
\hline S05001-9B & $\mathrm{C} 4418$ & 17.63 & $1.33 \mathrm{E}+00$ & $5.77 \mathrm{E}-01$ & $4.79 \mathrm{E}+00$ & $6.19 \mathrm{E}+00$ & ND \\
\hline S05001-9A & C4418 & 18.30 & $1.30 \mathrm{E}+00$ & $3.22 \mathrm{E}-01$ & $3.35 \mathrm{E}+00$ & $5.11 \mathrm{E}+00$ & ND \\
\hline S05001-10B & $\mathrm{C} 4416$ & 11.88 & $5.06 \mathrm{E}-01$ & $6.53 \mathrm{E}-01$ & $1.72 \mathrm{E}+00$ & $8.09 \mathrm{E}+00$ & ND \\
\hline S05001-10A & $\mathrm{C} 4416$ & 12.63 & 7.34E-01 & $2.64 E+00$ & $1.67 \mathrm{E}+01$ & $2.54 \mathrm{E}+01$ & ND \\
\hline S05001-11B & $\mathrm{C} 4432$ & 20.77 & $4.60 \mathrm{E}-01$ & $2.64 \mathrm{E}+00$ & $9.07 \mathrm{E}+00$ & $2.33 \mathrm{E}+01$ & ND \\
\hline S05001-11A & $\mathrm{C} 4432$ & 21.34 & 4.67E-01 & $5.65 \mathrm{E}+00$ & $9.73 \mathrm{E}+00$ & $5.05 \mathrm{E}+01$ & ND \\
\hline S05001-12A & $\mathrm{C} 4440$ & 6.70 & $7.06 \mathrm{E}-01$ & $5.07 \mathrm{E}-01$ & $8.64 \mathrm{E}+00$ & $1.47 \mathrm{E}+01$ & ND \\
\hline S05001-12 & $\mathrm{C} 4440$ & 7.10 & $8.05 \mathrm{E}-01$ & $1.69 \mathrm{E}+00$ & $2.93 E+01$ & $2.50 \mathrm{E}+01$ & ND \\
\hline S05001-13B & $\mathrm{C} 4445$ & 6.63 & $4.38 \mathrm{E}-01$ & $4.81 \mathrm{E}-01$ & $1.22 \mathrm{E}+01$ & $3.92 \mathrm{E}+00$ & ND \\
\hline S05001-13A-1 & $\mathrm{C} 4445$ & 7.13 & $3.97 \mathrm{E}-01$ & 4.42E-01 & $1.08 \mathrm{E}+01$ & $2.87 \mathrm{E}+00$ & ND \\
\hline S05001-13A-2 & $\mathrm{C} 4445$ & 7.13 & $5.29 \mathrm{E}-01$ & $1.80 \mathrm{E}+00$ & $2.72 \mathrm{E}+01$ & $1.48 \mathrm{E}+01$ & ND \\
\hline S05001-14B & C4438 & 13.88 & $7.57 \mathrm{E}-01$ & $5.88 \mathrm{E}-01$ & $5.98 \mathrm{E}+00$ & $1.32 \mathrm{E}+01$ & ND \\
\hline S05001-14A & $\mathrm{C} 4438$ & 14.63 & $4.17 \mathrm{E}-01$ & $4.74 \mathrm{E}-01$ & $5.29 \mathrm{E}+00$ & $1.11 \mathrm{E}+01$ & $\mathrm{ND}$ \\
\hline S05001-14A & $\mathrm{C} 4438$ & 14.63 & 4.03E-01 & $6.28 \mathrm{E}-01$ & $6.71 \mathrm{E}+00$ & $1.26 \mathrm{E}+01$ & $1.50 \mathrm{E}+00$ \\
\hline S05001-15B & C4448 & 17.38 & 4.12E-01 & $2.58 \mathrm{E}-01$ & $9.94 E-01$ & $6.33 \mathrm{E}+00$ & ND \\
\hline S05001-15A & $\mathrm{C} 4448$ & 18.13 & $3.12 \mathrm{E}-01$ & $2.60 \mathrm{E}-01$ & $3.54 \mathrm{E}+00$ & $9.80 \mathrm{E}+00$ & $8.68 \mathrm{E}-01$ \\
\hline S05001-17B & $\mathrm{C} 4436$ & 16.38 & $6.02 \mathrm{E}-01$ & $3.38 \mathrm{E}-01$ & $1.38 \mathrm{E}+00$ & $8.70 \mathrm{E}+00$ & $\mathrm{ND}$ \\
\hline S05001-17A & $\mathrm{C} 4436$ & 17.13 & 4.61E-01 & $4.88 \mathrm{E}-01$ & $7.08 \mathrm{E}+00$ & $1.86 \mathrm{E}+01$ & $2.64 \mathrm{E}+00$ \\
\hline S05001-18B & $\mathrm{C} 4434$ & 13.88 & $1.19 E+00$ & 7.03E-01 & $4.80 \mathrm{E}+00$ & $9.89 \mathrm{E}+00$ & ND \\
\hline
\end{tabular}


Table 4.3. (contd)

\begin{tabular}{|c|c|c|c|c|c|c|c|}
\hline $\begin{array}{c}\text { Sample } \\
\text { Number }\end{array}$ & $\begin{array}{l}\text { Probe } \\
\text { Hole } \\
\text { Number }\end{array}$ & $\begin{array}{c}\text { Mid- } \\
\text { Depth } \\
\text { (ft bgs) }\end{array}$ & Fluoride & Chloride & Nitrate & Sulfate & Phosphate \\
\hline S05001-18A & C4434 & 14.63 & 7.72E-01 & $3.70 \mathrm{E}-01$ & $1.44 \mathrm{E}+00$ & $1.73 \mathrm{E}+01$ & ND \\
\hline S05001-19B & C4428 & 15.30 & $3.81 \mathrm{E}-01$ & $2.64 \mathrm{E}-01$ & $5.61 E-01$ & $5.79 \mathrm{E}+00$ & ND \\
\hline S05001-19A & C4428 & 18.38 & $5.44 \mathrm{E}-01$ & 7.44E-01 & $6.09 \mathrm{E}+00$ & $5.47 \mathrm{E}+00$ & $1.76 \mathrm{E}+00$ \\
\hline S05001-19A Dup & $\mathrm{C} 4428$ & 18.38 & $5.50 \mathrm{E}-01$ & $9.16 \mathrm{E}-01$ & $7.01 \mathrm{E}+00$ & $7.09 \mathrm{E}+00$ & $1.72 \mathrm{E}+00$ \\
\hline S05001-20A & $\mathrm{C} 4426$ & 6.06 & $1.17 \mathrm{E}-01$ & $7.00 \mathrm{E}-01$ & $5.31 \mathrm{E}+00$ & $1.20 \mathrm{E}+02$ & ND \\
\hline S05001-20 & C4426 & 6.73 & $1.18 \mathrm{E}+00$ & $5.43 \mathrm{E}-01$ & $5.30 \mathrm{E}+00$ & $5.53 \mathrm{E}+01$ & ND \\
\hline S05001-21B-1 & $\mathrm{C} 4430$ & 18.88 & $5.93 \mathrm{E}-01$ & $1.06 \mathrm{E}+00$ & $6.92 \mathrm{E}+00$ & $1.63 \mathrm{E}+01$ & ND \\
\hline S05001-21B-2 & $\mathrm{C} 4430$ & 18.88 & $3.80 \mathrm{E}-01$ & $1.01 \mathrm{E}+00$ & $5.72 \mathrm{E}+00$ & $1.20 \mathrm{E}+01$ & ND \\
\hline S05001-21A & $\mathrm{C} 4430$ & 19.63 & $3.96 \mathrm{E}-01$ & $9.64 \mathrm{E}-01$ & $3.06 \mathrm{E}+00$ & $1.01 \mathrm{E}+01$ & ND \\
\hline \multicolumn{8}{|c|}{$\begin{array}{l}\text { Shaded cells indicate grab samples. } \\
\text { Bold values denote elevated concentrations. } \\
\text { Italicized values denote low concentrations. }\end{array}$} \\
\hline
\end{tabular}

respectively. The peak chloride-containing sample, at $5.65 \mu \mathrm{g} / \mathrm{g}$, contained approximately one-fourth as much chloride as the most contaminated sample measured from the $\mathrm{C} 4297$ borehole (contaminated borehole collected adjacent to Tank C-105).

Water-extractable nitrate was highest (approximately $30 \mu \mathrm{g} / \mathrm{g}$ of dry sediment) in the samples collected from probe holes $\mathrm{C} 4440$ and $\mathrm{C} 4445$, which were duplicate probe holes pushed at the northernnortheastern edge of the C-152 sampling site. These samples contained approximately $30 \%$ more waterextractable nitrate than the most contaminated sample collected from borehole C4297. Additionally, elevated nitrate $(>10 \mu \mathrm{g} / \mathrm{g})$ was observed in water extractions from seven other samples collected from probe holes C4406, C4408, C4410, C4416, and C4420. These samples were collected to the south and west of the leak and can potentially be used to determine a concentration gradient for nitrate, since samples collected further south of the leak site did not contain elevated water-extractable nitrate.

Two of the 1:1 sediment:water extractions contained elevated concentrations of sulfate $(>50 \mu \mathrm{g} / \mathrm{g})$ compared to the mean sulfate concentration of all the $1: 1$ sediment:water extractions: $15 \mu \mathrm{g} / \mathrm{g}$. The sediment samples came from probe holes C4426 and C4432, which were located at the southeastern end of the $\mathrm{C}-152$ pipeline leak.

The majority of the samples did not contain quantifiable amounts of water-extractable phosphate. However, four of the probe holes contained samples with appreciable amounts of phosphate (C4408, C4428, and C4438) and two probe holes, C4410 and C4436, contained significantly elevated amounts of phosphate, with 5.69 and $2.64 \mu \mathrm{g} / \mathrm{g}$, respectively. No water-extractable phosphate was found in the sediments collected from borehole C4297 near Tank C-105.

The water-extractable major cations in the C-152 vertical probe hole sediments are tabulated in Table 4.4. The distribution of the divalent alkaline-earth cations (magnesium and calcium) showed 
Table 4.4. Water-Extractable Major Cations in the C-152 Vertical Core and Grab Samples ( $\mu \mathrm{g} / \mathrm{g}$ dry sediment)

\begin{tabular}{|c|c|c|c|c|c|c|c|}
\hline $\begin{array}{l}\text { Sample } \\
\text { Number }\end{array}$ & $\begin{array}{l}\text { Probe } \\
\text { Hole } \\
\text { Number }\end{array}$ & $\begin{array}{l}\text { Mid- } \\
\text { Depth } \\
\text { (ft bgs) }\end{array}$ & Calcium & Magnesium & Strontium & Sodium & Potassium \\
\hline S05001-1A & C4406 & 12.29 & $5.91 \mathrm{E}+00$ & $1.54 \mathrm{E}+00$ & $3.27 \mathrm{E}-02$ & $2.96 \mathrm{E}+01$ & $3.76 \mathrm{E}+00$ \\
\hline S05001-1 & C4406 & 12.83 & $4.65 \mathrm{E}+00$ & $1.55 \mathrm{E}+00$ & 2.99E-02 & $1.40 \mathrm{E}+01$ & $(3.19 \mathrm{E}+00)$ \\
\hline S05001-2B & C4408 & 9.88 & $1.61 E+00$ & $3.22 E-01$ & $(8.70 \mathrm{E}-03)$ & $5.63 \mathrm{E}+01$ & $(2.10 \mathrm{E}+00)$ \\
\hline S05001-2A & C4408 & 10.63 & $1.59 E+00$ & $3.42 E-01$ & (8.66E-03) & $1.71 \mathrm{E}+02$ & $(1.79 \mathrm{E}+00)$ \\
\hline S05001-3B & C4404 & 20.38 & $2.75 \mathrm{E}+00$ & $6.55 \mathrm{E}-01$ & $(1.37 \mathrm{E}-02)$ & $1.77 \mathrm{E}+01$ & $(2.28 \mathrm{E}+00)$ \\
\hline S05001-3A & C4404 & 21.13 & $4.88 \mathrm{E}+00$ & $1.23 \mathrm{E}+00$ & $2.68 \mathrm{E}-02$ & $1.57 \mathrm{E}+01$ & $(2.95 \mathrm{E}+00)$ \\
\hline S05001-4B & $\mathrm{C} 4410$ & 21.80 & $1.03 E+00$ & $2.07 E-01$ & (7.03E-03) & $4.12 \mathrm{E}+01$ & $(1.69 \mathrm{E}+00)$ \\
\hline S05001-4A & $\mathrm{C} 4410$ & 23.38 & $1.05 E+00$ & $3.67 E-01$ & $(8.68 \mathrm{E}-03)$ & $1.46 \mathrm{E}+02$ & $(1.85 \mathrm{E}+00)$ \\
\hline S05001-5B & $\mathrm{C} 4414$ & 24.13 & $3.65 \mathrm{E}+00$ & $6.77 \mathrm{E}-01$ & $(1.42 \mathrm{E}-02)$ & $3.15 \mathrm{E}+01$ & $(2.11 \mathrm{E}+00)$ \\
\hline S05001-5A & C4414 & 24.80 & $3.08 \mathrm{E}+00$ & $5.83 \mathrm{E}-01$ & $(1.24 \mathrm{E}-02)$ & $3.11 \mathrm{E}+01$ & $(2.12 \mathrm{E}+00)$ \\
\hline S05001-6B & $\mathrm{C} 4412$ & 13.88 & $6.53 \mathrm{E}+00$ & $1.70 \mathrm{E}+00$ & $3.23 \mathrm{E}-02$ & $6.61 \mathrm{E}+00$ & $(2.55 \mathrm{E}+00)$ \\
\hline S05001-6A-1 & $\mathrm{C} 4412$ & 14.63 & $5.54 \mathrm{E}+00$ & $1.51 \mathrm{E}+00$ & $3.17 \mathrm{E}-02$ & $1.40 \mathrm{E}+01$ & $(2.63 \mathrm{E}+00)$ \\
\hline S05001-6A-2 & $\mathrm{C} 4412$ & 14.63 & $6.01 \mathrm{E}+00$ & $1.62 \mathrm{E}+00$ & $3.53 \mathrm{E}-02$ & $1.03 \mathrm{E}+01$ & $(2.54 \mathrm{E}+00)$ \\
\hline S05001-7B & C4422 & 11.88 & $3.54 \mathrm{E}+00$ & $6.32 \mathrm{E}-01$ & $(1.36 \mathrm{E}-02)$ & $3.35 \mathrm{E}+01$ & $(2.49 \mathrm{E}+00)$ \\
\hline S05001-7A & $\mathrm{C} 4422$ & 12.63 & $4.44 \mathrm{E}+00$ & 7.66E-01 & $1.58 \mathrm{E}-02$ & $2.65 \mathrm{E}+01$ & $(2.73 \mathrm{E}+00)$ \\
\hline S05001-8B & $\mathrm{C} 4420$ & 13.30 & $5.81 \mathrm{E}+00$ & $1.11 \mathrm{E}+00$ & $2.30 \mathrm{E}-02$ & $3.23 \mathrm{E}+01$ & $(2.66 \mathrm{E}+00)$ \\
\hline S05001-8A & $\mathrm{C} 4420$ & 16.88 & $3.28 \mathrm{E}+00$ & $6.40 \mathrm{E}-01$ & $(1.34 \mathrm{E}-02)$ & $3.06 \mathrm{E}+01$ & $(2.03 \mathrm{E}+00)$ \\
\hline S05001-9B & $\mathrm{C} 4418$ & 17.63 & $3.22 \mathrm{E}+00$ & $6.15 \mathrm{E}-01$ & $(1.35 \mathrm{E}-02)$ & $4.07 \mathrm{E}+01$ & $(2.58 \mathrm{E}+00)$ \\
\hline S05001-9A & C4418 & 18.30 & $2.70 \mathrm{E}+00$ & $5.13 \mathrm{E}-01$ & $(1.16 \mathrm{E}-02)$ & $3.84 \mathrm{E}+01$ & $(2.44 \mathrm{E}+00)$ \\
\hline S05001-10B & $\mathrm{C} 4416$ & 11.88 & $2.50 \mathrm{E}+00$ & $4.75 \mathrm{E}-01$ & $(1.14 \mathrm{E}-02)$ & $2.79 \mathrm{E}+01$ & $(2.08 \mathrm{E}+00)$ \\
\hline S05001-10A & $\mathrm{C} 4416$ & 12.63 & $5.92 \mathrm{E}+00$ & $1.14 \mathrm{E}+00$ & $2.12 \mathrm{E}-02$ & $4.24 \mathrm{E}+01$ & $(2.86 \mathrm{E}+00)$ \\
\hline S05001-11B & $\mathrm{C} 4432$ & 20.77 & $6.13 \mathrm{E}+00$ & $1.17 \mathrm{E}+00$ & $2.50 \mathrm{E}-02$ & $3.19 \mathrm{E}+01$ & $(3.09 \mathrm{E}+00)$ \\
\hline S05001-11A & $\mathrm{C} 4432$ & 21.34 & $8.46 \mathrm{E}+00$ & $1.41 \mathrm{E}+00$ & 2.83E-02 & $3.67 \mathrm{E}+01$ & $(2.97 \mathrm{E}+00)$ \\
\hline S05001-12A & $\mathrm{C} 4440$ & 6.70 & $1.53 \mathrm{E}+01$ & $3.28 E-01$ & 4.62E-02 & $1.53 \mathrm{E}+01$ & $3.97 \mathrm{E}+00$ \\
\hline S05001-12 & $\mathrm{C} 4440$ & 7.10 & $1.36 \mathrm{E}+01$ & $2.68 \mathrm{E}+00$ & $6.15 \mathrm{E}-02$ & $2.89 \mathrm{E}+01$ & $4.24 \mathrm{E}+00$ \\
\hline S05001-13B & $\mathrm{C} 4445$ & 6.63 & $7.35 \mathrm{E}+00$ & $1.47 \mathrm{E}+00$ & $2.80 \mathrm{E}-02$ & $1.73 \mathrm{E}+01$ & $5.30 \mathrm{E}+00$ \\
\hline S05001-13A-1 & $\mathrm{C} 4445$ & 7.13 & $7.56 \mathrm{E}+00$ & $1.43 \mathrm{E}+00$ & $2.81 \mathrm{E}-02$ & $1.85 \mathrm{E}+01$ & $4.06 \mathrm{E}+00$ \\
\hline S05001-13A-2 & $\mathrm{C} 4445$ & 7.13 & $9.76 \mathrm{E}+00$ & $1.35 \mathrm{E}+00$ & 4.35E-02 & $3.07 \mathrm{E}+01$ & $(3.49 \mathrm{E}+00)$ \\
\hline S05001-14B & $\mathrm{C} 4438$ & 13.88 & $3.78 \mathrm{E}+00$ & $6.80 \mathrm{E}-01$ & $1.78 \mathrm{E}-02$ & $3.05 \mathrm{E}+01$ & $(3.03 E+00)$ \\
\hline S05001-14A & $\mathrm{C} 4438$ & 14.63 & $1.45 E+00$ & $2.68 E-01$ & (7.97E-03) & $4.07 \mathrm{E}+01$ & $(1.89 \mathrm{E}+00)$ \\
\hline S05001-14A Dup & $\mathrm{C} 4438$ & 14.63 & $1.04 E+00$ & $2.05 E-01$ & $(6.29 \mathrm{E}-03)$ & $7.01 \mathrm{E}+01$ & $(1.77 \mathrm{E}+00)$ \\
\hline S05001-15B & $\mathrm{C} 4448$ & 17.38 & $4.36 \mathrm{E}+00$ & $9.55 \mathrm{E}-01$ & 2.03E-02 & $1.42 \mathrm{E}+01$ & $(2.15 \mathrm{E}+00)$ \\
\hline S05001-15A & C4448 & 18.13 & $9.44 E-01$ & $2.85 E-01$ & (5.34E-03) & $4.25 \mathrm{E}+01$ & $(1.42 \mathrm{E}+00)$ \\
\hline
\end{tabular}


Table 4.4. (contd)

\begin{tabular}{|c|c|c|c|c|c|c|c|}
\hline $\begin{array}{l}\text { Sample } \\
\text { Number }\end{array}$ & $\begin{array}{l}\text { Probe } \\
\text { Hole } \\
\text { Number }\end{array}$ & $\begin{array}{l}\text { Mid- } \\
\text { Depth } \\
\text { (ft bgs) }\end{array}$ & Calcium & Magnesium & Strontium & Sodium & Potassium \\
\hline S05001-17B & $\mathrm{C} 4436$ & 16.38 & $3.35 \mathrm{E}+00$ & $5.29 \mathrm{E}-01$ & $(1.35 \mathrm{E}-02)$ & $2.00 \mathrm{E}+01$ & $(1.99 \mathrm{E}+00)$ \\
\hline S05001-17A & C4436 & 17.13 & $1.02 E+00$ & $1.61 E-01$ & (4.49E-03) & $8.39 \mathrm{E}+01$ & $(1.21 \mathrm{E}+00)$ \\
\hline S05001-18B & $\mathrm{C} 4434$ & 13.88 & $3.30 \mathrm{E}+00$ & $4.83 \mathrm{E}-01$ & $(1.21 \mathrm{E}-02)$ & $2.73 \mathrm{E}+01$ & $(2.61 \mathrm{E}+00)$ \\
\hline S05001-18A & C4434 & 14.63 & $9.53 \mathrm{E}+00$ & $1.63 E-01$ & $2.89 \mathrm{E}-02$ & $2.98 \mathrm{E}+01$ & $(3.13 \mathrm{E}+00)$ \\
\hline S05001-19B & $\mathrm{C} 4428$ & 15.30 & $5.22 \mathrm{E}+00$ & $1.13 \mathrm{E}+00$ & $2.45 \mathrm{E}-02$ & $1.36 \mathrm{E}+01$ & $(2.29 \mathrm{E}+00)$ \\
\hline S05001-19A & $\mathrm{C} 4428$ & 18.38 & $6.67 E-01$ & $1.39 E-01$ & (5.69E-03) & $9.88 \mathrm{E}+01$ & $(1.27 \mathrm{E}+00)$ \\
\hline S05001-19A Dup & $\mathrm{C} 4428$ & 18.38 & $7.26 E-01$ & $1.75 E-01$ & $(5.43 \mathrm{E}-03)$ & $9.20 \mathrm{E}+01$ & $(1.33 \mathrm{E}+00)$ \\
\hline S05001-20A & $\mathrm{C} 4426$ & 6.06 & $3.30 \mathrm{E}+01$ & $2.39 \mathrm{E}+00$ & $9.25 \mathrm{E}-02$ & $3.30 \mathrm{E}+01$ & $5.15 \mathrm{E}+00$ \\
\hline S05001-20 & $\mathrm{C} 4426$ & 6.73 & $1.40 \mathrm{E}+01$ & $2.25 \mathrm{E}+00$ & $5.75 \mathrm{E}-02$ & $3.47 \mathrm{E}+01$ & $4.21 \mathrm{E}+00$ \\
\hline S05001-21B-1 & $\mathrm{C} 4430$ & 18.88 & $8.91 \mathrm{E}+00$ & $1.84 \mathrm{E}+00$ & $3.96 \mathrm{E}-02$ & $2.37 \mathrm{E}+01$ & $3.86 \mathrm{E}+00$ \\
\hline S05001-21B-2 & $\mathrm{C} 4430$ & 18.88 & $5.63 \mathrm{E}+00$ & $1.09 \mathrm{E}+00$ & $2.53 \mathrm{E}-02$ & $2.17 \mathrm{E}+01$ & $(2.86 \mathrm{E}+00)$ \\
\hline S05001-21A & $\mathrm{C} 4430$ & 19.63 & $3.84 \mathrm{E}+00$ & 7.35E-01 & $1.62 \mathrm{E}-02$ & $2.27 \mathrm{E}+01$ & $3.76 \mathrm{E}+00$ \\
\hline \multicolumn{8}{|c|}{$\begin{array}{l}\text { Shaded cells indicate grab samples. } \\
\text { Bold values denote elevated concentrations. } \\
\text { Italicized values denote low concentrations. }\end{array}$} \\
\hline
\end{tabular}

decreased quantities in several of the sediment samples analyzed. Specifically, vadose zone samples from probe holes C4408, C4410, C4428, C4436, C4438, and C4448 contained significantly less waterextractable calcium $(<2 \mu \mathrm{g} / \mathrm{g})$ than the average water-extractable calcium concentration of all the samples measured $(5.53 \mu \mathrm{g} / \mathrm{g})$. The vadose zone samples that contained the least amount of water-extractable calcium, at 0.67 and $0.73 \mathrm{mg} / \mathrm{g}$, came from probe hole C4428, which was located between the C-152 pipeline leak location and the 241-C-153 Diversion Box. Similarly, vadose zone samples from probe holes C4408, C4410, C4428, C4434, C4436, C4438, C4440, and C4448 contained significantly less water-extractable magnesium $(<0.4 \mu \mathrm{g} / \mathrm{g})$ than the average water-extractable magnesium concentration of all the samples measured $(0.9 \mu \mathrm{g} / \mathrm{g})$. The four samples that contained the least amount of waterextractable magnesium, at $0.161,0.163,0.139$, and $0.175 \mu \mathrm{g} / \mathrm{g}$, came from the three probe holes emplaced along the northeastern boundary of the C-152 pipeline leak (C4428, C4434, and C4436).

The concentrations of potassium and water-extractable strontium, the only other divalent cation reported in Table 4.4, were not sufficient to provide an adequate set of quantitative results to draw conclusions about their relative concentrations from one sample to another. However, the dominant monovalent cation, sodium, was present in sufficient concentration to make a comparison feasible. Seven samples collected from probe holes C4408, C4410, C4428, C4436, and C4438 contained significantly more water-extractable sodium (more than $50 \mu \mathrm{g} / \mathrm{g}$ ) than the average water-extractable sodium for all of the samples measured (39 $\mu \mathrm{g} / \mathrm{g}$ ) (Figure 4.1). The two samples containing the highest amount of waterextractable sodium, at 171 and $146 \mu \mathrm{g} / \mathrm{g}$, respectively, came from probe holes located along the western 

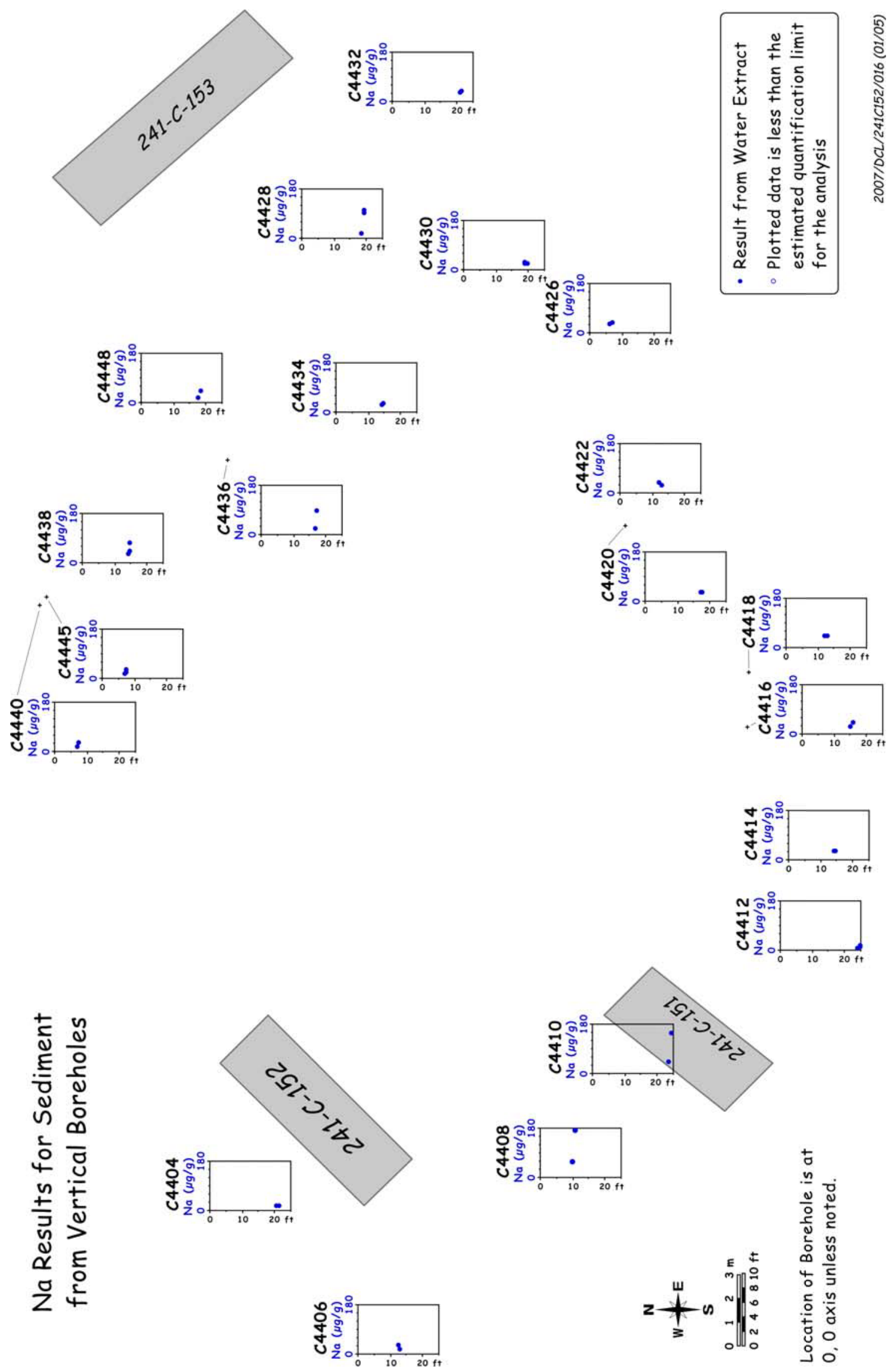

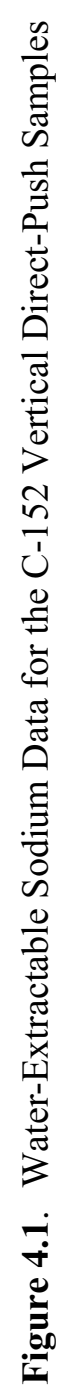


edge of the $\mathrm{C}-152$ pipeline leak (C4408 and $\mathrm{C} 4410)$. The remaining samples with elevated waterextractable sodium came from probe holes located along the northeastern edge of the $\mathrm{C}-152$ pipeline leak. The peak water-extractable sodium in the C-152 samples was approximately 1.7 times higher than the peak value measured in sediments collected near Tank C-105, and approximately 3 times lower than the peak value measured in sediments near Tank T-106. The fact that most of the samples containing elevated concentrations of water-extractable sodium also had decreased levels of calcium and/or magnesium is not surprising. These trends suggest that tank-related fluids that were high in sodium did seep into the vadose zone near these probe holes.

From the general concentration of the cationic constituents, it appears that there are two primary regions of contamination. The first zone is located south of the $\mathrm{C}-152$ Diversion Box and slightly north of the C-151 Diversion Box. The second zone of elevated water-extractable sodium is directly across the C-152 pipeline waste site to the east. It is possible that these two regions of contamination are independent of one another; however, an alternate explanation could be that the waste is from the same leak occurrence and leaked fluids traveled along a transfer line connecting the C-152 and C-153 Diversion Boxes (1943-1945 transfer line shown in Figure 1.2). Either way, the source or sources of waste contributing to contamination at this location can be described as moderately concentrated, sodium-bearing waste solutions. The sodium from this source has displaced most of the natural divalent cations from the cation-exchange sites in the sediments in the zone (depth) of analysis.

The water-extractable aluminum, iron, manganese silicon, and sulfur in the $\mathrm{C}-152$ probe hole sediments are shown in Table 4.5. The sulfur data were converted to water-extractable sulfate so that the results could be compared to the IC data presented in Table 4.3. The water-soluble aluminum and iron data both showed elevated values in samples from probe holes C4408, C4418, C4428, and C4438. Additionally, water-soluble aluminum was found to be elevated in samples from probe holes $\mathrm{C} 4410$ and C4436. It appears that these elevated values are a result of some chemical reaction between alkaline tank fluids and native sediments that formed precipitates of amorphous aluminum and/or iron phases that are more water-soluble than aluminum- and iron-rich phases in the native sediments. Two samples, both collected from probe hole $\mathrm{C} 4428$, contained elevated amounts of water-soluble manganese. As mentioned previously, both of these samples also contained elevated amounts of water-soluble aluminum and iron, further supporting the hypothesis that the vadose zone sediments in the vicinity of this probe hole have been chemically altered due to interaction with tank-related waste. This is further substantiated by the observance of elevated water-extractable silicon in the two probe holes emplaced closest to the northeastern edge of the $\mathrm{C}-152$ pipeline leak. The agreement between measuring the water extractions for sulfate directly with the IC and indirectly by converting the ICP measurements for sulfur to sulfate was very good (Tables 4.3 and 4.5). Besides validating the IC data, we can state that the water-extractable sulfur was in fact sulfate.

The water-extraction data for potentially mobile metals, such as technetium- 99 , uranium-238, chromium, molybdenum, and ruthenium are shown in Table 4.6. Four samples from three of the C-152 probe holes (C4408, C4410, and C4436) contained water-extractable technetium-99 (Figure 4.2). The highest detectable technetium-99, at 1.29 and $3.34 \mathrm{pCi} / \mathrm{g}$, respectively, came from the shallower probe hole emplaced midway between the C-152 and C-151 Diversion Boxes (C4408). The peak technetium-99 concentration measured in this probe hole $(3.34 \mathrm{pCi} / \mathrm{g})$ was approximately 2.5 times less than the peak water-extractable technetium-99 observed in samples from borehole C4297 and 100 to 2,000 times lower than those measured in boreholes emplaced near Tank T-106. 
Table 4.5. Water-Extractable Cations of Aluminum, Iron, Manganese Silicon, and Sulfur in the C-152 Vertical Core and Grab Samples ( $\mu \mathrm{g} / \mathrm{g}$ dry sediment)

\begin{tabular}{|c|c|c|c|c|c|c|c|}
\hline $\begin{array}{l}\text { Sample } \\
\text { Number }\end{array}$ & $\begin{array}{c}\text { Probe Hole } \\
\text { Number }\end{array}$ & $\begin{array}{c}\text { Mid- } \\
\text { Depth } \\
\text { (ft bgs) }\end{array}$ & Aluminum & Iron & Manganese & Silicon & $\begin{array}{l}\text { Sulfur } \\
\text { as } \mathrm{SO}_{4} \\
\end{array}$ \\
\hline S05001-1A & C4406 & 12.29 & $3.25 \mathrm{E}-02$ & $8.45 \mathrm{E}-02$ & $(3.13 \mathrm{E}-03)$ & $1.10 \mathrm{E}+01$ & $1.17 \mathrm{E}+01$ \\
\hline S05001-1 & $\mathrm{C} 4406$ & 12.83 & $5.84 \mathrm{E}-02$ & $6.48 \mathrm{E}-02$ & (2.67E-03) & $8.70 \mathrm{E}+00$ & $6.86 \mathrm{E}+00$ \\
\hline S05001-2B & C4408 & 9.88 & $9.40 \mathrm{E}-02$ & $1.80 \mathrm{E}-01$ & (3.06E-03) & $1.63 \mathrm{E}+01$ & $1.49 \mathrm{E}+01$ \\
\hline S05001-2A & $\mathrm{C} 4408$ & 10.63 & 2.12E-01 & $4.20 \mathrm{E}-01$ & (1.11E-02) & $1.67 \mathrm{E}+01$ & $1.25 \mathrm{E}+01$ \\
\hline S05001-3B & C4404 & 20.38 & 7.69E-02 & $4.80 \mathrm{E}-02$ & (8.19E-04) & $6.88 \mathrm{E}+00$ & $4.14 \mathrm{E}+00$ \\
\hline S05001-3A & $\mathrm{C} 4404$ & 21.13 & $4.54 \mathrm{E}-02$ & $3.24 \mathrm{E}-02$ & $(2.18 \mathrm{E}-03)$ & $7.85 \mathrm{E}+00$ & $8.25 \mathrm{E}+00$ \\
\hline S05001-4B & $\mathrm{C} 4410$ & 21.80 & $1.20 \mathrm{E}-01$ & $1.07 \mathrm{E}-01$ & (2.69E-03) & $9.67 \mathrm{E}+00$ & $9.66 \mathrm{E}+00$ \\
\hline S05001-4A & $\mathrm{C} 4410$ & 23.38 & $1.42 \mathrm{E}-01$ & $6.81 \mathrm{E}-02$ & $(2.00 \mathrm{E}-03)$ & $9.25 \mathrm{E}+00$ & $1.81 \mathrm{E}+01$ \\
\hline S05001-5B & $\mathrm{C} 4414$ & 24.13 & $2.62 \mathrm{E}-02$ & $5.22 \mathrm{E}-02$ & $(1.32 \mathrm{E}-03)$ & $1.17 \mathrm{E}+01$ & $1.13 \mathrm{E}+01$ \\
\hline S05001-5A & $\mathrm{C} 4414$ & 24.80 & 4.37E-02 & 5.34E-02 & $(1.35 \mathrm{E}-03)$ & $9.65 \mathrm{E}+00$ & $1.22 \mathrm{E}+01$ \\
\hline S05001-6B & $\mathrm{C} 4412$ & 13.88 & $(4.80 \mathrm{E}-02)$ & $2.31 \mathrm{E}-02$ & ND & $6.28 \mathrm{E}+00$ & $7.31 \mathrm{E}+00$ \\
\hline S05001-6A-1 & $\mathrm{C} 4412$ & 14.63 & $5.76 \mathrm{E}-02$ & $5.58 \mathrm{E}-02$ & (9.89E-04) & $7.51 \mathrm{E}+00$ & $1.20 \mathrm{E}+01$ \\
\hline S05001-6A-2 & $\mathrm{C} 4412$ & 14.63 & $5.16 \mathrm{E}-02$ & $3.02 \mathrm{E}-02$ & $(6.70 \mathrm{E}-04)$ & $6.69 \mathrm{E}+00$ & $1.01 \mathrm{E}+01$ \\
\hline S05001-7B & $\mathrm{C} 4422$ & 11.88 & $3.40 \mathrm{E}-02$ & $5.42 \mathrm{E}-02$ & ND & $1.42 \mathrm{E}+01$ & $1.03 \mathrm{E}+01$ \\
\hline S05001-7A & $\mathrm{C} 4422$ & 12.63 & $3.91 \mathrm{E}-02$ & $6.20 \mathrm{E}-02$ & ND & $1.36 \mathrm{E}+01$ & $1.03 \mathrm{E}+01$ \\
\hline S05001-8B & $\mathrm{C} 4420$ & 13.30 & $(2.83 \mathrm{E}-02)$ & $1.42 \mathrm{E}-01$ & (3.70E-03) & $1.28 \mathrm{E}+01$ & $1.61 \mathrm{E}+01$ \\
\hline S05001-8A & $\mathrm{C} 4420$ & 16.88 & $4.86 \mathrm{E}-02$ & 5.99E-02 & $(2.31 \mathrm{E}-03)$ & $9.14 \mathrm{E}+00$ & $1.78 \mathrm{E}+01$ \\
\hline S05001-9B & $\mathrm{C} 4418$ & 17.63 & $1.57 \mathrm{E}-01$ & 3.62E-01 & (4.19E-03) & $1.59 \mathrm{E}+01$ & $6.53 \mathrm{E}+00$ \\
\hline S05001-9A & $\mathrm{C} 4418$ & 18.30 & $5.16 \mathrm{E}-02$ & $8.55 \mathrm{E}-02$ & $(1.66 \mathrm{E}-03)$ & $1.49 \mathrm{E}+01$ & $5.33 \mathrm{E}+00$ \\
\hline S05001-10B & $\mathrm{C} 4416$ & 11.88 & $8.60 \mathrm{E}-02$ & $7.96 \mathrm{E}-02$ & $(1.65 \mathrm{E}-03)$ & $9.03 \mathrm{E}+00$ & $8.54 \mathrm{E}+00$ \\
\hline S05001-10A & C4416 & 12.63 & $(2.11 \mathrm{E}-02)$ & $6.83 \mathrm{E}-02$ & $(1.85 \mathrm{E}-03)$ & $1.27 \mathrm{E}+01$ & $2.53 \mathrm{E}+01$ \\
\hline S05001-11B & $\mathrm{C} 4432$ & 20.77 & $(2.44 \mathrm{E}-02)$ & $5.30 \mathrm{E}-02$ & $(1.07 \mathrm{E}-03)$ & $1.23 \mathrm{E}+01$ & $2.35 \mathrm{E}+01$ \\
\hline S05001-11A & $\mathrm{C} 4432$ & 21.34 & $(2.25 \mathrm{E}-02)$ & $2.30 \mathrm{E}-02$ & $(9.81 \mathrm{E}-04)$ & $9.67 \mathrm{E}+00$ & $5.04 E+01$ \\
\hline S05001-12A & $\mathrm{C} 4440$ & 6.70 & $(1.54 \mathrm{E}-02)$ & $1.51 \mathrm{E}-02$ & ND & $1.98 \mathrm{E}+01$ & $1.48 \mathrm{E}+01$ \\
\hline S05001-12 & $\mathrm{C} 4440$ & 7.10 & $6.97 \mathrm{E}-02$ & $2.36 \mathrm{E}-01$ & $1.58 \mathrm{E}-02$ & $1.71 \mathrm{E}+01$ & $2.44 \mathrm{E}+01$ \\
\hline S05001-13B & $\mathrm{C} 4445$ & 6.63 & 4.07E-02 & $6.54 \mathrm{E}-02$ & $1.63 \mathrm{E}-03$ & $1.44 \mathrm{E}+01$ & $4.67 \mathrm{E}+00$ \\
\hline S05001-13A-1 & $\mathrm{C} 4445$ & 7.13 & $2.98 \mathrm{E}-02$ & $6.08 \mathrm{E}-02$ & $1.36 \mathrm{E}-03$ & $1.34 \mathrm{E}+01$ & $3.40 \mathrm{E}+00$ \\
\hline S05001-13A-2 & $\mathrm{C} 4445$ & 7.13 & $5.62 \mathrm{E}-02$ & $1.47 \mathrm{E}-01$ & (1.11E-02) & $1.54 \mathrm{E}+01$ & $1.44 \mathrm{E}+01$ \\
\hline S05001-14B & $\mathrm{C} 4438$ & 13.88 & $5.56 \mathrm{E}-02$ & 8.93E-02 & $(2.58 \mathrm{E}-03)$ & $1.38 \mathrm{E}+01$ & $1.33 \mathrm{E}+01$ \\
\hline S05001-14A & C4438 & 14.63 & $9.14 \mathrm{E}-02$ & $1.37 \mathrm{E}-01$ & $(2.38 \mathrm{E}-03)$ & $1.08 \mathrm{E}+01$ & $1.13 \mathrm{E}+01$ \\
\hline S05001-14A Dup & $\mathrm{C} 4438$ & 14.63 & $1.78 \mathrm{E}-01$ & 3.14E-01 & $(4.65 \mathrm{E}-03)$ & $1.38 \mathrm{E}+01$ & $1.31 \mathrm{E}+01$ \\
\hline S05001-15B & $\mathrm{C} 4448$ & 17.38 & $6.52 \mathrm{E}-02$ & $5.69 \mathrm{E}-02$ & $(9.55 \mathrm{E}-04)$ & $1.05 \mathrm{E}+01$ & $6.49 \mathrm{E}+00$ \\
\hline S05001-15A & C4448 & 18.13 & $9.68 \mathrm{E}-02$ & $1.33 \mathrm{E}-01$ & $(1.64 \mathrm{E}-03)$ & $1.32 \mathrm{E}+01$ & $9.94 \mathrm{E}+00$ \\
\hline S05001-17B & $\mathrm{C} 4436$ & 16.38 & $9.41 \mathrm{E}-02$ & $7.60 \mathrm{E}-02$ & $(8.54 \mathrm{E}-04)$ & $1.48 \mathrm{E}+01$ & $9.45 \mathrm{E}+00$ \\
\hline S05001-17A & $\mathrm{C} 4436$ & 17.13 & 2.22E-01 & $2.97 \mathrm{E}-01$ & $(4.61 \mathrm{E}-03)$ & $3.01 \mathrm{E}+01$ & $1.85 \mathrm{E}+01$ \\
\hline S05001-18B & $\mathrm{C} 4434$ & 13.88 & $5.84 \mathrm{E}-02$ & $8.65 \mathrm{E}-02$ & $(6.78 \mathrm{E}-04)$ & $1.57 \mathrm{E}+01$ & $1.05 \mathrm{E}+01$ \\
\hline S05001-18A & $\mathrm{C} 4434$ & 14.63 & $5.32 \mathrm{E}-02$ & $5.82 \mathrm{E}-02$ & ND & $2.69 \mathrm{E}+01$ & $1.75 \mathrm{E}+01$ \\
\hline S05001-19B & $\mathrm{C} 4428$ & 15.30 & $5.05 \mathrm{E}-02$ & $4.39 \mathrm{E}-02$ & $(1.82 \mathrm{E}-03)$ & $1.04 \mathrm{E}+01$ & $6.28 \mathrm{E}+00$ \\
\hline S05001-19A & $\mathrm{C} 4428$ & 18.38 & 2.06E-01 & 4.85E-01 & $1.67 \mathrm{E}-02$ & $1.52 \mathrm{E}+01$ & $5.89 \mathrm{E}+00$ \\
\hline
\end{tabular}


Table 4.5. (contd)

\begin{tabular}{|c|c|c|c|c|c|c|c|}
\hline $\begin{array}{l}\text { Sample } \\
\text { Number }\end{array}$ & $\begin{array}{l}\text { Probe Hole } \\
\text { Number }\end{array}$ & $\begin{array}{l}\text { Mid- } \\
\text { Depth } \\
(\mathrm{ft} \text { bgs })\end{array}$ & Aluminum & Iron & Manganese & Silicon & $\begin{array}{l}\text { Sulfur } \\
\text { as } \mathrm{SO}_{4}\end{array}$ \\
\hline S05001-19A Dup & C4428 & 18.38 & 2.33E-01 & $6.56 \mathrm{E}-01$ & $1.55 \mathrm{E}-02$ & $1.59 \mathrm{E}+01$ & $6.42 \mathrm{E}+00$ \\
\hline S05001-20A & $\mathrm{C} 4426$ & 6.06 & ND & (1.01E-02) & $\mathrm{ND}$ & $1.47 \mathrm{E}+01$ & $1.19 \mathrm{E}+02$ \\
\hline S05001-20 & $\mathrm{C} 4426$ & 6.73 & $4.55 \mathrm{E}-02$ & $1.04 \mathrm{E}-01$ & $(6.69 \mathrm{E}-03)$ & $1.66 \mathrm{E}+01$ & $5.51 \mathrm{E}+01$ \\
\hline S05001-21B-1 & $\mathrm{C} 4430$ & 18.88 & $(1.79 \mathrm{E}-02)$ & $2.52 \mathrm{E}-02$ & $\mathrm{ND}$ & $1.29 \mathrm{E}+01$ & $1.63 \mathrm{E}+01$ \\
\hline S05001-21B-2 & $\mathrm{C} 4430$ & 18.88 & $3.88 \mathrm{E}-02$ & $5.35 \mathrm{E}-02$ & $(1.42 \mathrm{E}-03)$ & $1.07 \mathrm{E}+01$ & $1.19 \mathrm{E}+01$ \\
\hline S05001-21A & $\mathrm{C} 4430$ & 19.63 & $5.22 \mathrm{E}-02$ & $6.42 \mathrm{E}-02$ & $(8.36 \mathrm{E}-04)$ & $9.57 \mathrm{E}+00$ & $1.04 \mathrm{E}+01$ \\
\hline \multicolumn{8}{|c|}{$\begin{array}{l}\text { Shaded cells indicate grab samples. } \\
\text { Bold values denote elevated concentrations. } \\
\text { ND indicates the analyte was not detected. }\end{array}$} \\
\hline
\end{tabular}

Elevated water-extractable uranium-238 was found in eight samples collected from six probe holes (C4408, C4410, C4428, C4436, C4438, and C4448) (Figure 4.3). However, only one sample (S05001-4A), collected from probe hole $\mathrm{C} 4410$, contained significantly elevated water-extractable uranium-238 $(7.66 \mathrm{E}-01 \mu \mathrm{g} / \mathrm{g})$. A water-extractable uranium concentration of $7.66 \mathrm{E}-01 \mu \mathrm{g} / \mathrm{g}$ was more than 35 times higher than the peak water-extractable uranium-238 concentration measured at borehole $\mathrm{C} 4297$ $(2.18 \mathrm{E}-02 \mu \mathrm{g} / \mathrm{g})$ and approximately the same as that measured in borehole C4101 (near Tank T-106). This sample also contained the second highest pore-water-corrected alkalinity value of all the samples measured $\left(3.26 \mathrm{E}+03 \mathrm{mg} / \mathrm{L}\right.$ as $\left.\mathrm{CaCO}_{3}\right)$, indicating that this could be an artifact of uranyl-carbonate complexation of naturally occurring labile uranium rather than soluble tank-waste-related contaminant uranium. However, a mass scan of the sample was performed via inductively coupled mass spectrometry (IC-MS) over the range of 230 to 240 atomic mass units, and in addition to the expected uranium peaks at atomic mass units 235 and 238, a discernable peak was also observed at mass 236. Although the data is considered qualitative, the presence of uranium-236 in the 1:1 sediment:water extraction is a clear indicator that the sample contained uranium from Hanford irradiated fuel.

Elevated concentrations of water-extractable chromium $(>1.50 \mathrm{E}-02 \mu \mathrm{g} / \mathrm{g})$ were observed in four samples from probe holes C4408, C4434, C4436, and C4440. For comparative purposes, the average water-extractable chromium value for all of the $\mathrm{C}-152$ core and grab samples analyzed was $3.09 \mathrm{E}-03 \mu \mathrm{g} / \mathrm{g}$. Elevated concentrations of water-extractable molybdenum were not found in sediments from the vertical C-152 probe holes; however, this is not surprising given the relatively low concentrations of technetium-99 present in these samples. Water extractions from two of the probe holes, C4408 and $\mathrm{C} 4410$, contained elevated concentrations of ruthenium. Additionally, analysis of total ruthenium calculated from measurements at isotope 101 vs. 102 did not agree (i.e., there was not detectable ruthenium measured at mass 102), indicating the likely presence of fission-related ruthenium in these samples. If only natural ruthenium was present, the ICP-MS-processed data would have taken the measured concentration of ruthenium at each mass and divided it by the natural abundance of ruthenium at that mass to yield estimates of the total ruthenium content, and the totals from the measurement of each isotope would have agreed. 
Table 4.6. Water-Extractable Mobile Metals in the C-152 Vertical Core and Grab Samples $(\mu \mathrm{g} / \mathrm{g}$ dry sediment)

\begin{tabular}{|c|c|c|c|c|c|c|c|}
\hline $\begin{array}{l}\text { Sample } \\
\text { Number }\end{array}$ & $\begin{array}{c}\text { Probe } \\
\text { Hole } \\
\text { Number }\end{array}$ & $\begin{array}{l}\text { Mid- } \\
\text { Depth } \\
\text { (ft bgs) }\end{array}$ & $\begin{array}{c}\text { Technetium-99 } \\
\text { (pCi/g soil) }\end{array}$ & Uranium-238 & Chromium-53 & Molybdenum-95 & Ruthenium-101 \\
\hline S05001-1A & $\mathrm{C} 4406$ & 12.29 & ND & $1.50 \mathrm{E}-03$ & $3.40 \mathrm{E}-04$ & $1.30 \mathrm{E}-02$ & ND \\
\hline S05001-1 & $\mathrm{C} 4406$ & 12.83 & ND & 4.64E-04 & $(1.05 \mathrm{E}-04)$ & $1.20 \mathrm{E}-02$ & ND \\
\hline S05001-2B & $\mathrm{C} 4408$ & 9.88 & $1.29 \mathrm{E}+00$ & $3.14 \mathrm{E}-03$ & $1.25 \mathrm{E}-03$ & $1.51 \mathrm{E}-02$ & $(6.63 \mathrm{E}-05)$ \\
\hline S05001-2A & $\mathrm{C} 4408$ & 10.63 & $3.34 \mathrm{E}+00$ & $8.21 \mathrm{E}-02$ & $1.54 \mathrm{E}-02$ & $3.67 \mathrm{E}-02$ & 5.83E-04 \\
\hline S05001-3B & $\mathrm{C} 4404$ & 20.38 & $\mathrm{ND}$ & $5.62 \mathrm{E}-04$ & $(1.37 \mathrm{E}-04)$ & $5.28 \mathrm{E}-03$ & ND \\
\hline S05001-3A & $\mathrm{C} 4404$ & 21.13 & ND & 4.95E-04 & (1.07E-04) & $1.31 \mathrm{E}-02$ & ND \\
\hline S05001-4B & $\mathrm{C} 4410$ & 21.80 & $(2.85 \mathrm{E}-01)$ & $2.30 \mathrm{E}-02$ & $9.19 \mathrm{E}-04$ & $3.50 \mathrm{E}-02$ & $8.53 \mathrm{E}-04$ \\
\hline S05001-4A & $\mathrm{C} 4410$ & 23.38 & 8.92E-01 & $7.66 \mathrm{E}-01$ & $3.27 \mathrm{E}-03$ & $8.62 \mathrm{E}-02$ & $1.28 \mathrm{E}-03$ \\
\hline S05001-5B & $\mathrm{C} 4414$ & 24.13 & ND & $1.45 \mathrm{E}-03$ & $(2.47 \mathrm{E}-04)$ & $1.93 \mathrm{E}-02$ & ND \\
\hline S05001-5A & $\mathrm{C} 4414$ & 24.80 & ND & $9.07 \mathrm{E}-04$ & (1.99E-04) & $3.42 \mathrm{E}-02$ & ND \\
\hline S05001-6B & $\mathrm{C} 4412$ & 13.88 & $(2.20 \mathrm{E}-02)$ & $1.45 \mathrm{E}-04$ & $(7.51 \mathrm{E}-05)$ & $6.81 \mathrm{E}-03$ & ND \\
\hline S05001-6A-1 & $\mathrm{C} 4412$ & 14.63 & $(2.17 \mathrm{E}-02)$ & $3.56 \mathrm{E}-04$ & (1.12E-04) & $1.21 \mathrm{E}-02$ & ND \\
\hline S05001-6A-2 & $\mathrm{C} 4412$ & 14.63 & $(2.52 \mathrm{E}-02)$ & 2.72E-04 & (8.19E-05) & $8.48 \mathrm{E}-03$ & ND \\
\hline S05001-7B & $\mathrm{C} 4422$ & 11.88 & ND & $1.42 \mathrm{E}-03$ & $(2.10 \mathrm{E}-04)$ & 7.64E-03 & ND \\
\hline S05001-7A & $\mathrm{C} 4422$ & 12.63 & $(9.27 \mathrm{E}-03)$ & $8.23 \mathrm{E}-04$ & $(1.65 \mathrm{E}-04)$ & $1.94 \mathrm{E}-02$ & ND \\
\hline S05001-8B & $\mathrm{C} 4420$ & 13.30 & ND & $1.46 \mathrm{E}-03$ & $3.73 \mathrm{E}-04$ & $3.15 \mathrm{E}-02$ & ND \\
\hline S05001-8A & $\mathrm{C} 4420$ & 16.88 & ND & $1.01 \mathrm{E}-03$ & $3.44 \mathrm{E}-04$ & 4.09E-02 & ND \\
\hline S05001-9B & $\mathrm{C} 4418$ & 17.63 & ND & $1.65 \mathrm{E}-03$ & $8.56 \mathrm{E}-04$ & 4.34E-02 & ND \\
\hline S05001-9A & C4418 & 18.30 & ND & $1.68 \mathrm{E}-03$ & $(1.73 \mathrm{E}-04)$ & $1.29 \mathrm{E}-02$ & ND \\
\hline S05001-10B & $\mathrm{C} 4416$ & 11.88 & ND & $1.27 \mathrm{E}-03$ & $(1.48 \mathrm{E}-04)$ & $2.51 \mathrm{E}-02$ & ND \\
\hline S05001-10A & C4416 & 12.63 & ND & $2.14 \mathrm{E}-03$ & $3.16 \mathrm{E}-04$ & 5.89E-02 & ND \\
\hline S05001-11B & $\mathrm{C} 4432$ & 20.77 & ND & $1.04 \mathrm{E}-03$ & $3.62 \mathrm{E}-04$ & $6.10 \mathrm{E}-02$ & ND \\
\hline S05001-11A & $\mathrm{C} 4432$ & 21.34 & ND & 9.24E-04 & $3.78 \mathrm{E}-04$ & $6.24 \mathrm{E}-02$ & ND \\
\hline S05001-12A & $\mathrm{C} 4440$ & 6.70 & ND & $(2.38 \mathrm{E}-05)$ & $3.62 \mathrm{E}-02$ & $1.29 \mathrm{E}-02$ & ND \\
\hline S05001-12 & $\mathrm{C} 4440$ & 7.10 & ND & $1.09 \mathrm{E}-03$ & $3.72 \mathrm{E}-04$ & $1.41 \mathrm{E}-02$ & ND \\
\hline S05001-13B & $\mathrm{C} 4445$ & 6.63 & ND & $2.80 \mathrm{E}-04$ & 4.27E-04 & 8.04E-03 & ND \\
\hline S05001-13A-1 & $\mathrm{C} 4445$ & 7.13 & ND & 2.24E-04 & $1.36 \mathrm{E}-03$ & $4.78 \mathrm{E}-03$ & $(1.02 \mathrm{E}-05)$ \\
\hline S05001-13A-2 & $\mathrm{C} 4445$ & 7.13 & ND & $6.84 \mathrm{E}-04$ & $6.54 \mathrm{E}-04$ & $3.63 \mathrm{E}-03$ & $(7.11 \mathrm{E}-06)$ \\
\hline S05001-14B & $\mathrm{C} 4438$ & 13.88 & $(6.91 \mathrm{E}-02)$ & $3.04 \mathrm{E}-03$ & $6.63 \mathrm{E}-04$ & $5.15 \mathrm{E}-02$ & $(1.19 \mathrm{E}-04)$ \\
\hline S05001-14A & $\mathrm{C} 4438$ & 14.63 & $(4.94 \mathrm{E}-02)$ & $1.33 \mathrm{E}-02$ & $6.85 \mathrm{E}-04$ & $8.89 \mathrm{E}-02$ & $(1.65 \mathrm{E}-04)$ \\
\hline S05001-14A Dup & $\mathrm{C} 4438$ & 14.63 & $(1.57 \mathrm{E}-01)$ & $1.40 \mathrm{E}-01$ & $1.08 \mathrm{E}-03$ & $6.91 \mathrm{E}-02$ & (3.41E-04) \\
\hline S05001-15B & $\mathrm{C} 4448$ & 17.38 & $(6.22 \mathrm{E}-02)$ & $2.67 \mathrm{E}-03$ & $4.09 \mathrm{E}-04$ & $1.78 \mathrm{E}-02$ & ND \\
\hline S05001-15A & $\mathrm{C} 4448$ & 18.13 & $(2.81 \mathrm{E}-01)$ & $8.66 \mathrm{E}-02$ & $2.01 \mathrm{E}-03$ & $4.58 \mathrm{E}-02$ & $(3.18 \mathrm{E}-04)$ \\
\hline S05001-17B & $\mathrm{C} 4436$ & 16.38 & $(1.18 \mathrm{E}-01)$ & $3.86 \mathrm{E}-04$ & $3.98 \mathrm{E}-03$ & $2.31 \mathrm{E}-02$ & ND \\
\hline S05001-17A & $\mathrm{C} 4436$ & 17.13 & 8.01E-01 & $1.72 \mathrm{E}-02$ & $2.68 \mathrm{E}-02$ & $3.46 \mathrm{E}-02$ & $(3.51 \mathrm{E}-04)$ \\
\hline S05001-18B & $\mathrm{C} 4434$ & 13.88 & $(1.16 \mathrm{E}-02)$ & $3.67 \mathrm{E}-04$ & $3.95 \mathrm{E}-03$ & $2.66 \mathrm{E}-02$ & ND \\
\hline S05001-18A & $\mathrm{C} 4434$ & 14.63 & ND & $(8.07 \mathrm{E}-06)$ & $2.92 \mathrm{E}-02$ & $1.96 \mathrm{E}-02$ & ND \\
\hline S05001-19B & $\mathrm{C} 4428$ & 15.30 & $(9.30 \mathrm{E}-03)$ & $5.47 \mathrm{E}-04$ & $(1.25 \mathrm{E}-04)$ & $1.01 \mathrm{E}-02$ & ND \\
\hline S05001-19A & $\mathrm{C} 4428$ & 18.38 & $(1.38 \mathrm{E}-01)$ & $5.99 \mathrm{E}-02$ & $2.13 \mathrm{E}-03$ & $4.62 \mathrm{E}-02$ & $(1.66 \mathrm{E}-04)$ \\
\hline S05001-19A Dup & $\mathrm{C} 4428$ & 18.38 & $(8.79 \mathrm{E}-02)$ & $4.46 \mathrm{E}-02$ & $1.93 \mathrm{E}-03$ & $4.68 \mathrm{E}-02$ & $(1.37 \mathrm{E}-04)$ \\
\hline
\end{tabular}


Table 4.6. (contd)

\begin{tabular}{||l|c|c|c|c|c|c|c||}
\hline \hline $\begin{array}{c}\text { Sample } \\
\text { Number }\end{array}$ & $\begin{array}{c}\text { Probe } \\
\text { Hole } \\
\text { Number }\end{array}$ & $\begin{array}{c}\text { Mid- } \\
\text { Depth } \\
\text { (ft bgs) }\end{array}$ & $\begin{array}{c}\text { Technetium-99 } \\
\text { (pCi/g soil) }\end{array}$ & Uranium-238 & Chromium-53 & Molybdenum-95 & Ruthenium-101 \\
\hline \hline S05001-20A & C4426 & 6.06 & ND & $1.45 \mathrm{E}-03$ & $(7.38 \mathrm{E}-05)$ & $1.46 \mathrm{E}-02$ & ND \\
\hline S05001-20 & C4426 & 6.73 & ND & $1.63 \mathrm{E}-03$ & $(1.90 \mathrm{E}-04)$ & $2.15 \mathrm{E}-02$ & ND \\
\hline S05001-21B-1 & C4430 & 18.88 & $(1.09 \mathrm{E}-02)$ & $1.05 \mathrm{E}-03$ & $7.76 \mathrm{E}-04$ & $4.70 \mathrm{E}-02$ & ND \\
\hline S05001-21B-2 & C4430 & 18.88 & $(1.11 \mathrm{E}-02)$ & $6.98 \mathrm{E}-04$ & $(1.90 \mathrm{E}-04)$ & $4.57 \mathrm{E}-02$ & $(8.81 \mathrm{E}-06)$ \\
\hline S05001-21A & C4430 & 19.63 & ND & $7.29 \mathrm{E}-04$ & $(2.46 \mathrm{E}-04)$ & $4.71 \mathrm{E}-02$ & ND \\
\hline $\begin{array}{l}\text { Shaded cells indicate grab samples. } \\
\text { Bold values denote elevated concentrations. } \\
\text { ND indicates the analyte was not detected. } \\
\text { Parentheses indicate reported value was less than the limit of quantification for the analysis. }\end{array}$ \\
\hline
\end{tabular}

The mobile metal data confirm the results from the cation and metal water-extraction results in that tank-related fluids are present in the vadose zone near the $\mathrm{C}-152$ pipeline leak. Again, the results from the mobile metals analyses indicate that the same regions identified previously, south of the C-152 and north of the C-151 Diversion Boxes and across the C-152 pipeline leak site west of the C-153 Diversion Box, are the primary locations of the contamination. Unfortunately, comparison of the ratio data of nitrate to technetium-99 in samples from these regions was too scattered to provide insight on the possibility of more than one leak episode being responsible for the contamination.

\subsubsection{Vadose Zone Pore Water Chemical Composition}

The 1:1 water-extraction data was manipulated to derive the pore-water composition of the vadose zone sediments so that comparisons to pore-water-corrected conductivity measurements could be made and electrical balances (anions vs. cations) of the samples could be performed. From knowledge of the moisture content of the sediment samples taken from the liners of each direct-push sampler and the grab samples, the amount of deionized water that would be needed to make the water extraction exactly one part water (total of native pore water and added deionized water) to one part by weight dry sediment was calculated. The ratio of the total volume of water in the extraction to the native mass of pore water is the dilution factor. An assumption was made that the deionized water acted solely as a diluent of the existing pore water and that the deionized water did not dissolve any of the solids in the sediments. Thus, by correcting for the dilution, an estimate of the actual chemical composition of the native pore water in the vadose zone sediments could be derived.

The assumption that none of the solid is dissolved during the water-extraction process is simplistic. In comparisons of actual vadose zone sediment pore water, which were obtained via ultracentrifugation of sediments using unsaturated flow apparatus (UFA), to the dilution-corrected calculated pore waters from both contaminated and uncontaminated sediments from the SX and B-BX Tank Farms (see Serne et al. $2002 \mathrm{~b}, 2002 \mathrm{c}, 2002 \mathrm{~d}, 2002 \mathrm{e}, 2002 \mathrm{f}$ ), it was found that for highly contaminated sediments, the comparison is quite good. For slightly contaminated or uncontaminated sediments, the dilution-corrected waterextraction data is biased high by a factor of 2 to 7 for many constituents, such that the true pore water is less saline. For the C-152 data set, sufficient sample material was not available to enable the collection of actual pore water via ultracentrifugation. Therefore, it is assumed that the derived pore-water concentrations for the $\mathrm{C}-152$ samples are slightly biased to higher concentrations. 


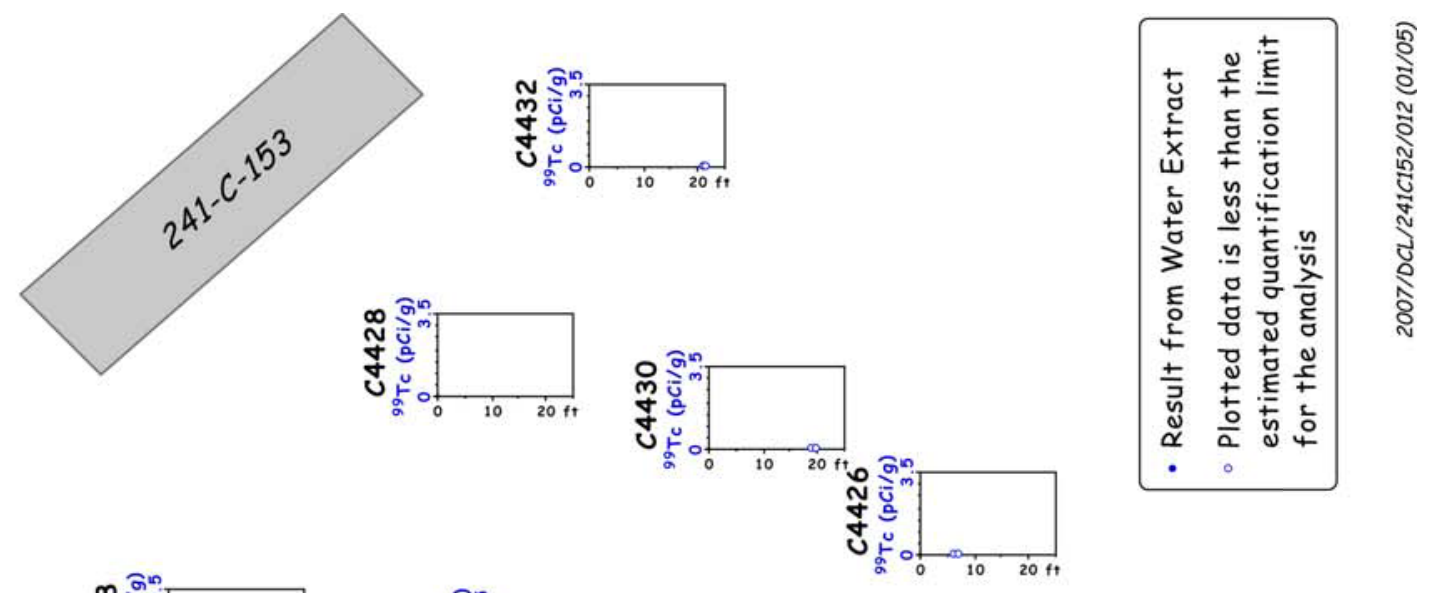

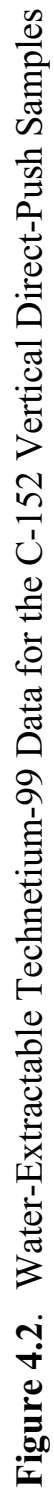
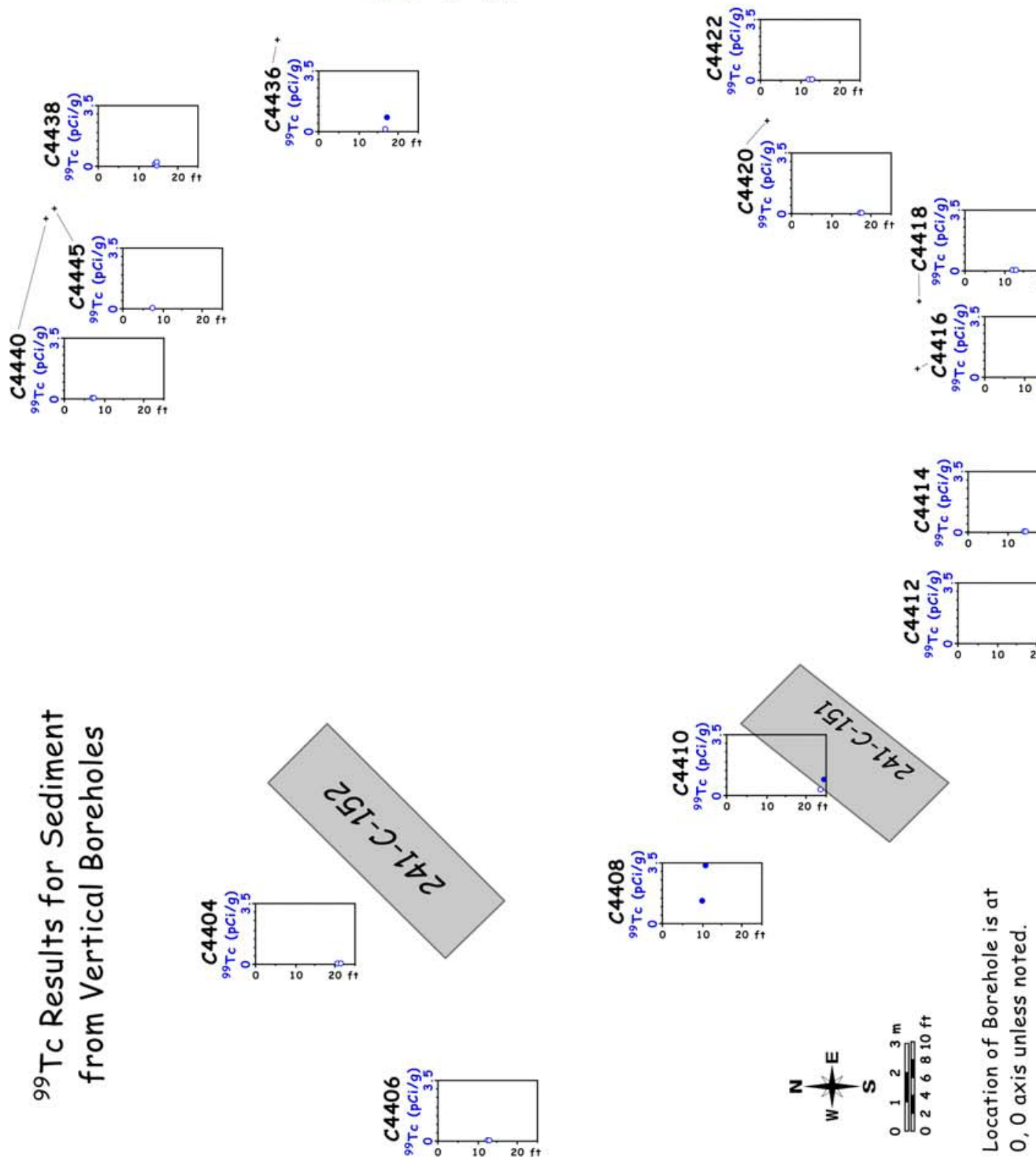

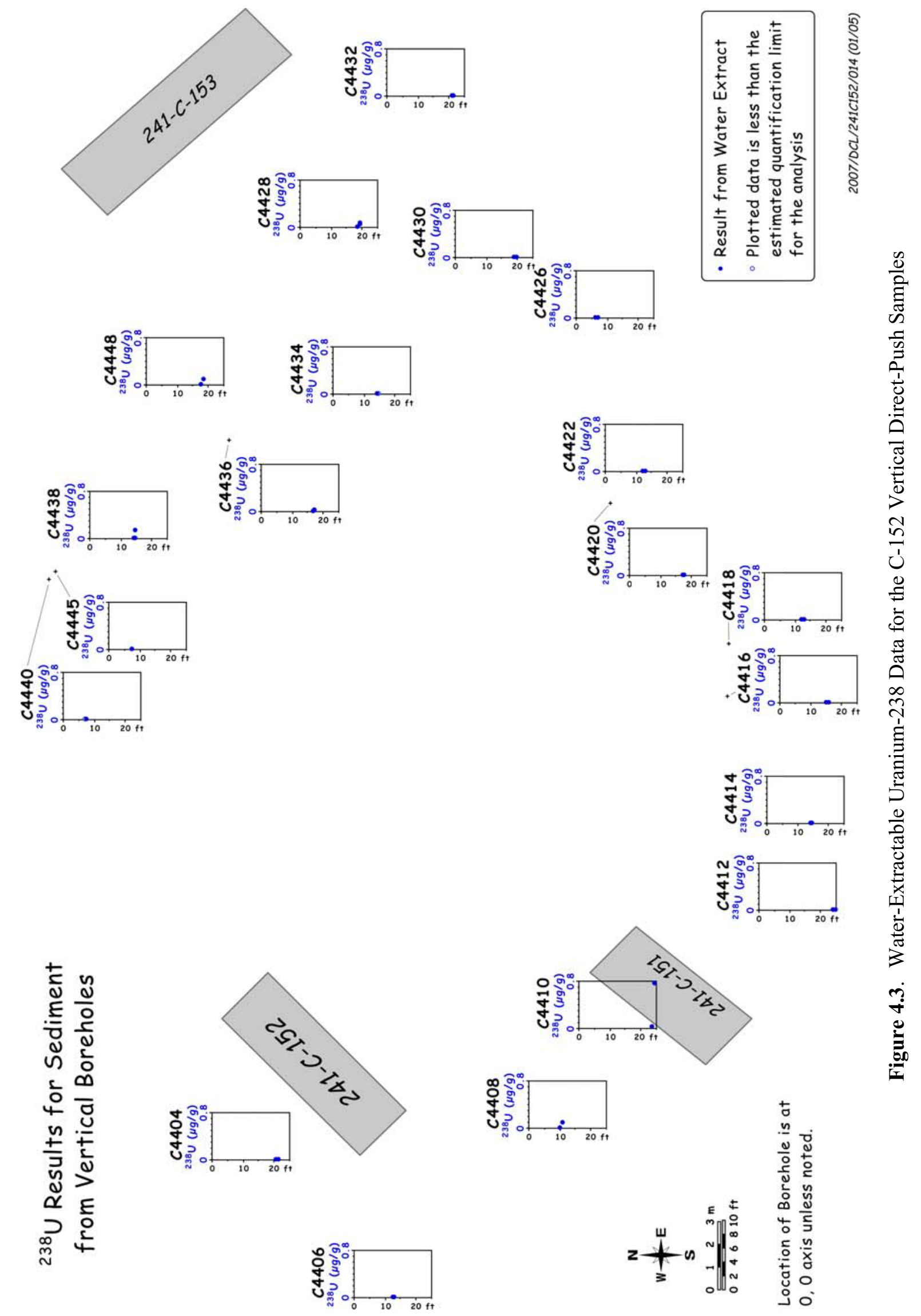
Tables 4.7 through 4.10 show the derived pore-water composition of key constituents in meq/L. Two of the sediment samples tested contained significantly more dissolved salts (approximately three times more than the average for all of the samples measured) than the rest of the vertical push samples analyzed as part of this study. Specifically, sample S05001-2A, from probe hole C4408, and sample S05001-4A, from probe hole $\mathrm{C} 4410$, contained $67.7 \mathrm{meq} / \mathrm{L}$ anions vs. $75.2 \mathrm{meq} / \mathrm{L}$ cations and $64.6 \mathrm{meq} / \mathrm{L}$ anions vs. $71.3 \mathrm{meq} / \mathrm{L}$ cations, respectively. Sample S05001-2A consisted of $71.7 \mathrm{meq} / \mathrm{L}$ sodium, with trace amounts of calcium $(0.68 \mathrm{meq} / \mathrm{L})$ and magnesium $(0.27 \mathrm{meq} / \mathrm{L})$, and no detectable potassium. The cation charge for this sample was compensated primarily by bicarbonate $(56.2 \mathrm{meq} / \mathrm{L})$ with lesser amounts of nitrate $(4.29 \mathrm{meq} / \mathrm{L})$, phosphate $(4.01 \mathrm{meq} / \mathrm{L})$, and sulfate $(2.48 \mathrm{meq} / \mathrm{L})$, and trace amounts of fluoride $(0.45 \mathrm{meq} / \mathrm{L})$ and chloride $(0.24 \mathrm{meq} / \mathrm{L})$.

Sample S05001-4A consisted of $68.7 \mathrm{meq} / \mathrm{L}$ sodium, with trace amounts of calcium $(0.50 \mathrm{meq} / \mathrm{L})$ and magnesium $(0.33 \mathrm{meq} / \mathrm{L})$, and no detectable potassium. The cation charge for this sample was compensated primarily by bicarbonate $(53.4 \mathrm{meq} / \mathrm{L})$ with lesser amounts of nitrate $(4.45 \mathrm{meq} / \mathrm{L})$, sulfate $(4.08 \mathrm{meq} / \mathrm{L})$, and phosphate $(1.94 \mathrm{meq} / \mathrm{L})$, and trace amounts of fluoride $(0.37 \mathrm{meq} / \mathrm{L})$ and chloride $(0.35 \mathrm{meq} / \mathrm{L})$. These concentrations are very dilute compared to the vadose zone pore waters found at the SX and BX tank farms where the total dissolved salt loads were as high as 7,000 to 17,000 and $1,000 \mathrm{meq} / \mathrm{L}$, respectively. At the borehole emplaced near Tank C-105 (C4297), the most saline pore water contained $212 \mathrm{meq} / \mathrm{L}$ cations and $223 \mathrm{meq} / \mathrm{L}$ anions. The most concentrated pore waters below Tank T-106 ranged from 200 to $250 \mathrm{meq} / \mathrm{L}$ each for cations and anions (total $\sim 450$ to $500 \mathrm{meq} / \mathrm{L}$ ) and below Tank TX-107, the most concentrated pore water had 850 total meq/L.

Overall, the calculated charge balance between cations and anions for all of the samples was quite good ( $<10 \%$ difference for most of the samples analyzed). However, sample S05001-10A contained more than twice as many dissolved anions (40.4 meq/L) as dissolved cations (13.2 meq/L). Based on comparison of the cation data for this sample vs. its companion sample (S05001-10B), it appears that the cation data for sample S05001-10A are biased low.

Sodium was present as the dominant water-extractable cation in all but one of the samples analyzed. Sample S05001-12A, from probe hole C4440, contained calcium as the dominant cation. Bicarbonate (measured via titration) was the primary anionic species in all but three of the samples analyzed. Sample S05001-11A from probe hole C4432 and samples S05001-20 and S05001-20A from probe hole C4426 contained sulfate as the dominant anion. The lack of samples containing calcium as the dominant cation indicates that the samples in this region have been impacted by a sodium-bearing waste fluid. The source(s) appears to be a moderately concentrated sodium-bearing waste solution that has displaced the natural divalent cations from the sediment cation-exchange sites in the sediments. The total vertical extent of the ion exchange front is unknown due to the lack of sediment samples from deeper in the vadose zone.

Of the four samples containing measurable amounts of technetium-99, the maximum concentration of technetium-99 in the C-152 vadose zone pore water was found in the samples from probe hole C4408. The peak sample measured, S05001-2A, contained a pore-water-corrected technetium-99 concentration of $3.21 \mathrm{E}+04 \mathrm{pCi} / \mathrm{L}$. This concentration was approximately five times less than the peak pore-watercorrected water-extractable technetium-99 concentration measured in the $\mathrm{C} 4297$ sediments from below Tank C-105. However, it should be noted that the samples collected around the C-152 pipeline were not collected as comprehensively as those at the $\mathrm{C} 4297$ borehole in the C Tank Farm; therefore, the limited 
Table 4.7. Calculated Pore Water Anion Concentrations in the C-152 Vertical Core and Grab Samples

\begin{tabular}{|c|c|c|c|c|c|c|c|c|}
\hline $\begin{array}{c}\text { Sample } \\
\text { Number }\end{array}$ & $\begin{array}{l}\text { Probe } \\
\text { Hole } \\
\text { Number }\end{array}$ & $\begin{array}{l}\text { Mid- } \\
\text { Depth } \\
\text { (ft bgs) }\end{array}$ & $\begin{array}{l}\text { Fluoride } \\
(\mathrm{meq} / \mathrm{L})\end{array}$ & $\begin{array}{c}\text { Chloride } \\
\text { (meq/L) }\end{array}$ & $\begin{array}{c}\text { Nitrate } \\
(\mathrm{meq} / \mathrm{L})\end{array}$ & $\begin{array}{c}\text { Sulfate } \\
(\mathrm{meq} / \mathrm{L})\end{array}$ & $\begin{array}{c}\text { Phosphate } \\
\text { (meq/L) }\end{array}$ & $\begin{array}{c}\text { Alkalinity } \\
(\mathrm{meq} / \mathrm{L})\end{array}$ \\
\hline S05001-1A & $\mathrm{C} 4406$ & 12.29 & $3.30 \mathrm{E}-01$ & $3.70 \mathrm{E}-01$ & $4.29 \mathrm{E}+00$ & $2.21 \mathrm{E}+00$ & ND & $1.06 \mathrm{E}+01$ \\
\hline S05001-1 & C4406 & 12.83 & $6.63 \mathrm{E}-01$ & $5.42 \mathrm{E}-01$ & $2.32 \mathrm{E}+00$ & $4.15 \mathrm{E}+00$ & ND & $2.31 \mathrm{E}+01$ \\
\hline S05001-2B & C4408 & 9.88 & $5.04 \mathrm{E}-01$ & $1.88 \mathrm{E}-01$ & $3.23 \mathrm{E}+00$ & $2.96 \mathrm{E}+00$ & $2.86 \mathrm{E}-01$ & $1.84 \mathrm{E}+01$ \\
\hline S05001-2A & C4408 & 10.63 & $4.53 \mathrm{E}-01$ & $2.35 \mathrm{E}-01$ & $4.29 \mathrm{E}+00$ & $2.48 \mathrm{E}+00$ & $4.01 \mathrm{E}+00$ & $5.62 \mathrm{E}+01$ \\
\hline S05001-3B & C4404 & 20.38 & $7.05 \mathrm{E}-01$ & $3.39 \mathrm{E}-01$ & $2.85 \mathrm{E}+00$ & $3.33 \mathrm{E}+00$ & ND & $2.89 \mathrm{E}+01$ \\
\hline S05001-3A & C4404 & 21.13 & $5.25 \mathrm{E}-01$ & $3.24 \mathrm{E}-01$ & $2.78 \mathrm{E}+00$ & $3.58 \mathrm{E}+00$ & ND & $1.82 \mathrm{E}+01$ \\
\hline S05001-4B & $\mathrm{C} 4410$ & 21.80 & $6.68 \mathrm{E}-01$ & $4.54 \mathrm{E}-01$ & $4.77 \mathrm{E}+00$ & $4.56 \mathrm{E}+00$ & ND & $3.18 \mathrm{E}+01$ \\
\hline S05001-4A & $\mathrm{C} 4410$ & 23.38 & $3.66 \mathrm{E}-01$ & $3.53 \mathrm{E}-01$ & $4.45 \mathrm{E}+00$ & $4.08 \mathrm{E}+00$ & $1.94 \mathrm{E}+00$ & $5.34 \mathrm{E}+01$ \\
\hline S05001-5B & C4414 & 24.13 & $6.26 \mathrm{E}-01$ & $4.63 \mathrm{E}-01$ & $4.87 \mathrm{E}+00$ & $4.04 \mathrm{E}+00$ & ND & $2.03 \mathrm{E}+01$ \\
\hline S05001-5A & $\mathrm{C} 4414$ & 24.80 & $3.58 \mathrm{E}-01$ & $4.57 \mathrm{E}-01$ & $2.11 \mathrm{E}+00$ & $2.56 \mathrm{E}+00$ & ND & $1.16 \mathrm{E}+01$ \\
\hline S05001-6B & $\mathrm{C} 4412$ & 13.88 & $5.16 \mathrm{E}-01$ & $2.77 \mathrm{E}-01$ & $2.47 \mathrm{E}+00$ & $5.52 \mathrm{E}+00$ & ND & $2.95 \mathrm{E}+01$ \\
\hline S05001-6A-1 & $\mathrm{C} 4412$ & 14.63 & $1.63 \mathrm{E}-01$ & $1.39 \mathrm{E}-01$ & $9.35 \mathrm{E}-01$ & $2.04 \mathrm{E}+00$ & ND & $6.48 \mathrm{E}+00$ \\
\hline S05001-6A-2 & $\mathrm{C} 4412$ & 14.63 & $5.68 \mathrm{E}-01$ & $4.94 \mathrm{E}-01$ & $3.26 \mathrm{E}+00$ & $7.52 \mathrm{E}+00$ & ND & $2.39 \mathrm{E}+01$ \\
\hline S05001-7B & $\mathrm{C} 4422$ & 11.88 & $5.79 \mathrm{E}-01$ & $7.90 \mathrm{E}-02$ & $5.74 \mathrm{E}-01$ & $1.77 \mathrm{E}+00$ & ND & $1.07 \mathrm{E}+01$ \\
\hline S05001-7A & C4422 & 12.63 & $6.11 \mathrm{E}-01$ & $2.12 \mathrm{E}-01$ & $1.47 \mathrm{E}+00$ & $2.75 \mathrm{E}+00$ & ND & $1.48 \mathrm{E}+01$ \\
\hline S05001-8B & $\mathrm{C} 4420$ & 13.30 & $2.55 \mathrm{E}-01$ & $4.09 \mathrm{E}-01$ & $3.32 \mathrm{E}+00$ & $2.69 \mathrm{E}+00$ & $\mathrm{ND}$ & $9.46 \mathrm{E}+00$ \\
\hline S05001-8A & $\mathrm{C} 4420$ & 16.88 & $3.62 \mathrm{E}-01$ & $4.91 \mathrm{E}-01$ & $2.34 \mathrm{E}+00$ & $3.92 \mathrm{E}+00$ & ND & $1.02 \mathrm{E}+01$ \\
\hline S05001-9B & $\mathrm{C} 4418$ & 17.63 & $5.58 \mathrm{E}-01$ & $1.29 \mathrm{E}-01$ & $1.23 \mathrm{E}+00$ & $1.02 \mathrm{E}+00$ & ND & $1.16 \mathrm{E}+01$ \\
\hline S05001-9A & C4418 & 18.30 & $9.16 \mathrm{E}-01$ & $1.22 \mathrm{E}-01$ & $1.45 \mathrm{E}+00$ & $1.42 \mathrm{E}+00$ & ND & $2.02 \mathrm{E}+01$ \\
\hline S05001-10B & $\mathrm{C} 4416$ & 11.88 & $6.58 \mathrm{E}-01$ & $4.54 \mathrm{E}-01$ & $1.37 \mathrm{E}+00$ & $4.15 \mathrm{E}+00$ & ND & $2.77 \mathrm{E}+01$ \\
\hline S05001-10A & $\mathrm{C} 4416$ & 12.63 & $2.12 \mathrm{E}-01$ & $4.06 \mathrm{E}-01$ & $2.95 \mathrm{E}+00$ & $2.90 \mathrm{E}+00$ & ND & $3.39 \mathrm{E}+01$ \\
\hline S05001-11B & $\mathrm{C} 4432$ & 20.77 & $1.80 \mathrm{E}-01$ & $5.53 \mathrm{E}-01$ & $2.18 \mathrm{E}+00$ & $3.60 \mathrm{E}+00$ & ND & $7.90 \mathrm{E}+00$ \\
\hline S05001-11A & $\mathrm{C} 4432$ & 21.34 & $2.57 \mathrm{E}-01$ & $1.67 \mathrm{E}+00$ & $3.29 \mathrm{E}+00$ & $1.10 \mathrm{E}+01$ & ND & $8.08 \mathrm{E}+00$ \\
\hline S05001-12A & $\mathrm{C} 4440$ & 6.70 & $5.42 \mathrm{E}-01$ & $2.10 \mathrm{E}-01$ & $4.10 \mathrm{E}+00$ & $4.48 \mathrm{E}+00$ & ND & $1.39 \mathrm{E}+01$ \\
\hline S05001-12 & $\mathrm{C} 4440$ & 7.10 & $1.93 \mathrm{E}-01$ & $2.16 \mathrm{E}-01$ & $4.29 \mathrm{E}+00$ & $2.35 \mathrm{E}+00$ & ND & $5.98 \mathrm{E}+00$ \\
\hline S05001-13B & $\mathrm{C} 4445$ & 6.63 & $4.08 \mathrm{E}-01$ & $2.40 \mathrm{E}-01$ & $7.00 \mathrm{E}+00$ & $1.45 \mathrm{E}+00$ & $2.75 \mathrm{E}+00$ & $1.50 \mathrm{E}+01$ \\
\hline S05001-13A-1 & $\mathrm{C} 4445$ & 7.13 & $2.65 \mathrm{E}-01$ & $1.59 \mathrm{E}-01$ & $4.45 \mathrm{E}+00$ & $7.58 \mathrm{E}-01$ & $1.42 \mathrm{E}+00$ & $1.19 \mathrm{E}+01$ \\
\hline S05001-13A-2 & $\mathrm{C} 4445$ & 7.13 & $1.26 \mathrm{E}-01$ & $2.30 \mathrm{E}-01$ & $3.97 \mathrm{E}+00$ & $1.40 \mathrm{E}+00$ & ND & $4.98 \mathrm{E}+00$ \\
\hline S05001-14B & $\mathrm{C} 4438$ & 13.88 & $3.41 \mathrm{E}-01$ & $1.42 \mathrm{E}-01$ & $1.65 \mathrm{E}+00$ & $2.35 \mathrm{E}+00$ & ND & $9.52 \mathrm{E}+00$ \\
\hline S05001-14A & $\mathrm{C} 4438$ & 14.63 & $2.24 \mathrm{E}-01$ & $1.36 \mathrm{E}-01$ & $1.74 \mathrm{E}+00$ & $2.35 \mathrm{E}+00$ & ND & $1.37 \mathrm{E}+01$ \\
\hline S05001-14A Dup & C4438 & 14.63 & $2.39 \mathrm{E}-01$ & $1.99 \mathrm{E}-01$ & $2.43 \mathrm{E}+00$ & $2.94 \mathrm{E}+00$ & $5.34 \mathrm{E}-01$ & $2.51 \mathrm{E}+01$ \\
\hline S05001-15B & C4448 & 17.38 & $7.21 \mathrm{E}-01$ & $2.43 \mathrm{E}-01$ & $1.07 \mathrm{E}+00$ & $4.40 \mathrm{E}+00$ & ND & $2.41 \mathrm{E}+01$ \\
\hline S05001-15A & $\mathrm{C} 4448$ & 18.13 & $2.03 \mathrm{E}-01$ & $9.08 \mathrm{E}-02$ & $1.41 \mathrm{E}+00$ & $2.52 \mathrm{E}+00$ & $3.38 \mathrm{E}-01$ & $1.87 \mathrm{E}+01$ \\
\hline S05001-17B & $\mathrm{C} 4436$ & 16.38 & $1.30 \mathrm{E}+00$ & $3.92 \mathrm{E}-01$ & $1.83 \mathrm{E}+00$ & $7.44 \mathrm{E}+00$ & ND & $3.28 \mathrm{E}+01$ \\
\hline S05001-17A & C4436 & 17.13 & $2.68 \mathrm{E}-01$ & $1.52 \mathrm{E}-01$ & $2.53 \mathrm{E}+00$ & $4.29 \mathrm{E}+00$ & $9.22 \mathrm{E}-01$ & $2.93 \mathrm{E}+01$ \\
\hline S05001-18B & $\mathrm{C} 4434$ & 13.88 & $7.37 \mathrm{E}-01$ & $2.34 \mathrm{E}-01$ & $1.83 \mathrm{E}+00$ & $2.44 \mathrm{E}+00$ & ND & $1.18 \mathrm{E}+01$ \\
\hline S05001-18A & $\mathrm{C} 4434$ & 14.63 & $8.58 \mathrm{E}-01$ & $2.21 \mathrm{E}-01$ & $9.77 \mathrm{E}-01$ & $7.63 \mathrm{E}+00$ & ND & $2.79 \mathrm{E}+01$ \\
\hline S05001-19B & $\mathrm{C} 4428$ & 15.30 & $7.37 \mathrm{E}-01$ & $2.75 \mathrm{E}-01$ & $6.68 \mathrm{E}-01$ & $4.44 \mathrm{E}+00$ & ND & $2.98 \mathrm{E}+01$ \\
\hline S05001-19A & C4428 & 18.38 & $1.69 \mathrm{E}-01$ & $1.24 \mathrm{E}-01$ & $1.16 \mathrm{E}+00$ & $6.73 \mathrm{E}-01$ & $3.28 \mathrm{E}-01$ & $2.02 \mathrm{E}+01$ \\
\hline S05001-19A Dup & $\mathrm{C} 4428$ & 18.38 & $1.73 \mathrm{E}-01$ & $1.55 \mathrm{E}-01$ & $1.35 \mathrm{E}+00$ & $8.83 \mathrm{E}-01$ & $3.25 \mathrm{E}-01$ & $2.08 \mathrm{E}+01$ \\
\hline S05001-20A & $\mathrm{C} 4426$ & 6.06 & ND & $2.34 \mathrm{E}-01$ & $2.03 \mathrm{E}+00$ & $2.96 \mathrm{E}+01$ & ND & $9.13 \mathrm{E}+00$ \\
\hline S05001-20 & $\mathrm{C} 4426$ & 6.73 & $3.47 \mathrm{E}-01$ & $8.55 \mathrm{E}-02$ & $9.55 \mathrm{E}-01$ & $6.44 \mathrm{E}+00$ & ND & $6.36 \mathrm{E}+00$ \\
\hline S05001-21B-1 & $\mathrm{C} 4430$ & 18.88 & $2.88 \mathrm{E}-01$ & $2.76 \mathrm{E}-01$ & $2.06 \mathrm{E}+00$ & $3.13 \mathrm{E}+00$ & ND & $1.02 \mathrm{E}+01$ \\
\hline S05001-21B-2 & $\mathrm{C} 4430$ & 18.88 & $2.47 \mathrm{E}-01$ & $3.50 \mathrm{E}-01$ & $2.28 \mathrm{E}+00$ & $3.08 \mathrm{E}+00$ & ND & $1.12 \mathrm{E}+01$ \\
\hline S05001-21A & $\mathrm{C} 4430$ & 19.63 & $3.19 \mathrm{E}-01$ & 4.17E-01 & $1.51 \mathrm{E}+00$ & $3.23 \mathrm{E}+00$ & ND & $1.40 \mathrm{E}+01$ \\
\hline \multicolumn{9}{|c|}{$\begin{array}{l}\text { Shaded cells indicate grab samples. } \\
\text { Bold values denote elevated concentrations. } \\
\text { ND indicates the analyte was not detected in the sample. }\end{array}$} \\
\hline
\end{tabular}


Table 4.8. Calculated Pore Water Cation Concentrations in the C-152 Vertical Core and Grab Samples

\begin{tabular}{|c|c|c|c|c|c|c|c|}
\hline $\begin{array}{c}\text { Sample } \\
\text { Number }\end{array}$ & $\begin{array}{c}\text { Probe Hole } \\
\text { Number }\end{array}$ & $\begin{array}{c}\text { Mid- } \\
\text { Depth } \\
\text { (ft bgs) }\end{array}$ & $\begin{array}{l}\text { Calcium } \\
(\mathrm{meq} / \mathrm{L})\end{array}$ & $\begin{array}{c}\text { Magnesium } \\
(\mathrm{meq} / \mathrm{L})\end{array}$ & $\begin{array}{c}\text { Strontium } \\
(\mathrm{meq} / \mathrm{L})\end{array}$ & $\begin{array}{l}\text { Sodium } \\
(\mathrm{meq} / \mathrm{L})\end{array}$ & $\begin{array}{c}\text { Potassium } \\
(\mathrm{meq} / \mathrm{L})\end{array}$ \\
\hline S05001-1A & C4406 & 12.29 & $2.46 \mathrm{E}+00$ & $1.19 \mathrm{E}+00$ & 7.01E-03 & $1.20 \mathrm{E}+01$ & $8.80 \mathrm{E}-01$ \\
\hline S05001-1 & C4406 & 12.83 & $6.27 \mathrm{E}+00$ & $3.87 \mathrm{E}+00$ & $2.08 \mathrm{E}-02$ & $1.85 \mathrm{E}+01$ & $2.42 \mathrm{E}+00$ \\
\hline S05001-2B & C4408 & 9.88 & $6.89 \mathrm{E}-01$ & $2.56 E-01$ & (1.91E-03) & $2.36 \mathrm{E}+01$ & $5.05 \mathrm{E}-01$ \\
\hline S05001-2A & C4408 & 10.63 & $6.80 \mathrm{E}-01$ & $2.70 E-01$ & $(1.90 \mathrm{E}-03)$ & $7.17 \mathbf{E}+01$ & $4.30 \mathrm{E}-01$ \\
\hline S05001-3B & C4404 & 20.38 & $4.58 \mathrm{E}+00$ & $2.01 \mathrm{E}+00$ & $(1.17 \mathrm{E}-02)$ & $2.88 \mathrm{E}+01$ & $2.13 \mathrm{E}+00$ \\
\hline S05001-3A & $\mathrm{C} 4404$ & 21.13 & $4.71 \mathrm{E}+00$ & $2.21 \mathrm{E}+00$ & $1.33 \mathrm{E}-02$ & $1.48 \mathrm{E}+01$ & $1.61 \mathrm{E}+00$ \\
\hline S05001-4B & $\mathrm{C} 4410$ & 21.80 & $1.07 \mathrm{E}+00$ & $3.96 \mathrm{E}-01$ & $(3.72 \mathrm{E}-03)$ & $4.16 \mathrm{E}+01$ & $9.83 \mathrm{E}-01$ \\
\hline S05001-4A & $\mathrm{C} 4410$ & 23.38 & $5.02 \mathrm{E}-01$ & $3.26 E-01$ & $(2.14 \mathrm{E}-03)$ & $6.87 E+01$ & $5.00 \mathrm{E}-01$ \\
\hline S05001-5B & $\mathrm{C} 4414$ & 24.13 & $2.81 \mathrm{E}+00$ & $9.63 \mathrm{E}-01$ & $(5.62 \mathrm{E}-03)$ & $2.37 \mathrm{E}+01$ & $9.15 \mathrm{E}-01$ \\
\hline S05001-5A & $\mathrm{C} 4414$ & 24.80 & $1.44 \mathrm{E}+00$ & $5.04 \mathrm{E}-01$ & $(2.97 \mathrm{E}-03)$ & $1.42 \mathrm{E}+01$ & $5.55 \mathrm{E}-01$ \\
\hline S05001-6B & $\mathrm{C} 4412$ & 13.88 & $1.07 \mathrm{E}+01$ & $5.16 \mathrm{E}+00$ & 2.72E-02 & $1.06 \mathrm{E}+01$ & $2.35 \mathrm{E}+00$ \\
\hline S05001-6A-1 & C4412 & 14.63 & $2.07 \mathrm{E}+00$ & $1.05 \mathrm{E}+00$ & $6.07 \mathrm{E}-03$ & $5.09 \mathrm{E}+00$ & $5.53 \mathrm{E}-01$ \\
\hline S05001-6A-2 & $\mathrm{C} 4412$ & 14.63 & $9.51 \mathrm{E}+00$ & $4.75 \mathrm{E}+00$ & 2.88E-02 & $1.59 \mathrm{E}+01$ & $2.26 \mathrm{E}+00$ \\
\hline S05001-7B & $\mathrm{C} 4422$ & 11.88 & $1.30 \mathrm{E}+00$ & $4.28 \mathrm{E}-01$ & $(2.56 \mathrm{E}-03)$ & $1.20 \mathrm{E}+01$ & $5.13 \mathrm{E}-01$ \\
\hline S05001-7A & $\mathrm{C} 4422$ & 12.63 & $2.63 \mathrm{E}+00$ & $8.40 \mathrm{E}-01$ & 4.79E-03 & $1.53 \mathrm{E}+01$ & $9.08 \mathrm{E}-01$ \\
\hline S05001-8B & $\mathrm{C} 4420$ & 13.30 & $2.12 \mathrm{E}+00$ & $7.46 \mathrm{E}-01$ & $4.29 \mathrm{E}-03$ & $1.15 \mathrm{E}+01$ & $5.45 \mathrm{E}-01$ \\
\hline S05001-8A & $\mathrm{C} 4420$ & 16.88 & $1.57 \mathrm{E}+00$ & 5.67E-01 & $(3.29 \mathrm{E}-03)$ & $1.43 \mathrm{E}+01$ & $5.48 \mathrm{E}-01$ \\
\hline S05001-9B & $\mathrm{C} 4418$ & 17.63 & $1.13 \mathrm{E}+00$ & $4.01 \mathrm{E}-01$ & $(2.44 \mathrm{E}-03)$ & $1.40 \mathrm{E}+01$ & $5.10 \mathrm{E}-01$ \\
\hline S05001-9A & $\mathrm{C} 4418$ & 18.30 & $1.61 \mathrm{E}+00$ & $5.65 \mathrm{E}-01$ & $(3.54 \mathrm{E}-03)$ & $2.23 \mathrm{E}+01$ & $8.15 \mathrm{E}-01$ \\
\hline S05001-10B & $\mathrm{C} 4416$ & 11.88 & $2.74 \mathrm{E}+00$ & $9.63 \mathrm{E}-01$ & $(6.44 \mathrm{E}-03)$ & $2.99 \mathrm{E}+01$ & $1.28 \mathrm{E}+00$ \\
\hline S05001-10A & $\mathrm{C} 4416$ & 12.63 & $1.44 \mathrm{E}+00$ & $5.14 \mathrm{E}-01$ & $2.65 \mathrm{E}-03$ & $1.01 \mathrm{E}+01$ & $3.93 \mathrm{E}-01$ \\
\hline S05001-11B & $\mathrm{C} 4432$ & 20.77 & $2.03 \mathrm{E}+00$ & $7.15 \mathrm{E}-01$ & $4.25 \mathrm{E}-03$ & $1.03 \mathrm{E}+01$ & $5.73 \mathrm{E}-01$ \\
\hline S05001-11A & $\mathrm{C} 4432$ & 21.34 & $3.94 \mathrm{E}+00$ & $1.22 \mathrm{E}+00$ & $6.78 \mathrm{E}-03$ & $1.67 \mathrm{E}+01$ & 7.78E-01 \\
\hline S05001-12A & $\mathrm{C} 4440$ & 6.70 & $1.00 \mathrm{E}+01$ & $3.96 \mathrm{E}-01$ & $1.55 \mathrm{E}-02$ & $9.74 \mathrm{E}+00$ & $1.46 \mathrm{E}+00$ \\
\hline S05001-12 & $\mathrm{C} 4440$ & 7.10 & $2.76 \mathrm{E}+00$ & $1.00 \mathrm{E}+00$ & $6.37 \mathrm{E}-03$ & $5.70 \mathrm{E}+00$ & 4.83E-01 \\
\hline S05001-13B & $\mathrm{C} 4445$ & 6.63 & $5.78 \mathrm{E}+00$ & $2.14 \mathrm{E}+00$ & $1.13 \mathrm{E}-02$ & $1.33 \mathrm{E}+01$ & $2.35 \mathrm{E}+00$ \\
\hline S05001-13A-1 & $\mathrm{C} 4445$ & 7.13 & $4.27 \mathrm{E}+00$ & $1.50 \mathrm{E}+00$ & $8.15 \mathrm{E}-03$ & $1.02 \mathrm{E}+01$ & $1.29 \mathrm{E}+00$ \\
\hline S05001-13A-2 & $\mathrm{C} 4445$ & 7.13 & $1.96 \mathrm{E}+00$ & $5.03 \mathrm{E}-01$ & $4.50 \mathrm{E}-03$ & $6.04 \mathrm{E}+00$ & $3.95 \mathrm{E}-01$ \\
\hline S05001-14B & $\mathrm{C} 4438$ & 13.88 & $1.44 \mathrm{E}+00$ & $4.78 \mathrm{E}-01$ & $3.47 \mathrm{E}-03$ & $1.13 \mathrm{E}+01$ & $6.48 \mathrm{E}-01$ \\
\hline S05001-14A & $\mathrm{C} 4438$ & 14.63 & $6.58 \mathrm{E}-01$ & $2.26 E-01$ & $(1.85 \mathrm{E}-03)$ & $1.80 \mathrm{E}+01$ & 4.83E-01 \\
\hline S05001-14A Dup & $\mathrm{C} 4438$ & 14.63 & $5.20 \mathrm{E}-01$ & $1.89 E-01$ & $(1.61 \mathrm{E}-03)$ & $3.43 \mathrm{E}+01$ & $4.98 \mathrm{E}-01$ \\
\hline S05001-15B & $\mathrm{C} 4448$ & 17.38 & $6.44 \mathrm{E}+00$ & $2.62 \mathrm{E}+00$ & $1.55 \mathrm{E}-02$ & $2.07 \mathrm{E}+01$ & $1.79 \mathrm{E}+00$ \\
\hline S05001-15A & $\mathrm{C} 4448$ & 18.13 & $5.20 \mathrm{E}-01$ & $2.90 E-01$ & $(1.51 \mathrm{E}-03)$ & $2.29 \mathrm{E}+01$ & $4.38 \mathrm{E}-01$ \\
\hline S05001-17B & $\mathrm{C} 4436$ & 16.38 & $6.09 \mathrm{E}+00$ & $1.79 \mathrm{E}+00$ & $(1.27 \mathrm{E}-02)$ & $3.57 \mathrm{E}+01$ & $2.04 \mathrm{E}+00$ \\
\hline S05001-17A & $\mathrm{C} 4436$ & 17.13 & $5.02 \mathrm{E}-01$ & $1.47 E-01$ & $(1.13 \mathrm{E}-03)$ & $4.03 E+01$ & $3.35 \mathrm{E}-01$ \\
\hline S05001-18B & $\mathrm{C} 4434$ & 13.88 & $1.73 \mathrm{E}+00$ & 4.70E-01 & $(3.26 \mathrm{E}-03)$ & $1.40 \mathrm{E}+01$ & $7.70 \mathrm{E}-01$ \\
\hline S05001-18A & $\mathrm{C} 4434$ & 14.63 & $8.93 \mathrm{E}+00$ & $2.84 E-01$ & $1.39 \mathrm{E}-02$ & $2.73 \mathrm{E}+01$ & $1.65 \mathrm{E}+00$ \\
\hline S05001-19B & C4428 & 15.30 & $8.53 \mathrm{E}+00$ & $3.42 \mathrm{E}+00$ & $2.06 \mathrm{E}-02$ & $2.18 \mathrm{E}+01$ & $2.11 \mathrm{E}+00$ \\
\hline
\end{tabular}


Table 4.8. (contd)

\begin{tabular}{|c|c|c|c|c|c|c|c|}
\hline $\begin{array}{l}\text { Sample } \\
\text { Number }\end{array}$ & $\begin{array}{c}\text { Probe Hole } \\
\text { Number }\end{array}$ & $\begin{array}{l}\text { Mid- } \\
\text { Depth } \\
\text { (ft bgs) }\end{array}$ & $\begin{array}{l}\text { Calcium } \\
(\mathrm{meq} / \mathrm{L})\end{array}$ & $\begin{array}{c}\text { Magnesium } \\
(\mathrm{meq} / \mathrm{L})\end{array}$ & $\begin{array}{c}\text { Strontium } \\
(\mathrm{meq} / \mathrm{L})\end{array}$ & $\begin{array}{c}\text { Sodium } \\
\text { (meq/L) }\end{array}$ & $\begin{array}{c}\text { Potassium } \\
\text { (meq/L) }\end{array}$ \\
\hline S05001-19A & C4428 & 18.38 & $1.75 E-01$ & $6.76 E-02$ & (7.67E-04) & $2.53 \mathrm{E}+01$ & $1.87 \mathrm{E}-01$ \\
\hline S05001-19A Dup & C4428 & 18.38 & $1.93 E-01$ & $8.64 E-02$ & $(7.42 \mathrm{E}-04)$ & $2.39 \mathrm{E}+01$ & $1.99 \mathrm{E}-01$ \\
\hline S05001-20A & $\mathrm{C} 4426$ & 6.06 & $1.74 \mathrm{E}+01$ & $2.33 \mathrm{E}+00$ & 2.49E-02 & $1.70 \mathrm{E}+01$ & $1.53 \mathrm{E}+00$ \\
\hline S05001-20 & $\mathrm{C} 4426$ & 6.73 & $3.48 \mathrm{E}+00$ & $1.03 \mathrm{E}+00$ & 7.33E-03 & $8.43 \mathrm{E}+00$ & $5.88 \mathrm{E}-01$ \\
\hline S05001-21B-1 & $\mathrm{C} 4430$ & 18.88 & $3.65 \mathrm{E}+00$ & $1.40 \mathrm{E}+00$ & $8.35 \mathrm{E}-03$ & $9.52 \mathrm{E}+00$ & $8.90 \mathrm{E}-01$ \\
\hline S05001-21B-2 & $\mathrm{C} 4430$ & 18.88 & $3.08 \mathrm{E}+00$ & $1.11 \mathrm{E}+00$ & $7.12 \mathrm{E}-03$ & $1.17 \mathrm{E}+01$ & $8.80 \mathrm{E}-01$ \\
\hline S05001-21A & $\mathrm{C} 4430$ & 19.63 & $2.61 \mathrm{E}+00$ & $9.22 \mathrm{E}-01$ & $5.66 \mathrm{E}-03$ & $1.51 \mathrm{E}+01$ & $9.25 \mathrm{E}-01$ \\
\hline \multicolumn{8}{|c|}{$\begin{array}{l}\text { Shaded cells indicate grab samples. } \\
\text { Bold values denote elevated concentrations. } \\
\text { Italicized values denote low concentrations. } \\
\text { Parentheses indicate the analyte was below the limit of quantification for the analysis. }\end{array}$} \\
\hline
\end{tabular}

depth coverage of the direct-push samples only provided a snapshot of the vadose zone at one location and one depth. The four samples containing measurable technetium-99 had pore-water-corrected concentrations that were 8 to 32 times the drinking water standard. The maximum concentration of dissolved uranium was found in a sample from probe hole C4410 at a concentration of $8.25 \mathrm{mg} / \mathrm{L}$, which was nearly twelve times higher than the peak water-extractable uranium concentration measured in samples from the C4297 borehole $(0.691 \mathrm{mg} / \mathrm{L})$. Two other direct-push samples contained elevated derived pore-water uranium concentrations, S05001-14A Dup from probe hole C4438 and S05001-15A from probe hole C4448, with values of 1.57 and $1.07 \mathrm{mg} / \mathrm{L}$, respectively.

\subsubsection{8-M Nitric Acid-Leachable Amounts of Selected Elements in the C-152 Sediments}

The same cores and grab samples that were characterized for water-extractable constituents were also characterized to see how much of the various constituents could be leached with hot 8-M nitric acid. A comparison between the quantities that were acid-leachable with those that are water-extractable often indicates the relative mobility of a given constituent and can sometimes differentiate man-disposed from naturally occurring constituents. The acid-leachable concentrations are shown in Tables 4.11 through 4.13 .

The acid-leach data for the major cations and metals in the samples, listed in Tables 4.11 and 4.12, show that the samples are generally composed of similar lithologic material (perceived mineral content). For most constituents, there was no sign of elevated values of acid-leachable concentrations in the C-152 sediments, with the exception of sodium, uranium-238, molybdenum, and ruthenium. The acid-leachable sodium, likely tank-waste-related, was elevated in five of the probe holes and had an average concentration that was about two times higher than the average concentration measured in all of the C-152 samples tested. 
Table 4.9. Calculated Pore Water Metal Concentrations in the C-152 Vertical Core and Grab Samples

\begin{tabular}{|c|c|c|c|c|c|}
\hline $\begin{array}{c}\text { Sample } \\
\text { Number }\end{array}$ & $\begin{array}{l}\text { Probe Hole } \\
\text { Number }\end{array}$ & $\begin{array}{l}\text { Mid- } \\
\text { Depth } \\
\text { (ft bgs) }\end{array}$ & $\begin{array}{c}\text { Aluminum } \\
(\mathrm{meq} / \mathrm{L})\end{array}$ & $\begin{array}{c}\text { Iron } \\
(\mathrm{meq} / \mathrm{L})\end{array}$ & $\begin{array}{c}\text { Silicon } \\
(\mathrm{meq} / \mathrm{L})\end{array}$ \\
\hline S05001-1A & C4406 & 12.29 & 3.39E-02 & 4.27E-02 & $1.07 \mathrm{E}+00$ \\
\hline S05001-1 & C4406 & 12.83 & $1.98 \mathrm{E}-01$ & $1.06 \mathrm{E}-01$ & $2.76 \mathrm{E}+00$ \\
\hline S05001-2B & C4408 & 9.88 & $1.01 \mathrm{E}-01$ & $9.38 \mathrm{E}-02$ & $1.64 \mathrm{E}+00$ \\
\hline S05001-2A & C4408 & 10.63 & $2.27 \mathrm{E}-01$ & $2.18 \mathrm{E}-01$ & $1.68 \mathrm{E}+00$ \\
\hline S05001-3B & C4404 & 20.38 & $3.19 \mathrm{E}-01$ & $9.65 \mathrm{E}-02$ & $2.68 \mathrm{E}+00$ \\
\hline S05001-3A & C4404 & 21.13 & $1.10 \mathrm{E}-01$ & $3.81 \mathrm{E}-02$ & $1.78 \mathrm{E}+00$ \\
\hline S05001-4B & C4410 & 21.80 & $3.11 \mathrm{E}-01$ & $1.34 \mathrm{E}-01$ & $2.34 \mathrm{E}+00$ \\
\hline S05001-4A & C4410 & 23.38 & $1.70 \mathrm{E}-01$ & $3.96 \mathrm{E}-02$ & $1.04 \mathrm{E}+00$ \\
\hline S05001-5B & C4414 & 24.13 & $5.06 \mathrm{E}-02$ & $4.88 \mathrm{E}-02$ & $2.11 \mathrm{E}+00$ \\
\hline S05001-5A & C4414 & 24.80 & $5.09 \mathrm{E}-02$ & $3.02 \mathrm{E}-02$ & $1.05 \mathrm{E}+00$ \\
\hline S05001-6B & C4412 & 13.88 & $1.97 \mathrm{E}-01$ & $4.61 \mathrm{E}-02$ & $2.42 \mathrm{E}+00$ \\
\hline S05001-6A-1 & C4412 & 14.63 & 5.37E-02 & $2.52 \mathrm{E}-02$ & $6.56 \mathrm{E}-01$ \\
\hline S05001-6A-2 & C4412 & 14.63 & $2.05 \mathrm{E}-01$ & $5.77 \mathrm{E}-02$ & $2.48 \mathrm{E}+00$ \\
\hline S05001-7B & C4422 & 11.88 & $3.11 \mathrm{E}-02$ & 2.41E-02 & $1.22 \mathrm{E}+00$ \\
\hline S05001-7A & $\mathrm{C} 4422$ & 12.63 & $5.78 \mathrm{E}-02$ & $4.45 \mathrm{E}-02$ & $1.88 \mathrm{E}+00$ \\
\hline S05001-8B & C4420 & 13.30 & $(2.58 \mathrm{E}-02)$ & $6.25 \mathrm{E}-02$ & $1.09 \mathrm{E}+00$ \\
\hline S05001-8A & C4420 & 16.88 & $5.83 \mathrm{E}-02$ & $3.48 \mathrm{E}-02$ & $1.03 \mathrm{E}+00$ \\
\hline S05001-9B & C4418 & 17.63 & $1.39 \mathrm{E}-01$ & $1.55 \mathrm{E}-01$ & $1.30 \mathrm{E}+00$ \\
\hline S05001-9A & C4418 & 18.30 & $7.68 \mathrm{E}-02$ & $6.15 \mathrm{E}-02$ & $2.07 \mathrm{E}+00$ \\
\hline S05001-10B & C4416 & 11.88 & $2.36 \mathrm{E}-01$ & $1.06 \mathrm{E}-01$ & $2.32 \mathrm{E}+00$ \\
\hline S05001-10A & C4416 & 12.63 & $(1.29 \mathrm{E}-02)$ & $2.02 \mathrm{E}-02$ & 7.23E-01 \\
\hline S05001-11B & C4432 & 20.77 & (2.01E-02) & 2.12E-02 & $9.55 \mathrm{E}-01$ \\
\hline S05001-11A & C4432 & 21.34 & (2.62E-02) & $1.30 \mathrm{E}-02$ & $1.05 \mathrm{E}+00$ \\
\hline S05001-12A & C4440 & 6.70 & $(2.51 \mathrm{E}-02)$ & $1.19 \mathrm{E}-02$ & $3.03 \mathrm{E}+00$ \\
\hline S05001-12 & C4440 & 7.10 & $3.52 \mathrm{E}-02$ & $5.77 \mathrm{E}-02$ & $8.08 \mathrm{E}-01$ \\
\hline S05001-13B & C4445 & 6.63 & $8.01 \mathrm{E}-02$ & $6.25 \mathrm{E}-02$ & $2.66 \mathrm{E}+00$ \\
\hline S05001-13A-1 & $\mathrm{C} 4445$ & 7.13 & $4.21 \mathrm{E}-02$ & 4.17E-02 & $1.77 \mathrm{E}+00$ \\
\hline S05001-13A-2 & $\mathrm{C} 4445$ & 7.13 & $2.82 \mathrm{E}-02$ & $3.60 \mathrm{E}-02$ & $7.24 \mathrm{E}-01$ \\
\hline S05001-14B & C4438 & 13.88 & $5.28 \mathrm{E}-02$ & 4.11E-02 & $1.23 \mathrm{E}+00$ \\
\hline S05001-14A & C4438 & 14.63 & 1.04E-01 & $7.55 \mathrm{E}-02$ & $1.15 \mathrm{E}+00$ \\
\hline S05001-14A Dup & C4438 & 14.63 & $2.23 \mathrm{E}-01$ & $1.90 \mathrm{E}-01$ & $1.61 \mathrm{E}+00$ \\
\hline S05001-15B & C4448 & 17.38 & $2.41 \mathrm{E}-01$ & $1.02 \mathrm{E}-01$ & $3.65 \mathrm{E}+00$ \\
\hline S05001-15A & C4448 & 18.13 & $1.33 \mathrm{E}-01$ & $8.84 \mathrm{E}-02$ & $1.71 \mathrm{E}+00$ \\
\hline S05001-17B & C4436 & 16.38 & $4.30 \mathrm{E}-01$ & $1.68 \mathrm{E}-01$ & $6.32 \mathrm{E}+00$ \\
\hline S05001-17A & C4436 & 17.13 & $2.74 \mathrm{E}-01$ & $1.77 \mathrm{E}-01$ & $3.47 \mathrm{E}+00$ \\
\hline
\end{tabular}


Table 4.9. (contd)

\begin{tabular}{||l|c|c|c|c|c||}
\hline $\begin{array}{c}\text { Sample } \\
\text { Number }\end{array}$ & $\begin{array}{c}\text { Probe Hole } \\
\text { Number }\end{array}$ & $\begin{array}{c}\text { Mid- } \\
\text { Depth } \\
\text { (ft bgs })\end{array}$ & $\begin{array}{c}\text { Aluminum } \\
(\mathrm{meq} / \mathrm{L})\end{array}$ & $\begin{array}{c}\text { Iron } \\
(\mathrm{meq} / \mathrm{L})\end{array}$ & $\begin{array}{c}\text { Silicon } \\
(\mathrm{meq} / \mathrm{L})\end{array}$ \\
\hline \hline S05001-18B & $\mathrm{C} 4434$ & 13.88 & $7.67 \mathrm{E}-02$ & $5.50 \mathrm{E}-02$ & $1.93 \mathrm{E}+00$ \\
\hline S05001-18A & $\mathrm{C} 4434$ & 14.63 & $1.25 \mathrm{E}-01$ & $6.63 \mathrm{E}-02$ & $5.92 \mathrm{E}+00$ \\
\hline S05001-19B & $\mathrm{C} 4428$ & 15.30 & $2.07 \mathrm{E}-01$ & $8.73 \mathrm{E}-02$ & $3.98 \mathrm{E}+00$ \\
\hline S05001-19A & $\mathrm{C} 4428$ & 18.38 & $1.35 \mathrm{E}-01$ & $1.54 \mathrm{E}-01$ & $9.36 \mathrm{E}-01$ \\
\hline S05001-19A Dup & $\mathrm{C} 4428$ & 18.38 & $1.56 \mathrm{E}-01$ & $2.11 \mathrm{E}-01$ & $9.90 \mathrm{E}-01$ \\
\hline S05001-20A & $\mathrm{C} 4426$ & 6.06 & ND & $(6.47 \mathrm{E}-03)$ & $1.81 \mathrm{E}+00$ \\
\hline S05001-20 & $\mathrm{C} 4426$ & 6.73 & $2.82 \mathrm{E}-02$ & $3.14 \mathrm{E}-02$ & $9.67 \mathrm{E}-01$ \\
\hline S05001-21B-1 & $\mathrm{C} 4430$ & 18.88 & $(1.85 \mathrm{E}-02)$ & $1.26 \mathrm{E}-02$ & $1.24 \mathrm{E}+00$ \\
\hline S05001-21B-2 & $\mathrm{C} 4430$ & 18.88 & $5.32 \mathrm{E}-02$ & $3.56 \mathrm{E}-02$ & $1.38 \mathrm{E}+00$ \\
\hline S05001-21A & C4430 & 19.63 & $8.90 \mathrm{E}-02$ & $5.29 \mathrm{E}-02$ & $1.53 \mathrm{E}+00$ \\
\hline $\begin{array}{l}\text { Shaded cells indicate grab samples. } \\
\text { ND indicates the analyte was not detected in the sample. } \\
\text { Parentheses indicate the analyte was below the limit of quantification for the analysis. }\end{array}$ \\
\hline
\end{tabular}

Acid-leachable uranium-238 was significantly elevated, at $38.1 \mu \mathrm{g} / \mathrm{g}$, in one sample collected from probe hole C4410 (S05001-4A) (Figure 4.4). Typically, it takes a significant amount of uranium contamination before the signal from contaminant uranium is detectable in acid extractions of Hanford sediment, which contains approximately $3-5 \mu \mathrm{g} / \mathrm{g}$ natural uranium. While this sample did contain the second highest pore-water-corrected alkalinity of all the samples measured, it is doubtful that the elevated uranium in the sample came from naturally present labile uranium or from a uranium-rich facies, such as a paleosol. Further interpretation of the acid extraction data indicates that there is also elevated molybdenum and ruthenium in sample S05001-4A. Additionally, there was elevated ruthenium in three additional samples: S05001-4B, S05001-14B, and S05001-14A Dup, from probe holes C4410 and C4438, respectively. The source of the elevated molybdenum and ruthenium was likely fission-produced isotopes from tank-waste-related contamination that has been sequestered with a species that is recalcitrant to water extraction.

A comparison of the water to acid-leachable quantities of each constituent was performed by taking the data in Tables 4.4 through 4.6 and dividing them by the data in Tables 4.11 through 4.13 . The data are not presented herein, but show that less than $0.1 \%$ of the acid-leachable quantities of the following elements were water-extractable: aluminum, barium, iron, magnesium, manganese, titanium, and zirconium. Less than $0.3 \%$ of the acid-leachable quantities of the following elements were waterextractable: calcium, copper, nickel, phosphorus (as phosphate), strontium, and zinc. Less than 1\% of the acid-leachable cobalt, chromium, potassium, and lead were water-extractable. Less than $10 \%$ of the acidleachable boron and uranium were water-extractable. Finally, less than $30 \%$ of the acid-leachable molybdenum, sodium, and sulfur (as sulfate) were water-extractable. 
Table 4.10. Calculated Pore Water Mobile Metal Concentrations of Key Contaminants of Concern in the C-152 Vertical Core and Grab Samples

\begin{tabular}{|c|c|c|c|c|c|}
\hline $\begin{array}{c}\text { Sample } \\
\text { Number }\end{array}$ & $\begin{array}{l}\text { Probe Hole } \\
\text { Number }\end{array}$ & $\begin{array}{c}\text { Mid- } \\
\text { Depth } \\
\text { (ft bgs) }\end{array}$ & $\begin{array}{c}\text { Technetium-99 } \\
(\mathrm{pCi} / \mathrm{L})\end{array}$ & $\begin{array}{c}\text { Uranium-238 } \\
(\mu \mathrm{g} / \mathrm{L})\end{array}$ & $\begin{array}{c}\text { Chromium-53 } \\
(\mu \mathrm{g} / \mathrm{L})\end{array}$ \\
\hline S05001-1A & C4406 & 12.29 & ND & $1.41 \mathrm{E}+01$ & $3.19 \mathrm{E}+00$ \\
\hline S05001-1 & C4406 & 12.83 & ND & $1.41 \mathrm{E}+01$ & $(3.20 \mathrm{E}+00)$ \\
\hline S05001-2B & C4408 & 9.88 & $1.24 E+04$ & $3.03 \mathrm{E}+01$ & $1.21 \mathrm{E}+01$ \\
\hline S05001-2A & C4408 & 10.63 & $3.21 E+04$ & $7.89 \mathrm{E}+02$ & $1.48 E+02$ \\
\hline S05001-3B & $\mathrm{C} 4404$ & 20.38 & ND & $2.10 \mathrm{E}+01$ & $(5.11 \mathrm{E}+00)$ \\
\hline S05001-3A & C4404 & 21.13 & ND & $1.08 \mathrm{E}+01$ & $(2.33 \mathrm{E}+00)$ \\
\hline S05001-4B & C4410 & 21.80 & $(6.62 \mathrm{E}+03)$ & $5.34 \mathrm{E}+02$ & $2.14 \mathrm{E}+01$ \\
\hline S05001-4A & C4410 & 23.38 & $9.62 E+03$ & $8.25 E+03$ & $3.52 \mathrm{E}+01$ \\
\hline S05001-5B & C4414 & 24.13 & ND & $2.51 \mathrm{E}+01$ & $(4.27 \mathrm{E}+00)$ \\
\hline S05001-5A & C4414 & 24.80 & ND & $9.51 \mathrm{E}+00$ & $(2.09 \mathrm{E}+00)$ \\
\hline S05001-6B & C4412 & 13.88 & $(8.13 \mathrm{E}+02)$ & $5.37 \mathrm{E}+00$ & $(2.78 \mathrm{E}+00)$ \\
\hline S05001-6A-1 & C4412 & 14.63 & $(1.82 \mathrm{E}+02)$ & $2.99 \mathrm{E}+00$ & $(9.38 \mathrm{E}-01)$ \\
\hline S05001-6A-2 & $\mathrm{C} 4412$ & 14.63 & $(8.99 \mathrm{E}+02)$ & $9.70 \mathrm{E}+00$ & $(2.92 \mathrm{E}+00)$ \\
\hline S05001-7B & $\mathrm{C} 4422$ & 11.88 & ND & $1.17 \mathrm{E}+01$ & $(1.73 \mathrm{E}+00)$ \\
\hline S05001-7A & C4422 & 12.63 & $(1.23 \mathrm{E}+02)$ & $1.09 \mathrm{E}+01$ & $(2.19 \mathrm{E}+00)$ \\
\hline S05001-8B & C4420 & 13.30 & ND & $1.20 \mathrm{E}+01$ & $3.06 \mathrm{E}+00$ \\
\hline S05001-8A & C4420 & 16.88 & ND & $1.09 \mathrm{E}+01$ & $3.70 \mathrm{E}+00$ \\
\hline S05001-9B & C4418 & 17.63 & ND & $1.30 \mathrm{E}+01$ & $6.78 \mathrm{E}+00$ \\
\hline S05001-9A & C4418 & 18.30 & ND & $2.25 \mathrm{E}+01$ & $(2.32 \mathrm{E}+00)$ \\
\hline S05001-10B & C4416 & 11.88 & ND & $3.12 \mathrm{E}+01$ & $(3.66 \mathrm{E}+00)$ \\
\hline S05001-10A & C4416 & 12.63 & ND & $1.17 \mathrm{E}+01$ & $1.73 \mathrm{E}+00$ \\
\hline S05001-11B & C4432 & 20.77 & ND & $7.70 \mathrm{E}+00$ & $2.69 \mathrm{E}+00$ \\
\hline S05001-11A & C4432 & 21.34 & ND & $9.68 \mathrm{E}+00$ & $3.96 \mathrm{E}+00$ \\
\hline S05001-12A & $\mathrm{C} 4440$ & 6.70 & ND & $(3.49 \mathrm{E}-01)$ & $5.30 \mathrm{E}+02$ \\
\hline S05001-12 & $\mathrm{C} 4440$ & 7.10 & ND & $4.96 \mathrm{E}+00$ & $1.69 \mathrm{E}+00$ \\
\hline S05001-13B & $\mathrm{C} 4445$ & 6.63 & ND & $4.96 \mathrm{E}+00$ & $7.56 \mathrm{E}+00$ \\
\hline S05001-13A-1 & C4445 & 7.13 & ND & $2.85 \mathrm{E}+00$ & $1.73 \mathrm{E}+01$ \\
\hline S05001-13A-2 & C4445 & 7.13 & ND & $1.27 \mathrm{E}+00$ & $2.96 \mathrm{E}+00$ \\
\hline S05001-14B & C4438 & 13.88 & $(5.90 \mathrm{E}+02)$ & $2.60 \mathrm{E}+01$ & $5.67 \mathrm{E}+00$ \\
\hline S05001-14A & $\mathrm{C} 4438$ & 14.63 & $(5.03 \mathrm{E}+02)$ & $1.36 \mathrm{E}+02$ & $6.98 \mathrm{E}+00$ \\
\hline S05001-14A Dup & C4438 & 14.63 & $(1.77 \mathrm{E}+03)$ & $1.57 E+03$ & $1.22 \mathrm{E}+01$ \\
\hline S05001-15B & C4448 & 17.38 & $(2.07 \mathrm{E}+03)$ & $8.91 \mathrm{E}+01$ & $1.36 \mathrm{E}+01$ \\
\hline S05001-15A & $\mathrm{C} 4448$ & 18.13 & $(3.47 \mathrm{E}+03)$ & $1.07 E+03$ & $2.49 \mathrm{E}+01$ \\
\hline S05001-17B & C4436 & 16.38 & $(4.83 E+03)$ & $1.59 \mathrm{E}+01$ & $1.63 E+02$ \\
\hline
\end{tabular}


Table 4.10. (contd)

\begin{tabular}{|c|c|c|c|c|c|}
\hline $\begin{array}{l}\text { Sample } \\
\text { Number }\end{array}$ & $\begin{array}{l}\text { Probe Hole } \\
\text { Number }\end{array}$ & $\begin{array}{l}\text { Mid- } \\
\text { Depth } \\
(\mathrm{ft} \text { bgs) }\end{array}$ & $\begin{array}{l}\text { Technetium-99 } \\
\quad(\mathrm{pCi} / \mathrm{L})\end{array}$ & $\begin{array}{l}\text { Uranium-238 } \\
(\mu \mathrm{g} / \mathrm{L})\end{array}$ & $\begin{array}{c}\text { Chromium-53 } \\
(\mu \mathrm{g} / \mathrm{L})\end{array}$ \\
\hline S05001-17A & $\mathrm{C} 4436$ & 17.13 & $8.86 E+03$ & $1.90 \mathrm{E}+02$ & $2.96 \mathrm{E}+02$ \\
\hline S05001-18B & C4434 & 13.88 & $(1.37 \mathrm{E}+02)$ & $4.34 \mathrm{E}+00$ & $4.67 \mathrm{E}+01$ \\
\hline S05001-18A & $\mathrm{C} 4434$ & 14.63 & ND & $(1.71 \mathrm{E}-01)$ & $6.17 \mathrm{E}+02$ \\
\hline S05001-19B & $\mathrm{C} 4428$ & 15.30 & $(3.43 \mathrm{E}+02)$ & $2.02 \mathrm{E}+01$ & $(4.59 \mathrm{E}+00)$ \\
\hline S05001-19A & C4428 & 18.38 & $(8.16 \mathrm{E}+02)$ & $3.54 \mathrm{E}+02$ & $1.26 \mathrm{E}+01$ \\
\hline S05001-19A Dup & C4428 & 18.38 & $(5.26 \mathrm{E}+02)$ & $2.67 \mathrm{E}+02$ & $1.16 \mathrm{E}+01$ \\
\hline S05001-20A & $\mathrm{C} 4426$ & 6.06 & ND & $1.71 \mathrm{E}+01$ & $(8.73 \mathrm{E}-01)$ \\
\hline S05001-20 & C4426 & 6.73 & ND & $9.12 \mathrm{E}+00$ & $(1.06 \mathrm{E}+00)$ \\
\hline S05001-21B-1 & $\mathrm{C} 4430$ & 18.88 & $(1.01 \mathrm{E}+02)$ & $9.65 \mathrm{E}+00$ & $7.16 \mathrm{E}+00$ \\
\hline S05001-21B-2 & $\mathrm{C} 4430$ & 18.88 & $(1.37 \mathrm{E}+02)$ & $8.60 \mathrm{E}+00$ & $(2.35 \mathrm{E}+00)$ \\
\hline S05001-21A & $\mathrm{C} 4430$ & 19.63 & ND & $1.12 \mathrm{E}+01$ & $(3.76 \mathrm{E}+00)$ \\
\hline \multicolumn{6}{|c|}{$\begin{array}{l}\text { Shaded cells indicate grab samples. } \\
\text { Bold values denote elevated concentrations. } \\
\text { Parentheses indicate the analyte was below the limit of quantification for the analysis. }\end{array}$} \\
\hline
\end{tabular}

The primary indications of tank contamination in these sediments were the elevated sodium levels in several of the samples, the presence of technetium-99 in water extractions from some of the sediments (Figure 4.5), the indication of fission product molybdenum and ruthenium in some of the sediments, and the high water-extractable and acid-leachable uranium values for several samples from various probe holes. The percentage of the acid-leachable uranium that was also water-extractable averaged $0.23 \%$ for most of the samples analyzed; however, it ranged from $1.02 \%$ to $9.79 \%$ in samples from probe holes C4408, C4410, C4428, C4436, C4438, and C4448. The water and acid-leachable uranium concentrations in sample S05001-4A from probe hole C4410 were 0.766 and $38.1 \mu \mathrm{g}$ of uranium per $\mathrm{g}$ of sediment. The acid-leachable uranium concentration of this sample was significantly greater than the peak concentration measured in the $\mathrm{C} 4297$ borehole samples $(0.046 \mu \mathrm{g} / \mathrm{g})$ from below Tank $\mathrm{C}-105$, very similar to the peak concentration measured in samples from borehole C3832 near Tank TX-104 (30.5 $\mu \mathrm{g} / \mathrm{g})$, and smaller than the values in contaminated sediments east of Tank BX-102 from borehole 299-E33-45, which contained 300 to $1,500 \mu \mathrm{g}$ of acid-leachable uranium per $\mathrm{g}$ of sediment. 
Table 4.11. Acid-Leachable Cations in the C-152 Vertical Core and Grab Samples ( $\mu \mathrm{g} / \mathrm{g}$ dry sediment)

\begin{tabular}{|c|c|c|c|c|c|c|c|}
\hline $\begin{array}{c}\text { Sample } \\
\text { Number }\end{array}$ & $\begin{array}{c}\text { Probe Hole } \\
\text { Number }\end{array}$ & $\begin{array}{l}\text { Mid- } \\
\text { Depth } \\
\text { (ft bgs) }\end{array}$ & Calcium & Magnesium & Strontium & Sodium & Potassium \\
\hline S05001-1A & $\mathrm{C} 4406$ & 12.29 & $9.13 \mathrm{E}+03$ & $3.57 \mathrm{E}+03$ & $2.74 \mathrm{E}+01$ & $(2.28 \mathrm{E}+02)$ & $8.22 \mathrm{E}+02$ \\
\hline S05001-1 & $\mathrm{C} 4406$ & 12.83 & $8.55 \mathrm{E}+03$ & $3.20 \mathrm{E}+03$ & $2.45 \mathrm{E}+01$ & $(1.93 E+02)$ & $7.88 \mathrm{E}+02$ \\
\hline S05001-2B & $\mathrm{C} 4408$ & 9.88 & $9.01 \mathrm{E}+03$ & $4.25 \mathrm{E}+03$ & $2.46 \mathrm{E}+01$ & $8.02 \mathrm{E}+02$ & $1.04 \mathrm{E}+03$ \\
\hline S05001-2A & $\mathrm{C} 4408$ & 10.63 & $5.62 \mathrm{E}+03$ & $2.36 \mathrm{E}+03$ & $1.69 \mathrm{E}+01$ & $9.10 \mathrm{E}+02$ & $7.18 \mathrm{E}+02$ \\
\hline S05001-3B & $\mathrm{C} 4404$ & 20.38 & $1.03 \mathrm{E}+04$ & $5.59 \mathrm{E}+03$ & $2.96 \mathrm{E}+01$ & $3.34 \mathrm{E}+02$ & $1.35 \mathrm{E}+03$ \\
\hline S05001-3A & $\mathrm{C} 4404$ & 21.13 & $1.12 \mathrm{E}+04$ & $6.35 \mathrm{E}+03$ & $3.10 \mathrm{E}+01$ & $4.59 \mathrm{E}+02$ & $1.55 \mathrm{E}+03$ \\
\hline S05001-4B & $\mathrm{C} 4410$ & 21.80 & $9.66 \mathrm{E}+03$ & $5.11 \mathrm{E}+03$ & $2.95 \mathrm{E}+01$ & $5.48 \mathrm{E}+02$ & $1.17 \mathrm{E}+03$ \\
\hline S05001-4A & $\mathrm{C} 4410$ & 23.38 & $2.09 \mathrm{E}+04$ & $4.94 \mathrm{E}+03$ & $7.18 \mathrm{E}+01$ & $1.05 E+03$ & $1.22 \mathrm{E}+03$ \\
\hline S05001-5B & C4414 & 24.13 & $1.04 \mathrm{E}+04$ & $5.02 \mathrm{E}+03$ & $3.43 \mathrm{E}+01$ & $5.60 \mathrm{E}+02$ & $1.20 \mathrm{E}+03$ \\
\hline S05001-5A & $\mathrm{C} 4414$ & 24.80 & $9.82 \mathrm{E}+03$ & $5.17 \mathrm{E}+03$ & $3.15 \mathrm{E}+01$ & $4.08 \mathrm{E}+02$ & $1.48 \mathrm{E}+03$ \\
\hline S05001-6B & $\mathrm{C} 4412$ & 13.88 & $8.66 \mathrm{E}+03$ & $4.34 \mathrm{E}+03$ & $2.85 \mathrm{E}+01$ & $2.69 \mathrm{E}+02$ & $9.09 \mathrm{E}+02$ \\
\hline S05001-6A-1 & $\mathrm{C} 4412$ & 14.63 & $1.13 \mathrm{E}+04$ & $5.51 \mathrm{E}+03$ & $3.49 \mathrm{E}+01$ & $3.35 \mathrm{E}+02$ & $1.12 \mathrm{E}+03$ \\
\hline S05001-6A-2 & $\mathrm{C} 4412$ & 14.63 & $8.27 \mathrm{E}+03$ & $3.07 \mathrm{E}+03$ & $3.09 \mathrm{E}+01$ & $(1.98 \mathrm{E}+02)$ & $7.60 \mathrm{E}+02$ \\
\hline S05001-7B & $\mathrm{C} 4422$ & 11.88 & $1.34 \mathrm{E}+04$ & $5.57 \mathrm{E}+03$ & $3.43 \mathrm{E}+01$ & $7.10 \mathrm{E}+02$ & $1.26 \mathrm{E}+03$ \\
\hline S05001-7A & $\mathrm{C} 4422$ & 12.63 & $1.10 \mathrm{E}+04$ & $5.38 \mathrm{E}+03$ & $3.15 \mathrm{E}+01$ & $9.13 E+02$ & $1.21 \mathrm{E}+03$ \\
\hline S05001-8B & $\mathrm{C} 4420$ & 13.30 & $9.70 \mathrm{E}+03$ & $5.18 \mathrm{E}+03$ & $3.81 \mathrm{E}+01$ & $5.36 \mathrm{E}+02$ & $1.12 \mathrm{E}+03$ \\
\hline S05001-8A & $\mathrm{C} 4420$ & 16.88 & $1.17 \mathrm{E}+04$ & $5.90 \mathrm{E}+03$ & $3.15 \mathrm{E}+01$ & $4.04 \mathrm{E}+02$ & $1.20 \mathrm{E}+03$ \\
\hline S05001-9B & $\mathrm{C} 4418$ & 17.63 & $1.11 \mathrm{E}+04$ & $5.77 \mathrm{E}+03$ & $3.68 \mathrm{E}+01$ & $9.58 \mathrm{E}+02$ & $1.48 \mathrm{E}+03$ \\
\hline S05001-9A & C4418 & 18.30 & $9.11 \mathrm{E}+03$ & $5.11 \mathrm{E}+03$ & $2.68 \mathrm{E}+01$ & $7.16 \mathrm{E}+02$ & $1.07 \mathrm{E}+03$ \\
\hline S05001-10B & $\mathrm{C} 4416$ & 11.88 & $7.77 \mathrm{E}+03$ & $4.96 \mathrm{E}+03$ & $2.92 \mathrm{E}+01$ & $5.15 \mathrm{E}+02$ & $9.86 \mathrm{E}+02$ \\
\hline S05001-10A & $\mathrm{C} 4416$ & 12.63 & $1.13 \mathrm{E}+04$ & $7.03 \mathrm{E}+03$ & $3.92 \mathrm{E}+01$ & $5.48 \mathrm{E}+02$ & $2.15 \mathrm{E}+03$ \\
\hline S05001-11B & $\mathrm{C} 4432$ & 20.77 & $1.03 \mathrm{E}+04$ & $6.19 \mathrm{E}+03$ & $4.19 \mathrm{E}+01$ & $5.08 \mathrm{E}+02$ & $1.98 \mathrm{E}+03$ \\
\hline S05001-11A & $\mathrm{C} 4432$ & 21.34 & $9.48 \mathrm{E}+03$ & $3.82 \mathrm{E}+03$ & $2.58 \mathrm{E}+01$ & $(2.57 \mathrm{E}+02)$ & $1.07 \mathrm{E}+03$ \\
\hline S05001-12A & $\mathrm{C} 4440$ & 6.70 & $9.82 \mathrm{E}+03$ & $4.21 \mathrm{E}+03$ & $2.60 \mathrm{E}+01$ & $(2.77 \mathrm{E}+02)$ & $1.21 \mathrm{E}+03$ \\
\hline S05001-12 & $\mathrm{C} 4440$ & 7.10 & $2.70 \mathrm{E}+04$ & $1.36 \mathrm{E}+04$ & $6.81 \mathrm{E}+01$ & $(8.67 \mathrm{E}+02)$ & $3.05 \mathrm{E}+03$ \\
\hline S05001-13B & $\mathrm{C} 4445$ & 6.63 & $8.12 \mathrm{E}+03$ & $6.39 \mathrm{E}+03$ & $3.79 \mathrm{E}+01$ & $(5.12 \mathrm{E}+02)$ & $2.09 \mathrm{E}+03$ \\
\hline S05001-13A-1 & $\mathrm{C} 4445$ & 7.13 & $8.15 \mathrm{E}+03$ & $6.49 \mathrm{E}+03$ & $4.30 \mathrm{E}+01$ & $(6.49 \mathrm{E}+02)$ & $2.19 \mathrm{E}+03$ \\
\hline S05001-13A-2 & $\mathrm{C} 4445$ & 7.13 & $1.97 \mathrm{E}+04$ & $8.15 \mathrm{E}+03$ & $3.67 \mathrm{E}+01$ & $3.81 \mathrm{E}+02$ & $1.94 \mathrm{E}+03$ \\
\hline S05001-14B & C4438 & 13.88 & $1.14 \mathrm{E}+04$ & $6.51 \mathrm{E}+03$ & $4.18 \mathrm{E}+01$ & $5.62 \mathrm{E}+02$ & $2.11 \mathrm{E}+03$ \\
\hline S05001-14A & $\mathrm{C} 4438$ & 14.63 & $9.65 \mathrm{E}+03$ & $3.77 \mathrm{E}+03$ & $3.14 \mathrm{E}+01$ & $3.98 \mathrm{E}+02$ & $1.24 \mathrm{E}+03$ \\
\hline S05001-14A Dup & $\mathrm{C} 4438$ & 14.63 & $1.21 \mathrm{E}+04$ & $5.37 \mathrm{E}+03$ & $3.60 \mathrm{E}+01$ & $6.79 \mathrm{E}+02$ & $1.60 \mathrm{E}+03$ \\
\hline S05001-15B & $\mathrm{C} 4448$ & 17.38 & $9.70 \mathrm{E}+03$ & $4.51 \mathrm{E}+03$ & $3.86 \mathrm{E}+01$ & $4.75 \mathrm{E}+02$ & $9.64 \mathrm{E}+02$ \\
\hline S05001-15A & $\mathrm{C} 4448$ & 18.13 & $9.49 \mathrm{E}+03$ & $5.44 \mathrm{E}+03$ & $3.10 \mathrm{E}+01$ & $4.94 \mathrm{E}+02$ & $1.22 \mathrm{E}+03$ \\
\hline S05001-17B & $\mathrm{C} 4436$ & 16.38 & $1.17 \mathrm{E}+04$ & $4.09 \mathrm{E}+03$ & $2.96 \mathrm{E}+01$ & $4.08 \mathrm{E}+02$ & $8.36 \mathrm{E}+02$ \\
\hline S05001-17A & $\mathrm{C} 4436$ & 17.13 & $8.06 \mathrm{E}+03$ & $4.74 \mathrm{E}+03$ & $2.64 \mathrm{E}+01$ & $6.47 \mathrm{E}+02$ & $9.69 \mathrm{E}+02$ \\
\hline S05001-18B & $\mathrm{C} 4434$ & 13.88 & $1.02 \mathrm{E}+04$ & $5.70 \mathrm{E}+03$ & $3.75 \mathrm{E}+01$ & $4.82 \mathrm{E}+02$ & $1.62 \mathrm{E}+03$ \\
\hline S05001-18A & $\mathrm{C} 4434$ & 14.63 & $7.76 \mathrm{E}+03$ & $4.01 \mathrm{E}+03$ & $2.55 \mathrm{E}+01$ & $3.43 \mathrm{E}+02$ & $8.27 \mathrm{E}+02$ \\
\hline
\end{tabular}


Table 4.11. (contd)

\begin{tabular}{|c|c|c|c|c|c|c|c|}
\hline $\begin{array}{l}\text { Sample } \\
\text { Number }\end{array}$ & $\begin{array}{l}\text { Probe Hole } \\
\text { Number }\end{array}$ & $\begin{array}{l}\text { Mid- } \\
\text { Depth } \\
\text { (ft bgs) }\end{array}$ & Calcium & Magnesium & Strontium & Sodium & Potassium \\
\hline S05001-19B & C4428 & 15.30 & $7.26 \mathrm{E}+03$ & $4.05 \mathrm{E}+03$ & $2.59 \mathrm{E}+01$ & $3.58 \mathrm{E}+02$ & $8.38 \mathrm{E}+02$ \\
\hline S05001-19A & C4428 & 18.38 & $8.82 \mathrm{E}+03$ & $6.02 \mathrm{E}+03$ & $3.40 \mathrm{E}+01$ & $9.39 \mathrm{E}+02$ & $2.03 \mathrm{E}+03$ \\
\hline S05001-20A & $\mathrm{C} 4426$ & 6.06 & $2.12 \mathrm{E}+04$ & $8.30 \mathrm{E}+03$ & $3.50 \mathrm{E}+01$ & $3.79 \mathrm{E}+02$ & $1.50 \mathrm{E}+03$ \\
\hline S05001-20 & $\mathrm{C} 4426$ & 6.73 & $1.81 \mathrm{E}+04$ & $9.72 \mathrm{E}+03$ & $4.93 \mathrm{E}+01$ & $7.91 \mathrm{E}+02$ & $2.06 \mathrm{E}+03$ \\
\hline S05001-21B-1 & C4430 & 18.88 & $9.32 \mathrm{E}+03$ & $5.34 \mathrm{E}+03$ & $3.71 \mathrm{E}+01$ & $3.27 \mathrm{E}+02$ & $1.77 \mathrm{E}+03$ \\
\hline S05001-21B-2 & $\mathrm{C} 4430$ & 18.88 & $8.97 \mathrm{E}+03$ & $4.14 \mathrm{E}+03$ & $2.75 \mathrm{E}+01$ & $2.78 \mathrm{E}+02$ & $1.27 \mathrm{E}+03$ \\
\hline S05001-21A & $\mathrm{C} 4430$ & 19.63 & $9.74 \mathrm{E}+03$ & $4.56 \mathrm{E}+03$ & $2.64 \mathrm{E}+01$ & $2.64 \mathrm{E}+02$ & $1.13 \mathrm{E}+03$ \\
\hline \multicolumn{8}{|c|}{$\begin{array}{l}\text { Shaded cells indicate grab samples. } \\
\text { Bold values denote elevated concentrations. }\end{array}$} \\
\hline
\end{tabular}

Table 4.12. Acid-Leachable Cations in the C-152 Vertical Core and Grab Samples ( $\mu \mathrm{g} / \mathrm{g}$ dry sediment)

\begin{tabular}{|c|c|c|c|c|c|c|c|}
\hline $\begin{array}{c}\text { Sample } \\
\text { Number }\end{array}$ & $\begin{array}{c}\text { Probe } \\
\text { Hole } \\
\text { Number }\end{array}$ & $\begin{array}{c}\text { Mid- } \\
\text { Depth } \\
\text { (ft bgs) }\end{array}$ & Aluminum & Iron & Manganese & $\begin{array}{c}\text { Phosphorus } \\
\text { as } \mathrm{PO}_{4} \\
\end{array}$ & $\begin{array}{c}\text { Sulfur as } \\
\mathrm{SO}_{4} \\
\end{array}$ \\
\hline S05001-1A & $\bar{C} 44406$ & 12.29 & $4.07 \mathrm{E}+03$ & $1.03 \mathrm{E}+04$ & $2.42 \mathrm{E}+02$ & $2.20 \mathrm{E}+03$ & $(1.42 \mathrm{E}+02)$ \\
\hline S05001-1 & C4406 & 12.83 & $3.56 \mathrm{E}+03$ & $8.34 \mathrm{E}+03$ & $2.00 \mathrm{E}+02$ & $1.76 \mathrm{E}+03$ & $(1.18 \mathrm{E}+02)$ \\
\hline S05001-2B & C4408 & 9.88 & $5.74 \mathrm{E}+03$ & $1.85 \mathrm{E}+04$ & $3.75 \mathrm{E}+02$ & $3.06 \mathrm{E}+03$ & $(1.48 \mathrm{E}+02)$ \\
\hline S05001-2A & C4408 & 10.63 & $3.12 \mathrm{E}+03$ & $7.77 \mathrm{E}+03$ & $2.05 \mathrm{E}+02$ & $1.58 \mathrm{E}+03$ & $(6.26 \mathrm{E}+01)$ \\
\hline S05001-3B & $\mathrm{C} 4404$ & 20.38 & $6.99 \mathrm{E}+03$ & $1.65 \mathrm{E}+04$ & $3.01 \mathrm{E}+02$ & $2.28 \mathrm{E}+03$ & $(1.58 \mathrm{E}+02)$ \\
\hline S05001-3A & C4404 & 21.13 & $8.18 \mathrm{E}+03$ & $1.81 \mathrm{E}+04$ & $3.24 \mathrm{E}+02$ & $2.03 \mathrm{E}+03$ & $(1.44 \mathrm{E}+02)$ \\
\hline S05001-4B & $\mathrm{C} 4410$ & 21.80 & $7.13 \mathrm{E}+03$ & $1.76 \mathrm{E}+04$ & $2.84 \mathrm{E}+02$ & $2.25 \mathrm{E}+03$ & $(1.54 \mathrm{E}+02)$ \\
\hline S05001-4A & $\mathrm{C} 4410$ & 23.38 & $4.46 \mathrm{E}+03$ & $9.34 \mathrm{E}+03$ & $2.59 \mathrm{E}+02$ & $3.09 \mathrm{E}+03$ & $(4.53 E+02)$ \\
\hline S05001-5B & C4414 & 24.13 & $7.17 \mathrm{E}+03$ & $1.68 \mathrm{E}+04$ & $3.06 \mathrm{E}+02$ & $2.22 \mathrm{E}+03$ & $(1.79 \mathrm{E}+02)$ \\
\hline S05001-5A & C4414 & 24.80 & $7.02 \mathrm{E}+03$ & $1.50 \mathrm{E}+04$ & $3.13 \mathrm{E}+02$ & $1.95 \mathrm{E}+03$ & $(1.25 \mathrm{E}+02)$ \\
\hline S05001-6B & $\mathrm{C} 4412$ & 13.88 & $5.68 \mathrm{E}+03$ & $1.35 \mathrm{E}+04$ & $2.57 \mathrm{E}+02$ & $1.73 \mathrm{E}+03$ & $(1.53 \mathrm{E}+02)$ \\
\hline S05001-6A-1 & $\mathrm{C} 4412$ & 14.63 & $6.48 \mathrm{E}+03$ & $1.54 \mathrm{E}+04$ & $3.50 \mathrm{E}+02$ & $2.44 \mathrm{E}+03$ & $(1.68 \mathrm{E}+02)$ \\
\hline S05001-6A-2 & $\mathrm{C} 4412$ & 14.63 & $3.47 \mathrm{E}+03$ & $8.16 \mathrm{E}+03$ & $1.95 \mathrm{E}+02$ & $1.79 \mathrm{E}+03$ & $(1.04 \mathrm{E}+02)$ \\
\hline S05001-7B & $\mathrm{C} 4422$ & 11.88 & $8.82 \mathrm{E}+03$ & $2.94 \mathrm{E}+04$ & $5.68 \mathrm{E}+02$ & $3.24 \mathrm{E}+03$ & $(1.80 \mathrm{E}+02)$ \\
\hline S05001-7A & C4422 & 12.63 & $1.01 \mathrm{E}+04$ & $3.43 \mathrm{E}+04$ & $5.12 \mathrm{E}+02$ & $3.09 \mathrm{E}+03$ & $(1.34 \mathrm{E}+02)$ \\
\hline S05001-8B & $\mathrm{C} 4420$ & 13.30 & $7.38 \mathrm{E}+03$ & $2.03 \mathrm{E}+04$ & $3.06 \mathrm{E}+02$ & $2.87 \mathrm{E}+03$ & $(2.48 \mathrm{E}+02)$ \\
\hline S05001-8A & $\mathrm{C} 4420$ & 16.88 & $7.73 \mathrm{E}+03$ & $1.70 \mathrm{E}+04$ & $3.98 \mathrm{E}+02$ & $2.03 \mathrm{E}+03$ & $(1.98 \mathrm{E}+02)$ \\
\hline S05001-9B & $\mathrm{C} 4418$ & 17.63 & $1.12 \mathrm{E}+04$ & $3.48 \mathrm{E}+04$ & $5.48 \mathrm{E}+02$ & $2.81 \mathrm{E}+03$ & $(9.64 \mathrm{E}+01)$ \\
\hline S05001-9A & C4418 & 18.30 & $8.17 \mathrm{E}+03$ & $2.77 \mathrm{E}+04$ & $4.77 \mathrm{E}+02$ & $2.90 \mathrm{E}+03$ & $(1.13 E+02)$ \\
\hline S05001-10B & C4416 & 11.88 & $6.11 \mathrm{E}+03$ & $1.72 \mathrm{E}+04$ & $3.03 \mathrm{E}+02$ & $2.47 \mathrm{E}+03$ & $(1.72 \mathrm{E}+02)$ \\
\hline S05001-10A & $\mathrm{C} 4416$ & 12.63 & $1.22 \mathrm{E}+04$ & $2.17 \mathrm{E}+04$ & $4.30 \mathrm{E}+02$ & $2.35 \mathrm{E}+03$ & $(9.04 \mathrm{E}+01)$ \\
\hline S05001-11B & C4432 & 20.77 & $1.06 \mathrm{E}+04$ & $1.93 \mathrm{E}+04$ & $3.58 \mathrm{E}+02$ & $1.92 \mathrm{E}+03$ & $(1.44 \mathrm{E}+02)$ \\
\hline
\end{tabular}


Table 4.12. (contd)

\begin{tabular}{|c|c|c|c|c|c|c|c|}
\hline $\begin{array}{c}\text { Sample } \\
\text { Number } \\
\end{array}$ & $\begin{array}{l}\text { Probe } \\
\text { Hole } \\
\text { Number } \\
\end{array}$ & $\begin{array}{c}\text { Mid- } \\
\text { Depth } \\
\text { (ft bgs) } \\
\end{array}$ & Aluminum & Iron & Manganese & $\begin{array}{c}\text { Phosphorus } \\
\text { as } \mathrm{PO}_{4} \\
\end{array}$ & $\begin{array}{c}\text { Sulfur as } \\
\mathrm{SO}_{4} \\
\end{array}$ \\
\hline S05001-11A & $\mathrm{C} 4432$ & 21.34 & $4.42 \mathrm{E}+03$ & $1.02 \mathrm{E}+04$ & $2.38 \mathrm{E}+02$ & $2.08 \mathrm{E}+03$ & $(1.76 \mathrm{E}+02)$ \\
\hline S05001-12A & C4440 & 6.70 & $4.87 \mathrm{E}+03$ & $1.40 \mathrm{E}+04$ & $3.39 \mathrm{E}+02$ & $2.94 \mathrm{E}+03$ & $(1.83 \mathrm{E}+02)$ \\
\hline S05001-12 & $\mathrm{C} 4440$ & 7.10 & $1.87 \mathrm{E}+04$ & $4.09 \mathrm{E}+04$ & $7.66 \mathrm{E}+02$ & $3.90 \mathrm{E}+03$ & $(4.13 E+02)$ \\
\hline S05001-13B & $\mathrm{C} 4445$ & 6.63 & $1.10 \mathrm{E}+04$ & $2.74 \mathrm{E}+04$ & $4.86 \mathrm{E}+02$ & $3.55 \mathrm{E}+03$ & $(1.48 \mathrm{E}+02)$ \\
\hline S05001-13A-1 & $\mathrm{C} 4445$ & 7.13 & $1.21 \mathrm{E}+04$ & $2.91 \mathrm{E}+04$ & $5.06 \mathrm{E}+02$ & $3.56 \mathrm{E}+03$ & $(1.39 \mathrm{E}+02)$ \\
\hline S05001-13A-2 & $\mathrm{C} 4445$ & 7.13 & $8.22 \mathrm{E}+03$ & $2.02 \mathrm{E}+04$ & $4.98 \mathrm{E}+02$ & $2.75 \mathrm{E}+03$ & $(1.98 \mathrm{E}+02)$ \\
\hline S05001-14B & $\mathrm{C} 4438$ & 13.88 & $1.14 \mathrm{E}+04$ & $2.21 \mathrm{E}+04$ & $4.33 \mathrm{E}+02$ & $2.08 \mathrm{E}+03$ & $(9.28 \mathrm{E}+01)$ \\
\hline S05001-14A & $\mathrm{C} 4438$ & 14.63 & $4.58 \mathrm{E}+03$ & $1.06 \mathrm{E}+04$ & $2.69 \mathrm{E}+02$ & $2.20 \mathrm{E}+03$ & $(7.50 \mathrm{E}+01)$ \\
\hline S05001-14A Dup & C4438 & 14.63 & $7.68 \mathrm{E}+03$ & $1.76 \mathrm{E}+04$ & $3.40 \mathrm{E}+02$ & $2.16 \mathrm{E}+03$ & $(1.06 \mathrm{E}+02)$ \\
\hline S05001-15B & $\mathrm{C} 4448$ & 17.38 & $6.46 \mathrm{E}+03$ & $1.84 \mathrm{E}+04$ & $2.87 \mathrm{E}+02$ & $2.56 \mathrm{E}+03$ & $(1.60 \mathrm{E}+02)$ \\
\hline S05001-15A & $\mathrm{C} 4448$ & 18.13 & $7.36 \mathrm{E}+03$ & $1.57 \mathrm{E}+04$ & $3.11 \mathrm{E}+02$ & $1.93 \mathrm{E}+03$ & $(1.51 \mathrm{E}+02)$ \\
\hline S05001-17B & $\mathrm{C} 4436$ & 16.38 & $5.66 \mathrm{E}+03$ & $1.54 \mathrm{E}+04$ & $2.47 \mathrm{E}+02$ & $2.24 \mathrm{E}+03$ & $(2.00 \mathrm{E}+02)$ \\
\hline S05001-17A & $\mathrm{C} 4436$ & 17.13 & $6.52 \mathrm{E}+03$ & $1.48 \mathrm{E}+04$ & $2.83 \mathrm{E}+02$ & $2.09 \mathrm{E}+03$ & $(1.42 \mathrm{E}+02)$ \\
\hline S05001-18B & C4434 & 13.88 & $9.51 \mathrm{E}+03$ & $2.08 \mathrm{E}+04$ & $3.85 \mathrm{E}+02$ & $2.08 \mathrm{E}+03$ & $(1.14 \mathrm{E}+02)$ \\
\hline S05001-18A & $\mathrm{C} 4434$ & 14.63 & $5.07 \mathrm{E}+03$ & $1.38 \mathrm{E}+04$ & $2.34 \mathrm{E}+02$ & $2.26 \mathrm{E}+03$ & $(1.74 \mathrm{E}+02)$ \\
\hline S05001-19B & $\mathrm{C} 4428$ & 15.30 & $5.76 \mathrm{E}+03$ & $1.56 \mathrm{E}+04$ & $2.53 \mathrm{E}+02$ & $2.36 \mathrm{E}+03$ & $(1.43 E+02)$ \\
\hline S05001-19A & C4428 & 18.38 & $9.12 \mathrm{E}+03$ & $1.69 \mathrm{E}+04$ & $3.58 \mathrm{E}+02$ & $2.03 \mathrm{E}+03$ & $(7.67 \mathrm{E}+01)$ \\
\hline S05001-20A & $\mathrm{C} 4426$ & 6.06 & $8.54 \mathrm{E}+03$ & $2.28 \mathrm{E}+04$ & $4.55 \mathrm{E}+02$ & $2.97 \mathrm{E}+03$ & $(4.27 \mathrm{E}+02)$ \\
\hline S05001-20 & $\mathrm{C} 4426$ & 6.73 & $1.34 \mathrm{E}+04$ & $3.84 \mathrm{E}+04$ & $6.60 \mathrm{E}+02$ & $4.13 \mathrm{E}+03$ & $(4.02 \mathrm{E}+02)$ \\
\hline S05001-21B-1 & $\mathrm{C} 4430$ & 18.88 & $7.73 \mathrm{E}+03$ & $1.46 \mathrm{E}+04$ & $3.82 \mathrm{E}+02$ & $2.11 \mathrm{E}+03$ & $(9.08 \mathrm{E}+01)$ \\
\hline S05001-21B-2 & $\mathrm{C} 4430$ & 18.88 & $5.37 \mathrm{E}+03$ & $1.12 \mathrm{E}+04$ & $2.69 \mathrm{E}+02$ & $1.87 \mathrm{E}+03$ & $(9.92 \mathrm{E}+01)$ \\
\hline S05001-21A & $\mathrm{C} 4430$ & 19.63 & $5.62 \mathrm{E}+03$ & $1.27 \mathrm{E}+04$ & $2.58 \mathrm{E}+02$ & $1.94 \mathrm{E}+03$ & $(1.39 \mathrm{E}+02)$ \\
\hline
\end{tabular}


Table 4.13. Acid-Leachable Mobile Metals in the C-152 Vertical Core and Grab Samples ( $\mu \mathrm{g} / \mathrm{g}$ dry sediment)

\begin{tabular}{|c|c|c|c|c|c|c|c|}
\hline $\begin{array}{l}\text { Sample } \\
\text { Number }\end{array}$ & $\begin{array}{l}\text { Probe } \\
\text { Hole } \\
\text { Number }\end{array}$ & $\begin{array}{l}\text { Mid- } \\
\text { Depth } \\
\text { (ft bgs) }\end{array}$ & $\begin{array}{l}\text { Technetium-99 } \\
\text { (pCi/g soil) }\end{array}$ & Uranium-238 & Chromium-53 & Molybdenum-95 & Ruthenium-101 \\
\hline S05001-1A & C4406 & 12.29 & ND & $3.38 \mathrm{E}-01$ & $\begin{array}{l}(4.75 \mathrm{E}+00) \\
\end{array}$ & $1.34 \mathrm{E}-01$ & $(2.04 \mathrm{E}-03)$ \\
\hline S05001-1 & $\mathrm{C} 4406$ & 12.83 & ND & $2.93 \mathrm{E}-01$ & $(4.66 \mathrm{E}+00)$ & $1.81 \mathrm{E}-01$ & $(2.14 \mathrm{E}-03)$ \\
\hline S05001-2B & C4408 & 9.88 & $(8.96 \mathrm{E}+00)$ & $3.90 \mathrm{E}-01$ & $(4.47 \mathrm{E}+00)$ & $1.21 \mathrm{E}-01$ & $(2.32 \mathrm{E}-03)$ \\
\hline S05001-2A & C4408 & 10.63 & $(1.51 \mathrm{E}+01)$ & $8.60 \mathrm{E}-01$ & $(4.01 \mathrm{E}+00)$ & $6.76 \mathrm{E}-02$ & $(3.76 \mathrm{E}-03)$ \\
\hline S05001-3B & C4404 & 20.38 & ND & $4.11 \mathrm{E}-01$ & $(9.78 \mathrm{E}+00)$ & $1.94 \mathrm{E}-01$ & ND \\
\hline S05001-3A & C4404 & 21.13 & ND & 4.94E-01 & $(1.20 \mathrm{E}+01)$ & $2.35 \mathrm{E}-01$ & ND \\
\hline S05001-4B & $\mathrm{C} 4410$ & 21.80 & $(1.57 \mathrm{E}+01)$ & $9.27 \mathrm{E}-01$ & $(9.70 \mathrm{E}+00)$ & $3.90 \mathrm{E}-01$ & 1.19E-02 \\
\hline S05001-4A & $\mathrm{C} 4410$ & 23.38 & $(3.28 \mathrm{E}+01)$ & $3.81 \mathrm{E}+01$ & $(8.82 \mathrm{E}+00)$ & $1.05 \mathrm{E}+00$ & $3.06 \mathrm{E}-02$ \\
\hline S05001-5B & C4414 & 24.13 & ND & $3.67 \mathrm{E}-01$ & $(7.91 \mathrm{E}+00)$ & $2.11 \mathrm{E}-01$ & $(9.17 \mathrm{E}-05)$ \\
\hline S05001-5A & C4414 & 24.80 & ND & $4.28 \mathrm{E}-01$ & $(7.91 \mathrm{E}+00)$ & $1.69 \mathrm{E}-01$ & $(1.15 \mathrm{E}-04)$ \\
\hline S05001-6B & $\mathrm{C} 4412$ & 13.88 & ND & $3.13 \mathrm{E}-01$ & $(6.77 \mathrm{E}+00)$ & $1.79 \mathrm{E}-01$ & $(2.05 \mathrm{E}-04)$ \\
\hline S05001-6A-1 & $\mathrm{C} 4412$ & 14.63 & ND & $4.02 \mathrm{E}-01$ & $(9.27 \mathrm{E}+00)$ & $2.43 \mathrm{E}-01$ & $(2.57 \mathrm{E}-05)$ \\
\hline S05001-6A-2 & C4412 & 14.63 & ND & $4.00 \mathrm{E}-01$ & $(4.17 \mathrm{E}+00)$ & $9.48 \mathrm{E}-02$ & $(1.37 \mathrm{E}-03)$ \\
\hline S05001-7B & $\mathrm{C} 4422$ & 11.88 & ND & $4.57 \mathrm{E}-01$ & $(7.65 \mathrm{E}+00)$ & $2.17 \mathrm{E}-01$ & (1.38E-03) \\
\hline S05001-7A & $\mathrm{C} 4422$ & 12.63 & $\mathrm{ND}$ & $4.78 \mathrm{E}-01$ & $(9.70 \mathrm{E}+00)$ & $4.53 \mathrm{E}-01$ & $(1.83 \mathrm{E}-03)$ \\
\hline S05001-8B & $\mathrm{C} 4420$ & 13.30 & ND & $3.63 \mathrm{E}-01$ & $(8.60 \mathrm{E}+00)$ & $2.86 \mathrm{E}-01$ & (2.29E-03) \\
\hline S05001-8A & $\mathrm{C} 4420$ & 16.88 & ND & 5.91E-01 & $(1.21 \mathrm{E}+01)$ & $3.36 \mathrm{E}-01$ & $(2.26 \mathrm{E}-03)$ \\
\hline S05001-9B & C4418 & 17.63 & ND & $5.10 \mathrm{E}-01$ & $(7.84 \mathrm{E}+00)$ & $3.81 \mathrm{E}-01$ & $(3.35 \mathrm{E}-03)$ \\
\hline S05001-9A & C4418 & 18.30 & ND & $4.76 \mathrm{E}-01$ & $(8.69 \mathrm{E}+00)$ & $2.68 \mathrm{E}-01$ & $(2.27 \mathrm{E}-03)$ \\
\hline S05001-10B & C4416 & 11.88 & ND & $3.33 \mathrm{E}-01$ & $(8.42 \mathrm{E}+00)$ & $3.18 \mathrm{E}-01$ & (2.74E-03) \\
\hline S05001-10A & C4416 & 12.63 & ND & 5.22E-01 & $(1.57 \mathrm{E}+01)$ & $2.67 \mathrm{E}-01$ & $(2.48 \mathrm{E}-03)$ \\
\hline S05001-11B & C4432 & 20.77 & ND & $5.41 \mathrm{E}-01$ & $(1.23 \mathrm{E}+01)$ & $3.46 \mathrm{E}-01$ & $(2.52 \mathrm{E}-03)$ \\
\hline S05001-11A & C4432 & 21.34 & ND & $3.52 \mathrm{E}-01$ & $(6.12 \mathrm{E}+00)$ & $1.95 \mathrm{E}-01$ & (2.40E-03) \\
\hline S05001-12A & C4440 & 6.70 & ND & $3.21 \mathrm{E}-01$ & $(4.95 \mathrm{E}+00)$ & $1.60 \mathrm{E}-01$ & $(2.85 \mathrm{E}-03)$ \\
\hline S05001-12 & C4440 & 7.10 & $(2.55 \mathrm{E}+00)$ & $1.12 \mathrm{E}+00$ & $(1.26 \mathrm{E}+01)$ & $3.37 \mathrm{E}-01$ & $(2.07 \mathrm{E}-04)$ \\
\hline S05001-13B & $\mathrm{C} 4445$ & 6.63 & $(1.69 \mathrm{E}+00)$ & $5.48 \mathrm{E}-01$ & $(1.19 \mathrm{E}+01)$ & $3.00 \mathrm{E}-01$ & $(1.03 \mathrm{E}-03)$ \\
\hline S05001-13A-1 & $\mathrm{C} 4445$ & 7.13 & $(3.83 \mathrm{E}+00)$ & 7.74E-01 & $(8.71 \mathrm{E}+00)$ & $2.14 \mathrm{E}-01$ & (3.80E-04) \\
\hline S05001-13A-2 & C4445 & 7.13 & ND & $4.42 \mathrm{E}-01$ & $(8.20 \mathrm{E}+00)$ & $1.47 \mathrm{E}-01$ & (3.44E-03) \\
\hline S05001-14B & C4438 & 13.88 & ND & $6.27 \mathrm{E}-01$ & $(1.76 \mathrm{E}+01)$ & 4.64E-01 & $1.90 \mathrm{E}-02$ \\
\hline S05001-14A & C4438 & 14.63 & $(7.34 \mathrm{E}+00)$ & $9.36 \mathrm{E}-01$ & $(5.67 \mathrm{E}+00)$ & $2.22 \mathrm{E}-01$ & $(1.24 \mathrm{E}-02)$ \\
\hline S05001-14A Dup & C4438 & 14.63 & $(1.13 \mathrm{E}+01)$ & $4.16 \mathrm{E}+00$ & $(9.30 \mathrm{E}+00)$ & $2.95 \mathrm{E}-01$ & $1.90 \mathrm{E}-02$ \\
\hline S05001-15B & C4448 & 17.38 & $4.20 \mathrm{E}+00$ & $4.08 \mathrm{E}-01$ & $(1.81 \mathrm{E}+01)$ & $6.06 \mathrm{E}-01$ & $(4.16 \mathrm{E}-03)$ \\
\hline S05001-15A & C4448 & 18.13 & $(7.56 \mathrm{E}+00)$ & $1.38 \mathrm{E}+00$ & $(1.09 \mathrm{E}+01)$ & $3.76 \mathrm{E}-01$ & $(7.55 \mathrm{E}-03)$ \\
\hline S05001-17B & C4436 & 16.38 & $(6.31 \mathrm{E}+00)$ & $4.41 \mathrm{E}-01$ & $(8.60 \mathrm{E}+00)$ & $3.79 \mathrm{E}-01$ & $(4.13 \mathrm{E}-03)$ \\
\hline S05001-17A & C4436 & 17.13 & $(9.33 \mathrm{E}+00)$ & $1.58 \mathrm{E}+00$ & $(9.59 \mathrm{E}+00)$ & $3.48 \mathrm{E}-01$ & $(8.39 \mathrm{E}-03)$ \\
\hline S05001-18B & C4434 & 13.88 & ND & $6.10 \mathrm{E}-01$ & $(1.35 \mathrm{E}+01)$ & $3.62 \mathrm{E}-01$ & (5.15E-03) \\
\hline S05001-18A & $\mathrm{C} 4434$ & 14.63 & ND & $2.86 \mathrm{E}-01$ & $(5.95 \mathrm{E}+00)$ & $1.73 \mathrm{E}-01$ & (3.64E-03) \\
\hline S05001-19B & C4428 & 15.30 & ND & $3.11 \mathrm{E}-01$ & $(7.56 \mathrm{E}+00)$ & $2.09 \mathrm{E}-01$ & $(3.74 \mathrm{E}-03)$ \\
\hline S05001-19A & $\mathrm{C} 4428$ & 18.38 & ND & $6.12 \mathrm{E}-01$ & $(1.24 \mathrm{E}+01)$ & $2.15 \mathrm{E}-01$ & (7.03E-03) \\
\hline S05001-20A & C4426 & 6.06 & ND & $6.50 \mathrm{E}-01$ & $(1.03 \mathrm{E}+01)$ & $3.23 \mathrm{E}-01$ & (3.35E-03) \\
\hline S05001-20 & $\mathrm{C} 4426$ & 6.73 & ND & $2.93 \mathrm{E}+00$ & $(6.64 \mathrm{E}+00)$ & $1.97 \mathrm{E}-01$ & $(9.73 \mathrm{E}-04)$ \\
\hline S05001-21B-1 & C4430 & 18.88 & $(5.99 \mathrm{E}+00)$ & $1.10 \mathrm{E}+00$ & $(1.63 \mathrm{E}+01)$ & $3.04 \mathrm{E}-01$ & $(4.34 \mathrm{E}-03)$ \\
\hline S05001-21B-2 & C4430 & 18.88 & ND & $3.15 \mathrm{E}-01$ & $(6.70 \mathrm{E}+00)$ & $1.48 \mathrm{E}-01$ & $(2.81 \mathrm{E}-03)$ \\
\hline S05001-21A & C4430 & 19.63 & $\mathrm{ND}$ & $5.05 \mathrm{E}-01$ & $(9.54 \mathrm{E}+00)$ & $2.12 \mathrm{E}-01$ & $(2.83 \mathrm{E}-03)$ \\
\hline \multicolumn{8}{|c|}{$\begin{array}{l}\text { Shaded cells indicate grab samples. } \\
\text { Bold values denote elevated concentrations. } \\
\text { Parentheses indicate reported value is less than the limit of quantification for the analysis. } \\
\text { ND indicates the analyte was not detected in the sample. }\end{array}$} \\
\hline
\end{tabular}



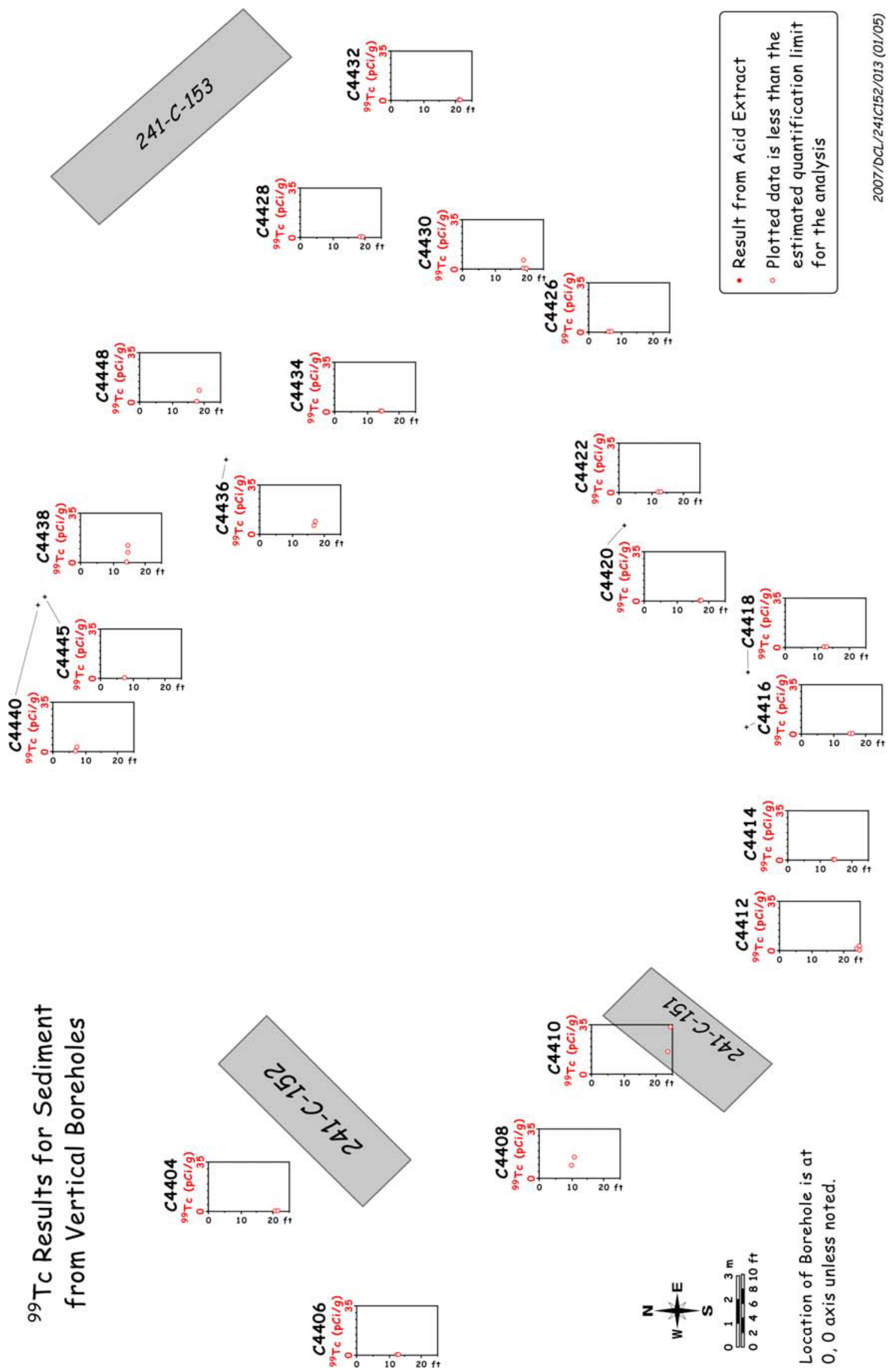

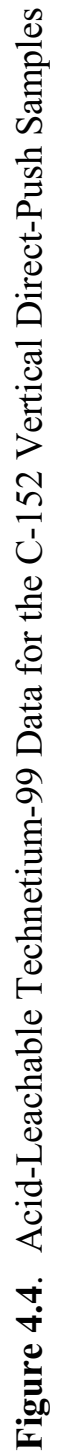




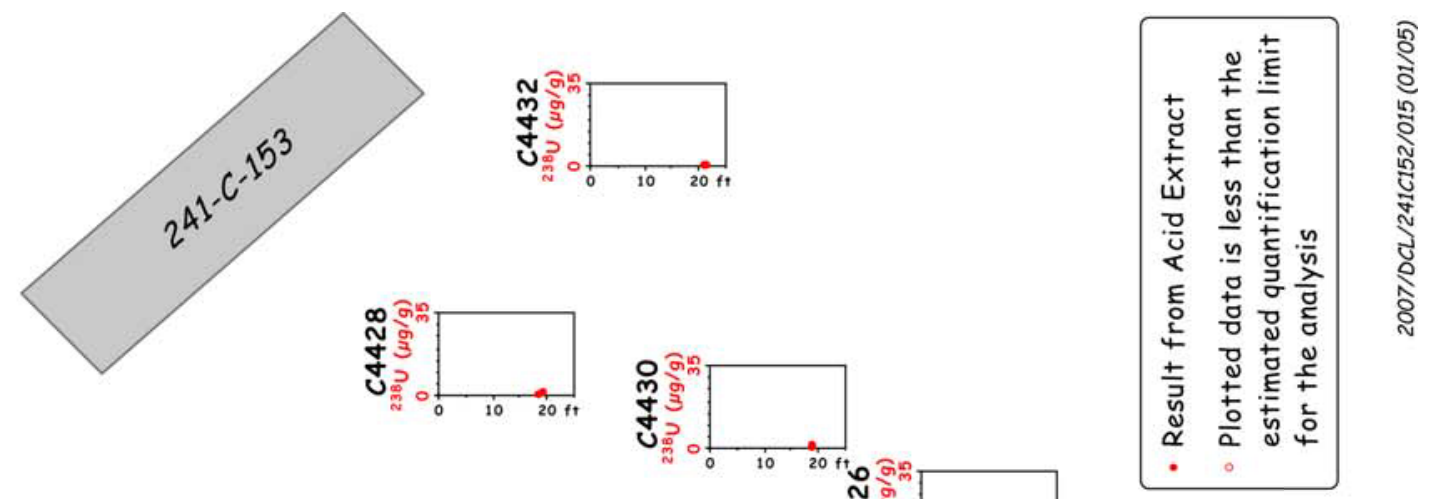

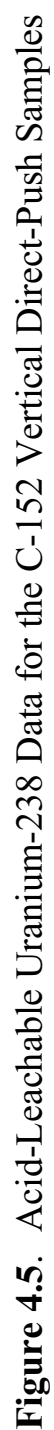
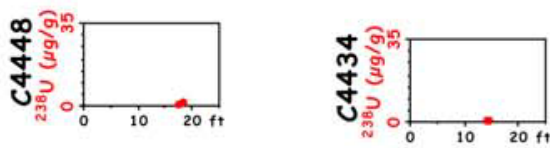

लू $0 \frac{1}{0} 10 \quad 20 \mathrm{ft}$
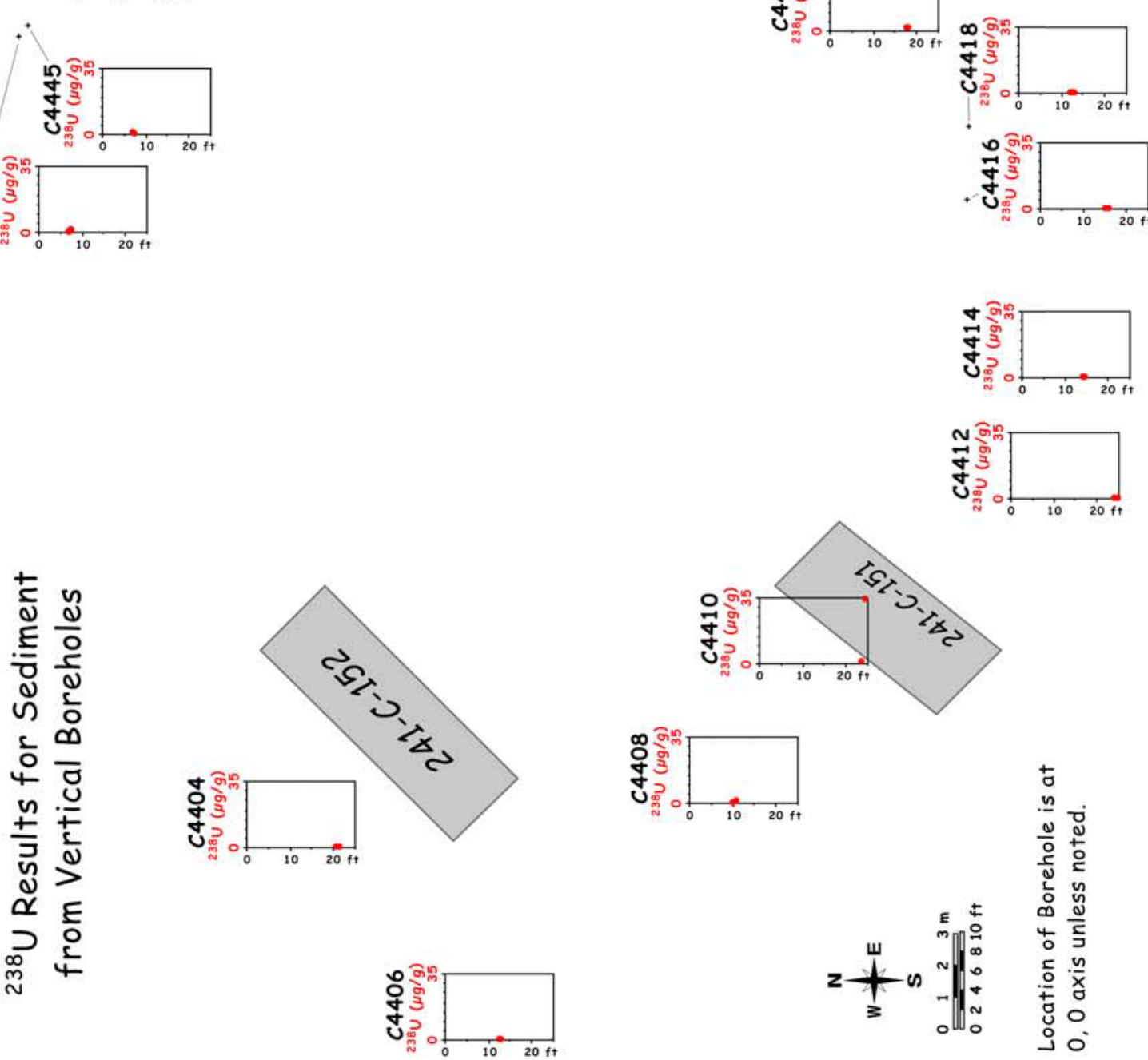


\subsubsection{Radionuclide Content in Vadose Zone Sediment from the C-152 Direct-Push Holes}

Aside from the technetium-99 and uranium data from the water extractions and acid leaches already presented, the direct measurement of bulk sediment samples for gamma-emitting radionuclides showed that only natural potassium- 40 was present in all of the samples, and the fission product isotope cesium-137 was present as a trace constituent $(<0.5 \mathrm{pCi} / \mathrm{g})$ in one of the samples. The GEA data are shown in Table 4.14 and confirm the gross-gamma field logs that did not detect the presence of any manmade gamma emitters in these samples. The one sample that contained a quantifiable concentration of a fission product isotope, cesium-137, also contained the highest concentration of water-extractable and acid-leachable uranium. Based on this, it seems likely that the significantly elevated uranium in this sample is a result of contamination from a tank-related waste source.

\subsubsection{Total Carbon, Calcium Carbonate, and Organic Carbon Content of Vadose Zone Sediment from the C-152 Vertical Push Samples}

Table 4.15 shows the total carbon, inorganic carbon, and organic carbon contents (calculated by difference) of the vadose zone sediment collected from the C-152 direct-push cores. The inorganic carbon was also converted to the equivalent calcium-carbonate content. The sediment in the Hanford formation $\mathrm{H} 2$ unit was, in general, relatively low in calcium carbonate $(<3 \mathrm{wt} \%)$ with little to no organic carbon. However, four samples contained $>3 \mathrm{wt} \%$ inorganic carbon as $\mathrm{CaCO}_{3}$; these samples were S05001-4A from probe hole C4410, S05001-12 from probe hole C4440, S05001-13A-2 from probe hole $\mathrm{C} 4445$, and S05001-20A from probe hole C4426. Of the four samples containing elevated inorganic carbon, only one (S05001-4A) also contained elevated water-extractable and acid-leachable uranium, and a second sample, S05001-12, contained elevated acid-leachable uranium. However, as mentioned in Section 4.1.2.2, a mass scan of the sample was performed via IC-MS over the range of 230 to 240 atomic mass units, and a discernable peak was observed at mass 236. Although the data are considered qualitative, the presence of uranium-236 in the 1:1 sediment:water extraction is a clear indicator that this sample contains processed Hanford fuel. As is found in most vadose sediments from the Hanford Site, there was very little (generally $<0.15 \mathrm{wt} \%$ ) organic carbon in the vadose zone sediments. These values are quite typical and compare well with other uncontaminated samples collected from other locations around the Hanford Site (Serne et al. 2004a, b; Brown et al. 2005).

\subsection{Vadose Zone Sediment from the Slant Probe Hole Direct-Push Samples}

\subsubsection{Moisture Content}

The moisture contents of the 43 core liners and 13 grab samples from the slant probe holes are shown in Table 4.16 and Figure 4.6. The intent of the slant probe hole sampling effort around the $\mathrm{C}-152$ pipeline leak was to collect vadose zone sediment as a function of depth directly beneath the pipe leak location. When practical, the sampling effort attempted to intercept contacts associated with regions of elevated moisture. The liner sets from three of the probe holes (C5107, C5108, and C5109) contained sediment with appreciably different moisture contents ( $>50 \%$ difference), indicating that a contact layer responsible for the zone of increased moisture was encountered within the 1.5 - $\mathrm{ft}$ sampling interval. Due to difficulties encountered when extruding the sediment from the core liners, the precise location of the contact within 
each set of cores was not readily determined. Because the friction generated between the sample and the wall of the liner was too great to be overcome by the extruder apparatus, most of the cores required part to most of the sediment to be "dug out" of the liner. Photographs of the sediment removed from each slant probe liner are included in Appendix A2 of this report.

Table 4.14. Gamma-Emitting Radionuclides in the C-152 Vertical Vadose Zone Sediments

\begin{tabular}{|c|c|c|c|c|}
\hline $\begin{array}{l}\text { Sample } \\
\text { Number }\end{array}$ & $\begin{array}{l}\text { Probe Hole } \\
\text { Number }\end{array}$ & $\begin{array}{l}\text { Mid-Depth } \\
\text { (ft bgs) }\end{array}$ & $\begin{array}{l}\text { Potassium-40 } \\
\text { (pCi/g soil) }\end{array}$ & $\begin{array}{l}\text { Cesium-137 } \\
\text { (pCi/g soil) }\end{array}$ \\
\hline S05001-1A & C4406 & 12.29 & $1.43 \mathrm{E}+01$ & ND \\
\hline S05001-1 & $\mathrm{C} 4406$ & 12.83 & $1.90 \mathrm{E}+01$ & ND \\
\hline S05001-2B & C4408 & 9.88 & $1.35 \mathrm{E}+01$ & ND \\
\hline S05001-2A & $\mathrm{C} 4408$ & 10.63 & $1.20 \mathrm{E}+01$ & ND \\
\hline S05001-3B & $\mathrm{C} 4404$ & 20.38 & $1.85 \mathrm{E}+01$ & ND \\
\hline S05001-3A & C4404 & 21.13 & $1.91 \mathrm{E}+01$ & ND \\
\hline S05001-4B & $\mathrm{C} 4410$ & 21.80 & $1.53 \mathrm{E}+01$ & ND \\
\hline S05001-4A & $\mathrm{C} 4410$ & 23.38 & $2.00 \mathrm{E}+01$ & $2.106 \mathrm{E}-01$ \\
\hline S05001-5B & $\mathrm{C} 4414$ & 24.13 & $1.58 \mathrm{E}+01$ & ND \\
\hline S05001-5A & $\mathrm{C} 4414$ & 24.80 & $1.64 \mathrm{E}+01$ & ND \\
\hline S05001-6B & $\mathrm{C} 4412$ & 13.88 & $1.96 \mathrm{E}+01$ & ND \\
\hline S05001-6A-1 & $\mathrm{C} 4412$ & 14.63 & $2.08 \mathrm{E}+01$ & ND \\
\hline S05001-6A-2 & $\mathrm{C} 4412$ & 14.63 & $1.80 \mathrm{E}+01$ & ND \\
\hline S05001-7B & $\mathrm{C} 4422$ & 11.88 & $1.61 \mathrm{E}+01$ & ND \\
\hline S05001-7A & $\mathrm{C} 4422$ & 12.63 & $1.21 \mathrm{E}+01$ & ND \\
\hline S05001-8B & $\mathrm{C} 4420$ & 13.30 & $1.40 \mathrm{E}+01$ & ND \\
\hline S05001-8A & C4420 & 16.88 & $1.87 \mathrm{E}+01$ & ND \\
\hline S05001-9B & $\mathrm{C} 4418$ & 17.63 & $1.45 \mathrm{E}+01$ & ND \\
\hline S05001-9A & $\mathrm{C} 4418$ & 18.30 & $1.20 \mathrm{E}+01$ & ND \\
\hline S05001-10B & $\mathrm{C} 4416$ & 11.88 & $6.09 \mathrm{E}+00$ & ND \\
\hline S05001-10A & $\mathrm{C} 4416$ & 12.63 & $1.64 \mathrm{E}+01$ & ND \\
\hline S05001-11B & $\mathrm{C} 4432$ & 20.77 & $1.52 \mathrm{E}+01$ & ND \\
\hline S05001-11A & $\mathrm{C} 4432$ & 21.34 & $1.30 \mathrm{E}+01$ & ND \\
\hline S05001-12A & $\mathrm{C} 4440$ & 6.70 & $1.64 \mathrm{E}+01$ & ND \\
\hline S05001-12 & $\mathrm{C} 4440$ & 7.10 & $1.80 \mathrm{E}+01$ & ND \\
\hline S05001-13B & $\mathrm{C} 4445$ & 6.63 & $1.75 \mathrm{E}+01$ & ND \\
\hline S05001-13A-1 & C4445 & 7.13 & $1.86 \mathrm{E}+01$ & ND \\
\hline S05001-13A-2 & $\mathrm{C} 4445$ & 7.13 & $1.78 \mathrm{E}+01$ & ND \\
\hline S05001-14B & $\mathrm{C} 4438$ & 13.88 & $1.65 \mathrm{E}+01$ & ND \\
\hline S05001-14A & $\mathrm{C} 4438$ & 14.63 & $1.61 \mathrm{E}+01$ & ND \\
\hline S05001-14A Dup & $\mathrm{C} 4438$ & 14.63 & $1.35 \mathrm{E}+01$ & ND \\
\hline S05001-15B & $\mathrm{C} 4448$ & 17.38 & $1.32 \mathrm{E}+01$ & ND \\
\hline S05001-15A & C4448 & 18.13 & $1.75 \mathrm{E}+01$ & ND \\
\hline
\end{tabular}


Table 4.14. (contd)

\begin{tabular}{|c|c|c|c|c|}
\hline $\begin{array}{l}\text { Sample } \\
\text { Number }\end{array}$ & $\begin{array}{l}\text { Probe Hole } \\
\text { Number }\end{array}$ & $\begin{array}{l}\text { Mid-Depth } \\
\text { (ft bgs) }\end{array}$ & $\begin{array}{c}\text { Potassium-40 } \\
\text { (pCi/g soil) }\end{array}$ & $\begin{array}{l}\text { Cesium-137 } \\
\text { (pCi/g soil) } \\
\end{array}$ \\
\hline S05001-17B & $\mathrm{C} 4436$ & 16.38 & $1.30 \mathrm{E}+01$ & ND \\
\hline S05001-17A & $\mathrm{C} 4436$ & 17.13 & $1.59 \mathrm{E}+01$ & ND \\
\hline S05001-18B & $\mathrm{C} 4434$ & 13.88 & $1.42 \mathrm{E}+01$ & ND \\
\hline S05001-18A & C4434 & 14.63 & $1.21 \mathrm{E}+01$ & ND \\
\hline S05001-19B & $\mathrm{C} 4428$ & 15.30 & $1.51 \mathrm{E}+01$ & ND \\
\hline S05001-19A & $\mathrm{C} 4428$ & 18.38 & $1.60 \mathrm{E}+01$ & ND \\
\hline S05001-20A & $\mathrm{C} 4426$ & 6.06 & $1.96 \mathrm{E}+01$ & ND \\
\hline S05001-20 & $\mathrm{C} 4426$ & 6.73 & $1.53 \mathrm{E}+01$ & ND \\
\hline S05001-21B-1 & $\mathrm{C} 4430$ & 18.88 & $1.55 \mathrm{E}+01$ & ND \\
\hline S05001-21B-2 & $\mathrm{C} 4430$ & 18.88 & $1.80 \mathrm{E}+01$ & ND \\
\hline S05001-21A & $\mathrm{C} 4430$ & 19.63 & $2.21 \mathrm{E}+01$ & ND \\
\hline
\end{tabular}

The average gravimetric moisture content for all of the slant push samples was $5.76 \mathrm{wt} \%$, with minimum and maximum moisture contents measured at $1.71 \%$ and $17.7 \mathrm{wt} \%$, respectively. The sediments containing the highest moisture contents were all collected shallowest in the vadose zone at locations near the edge of the impermeable cover overlying the pipeline leak. The two deepest samples collected as part of this campaign (approximately $80 \mathrm{ft} \mathrm{bgs}$ from probe holes C5104 and C5106) both contained elevated moisture (at $6.92 \%$ and $5.50 \mathrm{wt} \%$, respectively) when compared to the average moisture content in interspersed core samples collected within the Hanford formation $\mathrm{H} 2$ unit (3.1\%) at the nearby C Tank Farm characterization borehole (C4297, near Tank C-105) (Brown et al. 2006). Photographs of the grain size and texture of the deeper samples from probe holes C5104 and C5106 (sample strings B1HY36 and B1HY31, respectively [Appendix A2]) did not indicate the presence of a lithologic change within the sample strings. Therefore, it is possible that the deeper C-152 slant directpush samples from probe holes C5104 and C5106 could contain residual moisture from the C-152 pipeline leak. 
Table 4.15. Carbon Content of the C-152 Vertical Vadose Zone Samples

\begin{tabular}{|c|c|c|c|c|c|c|}
\hline $\begin{array}{c}\text { Sample } \\
\text { Number }\end{array}$ & $\begin{array}{c}\text { Probe Hole } \\
\text { Number } \\
\end{array}$ & $\begin{array}{r}\text { Mid- } \\
\text { Depth } \\
\text { (ft bgs) } \\
\end{array}$ & $\begin{array}{c}\text { Total Carbon } \\
(\%) \\
\end{array}$ & $\begin{array}{c}\text { Inorganic } \\
\text { Carbon } \\
(\%) \\
\end{array}$ & $\begin{array}{c}\text { Inorganic } \\
\text { Carbon as } \\
\mathrm{CaCO}_{3} \\
(\%) \\
\end{array}$ & $\begin{array}{c}\text { Organic } \\
\text { Carbon } \\
(\%) \\
\end{array}$ \\
\hline S05001-1A & $\mathrm{C} 4406$ & 12.29 & $2.07 \mathrm{E}-01$ & $1.64 \mathrm{E}-01$ & $1.37 \mathrm{E}+00$ & 4.27E-02 \\
\hline S05001-1 & C4406 & 12.83 & $1.84 \mathrm{E}-01$ & $1.31 \mathrm{E}-01$ & $1.09 \mathrm{E}+00$ & $5.33 \mathrm{E}-02$ \\
\hline S05001-2B & $\mathrm{C} 4408$ & 9.88 & $1.56 \mathrm{E}-01$ & $1.06 \mathrm{E}-01$ & 8.79E-01 & $5.02 \mathrm{E}-02$ \\
\hline S05001-2A & C4408 & 10.63 & $1.74 \mathrm{E}-01$ & $1.31 \mathrm{E}-01$ & $1.09 \mathrm{E}+00$ & $4.31 \mathrm{E}-02$ \\
\hline S05001-3B & $\mathrm{C} 4404$ & 20.38 & $2.21 \mathrm{E}-01$ & $1.84 \mathrm{E}-01$ & $1.53 \mathrm{E}+00$ & $3.67 \mathrm{E}-02$ \\
\hline S05001-3A & $\mathrm{C} 4404$ & 21.13 & $2.39 \mathrm{E}-01$ & $1.90 \mathrm{E}-01$ & $1.58 \mathrm{E}+00$ & $4.88 \mathrm{E}-02$ \\
\hline S05001-4B & $\mathrm{C} 4410$ & 21.80 & $1.74 \mathrm{E}-01$ & $1.46 \mathrm{E}-01$ & $1.22 \mathrm{E}+00$ & $2.71 \mathrm{E}-02$ \\
\hline S05001-4A & $\mathrm{C} 4410$ & 23.38 & 4.47E-01 & $4.38 \mathrm{E}-01$ & $3.64 \mathrm{E}+00$ & $9.60 \mathrm{E}-03$ \\
\hline S05001-5B & $\mathrm{C} 4414$ & 24.13 & $1.18 \mathrm{E}-01$ & $8.54 \mathrm{E}-02$ & $7.11 \mathrm{E}-01$ & $3.27 \mathrm{E}-02$ \\
\hline S05001-5A & $\mathrm{C} 4414$ & 24.80 & $1.82 \mathrm{E}-01$ & $1.56 \mathrm{E}-01$ & $1.30 \mathrm{E}+00$ & $2.56 \mathrm{E}-02$ \\
\hline S05001-6B & $\mathrm{C} 4412$ & 13.88 & $1.89 \mathrm{E}-01$ & $1.83 \mathrm{E}-01$ & $1.53 \mathrm{E}+00$ & $5.90 \mathrm{E}-03$ \\
\hline S05001-6A-1 & $\mathrm{C} 4412$ & 14.63 & $2.13 \mathrm{E}-01$ & $1.66 \mathrm{E}-01$ & $1.38 \mathrm{E}+00$ & 4.63E-02 \\
\hline S05001-6A-2 & $\mathrm{C} 4412$ & 14.63 & $2.16 \mathrm{E}-01$ & $1.86 \mathrm{E}-01$ & $1.55 \mathrm{E}+00$ & $3.00 \mathrm{E}-02$ \\
\hline S05001-7B & $\mathrm{C} 4422$ & 11.88 & $1.62 \mathrm{E}-01$ & $1.38 \mathrm{E}-01$ & $1.15 \mathrm{E}+00$ & $2.42 \mathrm{E}-02$ \\
\hline S05001-7A & $\mathrm{C} 4422$ & 12.63 & $9.60 \mathrm{E}-02$ & 7.29E-02 & $6.07 \mathrm{E}-01$ & $2.31 \mathrm{E}-02$ \\
\hline S05001-8B & $\mathrm{C} 4420$ & 13.30 & $1.35 \mathrm{E}-01$ & $1.07 \mathrm{E}-01$ & $8.87 \mathrm{E}-01$ & $2.82 \mathrm{E}-02$ \\
\hline S05001-8A & $\mathrm{C} 4420$ & 16.88 & $2.31 \mathrm{E}-01$ & $1.81 \mathrm{E}-01$ & $1.50 \mathrm{E}+00$ & $5.04 \mathrm{E}-02$ \\
\hline S05001-9B & $\mathrm{C} 4418$ & 17.63 & $1.17 \mathrm{E}-01$ & $7.85 \mathrm{E}-02$ & $6.54 \mathrm{E}-01$ & $3.88 \mathrm{E}-02$ \\
\hline S05001-9A & $\mathrm{C} 4418$ & 18.30 & $1.10 \mathrm{E}-01$ & $7.87 \mathrm{E}-02$ & $6.56 \mathrm{E}-01$ & $3.10 \mathrm{E}-02$ \\
\hline S05001-10B & $\mathrm{C} 4416$ & 11.88 & $8.47 \mathrm{E}-02$ & $4.83 \mathrm{E}-02$ & $4.02 \mathrm{E}-01$ & $3.64 \mathrm{E}-02$ \\
\hline S05001-10A & $\mathrm{C} 4416$ & 12.63 & $2.02 \mathrm{E}-01$ & $1.61 \mathrm{E}-01$ & $1.34 \mathrm{E}+00$ & $4.06 \mathrm{E}-02$ \\
\hline S05001-11B & $\mathrm{C} 4432$ & 20.77 & $1.99 \mathrm{E}-01$ & $1.73 \mathrm{E}-01$ & $1.44 \mathrm{E}+00$ & $2.59 \mathrm{E}-02$ \\
\hline S05001-11A & $\mathrm{C} 4432$ & 21.34 & $2.23 \mathrm{E}-01$ & $2.07 \mathrm{E}-01$ & $1.72 \mathrm{E}+00$ & $1.58 \mathrm{E}-02$ \\
\hline S05001-12A & $\mathrm{C} 4440$ & 6.70 & $1.85 \mathrm{E}-01$ & $1.14 \mathrm{E}-01$ & $9.52 \mathrm{E}-01$ & $7.02 \mathrm{E}-02$ \\
\hline S05001-12 & $\mathrm{C} 4440$ & 7.10 & $5.40 \mathrm{E}-01$ & $5.49 \mathrm{E}-01$ & $4.57 \mathrm{E}+00$ & ND \\
\hline S05001-13B & $\mathrm{C} 4445$ & 6.63 & $1.79 \mathrm{E}-01$ & $6.40 \mathrm{E}-02$ & 5.33E-01 & $1.15 \mathrm{E}-01$ \\
\hline S05001-13A-1 & $\mathrm{C} 4445$ & 7.13 & $1.50 \mathrm{E}-01$ & $1.61 \mathrm{E}-02$ & $1.34 \mathrm{E}-01$ & $1.34 \mathrm{E}-01$ \\
\hline S05001-13A-2 & $\mathrm{C} 4445$ & 7.13 & $6.06 \mathrm{E}-01$ & $5.87 \mathrm{E}-01$ & $4.89 \mathrm{E}+00$ & $1.89 \mathrm{E}-02$ \\
\hline S05001-14B & C4438 & 13.88 & $1.83 \mathrm{E}-01$ & $1.39 \mathrm{E}-01$ & $1.16 \mathrm{E}+00$ & $4.35 \mathrm{E}-02$ \\
\hline S05001-14A & $\mathrm{C} 4438$ & 14.63 & $1.91 \mathrm{E}-01$ & $1.64 \mathrm{E}-01$ & $1.37 \mathrm{E}+00$ & $2.65 \mathrm{E}-02$ \\
\hline S05001-14A Dup & $\mathrm{C} 4438$ & 14.63 & $2.11 \mathrm{E}-01$ & $1.85 \mathrm{E}-01$ & $1.54 \mathrm{E}+00$ & $2.55 \mathrm{E}-02$ \\
\hline S05001-15B & $\mathrm{C} 4448$ & 17.38 & $1.02 \mathrm{E}-01$ & 6.94E-02 & $5.78 \mathrm{E}-01$ & $3.27 \mathrm{E}-02$ \\
\hline S05001-15A & $\mathrm{C} 4448$ & 18.13 & $1.97 \mathrm{E}-01$ & $1.56 \mathrm{E}-01$ & $1.30 \mathrm{E}+00$ & 4.07E-02 \\
\hline S05001-17B & $\mathrm{C} 4436$ & 16.38 & $1.18 \mathrm{E}-01$ & 7.99E-02 & $6.66 \mathrm{E}-01$ & $3.81 \mathrm{E}-02$ \\
\hline S05001-17A & $\mathrm{C} 4436$ & 17.13 & $2.12 \mathrm{E}-01$ & $1.81 \mathrm{E}-01$ & $1.50 \mathrm{E}+00$ & $3.13 \mathrm{E}-02$ \\
\hline S05001-18B & $\mathrm{C} 4434$ & 13.88 & $2.05 \mathrm{E}-01$ & $1.35 \mathrm{E}-01$ & $1.12 \mathrm{E}+00$ & $7.08 \mathrm{E}-02$ \\
\hline S05001-18A & C4434 & 14.63 & $2.21 \mathrm{E}-01$ & $1.66 \mathrm{E}-01$ & $1.38 \mathrm{E}+00$ & $5.51 \mathrm{E}-02$ \\
\hline
\end{tabular}


Table 4.15. (contd)

\begin{tabular}{||l|c|c|c|c|c|c||}
\hline $\begin{array}{c}\text { Sample } \\
\text { Number }\end{array}$ & $\begin{array}{c}\text { Probe Hole } \\
\text { Number }\end{array}$ & $\begin{array}{c}\text { Mid- } \\
\text { Depth } \\
\text { (ft bgs) }\end{array}$ & $\begin{array}{c}\text { Total Carbon } \\
(\%)\end{array}$ & $\begin{array}{c}\text { Inorganic } \\
\text { Carbon } \\
(\%)\end{array}$ & $\begin{array}{c}\text { Inorganic } \\
\text { Carbon as } \\
\text { CaCO }_{3} \\
(\%)\end{array}$ & $\begin{array}{c}\text { Organic } \\
\text { Carbon } \\
(\%)\end{array}$ \\
\hline \hline S05001-19B & C4428 & 15.30 & $1.69 \mathrm{E}-01$ & $1.37 \mathrm{E}-01$ & $1.14 \mathrm{E}+00$ & $3.20 \mathrm{E}-02$ \\
\hline S05001-19A & C4428 & 18.38 & $1.95 \mathrm{E}-01$ & $1.55 \mathrm{E}-01$ & $1.29 \mathrm{E}+00$ & $4.07 \mathrm{E}-02$ \\
\hline S05001-19A Dup & C4428 & 18.38 & $2.33 \mathrm{E}-01$ & $2.01 \mathrm{E}-01$ & $1.67 \mathrm{E}+00$ & $3.23 \mathrm{E}-02$ \\
\hline S05001-20A & C4426 & 6.06 & $4.69 \mathrm{E}-01$ & $4.07 \mathrm{E}-01$ & $\mathbf{3 . 3 9 E}+\mathbf{0 0}$ & $6.14 \mathrm{E}-02$ \\
\hline S05001-20 & C4426 & 6.73 & $4.20 \mathrm{E}-01$ & $2.97 \mathrm{E}-01$ & $2.47 \mathrm{E}+00$ & $1.23 \mathrm{E}-01$ \\
\hline S05001-21B-1 & C4430 & 18.88 & $1.83 \mathrm{E}-01$ & $1.40 \mathrm{E}-01$ & $1.17 \mathrm{E}+00$ & $4.29 \mathrm{E}-02$ \\
\hline S05001-21B-2 & C4430 & 18.88 & $2.03 \mathrm{E}-01$ & $1.31 \mathrm{E}-01$ & $1.09 \mathrm{E}+00$ & $7.20 \mathrm{E}-02$ \\
\hline S05001-21A & \multicolumn{7}{|c|}{ C4430 } & 19.63 & $2.50 \mathrm{E}-01$ & $1.81 \mathrm{E}-01$ & $1.51 \mathrm{E}+00$ & $6.92 \mathrm{E}-02$ \\
\hline $\begin{array}{l}\text { Shaded cells indicate grab samples. } \\
\text { Bold values denote elevated concentrations. } \\
\text { ND indicates the analyte was not detected in the sample. }\end{array}$ \\
\hline
\end{tabular}

Table 4.16. Gravimetric Moisture Content of Samples Obtained from the C-152 Slant Direct-Push Probe Hole

\begin{tabular}{|c|c|c|c|c|}
\hline $\begin{array}{l}\text { Sample } \\
\text { Number }\end{array}$ & $\begin{array}{c}\text { Probe Hole } \\
\text { Number }\end{array}$ & $\begin{array}{l}\text { Pipe Length } \\
\text { (ft) }\end{array}$ & $\begin{array}{l}\text { Mid-Depth } \\
\text { (ft bgs) }\end{array}$ & $\begin{array}{c}\text { Moisture Content } \\
(\%)\end{array}$ \\
\hline B1HY25 & $\mathrm{C} 5108$ & 29.8 & 25.8 & 8.3 \\
\hline B1HY25A & C5108 & 29.3 & 25.3 & 4.8 \\
\hline B1HY25B & C5108 & 28.8 & 24.9 & 2.5 \\
\hline B1HY25C & C5108 & 28.3 & 24.5 & 5.5 \\
\hline B1HY26 & C5108 & 67.8 & 58.7 & 1.9 \\
\hline B1HY26A & C5108 & 67.3 & 58.2 & 2.4 \\
\hline B1HY26B & C5108 & 66.8 & 57.8 & 2.4 \\
\hline B1HY26C & C5108 & 66.3 & 57.4 & 3.9 \\
\hline B1HY27 & C5109 & 16.3 & 11.5 & 17.7 \\
\hline B1HY27A & C5109 & 15.8 & 11.1 & 13.3 \\
\hline B1HY27B & C5109 & 15.3 & 10.8 & Insufficient Sample \\
\hline B1HY28B & C5109 & 31.8 & 22.4 & 2.4 \\
\hline B1HY28C & C5109 & 31.3 & 22.1 & 4.0 \\
\hline B1HY29 & C5109 & 46.8 & 33.1 & 2.5 \\
\hline B1HY29A & C5109 & 46.3 & 32.7 & 2.7 \\
\hline B1HY29B & C5109 & 45.8 & 32.3 & 2.7 \\
\hline B1HY29C & C5109 & 45.3 & 32.0 & 4.6 \\
\hline B1HY30 & C5106 & 20.3 & 17.5 & 7.0 \\
\hline B1HY30A & C5106 & 19.8 & 17.1 & 8.3 \\
\hline B1HY30B & C5106 & 19.3 & 16.7 & 7.0 \\
\hline
\end{tabular}


Table 4.16. (contd)

\begin{tabular}{|c|c|c|c|c|}
\hline $\begin{array}{l}\text { Sample } \\
\text { Number }\end{array}$ & $\begin{array}{c}\text { Probe Hole } \\
\text { Number }\end{array}$ & $\begin{array}{l}\text { Pipe Length } \\
\text { (ft) }\end{array}$ & $\begin{array}{l}\text { Mid-Depth } \\
\text { (ft bgs) }\end{array}$ & $\begin{array}{c}\text { Moisture Content } \\
(\%)\end{array}$ \\
\hline B1HY30C & C5106 & 18.8 & 16.2 & 7.4 \\
\hline B1HY31 & C5106 & 91.8 & 79.5 & 1.7 \\
\hline B1HY31A & C5106 & 91.3 & 79.0 & 2.9 \\
\hline B1HY31B & C5106 & 90.8 & 78.6 & 3.0 \\
\hline B1HY31C & C5106 & 90.3 & 78.2 & 5.5 \\
\hline B1HY32 & C5107 & 18.8 & 13.3 & 11.4 \\
\hline B1HY32A & $\mathrm{C} 5107$ & 18.3 & 12.9 & 14.3 \\
\hline B1HY32B & C5107 & 17.8 & 12.5 & 9.1 \\
\hline B1HY32C & C5107 & 17.3 & 12.2 & 8.0 \\
\hline B1HY33 & $\mathrm{C} 5107$ & 24.3 & 17.1 & 3.8 \\
\hline B1HY33A & C5107 & 23.8 & 16.8 & 7.3 \\
\hline B1HY33B & C5107 & 23.3 & 16.4 & 5.4 \\
\hline B1HY33C & C5107 & 22.8 & 16.1 & 6.9 \\
\hline B1HY34 & C5107 & 60.8 & 43.0 & Insufficient Sample \\
\hline B1HY34A & $\mathrm{C} 5107$ & 60.3 & 42.6 & 2.5 \\
\hline B1HY34B & C5107 & 59.8 & 42.2 & 2.7 \\
\hline B1HY34C & C5107 & 59.3 & 41.9 & 3.8 \\
\hline B1HY35 & C5104 & 15.3 & 10.8 & 5.4 \\
\hline B1HY35A & C5104 & 14.8 & 10.4 & 6.3 \\
\hline B1HY35B & C5104 & 14.3 & 10.1 & 5.6 \\
\hline B1HY35C & C5104 & 13.8 & 9.7 & 6.4 \\
\hline B1HY36 & C5104 & 110.4 & 78.0 & 2.8 \\
\hline B1HY36A & C5104 & 109.8 & 77.6 & 2.7 \\
\hline B1HY36B & C5104 & 109.3 & 77.2 & 3.4 \\
\hline B1HY36C & C5104 & 108.8 & 76.9 & 6.9 \\
\hline B1JFP2 & C5105 & 14.8 & 7.4 & 11.8 \\
\hline B1JFP2A & C5105 & 14.3 & 7.1 & 8.6 \\
\hline B1JFP2B & C5105 & 13.8 & 6.9 & 12.4 \\
\hline B1JFP3 & C5105 & 27.9 & 13.9 & 6.6 \\
\hline B1JFP3A & C5105 & 27.3 & 13.6 & 6.3 \\
\hline B1JFP3B & C5105 & 26.8 & 13.4 & 9.4 \\
\hline B1JFP3C & C5105 & 26.3 & 13.1 & 5.6 \\
\hline B1JFP4 & C5105 & 84.8 & 42.4 & 2.8 \\
\hline B1JFP4A & C5105 & 84.3 & 42.1 & 2.9 \\
\hline B1JFP4B & C5105 & 83.8 & 41.9 & 2.9 \\
\hline B1JFP4C & C5105 & 83.3 & 41.6 & 3.3 \\
\hline
\end{tabular}



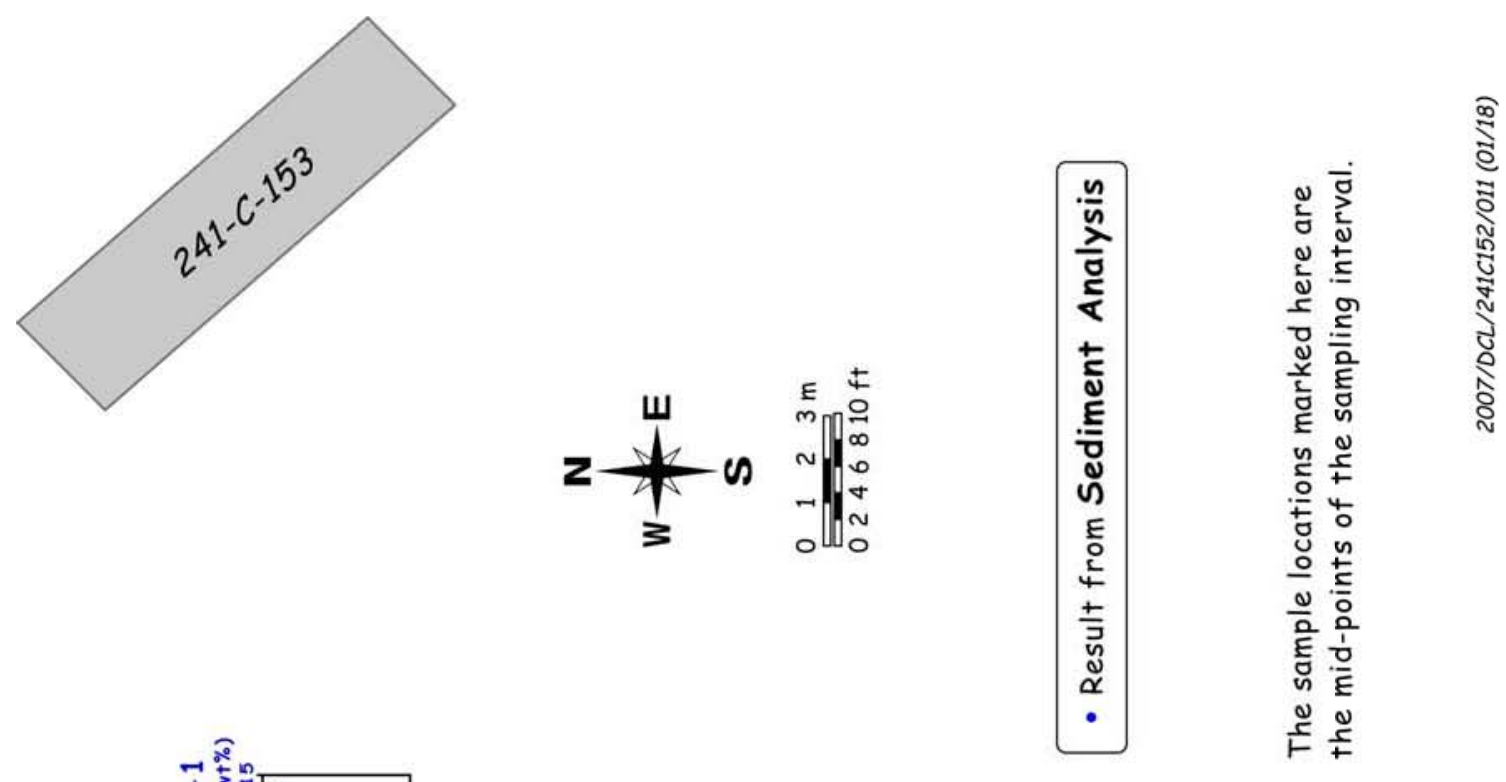

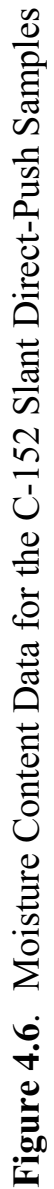
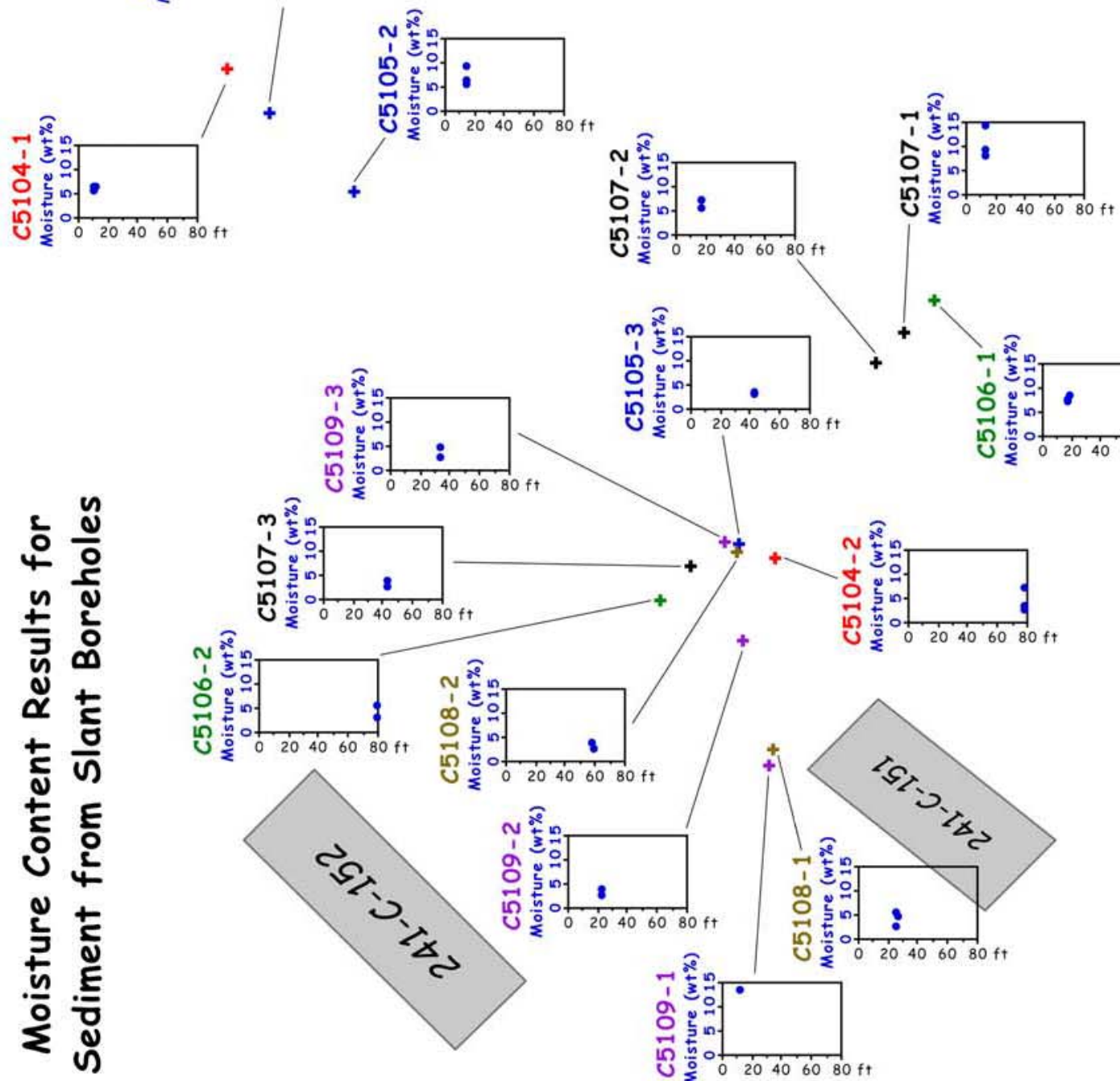

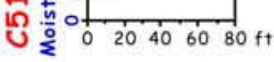

$3 \frac{\hbar}{2} 0 \frac{8}{20} 406080 \mathrm{ft}$
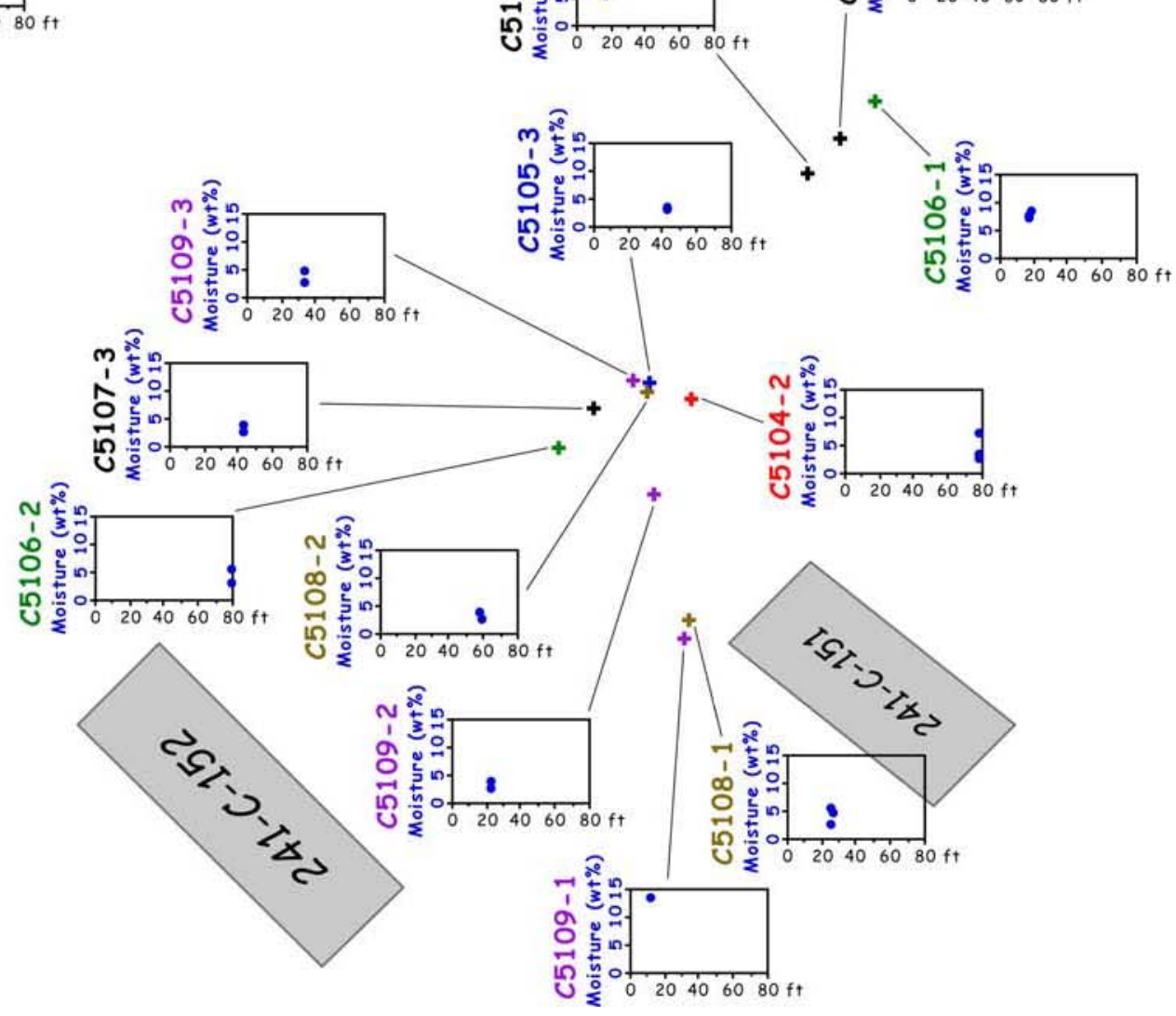


\subsubsection{1:1 Sediment:Water Extractions}

A subset of samples from the $\mathrm{C}-152$ slant probe holes was characterized by performing 1:1 sediment:water extractions. The following tables present the mass of a given constituent leached per gram of oven-dry sediment as measured in the water extractions. Other tables show dilution-corrected values that represent concentrations in the vadose zone pore water. As discussed in several other Vadose Zone Characterization Project reports, the dilution-corrected 1:1 sediment:water extractions are a reasonable estimate of the actual vadose zone pore water (see Serne et al. 2002a, 2002b, 2002c, 2002e, 2002f).

\subsubsection{1 pH and EC}

The 1:1 sediment:water extraction $\mathrm{pH}$ and $\mathrm{EC}$ data for the $\mathrm{C}-152$ slant core and grab samples are shown in Table 4.17. The $\mathrm{pH}$ is tabulated as measured in the 1:1 sediment:water extractions (Figure 4.7), but the EC is corrected for dilution and tabulated as if it was actual pore water. Nearly all of the samples tested had $\mathrm{pH}$ values in the normal range for Hanford sediments (between 7 and 8). However, eight of the samples (B1HY34A, B1HY34B, B1HY34C, B1JFP3A, B1JFP3B, B1JFP4A, B1JFP4B, and B1JFP4C) had elevated $\mathrm{pH}$ values ranging from 8.1 to 9.1 . The elevated $\mathrm{pH}$ data indicate the presence of caustictank-related waste and can potentially be used to constrain the zone of impact from the C-152 pipeline leak. Previous borehole reports have shown that regions of elevated soil $\mathrm{pH}$ are considered to be good indicators of the location of the original leak event or very near-field close to the initial tank waste entry zone (see Serne et al. 2002a, 2002b, 2002c, 2002e, 2002f). The elevated pH sediment samples were collected from probe holes $\mathrm{C} 5105$ and $\mathrm{C} 5107$ at depths ranging from 13 to $42 \mathrm{ft}$ bgs. The relative locations of these samples can be used to provide information on the lateral and vertical migration of the elevated $\mathrm{pH}$ front associated with the pipeline leak. Elevated soil $\mathrm{pH}$ in the shallow samples from probe hole $\mathrm{C} 5105$ indicates that the leak has caused an elevated $\mathrm{pH}$ front extending near the edge of the cap to the northeast of the leak. A soil $\mathrm{pH}$ measurement of 9.1 in the deepest sample collected from probe hole C5017 indicates that the $\mathrm{pH}$ front extended at least to a depth of $42 \mathrm{ft}$ bgs underneath the pipeline leak.

The pore-water-corrected EC data for all of the samples ranged from dilute $(1.22 \mathrm{mS} / \mathrm{cm}$ in probe hole $\mathrm{C} 5109)$ to mildly saline $(12.7 \mathrm{mS} / \mathrm{cm}$ in probe hole $\mathrm{C} 5105)$. There was a correlation between elevated $\mathrm{pH}$ and $\mathrm{EC}$; the two probe holes containing samples with elevated soil $\mathrm{pH}$ also contained the samples with the highest dilution-corrected pore-water conductivity. As mentioned in Section 4.1.1.1, sediment samples collected from the uncontaminated WMA C borehole (299-E27-22) contained elevated nitrate and were not truly indicative of uncontaminated conditions. Therefore, comparison of the average pore-water-corrected conductivity in uncontaminated boreholes from WMA A-AX (1.86 and 2.53 mS/cm from boreholes C4665 and C4257, respectively) (Brown et al. 2005) vs. these samples from the slant probe hole pushes indicates that the vadose zone sediment contained elevated dissolved salts from approximately 13 to at least $80 \mathrm{ft}$ bgs. 
Table 4.17. $\mathrm{pH}$ Values for 1:1 Sediment:Water Extractions and Dilution-Corrected EC Values from C-152 Slant Core Samples

\begin{tabular}{|c|c|c|c|c|}
\hline $\begin{array}{l}\text { Sample } \\
\text { Number }\end{array}$ & $\begin{array}{c}\text { Probe Hole } \\
\text { Number }\end{array}$ & $\begin{array}{l}\text { Mid-Depth } \\
\quad(\mathrm{ft} \text { bgs) }\end{array}$ & $\mathrm{pH}$ & $\begin{array}{l}\text { Conductivity } \\
(\mathrm{mS} / \mathrm{cm})\end{array}$ \\
\hline B1HY25A & C5108 & 25.3 & 7.17 & $3.21 \mathrm{E}+00$ \\
\hline B1HY25B & C5108 & 24.9 & 7.11 & $5.46 \mathrm{E}+00$ \\
\hline B1HY25C & C5108 & 24.5 & 7.62 & $4.37 \mathrm{E}+00$ \\
\hline B1HY26A & C5108 & 58.2 & 7.13 & $5.16 \mathrm{E}+00$ \\
\hline B1HY26B & C5108 & 57.8 & 7.16 & $5.40 \mathrm{E}+00$ \\
\hline B1HY26C & C5108 & 57.4 & 7.22 & $4.71 \mathrm{E}+00$ \\
\hline B1HY27A & C5109 & 11.1 & 7.47 & $1.22 \mathrm{E}+00$ \\
\hline B1HY28B & C5109 & 22.4 & 7.93 & $8.34 \mathrm{E}+00$ \\
\hline B1HY28C & C5109 & 22.1 & 7.82 & $5.99 \mathrm{E}+00$ \\
\hline B1HY29A & C5109 & 32.7 & 7.61 & $6.42 \mathrm{E}+00$ \\
\hline B1HY29B & C5109 & 32.3 & 7.62 & $6.71 \mathrm{E}+00$ \\
\hline B1HY29C & C5109 & 32.0 & 7.65 & $4.05 \mathrm{E}+00$ \\
\hline B1HY30A & C5106 & 17.1 & 7.57 & $2.20 \mathrm{E}+00$ \\
\hline B1HY30B & C5106 & 16.7 & 7.61 & $2.69 \mathrm{E}+00$ \\
\hline B1HY30C & C5106 & 16.2 & 7.70 & $3.01 \mathrm{E}+00$ \\
\hline B1HY31A & C5106 & 79.0 & 7.23 & $6.27 \mathrm{E}+00$ \\
\hline B1HY31B & C5106 & 78.6 & 7.24 & $5.81 \mathrm{E}+00$ \\
\hline B1HY31C & C5106 & 78.2 & 7.10 & $4.48 \mathrm{E}+00$ \\
\hline B1HY32A & C5107 & 12.9 & 7.45 & $1.42 \mathrm{E}+00$ \\
\hline B1HY32B & C5107 & 12.5 & 7.40 & $1.91 \mathrm{E}+00$ \\
\hline B1HY32C & C5107 & 12.2 & 7.45 & $2.52 \mathrm{E}+00$ \\
\hline B1HY33A & C5107 & 16.8 & 7.50 & $2.37 \mathrm{E}+00$ \\
\hline B1HY33B & C5107 & 16.4 & 7.41 & $2.77 \mathrm{E}+00$ \\
\hline B1HY33C & C5107 & 16.1 & 7.51 & $2.56 \mathrm{E}+00$ \\
\hline B1HY34A & C5107 & 42.6 & 9.10 & $8.08 \mathrm{E}+00$ \\
\hline B1HY34B & C5107 & 42.2 & 8.54 & $8.36 \mathrm{E}+00$ \\
\hline B1HY34C & C5107 & 41.9 & 8.49 & $8.48 \mathrm{E}+00$ \\
\hline B1HY35A & C5104 & 10.4 & 7.42 & $2.82 \mathrm{E}+00$ \\
\hline B1HY35B & C5104 & 10.1 & 7.44 & $2.93 \mathrm{E}+00$ \\
\hline B1HY35C & C5104 & 9.7 & 7.40 & $2.46 \mathrm{E}+00$ \\
\hline B1HY36A & C5104 & 77.6 & 7.00 & $7.73 \mathrm{E}+00$ \\
\hline B1HY36B & C5104 & 77.2 & 7.01 & $7.08 \mathrm{E}+00$ \\
\hline B1HY36C & C5104 & 76.9 & 7.10 & $4.33 \mathrm{E}+00$ \\
\hline B1JFP2A & C5105 & 7.1 & 7.45 & $1.71 \mathrm{E}+00$ \\
\hline B1JFP2B & C5105 & 6.9 & 7.46 & $1.30 \mathrm{E}+00$ \\
\hline B1JFP3A & C5105 & 13.6 & 8.21 & $5.84 \mathrm{E}+00$ \\
\hline B1JFP3B & C5105 & 13.4 & 8.40 & $4.09 \mathrm{E}+00$ \\
\hline B1JFP3C & C5105 & 13.1 & 7.67 & $3.76 \mathrm{E}+00$ \\
\hline B1JFP4A & C5105 & 42.1 & 8.13 & $1.27 \mathrm{E}+01$ \\
\hline B1JFP4B & C5105 & 41.9 & 8.08 & $1.16 \mathrm{E}+01$ \\
\hline B1JFP4C & C5105 & 41.6 & 8.14 & $1.06 \mathrm{E}+01$ \\
\hline \multicolumn{5}{|c|}{$\begin{array}{l}\text { Bold values denote elevated concentrations. } \\
\text { EC values are dilution corrected and represent pore-water concentrations not 1:1 extraction } \\
\text { values }\end{array}$} \\
\hline
\end{tabular}



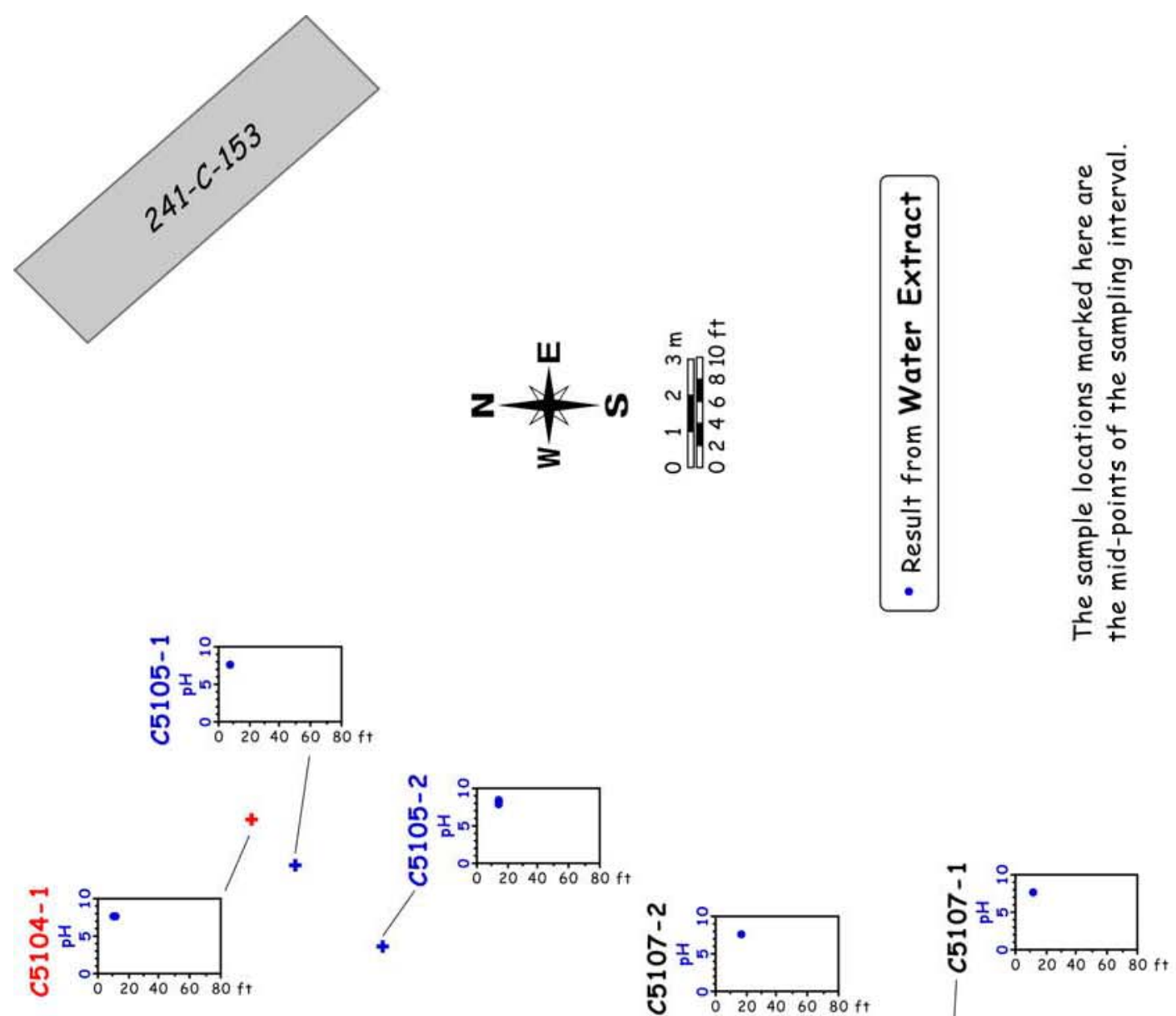

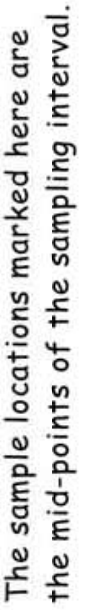

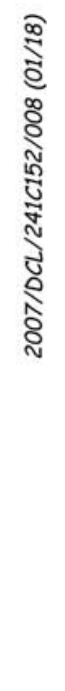

o

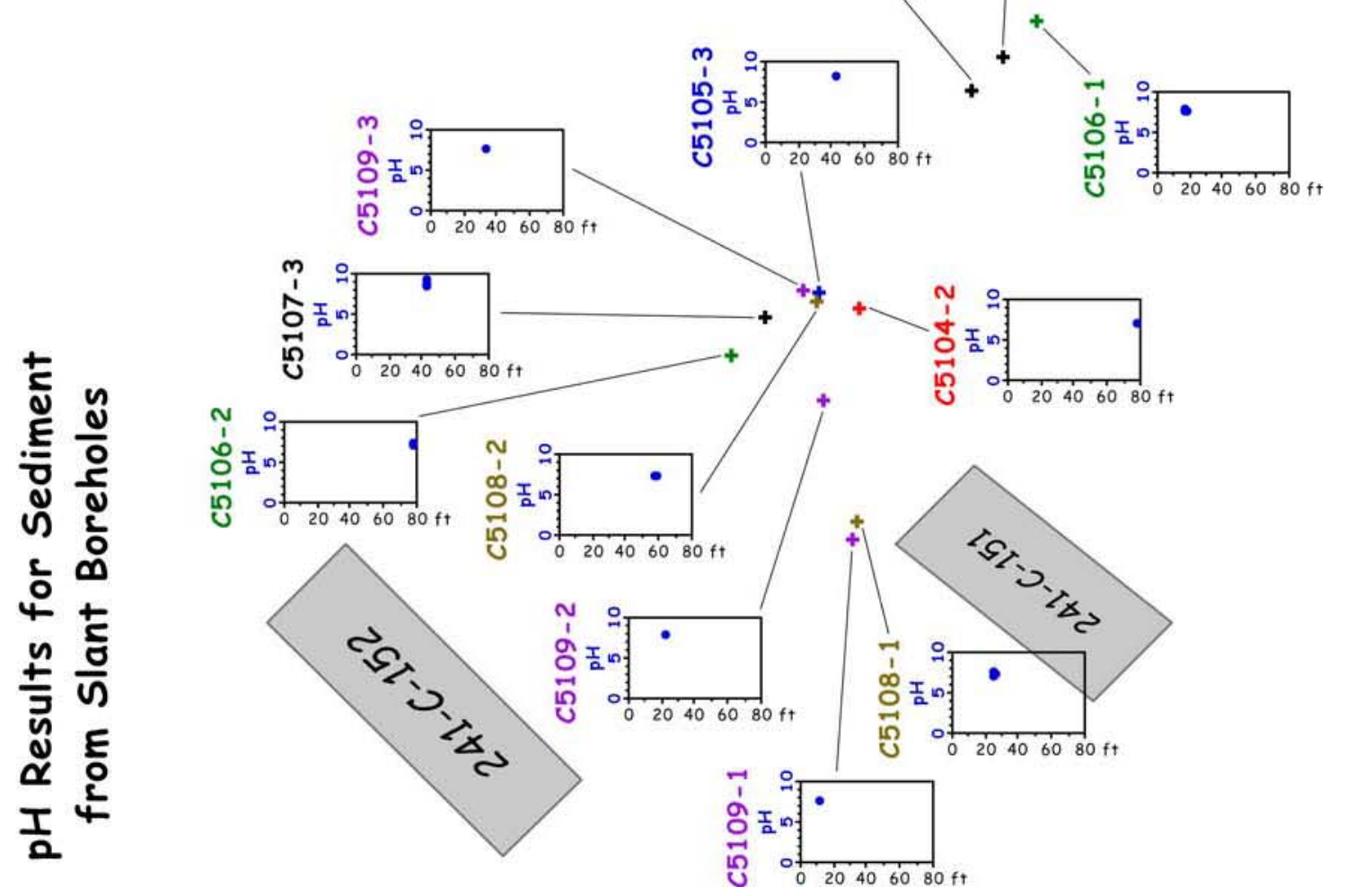




\subsubsection{Water Extraction Composition of the 1:1 Sediment:Water Extractions from the C-152 Slant Probe Hole Samples}

The water extraction values for major anions, cations, and several trace constituents are discussed in this section. The anion data are tabulated in Table 4.18 in units of mass per gram of oven-dry sediment. Elevated concentrations of fluoride, chloride, nitrate, sulfate, and phosphate were observed in water extractions of the C-152 slant push samples. Elevated fluoride was observed in all of the shallow probe hole samples and had a peak concentration of $1.60 \mu \mathrm{g} / \mathrm{g}$, which was more than twice the average fluoride concentration measured in the "uncontaminated" borehole at WMA C or the RCRA boreholes at WMA A-AX. Chloride was elevated in the deeper vadose zone samples, with a peak concentration of $13.6 \mu \mathrm{g} / \mathrm{g}$ measured in a sample from probe hole C5108 at approximately $60 \mathrm{ft}$ bgs. For comparison purposes, the peak water-extractable chloride measured in samples from borehole C4297, emplaced adjacent to Tank $\mathrm{C}-105$, was $21.1 \mu \mathrm{g} / \mathrm{g}$ and occurred at nearly $200 \mathrm{ft}$ bgs. The elevated chloride and fluoride are likely residual contaminants from the $\mathrm{C}-152$ pipeline leak, which contained an estimated 1.15 and $29.5 \mathrm{~kg}$ of fluoride and chloride, respectively (Wood et al. 2003).

Elevated water-extractable nitrate was only observed in one set of liners from the slant push campaign (Figure 4.8). Sediments from probe hole C5104, which were collected at approximately $78 \mathrm{ft}$ bgs, contained as much as $20 \mu \mathrm{g} / \mathrm{g}$ water-extractable nitrate, which was consistent with the peak concentrations measured in samples from borehole C4297, near Tank C-105. Water-extractable sulfate was elevated in sediments collected from the deepest two slant probe holes emplaced around the pipeline leak. As much as $88.3 \mu \mathrm{g} / \mathrm{g}$ sulfate was measured in the samples originating from approximately $80 \mathrm{ft}$ bgs. Finally, only two samples analyzed from the slant push campaign contained measurable water-extractable phosphate. Both of the samples were collected from probe hole C5105 at depths of approximately 13 and $42 \mathrm{ft}$ bgs, respectively. It was interesting that both of the samples came from the "B" or middle liner in the sample string and that no measurable phosphate was found in the remaining samples from the string. Given this, coupled with the lack of measurable phosphate in the rest of the vadose zone samples, it is likely that the two detectable phosphate measurements were biased due to contamination at the time of sampling.

Table 4.18. Water-Extractable Anions in the C-152 Slant Probe Hole Core Samples $(\mu \mathrm{g} / \mathrm{g}$ dry sediment)

\begin{tabular}{||l|c|c|c|c|c|c|c||}
\hline $\begin{array}{c}\text { Sample } \\
\text { Number }\end{array}$ & $\begin{array}{c}\text { Probe } \\
\text { Hole } \\
\text { Number }\end{array}$ & $\begin{array}{c}\text { Mid- } \\
\text { Depth } \\
\text { (ft bgs) }\end{array}$ & Fluoride & Chloride & Nitrate & Sulfate & Phosphate \\
\hline \hline B1HY25A & C5108 & 25.3 & $5.69 \mathrm{E}-01$ & $8.07 \mathrm{E}-01$ & $7.37 \mathrm{E}+00$ & $1.14 \mathrm{E}+01$ & ND \\
\hline B1HY25B & C5108 & 24.9 & $5.47 \mathrm{E}-01$ & $6.52 \mathrm{E}-01$ & $4.30 \mathrm{E}+00$ & $7.81 \mathrm{E}+00$ & ND \\
\hline B1HY25C & C5108 & 24.5 & $\mathbf{1 . 5 4 E + 0 0}$ & $2.73 \mathrm{E}+00$ & $9.61 \mathrm{E}-01$ & $1.60 \mathrm{E}+01$ & ND \\
\hline B1HY26A & C5108 & 58.2 & NA & $3.36 \mathrm{E}+00$ & $2.50 \mathrm{E}+00$ & $1.04 \mathrm{E}+01$ & ND \\
\hline B1HY26B & C5108 & 57.8 & NA & $\mathbf{4 . 3 4 E + 0 0}$ & $2.30 \mathrm{E}+00$ & $1.05 \mathrm{E}+01$ & ND \\
\hline B1HY26C & C5108 & 57.4 & $4.21 \mathrm{E}-01$ & $\mathbf{1 . 3 6 E}+\mathbf{0 1}$ & $1.53 \mathrm{E}+00$ & $1.79 \mathrm{E}+01$ & ND \\
\hline B1HY27A & C5109 & 11.1 & $\mathbf{8 . 6 8 E - 0 1}$ & ND & $5.61 \mathrm{E}+00$ & $1.94 \mathrm{E}+00$ & ND \\
\hline B1HY28B & C5109 & 22.4 & $3.64 \mathrm{E}-01$ & ND & $9.47 \mathrm{E}-01$ & $3.09 \mathrm{E}+00$ & ND \\
\hline B1HY28C & C5109 & 22.1 & $\mathbf{9 . 5 3 E - 0 1}$ & $1.09 \mathrm{E}+00$ & $2.56 \mathrm{E}+00$ & $8.77 \mathrm{E}+00$ & ND \\
\hline B1HY29A & C5109 & 32.7 & NA & ND & $4.18 \mathrm{E}+00$ & $7.43 \mathrm{E}+00$ & ND \\
\hline \hline
\end{tabular}


Table 4.18. (contd)

\begin{tabular}{|c|c|c|c|c|c|c|c|}
\hline $\begin{array}{c}\text { Sample } \\
\text { Number }\end{array}$ & $\begin{array}{l}\text { Probe } \\
\text { Hole } \\
\text { Number }\end{array}$ & $\begin{array}{c}\text { Mid- } \\
\text { Depth } \\
\text { (ft bgs) }\end{array}$ & Fluoride & Chloride & Nitrate & Sulfate & Phosphate \\
\hline B1HY29B & C5109 & 32.3 & $2.57 \mathrm{E}-01$ & ND & $4.09 \mathrm{E}+00$ & $7.88 \mathrm{E}+00$ & ND \\
\hline B1HY29C & C5109 & 32.0 & $4.30 \mathrm{E}-01$ & $9.50 \mathrm{E}-01$ & $3.40 \mathrm{E}+00$ & $1.08 \mathrm{E}+01$ & ND \\
\hline B1HY30A & C5106 & 17.1 & $1.09 \mathrm{E}+00$ & $1.18 \mathrm{E}+00$ & $7.05 \mathrm{E}+00$ & $1.28 \mathrm{E}+01$ & ND \\
\hline B1HY30B & C5106 & 16.7 & $1.19 E+00$ & $1.20 \mathrm{E}+00$ & $4.47 \mathrm{E}+00$ & $1.54 \mathrm{E}+01$ & ND \\
\hline B1HY30C & C5106 & 16.2 & $1.56 \mathrm{E}+00$ & $1.70 \mathrm{E}+00$ & $6.61 \mathrm{E}+00$ & $1.95 \mathrm{E}+01$ & ND \\
\hline B1HY31A & C5106 & 79.0 & NA & $2.78 \mathrm{E}+00$ & $6.75 \mathrm{E}+00$ & $3.66 \mathrm{E}+01$ & ND \\
\hline B1HY31B & C5106 & 78.6 & $2.87 \mathrm{E}-01$ & $2.87 \mathrm{E}+00$ & $6.77 \mathrm{E}+00$ & $3.67 \mathrm{E}+01$ & ND \\
\hline B1HY31C & C5106 & 78.2 & $5.14 \mathrm{E}-01$ & $4.67 \mathrm{E}+00$ & $3.58 \mathrm{E}+00$ & $5.93 \mathrm{E}+01$ & ND \\
\hline B1HY32A & C5107 & 12.9 & $9.48 \mathrm{E}-01$ & $1.19 \mathrm{E}+00$ & $7.74 \mathrm{E}+00$ & $1.27 \mathrm{E}+01$ & ND \\
\hline B1HY32B & C5107 & 12.5 & $1.03 E+00$ & $8.23 \mathrm{E}-01$ & $3.14 \mathrm{E}+00$ & $1.22 \mathrm{E}+01$ & ND \\
\hline B1HY32C & C5107 & 12.2 & $1.60 \mathrm{E}+00$ & $1.28 \mathrm{E}+00$ & $1.81 \mathrm{E}+00$ & $1.47 \mathrm{E}+01$ & ND \\
\hline B1HY33A & C5107 & 16.8 & $4.94 \mathrm{E}-01$ & $7.00 \mathrm{E}-01$ & $3.21 \mathrm{E}+00$ & $6.79 \mathrm{E}+00$ & ND \\
\hline B1HY33B & C5107 & 16.4 & 4.85E-01 & ND & $1.78 \mathrm{E}+00$ & $5.98 \mathrm{E}+00$ & ND \\
\hline B1HY33C & C5107 & 16.1 & $1.16 \mathrm{E}+00$ & $1.34 \mathrm{E}+00$ & ND & $9.72 \mathrm{E}+00$ & ND \\
\hline B1HY34A & C5107 & 42.6 & NA & ND & $2.42 \mathrm{E}+00$ & $1.46 \mathrm{E}+01$ & ND \\
\hline B1HY34B & C5107 & 42.2 & NA & ND & $2.69 \mathrm{E}+00$ & $2.07 \mathrm{E}+01$ & ND \\
\hline B1HY34C & C5107 & 41.9 & NA & $6.55 \mathrm{E}-01$ & $2.99 \mathrm{E}+00$ & $2.49 \mathrm{E}+01$ & ND \\
\hline B1HY35A & C5104 & 10.4 & 9.51E-01 & ND & $2.88 \mathrm{E}+00$ & $1.01 \mathrm{E}+01$ & ND \\
\hline B1HY35B & C5104 & 10.1 & 8.84E-01 & ND & $2.14 \mathrm{E}+00$ & $6.19 \mathrm{E}+00$ & ND \\
\hline B1HY35C & C5104 & 9.7 & 8.92E-01 & $1.36 \mathrm{E}+00$ & ND & $4.75 \mathrm{E}+00$ & ND \\
\hline B1HY36A & C5104 & 77.6 & NA & $2.58 \mathrm{E}+00$ & $1.97 E+01$ & $4.95 E+01$ & ND \\
\hline B1HY36B & C5104 & 77.2 & NA & $3.54 \mathrm{E}+00$ & $1.46 \mathrm{E}+01$ & $6.35 \mathrm{E}+01$ & ND \\
\hline B1HY36C & C5104 & 76.9 & NA & $6.80 \mathrm{E}+00$ & $9.79 \mathrm{E}+00$ & $8.83 E+01$ & ND \\
\hline B1JFP2A & C5105 & 7.1 & $6.86 \mathrm{E}-01$ & ND & $2.08 \mathrm{E}+00$ & $2.51 \mathrm{E}+00$ & ND \\
\hline B1JFP2B & C5105 & 6.9 & 8.51E-01 & $6.16 \mathrm{E}-01$ & $6.91 \mathrm{E}+00$ & $2.75 \mathrm{E}+00$ & ND \\
\hline B1JFP3A & C5105 & 13.6 & $4.05 \mathrm{E}-01$ & ND & $4.19 \mathrm{E}+00$ & $8.19 \mathrm{E}+00$ & ND \\
\hline B1JFP3B & C5105 & 13.4 & 8.87E-01 & ND & $2.51 \mathrm{E}+00$ & $1.15 \mathrm{E}+01$ & $2.57 \mathrm{E}+00$ \\
\hline B1JFP3C & C5105 & 13.1 & $1.46 \mathrm{E}+00$ & $1.66 \mathrm{E}+00$ & $1.59 \mathrm{E}+00$ & $1.56 \mathrm{E}+01$ & ND \\
\hline B1JFP4A & C5105 & 42.1 & $3.04 \mathrm{E}-01$ & ND & $3.34 \mathrm{E}+00$ & $7.38 \mathrm{E}+00$ & ND \\
\hline B1JFP4B & C5105 & 41.9 & $5.68 \mathrm{E}-01$ & $6.73 \mathrm{E}-01$ & $3.32 \mathrm{E}+00$ & $7.44 \mathrm{E}+00$ & $1.62 \mathrm{E}+00$ \\
\hline B1JFP4C & C5105 & 41.6 & NA & 7.70E-01 & $5.08 \mathrm{E}+00$ & $1.27 \mathrm{E}+01$ & ND \\
\hline
\end{tabular}



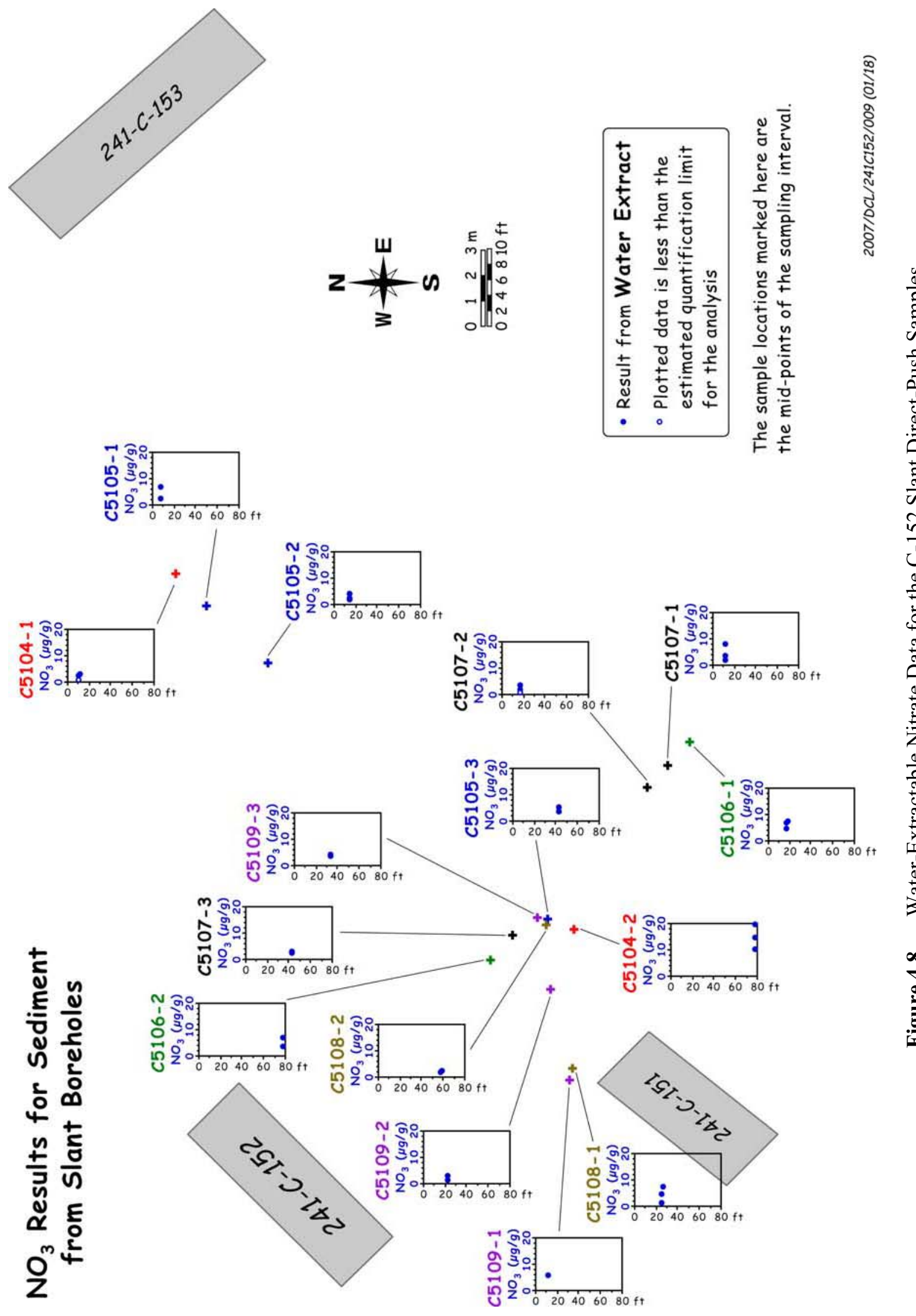

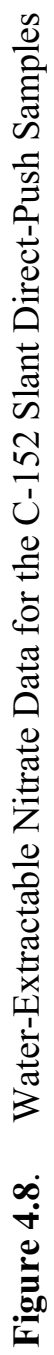


The water-extractable major cations in the $\mathrm{C}-152$ slant probe hole sediments are tabulated in Table 4.19. The distribution of the divalent alkaline-earth cations (magnesium and calcium) showed decreased quantities in nearly all of the slant push sediments analyzed. Specifically, the deepest vadose zone sample string collected from probe hole C5104 (at approximately $80 \mathrm{ft}$ bgs) was the only sample set that contained calcium as the dominant water-exchangeable cation in all three of the cores (Figure 4.9). Water-exchangeable sodium was the dominant cation in at least one of the core samples from each of the remaining vadose zone sample strings (Figure 4.10). This is an important finding since the high sodium content in tank waste creates an ion exchange front as it migrates through the vadose zone, where sodium replaces calcium as the dominant cation on the surface exchange sites of the sediment. Interrogation of the zone affected by this exchange process can provide an indication of the area affected by the leak event. Using the sodium exchange front as an indicator, waste from the $\mathrm{C}-152$ pipeline leak event has impacted the vadose zone at least as far as the edge of the impermeable cap placed over the spill site. Additionally, this exchange front has migrated to a depth of approximately $80 \mathrm{ft}$ bgs directly beneath the site of the spill. The maximum vertical extent of the exchange front is unknown at this time, as the deepest sample string (B1HY31) analyzed as part of this campaign contained at least one sample that had sodium as the dominant water-exchangeable cation.

It is interesting that in the B1HY31 sample string, the shallowest of the three cores collected was the only sample (of the three) that contained sodium as the dominant water-exchangeable cation. Additionally, although the shallowest six-inch core collected from this sample string contained elevated sodium, the concentration of water-extractable sodium in this sample was approximately four times lower than the peak water-extractable sodium concentration measured in the slant push cores samples $(93.3 \mu \mathrm{g} / \mathrm{g}$ at approximately $13 \mathrm{ft}$ bgs in probe hole C5105). This fact, coupled with the observation that the other sample string collected from approximately the same depth contained calcium as the dominant waterexchangeable cation, could indicate that the vertical extent of the ion exchange front occurred at approximately $80 \mathrm{ft}$ bgs at this locale; however, the relatively small sample set and lack of samples deeper in the vadose zone precluded a quantitative conclusion from being made.

Table 4.19. Water-Extractable Cations in the C-152 Slant Push Samples ( $\mu \mathrm{g} / \mathrm{g}$ dry sediment)

\begin{tabular}{||l|c|c|c|c|c|c|c||}
\hline $\begin{array}{c}\text { Sample } \\
\text { Number }\end{array}$ & $\begin{array}{c}\text { Probe } \\
\text { Hole } \\
\text { Number }\end{array}$ & $\begin{array}{c}\text { Mid- } \\
\text { Depth } \\
\text { (ft bgs })\end{array}$ & Calcium & Magnesium & Strontium & Sodium & Potassium \\
\hline \hline B1HY25A & C5108 & 25.3 & $2.66 \mathrm{E}+00$ & $6.57 \mathrm{E}-01$ & $(1.03 \mathrm{E}-02)$ & $\mathbf{2 . 8 5 E}+\mathbf{0 1}$ & $(3.55 \mathrm{E}+00)$ \\
\hline B1HY25B & C5108 & 24.9 & $2.95 \mathrm{E}+00$ & $7.62 \mathrm{E}-01$ & $(1.10 \mathrm{E}-02)$ & $\mathbf{2 . 1 8 E}+\mathbf{0 1}$ & $(3.87 \mathrm{E}+00)$ \\
\hline B1HY25C & C5108 & 24.5 & $2.80 \mathrm{E}+00$ & $7.86 \mathrm{E}-01$ & $(1.38 \mathrm{E}-02)$ & $\mathbf{4 . 7 9 E}+\mathbf{0 1}$ & $(6.99 \mathrm{E}+00)$ \\
\hline B1HY26A & C5108 & 58.2 & $6.76 \mathrm{E}+00$ & $2.54 \mathrm{E}+00$ & $(3.78 \mathrm{E}-02)$ & $(7.56 \mathrm{E}+00)$ & $(6.68 \mathrm{E}+00)$ \\
\hline B1HY26B & C5108 & 57.8 & $7.64 \mathrm{E}+00$ & $2.67 \mathrm{E}+00$ & $(4.28 \mathrm{E}-02)$ & $(8.03 \mathrm{E}+00)$ & $(7.18 \mathrm{E}+00)$ \\
\hline B1HY26C & C5108 & 57.4 & $\mathbf{1 . 0 8 E}+\mathbf{0 1}$ & $\mathbf{3 . 8 2 E}+\mathbf{0 0}$ & $(6.02 \mathrm{E}-02)$ & $1.34 \mathrm{E}+01$ & $(9.76 \mathrm{E}+00)$ \\
\hline B1HY27A & C5109 & 11.1 & $9.05 \mathrm{E}+00$ & $2.20 \mathrm{E}+00$ & $(3.90 \mathrm{E}-02)$ & $\mathbf{2 . 0 0 E}+\mathbf{0 1}$ & $(5.56 \mathrm{E}+00)$ \\
\hline B1HY28B & C5109 & 22.4 & $(6.50 E-01)$ & $(1.73 E-01)$ & $(8.04 \mathrm{E}-03)$ & $\mathbf{4 . 3 2 E + 0 1}$ & $(3.54 \mathrm{E}+00)$ \\
\hline B1HY28C & C5109 & 22.1 & $1.04 \mathrm{E}+00$ & $2.66 \mathrm{E}-01$ & $(6.95 \mathrm{E}-03)$ & $\mathbf{5 . 1 3 E}+\mathbf{0 1}$ & $(4.46 \mathrm{E}+00)$ \\
\hline B1HY29A & C5109 & 32.7 & $1.40 \mathrm{E}+00$ & $6.34 \mathrm{E}-01$ & $(8.21 \mathrm{E}-03)$ & $\mathbf{3 . 2 7 E}+\mathbf{0 1}$ & $(4.42 \mathrm{E}+00)$ \\
\hline B1HY29B & C5109 & 32.3 & $1.30 \mathrm{E}+00$ & $7.97 \mathrm{E}-01$ & $(8.56 \mathrm{E}-03)$ & $\mathbf{3 . 3 9 E}+\mathbf{0 1}$ & $(4.72 \mathrm{E}+00)$ \\
\hline \hline
\end{tabular}


Table 4.19. (contd)

\begin{tabular}{|c|c|c|c|c|c|c|c|}
\hline $\begin{array}{c}\text { Sample } \\
\text { Number } \\
\end{array}$ & $\begin{array}{l}\text { Probe } \\
\text { Hole } \\
\text { Number }\end{array}$ & $\begin{array}{l}\text { Mid- } \\
\text { Depth } \\
\text { (ft bgs) } \\
\end{array}$ & Calcium & Magnesium & Strontium & Sodium & Potassium \\
\hline B1HY29C & C5109 & 32.0 & $1.52 \mathrm{E}+00$ & $5.88 \mathrm{E}-01$ & $(8.63 \mathrm{E}-03)$ & $3.63 \mathrm{E}+01$ & $(4.70 \mathrm{E}+00)$ \\
\hline B1HY30A & C5106 & 17.1 & $3.36 \mathrm{E}+00$ & $5.88 \mathrm{E}-01$ & $(1.07 \mathrm{E}-02)$ & $3.27 \mathrm{E}+01$ & $(5.13 E+00)$ \\
\hline B1HY30B & C5106 & 16.7 & $3.83 \mathrm{E}+00$ & $7.03 \mathrm{E}-01$ & $(1.22 \mathrm{E}-02)$ & $3.25 \mathrm{E}+01$ & $(5.30 \mathrm{E}+00)$ \\
\hline B1HY30C & C5106 & 16.2 & $4.19 \mathrm{E}+00$ & $8.41 \mathrm{E}-01$ & $(1.66 \mathrm{E}-02)$ & $4.11 \mathrm{E}+01$ & $(6.81 \mathrm{E}+00)$ \\
\hline B1HY31A & C5106 & 79.0 & $1.19 \mathrm{E}+01$ & $5.08 \mathrm{E}+00$ & $(6.05 \mathrm{E}-02)$ & $(1.00 \mathrm{E}+01)$ & $(7.99 \mathrm{E}+00)$ \\
\hline B1HY31B & C5106 & 78.6 & $1.14 \mathrm{E}+01$ & $4.81 \mathrm{E}+00$ & $(5.95 \mathrm{E}-02)$ & $(9.96 \mathrm{E}+00)$ & $(8.25 \mathrm{E}+00)$ \\
\hline B1HY31C & C5106 & 78.2 & $1.36 \mathrm{E}+01$ & $5.89 \mathrm{E}+00$ & $(8.47 \mathrm{E}-02)$ & $1.90 \mathrm{E}+01$ & $(1.06 \mathrm{E}+01)$ \\
\hline B1HY32A & C5107 & 12.9 & $4.95 \mathrm{E}+00$ & $8.68 \mathrm{E}-01$ & $(1.63 \mathrm{E}-02)$ & $3.51 \mathrm{E}+01$ & $(5.62 \mathrm{E}+00)$ \\
\hline B1HY32B & C5107 & 12.5 & $4.59 \mathrm{E}+00$ & $8.43 \mathrm{E}-01$ & $(1.44 \mathrm{E}-02)$ & $2.71 \mathrm{E}+01$ & $(4.92 \mathrm{E}+00)$ \\
\hline B1HY32C & C5107 & 12.2 & $4.74 \mathrm{E}+00$ & $9.42 \mathrm{E}-01$ & $(1.72 \mathrm{E}-02)$ & $3.41 \mathrm{E}+01$ & $(6.16 \mathrm{E}+00)$ \\
\hline B1HY33A & C5107 & 16.8 & $1.76 \mathrm{E}+00$ & $3.41 \mathrm{E}-01$ & $(6.52 \mathrm{E}-03)$ & $3.31 \mathrm{E}+01$ & $(4.47 \mathrm{E}+00)$ \\
\hline B1HY33B & C5107 & 16.4 & $1.84 \mathrm{E}+00$ & $3.99 \mathrm{E}-01$ & $(6.88 \mathrm{E}-03)$ & $2.62 \mathrm{E}+01$ & $(4.71 \mathrm{E}+00)$ \\
\hline B1HY33C & C5107 & 16.1 & $3.38 \mathrm{E}+00$ & $8.26 \mathrm{E}-01$ & $(1.27 \mathrm{E}-02)$ & $3.08 \mathrm{E}+01$ & $(6.47 \mathrm{E}+00)$ \\
\hline B1HY34A & C5107 & 42.6 & $3.30 \mathrm{E}+00$ & $(1.43 E-01)$ & $(9.58 \mathrm{E}-03)$ & $3.64 \mathrm{E}+01$ & $(4.84 \mathrm{E}+00)$ \\
\hline B1HY34B & C5107 & 42.2 & $3.29 \mathrm{E}+00$ & $(1.11 E-01)$ & $(6.81 \mathrm{E}-03)$ & $4.80 \mathrm{E}+01$ & $(4.66 \mathrm{E}+00)$ \\
\hline B1HY34C & C5107 & 41.9 & $8.36 \mathrm{E}+00$ & $(1.64 E-02)$ & $(2.09 \mathrm{E}-02)$ & $6.50 \mathrm{E}+01$ & $(6.60 \mathrm{E}+00)$ \\
\hline B1HY35A & C5104 & 10.4 & $3.62 \mathrm{E}+00$ & 7.13E-01 & $(2.60 \mathrm{E}-02)$ & $3.06 \mathrm{E}+01$ & $(5.53 \mathrm{E}+00)$ \\
\hline B1HY35B & C5104 & 10.1 & $2.88 \mathrm{E}+00$ & $5.72 \mathrm{E}-01$ & $(8.93 \mathrm{E}-03)$ & $2.91 \mathrm{E}+01$ & $(5.14 \mathrm{E}+00)$ \\
\hline B1HY35C & C5104 & 9.7 & $3.31 \mathrm{E}+00$ & $6.91 \mathrm{E}-01$ & $(1.30 \mathrm{E}-02)$ & $2.58 \mathrm{E}+01$ & $(5.93 E+00)$ \\
\hline B1HY36A & C5104 & 77.6 & $1.86 \mathrm{E}+01$ & $4.11 \mathrm{E}+00$ & $(6.94 \mathrm{E}-02)$ & $(9.52 \mathrm{E}+00)$ & $(7.70 \mathrm{E}+00)$ \\
\hline B1HY36B & C5104 & 77.2 & $2.55 \mathrm{E}+01$ & $2.63 \mathrm{E}+00$ & $(8.61 \mathrm{E}-02)$ & $1.06 \mathrm{E}+01$ & $(8.28 \mathrm{E}+00)$ \\
\hline B1HY36C & C5104 & 76.9 & $3.55 \mathrm{E}+01$ & $1.14 \mathrm{E}+00$ & $(1.15 \mathrm{E}-01)$ & $1.56 \mathrm{E}+01$ & $(1.00 \mathrm{E}+01)$ \\
\hline B1JFP2A & C5105 & 7.1 & $3.13 \mathrm{E}+00$ & $9.86 \mathrm{E}-01$ & $(1.31 \mathrm{E}-02)$ & $2.28 \mathrm{E}+01$ & $(5.16 \mathrm{E}+00)$ \\
\hline B1JFP2B & C5105 & 6.9 & $5.51 \mathrm{E}+00$ & $1.74 \mathrm{E}+00$ & $(2.40 \mathrm{E}-02)$ & $2.26 \mathrm{E}+01$ & $(4.99 E+00)$ \\
\hline B1JFP3A & C5105 & 13.6 & $(4.35 E-01)$ & $(5.74 E-02)$ & $(2.91 \mathrm{E}-03)$ & $9.33 \mathrm{E}+01$ & $(3.51 \mathrm{E}+00)$ \\
\hline B1JFP3B & C5105 & 13.4 & $(7.05 E-01)$ & $(1.22 E-01)$ & $(4.19 \mathrm{E}-03)$ & $8.97 \mathrm{E}+01$ & $(3.95 \mathrm{E}+00)$ \\
\hline B1JFP3C & C5105 & 13.1 & $4.02 \mathrm{E}+00$ & $8.96 \mathrm{E}-01$ & $(1.54 \mathrm{E}-02)$ & $3.77 \mathrm{E}+01$ & $(6.21 \mathrm{E}+00)$ \\
\hline B1JFP4A & C5105 & 42.1 & $(5.91 E-01)$ & $(8.28 E-02)$ & $(3.86 \mathrm{E}-03)$ & $9.20 \mathrm{E}+01$ & $(4.66 \mathrm{E}+00)$ \\
\hline B1JFP4B & C5105 & 41.9 & $(5.07 E-01)$ & $(8.19 E-02)$ & $(2.74 \mathrm{E}-03)$ & $8.02 \mathrm{E}+01$ & $(3.69 \mathrm{E}+00)$ \\
\hline B1JFP4C & C5105 & 41.6 & $(4.92 E-01)$ & $(8.66 E-02)$ & $(2.96 \mathrm{E}-03)$ & $8.41 \mathrm{E}+01$ & $(3.99 \mathrm{E}+00)$ \\
\hline \multicolumn{8}{|c|}{$\begin{array}{l}\text { Bold values denote elevated concentrations. } \\
\text { Italicized values denote low concentrations. } \\
\text { Parentheses indicate reported value was less than the limit of quantification for the analysis. }\end{array}$} \\
\hline
\end{tabular}



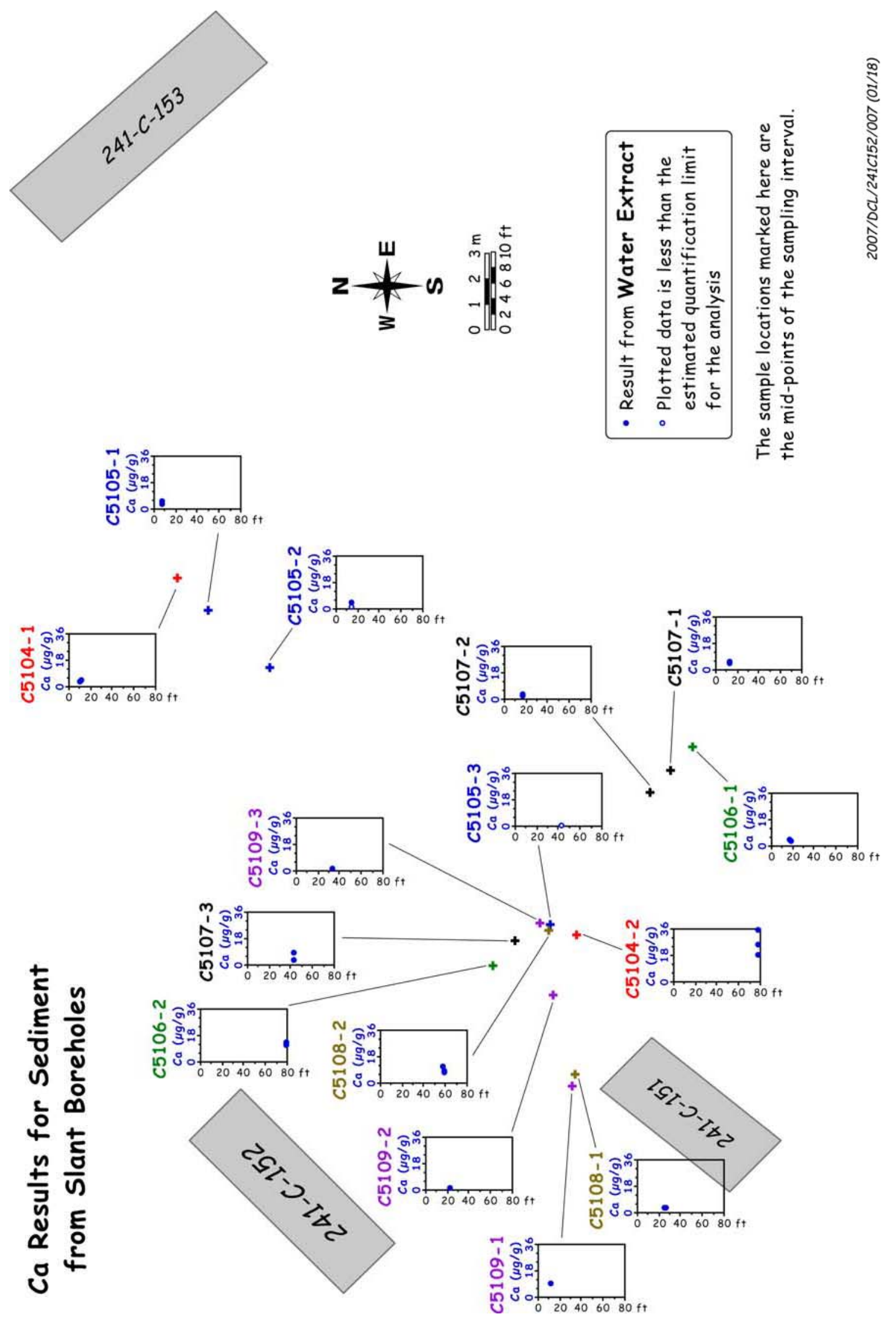

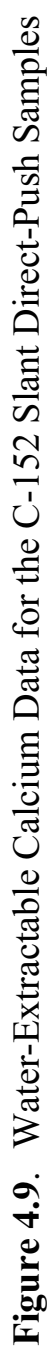



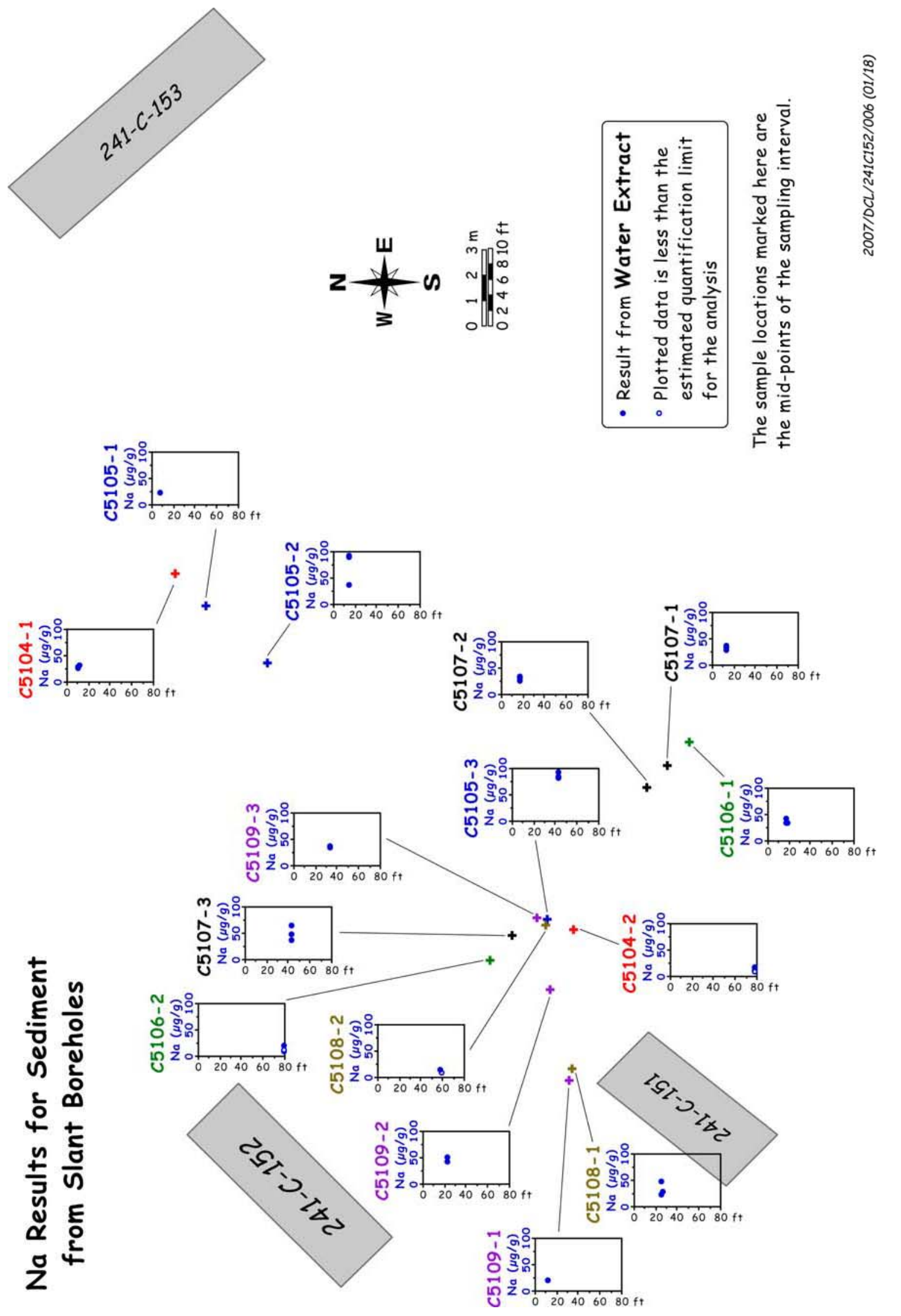

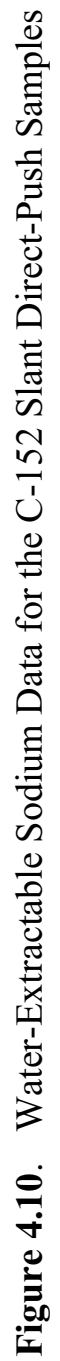


The water-extractable aluminum, iron, silicon, and sulfur in the C-152 slant probe hole sediments are shown in Table 4.20. The sulfur data were converted to water-extractable sulfur as sulfate so that the results could be compared to the IC data presented in Table 4.18. The agreement between measuring the water extractions for sulfate directly with the ion IC and indirectly by converting the ICP measurements for sulfur to sulfate was very good; besides validating the IC data, we can state that the water-extractable sulfur was in fact sulfate. The water-soluble aluminum and iron data did not show appreciably elevated values in any of the samples measured; elevated values of aluminum and iron can result from the chemical reaction between alkaline tank fluids and native sediments, which forms precipitates of amorphous aluminum and/or iron phases that are more water-soluble than aluminum- and iron-rich phases in the native sediments. As with the aluminum and iron data, the silicon concentrations in these samples did not indicate that the mineralogy of the native sediment had been altered due to interaction with caustic tank waste. However, this is not unexpected given that the mineral alteration zone is typically restrained immediately near the point of waste discharge, and these samples were collected much farther laterally and deeper than the projected leak location.

The water-extraction data for potentially mobile metals, such as technetium-99, uranium-238, chromium, molybdenum, and ruthenium are shown in Tables 4.21 and 4.22. Water-extractable technetium-99 was observed in all of the sample strings except for the shallowest samples collected in probe holes C5104, C5105, C5106, and C5107 (Figure 4.11). Probe holes C5104 and C5105 were emplaced to the northeast of the pipeline leak and were driven at angles of $45^{\circ}$ and $30^{\circ}$ from the horizontal, respectively. Probe holes C5106 and C5107 were emplaced to the southeast of the pipeline leak and were driven at angles of $60^{\circ}$ and $45^{\circ}$ from the horizontal, respectively. The shallow samples from these four probe holes were collected at depths ranging from 7 to $17 \mathrm{ft}$ bgs and were located adjacent (laterally) to the cap overlying the pipeline leak site. However, all four of these probe holes contained measurable concentrations of technetium-99 at their terminating depths.

It is not surprising that samples collected in the shallow vadose zone to the southeast or northeast of the pipeline leak did not contain appreciable amounts of technetium-99, as no technetium-99 was observed in this area during the vertical direct-push campaign (Section 4.1). Additionally, technetium-99 is considered to be a mobile element; as such, it tends to migrate deeper into the vadose zone via natural recharge in the years following a leak event. For example, although technetium- 99 was observed at various depths via the slant push samples, the peak water-extractable technetium-99 activity, at $28.6 \mathrm{pCi} / \mathrm{g}$, occurred in one of the deepest samples collected (B1HY36B from probe hole C5104 at approximately $77 \mathrm{ft}$ bgs). Additionally, the sample string containing the second-highest water-extractable technetium-99 activity, at $3.76 \mathrm{pCi} / \mathrm{g}$, was the deepest sample set collected (B1HY31A from probe hole C5106 at approximately $80 \mathrm{ft}$ bgs).

Although the intent of the direct-push sampling approach was to collect a series of samples as a function of depth directly beneath the projected location of the pipeline leak, the two deepest sample strings collected (C5104 and C5106 at 78 and $80 \mathrm{ft} \mathrm{bgs,} \mathrm{respectively)} \mathrm{were} \mathrm{separated} \mathrm{by} \mathrm{more} \mathrm{than} 11 \mathrm{ft}$ laterally. It should be noted that being able to collect samples so close to one another when approximately $100 \mathrm{ft}$ of pipe is driven into the ground at an angle using a hydraulic hammer unit is quite an accomplishment. Evaluation of the technetium-99 data indicates that the contamination has migrated deeper into the vadose zone than was initially proposed. Specifically, the area was covered with an impermeable material in the early 1990s in an attempt to retard migration of the contaminants. However, a sufficient period of time, in excess of 20 years, elapsed between the leak event and the placement of the cap over the spill site, and the initial covering of gravel, immediately after the spill, enabled migration of the mobile contaminants deep into the vadose zone. 
Table 4.20. Water-Extractable Cations in the C-152 Slant Push Samples ( $\mu \mathrm{g} / \mathrm{g}$ dry sediment)

\begin{tabular}{|c|c|c|c|c|c|c|}
\hline $\begin{array}{c}\text { Sample } \\
\text { Number }\end{array}$ & $\begin{array}{l}\text { Probe } \\
\text { Hole } \\
\text { Number }\end{array}$ & $\begin{array}{c}\text { Mid- } \\
\text { Depth } \\
\text { (ft bgs) }\end{array}$ & Aluminum & Iron & Silicon & Sulfur as $\mathrm{SO}_{4}$ \\
\hline B1HY25A & C5108 & 25.3 & $(6.44 \mathrm{E}-02)$ & $8.83 \mathrm{E}-02$ & $(7.29 \mathrm{E}+00)$ & $1.02 \mathrm{E}+01$ \\
\hline B1HY25B & C5108 & 24.9 & $(2.12 \mathrm{E}-01)$ & $8.70 \mathrm{E}-02$ & $(6.44 \mathrm{E}+00)$ & $7.11 \mathrm{E}+00$ \\
\hline B1HY25C & C5108 & 24.5 & (9.43E-02) & $6.16 \mathrm{E}-02$ & $(4.99 \mathrm{E}+00)$ & $1.70 \mathrm{E}+01$ \\
\hline B1HY26A & C5108 & 58.2 & (7.06E-02) & $(4.18 \mathrm{E}-02)$ & $(4.78 \mathrm{E}+00)$ & $1.08 \mathrm{E}+01$ \\
\hline B1HY26B & C5108 & 57.8 & (7.81E-02) & $(4.55 \mathrm{E}-02)$ & $(5.00 \mathrm{E}+00)$ & $1.05 \mathrm{E}+01$ \\
\hline B1HY26C & C5108 & 57.4 & $(4.56 \mathrm{E}-02)$ & $(2.04 \mathrm{E}-02)$ & $(4.99 \mathrm{E}+00)$ & $1.76 \mathrm{E}+01$ \\
\hline B1HY27A & C5109 & 11.1 & ND & (2.02E-02) & $1.22 \mathrm{E}+01$ & $(1.69 \mathrm{E}+00)$ \\
\hline B1HY28B & C5109 & 22.4 & $(2.03 \mathrm{E}-01)$ & $2.22 \mathrm{E}-01$ & $(8.11 \mathrm{E}+00)$ & $(2.85 \mathrm{E}+00)$ \\
\hline B1HY28C & C5109 & 22.1 & $(1.48 \mathrm{E}-01)$ & $1.26 \mathrm{E}-01$ & $(9.13 \mathrm{E}+00)$ & $8.94 \mathrm{E}+00$ \\
\hline B1HY29A & C5109 & 32.7 & $(1.86 \mathrm{E}-01)$ & $1.14 \mathrm{E}-01$ & $(5.96 \mathrm{E}+00)$ & $7.56 \mathrm{E}+00$ \\
\hline B1HY29B & C5109 & 32.3 & $(2.06 \mathrm{E}-01)$ & $1.10 \mathrm{E}-01$ & $(5.80 \mathrm{E}+00)$ & $8.51 \mathrm{E}+00$ \\
\hline B1HY29C & C5109 & 32.0 & $(1.69 \mathrm{E}-01)$ & $1.02 \mathrm{E}-01$ & $(5.87 \mathrm{E}+00)$ & $1.08 \mathrm{E}+01$ \\
\hline B1HY30A & C5106 & 17.1 & (3.68E-02) & (3.77E-02) & $(9.30 \mathrm{E}+00)$ & $1.25 \mathrm{E}+01$ \\
\hline B1HY30B & C5106 & 16.7 & $(2.15 \mathrm{E}-02)$ & (3.02E-02) & $(9.41 \mathrm{E}+00)$ & $1.62 \mathrm{E}+01$ \\
\hline B1HY30C & C5106 & 16.2 & $(3.00 \mathrm{E}-02)$ & $(4.14 \mathrm{E}-02)$ & $(9.54 \mathrm{E}+00)$ & $2.03 \mathrm{E}+01$ \\
\hline B1HY31A & C5106 & 79.0 & $(2.92 \mathrm{E}-02)$ & (1.11E-02) & $(5.51 \mathrm{E}+00)$ & $3.62 \mathrm{E}+01$ \\
\hline B1HY31B & C5106 & 78.6 & $(1.90 \mathrm{E}-02)$ & (5.93E-03) & $(4.19 \mathrm{E}+00)$ & $3.69 \mathrm{E}+01$ \\
\hline B1HY31C & C5106 & 78.2 & $(1.68 \mathrm{E}-02)$ & $(1.14 \mathrm{E}-02)$ & $(4.98 \mathrm{E}+00)$ & $5.89 \mathrm{E}+01$ \\
\hline B1HY32A & C5107 & 12.9 & $(4.54 \mathrm{E}-02)$ & $1.05 \mathrm{E}-01$ & $1.34 \mathrm{E}+01$ & $1.29 \mathrm{E}+01$ \\
\hline B1HY32B & C5107 & 12.5 & (4.70E-02) & $1.07 \mathrm{E}-01$ & $1.16 \mathrm{E}+01$ & $1.24 \mathrm{E}+01$ \\
\hline B1HY32C & C5107 & 12.2 & $(6.79 \mathrm{E}-02)$ & $1.07 \mathrm{E}-01$ & $1.13 \mathrm{E}+01$ & $1.59 \mathrm{E}+01$ \\
\hline B1HY33A & C5107 & 16.8 & $(8.22 \mathrm{E}-02)$ & $1.19 \mathrm{E}-01$ & $(7.36 \mathrm{E}+00)$ & $6.97 \mathrm{E}+00$ \\
\hline B1HY33B & C5107 & 16.4 & (7.94E-02) & $8.35 \mathrm{E}-02$ & $(7.01 \mathrm{E}+00)$ & $(5.84 \mathrm{E}+00)$ \\
\hline B1HY33C & C5107 & 16.1 & $(9.85 \mathrm{E}-02)$ & 9.32E-02 & $(5.75 \mathrm{E}+00)$ & $9.76 \mathrm{E}+00$ \\
\hline B1HY34A & C5107 & 42.6 & $(2.12 \mathrm{E}-01)$ & $6.44 \mathrm{E}-02$ & $1.67 \mathrm{E}+01$ & $1.53 \mathrm{E}+01$ \\
\hline B1HY34B & C5107 & 42.2 & $(2.21 \mathrm{E}-01)$ & $1.31 \mathrm{E}-01$ & $1.79 \mathrm{E}+01$ & $2.11 \mathrm{E}+01$ \\
\hline B1HY34C & C5107 & 41.9 & 4.93E-01 & $(1.02 \mathrm{E}-02)$ & $2.70 \mathrm{E}+01$ & $2.55 \mathrm{E}+01$ \\
\hline B1HY35A & C5104 & 10.4 & $(6.26 \mathrm{E}-02)$ & $1.34 \mathrm{E}-01$ & $1.18 \mathrm{E}+01$ & $1.03 \mathrm{E}+01$ \\
\hline B1HY35B & C5104 & 10.1 & $(5.76 \mathrm{E}-02)$ & $1.32 \mathrm{E}-01$ & $1.14 \mathrm{E}+01$ & $6.38 \mathrm{E}+00$ \\
\hline B1HY35C & C5104 & 9.7 & $(4.31 \mathrm{E}-02)$ & $9.10 \mathrm{E}-02$ & $(7.31 \mathrm{E}+00)$ & $(4.91 \mathrm{E}+00)$ \\
\hline B1HY36A & C5104 & 77.6 & ND & (6.07E-03) & $(3.91 \mathrm{E}+00)$ & $4.95 \mathrm{E}+01$ \\
\hline B1HY36B & C5104 & 77.2 & ND & (6.22E-03) & $(6.21 \mathrm{E}+00)$ & $6.36 \mathrm{E}+01$ \\
\hline B1HY36C & C5104 & 76.9 & ND & $(4.75 \mathrm{E}-03)$ & $(9.89 \mathrm{E}+00)$ & $8.63 \mathrm{E}+01$ \\
\hline B1JFP2A & C5105 & 7.1 & $(4.43 \mathrm{E}-02)$ & $1.29 \mathrm{E}-01$ & $(7.03 \mathrm{E}+00)$ & $(2.40 \mathrm{E}+00)$ \\
\hline B1JFP2B & C5105 & 6.9 & $(2.54 \mathrm{E}-02)$ & $(3.08 \mathrm{E}-02)$ & $(8.50 \mathrm{E}+00)$ & $(2.49 \mathrm{E}+00)$ \\
\hline B1JFP3A & C5105 & 13.6 & $(1.58 \mathrm{E}-01)$ & $1.60 \mathrm{E}-01$ & $(8.96 \mathrm{E}+00)$ & $9.22 \mathrm{E}+00$ \\
\hline B1JFP3B & C5105 & 13.4 & $(1.15 \mathrm{E}-01)$ & $1.48 \mathrm{E}-01$ & $1.18 \mathrm{E}+01$ & $1.26 \mathrm{E}+01$ \\
\hline B1JFP3C & C5105 & 13.1 & $(1.06 \mathrm{E}-01)$ & $2.50 \mathrm{E}-01$ & $(9.36 \mathrm{E}+00)$ & $1.91 \mathrm{E}+01$ \\
\hline B1JFP4A & C5105 & 42.1 & $4.97 \mathrm{E}-01$ & $1.84 \mathrm{E}-01$ & $(7.84 \mathrm{E}+00)$ & $8.54 \mathrm{E}+00$ \\
\hline B1JFP4B & C5105 & 41.9 & 4.12E-01 & $1.61 \mathrm{E}-01$ & $(7.26 \mathrm{E}+00)$ & $7.66 \mathrm{E}+00$ \\
\hline B1JFP4C & C5105 & 41.6 & $3.86 \mathrm{E}-01$ & $2.14 \mathrm{E}-01$ & $(8.51 \mathrm{E}+00)$ & $1.29 \mathrm{E}+01$ \\
\hline
\end{tabular}


Table 4.21. Water-Extractable Mobile Metals in the C-152 Slant Core Samples ( $\mu \mathrm{g} / \mathrm{g}$ dry sediment)

\begin{tabular}{|c|c|c|c|c|c|}
\hline $\begin{array}{l}\text { Sample } \\
\text { Number }\end{array}$ & $\begin{array}{c}\text { Probe Hole } \\
\text { Number }\end{array}$ & $\begin{array}{l}\text { Mid-Depth } \\
\text { (ft bgs) }\end{array}$ & $\begin{array}{l}\text { Technetium-99 } \\
\text { (pCi/g soil) }\end{array}$ & Uranium-238 & $\begin{array}{l}\text { Chromium-53 } \\
\text { ICP-MS }\end{array}$ \\
\hline B1HY25A & C5108 & 25.3 & $5.88 E-01$ & $3.55 \mathrm{E}-02$ & $7.96 \mathrm{E}-04$ \\
\hline B1HY25B & C5108 & 24.9 & 3.82E-01 & $1.41 \mathrm{E}-02$ & $(4.73 \mathrm{E}-04)$ \\
\hline B1HY25C & C5108 & 24.5 & (6.73E-02) & $5.59 \mathrm{E}-03$ & (2.81E-04) \\
\hline B1HY26A & C5108 & 58.2 & $8.14 E-01$ & $3.21 \mathrm{E}-04$ & $(1.88 \mathrm{E}-04)$ \\
\hline B1HY26B & C5108 & 57.8 & $7.70 \mathrm{E}-01$ & $3.79 \mathrm{E}-04$ & $(3.34 \mathrm{E}-04)$ \\
\hline B1HY26C & C5108 & 57.4 & $4.01 \mathrm{E}-01$ & $3.04 \mathrm{E}-04$ & (4.70E-04) \\
\hline B1HY27A & C5109 & 11.1 & $(3.12 \mathrm{E}-02)$ & $8.39 \mathrm{E}-04$ & $(4.63 \mathrm{E}-04)$ \\
\hline B1HY28B & C5109 & 22.4 & $4.20 \mathrm{E}-01$ & $7.41 \mathrm{E}-03$ & $(4.32 \mathrm{E}-04)$ \\
\hline B1HY28C & C5109 & 22.1 & (1.94E-01) & $5.94 \mathrm{E}-03$ & (4.81E-04) \\
\hline B1HY29A & C5109 & 32.7 & $4.23 \mathrm{E}-01$ & $3.10 \mathrm{E}-02$ & $1.43 \mathrm{E}-03$ \\
\hline B1HY29B & C5109 & 32.3 & $4.37 \mathrm{E}-01$ & $2.62 \mathrm{E}-02$ & $1.21 \mathrm{E}-03$ \\
\hline B1HY29C & C5109 & 32.0 & $2.98 E-01$ & $2.67 \mathrm{E}-02$ & $1.52 \mathrm{E}-03$ \\
\hline B1HY30A & C5106 & 17.1 & ND & $1.55 \mathrm{E}-03$ & (3.28E-04) \\
\hline B1HY30B & C5106 & 16.7 & $(1.02 \mathrm{E}-02)$ & $1.44 \mathrm{E}-03$ & (1.54E-04) \\
\hline B1HY30C & C5106 & 16.2 & ND & $1.19 \mathrm{E}-03$ & $2.33 \mathrm{E}-03$ \\
\hline B1HY31A & C5106 & 79.0 & $3.76 \mathrm{E}+00$ & $3.46 \mathrm{E}-04$ & $(3.59 \mathrm{E}-04)$ \\
\hline B1HY31B & C5106 & 78.6 & $3.60 \mathrm{E}+00$ & $2.54 \mathrm{E}-04$ & $(1.99 \mathrm{E}-04)$ \\
\hline B1HY31C & C5106 & 78.2 & $9.55 \mathrm{E}-01$ & $3.57 \mathrm{E}-04$ & $(2.60 \mathrm{E}-04)$ \\
\hline B1HY32A & C5107 & 12.9 & $(1.57 \mathrm{E}-02)$ & $1.21 \mathrm{E}-03$ & $(2.55 \mathrm{E}-04)$ \\
\hline B1HY32B & C5107 & 12.5 & $(1.54 \mathrm{E}-02)$ & $8.31 \mathrm{E}-04$ & (3.27E-04) \\
\hline B1HY32C & C5107 & 12.2 & ND & $9.19 \mathrm{E}-04$ & (1.48E-04) \\
\hline B1HY33A & C5107 & 16.8 & $(1.55 \mathrm{E}-02)$ & $2.62 \mathrm{E}-03$ & $5.44 \mathrm{E}-04$ \\
\hline B1HY33B & C5107 & 16.4 & (3.06E-02) & $7.20 \mathrm{E}-03$ & $5.57 \mathrm{E}-04$ \\
\hline B1HY33C & C5107 & 16.1 & (1.02E-02) & $2.43 \mathrm{E}-03$ & (2.35E-04) \\
\hline B1HY34A & C5107 & 42.6 & $7.51 \mathrm{E}-01$ & $7.40 \mathrm{E}-04$ & 1.92E-02 \\
\hline B1HY34B & C5107 & 42.2 & $1.16 \mathrm{E}+00$ & $8.81 \mathrm{E}-04$ & $2.74 \mathrm{E}-02$ \\
\hline B1HY34C & C5107 & 41.9 & $1.75 \mathrm{E}+00$ & $2.12 \mathrm{E}-04$ & 5.58E-02 \\
\hline B1HY35A & C5104 & 10.4 & $(1.13 \mathrm{E}-01)$ & $1.77 \mathrm{E}-02$ & $(3.31 \mathrm{E}-04)$ \\
\hline B1HY35B & C5104 & 10.1 & (3.15E-02) & 1.07E-02 & (3.78E-04) \\
\hline B1HY35C & C5104 & 9.7 & $(1.03 \mathrm{E}-02)$ & $6.89 \mathrm{E}-03$ & $1.11 \mathrm{E}-03$ \\
\hline B1HY36A & C5104 & 77.6 & $1.31 \mathrm{E}+01$ & $1.60 \mathrm{E}-04$ & $1.32 E-01$ \\
\hline B1HY36B & C5104 & 77.2 & $2.86 \mathrm{E}+01$ & $3.68 \mathrm{E}-05$ & $4.74 E-01$ \\
\hline B1HY36C & C5104 & 76.9 & $1.20 \mathrm{E}+01$ & $(7.93 \mathrm{E}-06)$ & $1.32 E-01$ \\
\hline B1JFP2A & C5105 & 7.1 & $(1.61 \mathrm{E}-01)$ & $5.90 \mathrm{E}-04$ & $6.90 \mathrm{E}-04$ \\
\hline B1JFP2B & C5105 & 6.9 & $(5.15 \mathrm{E}-02)$ & $1.65 \mathrm{E}-03$ & $5.75 \mathrm{E}-04$ \\
\hline B1JFP3A & C5105 & 13.6 & $(1.81 \mathrm{E}-01)$ & 1.22E-01 & $1.28 \mathrm{E}-03$ \\
\hline B1JFP3B & C5105 & 13.4 & (9.00E-02) & 1.32E-01 & $7.52 \mathrm{E}-04$ \\
\hline B1JFP3C & C5105 & 13.1 & $(2.26 \mathrm{E}-01)$ & 1.12E-02 & $1.03 \mathrm{E}-03$ \\
\hline B1JFP4A & C5105 & 42.1 & 6.03E-01 & $5.79 \mathrm{E}-02$ & $2.48 \mathrm{E}-03$ \\
\hline B1JFP4B & C5105 & 41.9 & $5.24 \mathrm{E}-01$ & $4.24 \mathrm{E}-02$ & $1.73 \mathrm{E}-03$ \\
\hline B1JFP4C & C5105 & 41.6 & 3.97E-01 & 2.89E-02 & $1.86 \mathrm{E}-03$ \\
\hline \multicolumn{6}{|c|}{$\begin{array}{l}\text { Parentheses indicate reported value was less than the limit of quantification for the analysis. Bold values denote } \\
\text { elevated concentrations. ND indicates the analyte was not detected in the sample. Italicized data indicate result } \\
\text { that were above the highest check standard, but are believed to be valid. }\end{array}$} \\
\hline
\end{tabular}


Table 4.22. Water-Extractable Mobile Metals in the C-152 Slant Core Samples ( $\mu \mathrm{g} / \mathrm{g}$ dry sediment)

\begin{tabular}{|c|c|c|c|c|c|c|c|}
\hline $\begin{array}{l}\text { Sample } \\
\text { Number }\end{array}$ & $\begin{array}{c}\text { Probe } \\
\text { Hole } \\
\text { Number }\end{array}$ & $\begin{array}{c}\text { Mid- } \\
\text { Depth } \\
\text { (ft bgs) }\end{array}$ & Molybdenum-95 & Molybdenum-97 & Molybdenum-98 & Ruthenium-101 & Ruthenium-102 \\
\hline B1HY25A & C5108 & 25.3 & $1.10 \mathrm{E}-01$ & $1.63 E-01$ & $7.63 \mathrm{E}-02$ & $6.29 \mathrm{E}-04$ & $3.03 \mathrm{E}-04$ \\
\hline B1HY25B & C5108 & 24.9 & $6.93 \mathrm{E}-02$ & $9.53 \mathrm{E}-02$ & $5.20 \mathrm{E}-02$ & $2.49 \mathrm{E}-04$ & (1.13E-04) \\
\hline B1HY25C & C5108 & 24.5 & $1.83 E-01$ & $1.97 E-01$ & $1.69 E-01$ & $(1.06 \mathrm{E}-04)$ & (5.39E-05) \\
\hline B1HY26A & C5108 & 58.2 & $1.03 \mathrm{E}-01$ & $1.57 E-01$ & $7.18 \mathrm{E}-02$ & $(4.20 \mathrm{E}-05)$ & $(3.65 \mathrm{E}-05)$ \\
\hline B1HY26B & C5108 & 57.8 & $9.85 \mathrm{E}-02$ & $1.49 E-01$ & $6.85 \mathrm{E}-02$ & (4.41E-05) & (3.36E-05) \\
\hline B1HY26C & C5108 & 57.4 & $1.37 E-01$ & $1.90 E-01$ & $1.04 \mathrm{E}-01$ & (3.94E-05) & (3.94E-05) \\
\hline B1HY27A & C5109 & 11.1 & $4.49 \mathrm{E}-03$ & $4.90 \mathrm{E}-03$ & $4.13 \mathrm{E}-03$ & $(9.65 \mathrm{E}-05)$ & (6.59E-05) \\
\hline B1HY28B & C5109 & 22.4 & $1.58 \mathrm{E}-02$ & $2.17 \mathrm{E}-02$ & $1.18 \mathrm{E}-02$ & $(6.06 \mathrm{E}-05)$ & $(3.31 \mathrm{E}-05)$ \\
\hline B1HY28C & C5109 & 22.1 & $6.90 \mathrm{E}-02$ & $8.01 \mathrm{E}-02$ & $6.06 \mathrm{E}-02$ & (1.09E-04) & $(5.32 \mathrm{E}-05)$ \\
\hline B1HY29A & C5109 & 32.7 & $5.14 \mathrm{E}-02$ & $7.75 \mathrm{E}-02$ & $3.50 \mathrm{E}-02$ & $3.98 \mathrm{E}-04$ & $(1.81 \mathrm{E}-04)$ \\
\hline B1HY29B & C5109 & 32.3 & $4.44 \mathrm{E}-02$ & $6.69 \mathrm{E}-02$ & $2.96 \mathrm{E}-02$ & $3.69 \mathrm{E}-04$ & $(1.60 \mathrm{E}-04)$ \\
\hline B1HY29C & C5109 & 32.0 & $8.44 \mathrm{E}-02$ & $1.12 E-01$ & $6.69 \mathrm{E}-02$ & $3.96 \mathrm{E}-04$ & (1.93E-04) \\
\hline B1HY30A & C5106 & 17.1 & $5.38 \mathrm{E}-02$ & $5.50 \mathrm{E}-02$ & $5.06 \mathrm{E}-02$ & $(6.52 \mathrm{E}-06)$ & $(5.51 \mathrm{E}-06)$ \\
\hline B1HY30B & C5106 & 16.7 & $6.78 \mathrm{E}-02$ & $6.84 \mathrm{E}-02$ & $6.32 \mathrm{E}-02$ & $(4.52 \mathrm{E}-06)$ & $(6.03 \mathrm{E}-06)$ \\
\hline B1HY30C & C5106 & 16.2 & $1.09 \mathrm{E}-01$ & $1.11 E-01$ & $1.05 \mathrm{E}-01$ & $(4.53 \mathrm{E}-06)$ & $(4.53 \mathrm{E}-06)$ \\
\hline B1HY31A & C5106 & 79.0 & $1.41 \mathrm{E}-02$ & $1.41 \mathrm{E}-02$ & $1.30 \mathrm{E}-02$ & $1.77 \mathrm{E}-04$ & $(9.58 \mathrm{E}-05)$ \\
\hline B1HY31B & C5106 & 78.6 & $1.24 \mathrm{E}-02$ & $1.19 \mathrm{E}-02$ & $1.06 \mathrm{E}-02$ & $1.50 \mathrm{E}-04$ & $(8.22 \mathrm{E}-05)$ \\
\hline B1HY31C & C5106 & 78.2 & $8.48 \mathrm{E}-02$ & 8.55E-02 & $7.85 \mathrm{E}-02$ & $(8.25 \mathrm{E}-05)$ & $(5.58 \mathrm{E}-05)$ \\
\hline B1HY32A & C5107 & 12.9 & $5.37 \mathrm{E}-02$ & $5.39 \mathrm{E}-02$ & 4.97E-02 & $(7.73 \mathrm{E}-06)$ & $(6.70 \mathrm{E}-06)$ \\
\hline B1HY32B & C5107 & 12.5 & $5.34 \mathrm{E}-02$ & $5.32 \mathrm{E}-02$ & 4.91E-02 & $(3.52 \mathrm{E}-06)$ & $(1.21 \mathrm{E}-05)$ \\
\hline B1HY32C & C5107 & 12.2 & $9.00 \mathrm{E}-02$ & $9.03 \mathrm{E}-02$ & $8.35 \mathrm{E}-02$ & $(6.80 \mathrm{E}-06)$ & $(8.90 \mathrm{E}-06)$ \\
\hline B1HY33A & C5107 & 16.8 & $6.35 \mathrm{E}-02$ & $6.72 \mathrm{E}-02$ & $5.95 \mathrm{E}-02$ & $(3.60 \mathrm{E}-05)$ & $(1.88 \mathrm{E}-05)$ \\
\hline B1HY33B & C5107 & 16.4 & $5.41 \mathrm{E}-02$ & $5.79 \mathrm{E}-02$ & $4.88 \mathrm{E}-02$ & $(2.51 \mathrm{E}-05)$ & $(1.50 \mathrm{E}-05)$ \\
\hline B1HY33C & C5107 & 16.1 & $2.56 E-01$ & $2.58 E-01$ & $2.25 E-01$ & $(1.76 \mathrm{E}-05)$ & $(1.26 \mathrm{E}-05)$ \\
\hline B1HY34A & C5107 & 42.6 & $7.13 \mathrm{E}-02$ & $1.04 \mathrm{E}-01$ & $4.87 \mathrm{E}-02$ & $(1.08 \mathrm{E}-04)$ & $(6.17 \mathrm{E}-05)$ \\
\hline B1HY34B & C5107 & 42.2 & $1.20 E-01$ & $1.82 E-01$ & $8.15 \mathrm{E}-02$ & $2.11 \mathrm{E}-04$ & $(1.02 \mathrm{E}-04)$ \\
\hline B1HY34C & C5107 & 41.9 & $1.72 E-01$ & $2.55 E-01$ & $1.15 E-01$ & $2.01 \mathrm{E}-04$ & $(9.76 \mathrm{E}-05)$ \\
\hline B1HY35A & C5104 & 10.4 & $1.28 \mathrm{E}-02$ & $1.45 \mathrm{E}-02$ & $1.04 \mathrm{E}-02$ & $(6.85 \mathrm{E}-05)$ & $(3.83 \mathrm{E}-05)$ \\
\hline B1HY35B & C5104 & 10.1 & $1.99 \mathrm{E}-02$ & $2.15 \mathrm{E}-02$ & $1.72 \mathrm{E}-02$ & $(4.33 \mathrm{E}-05)$ & $(2.27 \mathrm{E}-05)$ \\
\hline B1HY35C & C5104 & 9.7 & $6.39 \mathrm{E}-02$ & $6.31 \mathrm{E}-02$ & $5.79 \mathrm{E}-02$ & $(1.82 \mathrm{E}-05)$ & $(1.42 \mathrm{E}-05)$ \\
\hline B1HY36A & C5104 & 77.6 & $3.37 \mathrm{E}-02$ & $3.49 \mathrm{E}-02$ & $3.20 \mathrm{E}-02$ & $2.49 \mathrm{E}-03$ & $1.22 \mathrm{E}-03$ \\
\hline B1HY36B & C5104 & 77.2 & $2.44 \mathrm{E}-02$ & $2.45 \mathrm{E}-02$ & $2.24 \mathrm{E}-02$ & $3.00 \mathrm{E}-03$ & $1.38 \mathrm{E}-03$ \\
\hline B1HY36C & C5104 & 76.9 & $7.11 \mathrm{E}-02$ & 7.02E-02 & $6.61 \mathrm{E}-02$ & $2.84 \mathrm{E}-03$ & $1.34 \mathrm{E}-03$ \\
\hline B1JFP2A & C5105 & 7.1 & $4.60 \mathrm{E}-02$ & 4.57E-02 & 4.19E-02 & $(1.16 \mathrm{E}-05)$ & $(1.37 \mathrm{E}-05)$ \\
\hline B1JFP2B & C5105 & 6.9 & $1.07 \mathrm{E}-02$ & $1.04 \mathrm{E}-02$ & $9.27 \mathrm{E}-03$ & $(8.61 \mathrm{E}-06)$ & $(1.87 \mathrm{E}-05)$ \\
\hline B1JFP3A & C5105 & 13.6 & $6.27 \mathrm{E}-02$ & $7.12 \mathrm{E}-02$ & $5.45 \mathrm{E}-02$ & $2.91 \mathrm{E}-04$ & $(1.29 \mathrm{E}-04)$ \\
\hline B1JFP3B & C5105 & 13.4 & $1.71 E-01$ & $1.82 E-01$ & $1.49 E-01$ & $3.73 \mathrm{E}-04$ & $(1.64 \mathrm{E}-04)$ \\
\hline B1JFP3C & C5105 & 13.1 & $1.31 E-01$ & $1.43 E-01$ & $1.16 E-01$ & $(9.30 \mathrm{E}-05)$ & $(5.48 \mathrm{E}-05)$ \\
\hline B1JFP4A & C5105 & 42.1 & $2.94 \mathrm{E}-02$ & $3.79 \mathrm{E}-02$ & $2.23 \mathrm{E}-02$ & $2.10 \mathrm{E}-04$ & $(1.23 \mathrm{E}-04)$ \\
\hline B1JFP4B & C5105 & 41.9 & $3.22 \mathrm{E}-02$ & $4.16 \mathrm{E}-02$ & $2.45 \mathrm{E}-02$ & $5.91 \mathrm{E}-04$ & $2.60 \mathrm{E}-04$ \\
\hline B1JFP4C & C5105 & 41.6 & $7.34 \mathrm{E}-02$ & $8.95 \mathrm{E}-02$ & $6.07 \mathrm{E}-02$ & $2.80 \mathrm{E}-04$ & $(1.38 \mathrm{E}-04)$ \\
\hline
\end{tabular}



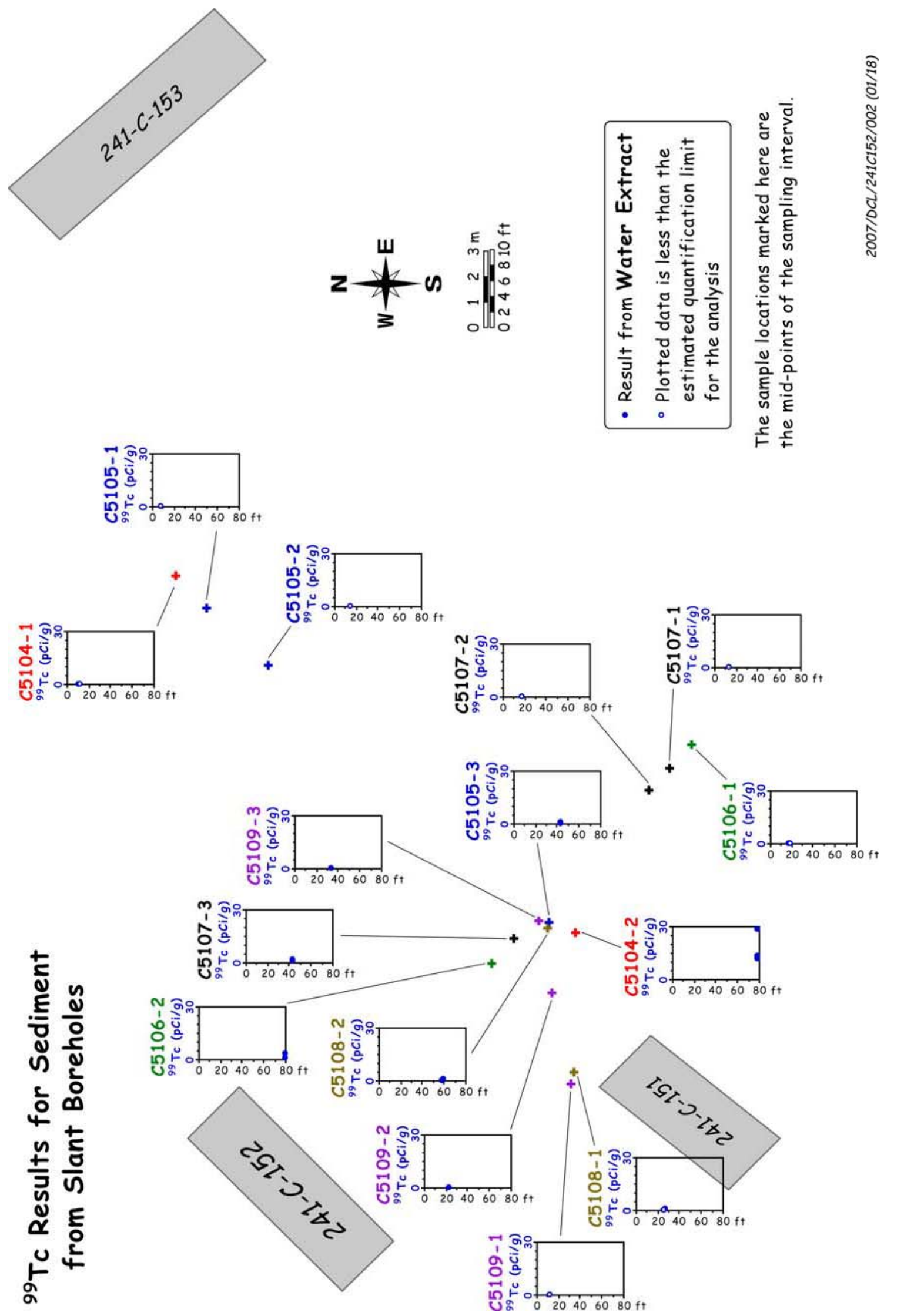

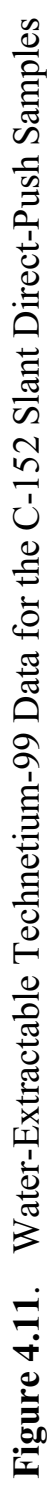


Elevated water-extractable uranium-238 was found in several of the slant push probe samples (Figure 4.12). Core samples from probe holes C5104, C5105, C5108, and C5109 all contained waterextractable uranium in excess of $0.01 \mu \mathrm{g} / \mathrm{g}$. The peak water-extractable uranium concentration, at $0.132 \mu \mathrm{g} / \mathrm{g}$, was measured in probe hole C5105 sample B1JFP3B at $13.4 \mathrm{ft}$ bgs. The deepest sample string that contained elevated water-extractable uranium was also collected from probe hole C5105 (B1JFP4) at a depth of approximately $42 \mathrm{ft}$ bgs. Overall, the amount of contaminant uranium, measured via water extraction of the sediment, in the direct-push samples was quite small, especially considering that Hanford sediment contains 1-3 $\mu \mathrm{g} / \mathrm{g}$ natural uranium. All that can be quantitatively stated upon evaluation of the water-extraction uranium data is that the vadose zone in the vicinity of the pipeline leak is contaminated with Hanford process uranium from shallow in the vadose zone (near the edge of the cap) to at least $40 \mathrm{ft}$ bgs.

Several of the slant push sediments contained significantly elevated concentrations of waterextractable chromium. Chromium released during water extraction of sediments is that which is in the more toxic, highly mobile, hexavalent state $(\mathrm{Cr}[\mathrm{VI}])$. The peak water-extractable chromium concentration was measured in one of the deepest samples collected: $0.474 \mu \mathrm{g} / \mathrm{g}$ in sample B1HY36B from probe hole $\mathrm{C} 5104$ collected at $77.2 \mathrm{ft}$ bgs. The next highest chromium-containing sample, B1HY34C, at $0.053 \mu \mathrm{g} / \mathrm{g}$, was retrieved from probe hole C5107 at a depth of $42 \mathrm{ft}$ bgs. Not surprisingly, the shallowest sample string collected from each probe hole did not contain measurable water-extractable chromium. These results are similar to those of other mobile contaminants, such as technetium-99, in which much of the contamination appears to have migrated deep into the vadose zone (at least $80 \mathrm{ft}$ bgs) despite efforts to limit infiltration.

Technetium-99 was not the only fission product measured in the water extraction samples; fissionproduced molybdenum and ruthenium were both detected in sediments from the various slant push samples. Since ICP-MS instruments measure elements based on their natural relative abundance, data reported for multiple isotopes of the same element should be the same concentration if they were present as a result of a naturally occurring source. However, when the isotopes are man-made (i.e., fission produced), the reported concentrations are often quite different. Table 4.22 contains the water extraction results for multiple isotopes of molybdenum and ruthenium. Within these data, several sample strings can be identified as containing fission product molybdenum and/or ruthenium at measurable concentrations. While the data are not quantitative in their measurement of fission-produced molybdenum or ruthenium, they are indicative of the zones in which the fission product elements are present. Both molybdenum and ruthenium form oxyanions in oxidized environments, such as the Hanford vadose zone. In their oxyanioinc forms, both molybdate and ruthenate have negative overall charges, and as a result, are quite mobile in the subsurface. Therefore, it is logical that fission-produced isotopes of molybdenum and ruthenium were primarily observed in the 40 to $60 \mathrm{ft}$ bgs depth interval.

\subsubsection{Vadose Zone Pore Water Chemical Composition}

The 1:1 water-extraction data were manipulated to derive the pore-water composition of the vadose zone sediments so that comparisons to pore-water-corrected conductivity measurements could be made and electrical balances (anions vs. cation) of the samples could be performed. From knowledge of the moisture content of the sediment samples taken from the liners of each direct-push sample string, the amount of deionized water that would be needed to make the water extraction exactly one part water 

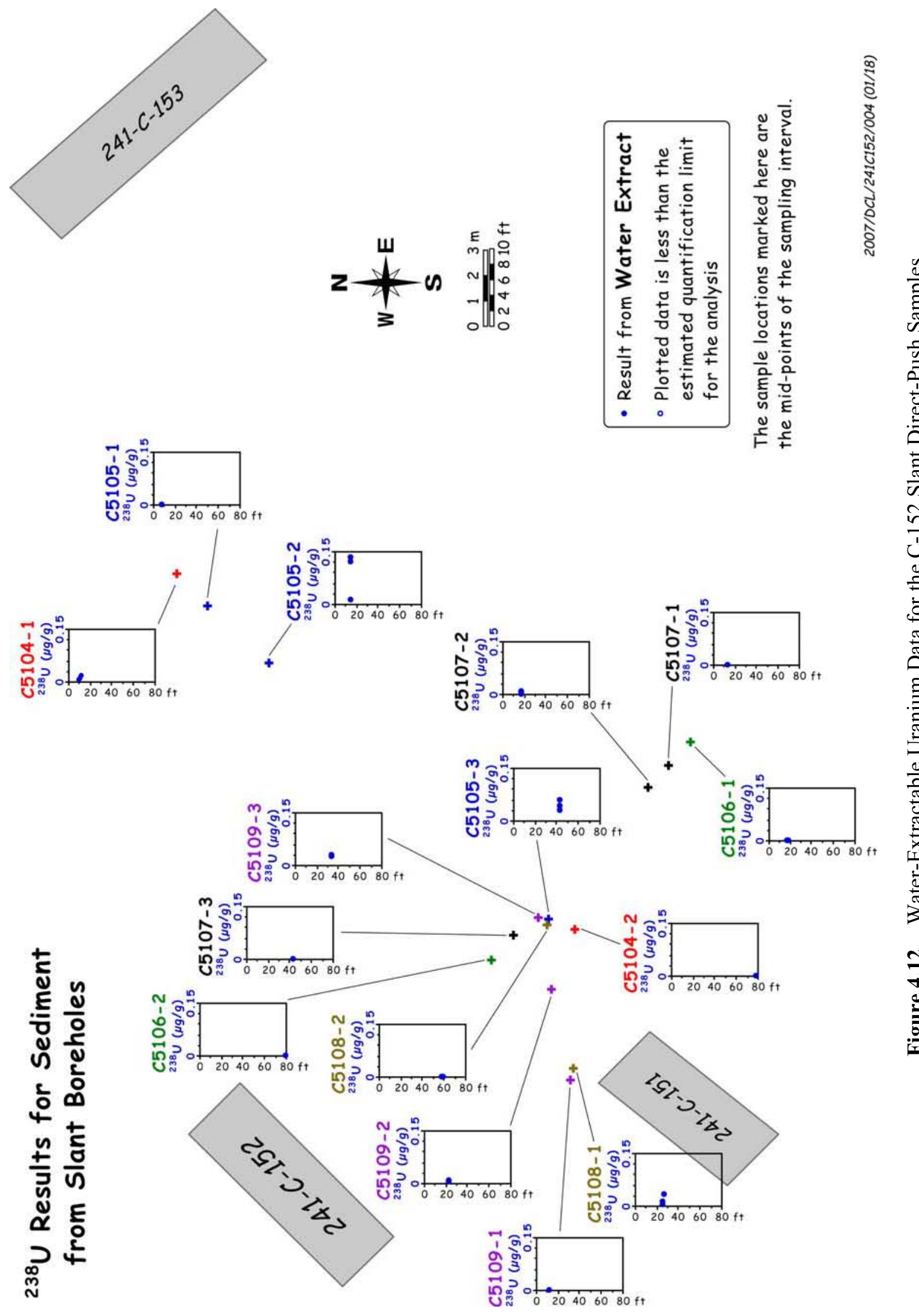

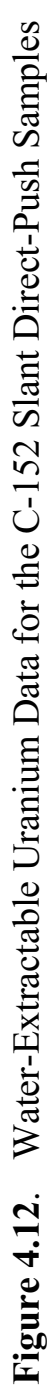


(total of native pore water and added deionized water) to one part by weight oven-dry sediment was calculated. The ratio of the total volume of water in the extract to the native mass of pore water is the dilution factor. An assumption was made that the deionized water acted solely as a diluent of the existing pore water and that the deionized water did not dissolve any of the solids in the sediments. Thus, by correcting for the dilution, an estimate of the actual chemical composition of the native pore water in the vadose zone sediments could be derived.

Tables 4.23 through 4.25 show the derived pore-water composition of key constituents in meq/L. Several of the sample strings contained sediment with considerably more dissolved salts than the vertical direct-push samples. While the chemical make-ups were similar (i.e., same dominant cations and anions), the maximum concentrations measured in the slant push samples (144 and $139 \mathrm{meq} / \mathrm{L}$ cations and anions, respectively) were approximately twice as high as the maximum concentrations measured in the vertical push samples (75.2 and $67.7 \mathrm{meq} / \mathrm{L}$ cations and anions, respectively). The slant push sample with the highest dissolved salt load (B1JFP4A) was collected from probe hole C5105 at a depth of approximately $42 \mathrm{ft}$ bgs (Figure 4.13). The sample consisted of $139 \mathrm{meq} / \mathrm{L}$ sodium, with less than quantitative concentrations of calcium $(1.02 \mathrm{meq} / \mathrm{L})$, magnesium $(0.236 \mathrm{meq} / \mathrm{L})$, and potassium $(4.13 \mathrm{meq} / \mathrm{L})$. The cations in sample B1JFP4A were balanced primarily by bicarbonate $(131 \mathrm{meq} / \mathrm{L})$, with lesser amounts of sulfate $(5.34 \mathrm{meq} / \mathrm{L})$, nitrate $(1.87 \mathrm{meq} / \mathrm{L})$, and chloride $(0.556 \mathrm{meq} / \mathrm{L})$. Again, these concentrations are very dilute compared to the vadose zone pore waters found at the SX and BX tank farms, but were close to those measured in borehole $\mathrm{C} 4297$ near Tank C-105, in which the most saline pore water contained $212 \mathrm{meq} / \mathrm{L}$ cations and $223 \mathrm{meq} / \mathrm{L}$ anions. Overall, the calculated charge balance between cations and anions for all of the samples was quite good $(<10 \%$ difference for most of the samples analyzed).

Sodium was present as the dominant cation in all but seven of the samples analyzed. For these seven samples, all of which were collected at the terminus of the deepest probe holes, calcium was the dominant cation in solution. Bicarbonate (measured via titration) was the primary anionic species in all but six of the samples analyzed. The remaining six samples had sulfate as the dominant anionic species in the water extractions. Of these six samples, five were the same samples that contained calcium as the dominant exchangeable cation. This is particularly interesting because as previously mentioned, these results could be used to determine the location of an ion exchange front, in which sodium displaced calcium as the dominant exchangeable cation on the surface exchange sites. Accordingly, this exchange front could be occurring between 60 and $80 \mathrm{ft}$ bgs, depending upon the lateral proximity to the projected leak location.

Numerous samples contained calculated technetium-99 pore-water concentrations well in excess of the current drinking water standard $(900 \mathrm{pCi} / \mathrm{L})$. In all, 21 of the 41 slant push liners contained sediment with measurable concentrations of technetium-99. The maximum pore-water technetium- 99 concentration (at $835,000 \mathrm{pCi} / \mathrm{L}$ ) occurred in sample B1HY36B, which was collected from approximately $78 \mathrm{ft}$ bgs in probe hole C5105. This concentration is more than an order of magnitude greater than the peak concentration measured in the C-152 vertical probe holes and was approximately a factor of two greater than the peak concentration measured in the $\mathrm{C} 4297$ borehole, near Tank C-105, samples. The maximum pore-water concentration of dissolved uranium was found much shallower in the vadose zone (approximately $42 \mathrm{ft}$ bgs in probe hole C5105) at a concentration of 2,010 $\mu \mathrm{g} / \mathrm{L}$. In all, 21 of the 41 slant push liner samples contained calculated pore-water uranium concentrations in excess of $30 \mu \mathrm{g} / \mathrm{L}$, the maximum concentration level for drinking water. Significantly elevated $(13,800 \mu \mathrm{g} / \mathrm{L})$ pore-water chromium was observed in the deeper vadose zone samples from probe hole C5104. The current drinking water standard for chromium is $100 \mu \mathrm{g} / \mathrm{L}$; only six of the 41 slant liner samples analyzed contained calculated pore-water 
chromium concentrations in excess of the drinking water standard. All of these samples were collected from two sample strings; one set was collected from approximately $42 \mathrm{ft}$ bgs in probe hole C5107 and the other was collected from approximately $78 \mathrm{ft}$ bgs in probe hole C5104.

Table 4.23. Calculated Pore Water Anion Concentrations in the C-152 Slant Core Samples

\begin{tabular}{|c|c|c|c|c|c|c|c|c|}
\hline $\begin{array}{c}\text { Sample } \\
\text { Number }\end{array}$ & $\begin{array}{c}\text { Probe } \\
\text { Hole } \\
\text { Number }\end{array}$ & $\begin{array}{l}\text { Mid- } \\
\text { Depth } \\
\text { (ft bgs) }\end{array}$ & $\begin{array}{l}\text { Fluoride } \\
(\mathrm{meq} / \mathrm{L})\end{array}$ & $\begin{array}{l}\text { Chloride } \\
\text { (meq/L) }\end{array}$ & $\begin{array}{c}\text { Nitrate } \\
(\mathrm{meq} / \mathrm{L})\end{array}$ & $\begin{array}{l}\text { Sulfate } \\
(\mathrm{meq} / \mathrm{L})\end{array}$ & $\begin{array}{c}\text { Phosphate } \\
\text { (meq/L) }\end{array}$ & $\begin{array}{c}\text { Alkalinity } \\
(\mathrm{meq} / \mathrm{L})\end{array}$ \\
\hline "B1HY25A & C5108 & 25.3 & $6.25 \mathrm{E}-01$ & 4.75E-01 & $2.48 \mathrm{E}+00$ & $24.97 \mathrm{E}+00$ & ND & $2.52 \mathrm{E}+01$ \\
\hline B1HY25B & C5108 & 24.9 & $1.15 \mathrm{E}+00$ & $7.35 \mathrm{E}-01$ & $2.77 \mathrm{E}+00$ & $6.49 \mathrm{E}+00$ & ND & $4.69 \mathrm{E}+01$ \\
\hline B1HY25C & C5108 & 24.5 & $1.47 \mathrm{E}+00$ & $1.39 \mathrm{E}+00$ & $2.81 \mathrm{E}-01$ & $6.02 \mathrm{E}+00$ & ND & $3.70 \mathrm{E}+01$ \\
\hline B1HY26A & C5108 & 58.2 & NA & $3.94 \mathrm{E}+00$ & $1.68 \mathrm{E}+00$ & $9.01 \mathrm{E}+00$ & ND & $3.60 \mathrm{E}+01$ \\
\hline B1HY26B & C5108 & 57.8 & NA & $5.20 \mathrm{E}+00$ & $1.58 \mathrm{E}+00$ & $9.32 \mathrm{E}+00$ & ND & $3.48 \mathrm{E}+01$ \\
\hline B1HY26C & C5108 & 57.4 & $5.73 \mathrm{E}-01$ & $9.94 \mathrm{E}+00$ & $6.39 \mathrm{E}-01$ & $9.63 \mathrm{E}+00$ & ND & $2.29 \mathrm{E}+01$ \\
\hline B1HY27A & C5109 & 11.1 & $3.43 \mathrm{E}-01$ & ND & $6.79 \mathrm{E}-01$ & $3.04 \mathrm{E}-01$ & ND & $1.16 \mathrm{E}+01$ \\
\hline B1HY28B & C5109 & 22.4 & $8.14 \mathrm{E}-01$ & ND & $6.48 \mathrm{E}-01$ & $2.73 \mathrm{E}+00$ & ND & $8.54 \mathrm{E}+01$ \\
\hline B1HY28C & C5109 & 22.1 & $1.26 \mathrm{E}+00$ & $7.75 \mathrm{E}-01$ & $1.04 \mathrm{E}+00$ & $4.59 \mathrm{E}+00$ & ND & $5.61 \mathrm{E}+01$ \\
\hline B1HY29A & C5109 & 32.7 & NA & ND & $2.53 \mathrm{E}+00$ & $5.80 \mathrm{E}+00$ & ND & $5.62 \mathrm{E}+01$ \\
\hline B1HY29B & C5109 & 32.3 & 5.04E-01 & ND & $2.47 \mathrm{E}+00$ & $6.12 \mathrm{E}+00$ & ND & $5.83 \mathrm{E}+01$ \\
\hline B1HY29C & C5109 & 32.0 & 4.91E-01 & $5.82 \mathrm{E}-01$ & $1.19 \mathrm{E}+00$ & $4.86 \mathrm{E}+00$ & ND & $3.79 \mathrm{E}+01$ \\
\hline B1HY30A & C5106 & 17.1 & $6.93 \mathrm{E}-01$ & $4.01 \mathrm{E}-01$ & $1.37 \mathrm{E}+00$ & $3.20 \mathrm{E}+00$ & ND & $1.62 \mathrm{E}+01$ \\
\hline B1HY30B & C5106 & 16.7 & $9.00 \mathrm{E}-01$ & $4.87 \mathrm{E}-01$ & $1.04 \mathrm{E}+00$ & $4.62 \mathrm{E}+00$ & ND & $1.98 \mathrm{E}+01$ \\
\hline B1HY30C & C5106 & 16.2 & $1.11 \mathrm{E}+00$ & $6.48 \mathrm{E}-01$ & $1.44 \mathrm{E}+00$ & $5.49 \mathrm{E}+00$ & ND & $2.25 \mathrm{E}+01$ \\
\hline B1HY31A & C5106 & 79.0 & NA & $2.68 \mathrm{E}+00$ & $3.72 \mathrm{E}+00$ & $2.60 \mathrm{E}+01$ & ND & $2.59 \mathrm{E}+01$ \\
\hline B1HY31B & C5106 & 78.6 & $4.98 \mathrm{E}-01$ & $2.66 \mathrm{E}+00$ & $3.59 \mathrm{E}+00$ & $2.51 \mathrm{E}+01$ & ND & $2.45 \mathrm{E}+01$ \\
\hline B1HY31C & C5106 & 78.2 & $4.92 \mathrm{E}-01$ & $2.39 \mathrm{E}+00$ & $1.05 \mathrm{E}+00$ & $2.24 \mathrm{E}+01$ & ND & $1.75 \mathrm{E}+01$ \\
\hline B1HY32A & C5107 & 12.9 & $3.50 \mathrm{E}-01$ & $2.35 \mathrm{E}-01$ & $8.75 \mathrm{E}-01$ & $1.85 \mathrm{E}+00$ & ND & $1.07 \mathrm{E}+01$ \\
\hline B1HY32B & C5107 & 12.5 & $5.99 \mathrm{E}-01$ & $2.57 \mathrm{E}-01$ & 5.59E-01 & $2.80 \mathrm{E}+00$ & ND & $1.60 \mathrm{E}+01$ \\
\hline B1HY32C & C5107 & 12.2 & $1.06 \mathrm{E}+00$ & 4.54E-01 & $3.66 \mathrm{E}-01$ & $3.83 \mathrm{E}+00$ & ND & $1.95 \mathrm{E}+01$ \\
\hline B1HY33A & C5107 & 16.8 & $3.56 \mathrm{E}-01$ & $2.71 \mathrm{E}-01$ & $7.09 \mathrm{E}-01$ & $1.94 \mathrm{E}+00$ & ND & $2.10 \mathrm{E}+01$ \\
\hline B1HY33B & C5107 & 16.4 & 4.74E-01 & ND & $5.33 \mathrm{E}-01$ & $2.31 \mathrm{E}+00$ & ND & $2.44 \mathrm{E}+01$ \\
\hline B1HY33C & C5107 & 16.1 & $8.81 \mathrm{E}-01$ & $5.44 \mathrm{E}-01$ & ND & $2.91 \mathrm{E}+00$ & ND & $2.19 \mathrm{E}+01$ \\
\hline B1HY34A & C5107 & 42.6 & NA & ND & $1.54 \mathrm{E}+00$ & $1.20 \mathrm{E}+01$ & ND & $6.60 \mathrm{E}+01$ \\
\hline B1HY34B & C5107 & 42.2 & NA & ND & $1.58 \mathrm{E}+00$ & $1.57 \mathrm{E}+01$ & ND & $6.99 \mathrm{E}+01$ \\
\hline B1HY34C & C5107 & 41.9 & NA & $4.93 \mathrm{E}-01$ & $1.29 \mathrm{E}+00$ & $1.38 \mathrm{E}+01$ & ND & $7.87 \mathrm{E}+01$ \\
\hline B1HY35A & C5104 & 10.4 & $7.92 \mathrm{E}-01$ & ND & $7.34 \mathrm{E}-01$ & $3.33 \mathrm{E}+00$ & ND & $2.39 \mathrm{E}+01$ \\
\hline B1HY35B & C5104 & 10.1 & $8.31 \mathrm{E}-01$ & ND & $6.17 \mathrm{E}-01$ & $2.30 \mathrm{E}+00$ & ND & $2.65 \mathrm{E}+01$ \\
\hline B1HY35C & C5104 & 9.7 & $7.33 \mathrm{E}-01$ & $5.96 \mathrm{E}-01$ & ND & $1.54 \mathrm{E}+00$ & ND & $2.19 \mathrm{E}+01$ \\
\hline B1HY36A & C5104 & 77.6 & NA & $2.69 \mathrm{E}+00$ & $1.17 \mathrm{E}+01$ & $3.82 \mathrm{E}+01$ & ND & $2.37 \mathrm{E}+01$ \\
\hline B1HY36B & C5104 & 77.2 & NA & $2.91 \mathrm{E}+00$ & $6.87 \mathrm{E}+00$ & $3.85 \mathrm{E}+01$ & ND & $1.95 \mathrm{E}+01$ \\
\hline B1HY36C & C5104 & 76.9 & NA & $2.77 \mathrm{E}+00$ & $2.28 \mathrm{E}+00$ & $2.66 \mathrm{E}+01$ & ND & $1.04 \mathrm{E}+01$ \\
\hline B1JFP2A & C5105 & 7.1 & $4.18 \mathrm{E}-01$ & ND & $3.87 \mathrm{E}-01$ & $6.05 \mathrm{E}-01$ & ND & $1.58 \mathrm{E}+01$ \\
\hline B1JFP2B & C5105 & 6.9 & $3.60 \mathrm{E}-01$ & $1.40 \mathrm{E}-01$ & $8.97 \mathrm{E}-01$ & $4.60 \mathrm{E}-01$ & ND & $1.12 \mathrm{E}+01$ \\
\hline B1JFP3A & C5105 & 13.6 & $3.40 \mathrm{E}-01$ & $<2.49 \mathrm{E}-01$ & $1.08 \mathrm{E}+00$ & $2.72 \mathrm{E}+00$ & ND & $6.02 \mathrm{E}+01$ \\
\hline B1JFP3B & C5105 & 13.4 & 4.99E-01 & $<1.71 \mathrm{E}-01$ & $4.33 \mathrm{E}-01$ & $2.56 \mathrm{E}+00$ & 8.69E-01 & $4.21 \mathrm{E}+01$ \\
\hline B1JFP3C & C5105 & 13.1 & $1.38 \mathrm{E}+00$ & $8.45 \mathrm{E}-01$ & $4.63 \mathrm{E}-01$ & $5.85 \mathrm{E}+00$ & ND & $2.96 \mathrm{E}+01$ \\
\hline B1JFP4A & C5105 & 42.1 & $5.56 \mathrm{E}-01$ & ND & $1.87 \mathrm{E}+00$ & $5.34 \mathrm{E}+00$ & ND & $1.31 \mathrm{E}+02$ \\
\hline B1JFP4B & C5105 & 41.9 & $1.04 \mathrm{E}+00$ & $6.62 \mathrm{E}-01$ & $1.87 \mathrm{E}+00$ & $5.41 \mathrm{E}+00$ & $1.78 \mathrm{E}+00$ & $1.30 \mathrm{E}+02$ \\
\hline B1JFP4C & C5105 & 41.6 & NA & $6.58 \mathrm{E}-01$ & $2.48 \mathrm{E}+00$ & $8.02 \mathrm{E}+00$ & ND & $1.00 \mathrm{E}+02$ \\
\hline
\end{tabular}



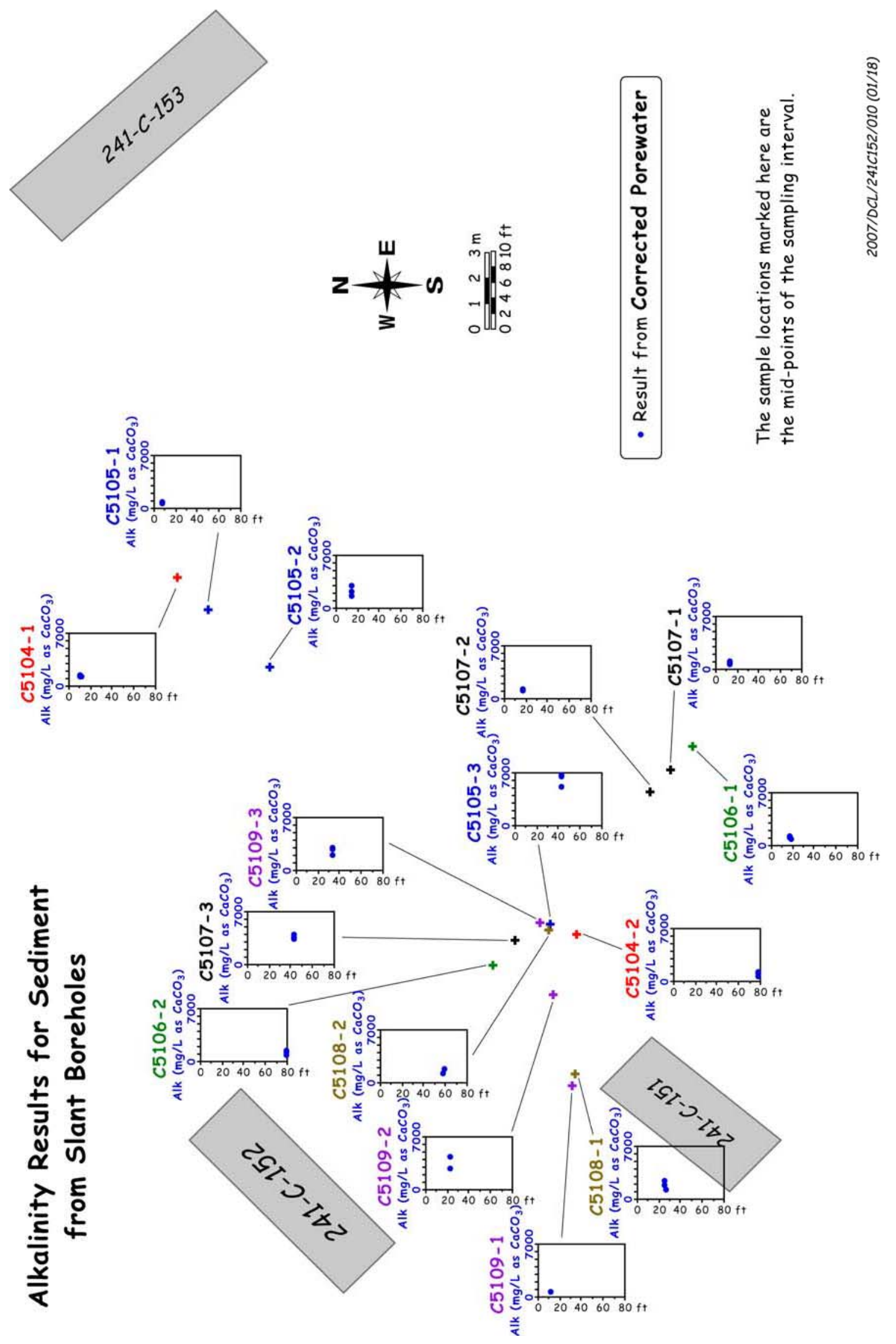

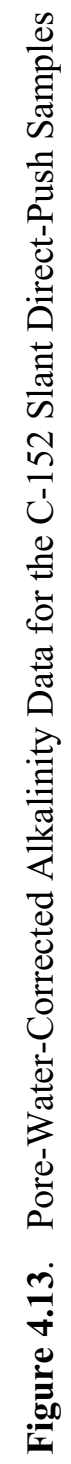


Table 4.24. Calculated Pore Water Cation Concentrations in the C-152 Slant Core Samples

\begin{tabular}{|c|c|c|c|c|c|c|}
\hline $\begin{array}{l}\text { Sample } \\
\text { Number }\end{array}$ & $\begin{array}{c}\text { Probe Hole } \\
\text { Number }\end{array}$ & $\begin{array}{l}\text { Mid-Depth } \\
\text { (ft bgs) }\end{array}$ & $\begin{array}{l}\text { Calcium } \\
(\mathrm{meq} / \mathrm{L})\end{array}$ & $\begin{array}{c}\text { Magnesium } \\
(\mathrm{meq} / \mathrm{L})\end{array}$ & $\begin{array}{c}\text { Sodium } \\
\text { (meq/L) }\end{array}$ & $\begin{array}{l}\text { Potassium } \\
(\mathrm{meq} / \mathrm{L})\end{array}$ \\
\hline "B1HY25A & C5108 & 25.3 & $2.77 \mathrm{E}+00$ & $1.13 \mathrm{E}+00$ & $2.59 \mathrm{E}+01$ & $\begin{array}{l}(1.89 \mathrm{E}+00) \\
\end{array}$ \\
\hline B1HY25B & C5108 & 24.9 & $5.88 \mathrm{E}+00$ & $2.51 \mathrm{E}+00$ & $3.80 \mathrm{E}+01$ & $(3.95 \mathrm{E}+00)$ \\
\hline B1HY25C & C5108 & 24.5 & $2.53 \mathrm{E}+00$ & $1.17 \mathrm{E}+00$ & $3.78 \mathrm{E}+01$ & $(3.24 \mathrm{E}+00)$ \\
\hline B1HY26A & C5108 & 58.2 & $1.40 \mathrm{E}+01$ & $8.69 \mathrm{E}+00$ & $(1.37 \mathrm{E}+01)$ & $(7.11 \mathrm{E}+00)$ \\
\hline B1HY26B & C5108 & 57.8 & $1.62 \mathrm{E}+01$ & $9.33 \mathrm{E}+00$ & $(1.48 \mathrm{E}+01)$ & $(7.79 \mathrm{E}+00)$ \\
\hline B1HY26C & C5108 & 57.4 & $1.39 \mathrm{E}+01$ & $8.13 \mathrm{E}+00$ & $1.51 \mathrm{E}+01$ & $(6.45 \mathrm{E}+00)$ \\
\hline B1HY27A & C5109 & 11.1 & $3.39 \mathrm{E}+00$ & $1.36 \mathrm{E}+00$ & $6.52 \mathrm{E}+00$ & $(1.07 \mathrm{E}+00)$ \\
\hline B1HY28B & C5109 & 22.4 & $(1.38 \mathrm{E}+00)$ & (6.04E-01) & $7.98 \mathrm{E}+01$ & $(3.85 \mathrm{E}+00)$ \\
\hline B1HY28C & C5109 & 22.1 & $1.30 \mathrm{E}+00$ & $5.50 \mathrm{E}-01$ & $5.61 \mathrm{E}+01$ & $(2.87 \mathrm{E}+00)$ \\
\hline B1HY29A & C5109 & 32.7 & $2.63 \mathrm{E}+00$ & $1.96 \mathrm{E}+00$ & $5.34 \mathrm{E}+01$ & $(4.24 \mathrm{E}+00)$ \\
\hline B1HY29B & C5109 & 32.3 & $2.41 \mathrm{E}+00$ & $2.45 \mathrm{E}+00$ & $5.50 \mathrm{E}+01$ & $(4.50 \mathrm{E}+00)$ \\
\hline B1HY29C & C5109 & 32.0 & $1.65 \mathrm{E}+00$ & $1.05 \mathrm{E}+00$ & $3.43 \mathrm{E}+01$ & $(2.61 \mathrm{E}+00)$ \\
\hline B1HY30A & C5106 & 17.1 & $2.02 \mathrm{E}+00$ & $5.82 \mathrm{E}-01$ & $1.71 \mathrm{E}+01$ & $(1.58 \mathrm{E}+00)$ \\
\hline B1HY30B & C5106 & 16.7 & $2.75 \mathrm{E}+00$ & $8.32 \mathrm{E}-01$ & $2.03 \mathrm{E}+01$ & $(1.95 \mathrm{E}+00)$ \\
\hline B1HY30C & C5106 & 16.2 & $2.83 \mathrm{E}+00$ & $9.37 \mathrm{E}-01$ & $2.42 \mathrm{E}+01$ & $(2.36 \mathrm{E}+00)$ \\
\hline B1HY31A & C5106 & 79.0 & $2.02 \mathrm{E}+01$ & $1.43 \mathrm{E}+01$ & $(1.49 \mathrm{E}+01)$ & $(6.98 \mathrm{E}+00)$ \\
\hline B1HY31B & C5106 & 78.6 & $1.88 \mathrm{E}+01$ & $1.30 \mathrm{E}+01$ & $(1.43 \mathrm{E}+01)$ & $(6.95 \mathrm{E}+00)$ \\
\hline B1HY31C & C5106 & 78.2 & $1.23 \mathrm{E}+01$ & $8.81 \mathrm{E}+00$ & $1.50 \mathrm{E}+01$ & $(4.92 \mathrm{E}+00)$ \\
\hline B1HY32A & C5107 & 12.9 & $1.73 \mathrm{E}+00$ & $5.00 \mathrm{E}-01$ & $1.07 \mathrm{E}+01$ & $(1.01 \mathrm{E}+00)$ \\
\hline B1HY32B & C5107 & 12.5 & $2.53 \mathrm{E}+00$ & 7.67E-01 & $1.30 \mathrm{E}+01$ & $(1.39 \mathrm{E}+00)$ \\
\hline B1HY32C & C5107 & 12.2 & $2.97 \mathrm{E}+00$ & $9.73 \mathrm{E}-01$ & $1.86 \mathrm{E}+01$ & $(1.98 \mathrm{E}+00)$ \\
\hline B1HY33A & C5107 & 16.8 & $1.21 \mathrm{E}+00$ & $3.84 \mathrm{E}-01$ & $1.97 \mathrm{E}+01$ & $(1.57 \mathrm{E}+00)$ \\
\hline B1HY33B & C5107 & 16.4 & $1.71 \mathrm{E}+00$ & 6.09E-01 & $2.12 \mathrm{E}+01$ & $(2.24 \mathrm{E}+00)$ \\
\hline B1HY33C & C5107 & 16.1 & $2.43 \mathrm{E}+00$ & $9.79 \mathrm{E}-01$ & $1.93 \mathrm{E}+01$ & $(2.38 \mathrm{E}+00)$ \\
\hline B1HY34A & C5107 & 42.6 & $6.50 \mathrm{E}+00$ & $(4.67 \mathrm{E}-01)$ & $6.27 \mathrm{E}+01$ & $(4.90 \mathrm{E}+00)$ \\
\hline B1HY34B & C5107 & 42.2 & $5.98 \mathrm{E}+00$ & (3.32E-01) & $7.61 \mathrm{E}+01$ & $(4.35 \mathrm{E}+00)$ \\
\hline B1HY34C & C5107 & 41.9 & $1.11 \mathrm{E}+01$ & (3.61E-02) & $7.54 \mathrm{E}+01$ & $(4.50 \mathrm{E}+00)$ \\
\hline B1HY35A & C5104 & 10.4 & $2.86 \mathrm{E}+00$ & $9.28 \mathrm{E}-01$ & $2.10 \mathrm{E}+01$ & $(2.24 \mathrm{E}+00)$ \\
\hline B1HY35B & C5104 & 10.1 & $2.57 \mathrm{E}+00$ & $8.40 \mathrm{E}-01$ & $2.26 \mathrm{E}+01$ & $(2.35 \mathrm{E}+00)$ \\
\hline B1HY35C & C5104 & 9.7 & $2.58 \mathrm{E}+00$ & $8.87 \mathrm{E}-01$ & $1.75 \mathrm{E}+01$ & $(2.37 \mathrm{E}+00)$ \\
\hline B1HY36A & C5104 & 77.6 & $3.43 \mathrm{E}+01$ & $1.25 \mathrm{E}+01$ & $(1.53 \mathrm{E}+01)$ & $(7.29 \mathrm{E}+00)$ \\
\hline B1HY36B & C5104 & 77.2 & $3.70 \mathrm{E}+01$ & $6.30 \mathrm{E}+00$ & $1.35 \mathrm{E}+01$ & $(6.17 \mathrm{E}+00)$ \\
\hline B1HY36C & C5104 & 76.9 & $2.56 \mathrm{E}+01$ & $1.36 \mathrm{E}+00$ & $9.80 \mathrm{E}+00$ & $(3.71 \mathrm{E}+00)$ \\
\hline B1JFP2A & C5105 & 7.1 & $1.81 \mathrm{E}+00$ & $9.38 \mathrm{E}-01$ & $1.15 \mathrm{E}+01$ & $(1.53 \mathrm{E}+00)$ \\
\hline B1JFP2B & C5105 & 6.9 & $2.21 \mathrm{E}+00$ & $1.15 \mathrm{E}+00$ & $7.90 \mathrm{E}+00$ & $(1.03 \mathrm{E}+00)$ \\
\hline B1JFP3A & C5105 & 13.6 & $(3.46 \mathrm{E}-01)$ & (7.53E-02) & $6.47 \mathrm{E}+01$ & $(1.43 \mathrm{E}+00)$ \\
\hline B1JFP3B & C5105 & 13.4 & $(3.76 \mathrm{E}-01)$ & $(1.07 \mathrm{E}-01)$ & $4.17 \mathrm{E}+01$ & $(1.08 \mathrm{E}+00)$ \\
\hline B1JFP3C & C5105 & 13.1 & $3.61 \mathrm{E}+00$ & $1.33 \mathrm{E}+00$ & $2.96 \mathrm{E}+01$ & $(2.86 \mathrm{E}+00)$ \\
\hline B1JFP4A & C5105 & 42.1 & $(1.02 \mathrm{E}+00)$ & $(2.36 \mathrm{E}-01)$ & $1.39 \mathrm{E}+02$ & $(4.13 \mathrm{E}+00)$ \\
\hline B1JFP4B & C5105 & 41.9 & $(8.82 \mathrm{E}-01)$ & $(2.35 \mathrm{E}-01)$ & $1.22 \mathrm{E}+02$ & $(3.30 \mathrm{E}+00)$ \\
\hline B1JFP4C & C5105 & 41.6 & (7.43E-01) & $(2.16 \mathrm{E}-01)$ & $1.11 \mathrm{E}+02$ & $(3.09 \mathrm{E}+00)$ \\
\hline
\end{tabular}


Table 4.25. Calculated Pore Water Mobile Metal Concentrations of Key Contaminants of Concern in the C-152 Slant Core and Grab Samples

\begin{tabular}{|c|c|c|c|c|c|}
\hline $\begin{array}{l}\text { Sample } \\
\text { Number }\end{array}$ & $\begin{array}{l}\text { Probe Hole } \\
\text { Number }\end{array}$ & $\begin{array}{l}\text { Mid-Depth } \\
\text { (ft bgs) }\end{array}$ & $\begin{array}{l}\text { Technetium-99 } \\
(\mathrm{pCi} / \mathrm{L})\end{array}$ & $\begin{array}{l}\text { Uranium-238 } \\
(\mu \mathrm{g} / \mathrm{L})\end{array}$ & $\begin{array}{l}\text { Chromium-53 } \\
(\mu \mathrm{g} / \mathrm{L})\end{array}$ \\
\hline B1HY25A & C5108 & 25.3 & $1.23 E+04$ & $7.42 \mathrm{E}+02$ & $1.66 \mathrm{E}+01$ \\
\hline B1HY25B & C5108 & 24.9 & $1.53 E+04$ & $5.65 \mathrm{E}+02$ & $(1.89 \mathrm{E}+01)$ \\
\hline B1HY25C & C5108 & 24.5 & $(1.22 \mathrm{E}+03)$ & $1.01 \mathrm{E}+02$ & $(5.09 \mathrm{E}+00)$ \\
\hline B1HY26A & C5108 & 58.2 & $3.39 \mathrm{E}+04$ & $1.33 \mathrm{E}+01$ & $(7.81 \mathrm{E}+00)$ \\
\hline B1HY26B & C5108 & 57.8 & $3.27 \mathrm{E}+04$ & $1.61 \mathrm{E}+01$ & $(1.42 \mathrm{E}+01)$ \\
\hline B1HY26C & C5108 & 57.4 & $1.04 \mathrm{E}+04$ & $7.87 \mathrm{E}+00$ & $(1.21 \mathrm{E}+01)$ \\
\hline B1HY27A & C5109 & 11.1 & $(2.34 \mathrm{E}+02)$ & $6.30 \mathrm{E}+00$ & $(3.47 \mathrm{E}+00)$ \\
\hline B1HY28B & C5109 & 22.4 & $1.78 \mathrm{E}+04$ & $3.14 \mathrm{E}+02$ & $(1.83 \mathrm{E}+01)$ \\
\hline B1HY28C & C5109 & 22.1 & $(4.88 \mathrm{E}+03)$ & $1.49 \mathrm{E}+02$ & $(1.21 \mathrm{E}+01)$ \\
\hline B1HY29A & C5109 & 32.7 & $1.58 \mathrm{E}+04$ & $1.16 E+03$ & $5.35 \mathrm{E}+01$ \\
\hline B1HY29B & C5109 & 32.3 & $1.63 E+04$ & $9.78 \mathrm{E}+02$ & $4.52 \mathrm{E}+01$ \\
\hline B1HY29C & C5109 & 32.0 & $6.46 \mathrm{E}+03$ & $5.79 \mathrm{E}+02$ & $3.29 \mathrm{E}+01$ \\
\hline B1HY30A & C5106 & 17.1 & ND & $1.86 \mathrm{E}+01$ & $(3.94 \mathrm{E}+00)$ \\
\hline B1HY30B & C5106 & 16.7 & $(1.47 \mathrm{E}+02)$ & $2.08 \mathrm{E}+01$ & $(2.21 \mathrm{E}+00)$ \\
\hline B1HY30C & C5106 & 16.2 & ND & $1.61 \mathrm{E}+01$ & $3.15 \mathrm{E}+01$ \\
\hline B1HY31A & C5106 & 79.0 & $1.28 \mathrm{E}+05$ & $1.18 \mathrm{E}+01$ & $(1.23 \mathrm{E}+01)$ \\
\hline B1HY31B & C5106 & 78.6 & $1.19 \mathrm{E}+05$ & $8.35 \mathrm{E}+00$ & $(6.55 \mathrm{E}+00)$ \\
\hline B1HY31C & C5106 & 78.2 & $1.74 \mathrm{E}+04$ & $6.50 \mathrm{E}+00$ & $(4.73 \mathrm{E}+00)$ \\
\hline B1HY32A & C5107 & 12.9 & $(1.10 \mathrm{E}+02)$ & $8.45 \mathrm{E}+00$ & $(1.79 \mathrm{E}+00)$ \\
\hline B1HY32B & C5107 & 12.5 & $(1.70 \mathrm{E}+02)$ & $9.19 \mathrm{E}+00$ & $(3.62 \mathrm{E}+00)$ \\
\hline B1HY32C & C5107 & 12.2 & ND & $1.15 \mathrm{E}+01$ & $(1.85 \mathrm{E}+00)$ \\
\hline B1HY33A & C5107 & 16.8 & $(2.12 \mathrm{E}+02)$ & $3.59 \mathrm{E}+01$ & $7.45 \mathrm{E}+00$ \\
\hline B1HY33B & C5107 & 16.4 & $(5.68 \mathrm{E}+02)$ & $1.34 \mathrm{E}+02$ & $1.03 \mathrm{E}+01$ \\
\hline B1HY33C & C5107 & 16.1 & $(1.47 \mathrm{E}+02)$ & $3.50 \mathrm{E}+01$ & $(3.38 \mathrm{E}+00)$ \\
\hline B1HY34A & C5107 & 42.6 & $2.97 E+04$ & $2.93 \mathrm{E}+01$ & $7.61 \mathrm{E}+02$ \\
\hline B1HY34B & C5107 & 42.2 & $4.22 \mathrm{E}+04$ & $3.21 \mathrm{E}+01$ & $9.98 \mathrm{E}+02$ \\
\hline B1HY34C & C5107 & 41.9 & $4.67 \mathrm{E}+04$ & $5.64 \mathrm{E}+00$ & $1.49 \mathrm{E}+03$ \\
\hline B1HY35A & C5104 & 10.4 & $(1.78 \mathrm{E}+03)$ & $2.80 \mathrm{E}+02$ & $(5.24 \mathrm{E}+00)$ \\
\hline B1HY35B & C5104 & 10.1 & $(5.62 \mathrm{E}+02)$ & $1.92 \mathrm{E}+02$ & $(6.76 \mathrm{E}+00)$ \\
\hline B1HY35C & C5104 & 9.7 & $(1.61 \mathrm{E}+02)$ & $1.08 \mathrm{E}+02$ & $1.73 \mathrm{E}+01$ \\
\hline B1HY36A & C5104 & 77.6 & $4.86 \mathrm{E}+05$ & $5.91 \mathrm{E}+00$ & $4.89 E+03$ \\
\hline B1HY36B & C5104 & 77.2 & $8.35 E+05$ & $1.07 \mathrm{E}+00$ & $1.38 E+04$ \\
\hline B1HY36C & C5104 & 76.9 & $1.73 E+05$ & $(1.15 E-01)$ & $1.91 E+03$ \\
\hline B1JFP2A & C5105 & 7.1 & $(1.86 \mathrm{E}+03)$ & $6.82 \mathrm{E}+00$ & $7.98 \mathrm{E}+00$ \\
\hline B1JFP2B & C5105 & 6.9 & $(4.14 \mathrm{E}+02)$ & $1.33 \mathrm{E}+01$ & $4.62 \mathrm{E}+00$ \\
\hline B1JFP3A & C5105 & 13.6 & $(2.88 \mathrm{E}+03)$ & $1.94 \mathrm{E}+03$ & $2.05 \mathrm{E}+01$ \\
\hline B1JFP3B & C5105 & 13.4 & $(9.62 \mathrm{E}+02)$ & $1.41 \mathrm{E}+03$ & $8.03 \mathrm{E}+00$ \\
\hline B1JFP3C & C5105 & 13.1 & $(4.08 \mathrm{E}+03)$ & $2.02 E+02$ & $1.85 \mathrm{E}+01$ \\
\hline B1JFP4A & C5105 & 42.1 & $2.09 \mathrm{E}+04$ & $2.01 \mathrm{E}+03$ & $8.62 \mathrm{E}+01$ \\
\hline B1JFP4B & C5105 & 41.9 & $1.83 E+04$ & $1.48 \mathrm{E}+03$ & $6.02 \mathrm{E}+01$ \\
\hline B1JFP4C & C5105 & 41.6 & $1.20 \mathrm{E}+04$ & $8.74 \mathrm{E}+02$ & $5.64 \mathrm{E}+01$ \\
\hline
\end{tabular}




\subsubsection{8-M Nitric Acid-Leachable Amounts of Selected Elements in the C-152 Slant Push Sediments}

The same core samples that were characterized for water-extractable constituents were also characterized to see how much of the various constituents could be leached with hot 8-M nitric acid. A comparison between the quantities that were acid-leachable with those that are water-extractable often indicates the relative mobility of a given constituent and can sometimes differentiate man-disposed from naturally occurring constituents. The acid-leachable concentrations are shown in Tables 4.26 through 4.28.

The acid extract data for the major cations and metals in the sediments, Tables 4.26 and 4.27, show that the samples are generally composed of similar lithologic material (perceived mineral content). For most constituents, there was no sign of elevated values of acid-leachable concentrations in the C-152 slant push sediments, with the exception of sodium, technetium-99, molybdenum, and ruthenium. The acidleachable sodium, likely tank-waste-related, was elevated shallow in the vadose zone in probe holes C5107 and C5105, both at approximately $13 \mathrm{ft}$ bgs. Acid-leachable technetium- 99 was measurable in 4 of the 41 slant push samples (Figure 4.14). Unlike the water-extractable technetium-99, the acidleachable technetium-99 was only measured in samples from the deepest two probe holes emplaced at the site. There was a significant difference between the water-extractable and acid-leachable concentrations of technetium-99 in all of the samples in which both extracts yielded quantifiable values. In all cases, the acid-leachable technetium-99 concentration was significantly higher. The difference in measured technetium-99 values between the water extractions and acid leaches ranged from a low of $191 \%$ for sample B1HY36B to a high of 4,220\% for sample B1HY31C. In previous borehole reports, the acidleachable technetium-99 has been considered to be less valid than the water-extractable technetium- 99 data, and as such, has been reported as qualitative. However, this trend, in which acid-leachable concentrations of technetium-99 are significantly higher than water-extractable technetium-99 concentrations from separate aliquots from the same homogenized sample, has occurred in many of the contaminated boreholes measured as part of the Single-Shell Tank Vadose Zone Project, as well as in many of the residual tank sludge samples analyzed as part of the Geochemical Testing and Residual Tank Waste Model Development Project. A current hypothesis is that some of the technetium-99 is being sequestered with iron oxides that result from the interaction of caustic tank waste with the vadose zone sediment or tank sludge. From a long-term risk standpoint, it is imperative to quantitate the total concentration of technetium-99 present in these samples; therefore, additional analyses were performed (presented in Section 4.3) to determine if these elevated values of technetium-99 were real or just artifacts of analysis.

Further interpretation of the acid extract data indicates that there was elevated ruthenium in several of the slant push core samples. Elevated acid-leachable ruthenium was observed in slant push samples from probe holes C5104, C5105, C5107, and C5108 ranging in depth from approximately 10 to $25 \mathrm{ft}$ bgs. The source of the elevated ruthenium was likely fission-produced isotopes from tank-waste-related contamination that has been sequestered with a species that is recalcitrant to water leaching.

A comparison of the water to acid-leachable quantities of each constituent was performed by taking the data in Tables 4.19 through 4.21 and dividing them by the data in Tables 4.26 through 4.28. The data are not presented herein, but show that less than $0.1 \%$ of the acid-leachable quantities of the following elements were water-extractable: aluminum, barium, boron, iron, manganese, titanium, zinc, and zirconium. Less than $0.35 \%$ of the acid-leachable quantities of the following elements were waterextractable: calcium, nickel, magnesium, phosphorus (as phosphate), and strontium. Less than $2 \%$ of the 
acid-leachable cobalt, chromium, potassium, and zirconium were water-extractable. Finally, less than $15 \%$ of the acid-leachable sodium and uranium were water-extractable.

Table 4.26. Acid-Leachable Cations in the C-152 Slant Core and Grab Samples ( $\mu \mathrm{g} / \mathrm{g}$ dry sediment)

\begin{tabular}{|c|c|c|c|c|c|c|c|}
\hline $\begin{array}{l}\text { Sample } \\
\text { Number }\end{array}$ & $\begin{array}{c}\text { Probe Hole } \\
\text { Number }\end{array}$ & $\begin{array}{l}\text { Mid- } \\
\text { Depth } \\
\text { (ft bgs) }\end{array}$ & Calcium & Magnesium & Strontium & Sodium & Potassium \\
\hline B1HY25A & C55108 & 25.3 & $9.49 \mathrm{E}+03$ & $20.63 \mathrm{E}+03$ & $3.20 \mathrm{E}+01$ & $4.32 \mathrm{E}+02$ & 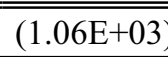 \\
\hline B1HY25B & C5108 & 24.9 & $9.61 \mathrm{E}+03$ & $5.45 \mathrm{E}+03$ & $3.10 \mathrm{E}+01$ & $4.48 \mathrm{E}+02$ & $(8.32 \mathrm{E}+02)$ \\
\hline B1HY25C & C5108 & 24.5 & $8.70 \mathrm{E}+03$ & $4.98 \mathrm{E}+03$ & $3.58 \mathrm{E}+01$ & $7.53 \mathrm{E}+02$ & $(1.06 \mathrm{E}+03)$ \\
\hline B1HY26A & C5108 & 58.2 & $8.22 \mathrm{E}+03$ & $4.83 \mathrm{E}+03$ & $2.91 \mathrm{E}+01$ & $3.25 \mathrm{E}+02$ & $(9.10 \mathrm{E}+02)$ \\
\hline B1HY26B & C5108 & 57.8 & $9.99 \mathrm{E}+03$ & $5.19 \mathrm{E}+03$ & $3.74 \mathrm{E}+01$ & $4.16 \mathrm{E}+02$ & $(1.03 \mathrm{E}+03)$ \\
\hline B1HY26C & C5108 & 57.4 & $9.74 \mathrm{E}+03$ & $5.00 \mathrm{E}+03$ & $3.28 \mathrm{E}+01$ & $3.94 \mathrm{E}+02$ & $(9.84 \mathrm{E}+02)$ \\
\hline B1HY27A & C5109 & 11.1 & $9.97 \mathrm{E}+03$ & $6.03 \mathrm{E}+03$ & $4.29 \mathrm{E}+01$ & $6.62 \mathrm{E}+02$ & $1.47 \mathrm{E}+03$ \\
\hline B1HY28B & C5109 & 22.4 & $8.97 \mathrm{E}+03$ & $4.64 \mathrm{E}+03$ & $3.92 \mathrm{E}+01$ & $8.46 \mathrm{E}+02$ & $(8.65 \mathrm{E}+02)$ \\
\hline B1HY28C & C5109 & 22.1 & $8.54 \mathrm{E}+03$ & $4.89 \mathrm{E}+03$ & $3.62 \mathrm{E}+01$ & $8.18 \mathrm{E}+02$ & $(8.85 \mathrm{E}+02)$ \\
\hline B1HY29A & C5109 & 32.7 & $1.01 \mathrm{E}+04$ & $5.47 \mathrm{E}+03$ & $3.47 \mathrm{E}+01$ & $4.12 \mathrm{E}+02$ & $(9.32 \mathrm{E}+02)$ \\
\hline B1HY29B & C5109 & 32.3 & $9.10 \mathrm{E}+03$ & $5.20 \mathrm{E}+03$ & $3.17 \mathrm{E}+01$ & $4.29 \mathrm{E}+02$ & $(9.10 \mathrm{E}+02)$ \\
\hline B1HY29C & C5109 & 32.0 & $1.02 \mathrm{E}+04$ & $5.52 \mathrm{E}+03$ & $3.33 \mathrm{E}+01$ & $3.95 \mathrm{E}+02$ & $(9.53 \mathrm{E}+02)$ \\
\hline B1HY30A & C5106 & 17.1 & $1.02 \mathrm{E}+04$ & $6.20 \mathrm{E}+03$ & $3.69 \mathrm{E}+01$ & $5.09 \mathrm{E}+02$ & $1.36 \mathrm{E}+03$ \\
\hline B1HY30B & C5106 & 16.7 & $7.87 \mathrm{E}+03$ & $4.80 \mathrm{E}+03$ & $3.61 \mathrm{E}+01$ & $4.54 \mathrm{E}+02$ & $(1.02 \mathrm{E}+03)$ \\
\hline B1HY30C & C5106 & 16.2 & $8.92 \mathrm{E}+03$ & $5.86 \mathrm{E}+03$ & $3.87 \mathrm{E}+01$ & $7.49 \mathrm{E}+02$ & $1.44 \mathrm{E}+03$ \\
\hline B1HY31A & & 79.0 & $8.69 \mathrm{E}+03$ & $4.69 \mathrm{E}+03$ & $3.81 \mathrm{E}+01$ & $4.59 \mathrm{E}+02$ & $(1.08 \mathrm{E}+03)$ \\
\hline B1HY31B & C5106 & 78.6 & $1.01 \mathrm{E}+04$ & $5.05 \mathrm{E}+03$ & $3.54 \mathrm{E}+01$ & $3.73 \mathrm{E}+02$ & $(1.06 \mathrm{E}+03)$ \\
\hline B1HY31C & C5106 & 78.2 & $9.30 \mathrm{E}+03$ & $4.85 \mathrm{E}+03$ & $4.17 \mathrm{E}+01$ & $4.19 \mathrm{E}+02$ & $(9.90 \mathrm{E}+02)$ \\
\hline B1HY32A & C5107 & 12.9 & $1.04 \mathrm{E}+04$ & $5.26 \mathrm{E}+03$ & $3.88 \mathrm{E}+01$ & $9.37 E+02$ & $(1.14 \mathrm{E}+03)$ \\
\hline B1HY32B & C5107 & 12.5 & $9.01 \mathrm{E}+03$ & $4.71 \mathrm{E}+03$ & $3.46 \mathrm{E}+01$ & $7.29 \mathrm{E}+02$ & $(9.84 \mathrm{E}+02)$ \\
\hline B1HY32C & C5107 & 12.2 & $9.55 \mathrm{E}+03$ & $4.94 \mathrm{E}+03$ & $3.61 \mathrm{E}+01$ & $9.38 E+02$ & $(1.06 \mathrm{E}+03)$ \\
\hline B1HY33A & C5107 & 16.8 & $1.03 \mathrm{E}+04$ & $5.89 \mathrm{E}+03$ & $3.38 \mathrm{E}+01$ & $4.99 \mathrm{E}+02$ & $(1.22 \mathrm{E}+03)$ \\
\hline B1HY33B & C5107 & 16.4 & $9.49 \mathrm{E}+03$ & $5.17 \mathrm{E}+03$ & $3.42 \mathrm{E}+01$ & $4.20 \mathrm{E}+02$ & $(1.11 \mathrm{E}+03)$ \\
\hline B1HY33C & C5107 & 16.1 & $1.10 \mathrm{E}+04$ & $5.77 \mathrm{E}+03$ & $3.65 \mathrm{E}+01$ & $5.66 \mathrm{E}+02$ & $(1.33 \mathrm{E}+03)$ \\
\hline B1HY34A & C5107 & 42.6 & $8.80 \mathrm{E}+03$ & $4.76 \mathrm{E}+03$ & $3.24 \mathrm{E}+01$ & $4.65 \mathrm{E}+02$ & $(1.02 \mathrm{E}+03)$ \\
\hline B1HY34B & C5107 & 42.2 & $9.40 \mathrm{E}+03$ & $5.26 \mathrm{E}+03$ & $3.46 \mathrm{E}+01$ & $5.02 \mathrm{E}+02$ & $(1.08 \mathrm{E}+03)$ \\
\hline B1HY34C & C5107 & 41.9 & $9.99 \mathrm{E}+03$ & $4.97 \mathrm{E}+03$ & $3.26 \mathrm{E}+01$ & $4.82 \mathrm{E}+02$ & $(1.01 \mathrm{E}+03$ \\
\hline B1HY35A & C5104 & 10.4 & $9.65 \mathrm{E}+03$ & $4.59 \mathrm{E}+03$ & $3.21 \mathrm{E}+01$ & $6.65 \mathrm{E}+02$ & $(7.68 \mathrm{E}+02)$ \\
\hline B1HY35B & C5104 & 10.1 & $7.95 \mathrm{E}+03$ & $4.13 \mathrm{E}+03$ & $2.80 \mathrm{E}+01$ & $6.40 \mathrm{E}+02$ & $(6.38 \mathrm{E}+02)$ \\
\hline B1HY35C & C5104 & 9.7 & $6.26 \mathrm{E}+03$ & $3.32 \mathrm{E}+03$ & $2.52 \mathrm{E}+01$ & $6.94 \mathrm{E}+02$ & $(7.53 \mathrm{E}+02)$ \\
\hline B1HY36A & C5104 & 77.6 & $9.30 \mathrm{E}+03$ & $4.70 \mathrm{E}+03$ & $5.55 \mathrm{E}+01$ & $3.16 \mathrm{E}+02$ & $(8.35 \mathrm{E}+02)$ \\
\hline B1HY36B & C5104 & 77.2 & $8.44 \mathrm{E}+03$ & $4.37 \mathrm{E}+03$ & $3.27 \mathrm{E}+01$ & $2.96 \mathrm{E}+02$ & $(8.97 \mathrm{E}+02)$ \\
\hline B1HY36C & C5104 & 76.9 & $1.12 \mathrm{E}+04$ & $4.69 \mathrm{E}+03$ & $3.42 \mathrm{E}+01$ & $3.50 \mathrm{E}+02$ & $(9.76 \mathrm{E}+02)$ \\
\hline B1JFP2A & C5105 & 7.1 & $9.75 \mathrm{E}+03$ & $5.95 \mathrm{E}+03$ & $3.09 \mathrm{E}+01$ & $7.23 \mathrm{E}+02$ & $(9.26 \mathrm{E}+02)$ \\
\hline B1JFP2B & C5105 & 6.9 & $1.10 \mathrm{E}+04$ & $5.95 \mathrm{E}+03$ & $3.47 \mathrm{E}+01$ & $4.55 \mathrm{E}+02$ & $(1.23 \mathrm{E}+03)$ \\
\hline B1JFP3A & C5105 & 13.6 & $8.54 \mathrm{E}+03$ & $4.85 \mathrm{E}+03$ & $4.02 \mathrm{E}+01$ & $1.02 \mathrm{E}+03$ & $(1.25 \mathrm{E}+03)$ \\
\hline B1JFP3B & C5105 & 13.4 & $9.16 \mathrm{E}+03$ & $5.09 \mathrm{E}+03$ & $3.58 \mathrm{E}+01$ & $1.10 E+03$ & $1.41 \mathrm{E}+03$ \\
\hline
\end{tabular}


Table 4.26. (contd)

\begin{tabular}{||c|c|c|c|c|c|c|c|}
\hline $\begin{array}{c}\text { Sample } \\
\text { Number }\end{array}$ & $\begin{array}{c}\text { Probe Hole } \\
\text { Number }\end{array}$ & $\begin{array}{c}\text { Mid- } \\
\text { Depth } \\
\text { (ft bgs) }\end{array}$ & Calcium & Magnesium & Strontium & Sodium & Potassium \\
\hline \hline B1JFP3C & C5105 & 13.1 & $9.29 \mathrm{E}+03$ & $4.46 \mathrm{E}+03$ & $3.84 \mathrm{E}+01$ & $\mathbf{1 . 0 1 E}+\mathbf{0 3}$ & $(8.87 \mathrm{E}+02)$ \\
\hline B1JFP4A & C5105 & 42.1 & $8.85 \mathrm{E}+03$ & $4.91 \mathrm{E}+03$ & $3.53 \mathrm{E}+01$ & $8.04 \mathrm{E}+02$ & $(1.14 \mathrm{E}+03)$ \\
\hline B1JFP4B & C5105 & 41.9 & $9.25 \mathrm{E}+03$ & $4.91 \mathrm{E}+03$ & $3.34 \mathrm{E}+01$ & $6.75 \mathrm{E}+02$ & $(9.73 \mathrm{E}+02)$ \\
\hline B1JFP4C & C5105 & 41.6 & $9.01 \mathrm{E}+03$ & $4.86 \mathrm{E}+03$ & $3.30 \mathrm{E}+01$ & $7.15 \mathrm{E}+02$ & $(1.13 \mathrm{E}+03)$ \\
\hline
\end{tabular}

Bold values denote elevated concentrations.

Parentheses indicate the analyte was below the limit of quantification for the analysis.

The primary indications of tank contamination in these sediments were the elevated sodium levels in several of the samples, the presence of technetium-99 in water extractions and acid leaches of some of the sediments, the indication of fission product molybdenum and ruthenium in some of the sediments, and the elevated water-extractable uranium values for several samples from various probe holes (Figure 4.15). The percentage of acid-leachable uranium that was also water-extractable averaged less than $0.2 \%$ for most of the samples analyzed; however, it was as high as $10.8 \%$ in a sample (B1JFP3A) collected from probe hole C5105 at a depth of approximately $13 \mathrm{ft}$ bgs. The water and acid-leachable uranium concentrations in sample B1JFP3A were 0.122 and $1.13 \mu \mathrm{g}$ of uranium per $\mathrm{g}$ of sediment. The acid-leachable uranium concentration of this sample was approximately a factor of three greater than the peak concentration measured in the $\mathrm{C} 4297$ borehole samples $(0.046 \mu \mathrm{g} / \mathrm{g})$ from below Tank C-105, but considerably lower than the peak concentration measured in the $\mathrm{C}-152$ vertical push samples: $38.1 \mu \mathrm{g}$ of uranium per $\mathrm{g}$ of sediment in sample S05001-4A from probe hole C4410.

Table 4.27. Acid-Leachable Cations in the C-152 Slant Core and Grab Samples ( $\mu \mathrm{g} / \mathrm{g}$ dry sediment)

\begin{tabular}{||c|c|c|c|c|c|c|c||}
\hline \hline $\begin{array}{c}\text { Sample } \\
\text { Number }\end{array}$ & $\begin{array}{c}\text { Probe Hole } \\
\text { Number }\end{array}$ & $\begin{array}{c}\text { Mid- } \\
\text { Depth } \\
\text { ft bgs) }\end{array}$ & Aluminum & Iron & Manganese & $\begin{array}{c}\text { Phosphorus } \\
\text { as }_{4}\end{array}$ & $\begin{array}{c}\text { Sulfur as } \\
\text { SO }_{4}\end{array}$ \\
\hline \hline B1HY25A & C5108 & 25.3 & $7.77 \mathrm{E}+03$ & $1.86 \mathrm{E}+04$ & $3.33 \mathrm{E}+02$ & $1.97 \mathrm{E}+03$ & ND \\
\hline B1HY25B & C5108 & 24.9 & $6.96 \mathrm{E}+03$ & $1.77 \mathrm{E}+04$ & $2.93 \mathrm{E}+02$ & $2.16 \mathrm{E}+03$ & ND \\
\hline B1HY25C & C5108 & 24.5 & $7.85 \mathrm{E}+03$ & $2.03 \mathrm{E}+04$ & $3.01 \mathrm{E}+02$ & $2.35 \mathrm{E}+03$ & ND \\
\hline B1HY26A & C5108 & 58.2 & $6.21 \mathrm{E}+03$ & $1.50 \mathrm{E}+04$ & $2.46 \mathrm{E}+02$ & $1.78 \mathrm{E}+03$ & ND \\
\hline B1HY26B & C5108 & 57.8 & $7.23 \mathrm{E}+03$ & $1.75 \mathrm{E}+04$ & $2.76 \mathrm{E}+02$ & $1.96 \mathrm{E}+03$ & ND \\
\hline B1HY26C & C5108 & 57.4 & $6.66 \mathrm{E}+03$ & $1.68 \mathrm{E}+04$ & $2.91 \mathrm{E}+02$ & $1.92 \mathrm{E}+03$ & ND \\
\hline B1HY27A & C5109 & 11.1 & $1.03 \mathrm{E}+04$ & $2.59 \mathrm{E}+04$ & $4.22 \mathrm{E}+02$ & $2.95 \mathrm{E}+03$ & ND \\
\hline B1HY28B & C5109 & 22.4 & $7.01 \mathrm{E}+03$ & $2.00 \mathrm{E}+04$ & $3.07 \mathrm{E}+02$ & $2.58 \mathrm{E}+03$ & ND \\
\hline B1HY28C & C5109 & 22.1 & $7.09 \mathrm{E}+03$ & $2.03 \mathrm{E}+04$ & $3.02 \mathrm{E}+02$ & $2.45 \mathrm{E}+03$ & ND \\
\hline B1HY29A & C5109 & 32.7 & $7.02 \mathrm{E}+03$ & $1.65 \mathrm{E}+04$ & $3.01 \mathrm{E}+02$ & $1.66 \mathrm{E}+03$ & ND \\
\hline B1HY29B & C5109 & 32.3 & $6.97 \mathrm{E}+03$ & $1.58 \mathrm{E}+04$ & $2.77 \mathrm{E}+02$ & $1.69 \mathrm{E}+03$ & ND \\
\hline B1HY29C & C5109 & 32.0 & $6.92 \mathrm{E}+03$ & $1.59 \mathrm{E}+04$ & $3.11 \mathrm{E}+02$ & $1.65 \mathrm{E}+03$ & ND \\
\hline B1HY30A & C5106 & 17.1 & $9.44 \mathrm{E}+03$ & $2.10 \mathrm{E}+04$ & $3.60 \mathrm{E}+02$ & $2.15 \mathrm{E}+03$ & ND \\
\hline B1HY30B & C5106 & 16.7 & $7.48 \mathrm{E}+03$ & $1.69 \mathrm{E}+04$ & $2.85 \mathrm{E}+02$ & $1.89 \mathrm{E}+03$ & ND \\
\hline B1HY30C & C5106 & 16.2 & $1.01 \mathrm{E}+04$ & $2.40 \mathrm{E}+04$ & $3.77 \mathrm{E}+02$ & $2.87 \mathrm{E}+03$ & ND \\
\hline
\end{tabular}


Table 4.27. (contd)

\begin{tabular}{|c|c|c|c|c|c|c|c|}
\hline $\begin{array}{c}\text { Sample } \\
\text { Number }\end{array}$ & $\begin{array}{l}\text { Probe Hole } \\
\text { Number }\end{array}$ & $\begin{array}{c}\text { Mid- } \\
\text { Depth } \\
\text { (ft bgs) }\end{array}$ & Aluminum & Iron & Manganese & $\begin{array}{l}\text { Phosphorus } \\
\text { as } \mathrm{PO}_{4}\end{array}$ & $\begin{array}{c}\text { Sulfur as } \\
\mathrm{SO}_{4}\end{array}$ \\
\hline B1HY31A & C5106 & 79.0 & $7.06 \mathrm{E}+03$ & $1.67 \mathrm{E}+04$ & $2.68 \mathrm{E}+02$ & $1.84 \mathrm{E}+03$ & ND \\
\hline B1HY31B & C5106 & 78.6 & $6.76 \mathrm{E}+03$ & $1.69 \mathrm{E}+04$ & $2.87 \mathrm{E}+02$ & $1.95 \mathrm{E}+03$ & $(1.09 \mathrm{E}+01)$ \\
\hline B1HY31C & C5106 & 78.2 & $6.56 \mathrm{E}+03$ & $1.71 \mathrm{E}+04$ & $2.93 \mathrm{E}+02$ & $2.00 \mathrm{E}+03$ & ND \\
\hline B1HY32A & C5107 & 12.9 & $1.12 \mathrm{E}+04$ & $3.54 \mathrm{E}+04$ & $5.44 \mathrm{E}+02$ & $2.67 \mathrm{E}+03$ & ND \\
\hline B1HY32B & C5107 & 12.5 & $8.97 \mathrm{E}+03$ & $3.18 \mathrm{E}+04$ & $4.94 \mathrm{E}+02$ & $2.62 \mathrm{E}+03$ & ND \\
\hline B1HY32C & C5107 & 12.2 & $9.12 \mathrm{E}+03$ & $3.09 \mathrm{E}+04$ & $4.62 \mathrm{E}+02$ & $2.79 \mathrm{E}+03$ & ND \\
\hline B1HY33A & C5107 & 16.8 & $8.61 \mathrm{E}+03$ & $1.86 \mathrm{E}+04$ & $3.23 \mathrm{E}+02$ & $1.77 \mathrm{E}+03$ & ND \\
\hline B1HY33B & C5107 & 16.4 & $7.33 \mathrm{E}+03$ & $1.66 \mathrm{E}+04$ & $2.76 \mathrm{E}+02$ & $1.80 \mathrm{E}+03$ & ND \\
\hline B1HY33C & C5107 & 16.1 & $8.12 \mathrm{E}+03$ & $2.03 \mathrm{E}+04$ & $3.73 \mathrm{E}+02$ & $2.33 \mathrm{E}+03$ & ND \\
\hline B1HY34A & C5107 & 42.6 & $6.51 \mathrm{E}+03$ & $1.59 \mathrm{E}+04$ & $2.60 \mathrm{E}+02$ & $1.84 \mathrm{E}+03$ & ND \\
\hline B1HY34B & C5107 & 42.2 & $6.74 \mathrm{E}+03$ & $1.58 \mathrm{E}+04$ & $2.69 \mathrm{E}+02$ & $1.63 \mathrm{E}+03$ & ND \\
\hline B1HY34C & C5107 & 41.9 & $6.62 \mathrm{E}+03$ & $1.56 \mathrm{E}+04$ & $2.69 \mathrm{E}+02$ & $1.68 \mathrm{E}+03$ & ND \\
\hline B1HY35A & C5104 & 10.4 & $7.44 \mathrm{E}+03$ & $2.97 \mathrm{E}+04$ & $4.60 \mathrm{E}+02$ & $3.17 \mathrm{E}+03$ & ND \\
\hline B1HY35B & C5104 & 10.1 & $6.52 \mathrm{E}+03$ & $2.72 \mathrm{E}+04$ & $3.97 \mathrm{E}+02$ & $3.26 \mathrm{E}+03$ & $(1.78 \mathrm{E}+01)$ \\
\hline B1HY35C & C5104 & 9.7 & $5.89 \mathrm{E}+03$ & $2.02 \mathrm{E}+04$ & $2.76 \mathrm{E}+02$ & $2.15 \mathrm{E}+03$ & ND \\
\hline B1HY36A & C5104 & 77.6 & $5.97 \mathrm{E}+03$ & $1.52 \mathrm{E}+04$ & $2.49 \mathrm{E}+02$ & $1.75 \mathrm{E}+03$ & ND \\
\hline B1HY36B & C5104 & 77.2 & $5.41 \mathrm{E}+03$ & $1.45 \mathrm{E}+04$ & $2.59 \mathrm{E}+02$ & $1.92 \mathrm{E}+03$ & $(7.07 \mathrm{E}+01)$ \\
\hline B1HY36C & C5104 & 76.9 & $5.68 \mathrm{E}+03$ & $1.51 \mathrm{E}+04$ & $2.48 \mathrm{E}+02$ & $1.87 \mathrm{E}+03$ & $(3.18 \mathrm{E}+01)$ \\
\hline B1JFP2A & C5105 & 7.1 & $7.22 \mathrm{E}+03$ & $3.16 \mathrm{E}+04$ & $4.69 \mathrm{E}+02$ & $4.13 \mathrm{E}+03$ & ND \\
\hline B1JFP2B & C5105 & 6.9 & $7.36 \mathrm{E}+03$ & $2.37 \mathrm{E}+04$ & $3.95 \mathrm{E}+02$ & $3.44 \mathrm{E}+03$ & $(4.19 \mathrm{E}+01)$ \\
\hline B1JFP3A & C5105 & 13.6 & $7.39 \mathrm{E}+03$ & $1.89 \mathrm{E}+04$ & $3.38 \mathrm{E}+02$ & $1.96 \mathrm{E}+03$ & ND \\
\hline B1JFP3B & C5105 & 13.4 & $7.92 \mathrm{E}+03$ & $2.07 \mathrm{E}+04$ & $3.73 \mathrm{E}+02$ & $2.27 \mathrm{E}+03$ & ND \\
\hline B1JFP3C & C5105 & 13.1 & $7.52 \mathrm{E}+03$ & $2.83 \mathrm{E}+04$ & $4.02 \mathrm{E}+02$ & $3.46 \mathrm{E}+03$ & $(3.14 \mathrm{E}+01)$ \\
\hline B1JFP4A & C5105 & 42.1 & $6.97 \mathrm{E}+03$ & $1.55 \mathrm{E}+04$ & $2.66 \mathrm{E}+02$ & $1.46 \mathrm{E}+03$ & ND \\
\hline B1JFP4B & C5105 & 41.9 & $6.22 \mathrm{E}+03$ & $1.48 \mathrm{E}+04$ & $2.62 \mathrm{E}+02$ & $1.53 \mathrm{E}+03$ & ND \\
\hline B1JFP4C & C5105 & 41.6 & $6.58 \mathrm{E}+03$ & $1.53 \mathrm{E}+04$ & $2.72 \mathrm{E}+02$ & $1.50 \mathrm{E}+03$ & ND \\
\hline
\end{tabular}

Table 4.28. Acid-Leachable Mobile Metals in the C-152 Slant Core and Grab Samples ( $\mu \mathrm{g} / \mathrm{g}$ dry sediment)

\begin{tabular}{||c|c|c|c|c|c|c|c||}
\hline $\begin{array}{c}\text { Sample } \\
\text { Number }\end{array}$ & $\begin{array}{c}\text { Probe } \\
\text { Hole } \\
\text { Number }\end{array}$ & $\begin{array}{c}\text { Mid- } \\
\text { Depth } \\
\text { (ft bgs) }\end{array}$ & $\begin{array}{c}\text { Technetium-99 } \\
\text { (pCi/g soil) }\end{array}$ & Uranium-238 & Chromium-53 & Molybdenum-95 & Ruthenium-101 \\
\hline \hline B1HY25A & C5108 & 25.3 & $(1.22 \mathrm{E}+01)$ & $9.38 \mathrm{E}-01$ & $(1.88 \mathrm{E}+01)$ & $(7.49 \mathrm{E}-01)$ & $4.76 \mathrm{E}-01$ \\
\hline B1HY25B & C5108 & 24.9 & $(1.58 \mathrm{E}+01)$ & $7.09 \mathrm{E}-01$ & $(1.73 \mathrm{E}+01)$ & $(6.78 \mathrm{E}-01)$ & $4.71 \mathrm{E}-01$ \\
\hline B1HY25C & C5108 & 24.5 & $(7.23 \mathrm{E}+00)$ & $7.48 \mathrm{E}-01$ & $(2.62 \mathrm{E}+01)$ & $(2.26 \mathrm{E}+00)$ & $\mathbf{2 . 0 1 E}+\mathbf{0 0}$ \\
\hline B1HY26A & C5108 & 58.2 & $(7.95 \mathrm{E}+00)$ & $4.16 \mathrm{E}-01$ & $(1.30 \mathrm{E}+01)$ & $(5.39 \mathrm{E}-01)$ & $3.62 \mathrm{E}-01$ \\
\hline B1HY26B & C5108 & 57.8 & $(1.05 \mathrm{E}+01)$ & $5.19 \mathrm{E}-01$ & $(1.70 \mathrm{E}+01)$ & $(6.14 \mathrm{E}-01)$ & $4.38 \mathrm{E}-01$ \\
\hline
\end{tabular}


Table 4.28. (contd)

\begin{tabular}{|c|c|c|c|c|c|c|c|}
\hline $\begin{array}{l}\text { Sample } \\
\text { Number }\end{array}$ & $\begin{array}{c}\text { Probe } \\
\text { Hole } \\
\text { Number }\end{array}$ & $\begin{array}{l}\text { Mid- } \\
\text { Depth } \\
\text { (ft bgs) }\end{array}$ & $\begin{array}{l}\text { Technetium-99 } \\
\text { (pCi/g soil) }\end{array}$ & Uranium-238 & Chromium-53 & Molybdenum-95 & Ruthenium-101 \\
\hline B1HY26C & C5108 & 57.4 & $(1.29 \mathrm{E}+01)$ & $4.01 \mathrm{E}-01$ & $(2.45 \mathrm{E}+01)$ & $(1.07 \mathrm{E}+00)$ & $7.98 \mathrm{E}-01$ \\
\hline B1HY27A & C5109 & 11.1 & $(6.71 \mathrm{E}+00)$ & $5.24 \mathrm{E}-01$ & $(1.47 \mathrm{E}+01)$ & $(3.59 \mathrm{E}-01)$ & $3.22 \mathrm{E}-01$ \\
\hline B1HY28B & C5109 & 22.4 & $(1.66 \mathrm{E}+01)$ & $5.68 \mathrm{E}-01$ & $(1.66 \mathrm{E}+01)$ & $(5.04 \mathrm{E}-01)$ & $4.05 \mathrm{E}-01$ \\
\hline B1HY28C & C5109 & 22.1 & $(9.30 \mathrm{E}+00)$ & $5.13 \mathrm{E}-01$ & $(1.68 \mathrm{E}+01)$ & $(6.90 \mathrm{E}-01)$ & $5.80 \mathrm{E}-01$ \\
\hline B1HY29A & C5109 & 32.7 & $(1.50 \mathrm{E}+01)$ & 8.72E-01 & $(1.54 \mathrm{E}+01)$ & $(6.45 \mathrm{E}-01)$ & 4.20E-01 \\
\hline B1HY29B & C5109 & 32.3 & $(1.77 \mathrm{E}+01)$ & $8.09 \mathrm{E}-01$ & $(1.67 \mathrm{E}+01)$ & $(6.15 \mathrm{E}-01)$ & $3.99 \mathrm{E}-01$ \\
\hline B1HY29C & C5109 & 32.0 & $(2.06 \mathrm{E}+01)$ & $7.38 \mathrm{E}-01$ & $(2.62 \mathrm{E}+01)$ & $(8.12 \mathrm{E}-01)$ & $5.86 \mathrm{E}-01$ \\
\hline B1HY30A & C5106 & 17.1 & $(3.23 \mathrm{E}+00)$ & $5.56 \mathrm{E}-01$ & $(1.74 \mathrm{E}+01)$ & $(3.30 \mathrm{E}-01)$ & $2.98 \mathrm{E}-01$ \\
\hline B1HY30B & C5106 & 16.7 & $(2.43 \mathrm{E}+00)$ & 4.71E-01 & $(1.50 \mathrm{E}+01)$ & $(3.20 \mathrm{E}-01)$ & 2.91E-01 \\
\hline B1HY30C & C5106 & 16.2 & $(1.66 \mathrm{E}+00)$ & $5.23 \mathrm{E}-01$ & $(2.81 \mathrm{E}+01)$ & $(1.07 \mathrm{E}+00)$ & $9.76 \mathrm{E}-01$ \\
\hline B1HY31A & C5106 & 79.0 & $(1.84 \mathrm{E}+01)$ & 7.01E-01 & $(1.29 \mathrm{E}+01)$ & $(2.78 \mathrm{E}-01)$ & $2.51 \mathrm{E}-01$ \\
\hline B1HY31B & C5106 & 78.6 & $(3.26 \mathrm{E}+01)$ & $4.55 \mathrm{E}-01$ & $(1.69 \mathrm{E}+01)$ & (3.69E-01) & $3.25 \mathrm{E}-01$ \\
\hline B1HY31C & C5106 & 78.2 & $4.03 \mathrm{E}+01$ & $5.81 \mathrm{E}-01$ & $(2.26 \mathrm{E}+01)$ & $(6.62 \mathrm{E}-01)$ & $6.10 \mathrm{E}-01$ \\
\hline B1HY32A & C5107 & 12.9 & $(5.91 \mathrm{E}+00)$ & $5.27 \mathrm{E}-01$ & $(2.04 \mathrm{E}+01)$ & $(5.86 \mathrm{E}-01)$ & $5.35 \mathrm{E}-01$ \\
\hline B1HY32B & C5107 & 12.5 & $(3.59 \mathrm{E}+00)$ & 4.72E-01 & $(1.74 \mathrm{E}+01)$ & $(4.95 \mathrm{E}-01)$ & $4.58 \mathrm{E}-01$ \\
\hline B1HY32C & C5107 & 12.2 & $(3.54 \mathrm{E}+00)$ & $6.10 \mathrm{E}-01$ & $(2.34 \mathrm{E}+01)$ & $(1.01 \mathrm{E}+00)$ & 9.32E-01 \\
\hline B1HY33A & C5107 & 16.8 & $(5.22 \mathrm{E}+00)$ & $5.43 \mathrm{E}-01$ & $(2.21 \mathrm{E}+01)$ & $(4.43 \mathrm{E}-01)$ & $3.88 \mathrm{E}-01$ \\
\hline B1HY33B & C5107 & 16.4 & $(6.16 \mathrm{E}+00)$ & $6.39 \mathrm{E}-01$ & $(1.58 \mathrm{E}+01)$ & $(3.87 \mathrm{E}-01)$ & $3.32 \mathrm{E}-01$ \\
\hline B1HY33C & C5107 & 16.1 & $(5.41 \mathrm{E}+00)$ & $6.44 \mathrm{E}-01$ & $(2.43 \mathrm{E}+01)$ & $(1.26 \mathrm{E}+00)$ & $1.14 \mathrm{E}+00$ \\
\hline B1HY34A & C5107 & 42.6 & $(1.09 \mathrm{E}+01)$ & 8.30E-01 & $(1.63 \mathrm{E}+01)$ & (5.14E-01) & $3.58 \mathrm{E}-01$ \\
\hline B1HY34B & C5107 & 42.2 & $(1.59 \mathrm{E}+01)$ & $8.31 \mathrm{E}-01$ & $(2.06 \mathrm{E}+01)$ & $(6.71 \mathrm{E}-01)$ & $4.40 \mathrm{E}-01$ \\
\hline B1HY34C & C5107 & 41.9 & $(2.83 \mathrm{E}+01)$ & $8.11 \mathrm{E}-01$ & $(3.03 \mathrm{E}+01)$ & $(9.49 \mathrm{E}-01)$ & $6.69 \mathrm{E}-01$ \\
\hline B1HY35A & C5104 & 10.4 & $(2.79 \mathrm{E}+01)$ & $7.12 \mathrm{E}-01$ & $(1.12 \mathrm{E}+01)$ & $(3.20 \mathrm{E}-01)$ & $(2.71 \mathrm{E}-01)$ \\
\hline B1HY35B & C5104 & 10.1 & $(1.28 \mathrm{E}+01)$ & $6.73 \mathrm{E}-01$ & $(1.08 \mathrm{E}+01)$ & $(3.52 \mathrm{E}-01)$ & $3.18 \mathrm{E}-01$ \\
\hline B1HY35C & C5104 & 9.7 & $(4.44 \mathrm{E}+00)$ & $4.43 \mathrm{E}-01$ & $(1.78 \mathrm{E}+01)$ & $(1.47 \mathrm{E}+00)$ & $1.38 \mathrm{E}+00$ \\
\hline B1HY36A & C5104 & 77.6 & $4.71 \mathrm{E}+01$ & $4.51 \mathrm{E}-01$ & $(1.36 \mathrm{E}+01)$ & $(3.55 \mathrm{E}-01)$ & $3.25 \mathrm{E}-01$ \\
\hline B1HY36B & C5104 & 77.2 & $5.48 \mathrm{E}+01$ & $4.56 \mathrm{E}-01$ & $(1.51 \mathrm{E}+01)$ & $(3.42 \mathrm{E}-01)$ & $3.01 \mathrm{E}-01$ \\
\hline B1HY36C & C5104 & 76.9 & $6.06 \mathrm{E}+01$ & $1.87 \mathrm{E}+00$ & $(3.72 \mathrm{E}+01)$ & $(8.28 \mathrm{E}-01)$ & 7.63E-01 \\
\hline B1JFP2A & C5105 & 7.1 & $(3.94 \mathrm{E}+00)$ & $5.01 \mathrm{E}-01$ & $(1.80 \mathrm{E}+01)$ & $(8.11 \mathrm{E}-01)$ & $7.61 \mathrm{E}-01$ \\
\hline B1JFP2B & C5105 & 6.9 & $(4.39 \mathrm{E}+00)$ & 4.62E-01 & $(1.09 \mathrm{E}+01)$ & $(2.50 \mathrm{E}-01)$ & $(2.41 \mathrm{E}-01)$ \\
\hline B1JFP3A & C5105 & 13.6 & $(1.10 \mathrm{E}+01)$ & $1.13 \mathrm{E}+00$ & $(1.77 \mathrm{E}+01)$ & $(4.37 \mathrm{E}-01)$ & $3.46 \mathrm{E}-01$ \\
\hline B1JFP3B & C5105 & 13.4 & $(8.51 \mathrm{E}+00)$ & $1.69 \mathrm{E}+00$ & $(1.75 \mathrm{E}+01)$ & $(4.89 \mathrm{E}-01)$ & 4.14E-01 \\
\hline B1JFP3C & C5105 & 13.1 & $(1.61 \mathrm{E}+01)$ & $8.10 \mathrm{E}-01$ & $(2.59 \mathrm{E}+01)$ & $(1.79 \mathrm{E}+00)$ & $1.65 \mathrm{E}+00$ \\
\hline B1JFP4A & C5105 & 42.1 & $(2.00 \mathrm{E}+01)$ & $9.49 \mathrm{E}-01$ & $(2.01 \mathrm{E}+01)$ & $(5.74 \mathrm{E}-01)$ & 4.57E-01 \\
\hline B1JFP4B & C5105 & 41.9 & $(2.07 \mathrm{E}+01)$ & 7.19E-01 & $(1.80 \mathrm{E}+01)$ & $(5.43 \mathrm{E}-01)$ & 4.01E-01 \\
\hline B1JFP4C & C5105 & 41.6 & $(1.57 \mathrm{E}+01)$ & $7.30 \mathrm{E}-01$ & $(3.08 \mathrm{E}+01)$ & $(8.36 \mathrm{E}-01)$ & $6.65 \mathrm{E}-01$ \\
\hline
\end{tabular}




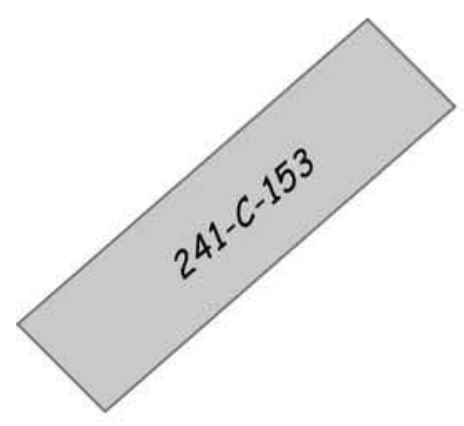

$$
z \frac{\int^{W}}{\frac{4}{2}}
$$

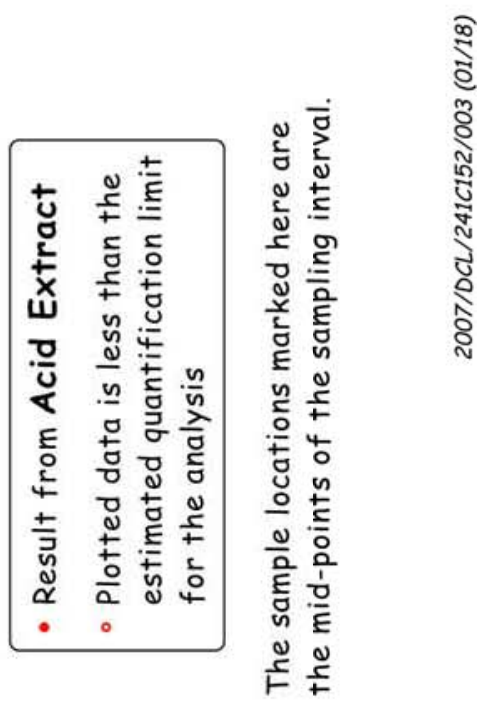

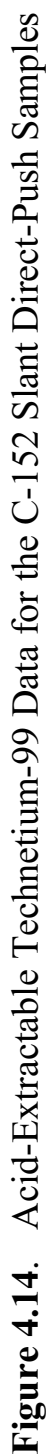
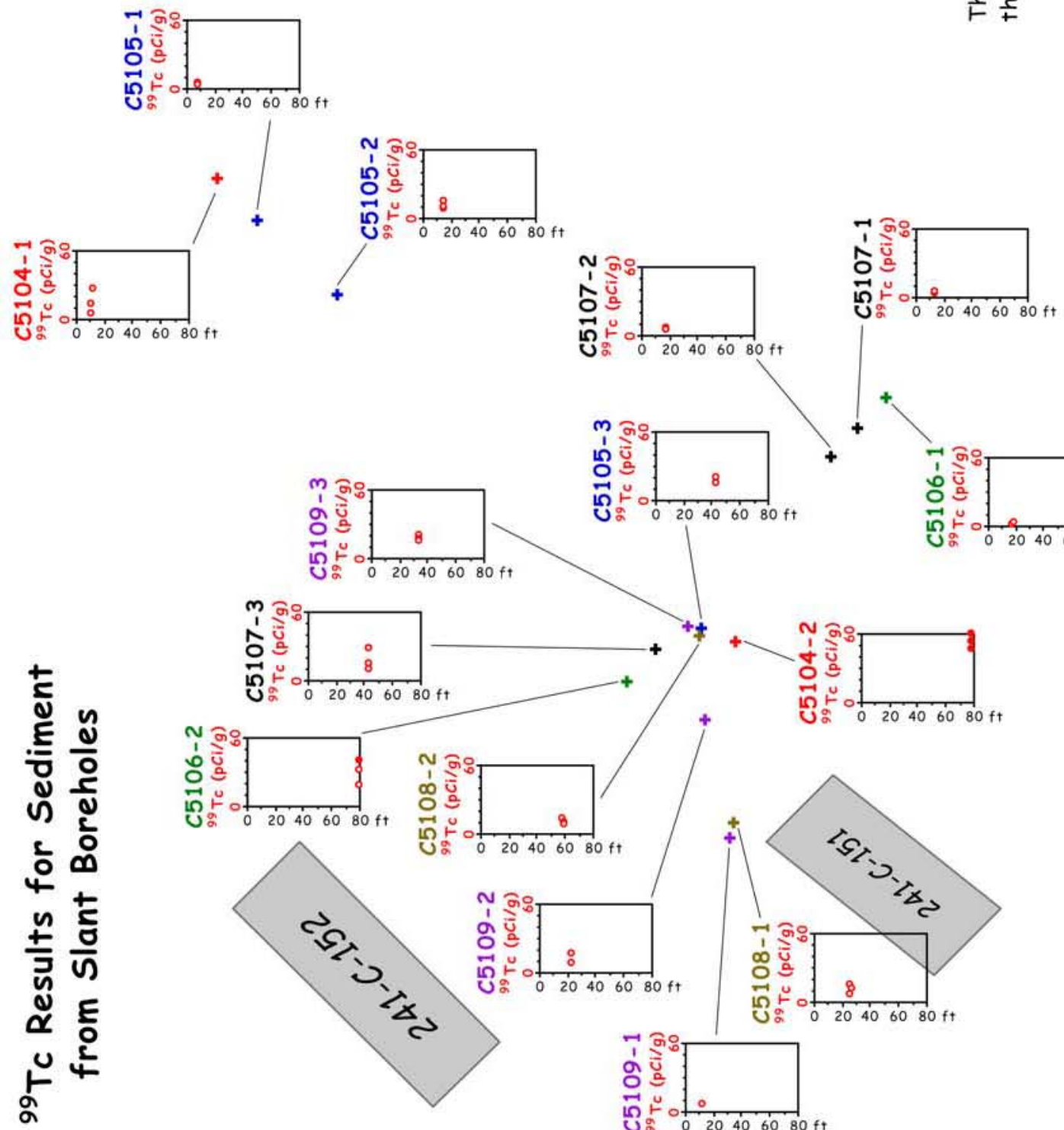


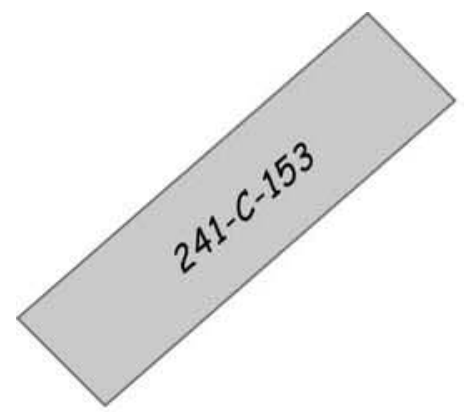

$$
z \frac{\frac{w}{4}}{\frac{1}{3}} \sqrt{\frac{m}{2}}
$$

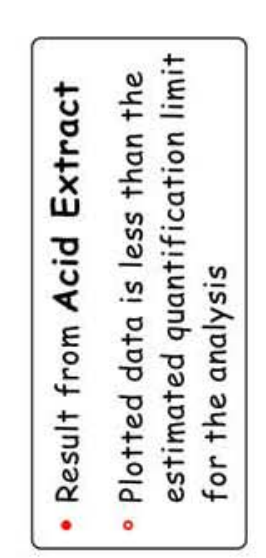

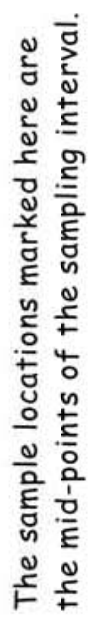

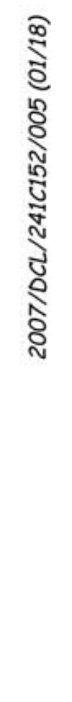

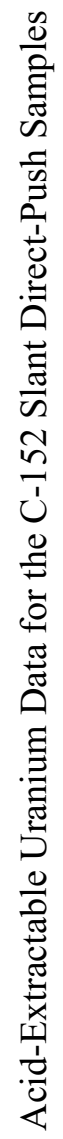
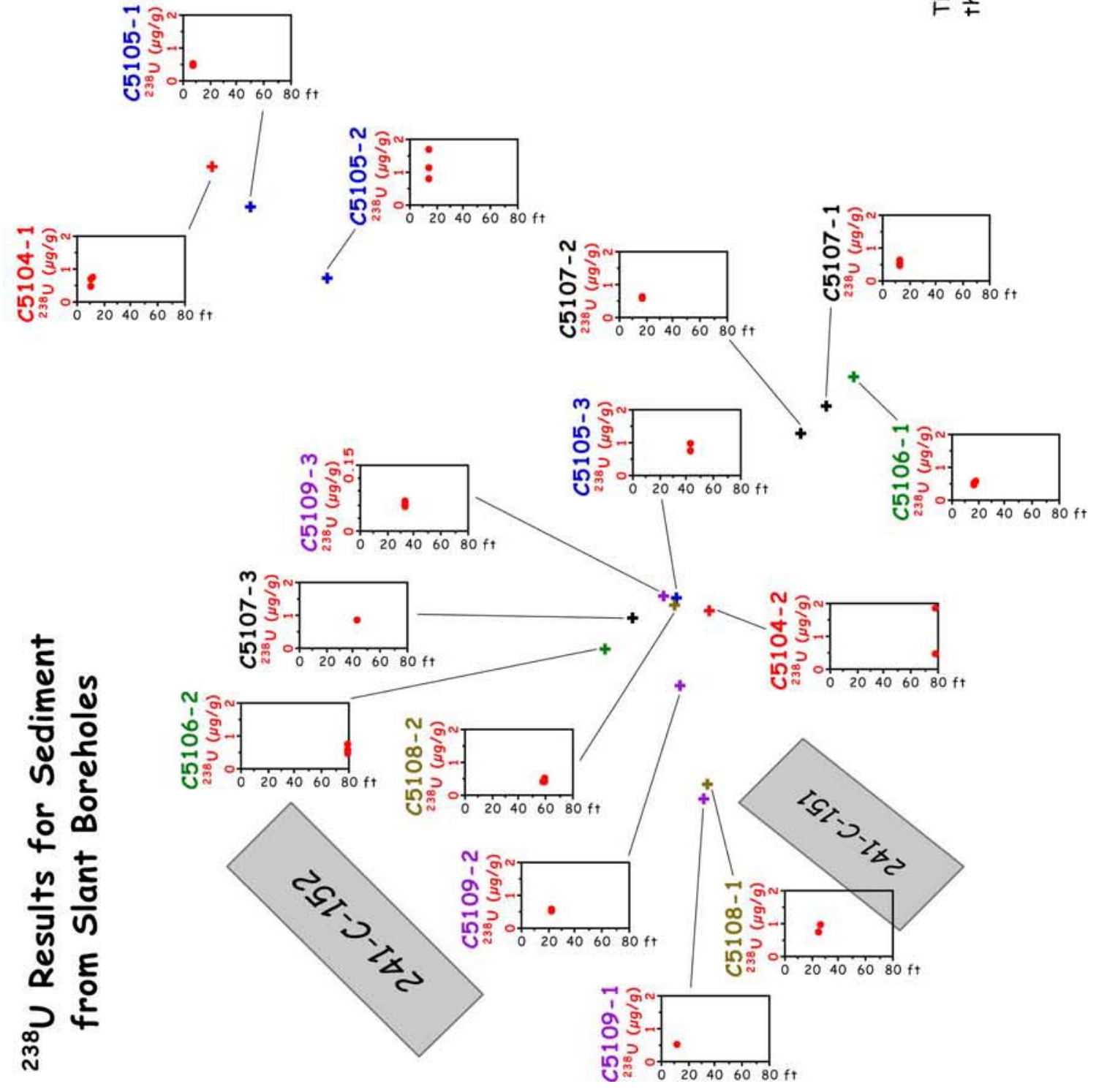

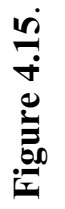




\subsubsection{Radionuclide Content in Vadose Zone Sediment from the C-152 Slant Push Holes}

Aside from the technetium-99 and uranium data from the water and acid extracts already presented, the direct measurement of bulk sediment samples for gamma-emitting radionuclides showed that only natural potassium- 40 was present in the sediments. Analysis of these samples did not detect the fission product isotope cesium-137 at measurable activities. The GEA data are shown in Table 4.29 and confirm the gross-gamma field logs in the probe holes did not detect the presence of any man-made gamma emitters at the depths in which these samples were collected.

Table 4.29. Gamma-Emitting Radionuclides in the C-152 Slant Push Vadose Zone Sediments

\begin{tabular}{|l|c|c|c|c||}
\hline $\begin{array}{c}\text { Sample } \\
\text { Number }\end{array}$ & $\begin{array}{c}\text { Probe Hole } \\
\text { Number }\end{array}$ & $\begin{array}{c}\text { Mid-Depth } \\
\text { (ft bgs) }\end{array}$ & $\begin{array}{c}\text { Potassium-40 } \\
\text { (pCi/g soil) }\end{array}$ & $\begin{array}{c}\text { Potassium-40 Error } \\
\text { (pCi/g soil) }\end{array}$ \\
\hline \hline B1HY25A & C5108 & 25.3 & $1.694 \mathrm{E}+01$ & $9.065 \mathrm{E}-01$ \\
\hline B1HY25B & C5108 & 24.9 & $1.590 \mathrm{E}+01$ & $8.620 \mathrm{E}-01$ \\
\hline B1HY25C & C5108 & 24.5 & $1.498 \mathrm{E}+01$ & $7.657 \mathrm{E}-01$ \\
\hline B1HY26A & C5108 & 58.2 & $1.300 \mathrm{E}+01$ & $7.224 \mathrm{E}-01$ \\
\hline B1HY26B & C5108 & 57.8 & $1.542 \mathrm{E}+01$ & $7.781 \mathrm{E}-01$ \\
\hline B1HY26C & C5108 & 57.4 & $1.397 \mathrm{E}+01$ & $7.689 \mathrm{E}-01$ \\
\hline B1HY27A & C5109 & 11.1 & $1.570 \mathrm{E}+01$ & $7.771 \mathrm{E}-01$ \\
\hline B1HY28B & C5109 & 22.4 & $1.654 \mathrm{E}+01$ & $8.615 \mathrm{E}-01$ \\
\hline B1HY28C & C5109 & 22.1 & $1.536 \mathrm{E}+01$ & $8.965 \mathrm{E}-01$ \\
\hline B1HY29A & C5109 & 32.7 & $1.412 \mathrm{E}+01$ & $9.423 \mathrm{E}-01$ \\
\hline B1HY29B & C5109 & 32.3 & $1.338 \mathrm{E}+01$ & $7.318 \mathrm{E}-01$ \\
\hline B1HY29C & C5109 & 32.0 & $1.194 \mathrm{E}+01$ & $6.503 \mathrm{E}-01$ \\
\hline B1HY30A & C5106 & 17.1 & $1.701 \mathrm{E}+01$ & $8.111 \mathrm{E}-01$ \\
\hline B1HY30B & C5106 & 16.7 & $1.479 \mathrm{E}+01$ & $7.941 \mathrm{E}-01$ \\
\hline B1HY30C & C5106 & 16.2 & $1.626 \mathrm{E}+01$ & $8.393 \mathrm{E}-01$ \\
\hline B1HY31A & C5106 & 79.0 & $1.849 \mathrm{E}+01$ & $8.841 \mathrm{E}-01$ \\
\hline B1HY31B & C5106 & 78.6 & $1.711 \mathrm{E}+01$ & $9.418 \mathrm{E}-01$ \\
\hline B1HY31C & C5106 & 78.2 & $1.632 \mathrm{E}+01$ & $7.961 \mathrm{E}-01$ \\
\hline B1HY32A & C5107 & 12.9 & $1.387 \mathrm{E}+01$ & $6.867 \mathrm{E}-01$ \\
\hline B1HY32B & C5107 & 12.5 & $1.416 \mathrm{E}+01$ & $7.381 \mathrm{E}-01$ \\
\hline B1HY32C & C5107 & 12.2 & $1.328 \mathrm{E}+01$ & $6.956 \mathrm{E}-01$ \\
\hline B1HY33A & C5107 & 16.8 & $1.497 \mathrm{E}+01$ & $7.519 \mathrm{E}-01$ \\
\hline B1HY33B & C5107 & 16.4 & $1.415 \mathrm{E}+01$ & $7.543 \mathrm{E}-01$ \\
\hline B1HY33C & C5107 & 16.1 & $1.465 \mathrm{E}+01$ & $7.730 \mathrm{E}-01$ \\
\hline B1HY34A & C5107 & 42.6 & $1.367 \mathrm{E}+01$ & $9.283 \mathrm{E}-01$ \\
\hline B1HY34B & C5107 & 42.2 & $1.350 \mathrm{E}+01$ & $8.562 \mathrm{E}-01$ \\
\hline B1HY34C & C5107 & 41.9 & $1.259 \mathrm{E}+01$ & $7.944 \mathrm{E}-01$ \\
\hline B1HY35A & C5104 & 10.4 & $1.029 \mathrm{E}+01$ & $6.279 \mathrm{E}-01$ \\
\hline B1HY35B & C5104 & 10.1 & $1.785 \mathrm{E}+01$ & $8.727 \mathrm{E}-01$ \\
\hline B1HY35C & C5104 & 9.7 & $1.744 \mathrm{E}+01$ & $8.791 \mathrm{E}-01$ \\
\hline B1HY36A & C5104 & 77.6 & $1.633 \mathrm{E}+01$ & $8.414 \mathrm{E}-01$ \\
\hline B1HY36B & C5104 & 77.2 & $1.565 \mathrm{E}+01$ & $8.269 \mathrm{E}-01$ \\
\hline
\end{tabular}


Table 4.29. (contd)

\begin{tabular}{||c|c|c|c|c||}
\hline $\begin{array}{c}\text { Sample } \\
\text { Number }\end{array}$ & $\begin{array}{c}\text { Probe Hole } \\
\text { Number }\end{array}$ & $\begin{array}{c}\text { Mid-Depth } \\
\text { (ft bgs) }\end{array}$ & $\begin{array}{c}\text { Potassium-40 } \\
\text { (pCi/g soil) }\end{array}$ & $\begin{array}{c}\text { Potassium-40 Error } \\
\text { (pCi/g soil) }\end{array}$ \\
\hline \hline B1HY36C & C5104 & 76.9 & $1.615 \mathrm{E}+01$ & $8.105 \mathrm{E}-01$ \\
\hline B1JFP2A & C5105 & 7.1 & $1.557 \mathrm{E}+01$ & $7.820 \mathrm{E}-01$ \\
\hline B1JFP2B & C5105 & 6.9 & $1.841 \mathrm{E}+01$ & $9.195 \mathrm{E}-01$ \\
\hline B1JFP3A & C5105 & 13.6 & $1.157 \mathrm{E}+01$ & $8.414 \mathrm{E}-01$ \\
\hline B1JFP3B & C5105 & 13.4 & $1.130 \mathrm{E}+01$ & $7.970 \mathrm{E}-01$ \\
\hline B1JFP3C & C5105 & 13.1 & $1.174 \mathrm{E}+01$ & $7.458 \mathrm{E}-01$ \\
\hline B1JFP4A & C5105 & 42.1 & $9.679 \mathrm{E}+00$ & $6.509 \mathrm{E}-01$ \\
\hline B1JFP4B & C5105 & 41.9 & $1.510 \mathrm{E}+01$ & $7.822 \mathrm{E}-01$ \\
\hline B1JFP4C & C5105 & 41.6 & $1.470 \mathrm{E}+01$ & $7.741 \mathrm{E}-01$ \\
\hline \hline
\end{tabular}

\subsubsection{Total Carbon, Calcium Carbonate, and Organic Carbon Content of Vadose Zone Sediment from the C-152 Slant Push Holes}

Table 4.30 shows the total, inorganic, and organic carbon contents (calculated by difference) of the vadose zone sediment collected from the $\mathrm{C}-152$ slant push cores. The inorganic carbon was also converted to the equivalent calcium-carbonate content. The sediment in the Hanford formation $\mathrm{H} 2$ unit was in general relatively low in calcium carbonate $(<3 \mathrm{wt} \%)$. As is the case with most vadose sediments from the Hanford Site, there was very little (generally $<0.15 \mathrm{wt} \%$ ) organic carbon in the slant push samples. These values are quite typical and compare well with other samples collected from other locations around the Hanford Site (Serne et al. 2004a, b; Brown et al. 2005).

Table 4.30. Carbon Content of the C-152 Slant Push Vadose Zone Samples

\begin{tabular}{||c|c|c|c|c|c|c||}
\hline $\begin{array}{c}\text { Sample } \\
\text { Number }\end{array}$ & $\begin{array}{c}\text { Probe Hole } \\
\text { Number }\end{array}$ & $\begin{array}{c}\text { Mid- } \\
\text { Depth } \\
\text { (ft bgs) }\end{array}$ & $\begin{array}{c}\text { Total Carbon } \\
(\%)\end{array}$ & $\begin{array}{c}\text { Inorganic } \\
\text { Carbon } \\
(\%)\end{array}$ & $\begin{array}{c}\text { Inorganic } \\
\text { Carbon as } \\
\text { CaCO }_{3} \\
(\%)\end{array}$ & $\begin{array}{c}\text { Organic Carbon } \\
(\%)\end{array}$ \\
\hline \hline B1HY25A & C5108 & 25.3 & $2.23 \mathrm{E}-01$ & $2.16 \mathrm{E}-01$ & $1.80 \mathrm{E}+00$ & $7.15 \mathrm{E}-03$ \\
\hline B1HY25B & C5108 & 24.9 & $1.87 \mathrm{E}-01$ & $1.59 \mathrm{E}-01$ & $1.33 \mathrm{E}+00$ & $2.81 \mathrm{E}-02$ \\
\hline B1HY25C & C5108 & 24.5 & $1.85 \mathrm{E}-01$ & $1.30 \mathrm{E}-01$ & $1.09 \mathrm{E}+00$ & $5.50 \mathrm{E}-02$ \\
\hline B1HY26A & C5108 & 58.2 & $2.47 \mathrm{E}-01$ & $2.40 \mathrm{E}-01$ & $2.00 \mathrm{E}+00$ & $7.30 \mathrm{E}-03$ \\
\hline B1HY26B & C5108 & 57.8 & $2.23 \mathrm{E}-01$ & $1.87 \mathrm{E}-01$ & $1.56 \mathrm{E}+00$ & $3.60 \mathrm{E}-02$ \\
\hline B1HY26C & C5108 & 57.4 & $2.58 \mathrm{E}-01$ & $2.32 \mathrm{E}-01$ & $1.93 \mathrm{E}+00$ & $2.57 \mathrm{E}-02$ \\
\hline B1HY27A & C5109 & 11.1 & $2.33 \mathrm{E}-01$ & $1.46 \mathrm{E}-01$ & $1.22 \mathrm{E}+00$ & $8.67 \mathrm{E}-02$ \\
\hline B1HY28B & C5109 & 22.4 & $1.62 \mathrm{E}-01$ & $1.43 \mathrm{E}-01$ & $1.19 \mathrm{E}+00$ & $1.91 \mathrm{E}-02$ \\
\hline B1HY28C & C5109 & 22.1 & $1.95 \mathrm{E}-01$ & $1.53 \mathrm{E}-01$ & $1.27 \mathrm{E}+00$ & $4.17 \mathrm{E}-02$ \\
\hline B1HY29A & C5109 & 32.7 & $2.89 \mathrm{E}-01$ & $2.78 \mathrm{E}-01$ & $2.31 \mathrm{E}+00$ & $1.10 \mathrm{E}-02$ \\
\hline B1HY29B & C5109 & 32.3 & $2.35 \mathrm{E}-01$ & $2.19 \mathrm{E}-01$ & $1.83 \mathrm{E}+00$ & $1.57 \mathrm{E}-02$ \\
\hline B1HY29C & C5109 & 32.0 & $2.46 \mathrm{E}-01$ & $2.34 \mathrm{E}-01$ & $1.95 \mathrm{E}+00$ & $1.24 \mathrm{E}-02$ \\
\hline B1HY30A & C5106 & 17.1 & $2.13 \mathrm{E}-01$ & $2.09 \mathrm{E}-01$ & $1.74 \mathrm{E}+00$ & $4.10 \mathrm{E}-03$ \\
\hline B1HY30B & C5106 & 16.7 & $1.61 \mathrm{E}-01$ & $1.50 \mathrm{E}-01$ & $1.25 \mathrm{E}+00$ & $1.07 \mathrm{E}-02$ \\
\hline
\end{tabular}


Table 4.30. (contd)

\begin{tabular}{|c|c|c|c|c|c|c|}
\hline $\begin{array}{l}\text { Sample } \\
\text { Number }\end{array}$ & $\begin{array}{l}\text { Probe Hole } \\
\text { Number }\end{array}$ & $\begin{array}{l}\text { Mid- } \\
\text { Depth } \\
\text { (ft bgs) }\end{array}$ & $\begin{array}{c}\text { Total Carbon } \\
(\%)\end{array}$ & $\begin{array}{c}\text { Inorganic } \\
\text { Carbon } \\
(\%)\end{array}$ & $\begin{array}{c}\text { Inorganic } \\
\text { Carbon as } \\
\mathrm{CaCO}_{3} \\
(\%)\end{array}$ & $\begin{array}{c}\text { Organic Carbon } \\
(\%)\end{array}$ \\
\hline B1HY30C & C5106 & 16.2 & $1.23 \mathrm{E}-01$ & $9.40 \mathrm{E}-02$ & $7.83 \mathrm{E}-01$ & $2.94 \mathrm{E}-02$ \\
\hline B1HY31A & C5106 & 79.0 & $2.32 \mathrm{E}-01$ & $2.25 \mathrm{E}-01$ & $1.88 \mathrm{E}+00$ & $7.00 \mathrm{E}-03$ \\
\hline B1HY31B & C5106 & 78.6 & $1.87 \mathrm{E}-01$ & $1.85 \mathrm{E}-01$ & $1.54 \mathrm{E}+00$ & $1.70 \mathrm{E}-03$ \\
\hline B1HY31C & C5106 & 78.2 & $2.83 \mathrm{E}-01$ & $2.49 \mathrm{E}-01$ & $2.08 \mathrm{E}+00$ & 3.39E-02 \\
\hline B1HY32A & C5107 & 12.9 & $1.45 \mathrm{E}-01$ & $1.30 \mathrm{E}-01$ & $1.08 \mathrm{E}+00$ & $1.51 \mathrm{E}-02$ \\
\hline B1HY32B & C5107 & 12.5 & $1.27 \mathrm{E}-01$ & $8.67 \mathrm{E}-02$ & $7.22 \mathrm{E}-01$ & $4.00 \mathrm{E}-02$ \\
\hline B1HY32C & C5107 & 12.2 & $1.33 \mathrm{E}-01$ & $1.11 \mathrm{E}-01$ & $9.20 \mathrm{E}-01$ & $2.22 \mathrm{E}-02$ \\
\hline B1HY33A & C5107 & 16.8 & $2.40 \mathrm{E}-01$ & $2.14 \mathrm{E}-01$ & $1.78 \mathrm{E}+00$ & $2.57 \mathrm{E}-02$ \\
\hline B1HY33B & C5107 & 16.4 & $2.26 \mathrm{E}-01$ & $2.00 \mathrm{E}-01$ & $1.66 \mathrm{E}+00$ & $2.61 \mathrm{E}-02$ \\
\hline B1HY33C & C5107 & 16.1 & $2.25 \mathrm{E}-01$ & $2.24 \mathrm{E}-01$ & $1.86 \mathrm{E}+00$ & $1.20 \mathrm{E}-03$ \\
\hline B1HY34A & C5107 & 42.6 & $2.34 \mathrm{E}-01$ & $2.07 \mathrm{E}-01$ & $1.73 \mathrm{E}+00$ & $2.69 \mathrm{E}-02$ \\
\hline B1HY34B & C5107 & 42.2 & $2.76 \mathrm{E}-01$ & $2.36 \mathrm{E}-01$ & $1.97 \mathrm{E}+00$ & $3.92 \mathrm{E}-02$ \\
\hline B1HY34C & C5107 & 41.9 & 3.07E-01 & $3.05 \mathrm{E}-01$ & $2.54 \mathrm{E}+00$ & $2.30 \mathrm{E}-03$ \\
\hline B1HY35A & C5104 & 10.4 & $1.40 \mathrm{E}-01$ & $1.16 \mathrm{E}-01$ & $9.67 \mathrm{E}-01$ & $2.36 \mathrm{E}-02$ \\
\hline B1HY35B & C5104 & 10.1 & $1.01 \mathrm{E}-01$ & $7.80 \mathrm{E}-02$ & $6.50 \mathrm{E}-01$ & $2.26 \mathrm{E}-02$ \\
\hline B1HY35C & C5104 & 9.7 & $8.67 \mathrm{E}-02$ & $2.18 \mathrm{E}-02$ & $1.82 \mathrm{E}-01$ & $6.49 \mathrm{E}-02$ \\
\hline B1HY36A & C5104 & 77.6 & $2.00 \mathrm{E}-01$ & $1.95 \mathrm{E}-01$ & $1.62 \mathrm{E}+00$ & $5.30 \mathrm{E}-03$ \\
\hline B1HY36B & C5104 & 77.2 & $2.39 \mathrm{E}-01$ & $2.21 \mathrm{E}-01$ & $1.84 \mathrm{E}+00$ & $1.78 \mathrm{E}-02$ \\
\hline B1HY36C & C5104 & 76.9 & $2.14 \mathrm{E}-01$ & $1.92 \mathrm{E}-01$ & $1.60 \mathrm{E}+00$ & $2.20 \mathrm{E}-02$ \\
\hline B1JFP2A & C5105 & 7.1 & $1.33 \mathrm{E}-01$ & $8.07 \mathrm{E}-02$ & $6.72 \mathrm{E}-01$ & $5.26 \mathrm{E}-02$ \\
\hline B1JFP2B & C5105 & 6.9 & $2.39 \mathrm{E}-01$ & $2.03 \mathrm{E}-01$ & $1.69 \mathrm{E}+00$ & $3.63 \mathrm{E}-02$ \\
\hline B1JFP3A & C5105 & 13.6 & $1.48 \mathrm{E}-01$ & $1.40 \mathrm{E}-01$ & $1.17 \mathrm{E}+00$ & $8.30 \mathrm{E}-03$ \\
\hline B1JFP3B & C5105 & 13.4 & $1.39 \mathrm{E}-01$ & $1.23 \mathrm{E}-01$ & $1.02 \mathrm{E}+00$ & $1.57 \mathrm{E}-02$ \\
\hline B1JFP3C & C5105 & 13.1 & $9.77 \mathrm{E}-02$ & $5.92 \mathrm{E}-02$ & $4.93 \mathrm{E}-01$ & $3.85 \mathrm{E}-02$ \\
\hline B1JFP4A & C5105 & 42.1 & $2.17 \mathrm{E}-01$ & $1.90 \mathrm{E}-01$ & $1.58 \mathrm{E}+00$ & $2.72 \mathrm{E}-02$ \\
\hline B1JFP4B & C5105 & 41.9 & $2.63 \mathrm{E}-01$ & $2.59 \mathrm{E}-01$ & $2.15 \mathrm{E}+00$ & $4.70 \mathrm{E}-03$ \\
\hline B1JFP4C & C5105 & 41.6 & $2.57 \mathrm{E}-01$ & $2.48 \mathrm{E}-01$ & $2.06 \mathrm{E}+00$ & $9.60 \mathrm{E}-03$ \\
\hline
\end{tabular}

\subsection{Tier II Sample Investigations}

Upon completion of the Tier I testing, a subset of samples from the slant push-sampling campaign were subjected to Tier II analyses. These additional analyses were performed to further investigate the discrepancy between water-extractable and acid-leachable technetium-99 in the direct-push samples. Specifically, aliquots of sample material were tested for their total exchangeable fraction of technetium-99 using ammonium acetate solution to extract the sediment. Additionally, iron-rich particles in the sediment were separated from the samples using a strong magnet and taken through a microwave digestion process. These samples were analyzed for total technetium-99 to investigate the relationship between iron and technetium-99 content in the samples. Results from these tests are presented in the following sections. 


\subsubsection{Ammonium Acetate Extractions}

The exchangeable fraction of technetium-99 in the C-152 direct-push samples is presented in Table 4.31 and Figure 4.16 in units of $\mu \mathrm{g} / \mathrm{g}$ of dry sediment. For reference, Table 4.31 and Figure 4.16 also contain the water-extractable and acid-leachable technetium-99 contents of the samples (also reported in units of $\mu \mathrm{g} / \mathrm{g}$ of dry sediment). The two sample strings containing the highest concentrations of technetium-99 were evaluated using this technique; of these two data sets, only the sample string with the highest technetium-99 contamination resulted in quantifiable concentrations of cation-exchangeable technetium-99. For these three samples from probe hole $\mathrm{C} 5104$, there was no consistent trend among the water-extractable and cation-exchangeable technetium-99 fractions. Two of the samples contained $28 \%$ and 33\% more cation-exchangeable technetium-99 (samples B1HY36C and B1HY36A, respectively) than water-extractable technetium-99, and one of the samples (B1HY36B) contained 32\% less cationexchangeable technetium-99 than water-extractable technetium-99. In all cases, the amount of technetium-99 that was either water-extractable or cation-exchangeable was significantly less than the amount that was removed via acid leaching. The amount of acid-leachable technetium-99 that was waterextractable ranged from $2.4 \%$ to $52 \%$; the amount of acid-leachable technetium- 99 that was cationexchangeable ranged from $27 \%$ to $42 \%$.

Table 4.31. Exchangeable Technetium-99 in the C-152 Vadose Zone Samples

\begin{tabular}{||l|c|c|c|c|c||}
\hline $\begin{array}{c}\text { Sample } \\
\text { Number }\end{array}$ & $\begin{array}{c}\text { Probe Hole } \\
\text { Number }\end{array}$ & $\begin{array}{c}\text { Mid-Depth } \\
(\mathrm{ft} \text { bgs })\end{array}$ & $\begin{array}{c}\text { Water-Extractable } \\
\text { Technetium-99 } \\
(\mu \mathrm{g} / \mathrm{g})\end{array}$ & $\begin{array}{c}\text { Acid-Leachable } \\
\text { Technetium-99 } \\
(\mu \mathrm{g} / \mathrm{g})\end{array}$ & $\begin{array}{c}\text { Cation-Exchangeable } \\
\text { Technetium-99 } \\
(\mu \mathrm{g} / \mathrm{g})\end{array}$ \\
\hline \hline B1HY31A & C5106 & 79.0 & $2.22 \mathrm{E}-04$ & $(1.08 \mathrm{E}-03)$ & $(1.71 \mathrm{E}-04)$ \\
\hline B1HY31B & C5106 & 78.6 & $2.12 \mathrm{E}-04$ & $(1.92 \mathrm{E}-03)$ & $(1.51 \mathrm{E}-04)$ \\
\hline B1HY31C & C5106 & 78.2 & $5.63 \mathrm{E}-05$ & $2.38 \mathrm{E}-03$ & $(9.44 \mathrm{E}-05)$ \\
\hline B1HY36A & C5104 & 77.6 & $7.74 \mathrm{E}-04$ & $2.77 \mathrm{E}-03$ & $1.16 \mathrm{E}-03$ \\
\hline B1HY36B & C5104 & 77.2 & $1.69 \mathrm{E}-03$ & $3.23 \mathrm{E}-03$ & $1.15 \mathrm{E}-03$ \\
\hline B1HY36C & C5104 & 76.9 & $7.08 \mathrm{E}-04$ & $3.57 \mathrm{E}-03$ & $9.76 \mathrm{E}-04$ \\
\hline \multicolumn{7}{|l}{ Parentheses indicate reported value is less than the limit of quantification for the analysis. } \\
\hline
\end{tabular}

Table 4.32 contains the cation-exchangeable technetium-99 for samples B1HY31A and B1HY36A as a function of time. Like Table 4.31, the data are reported in units of $\mu \mathrm{g} / \mathrm{g}$ of oven-dry sediment. As with the previous data set, only samples from probe hole C5104 resulted in quantitative data. However, the same trend is present in both of the samples analyzed (B1HY31A and B1HY36A), in which more technetium-99 was released as a function of time. For sample B1HY36, approximately $17 \%$ more technetium- 99 was exchanged after 24 hours than was present in solution after just 2 hours of reaction time. For this same sample, approximately $10 \%$ more calcium and $20 \%$ more magnesium was exchanged after 24 hours than was present in solution after just 2 hours of reaction time (Table 4.33). These results indicate that a yet unidentified kinetic process (i.e., diffusion or dissolution) is affecting the release of a portion of the exchangeable technetium-99 present in these samples. 


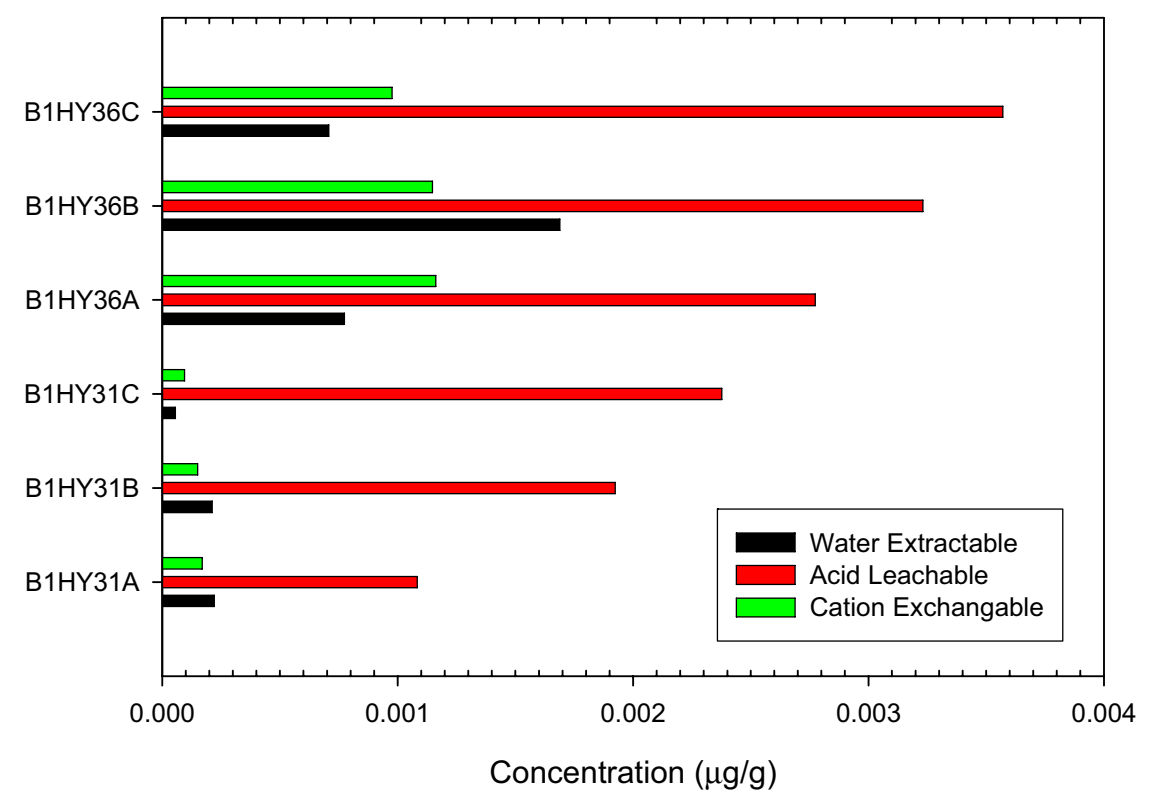

Figure 4.16. Extractable Technetium-99 in the C-152 Slant Push Samples

Table 4.32. Time-Resolved Exchangeable Technetium-99 in the C-152 Slant Push Samples

\begin{tabular}{||c|c|c|c|c||}
\hline $\begin{array}{c}\text { Sample } \\
\text { Number }\end{array}$ & $\begin{array}{c}\text { Probe Hole } \\
\text { Number }\end{array}$ & $\begin{array}{c}\text { Mid-Depth } \\
(\mathrm{ft} \text { bgs })\end{array}$ & $\begin{array}{c}\text { Time Point } \\
(\text { Hours })\end{array}$ & $\begin{array}{c}\text { Cation-Exchangeable } \\
\text { Technetium-99 }(\mu \mathrm{g} / \mathrm{g})\end{array}$ \\
\hline \hline B1HY31A & C5106 & 79.0 & 2 & $(1.02 \mathrm{E}-04)$ \\
\hline B1HY31A & C5106 & 79.0 & 4 & $(1.18 \mathrm{E}-04)$ \\
\hline B1HY31A & C5106 & 79.0 & 24 & $(1.71 \mathrm{E}-04)$ \\
\hline B1HY36A & C5104 & 77.6 & 2 & $9.59 \mathrm{E}-04$ \\
\hline B1HY36A & C5104 & 77.6 & 4 & $9.96 \mathrm{E}-04$ \\
\hline B1HY36A & C5104 & 77.6 & 24 & $1.16 \mathrm{E}-03$ \\
\hline \multicolumn{4}{|l|}{ Parentheses indicate reported value is less than the limit of quantification for the analysis. } \\
\hline
\end{tabular}

Table 4.33. Time-Resolved Exchangeable Cations in the C-152 Slant Push Samples

\begin{tabular}{||l|c|c|c|c|c|c||}
\hline $\begin{array}{c}\text { Sample } \\
\text { Number }\end{array}$ & $\begin{array}{c}\text { Probe Hole } \\
\text { Number }\end{array}$ & $\begin{array}{c}\text { Mid-Depth } \\
(\mathrm{ft} \text { bgs })\end{array}$ & $\begin{array}{c}\text { Time Point } \\
(\text { Hours })\end{array}$ & $\begin{array}{c}\text { Calcium } \\
(\mu \mathrm{g} / \mathrm{g})\end{array}$ & $\begin{array}{c}\text { Magnesium } \\
(\mu \mathrm{g} / \mathrm{g})\end{array}$ & $\begin{array}{c}\text { Sodium } \\
(\mu \mathrm{g} / \mathrm{g})\end{array}$ \\
\hline \hline B1HY31A & C5106 & 79.0 & 2 & $9.42 \mathrm{E}+02$ & $1.27 \mathrm{E}+02$ & $(2.06 \mathrm{E}+01)$ \\
\hline B1HY31A & C5106 & 79.0 & 4 & $9.97 \mathrm{E}+02$ & $1.40 \mathrm{E}+02$ & $(2.24 \mathrm{E}+01)$ \\
\hline B1HY31A & C5106 & 79.0 & 24 & $1.04 \mathrm{E}+03$ & $1.55 \mathrm{E}+02$ & $(2.39 \mathrm{E}+01)$ \\
\hline B1HY36A & C5104 & 77.6 & 2 & $9.58 \mathrm{E}+02$ & $8.09 \mathrm{E}+01$ & $(2.06 \mathrm{E}+01)$ \\
\hline B1HY36A & C5104 & 77.6 & 4 & $1.03 \mathrm{E}+03$ & $8.87 \mathrm{E}+01$ & $(2.27 \mathrm{E}+01)$ \\
\hline B1HY36A & C5104 & 77.6 & 24 & $1.07 \mathrm{E}+03$ & $1.01 \mathrm{E}+02$ & $(2.41 \mathrm{E}+01)$ \\
\hline
\end{tabular}




\subsubsection{Magnetic Separation and Digestion}

The total technetium-99 content of the iron-rich material in the deeper samples from probe holes C5104 and C5106 is presented in Table 4.34 in units of $\mu \mathrm{g} / \mathrm{g}$ of oven-dry sediment. For reference, Table 4.34 also contains the water-extractable and acid-leachable technetium-99 contents of the samples (also reported in units of $\mu \mathrm{g} / \mathrm{g}$ of oven-dry sediment). In all cases, approximately an order of magnitude more technetium-99 was present in digests of the iron-rich material than in acid leaches of the bulk sample. It must be noted that microwave-assisted sample digestion results in complete sample dissolution, while acid leaching does not dissolve recalcitrant minerals. This is the first time that microwavedigested technetium-99 results have been reported in a Vadose Zone Characterization report; therefore, the samples were further treated using TEVA resin and reanalyzed for technetium-99 using ICP-MS (Table 4.35). Although data for the blank spikes are not reported in Table 4.35, recoveries were excellent, at $95.7 \%$ and $96.0 \%$, respectively.

Table 4.34. Technetium-99 in Iron-Rich Material from the C-152 Slant Push Samples

\begin{tabular}{|l|c|c|c|c|c||}
\hline $\begin{array}{c}\text { Sample } \\
\text { Number }\end{array}$ & $\begin{array}{c}\text { Probe Hole } \\
\text { Number }\end{array}$ & $\begin{array}{c}\text { Mid-Depth } \\
(\mathrm{ft} \text { bgs })\end{array}$ & $\begin{array}{c}\text { Water- Extractable } \\
\text { Technetium-99 }(\mu \mathrm{g} / \mathrm{g})\end{array}$ & $\begin{array}{c}\text { Acid-Leachable } \\
\text { Technetium-99 }(\mu \mathrm{g} / \mathrm{g})\end{array}$ & $\begin{array}{c}\text { Iron-Rich Digested } \\
\text { Technetium-99 }(\mu \mathrm{g} / \mathrm{g})\end{array}$ \\
\hline \hline B1HY31A & C5106 & 79.0 & $2.22 \mathrm{E}-04$ & $(1.08 \mathrm{E}-03)$ & $2.54 \mathrm{E}-02$ \\
\hline B1HY31B & C5106 & 78.6 & $2.12 \mathrm{E}-04$ & $(1.92 \mathrm{E}-03)$ & $2.45 \mathrm{E}-02$ \\
\hline B1HY31C & C5106 & 78.2 & $5.63 \mathrm{E}-05$ & $2.38 \mathrm{E}-03$ & $3.08 \mathrm{E}-02$ \\
\hline B1HY36A & C5104 & 77.6 & $7.74 \mathrm{E}-04$ & $2.77 \mathrm{E}-03$ & $2.14 \mathrm{E}-02$ \\
\hline B1HY36B & C5104 & 77.2 & $1.69 \mathrm{E}-03$ & $3.23 \mathrm{E}-03$ & $2.54 \mathrm{E}-02$ \\
\hline B1HY36C & C5104 & 76.9 & $7.08 \mathrm{E}-04$ & $3.57 \mathrm{E}-03$ & $3.17 \mathrm{E}-02$ \\
\hline \multicolumn{7}{|l|}{ Parentheses indicate reported value is less than the limit of quantification for the analysis. } \\
\hline
\end{tabular}

Table 4.35. Technetium-99 in Acid Leaches and Microwave Digests of the C-152 Slant Push Samples

\begin{tabular}{||l|c|c|c|c|c||}
\hline $\begin{array}{c}\text { Sample } \\
\text { Number }\end{array}$ & $\begin{array}{c}\text { Probe Hole } \\
\text { Number }\end{array}$ & $\begin{array}{c}\text { Mid-Depth } \\
(\mathrm{ft} \text { bgs })\end{array}$ & $\begin{array}{c}\text { Acid-Leachable } \\
\text { Technetium-99 }(\mu \mathrm{g} / \mathrm{g})\end{array}$ & $\begin{array}{c}\text { Iron-Rich Digested } \\
\text { Technetium-99 }(\mu \mathrm{g} / \mathrm{g})\end{array}$ & $\begin{array}{c}\text { TEVA Resin-Treated } \\
\text { Iron-Rich Digested } \\
\text { Technetium-99 }(\mu \mathrm{g} / \mathrm{g})\end{array}$ \\
\hline \hline B1HY31A & C5106 & 79.0 & $(1.08 \mathrm{E}-03)$ & $2.54 \mathrm{E}-02$ & $2.45 \mathrm{E}-02$ \\
\hline B1HY31B & C5106 & 78.6 & $(1.92 \mathrm{E}-03)$ & $3.08 \mathrm{E}-02$ & $(2.74 \mathrm{E}-04)$ \\
\hline B1HY31C & C5106 & 78.2 & $2.38 \mathrm{E}-03$ & $2.14 \mathrm{E}-02$ & $(2.77 \mathrm{E}-04)$ \\
\hline B1HY36A & C5104 & 77.6 & $2.77 \mathrm{E}-03$ & $2.54 \mathrm{E}-02$ & $1.83 \mathrm{E}-03$ \\
\hline B1HY36B & C5104 & 77.2 & $3.23 \mathrm{E}-03$ & $3.17 \mathrm{E}-02$ & $1.13 \mathrm{E}-03$ \\
\hline B1HY36C & C5104 & 76.9 & $3.57 \mathrm{E}-03$ & $2.98 \mathrm{E}-03$ \\
\hline Parentheses indicate reported value is less than the limit of quantification for the analysis. & \\
\hline
\end{tabular}

Evaluation of the resin-treated, microwave-digested samples indicated that an analytical interferant caused the technetium-99 results of the untreated microwave-digested samples to be biased high. Two of the three resin-treated, microwave-assisted digestates for which quantitative measurements were made contained $236 \%$ and $421 \%$ more technetium- 99 than the water-extracted samples and $66 \%$ and $83 \%$ as much technetium-99 as the acid-leached samples. However, one of the resin-treated microwave-digested 
samples (B1HY36B) contained less technetium-99 than a separate aliquot of sediment that was waterextracted. It is difficult to draw a definitive conclusion from these data at this time; however, it does appear that there are quantifiable differences in the amount of technetium-99 that is extractable using water vs. that removed using more aggressive techniques. Based on these results, it is possible that a fraction of technetium-99 in these samples could be associated with a recalcitrant mineral phase. However, before this hypothesis can be confirmed, additional work with these samples should be performed. These tests would include additional sediment extractions using various solutions followed by resin treatment to remove dissolved species which appear to be causing mass interferants in the mass spectrometer. Additionally, more effort should be expended to identify the analytical bias (mass interferant[s]) in the untreated microwave-digested samples. 


\subsection{Summary and Observations}

In this section, summary information about the interpretation of the C-152 vertical and slant directpush sediment characterization data is presented. Interpretation of the data has been included to aid in making decisions on what interim actions and future studies are needed to make sound remediation decisions at the $\mathrm{C}-152$ pipeline leak location.

\subsection{Sampling Summary near the C-152 Pipeline Leak}

A geologic investigation in the vicinity of UPR-200-E-82 (a loss of approximately 2,600 gallons of cesium-137 Recovery Process feed solution containing an estimated 11,300 Ci of cesium-137 and $5 \mathrm{Ci}$ of technetium-99), also known as the C-152 pipeline leak, was performed using two hydraulic hammer direct-push campaigns. The first campaign was performed during fiscal year 2005 and utilized pairs of vertical direct-push probe holes. A total of 41 direct pushes were completed to characterize vadose zone moisture and the distribution of contaminant (Figure 5.1). A total of 20 sample sets, containing up to two core liners and one grab sample each, were delivered to the laboratory for characterization and analysis. The samples were collected around the documented location of the C-152 pipeline leak and created an approximately 120 -ft-diameter circle around the waste site.

Upon evaluation of the data from the vertical push campaign, it was determined that additional samples were necessary to better understand the extent of vadose zone contamination at the C-152 pipeline leak site. Therefore, during fiscal year 2006, six locations around the northeastern, southern, and southwestern edge of the gunite cap overlying the pipeline leak site were selected for emplacement of six direct-push probe holes pushed at angles of $30^{\circ}, 45^{\circ}$, or $60^{\circ}$ from the horizontal (Figure 5.1). These probe holes were emplaced to interrogate the vadose zone beneath the impermeable gunite cap. One goal of this sampling campaign was to collect vadose zone material as a function of depth directly beneath the projected pipeline leak location. Another goal of this effort was to collect samples from multiple depths within each direct-push probe hole, enabling some information to be gleaned on the lateral and vertical spread of contamination underneath the gunite cap. The sampling campaign resulted in 15 sample strings consisting of 13 grab samples and 43 core samples (contained in the 1.25-inch [inside diameter] by 6-inch stainless-steel liners).

\subsection{Physical Geology Model}

Assessment of data from nearby boreholes coupled with analysis of material recovered from the direct-push holes has led to the interpretation that the deposits beneath C-152 consisted predominantly of sand-dominated facies of the Hanford formation (H2 unit). While coarser, gravelly facies of the H1 unit of the Hanford formation occurred immediately to the north and east beneath C Tank Farm, these coarse sediments increasingly grade into finer-grained, sand-dominated deposits to the southwest. Multiple moisture boundaries and the predominance of sand recovered from cores seem to suggest sand, not gravel, is the dominant sediment type in the vicinity of the C-152 Diversion Box. However, cores were collected with a bias toward higher moisture zones, which generally show a more fine-grained texture. Therefore, sediments between zones of elevated moisture could be composed of coarser sand and/or gravels that are more representative of the $\mathrm{H} 1$ unit. 


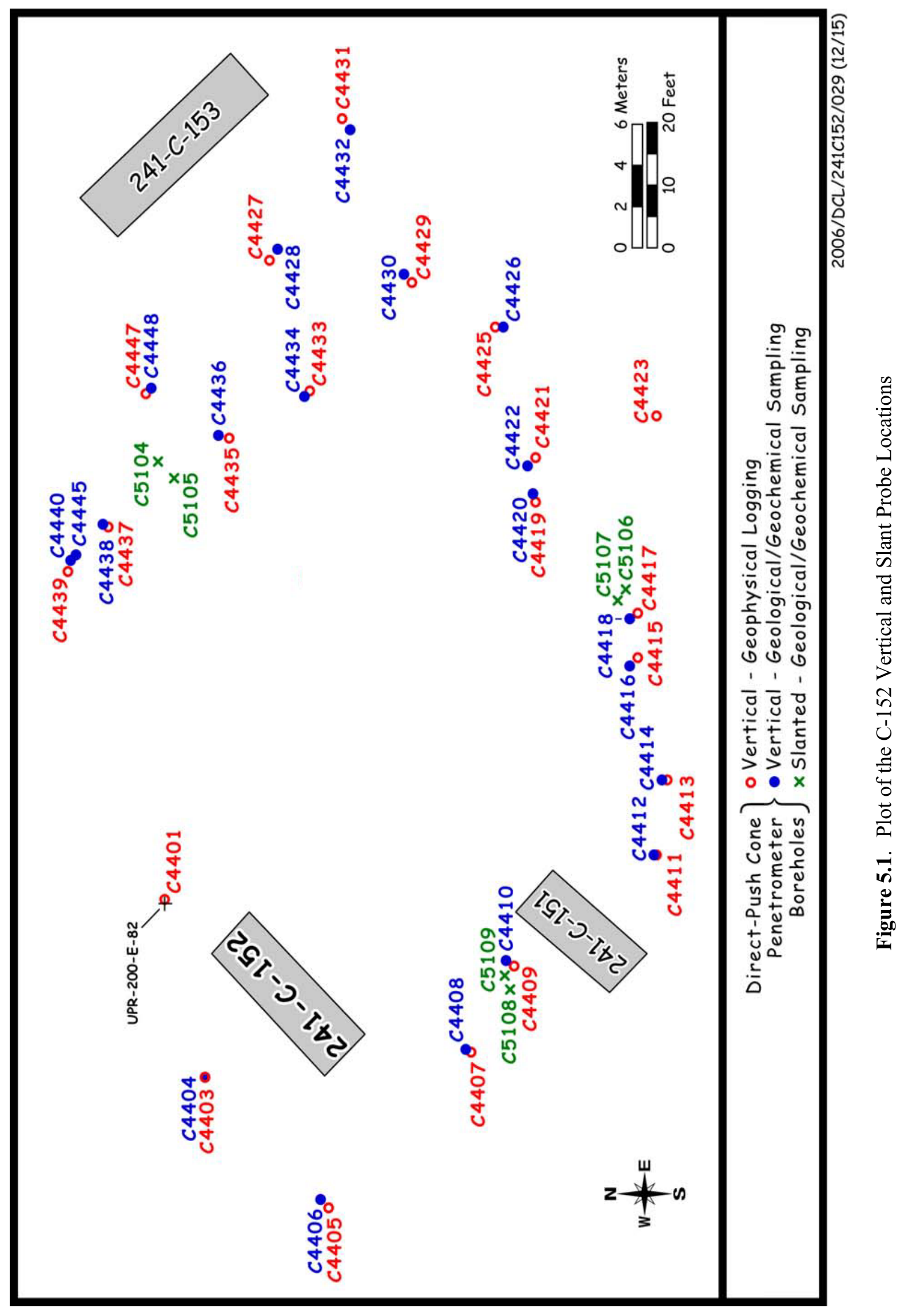




\subsection{Moisture Content}

Based on correlations of the neutron-moisture logs, it appears that there are at least four major moisture (likely lithologic) boundaries present within $40 \mathrm{ft}$ of the ground surface. No significant moisture boundaries were present below 40 to $80 \mathrm{ft}$ bgs, the maximum depth reached by the direct-push sampler at the $\mathrm{C}-152$ waste site. This suggests that additional fine-grained layers and/or capillary boundaries were not present between 40 and $80 \mathrm{ft}$ bgs.

While all four of the moisture (lithologic) boundaries were sampled via coring by direct push, some of these boundaries were sampled more than others. During downward migration of fluids away from the diversion boxes, some dissolved contaminants may become attenuated by water/sediment chemical interactions as fluids percolated deeper into the vadose zone. Therefore, sediment samples collected for pore-water chemistry were compared and evaluated separately to test for chemical fractionation between the four different high-moisture zones. No direct correlation could be drawn between constituents and/or contaminants observed in the samples with respect to which zone or lithofacies they were collected from. Therefore, it does not appear that contamination is preferentially traveling along a single litho-facie.

\subsection{Contamination Profile around the C-152 Pipeline Leak}

The following paragraphs describe measurements of various parameters that imply a plausible lateral and vertical extent of waste migration from the C-152 pipeline leak. Several parameters, including $\mathrm{pH}$, EC, nitrate, technetium-99, sodium, and uranium concentrations in water extractions and/or acid leaches were used as indicators to determine the subsurface regions contacted by tank waste that presumably discharged from the cracked V122 pipeline.

The first parameter measured was the $\mathrm{pH}$ of water extractions of the vadose zone sediment. Based on the assumption that tank-related waste fluids are generally caustic, and often very caustic $(>1 \mathrm{M}$ free hydroxide), elevated $\mathrm{pH}$ profiles should be indicative of the near-field region close to the location where the caustic fluid entered the sediments. Over one-third of the vertical push samples analyzed had slightly elevated (8.0-8.5) to significantly elevated (8.5-10) soil $\mathrm{pH}$. The elevated $\mathrm{pH}$ data indicate the presence of caustic-tank-related waste and can potentially be used to constrain the lateral zone of impact from the $\mathrm{C}-152$ pipeline leak. The vertical push samples containing marginally elevated soil $\mathrm{pH}$ were collected primarily along the southern and southwestern edge of the pipeline leak site. Based on this, the two regions most impacted by tank-related waste solutions are at locations approximately midway between the 241-C-151 and C-152 Diversion Boxes and across the C-152 waste site and west of the 241-C-153 Diversion Box. It is possible that tank-related waste lost from the V122 pipeline traveled laterally to the northeast along the compaction zone that would have been generated during the construction of the diversion boxes and subsequent piping networks. Additionally, the bedding surfaces in the region of the C-152 leak have a pronounced dip to the northeast, which would serve to enhance a northeasterly lateral migration of surface/subsurface contamination across the C-152 leak site.

For the C-152 slant push samples, nearly all of the samples tested had soil $\mathrm{pH}$ values in the normal range for Hanford sediments; however, eight of the samples had elevated $\mathrm{pH}$ values ranging from 8.1 to 9.1. All eight of the elevated soil $\mathrm{pH}$ values came from just two of the slant push probe holes: $\mathrm{C} 5105$ and C5107. The elevated soil $\mathrm{pH}$ in shallow samples (approximately $13 \mathrm{ft}$ bgs) from probe hole $\mathrm{C} 5105$ confirmed the findings from the vertical push campaign in that the tank waste impact zone extends 
beyond the edge of the gunite cap to the northeast of the pipeline leak. The vadose zone samples from probe hole $\mathrm{C} 5107$, which had an elevated soil $\mathrm{pH}$, were collected much deeper in the vadose zone (approximately $42 \mathrm{ft}$ bgs) from a location that was directly beneath the projected leak site. These results confirm that an elevated $\mathrm{pH}$ front extends deeper (at least $42 \mathrm{ft}$ bgs) into the vadose zone at this location than was previously believed.

The second parameter that was assessed to estimate the lateral extent of the leaked plume was the dilution-corrected, water-extraction EC. UPR-200-E-82 is estimated to have contained $1170 \mathrm{~kg}$ sodium, $818 \mathrm{~kg}$ nitrate, and $698 \mathrm{~kg}$ nitrite (Wood et al. 2003). However, the pore-water-corrected EC data for all of the vertical push samples were dilute and variable, with a range of 1.03 to $6.71 \mathrm{mS} / \mathrm{cm}$. The average pore-water-corrected EC for all 45 vertical push samples analyzed as part of this study was $2.87 \mathrm{mS} / \mathrm{cm}$, which was significantly lower than the average calculated pore-water EC $(9.08 \mathrm{mS} / \mathrm{cm})$ in samples from the uncontaminated borehole emplaced north of WMA C (299-E27-22) as part of the C4297 characterization effort, although the sediment samples collected from the 299-E27-22 borehole contained elevated nitrate and were not truly indicative of uncontaminated conditions. Therefore, samples from a study completed near WMA A-AX were used for comparison purposes instead. Two uncontaminated boreholes, emplaced during the construction of groundwater monitoring wells at WMA A-AX, C4665, and C4257, contained average pore-water-corrected conductivities of 1.86 and $2.53 \mathrm{mS} / \mathrm{cm}$, respectively. Based on this, it appears that either 1) there was not a significant lateral spread of the saline component (i.e., sodium and nitrate) in the C-152 pipeline leak waste plume, or 2) that sufficient recharge has occurred to drive the bulk of the saline components deeper into the vadose zone.

The pore-water-corrected EC data for the slant push samples ranged from dilute $(1.22 \mathrm{mS} / \mathrm{cm}$ in probe hole C5109) to mildly saline $(12.7 \mathrm{mS} / \mathrm{cm}$ in probe hole C5105). There was a correlation between elevated $\mathrm{pH}$ and EC; the two probe holes containing samples with elevated soil $\mathrm{pH}$ (C5105 and C5107) also contained the samples with the highest dilution-corrected pore-water EC. As mentioned in Section 3.1, multiple sample strings (up to 3) were collected from each slant push hole. It is interesting to note that elevated EC was not observed in any of the samples collected within $20 \mathrm{ft}$ of the ground surface. Given that the UPR at this location resulted in the ponding of waste at the ground surface, coupled with the fact that most of the shallow slant push vadose zone samples were collected at or near the edge of the gunite cap, indicates that there was a large vertical transport component for the saline waste components. The elevated pore-water-corrected EC observed in the deepest slant push samples emplaced at this site confirms that dissolved salts (or the saline component of the tank waste stream) have migrated to at least $80 \mathrm{ft}$ bgs.

The third parameter that was used to investigate the extent of tank-waste-related contamination in the vadose zone was sodium. Seven sediment samples collected from vertical probe holes C4408, C4410, C4428, C4436, and C4438 contained significantly more water-extractable sodium (more than $50 \mu \mathrm{g} / \mathrm{g}$ ) than the average water-extractable sodium for all of the vertical push samples measured $(39 \mu \mathrm{g} / \mathrm{g})$. The two samples containing the highest amount of water-extractable sodium, at 171 and $146 \mu \mathrm{g} / \mathrm{g}$, respectively, came from probe holes located along the western edge of the $\mathrm{C}-152$ sampling campaign (C4408

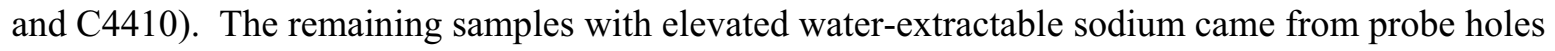
located along the northeastern edge of the C-152 sampling campaign. Although the total concentration of water-extractable sodium was not always considered elevated, sodium was present as the dominant cation in all but one of the vertical push samples analyzed. Only sample S05001-12A, from probe hole C4440, contained calcium as the dominant cation. The lack of samples containing calcium as the dominant 
water-extractable cation indicates that the sediments in this region have been impacted by a sodiumbearing waste liquid that has displaced the natural divalent cations from the cation exchange sites in the sediments. From the general concentrations of the cationic constituents, the two regions with the highest soil $\mathrm{pH}$ were again highlighted as the two primary locations of contamination resulting from the lateral spread of waste from the $\mathrm{C}-152$ pipeline leak: the area midway between the C-151 and C-152 Diversion Boxes and the area across the C-152 pipeline waste west the 241-C-153 Diversion Box.

The distribution of divalent alkaline-earth cations (magnesium and calcium) showed decreased quantities in nearly all of the slant push sediments analyzed. Specifically, the deepest vadose zone sample string collected from probe hole C5104 (at approximately $80 \mathrm{ft}$ bgs) was the only sample set that contained calcium as the dominant water-exchangeable cation in all three of the cores. Water-exchangeable sodium was the dominant cation in at least one of the core samples from each of the remaining vadose zone sample strings. Using the sodium exchange front as an indicator, these results confirm the vertical push data, which indicate that waste from the C-152 pipeline leak event has impacted the vadose zone at least as far as the edge of the impermeable cap placed over the spill site. Additionally, the vertical push samples reveal that the exchange front has migrated to a depth of approximately $80 \mathrm{ft}$ bgs directly beneath the site of the spill.

The maximum vertical extent of the exchange front is unknown at this time, as the deepest sample string (B1HY31) analyzed as part of this campaign contained at least one sample that had sodium as the dominant water-exchangeable cation. It is interesting that in the B1HY31 sample string, the shallowest of the three cores collected was the only sample (of the three) that contained sodium as the dominant waterexchangeable cation. Additionally, although the shallowest six-inch core collected from this sample string contained elevated sodium, the concentration of water-extractable sodium in this sample was approximately four times lower than the peak water-extractable sodium concentration measured in the slant push core samples $(93.3 \mu \mathrm{g} / \mathrm{g}$ at approximately $13 \mathrm{ft}$ bgs in probe hole C5105). This artifact, coupled with the observation that the other sample string collected from approximately the same depth contained calcium as the dominant water-exchangeable cation, could indicate that the vertical extent of the ion exchange front occurred at approximately $80 \mathrm{ft}$ bgs at this locale; however, the relatively small sample set and lack of samples deeper in the vadose zone precluded a quantitative conclusion from being made.

Water-extractable uranium is another parameter that can be used to investigate subsurface contamination. Naturally occurring uranium is present in a crystalline form that is very recalcitrant to water leaching. Therefore, elevated amounts of uranium in the 1:1 sediment:water extractions are typically indicative of contaminant uranium. Elevated water-leachable uranium-238 was found in eight samples collected from six of the vertical probe holes (C4408, C4410, C4428, C4436, C4438, and C4448). However, only one sample (S05001-4A), collected from probe hole C4410, contained significantly elevated water-extractable uranium-238 (7.66E-01 $\mu \mathrm{g} / \mathrm{g})$. A water-extractable uranium concentration of $7.66 \mathrm{E}-01 \mu \mathrm{g} / \mathrm{g}$ was more than 35 times higher than the peak water-extractable uranium-238 concentration measured at borehole C4297 (2.18E-02 $\mu \mathrm{g} / \mathrm{g}$ ) near Tank C-105. Sample S05001-4A, from probe hole $\mathrm{C} 4410$, contained the second highest pore-water-corrected alkalinity value of all the samples measured $\left(3.26 \mathrm{E}+03 \mathrm{mg} / \mathrm{L}\right.$ as $\left.\mathrm{CaCO}_{3}\right)$, indicating that the elevated water-extractable uranium could be an artifact of uranyl-carbonate complexation of naturally occurring labile uranium. However, a mass scan of the sample was performed via IC-MS over the range of 230 to 240 atomic mass units, and in addition to the expected uranium peaks at atomic mass units 235 and 238, a discernable peak was also observed at 
mass 236. Although the data is considered qualitative, the presence of uranium-236 in the 1:1 sediment:water extraction is a clear indicator that the sample contained uranium from Hanford fuel reprocessing. Again, this sample was collected from one of the two primary lateral spread zones identified via the soil $\mathrm{pH}$ and cationic composition analyses of the 1:1 sediment:water extractions.

Elevated water-extractable uranium-238 was found in several of the slant push probe samples. Core samples from probe holes C5104, C5105, C5108, and C5109 all contained water-extractable uranium in excess of $0.01 \mu \mathrm{g} / \mathrm{g}$. The peak water-extractable uranium concentration, at $0.132 \mu \mathrm{g} / \mathrm{g}$, was measured in sample B1JFP3B (probe hole C5105) at $13.4 \mathrm{ft}$ bgs. A peak uranium-238 concentration of $0.132 \mu \mathrm{g} / \mathrm{g}$ was approximately six times lower than the peak concentration measured in the vertical push samples. Also, it is interesting that the peak concentration was found in a slant push sample collected from the opposite side of the pipeline leak than the peak vertical push sample, particularly given that slant push samples were collected at locations (laterally) between the projected leak site, and at approximately the same depth bgs as the peak vertical push sample. This could indicate that the high water-extractable uranium observed in the vertical push sample from probe hole $\mathrm{C} 4410$ was unrelated to the pipeline leak. The deepest sample string that contained elevated water-extractable uranium was also collected from probe hole C5105 (B1JFP4), at a depth of approximately $42 \mathrm{ft}$ bgs. Overall, the amount of contaminant uranium, measured via water extraction of the sediment, in the direct-push samples was quite small, especially considering that Hanford sediment contains $1-3 \mu \mathrm{g} / \mathrm{g}$ natural uranium. All that can be quantitatively stated upon evaluation of the water-extraction uranium data is that the vadose zone in the vicinity of the pipeline leak is contaminated with Hanford process uranium from shallow in the vadose zone (near the edge of the cap) to at least $40 \mathrm{ft}$ bgs.

The fifth parameter evaluated to define the lateral extent of contamination was nitrate. Waterextractable nitrate was highest (approximately $30 \mu \mathrm{g} / \mathrm{g}$ of dry sediment) in the vertical push samples collected from probe holes $\mathrm{C} 4440$ and $\mathrm{C} 4445$, which were duplicate probe holes drilled at the northernnortheastern edge of the $\mathrm{C}-152$ pipeline leak. These samples contained approximately $30 \%$ more waterextractable nitrate than the most contaminated sample collected from borehole C429, near Tank C-105.

Additionally, elevated nitrate $(>10 \mu \mathrm{g} / \mathrm{g})$ was observed in water extractions from seven other samples collected from probe holes C4406, C4408, C4410, C4416, and C4420. These samples were collected to the south and west of the $\mathrm{C}-152$ pipeline leak, and can potentially be used to determine a concentration gradient for nitrate, based on a single leak event scenario, because samples collected farther south of the leak site did not contain elevated water-extractable nitrate. Conversely, elevated water-extractable nitrate was only observed in one sample string from the slant push campaign. Sediments from probe hole C5104, which were collected at approximately $78 \mathrm{ft} \mathrm{bgs,} \mathrm{contained} \mathrm{as} \mathrm{much} \mathrm{as} 20 \mu \mathrm{g} / \mathrm{g}$ water-extractable nitrate, which was consistent with the peak concentrations measured in samples from borehole C4297. It was surprising that the slant push holes emplaced to the south and southeast of the pipeline leak did not confirm the presence of the water-extractable nitrate measured in the vertical push samples. However, nitrate is a mobile contaminant in the subsurface; as such, its presence deeper in the vadose zone in probe hole $\mathrm{C} 5104$ was consistent with the cation and conductivity data discussed in the preceding paragraphs.

The final indicator species often used to define the extent of contamination is technetium-99 in waterextraction samples. Four samples from three of the vertical C-152 probe holes (C4408, C4410, and C4436) contained water-extractable technetium-99. The highest detectable technetium-99 activities, at 1.29 and $3.34 \mathrm{pCi} / \mathrm{g}$, respectively, came from the shallower probe hole emplaced midway between the C-151 and C-152 Diversion Boxes (C4408). The peak technetium-99 concentration measured in this 
probe hole $(3.34 \mathrm{pCi} / \mathrm{g})$ was approximately 2.5 times less than the peak water-extractable technetium-99 observed in samples from borehole C4297, near Tank C-105. The inability to find a significant technetium-99 signature, given that an estimated $5 \mathrm{Ci}$ of technetium-99 was released to the vadose zone as a result of the pipeline leak, was perhaps the main impetus to conduct the slant push-sampling campaign.

As a result of the second sampling campaign, water-extractable technetium-99 was observed in all of the slant probe hole sample strings except for the shallowest samples collected in probe holes C5104, C5105, C5106 and C5107. Probe holes C5104 and C5105 were emplaced to the northeast of the pipeline leak and were driven at angles of $45^{\circ}$ and $30^{\circ}$ from the horizontal, respectively. Probe holes C5106 and C5107 were emplaced to the southeast of the pipeline leak and were driven at angles of $60^{\circ}$ and $45^{\circ}$ from the horizontal, respectively. The shallow samples from these four probe holes were collected at depths ranging from 7 to $17 \mathrm{ft}$ bgs and were located adjacent (laterally) to the cap overlying the pipeline leak site. However, all four of these probe holes contained measurable concentrations of technetium-99 at their terminating depths. It is not surprising that samples collected in the shallow vadose zone to the southeast or northeast of the pipeline leak did not contain appreciable amounts of technetium-99, as no technetium-99 was observed in this area during the vertical direct-push campaign (Section 4.1). Additionally, technetium-99 is considered to be a conservative element; as such, it tends to migrate deeper into the vadose zone via natural recharge in the years following a leak event. For example, although technetium-99 was observed at various depths via the slant push samples, the peak water-extractable technetium-99 activity, at $28.6 \mathrm{pCi} / \mathrm{g}$, occurred in one of the deepest samples collected (B1HY36B from probe hole C5104 at approximately $77 \mathrm{ft}$ bgs). Additionally, the sample string containing the second-highest waterextractable technetium-99 activity, at $3.76 \mathrm{pCi} / \mathrm{g}$, was the deepest sample collected (B1HY31A from probe hole $\mathrm{C} 5106$ at approximately $80 \mathrm{ft}$ bgs). Although the intent of the direct-push sampling approach was to collect a series of samples as a function of depth directly beneath the projected location of the pipeline leak, the two deepest sample strings collected (C5104 and C5106 at 78 and $80 \mathrm{ft}$ bgs, respectively) were separated by more than $11 \mathrm{ft}$ laterally. It should be noted that being able to collect samples so close to one another when approximately $100 \mathrm{ft}$ of pipe is driven into the ground at an angle using a hydraulic hammer unit is quite an accomplishment. Evaluation of the technetium-99 data indicates that the contamination has migrated deeper into the vadose zone than was initially proposed. Specifically, the area was covered with an impermeable material in the early 1990s in an attempt to retard migration of the contaminants. However, a sufficient period of time, in excess of 20 years, elapsed between the leak event and the placement of the cap over the spill site; further, the leak was originally covered with gravel, which enabled migration of the mobile contaminants deep into the vadose zone.

\subsection{Source of Contamination around the C-152 Waste Site}

UPR 200-E-82 was a waste-loss event near the 241-C-152 Diversion Box and involved the loss of approximately 2,600 gallons of cesium-137 Recovery Process feed solution from pipeline V122 (Wood et al. 2003). The leak event created a surface puddle measuring 100 gallons in volume, which was covered over with clean gravel in 1969. It is estimated that $11,300 \mathrm{Ci}$ of cesium-137, $18.3 \mathrm{~kg}$ of uranium, and $5.01 \mathrm{Ci}$ of technetium-99 were released to the subsurface.

After evaluating all the characterization and analytical data, there is no question that the vadose zone surrounding the $\mathrm{C}-152$ waste site has been contaminated by tank-related waste from the $\mathrm{C}-152$ pipeline leak event. The primary indications of tank contamination in vertical push sediments were the elevated 
sodium levels in several of the samples, the presence of technetium-99 in water extractions from some of the sediments, the indication of fission product molybdenum and ruthenium in some of the sediments, and the high water-extractable and acid-leachable uranium values for several samples from various probe holes. The two lateral regions that contained the largest amount of contaminants, either in concentration or by total, were located midway between the C-152 and C-151 Diversion Boxes, and east of the C-152 waste site near the C-153 Diversion Box. Without the use of a more sophisticated analytical technique, such as isotope signature analysis of ruthenium fission isotopes, it is impossible to determine if the contamination observed at these two locations is from the same waste source or is a result of entirely different leak events. However, it does appear likely that the contamination is from a single leak event, and that the waste traveled laterally to the northeast along the compaction zone (represented by the dashed arrow in Figure 5.1) that would have been generated during the construction of the diversion boxes and subsequent piping networks and/or traveled to the northeast with the aid of the tilting bedding surfaces in the region of the C-152 leak, which have a pronounced dip to the northeast.

The primary indications of tank contamination in the slant push sediments were the elevated sodium levels in several of the samples, the presence of technetium-99 in water extractions, and acid leaches of some of the sediments, the indication of fission product molybdenum and ruthenium in some of the sediments, and the elevated water-extractable uranium values for several samples from various probe holes. Results from the slant push campaign have shown that mobile contaminants have migrated deep into the vadose zone at this location. Although a lateral migration of contamination was documented via analysis of the vertical push samples, a significant enough driving force has been present to push the mobile contaminants at least as deep as $80 \mathrm{ft}$ bgs.

\subsection{Detailed Characterization to Elucidate Controlling Geochemical Processes}

The more detailed characterization activities of the direct-push samples added some insight on 1) the processes that control the observed distribution of contaminants and 2) the migration potential of key contaminants in the future. The pore waters, calculated by dilution correction of the 1:1 water extractions in the sediment from the direct-push samples, were dominated by sodium and bicarbonate for sediments with obvious signs of tank fluids. The most concentrated pore water in the $\mathrm{H} 2$ unit is shown in Table 5.1 in units of $\mathrm{meq} / \mathrm{L}$. Also included in the table for comparison are the maximum pore-water concentrations found in other characterization work previously reported for the B, BX, C, and SX Tank Farms.

For the C-152 direct-push samples, the most saline calculated pore water resided in the $\mathrm{H} 2$ unit and had a chemical composition of $139 \mathrm{meq} / \mathrm{L}$ sodium, with less than quantitative concentrations of calcium $(1.02 \mathrm{meq} / \mathrm{L})$, magnesium $(0.236 \mathrm{meq} / \mathrm{L})$, and potassium $(4.13 \mathrm{meq} / \mathrm{L})$. The cations were balanced primarily by bicarbonate $(131 \mathrm{meq} / \mathrm{L})$, with lesser amounts of sulfate $(5.34 \mathrm{meq} / \mathrm{L})$, nitrate $(1.87 \mathrm{meq} / \mathrm{L})$, and chloride $(0.556 \mathrm{meq} / \mathrm{L})$. As shown in Table 5.1, the most concentrated calculated pore water from the C-152 direct-push-sampling campaigns was less concentrated, and in some cases much less concentrated, than pore waters found in the vadose zone sediments from the B, BX, C, or SX Tank Farms. 


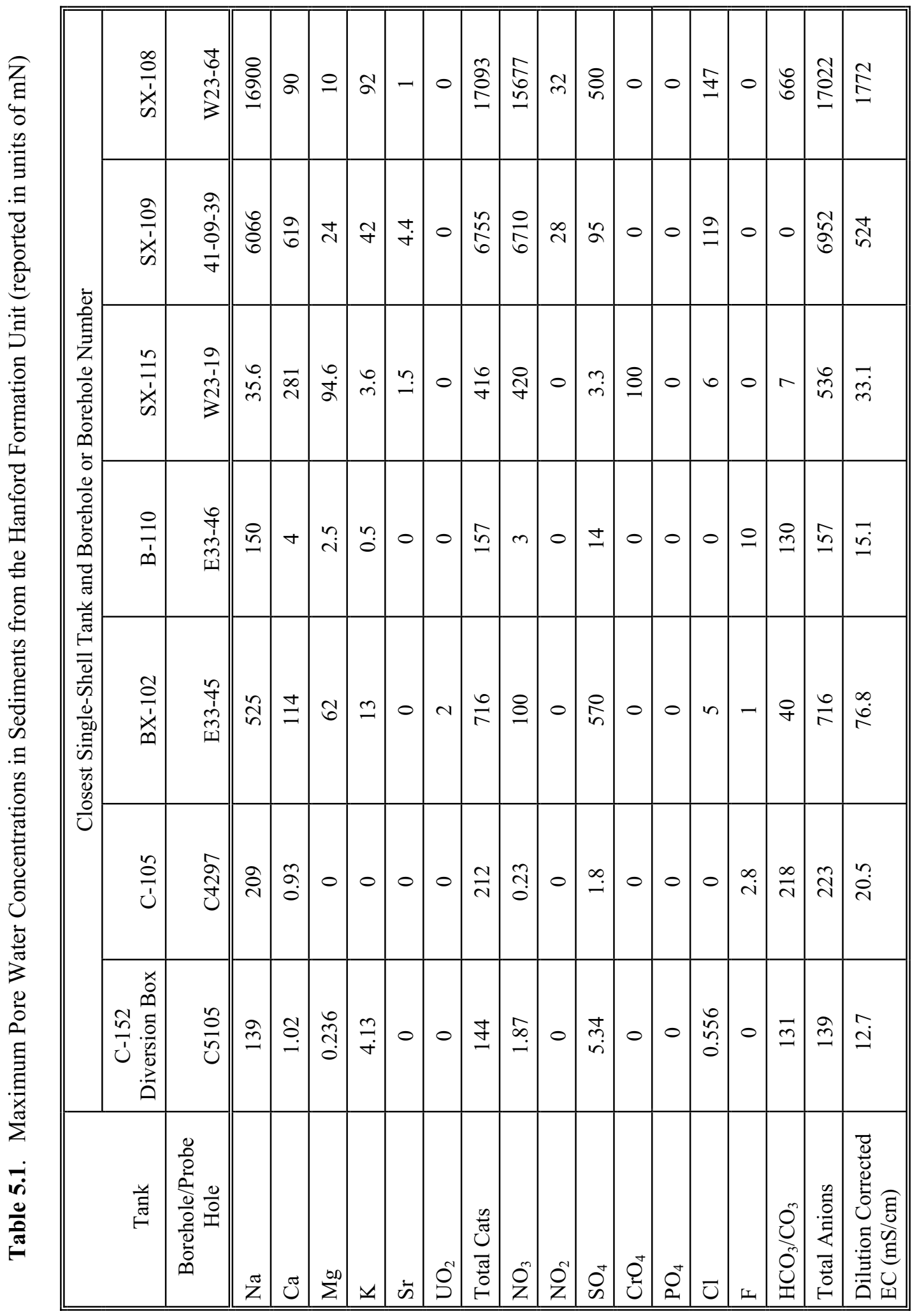


The distribution of the water-extractable major cations in the direct-push sediment samples indicate that an ion-exchange process dominates the pore-water/sediment interactions where tank fluid has passed by or currently exists. The depth profiles for the divalent alkaline earth cations (calcium, magnesium, and strontium) vs. odium show depleted alkaline earth cation concentrations in the shallow Hanford formation $\mathrm{H} 1$ sediments down to a depth of at least $80 \mathrm{ft}$ bgs. Conversely, the water-extractable sodium concentrations in this zone were elevated. The slant push sample with the highest dissolved salt load (B1JFP4A) was collected from probe hole C5105 at a depth of approximately $42 \mathrm{ft}$ bgs. Not surprisingly, the peak EC value also occurred at this depth. These trends suggest that tank fluids that are high in sodium are present at this location. The lack of a significant amount of nitrate at this depth, coupled with a measurable increase in nitrate deeper at this location, indicates that the contamination has been present for a sufficiently long period of time to facilitate the migration of more mobile contaminants (i.e., nitrate and technetium-99) deeper into the vadose zone.

\subsection{Estimates of Contaminant Sorption-Desorption Values}

This section provides the measurements and data synthesis used to provide estimates of the adsorption-desorption tendencies of key risk contaminants. Site-specific sorption or desorption studies were not specifically performed; however, by combining the data from the dilution-corrected 1:1 water extractions, which represent the pore water, with the concentrations measured in the acid leaches, which are approximate measures of the total leachable concentrations in the sediment, an estimate of the desorption $\mathrm{K}_{\mathrm{d}}$ values for contaminants of interest could be made. For a contaminant that is quite soluble in the water extraction (this is approximately equivalent to stating that the contaminant resides mainly in the pore water within the sediment), one needs to subtract the amount that was present in the pore water from the total amount present in the moist sediment sample to obtain a value for the amount that would remain on the solid at equilibrium with the pore fluid. Potential contaminants of concern that have been selected for discussion include technetium-99, uranium, chromium (VI), and nitrate.

Semi-quantitative estimates of desorption $\mathrm{K}_{\mathrm{d}}$ values for technetium-99, chromium, and uranium can be calculated using the inventory estimates (mass or activity per gram of sediment) divided by the estimated pore-water concentration of the constituent. These values are found in Tables 4.13 and 4.28 (acid leaches) and Tables 4.10 and 4.25 (pore waters), respectively. For the vertical push samples, no acid-leachable technetium-99 was found in the samples; therefore, a conservative technetium-99 $\mathrm{Kd}$ value of " 0 " has been assigned to these samples. Table 5.2 shows the estimated desorption $\mathrm{K}_{\mathrm{d}}$ values for the vertical push samples and Table 5.3 shows the desorption $K_{d}$ values for the slant push samples. In Tables 5.2 and 5.3, the depths where the bulk of the contamination was present are highlighted in red (bold) type and the desorption $\mathrm{K}_{\mathrm{d}}$ values that suggest contamination being present at even very low concentrations are highlighted in yellow (darker) shading. The blue shading in Tables 5.2 and 5.3 designate data that are more dominated by natural constituents or impacted by low-precision, analytical values. Based on Table 5.2, a specific trend became apparent. Where there were significant concentrations of contaminants in the sediments, the $K_{d}$ values for uranium were smaller than their values in samples with no obvious signs of tank-related fluids. This is caused by several reasons: 1) the presence of more saline pore waters (competing ions), 2) higher contributions of complexed species (uranyl carbonates) for uranium, which are generally more water-leachable, and 3) natural uranium not being as water-extractable as Hanford process uranium. The four samples that had quantitative $\mathrm{K}_{\mathrm{d}}$ values for technetium-99 were all consistent with previously reported $K_{d}$ values for technetium-99 at Hanford (0-0.1 $\mathrm{mL} / \mathrm{g})$. 
Upon evaluation of the desorption $\mathrm{K}_{\mathrm{d}}$ data in Table 5.3, several trends became apparent. As with the data presented in Table 5.2, where there were significant concentrations of contaminants in the sediments, the $\mathrm{K}_{\mathrm{d}}$ values for uranium were smaller than their values in samples with no obvious signs of tank-related fluids. Table 5.3 also contained quantitative $\mathrm{K}_{\mathrm{d}}$ values for chromium, in which the mobility of chromium was significantly enhanced in zones with obvious signs of tank-related waste. The large divergence between the vertical and slant push samples occurred with the $K_{d}$ values for technetium-99. As mentioned in Section 4.1.4, acid leaches of the vertical push sediment samples did not result in quantitative results for technetium-99. This was not surprising as technetium-99 is believed to be in the pertechnetate form in oxidizing environments (such as the Hanford vadose zone). Therefore, a water extraction should be an adequate process to remove all of the technetium-99 from the sediment. However, in the case of the slant push samples, there were significant differences in the water-extractable and acid-leachable technetium-99 contents (i.e., the acid leaches removed significantly more technetium-99 than the water extractions). When the technetium-99 results, using the acid leach data to represent sediment total technetium-99, are converted to $K_{d}$ values, a much larger range in $K_{d}$ values is observed. The $K_{d}$ values for technetium-99 in the slant push samples ranged from 0.0656 to $2.32 \mathrm{~mL} / \mathrm{g}$. A $\mathrm{K}_{\mathrm{d}}$ value for technetium-99 in excess of $1 \mathrm{~mL} / \mathrm{g}$ is not expected at the Hanford Site (Cantrell et al. 2003). Of the four quantitative $\mathrm{K}_{\mathrm{d}}$ values reported in Table 5.3, only one was above $1 \mathrm{~mL} / \mathrm{g}$.

Table 5.2. Desorption $\mathrm{K}_{\mathrm{d}}$ Values $(\mathrm{mL} / \mathrm{g})$ for Potential Contaminants of Concern in the $\mathrm{C}-152$ Vertical Push Samples

\begin{tabular}{||l|c|c|c|c|c||}
\hline $\begin{array}{c}\text { Sample } \\
\text { Number }\end{array}$ & $\begin{array}{c}\text { Borehole } \\
\text { Number }\end{array}$ & $\begin{array}{c}\text { Mid-Depth } \\
(\mathrm{ft} \text { bgs })\end{array}$ & $\begin{array}{c}\text { Technetium-99 } \\
\mathrm{K}_{\mathrm{d}} \\
(\mathrm{mL} / \mathrm{g})\end{array}$ & $\begin{array}{c}\text { Uranium-238 } \\
\mathrm{K}_{\mathrm{d}} \\
(\mathrm{mL} / \mathrm{g})\end{array}$ & $\begin{array}{c}\text { Chromium } \\
\mathrm{K}_{\mathrm{d}} \\
(\mathrm{mL} / \mathrm{g})\end{array}$ \\
\hline \hline S05001-1A & C4406 & 12.29 & $\mathrm{ND}$ & $2.40 \mathrm{E}+01$ & $(1.49 \mathrm{E}+03)$ \\
\hline S05001-1 (grab) & C4406 & 12.83 & $\mathrm{ND}$ & $2.08 \mathrm{E}+01$ & $(1.46 \mathrm{E}+03)$ \\
\hline S05001-2B & C4408 & 9.88 & $\mathbf{0}$ & $1.29 \mathrm{E}+01$ & $(3.69 \mathrm{E}+02)$ \\
\hline S05001-2A & C4408 & 10.63 & $\mathbf{0}$ & $1.09 \mathrm{E}+00$ & $(2.71 \mathrm{E}+01)$ \\
\hline S05001-3B & C4404 & 20.38 & ND & $1.96 \mathrm{E}+01$ & $(1.91 \mathrm{E}+03)$ \\
\hline S05001-3A & C4404 & 21.13 & ND & $4.57 \mathrm{E}+01$ & $(5.15 \mathrm{E}+03)$ \\
\hline S05001-4B & C4410 & 21.80 & $(0)$ & $1.74 \mathrm{E}+00$ & $(4.53 \mathrm{E}+02)$ \\
\hline S05001-4A & C4410 & 23.38 & $\mathbf{0}$ & $4.62 \mathrm{E}+00$ & $(2.51 \mathrm{E}+02)$ \\
\hline S05001-5B & C4414 & 24.13 & ND & $1.46 \mathrm{E}+01$ & $(1.85 \mathrm{E}+03)$ \\
\hline S05001-5A & C4414 & 24.80 & ND & $4.50 \mathrm{E}+01$ & $(3.78 \mathrm{E}+03)$ \\
\hline S05001-6B & C4412 & 13.88 & $(0)$ & $5.83 \mathrm{E}+01$ & $(2.44 \mathrm{E}+03)$ \\
\hline S05001-6A-1 & C4412 & 14.63 & $(0)$ & $1.34 \mathrm{E}+02$ & $(9.88 \mathrm{E}+03)$ \\
\hline S05001-6A-2 & C4412 & 14.63 & $(0)$ & $4.12 \mathrm{E}+01$ & $(1.43 \mathrm{E}+03)$ \\
\hline S05001-7B & C4422 & 11.88 & ND & $3.91 \mathrm{E}+01$ & $(4.42 \mathrm{E}+03)$ \\
\hline S05001-7A & C4422 & 12.63 & $(0)$ & $4.39 \mathrm{E}+01$ & $(4.43 \mathrm{E}+03)$ \\
\hline S05001-8B & C4420 & 13.30 & ND & $3.03 \mathrm{E}+01$ & $(2.81 \mathrm{E}+03)$ \\
\hline S05001-8A & C4420 & 16.88 & ND & $5.42 \mathrm{E}+01$ & $(3.27 \mathrm{E}+03)$ \\
\hline S05001-9B & C4418 & 17.63 & ND & $3.92 \mathrm{E}+01$ & $(1.16 \mathrm{E}+03)$ \\
\hline S05001-9A & C4418 & 18.30 & ND & $2.12 \mathrm{E}+01$ & $(3.75 \mathrm{E}+03)$ \\
\hline S05001-10B & C4416 & 11.88 & ND & $1.07 \mathrm{E}+01$ & $(2.30 \mathrm{E}+03)$ \\
\hline
\end{tabular}


Table 5.2. (contd)

\begin{tabular}{|c|c|c|c|c|c|}
\hline $\begin{array}{l}\text { Sample } \\
\text { Number }\end{array}$ & $\begin{array}{l}\text { Borehole } \\
\text { Number }\end{array}$ & $\begin{array}{l}\text { Mid-Depth } \\
\text { (ft bgs) }\end{array}$ & $\begin{array}{c}\text { Technetium-99 } \\
\mathrm{K}_{\mathrm{d}} \\
(\mathrm{mL} / \mathrm{g})\end{array}$ & $\begin{array}{c}\text { Uranium-238 } \\
\mathrm{K}_{\mathrm{d}} \\
(\mathrm{mL} / \mathrm{g})\end{array}$ & $\begin{array}{c}\text { Chromium } \\
\mathrm{K}_{\mathrm{d}} \\
(\mathrm{mL} / \mathrm{g})\end{array}$ \\
\hline S05001-10A & C4416 & 12.63 & NDD & $4.46 \mathrm{E}+01$ & $(9.08 \mathrm{E}+03)$ \\
\hline S05001-11B & $\mathrm{C} 4432$ & 20.77 & ND & $7.03 \mathrm{E}+01$ & $(4.57 \mathrm{E}+03)$ \\
\hline S05001-11A & C4432 & 21.34 & ND & $3.64 \mathrm{E}+01$ & $(1.55 \mathrm{E}+03)$ \\
\hline S05001-12A & $\mathrm{C} 4440$ & 6.70 & ND & $(9.20 \mathrm{E}+02)$ & $(9.34 \mathrm{E}+00)$ \\
\hline S05001-12 (grab) & $\mathrm{C} 4440$ & 7.10 & ND & $2.26 \mathrm{E}+02$ & $(7.46 \mathrm{E}+03)$ \\
\hline S05001-13B & $\mathrm{C} 4445$ & 6.63 & NA & $1.10 \mathrm{E}+02$ & $(1.57 \mathrm{E}+03)$ \\
\hline S05001-13A-1 & $\mathrm{C} 4445$ & 7.13 & ND & $2.72 \mathrm{E}+02$ & $(5.03 \mathrm{E}+02)$ \\
\hline S05001-13A-2 & $\mathrm{C} 4445$ & 7.13 & $(0)$ & $3.48 \mathrm{E}+02$ & $(2.77 \mathrm{E}+03)$ \\
\hline S05001-14B & $\mathrm{C} 4438$ & 13.88 & $(0)$ & $2.41 \mathrm{E}+01$ & $(3.10 \mathrm{E}+03)$ \\
\hline S05001-14A & C4438 & 14.63 & $(0)$ & $6.88 \mathrm{E}+00$ & $(8.12 \mathrm{E}+02)$ \\
\hline S05001-14A Dup & C4438 & 14.63 & $(0)$ & $2.65 \mathrm{E}+00$ & $(7.62 \mathrm{E}+02)$ \\
\hline S05001-15B & $\mathrm{C} 4448$ & 17.38 & $(0)$ & $4.58 \mathrm{E}+00$ & $(1.33 \mathrm{E}+03)$ \\
\hline S05001-15A & C4448 & 18.13 & $(0)$ & $1.29 \mathrm{E}+00$ & $(4.38 \mathrm{E}+02)$ \\
\hline S05001-17B & $\mathrm{C} 4436$ & 16.38 & 0 & $2.77 \mathrm{E}+01$ & $(5.28 \mathrm{E}+01)$ \\
\hline S05001-17A & $\mathrm{C} 4436$ & 17.13 & $(0)$ & $8.32 \mathrm{E}+00$ & $(3.24 \mathrm{E}+01)$ \\
\hline S05001-18B & C4434 & 13.88 & ND & $1.41 \mathrm{E}+02$ & $(2.89 \mathrm{E}+02)$ \\
\hline S05001-18A & $\mathrm{C} 4434$ & 14.63 & $(0)$ & $(1.67 \mathrm{E}+03)$ & $(9.64 \mathrm{E}+00)$ \\
\hline S05001-19B & $\mathrm{C} 4428$ & 15.30 & $(0)$ & $1.54 \mathrm{E}+01$ & $(1.65 \mathrm{E}+03)$ \\
\hline S05001-19A & $\mathrm{C} 4428$ & 18.38 & $(0)$ & $1.73 \mathrm{E}+00$ & $(9.84 \mathrm{E}+02)$ \\
\hline S05001-20A & $\mathrm{C} 4426$ & 6.06 & ND & $3.80 \mathrm{E}+01$ & $(1.18 \mathrm{E}+04)$ \\
\hline S05001-20 (grab) & $\mathrm{C} 4426$ & 6.73 & ND & $3.21 \mathrm{E}+02$ & $(6.26 \mathrm{E}+03)$ \\
\hline S05001-21B-1 & $\mathrm{C} 4430$ & 18.88 & $(0)$ & $1.14 \mathrm{E}+02$ & $(2.28 \mathrm{E}+03)$ \\
\hline S05001-21B-2 & C4430 & 18.88 & $(0)$ & $3.66 \mathrm{E}+01$ & $(2.85 \mathrm{E}+03)$ \\
\hline S05001-21A & $\mathrm{C} 4430$ & 19.63 & ND & $4.51 \mathrm{E}+01$ & $(2.54 \mathrm{E}+03)$ \\
\hline \multicolumn{6}{|c|}{$\begin{array}{l}\text { ND indicates the calculation resulted in a negative value. } \\
\text { NA indicates the sample was not analyzed for the given constituent. } \\
\text { Parentheses indicate reported value is less than the limit of quantification for the analysis. } \\
\text { Faint blue (light) shading data are likely more dominated by natural constituents. } \\
\text { Red (bold) type signifies depths where sediments show obvious signs of some tank-related fluids. } \\
\text { Yellow (dark) shading signifies } \mathrm{K}_{\mathrm{d}} \text { values that are dominated by tank fluids. }\end{array}$} \\
\hline
\end{tabular}

\subsection{Other Geochemical Characterization Observations}

Upon completion of the Tier I testing, a subset of samples from the slant push-sampling campaign were subjected to Tier II analyses. These additional analyses were performed to further investigate the discrepancy between water-extractable and acid-leachable technetium-99 in the direct-push samples. Specifically, aliquots of sediment from the two deepest sample strings from the slant push campaign (which had the highest technetium-99 contents) were tested for their total exchangeable fraction of technetium-99 using ammonium acetate. Additionally, iron-rich particles in these sediments were 
extracted using magnetic separation and taken through a microwave digestion process. These digestates were analyzed for total technetium-99 to investigate the relationship between iron and technetium-99 content in the sediments.

Table 5.3. Desorption $\mathrm{K}_{\mathrm{d}}$ Values $(\mathrm{mL} / \mathrm{g}$ ) for Potential Contaminants of Concern in the C-152 Slant Push Samples

\begin{tabular}{|c|c|c|c|c|c|}
\hline $\begin{array}{l}\text { Sample } \\
\text { Number }\end{array}$ & $\begin{array}{l}\text { Borehole } \\
\text { Number }\end{array}$ & $\begin{array}{l}\text { Mid-Depth } \\
\text { (ft bgs) }\end{array}$ & $\begin{array}{c}\text { Technetium-99 } \\
\mathrm{K}_{\mathrm{d}} \\
(\mathrm{mL} / \mathrm{g})\end{array}$ & $\begin{array}{c}\text { Uranium-238 } \\
\mathrm{K}_{\mathrm{d}} \\
(\mathrm{mL} / \mathrm{g})\end{array}$ & $\begin{array}{c}\text { Chromium } \\
\mathrm{K}_{\mathrm{d}} \\
(\mathrm{mL} / \mathrm{g})\end{array}$ \\
\hline B1HY25A & C5108 & 25.3 & $(9.97 \mathrm{E}-01)$ & $1.26 \mathrm{E}+00$ & $1.13 \mathrm{E}+03$ \\
\hline B1HY25B & C5108 & 24.9 & $(1.04 \mathrm{E}+00)$ & $1.26 \mathrm{E}+00$ & $(9.14 \mathrm{E}+02)$ \\
\hline B1HY25C & C5108 & 24.5 & $(5.93 \mathrm{E}+00)$ & $7.39 \mathrm{E}+00$ & $(5.15 E+03)$ \\
\hline B1HY26A & C5108 & 58.2 & $(2.35 \mathrm{E}-01)$ & $3.12 \mathrm{E}+01$ & $(1.67 \mathrm{E}+03)$ \\
\hline B1HY26B & C5108 & 57.8 & $(3.21 \mathrm{E}-01)$ & $3.22 \mathrm{E}+01$ & $(1.20 \mathrm{E}+03)$ \\
\hline B1HY26C & C5108 & 57.4 & $(1.24 \mathrm{E}+00)$ & $5.09 \mathrm{E}+01$ & $(2.02 \mathrm{E}+03)$ \\
\hline B1HY27A & C5109 & 11.1 & $(2.87 \mathrm{E}+01)$ & $8.32 \mathrm{E}+01$ & $(4.24 \mathrm{E}+03)$ \\
\hline B1HY28B & C5109 & 22.4 & $(9.33 \mathrm{E}-01)$ & $1.81 \mathrm{E}+00$ & $(9.08 \mathrm{E}+02)$ \\
\hline B1HY28C & C5109 & 22.1 & $(1.91 \mathrm{E}+00)$ & $3.44 \mathrm{E}+00$ & $(1.39 \mathrm{E}+03)$ \\
\hline B1HY29A & C5109 & 32.7 & $(9.48 \mathrm{E}-01)$ & $7.50 \mathrm{E}-01$ & $2.87 \mathrm{E}+02$ \\
\hline B1HY29B & C5109 & 32.3 & $(1.09 \mathrm{E}+00)$ & $8.27 \mathrm{E}-01$ & $3.69 \mathrm{E}+02$ \\
\hline B1HY29C & C5109 & 32.0 & $(3.18 \mathrm{E}+00)$ & $1.27 \mathrm{E}+00$ & $7.96 \mathrm{E}+02$ \\
\hline B1HY30A & C5106 & 17.1 & ND & $2.99 \mathrm{E}+01$ & $(4.41 \mathrm{E}+03)$ \\
\hline B1HY30B & C5106 & 16.7 & $(1.65 \mathrm{E}+01)$ & $2.27 \mathrm{E}+01$ & $(6.81 \mathrm{E}+03)$ \\
\hline B1HY30C & C5106 & 16.2 & ND & $3.24 \mathrm{E}+01$ & $8.92 \mathrm{E}+02$ \\
\hline B1HY31A & C5106 & 79.0 & $(1.43 \mathrm{E}-01)$ & $5.94 \mathrm{E}+01$ & $(1.05 \mathrm{E}+03)$ \\
\hline B1HY31B & C5106 & 78.6 & $(2.75 \mathrm{E}-01)$ & $5.45 \mathrm{E}+01$ & $(2.58 \mathrm{E}+03)$ \\
\hline B1HY31C & C5106 & 78.2 & $2.32 \mathrm{E}+00$ & $8.94 \mathrm{E}+01$ & $(4.76 \mathrm{E}+03)$ \\
\hline B1HY32A & C5107 & 12.9 & $(5.36 \mathrm{E}+01)$ & $6.24 \mathrm{E}+01$ & $(1.14 \mathrm{E}+04)$ \\
\hline B1HY32B & C5107 & 12.5 & $(2.12 \mathrm{E}+01)$ & $5.14 \mathrm{E}+01$ & $(4.80 \mathrm{E}+03)$ \\
\hline B1HY32C & C5107 & 12.2 & ND & $5.29 \mathrm{E}+01$ & $(1.26 \mathrm{E}+04)$ \\
\hline B1HY33A & C5107 & 16.8 & $(2.46 \mathrm{E}+01)$ & $1.51 \mathrm{E}+01$ & $2.96 \mathrm{E}+03$ \\
\hline B1HY33B & C5107 & 16.4 & $(1.08 \mathrm{E}+01)$ & $4.78 \mathrm{E}+00$ & $1.53 \mathrm{E}+03$ \\
\hline B1HY33C & C5107 & 16.1 & $(3.67 \mathrm{E}+01)$ & $1.84 \mathrm{E}+01$ & $(7.18 \mathrm{E}+03)$ \\
\hline B1HY34A & C5107 & 42.6 & $(3.65 \mathrm{E}-01)$ & $2.83 \mathrm{E}+01$ & $2.15 \mathrm{E}+01$ \\
\hline B1HY34B & C5107 & 42.2 & $(3.77 \mathrm{E}-01)$ & $2.59 \mathrm{E}+01$ & $2.07 \mathrm{E}+01$ \\
\hline B1HY34C & C5107 & 41.9 & $(6.06 \mathrm{E}-01)$ & $1.44 \mathrm{E}+02$ & $2.03 \mathrm{E}+01$ \\
\hline B1HY35A & C5104 & 10.4 & $(1.56 \mathrm{E}+01)$ & $2.54 \mathrm{E}+00$ & $(2.15 \mathrm{E}+03)$ \\
\hline B1HY35B & C5104 & 10.1 & $(2.28 \mathrm{E}+01)$ & $3.50 \mathrm{E}+00$ & $(1.59 \mathrm{E}+03)$ \\
\hline B1HY35C & C5104 & 9.7 & $(2.76 \mathrm{E}+01)$ & $4.12 \mathrm{E}+00$ & $1.03 \mathrm{E}+03$ \\
\hline B1HY36A & C5104 & 77.6 & $9.69 \mathrm{E}-02$ & $7.63 \mathrm{E}+01$ & $2.79 \mathrm{E}+00$ \\
\hline B1HY36B & C5104 & 77.2 & $6.56 \mathrm{E}-02$ & $4.26 \mathrm{E}+02$ & $1.09 \mathrm{E}+00$ \\
\hline
\end{tabular}


Table 5.3. (contd)

\begin{tabular}{|c|c|c|c|c|c|}
\hline $\begin{array}{l}\text { Sample } \\
\text { Number }\end{array}$ & $\begin{array}{l}\text { Borehole } \\
\text { Number }\end{array}$ & $\begin{array}{l}\text { Mid-Depth } \\
\text { (ft bgs) }\end{array}$ & $\begin{array}{c}\text { Technetium-99 } \\
\mathrm{K}_{\mathrm{d}} \\
(\mathrm{mL} / \mathrm{g})\end{array}$ & $\begin{array}{c}\text { Uranium-238 } \\
\mathrm{K}_{\mathrm{d}} \\
(\mathrm{mL} / \mathrm{g})\end{array}$ & $\begin{array}{c}\text { Chromium } \\
\mathrm{K}_{\mathrm{d}} \\
(\mathrm{mL} / \mathrm{g})\end{array}$ \\
\hline B1HY36C & C5104 & 76.9 & $3.49 \mathrm{E}-01$ & $(1.63 \mathrm{E}+04)$ & $1.95 \mathrm{E}+01$ \\
\hline B1JFP2A & C5105 & 7.1 & $(2.11 \mathrm{E}+00)$ & $7.35 \mathrm{E}+01$ & $2.26 \mathrm{E}+03$ \\
\hline B1JFP2B & C5105 & 6.9 & $(1.06 \mathrm{E}+01)$ & $3.48 \mathrm{E}+01$ & $2.36 \mathrm{E}+03$ \\
\hline B1JFP3A & C5105 & 13.6 & $(3.81 \mathrm{E}+00)$ & $5.82 \mathrm{E}-01$ & $8.66 \mathrm{E}+02$ \\
\hline B1JFP3B & C5105 & 13.4 & $(8.84 \mathrm{E}+00)$ & $1.20 \mathrm{E}+00$ & $2.18 \mathrm{E}+03$ \\
\hline B1JFP3C & C5105 & 13.1 & $(3.94 \mathrm{E}+00)$ & $4.02 \mathrm{E}+00$ & $1.40 \mathrm{E}+03$ \\
\hline B1JFP4A & C5105 & 42.1 & $(9.56 \mathrm{E}-01)$ & $4.72 \mathrm{E}-01$ & $2.33 \mathrm{E}+02$ \\
\hline B1JFP4B & C5105 & 41.9 & $(1.13 \mathrm{E}+00)$ & $4.86 \mathrm{E}-01$ & $2.99 \mathrm{E}+02$ \\
\hline B1JFP4C & C5105 & 41.6 & $(1.30 \mathrm{E}+00)$ & $8.35 \mathrm{E}-01$ & $5.47 \mathrm{E}+02$ \\
\hline \multicolumn{6}{|c|}{$\begin{array}{l}\text { ND indicates the calculation resulted in a negative value. } \\
\text { Parentheses indicate reported value is less than the limit of quantification for the analysis. } \\
\text { Faint blue (light) shading data are likely more dominated by natural constituents. } \\
\text { Red (bold) type signifies depths where sediments show obvious signs of some tank-related fluids. } \\
\text { Yellow (dark) shading signifies } \mathrm{K}_{\mathrm{d}} \text { values that are dominated by tank fluids. }\end{array}$} \\
\hline
\end{tabular}

Of the two sample strings containing the highest concentrations of technetium-99, only the sample string with the highest technetium-99 contamination resulted in quantifiable concentrations of cationexchangeable technetium-99. For these three samples from probe hole C5104, there was no consistent trend between the water-extractable and cation-exchangeable technetium-99 fractions. Two of the samples contained $28 \%$ and $33 \%$ more cation-exchangeable technetium-99 (samples B1HY36C and B1HY36A, respectively) than water-extractable technetium-99, and one of the samples (B1HY36B) contained 32\% less cation-exchangeable technetium-99 than water-extractable technetium-99. In all cases, the amount of technetium-99 that was either water-extractable or cation-exchangeable was significantly less than the amount that was removed via acid leaching. The amount of acid-leachable technetium-99 that was water-extractable ranged from $2.4 \%$ to $52 \%$; the amount of acid-leachable technetium-99 that was cation-exchangeable ranged from $27 \%$ to $42 \%$.

Another interesting trend became apparent when the exchangeable technetium-99 content was evaluated as a function of time. More technetium- 99 was released with increased contact time. For sample B1HY36, approximately 17\% more technetium-99 was exchanged after 24 hours than was present in solution after just 2 hours of reaction time. For this same sample, approximately $10 \%$ more calcium and $20 \%$ more magnesium was exchanged after 24 hours than was present in solution after just 2 hours of reaction time (Table 4.33). These results indicate that a yet unidentified kinetic process (i.e., diffusion or dissolution) is affecting the release of a portion of the exchangeable technetium-99 and cations, such as calcium and magnesium, present in these sediments.

Approximately an order of magnitude more technetium-99 was present in digests of the magnetic iron-rich particles than in acid leaches of the bulk sediment. It must be noted that microwave-assisted sample digestion results in complete sample dissolution, while acid leaching does not dissolve recalcitrant minerals. This is the first time that microwave-digested technetium-99 results have been reported in a Vadose Zone Characterization report; therefore, the samples were further treated using TEVA resin and 
reanalyzed for technetium-99 using ICP-MS. Evaluation of the resin-treated, microwave-digested samples indicated that an analytical interferant caused the results of the untreated microwave-digested samples to be biased high. Two of the three resin-treated samples for which quantitative measurements were made contained $236 \%$ and $421 \%$ more technetium- 99 than the water-extracted samples and $66 \%$ and $83 \%$ as much technetium-99 as the acid-leached samples. However, one of the resin-treated, microwavedigested samples (B1HY36B) contained less technetium-99 than a separate aliquot of sediment that was water-extracted. It is difficult to draw a definitive conclusion from these data at this time; however, it does appear that there are quantifiable differences in the amount of technetium-99 that is extractable using water vs. that removed using more aggressive techniques. Based on these results, it is possible that a fraction of technetium-99 in these samples could be associated with a recalcitrant mineral phase. However, before this hypothesis can be confirmed, additional work with these samples should be performed.

The implication that water extraction of contaminated sediment samples is not sufficient to identify the total technetium-99 content of the samples is important. As mentioned previously, differences have been observed between the water-extractable and acid-leachable technetium- 99 contents of samples from numerous characterization campaigns. The discrepancy between water-extractable and acid-leachable technetium-99 was in the past, dismissed as an analytical bias, and the water-extractable results were used to calculate inventory estimates. Conservative $\mathrm{K}_{\mathrm{d}}$ values $(0 \mathrm{~mL} / \mathrm{g})$ were always recommended for technetium-99; however, if a more aggressive dissolution technique is required to determine the total technetium-99 content of contaminated sediments, previous inventory estimates could be biased low. The results presented in this report warrant further evaluation so that an appropriate procedure can be identified to extract/measure the total content of technetium-99 in contaminated sediment samples. 


\subsection{References}

American Society for Testing and Materials (ASTM) D2488-93. 1993. Standard Practice for Materials, West Conshohocken, Pennsylvania.

American Society for Testing and Materials (ASTM) D2216-98. 1998. Test Method for Laboratory Determination of Water (Moisture) Content of Soil and Rock by Mass. American Society for Testing and Materials, West Conshohocken, Pennsylvania.

American Society for Testing and Materials (ASTM) D2488-93. 1993. Standard Practice for Description and Identification of Soils (Visual-Manual Procedure). American Society for Testing and Materials, West Conshohocken, Pennsylvania.

American Society for Testing and Materials (ASTM) E1915-01. 2001. Standard Test Methods for Analysis of Metal Bearing Ores and Related Materials by Combustion Infrared Absorption Spectrometry. American Society for Testing and Materials, West Conshohocken, Pennsylvania.

American Society of Agronomy (ASA). 1996. Methods of Soil Analysis-Part 3, Chemical Methods, SSSA Book Series 5, ed. DL Sparks, Soil Science Society of America, Madison, Wisconsin.

Bjornstad BN, GV Last, and DG Horton. 2003. "Hydrogeology of the Hanford Site Vadose Zone." $4^{\text {th }}$ Symposium on the Hydrogeology of Washington State, Abstracts with Programs, p. 61. http://www.ecy.wa.gov/events/hg/abstracts2003.pdf

Bjornstad BN. 2006. On the Trail of the Ice Age Floods: A Geological Field Guide to the Mid-Columbia Basin. Keokee Co. Publishing, Inc., Sandpoint, Idaho.

Brown CF, RJ Serne, BN Bjornstad, DG Horton, and DC Lanigan. 2006. Characterization of Vadose Zone Sediments Below the C Tank Farm: Borehole C4297 and RCRA Borehole 299-E27-22.

PNNL-15503, Pacific Northwest National Laboratory, Richland, Washington.

Brown CF, RJ Serne, HT Schaef, BA Williams, MM Valenta, VL LeGore, MJ Lindberg, KN Geiszler, SR Baum, IV Kutnyakov, TS Vickerman, and RE Clayton. 2005. Investigation of Accelerated Casing Corrosion in Wells from Waste Management Area A-AX: Wells 299-E24-19 and 299-E25-46.

PNNL-15141, Pacific Northwest National Laboratory, Richland, Washington.

Cantrell KJ, RJ Serne, and GV Last. 2003. Hanford Contaminant Distribution Coefficient Database and Users Guide. PNNL-13895 Rev. 1, Pacific Northwest National Laboratory, Richland, Washington.

Connelly MP, JV Borghese, CD Delaney, BH Ford, JW Lindberg, and SJ Trent. 1992. Hydrogeologic Model for the 200 East Groundwater Aggregate Area. WHC-SD-EN-TI-019, Westinghouse Hanford Company, Richland, Washington.

Crumpler JD. 2003. Site Specific SST Phase 1 RFI/CMS Work Plan Addendum for WMAs C, A-AX and $U$. RPP-16608, CH2M HILL Hanford Group, Inc., Richland, Washington. 
DOE (U.S. Department of Energy). 1998. Vadose Zone Characterization Project at the Hanford Tank Farms, C Tank Farm Report. GJO-HAN-27, prepared by U.S. Department of Energy Grand Junction Office for U.S. Department of Energy, Richland Operations Office, Richland, Washington.

DOE (U.S. Department of Energy). 1999. Phase 1 RCRA Facility Investigation/Corrective Measures Study Work Plan for the SST Waste Management Areas. DOE/RL-99-36, Rev. 0, U.S. Department of Energy, Richland Operations Office, Richland, Washington.

DOE (U.S. Department of Energy). 2002. Standardized Stratigraphic Nomenclature for Post-RingoldFormation Sediments Within the Pasco Basin. DOE/RL-2002-39, U.S. Department of Energy, Richland Operations Office, Richland, Washington.

EPA Method 300.0A. 1984. Test Method for the Determination of Inorganic Anions in Water by Ion Chromatography. EPA-600/4-84-017, U.S. Environmental Protection Agency, Washington, D.C.

EPA Method 3050B. 2000a. "Acid Digestion of Sediments, Sludges, and Soils." Test Methods for Evaluating Solid Waste, Physical/Chemical Methods. EPA Publication SW-846, U.S. Environmental Protection Agency, Washington, D.C. Online manual, Available URL: http://www.epa.gov/epaoswer/hazwaste/test/sw846.htm

EPA Method 6010B. 2000b. "Inductively Coupled Plasma-Atomic Emission Spectrometry." Test Methods for Evaluating Solid Waste, Physical/Chemical Methods. EPA Publication SW-846, U.S. Environmental Protection Agency, Washington, D.C. Online manual, Available URL: http://www.epa.gov/epaoswer/hazwaste/test/sw846.htm

EPA Method 6020. 2000c. "Inductively Coupled Plasma-Mass Spectrometry." Test Methods for Evaluating Solid Waste, Physical/Chemical Methods. EPA Publication SW-846, U.S. Environmental Protection Agency, Washington, D.C. Online manual, Available URL: http://www.epa.gov/epaoswer/hazwaste/test/sw846.htm

Folk RL. 1968. Petrology of Sedimentary Rocks. Hemphill, Austin, Texas.

Horton DG and SM Narbutovskih. 2001. RCRA Groundwater Monitoring Plan for Single-Shell Tank Waste Management Area C at the Hanford Site. PNNL-13024, Pacific Northwest National Laboratory, Richland, Washington.

Lindsey KA, BN Bjornstad, JW Lindberg, and KM Hoffman. 1992. Geologic Setting of the 200 East Area - An Update. WHC-SD-EN-TI-012, Westinghouse Hanford Company, Richland, Washington.

Lindsey KA, KD Reynolds, and VM Johnson. 2004. 241-C Tank Farm Geologic and Stratigraphic Analysis. RPP-18290, Rev. 1, CH2M HILL Hanford Group, Inc., Richland, Washington.

Pacific Northwest Laboratory (PNL). 1990. Procedures for Groundwater Investigations. PNL MA-567, Pacific Northwest Laboratory, Richland, Washington. 
Pacific Northwest National Laboratory (PNNL). 1997. Gamma Energy Analysis Operation and Instrument Verification Using the Genie2000 ${ }^{T M}$ Support Software. PNNL-RRL-01, Pacific Northwest National Laboratory, Richland, Washington.

Pacific Northwest National Laboratory (PNNL). 1998. Inductively Coupled Plasma Mass Spectrometric (ICP-MS) Analysis. PNNL-AGG-415, Pacific Northwest National Laboratory, Richland, Washington.

Pacific Northwest National Laboratory (PNNL). 2005. Soil Water Content. PNNL-AGG-WC-001

Rev. 0, Pacific Northwest National Laboratory, Richland, Washington.

Price WH and KR Fecht. 1976. Geology of the 241-C Tank Farm. ARH-LD-132, Atlantic Richfield Hanford Company, Richland, Washington.

Randall R and R Price. 2005. Small Diameter Geophysical Logging at the 241-C-152 Diversion Box. Subcontract report prepared by Pacific Northwest Geophysics and Three Rivers Scientific for CH2M Hill Hanford Group, Inc, Richland, Washington.

Rhoades JD. 1996. "Salinity: Electrical Conductivity and Total Dissolved Solids." In Methods of Soil Analysis Part 3, ed. JM Bigham, pp. 417-435. American Society of Agronomy, Madison, Wisconsin.

Serne RJ, HT Schaef, BN Bjornstad, BA Williams, DC Lanigan, DG Horton, RE Clayton, VL LeGore, MJ O'Hara, CF Brown, KE Parker, IV Kutnyakov, JN Serne, AV Mitroshkov, GV Last, SC Smith, CW Lindenmeier, JM Zachara, and DS Burke. 2002a. Characterization of Vadose Zone Sediment: Uncontaminated RCRA Borehole Core Samples and Composite Samples. PNNL-13757-1, Pacific Northwest National Laboratory, Richland, Washington.

Serne RJ, HT Schaef, BN Bjornstad, DC Lanigan, GW Gee, CW Lindenmeier, RE Clayton, VL LeGore, MJ O'Hara, CF Brown, RD Orr, GV Last, IV Kutnyakov, DS Burke, TC Wilson, and BA Williams. 2002b. Characterization of Vadose Zone Sediment: Borehole 299-W23-19 [SX-115] in the S-SX Waste Management Area. PNNL-13757-2, Pacific Northwest National Laboratory, Richland, Washington.

Serne RJ, GV Last, HT Schaef, DC Lanigan, CW Lindenmeier, CC Ainsworth, RE Clayton, VL LeGore, MJ O'Hara, CF Brown, RD Orr, IV Kutnyakov, TC Wilson, KB Wagnon, BA Williams, and DB Burke. 2002c. Characterization of Vadose Zone Sediment, Part 4: Slant Borehole SX-108 in the S-SX Waste Management Area. PNNL-13757-4, Pacific Northwest National Laboratory, Richland, Washington.

Serne RJ, GV Last, GW Gee, HT Schaef, DC Lanigan, CW Lindenmeier, RE Clayton, VL LeGore, RD Orr, MJ O'Hara, CF Brown, DS Burke, AT Owen, IV Kutnyakov, and TC Wilson. 2002d. Characterization of Vadose Zone Sediment: Borehole 41-09-39 in the S-SX Waste Management Area. PNNL-13757-3, Pacific Northwest National Laboratory, Richland, Washington.

Serne RJ, GV Last, GW Gee, HT Schaef, DC Lanigan, CW Lindenmeier, MJ Lindberg, RE Clayton, VL LeGore, RD Orr, IV Kutnyakov, SR Baum, KN Geiszler, CF Brown, MM Valenta, and TS Vickerman. 2002e. Characterization of Vadose Zone Sediment: Borehole 299-E33-45 Near BX-102 in the B-BX-BY Waste Management Area. PNNL-14083, Pacific Northwest National Laboratory, Richland, Washington. 
Serne RJ, BN Bjornstad, GW Gee, HT Schaef, DC Lanigan, CW Lindenmeier, RD Orr, VL LeGore, RE Clayton, MJ Lindberg, IV Kutnyakov, SR Baum, KN Geiszler, MM Valenta, TS Vickerman, and LJ Royack. 2002f. Characterization of Vadose Zone Sediment: Borehole 299-E33-46 Near B-110 in the B-BX-BY Waste Management Area. PNNL-14119, Pacific Northwest National Laboratory, Richland, Washington.

Serne RJ, BN Bjornstad, DG Horton, DC Lanigan, CW Lindenmeier, MJ Lindberg, RE Clayton, VL LeGore, RD Orr, IV Kutnyakov, SR Baum, KN Geiszler, MM Valenta, and TS Vickerman. 2004a. Characterization of Vadose Zone Sediments Below the TX Tank Farm: Boreholes C3830, C3831, C3832 and RCRA Borehole 299-W10-27. PNNL-14594, Pacific Northwest National Laboratory, Richland, Washington.

Serne RJ, BN Bjornstad, DG Horton, DC Lanigan, HT Schaef, CW Lindenmeier, MJ Lindberg, RE Clayton, VL LeGore, KN Geiszler, SR Baum, MM Valenta, IV Kutnyakov, TS Vickerman, RD Orr, and CF Brown. 2004b. Characterization of Vadose Zone Sediments Below the T Tank Farm: Boreholes C4104, C4105, 299-W10-196, and RCRA Borehole 299-W11-39. PNNL-14849, Pacific Northwest National Laboratory, Richland, Washington,

USGS (United States Geological Survey). 2001. "Alkalinity and Acid Neutralizing Capacity." National Field Manual for the Collection of Water-Quality Data, $2^{\text {nd }}$ ed., eds. SA Rounds and FD Wilde. March 23, 2004 Available URL: http://water.usgs.gov/owq/FieldManual/Chapter6/section6.6/html/section6.6.htm

Wentworth, CK. 1922. "A Grade Scale and Class Terms for Clastic Sediments." Journal of Geology, 30:377-392.

Williams BA, BN Bjornstad, R Schalla, and WD Webber. 2000. Revised Hydrogeology for the Suprabasalt Aquifer System, 200-East Area and Vicinity, Hanford Site, Washington. PNNL-12261, Pacific Northwest National Laboratory, Richland, Washington.

Wood MI, TE Jones, BN Bjornstad, DG Horton, SM Narbutovskih, and R Schalla. 2003. Subsurface Conditions Description of the $C$ and $A-A X$ Waste Management Areas. RPP-14430, Rev. 0, CH2M HILL Hanford Group, Inc., Richland, Washington. 


\section{Appendix A}

Photographs of Samples from C-152 Probe Holes 


\section{Contents}

Appendix A1. Photographs of Samples from the C-152 Probe Holes ............................................ A.1

Appendix A2. Photographs of Samples from the C-152 Slant Probe Holes.................................... A.14

\section{Figures}

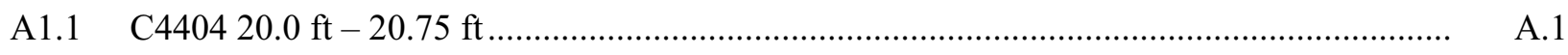

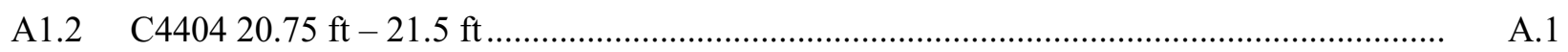

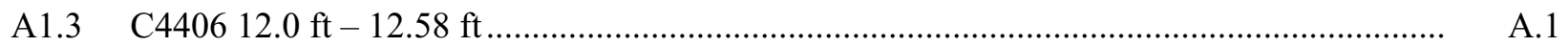

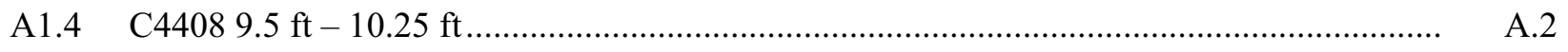

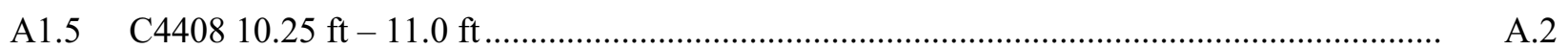

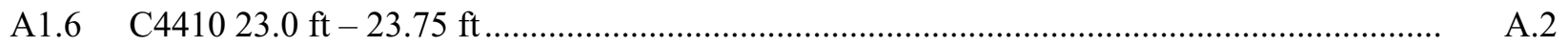

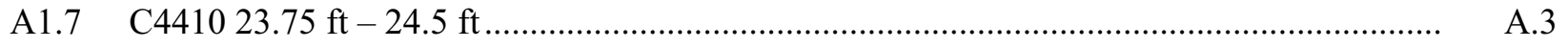

A1.8 C4412 23.5 ft-24.25 ft ............................................................................. A.

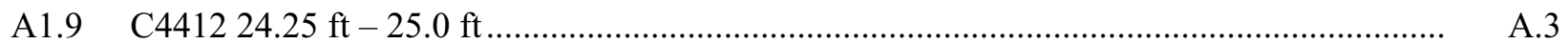

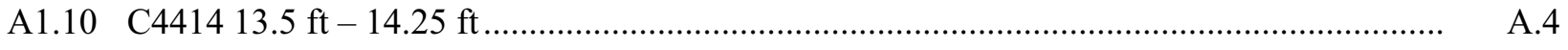

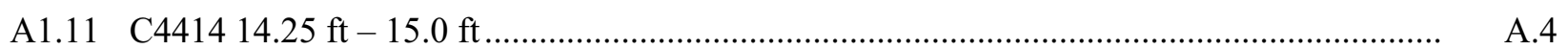

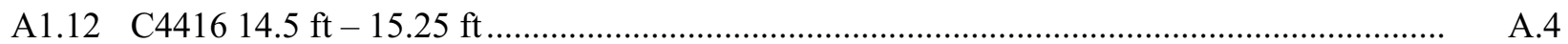

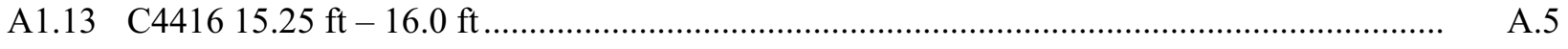

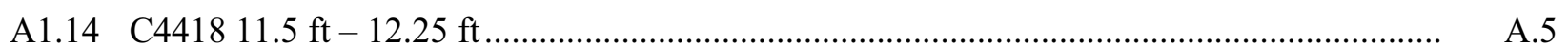

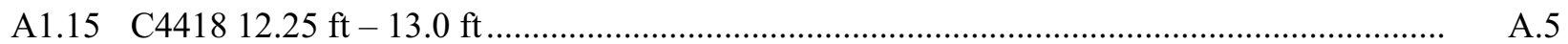

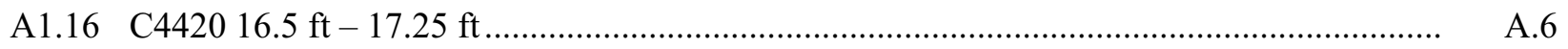

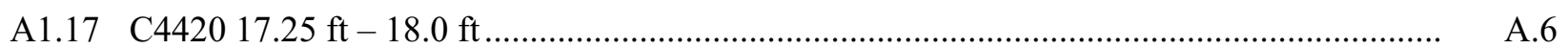

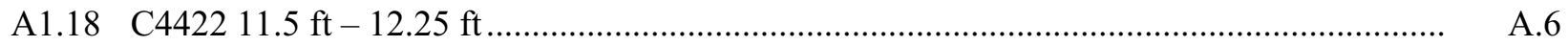

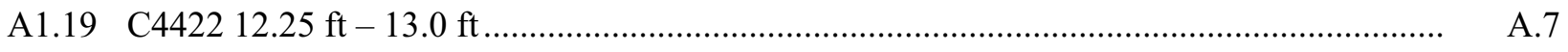

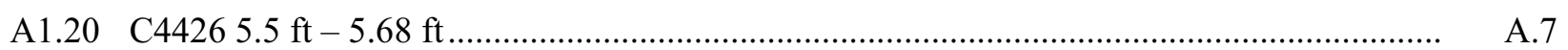

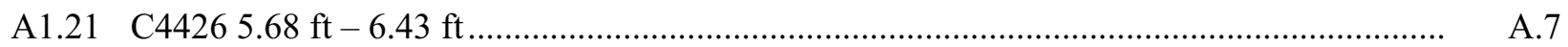

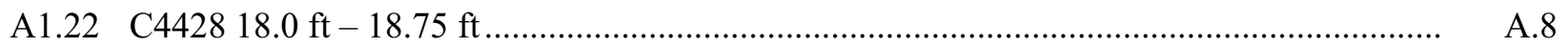

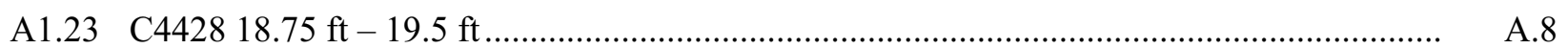

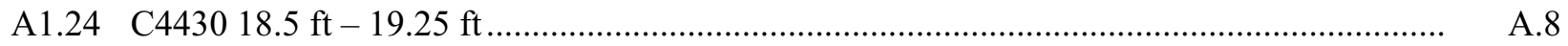

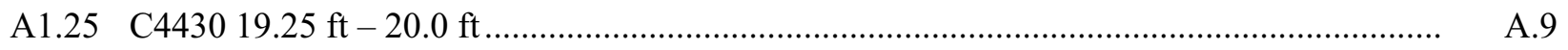

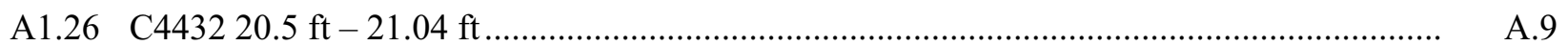

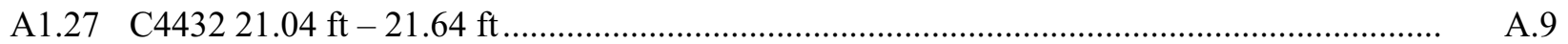

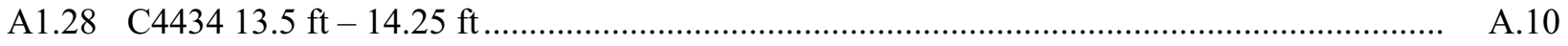

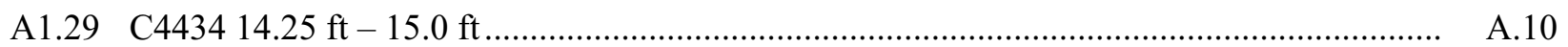




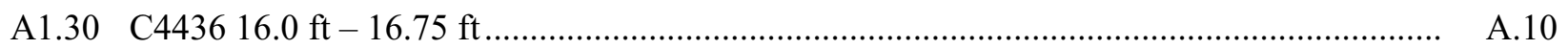

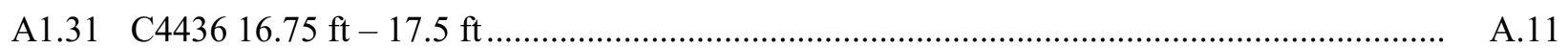

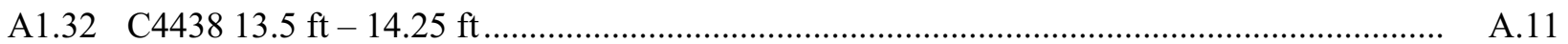

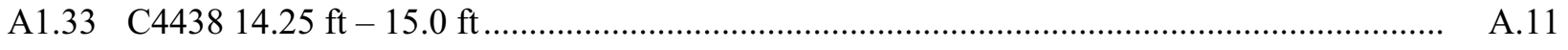

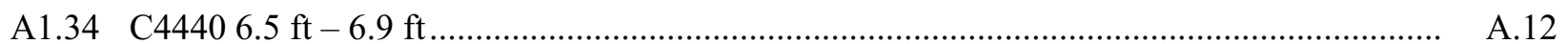

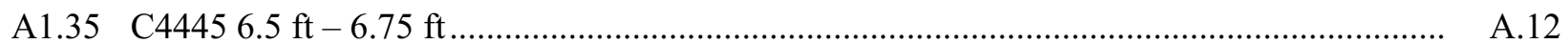

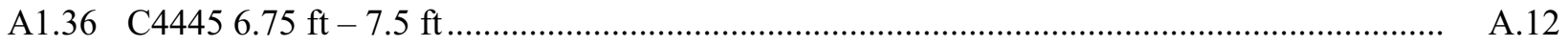

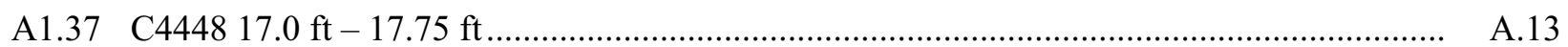

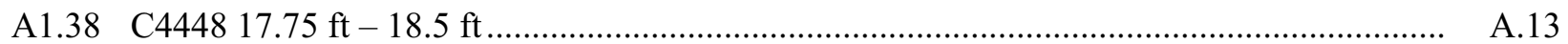

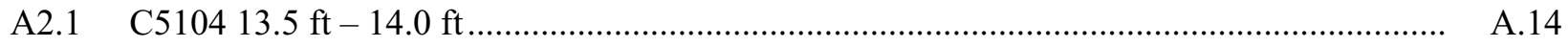

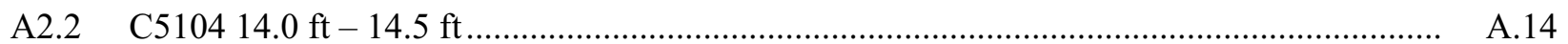

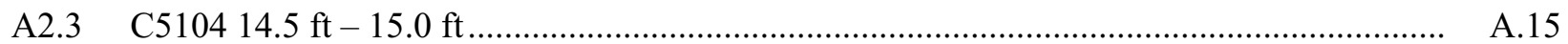

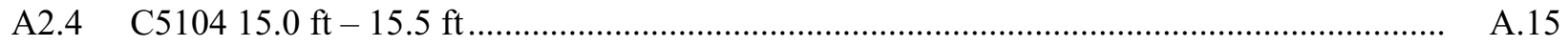

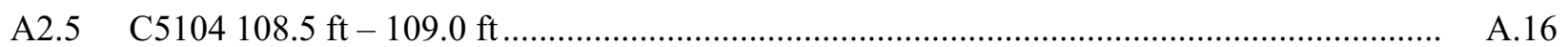

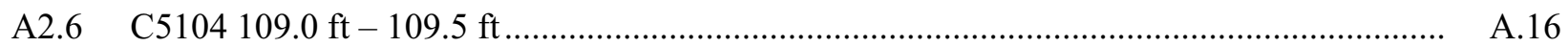

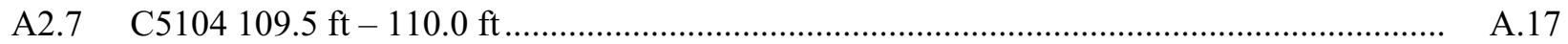

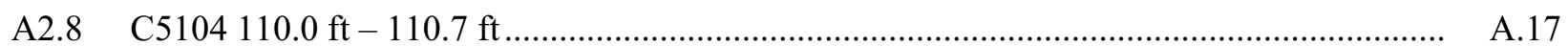

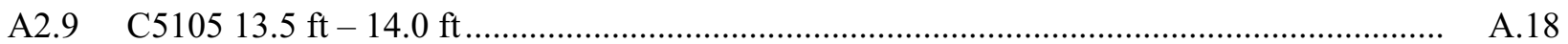

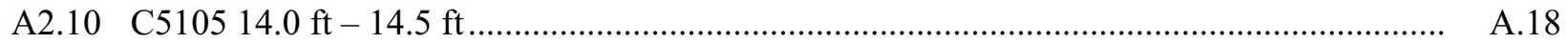

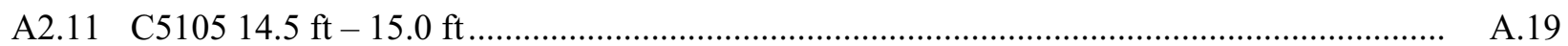

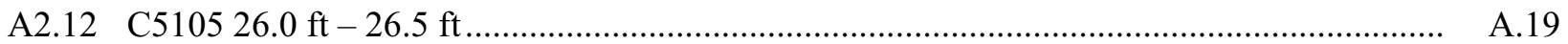

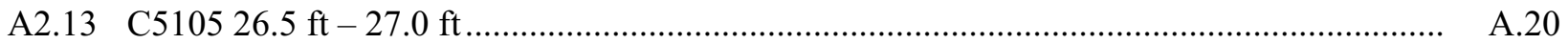

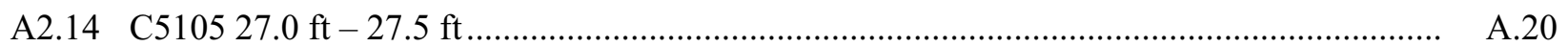

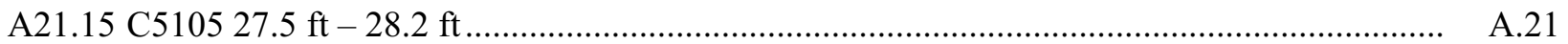

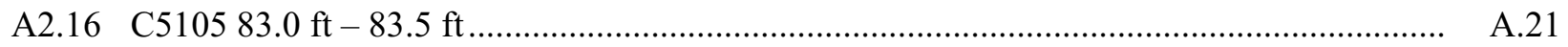

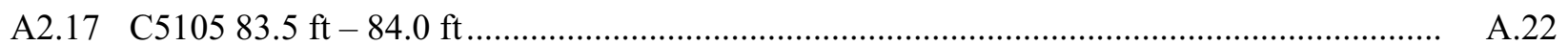

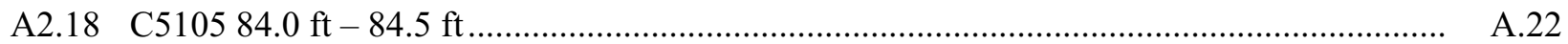

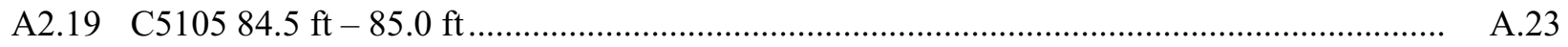

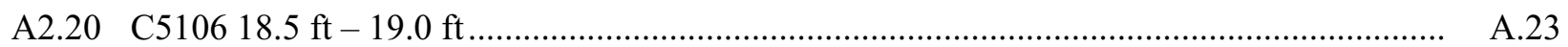

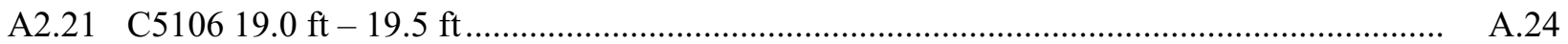

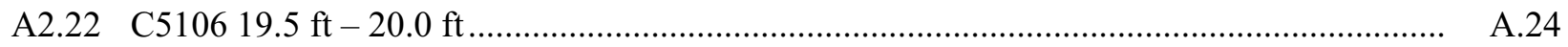

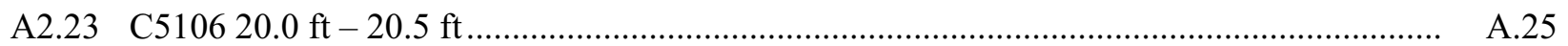

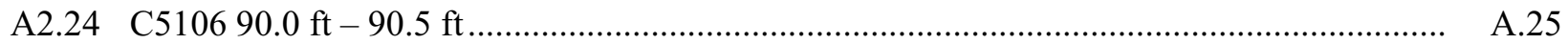

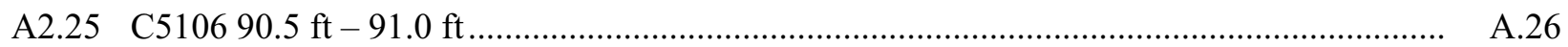

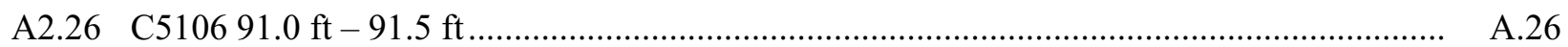

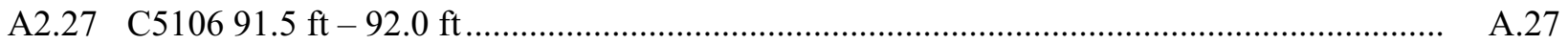

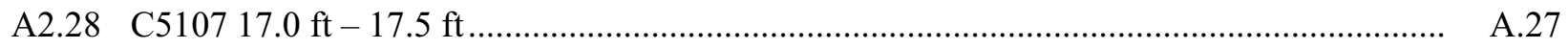

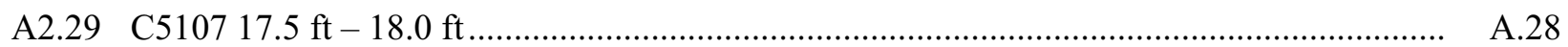

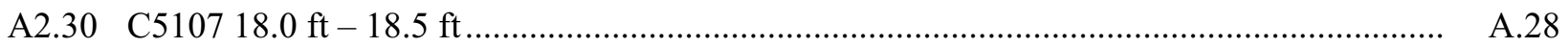




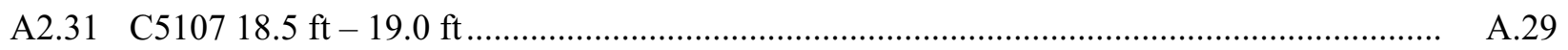

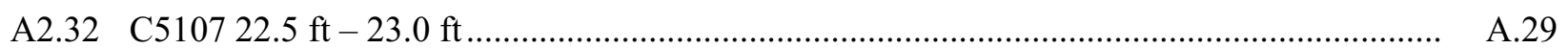

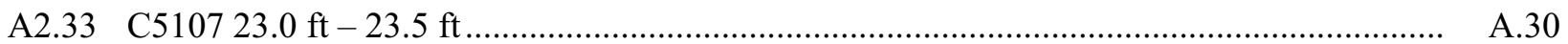

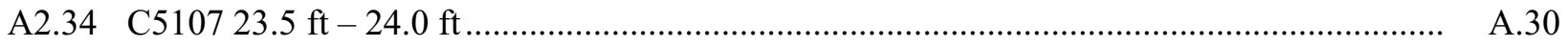

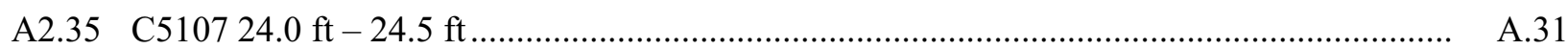

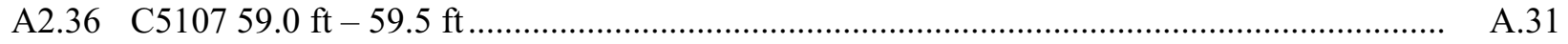

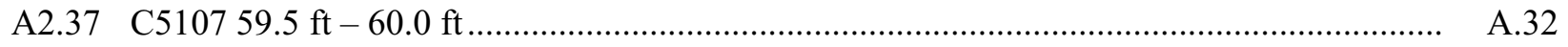

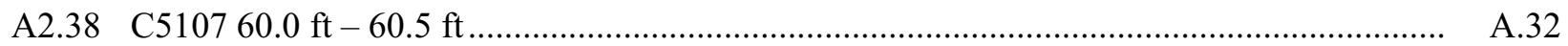

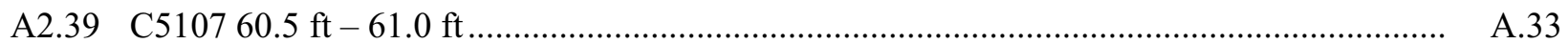

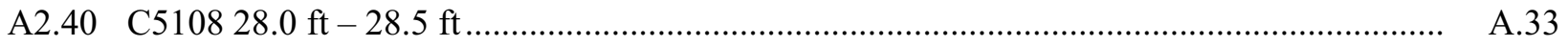

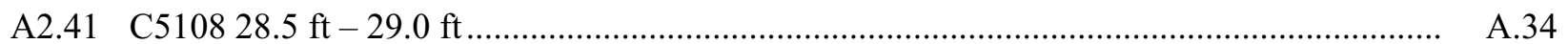

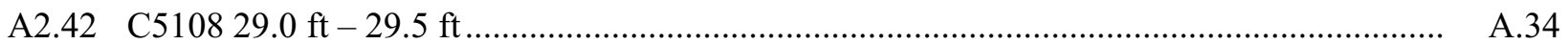

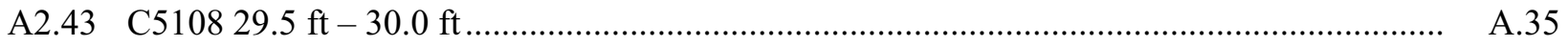

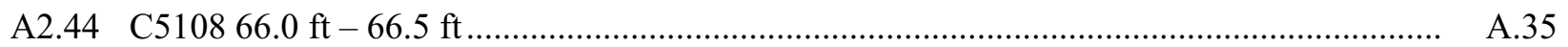

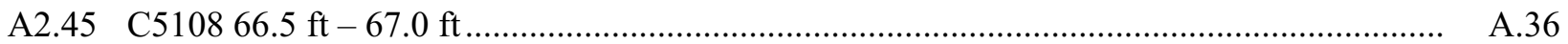

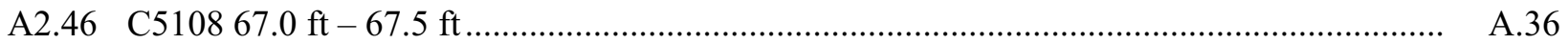

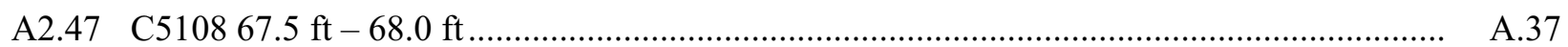

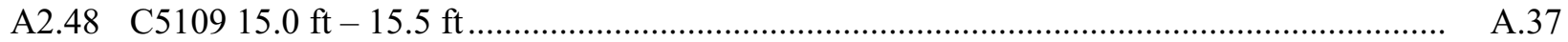

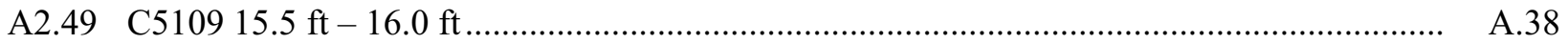

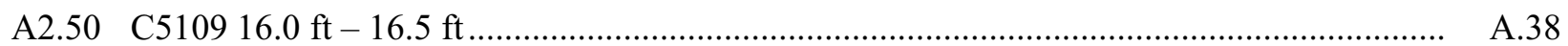

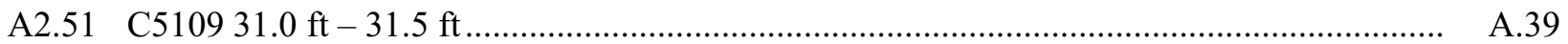

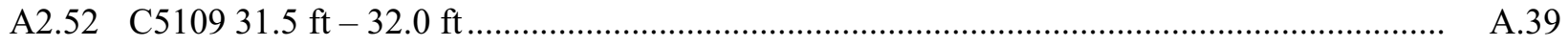

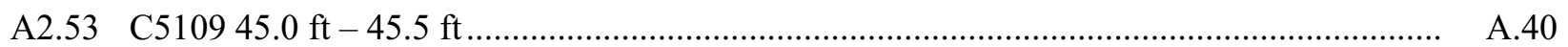

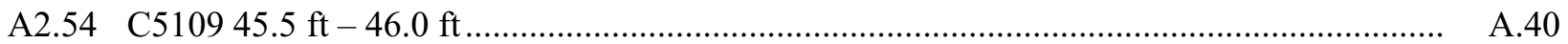

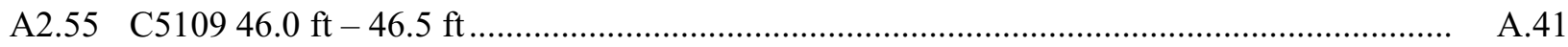

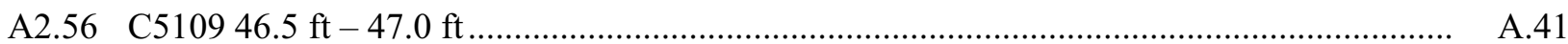


Appendix A1. Photographs of Samples from the C-152 Vertical Probe Holes

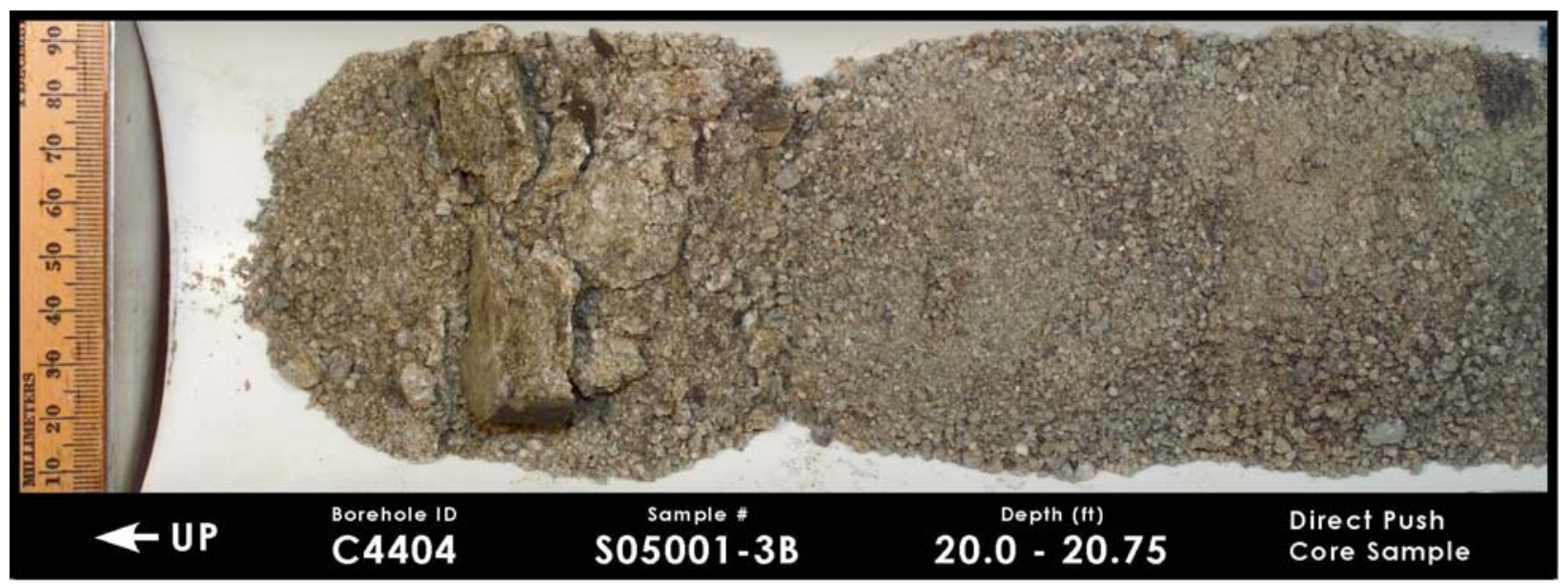

Figure A1.1. C4404 $20.0 \mathrm{ft}-20.75 \mathrm{ft}$

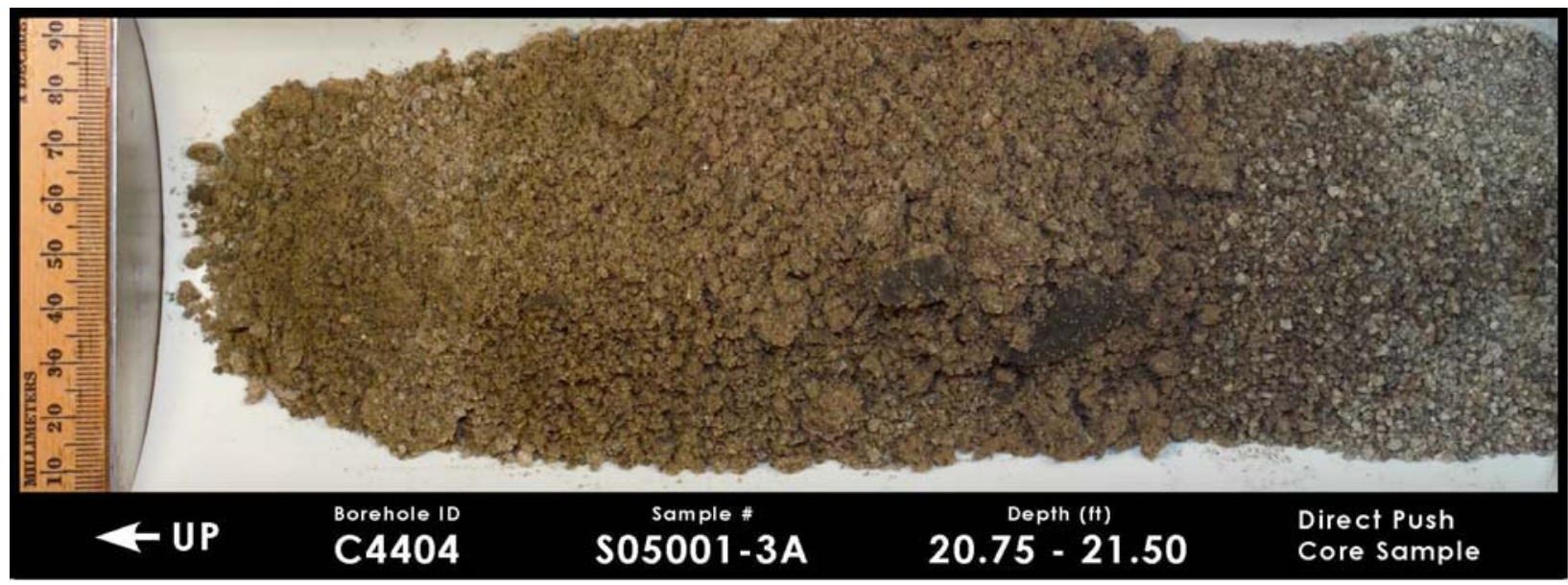

Figure A1.2. C4404 $20.75 \mathrm{ft}-21.5 \mathrm{ft}$

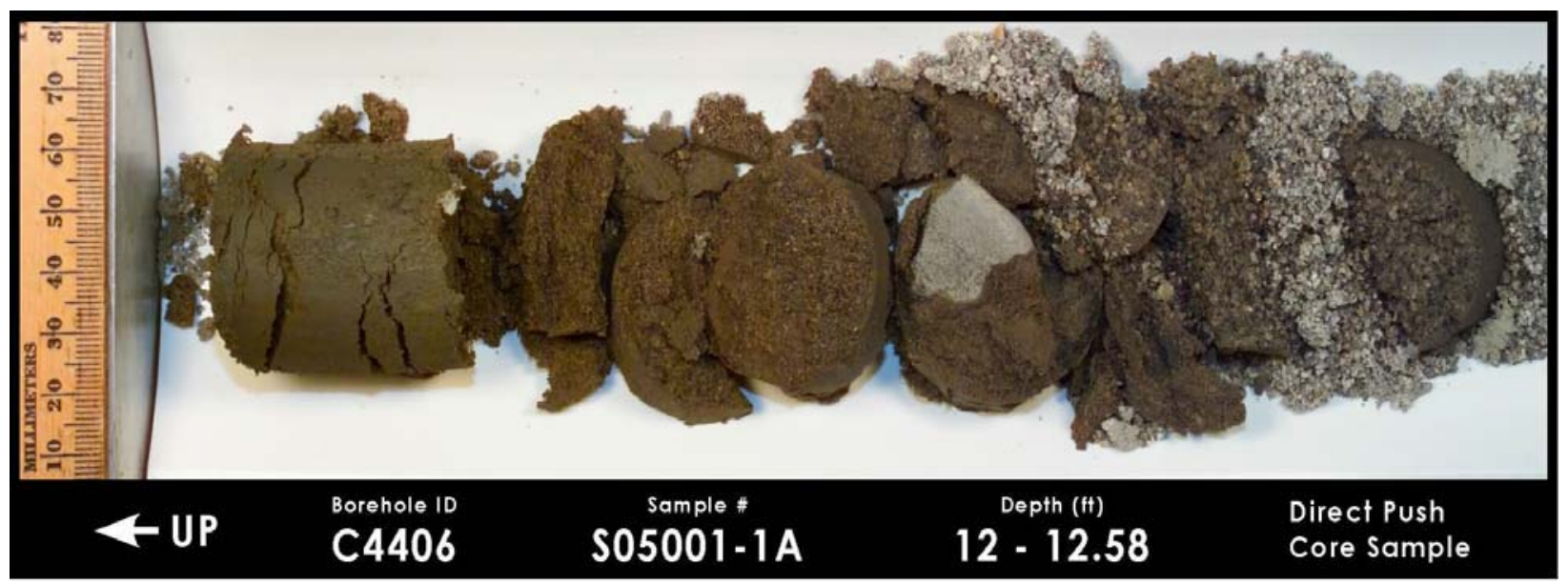

Figure A1.3. C4406 $12.0 \mathrm{ft}-12.58 \mathrm{ft}$ 


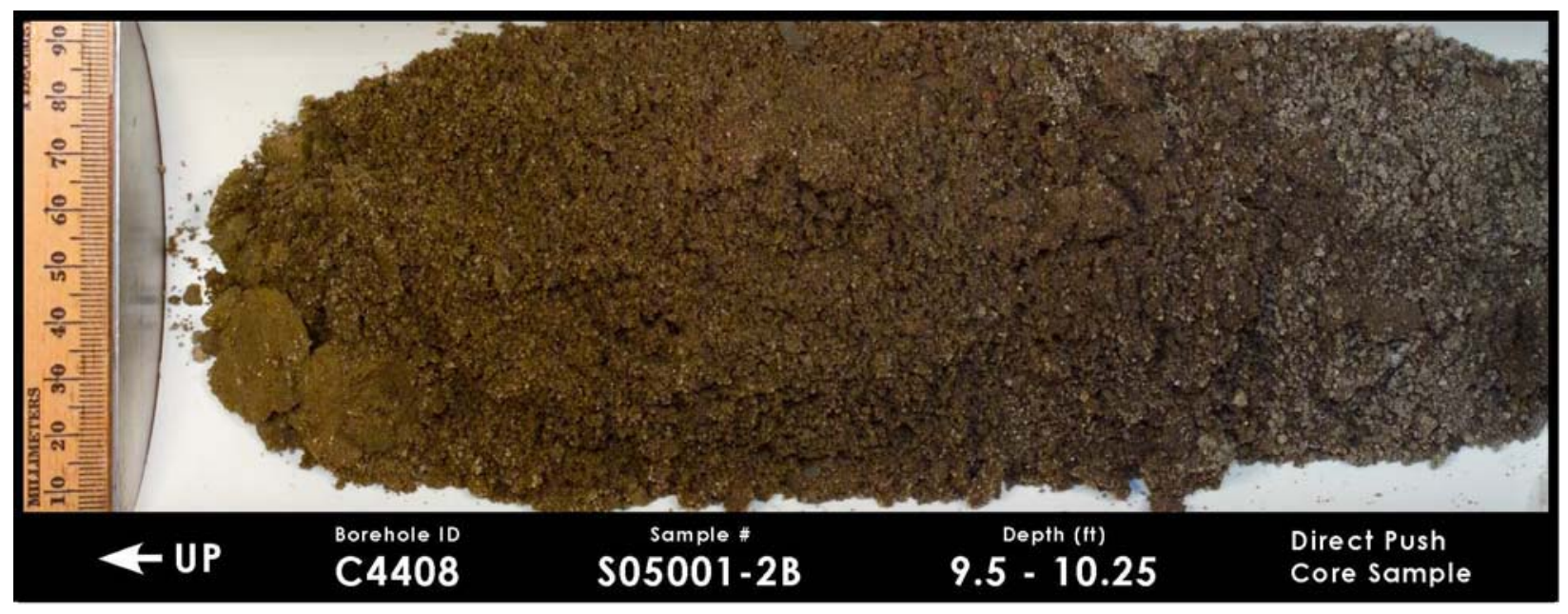

Figure A1.4. C4408 $9.5 \mathrm{ft}-10.25 \mathrm{ft}$

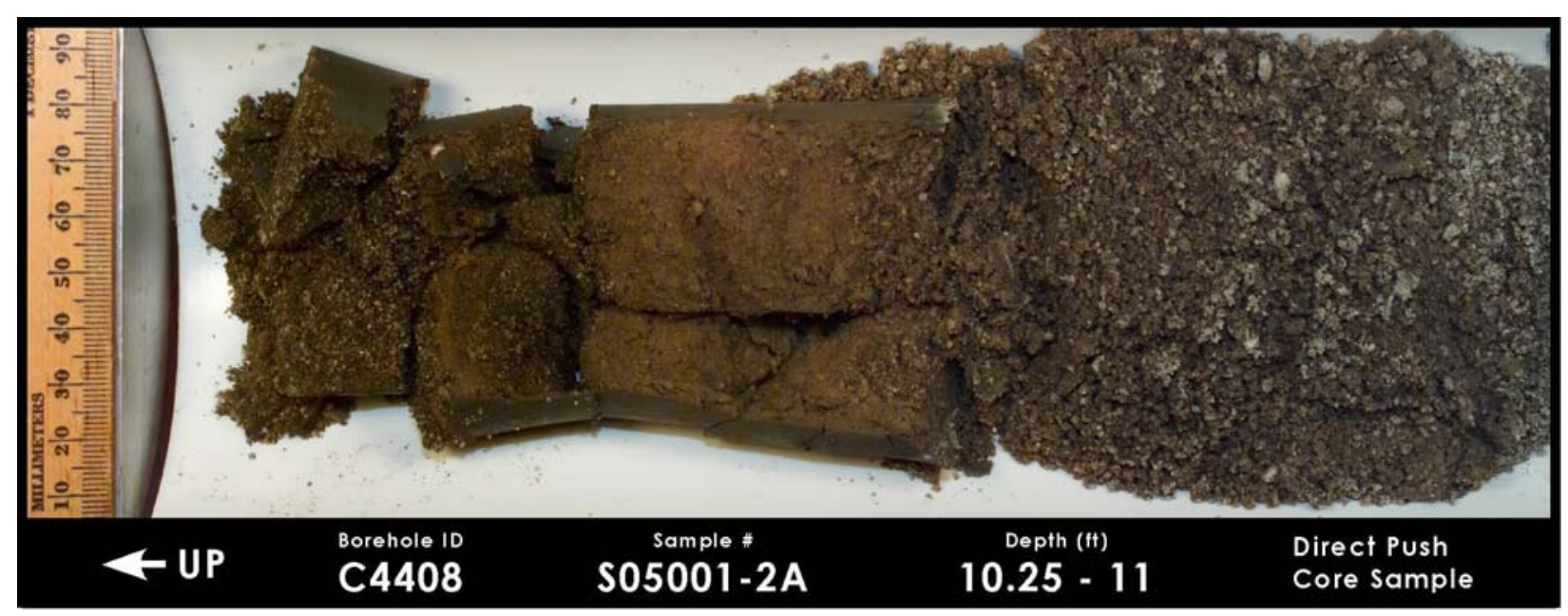

Figure A1.5. C4408 $10.25 \mathrm{ft}-11.0 \mathrm{ft}$

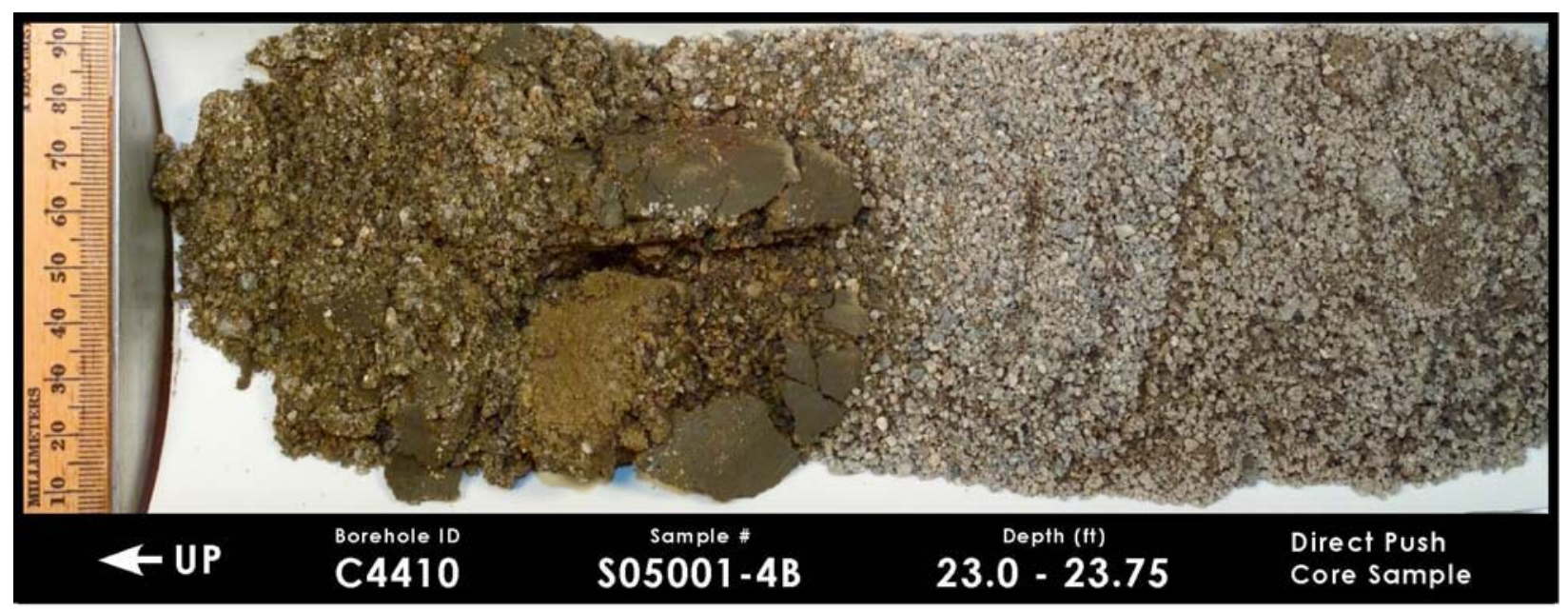

Figure A1.6. C4410 $23.0 \mathrm{ft}-23.75 \mathrm{ft}$ 


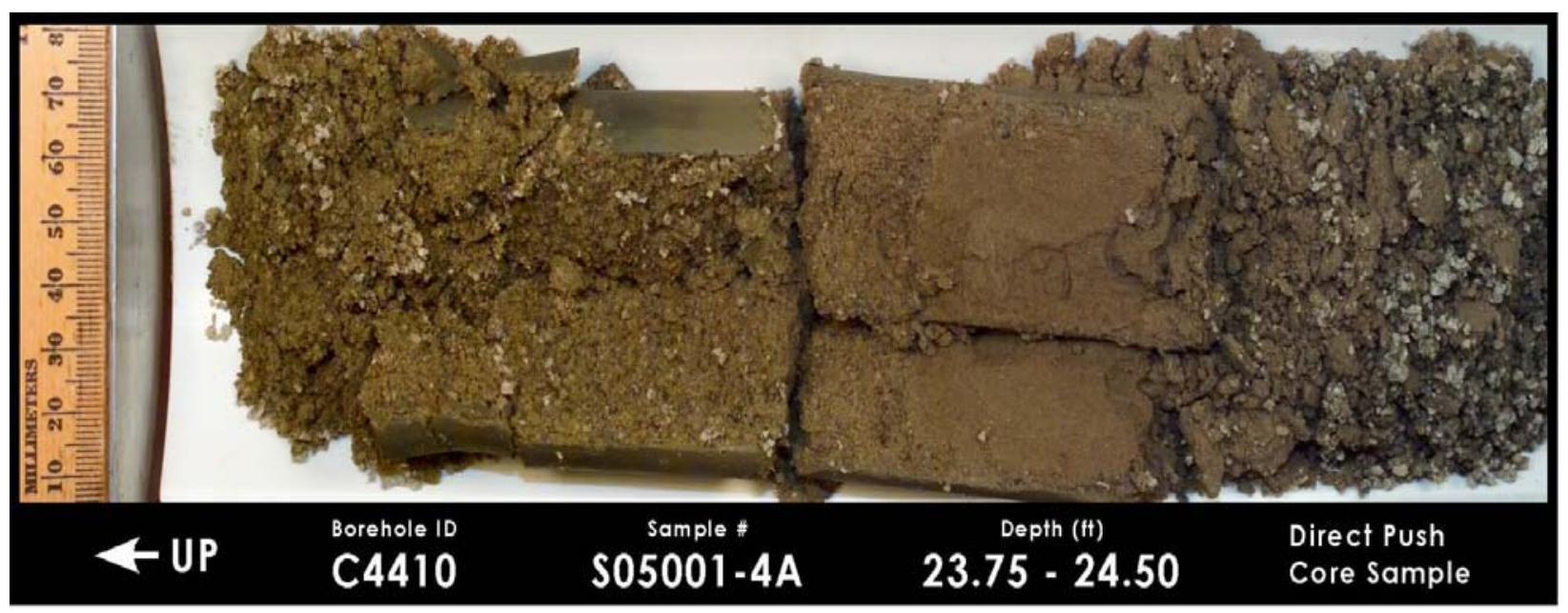

Figure A1.7. C4410 $23.75 \mathrm{ft}-24.5 \mathrm{ft}$

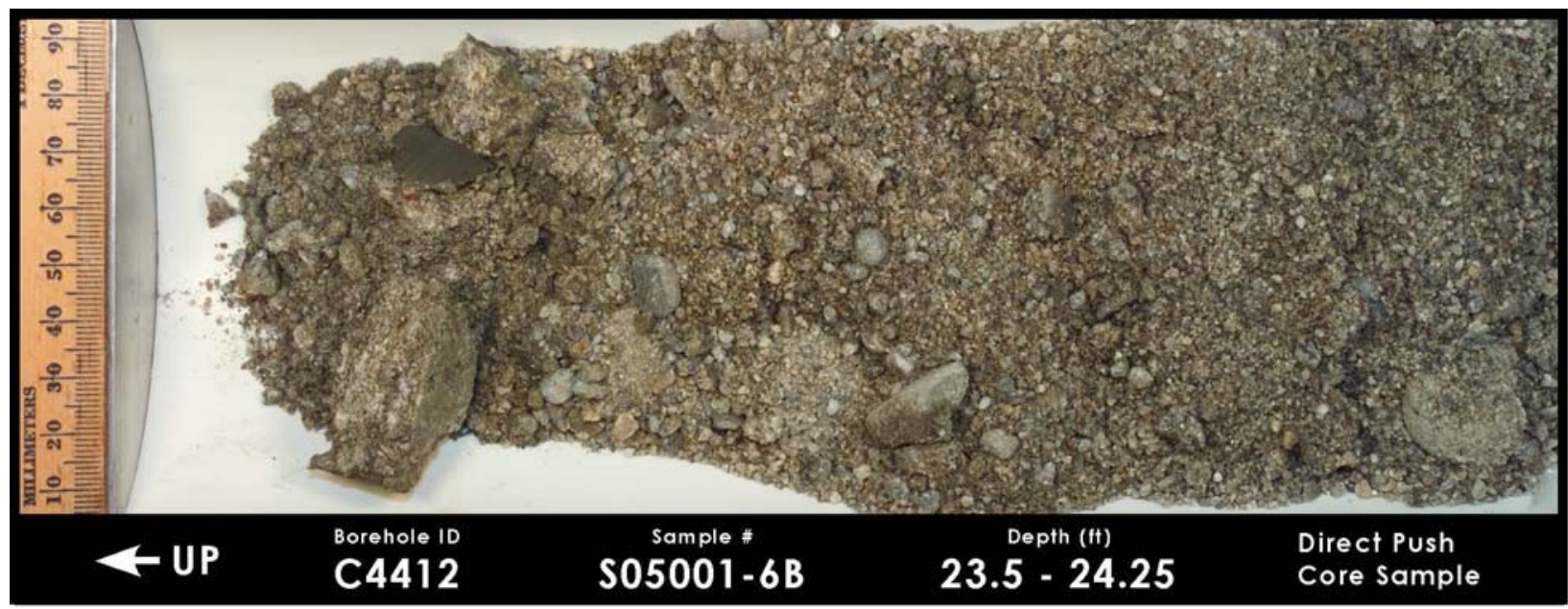

Figure A1.8. C4412 $23.5 \mathrm{ft}-24.25 \mathrm{ft}$

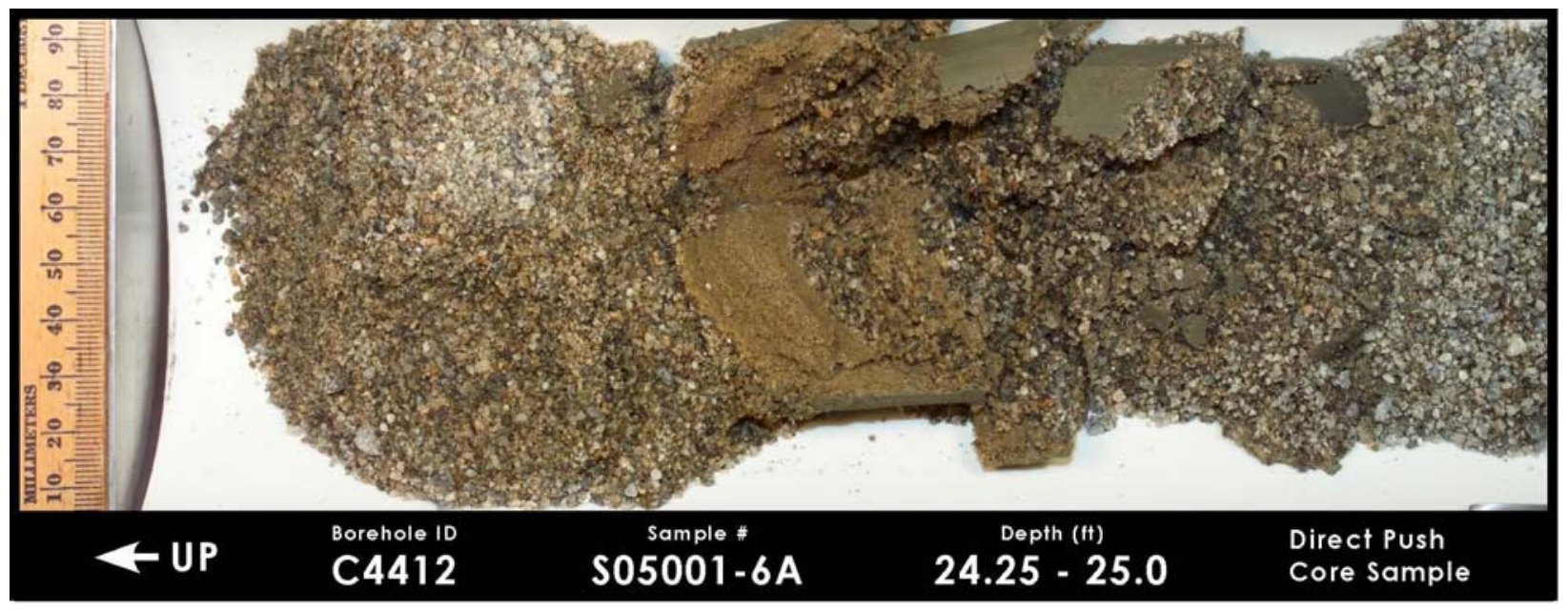

Figure A1.9. C4412 $24.25 \mathrm{ft}-25.0 \mathrm{ft}$ 


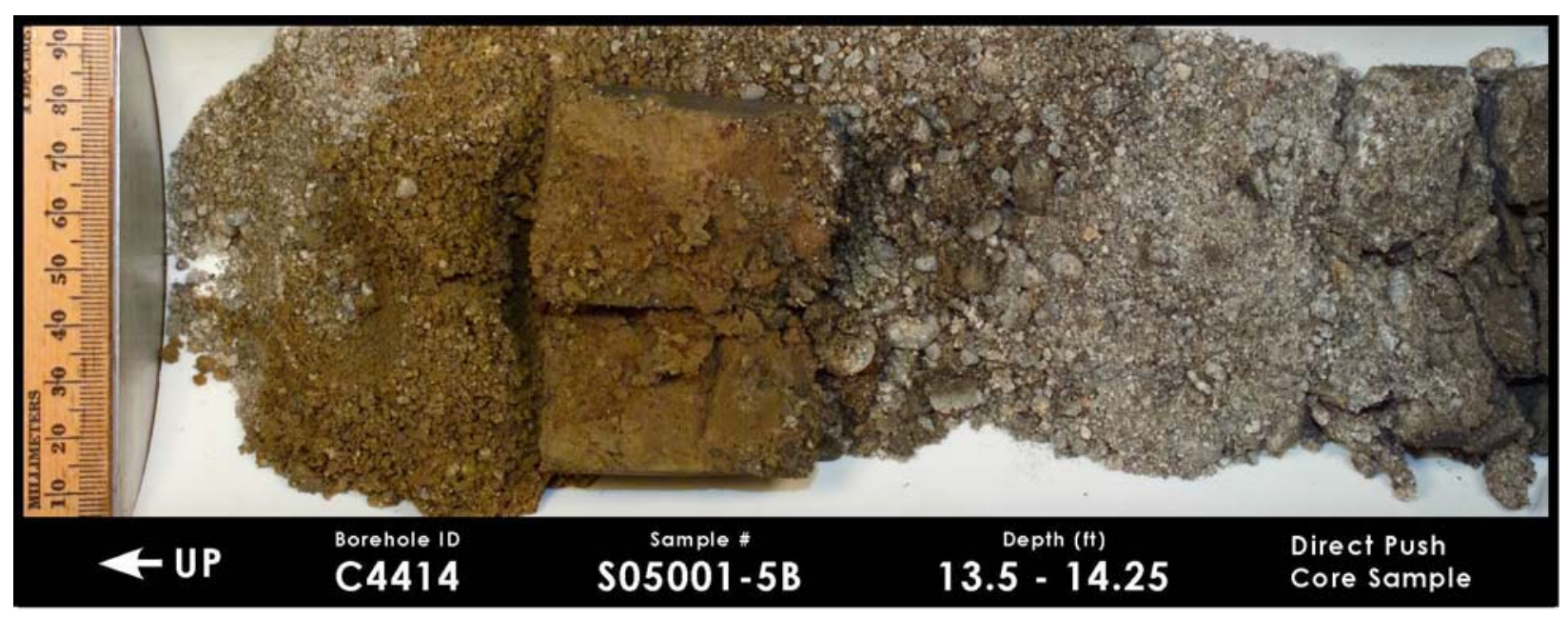

Figure A1.10. C4414 $13.5 \mathrm{ft}-14.25 \mathrm{ft}$

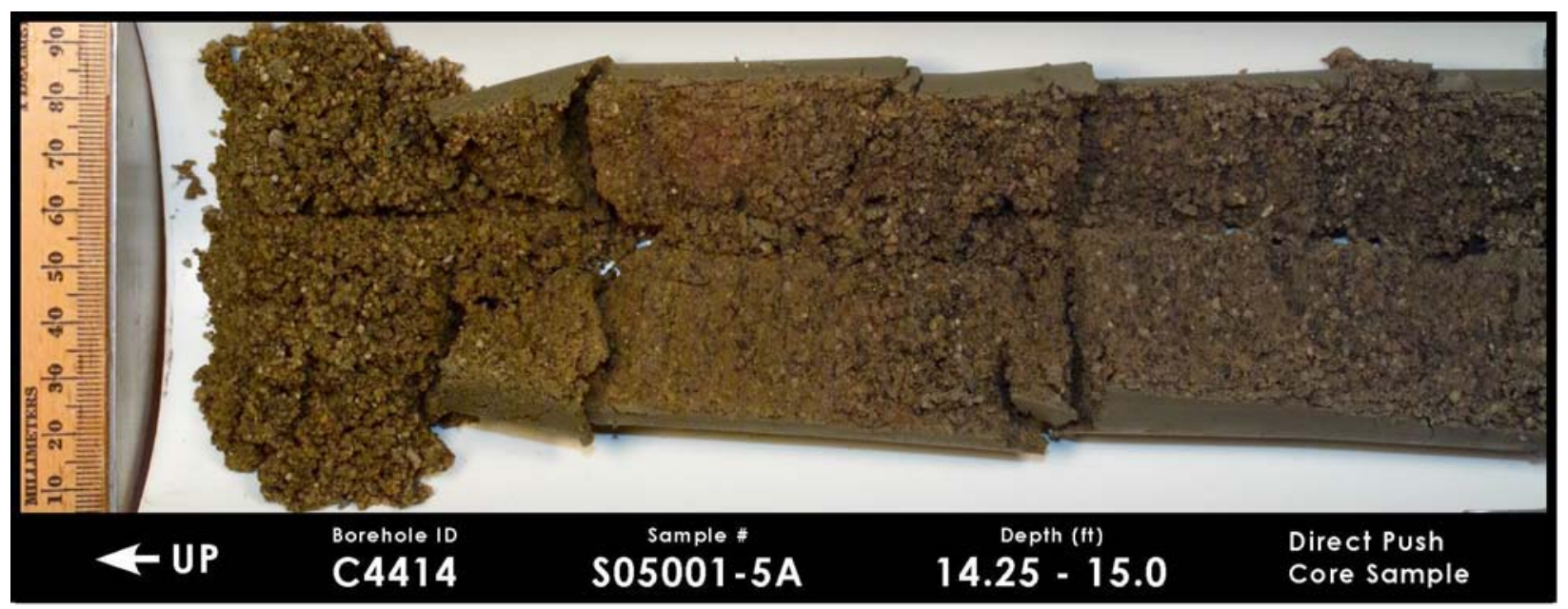

Figure A1.11. C4414 $14.25 \mathrm{ft}-15.0 \mathrm{ft}$

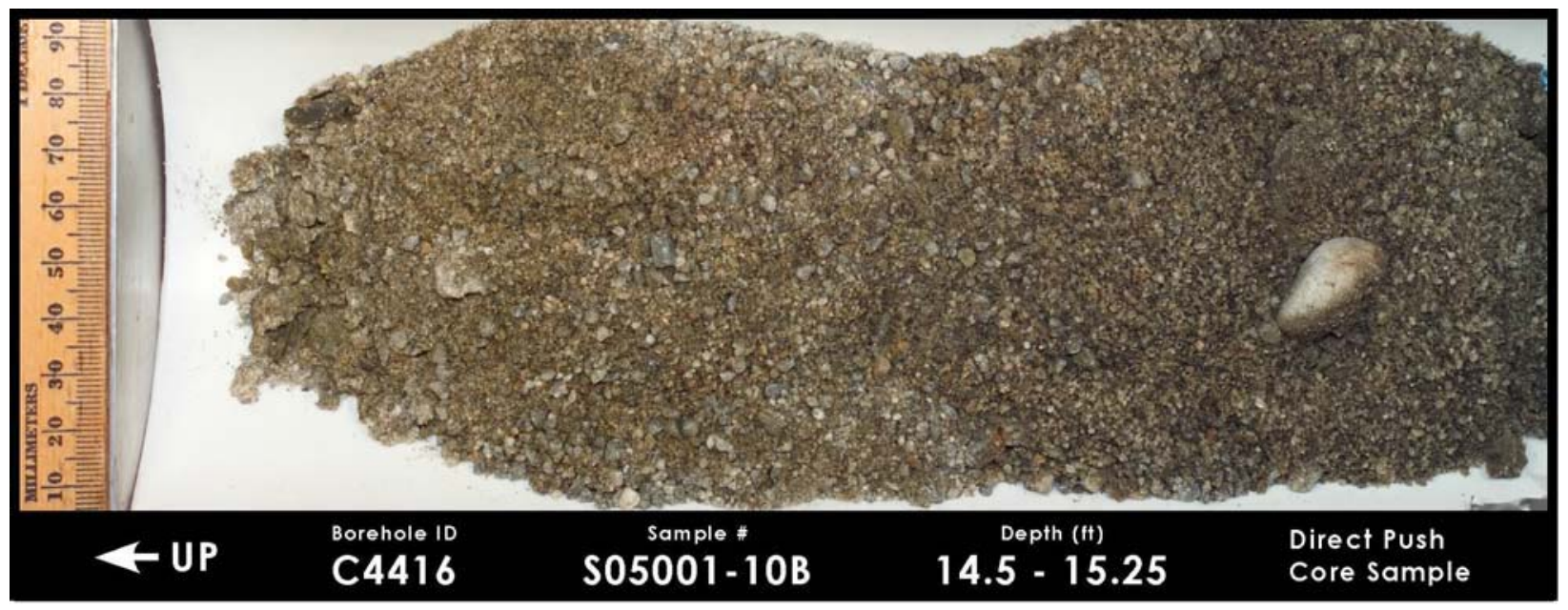

Figure A1.12. C4416 $14.5 \mathrm{ft}-15.25 \mathrm{ft}$ 


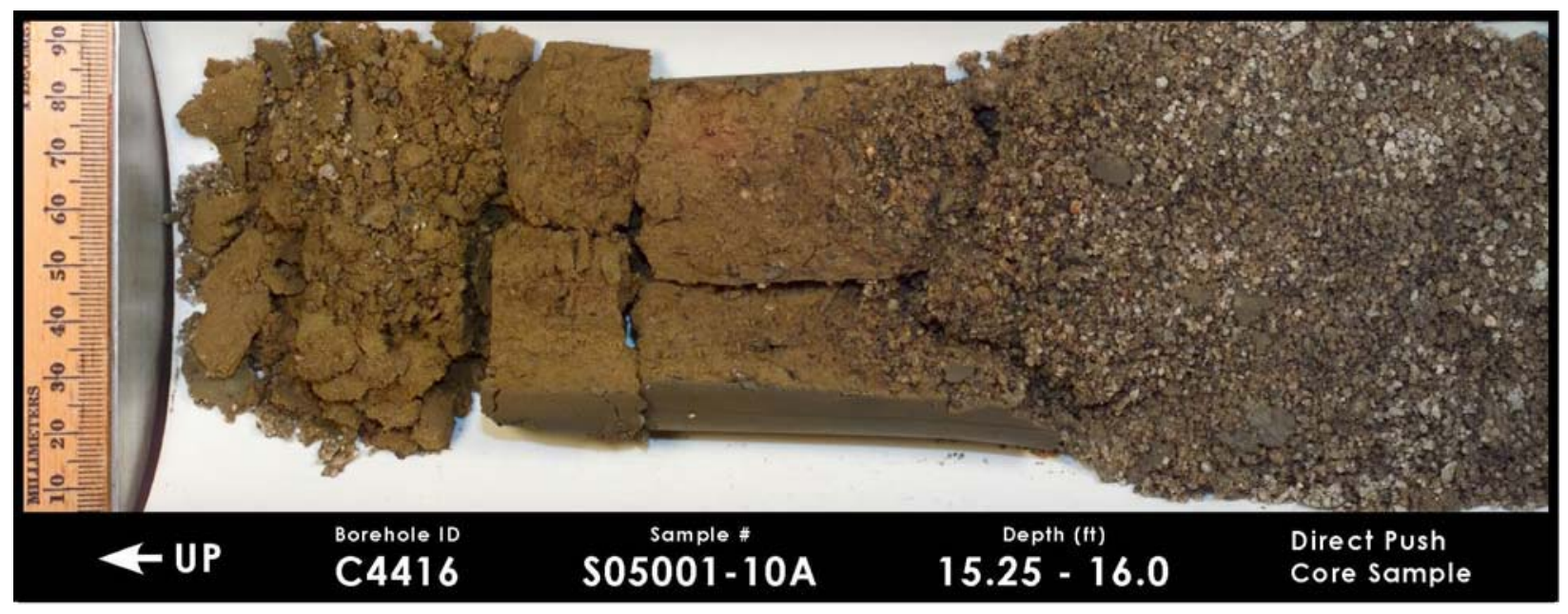

Figure A1.13. C4416 $15.25 \mathrm{ft}-16.0 \mathrm{ft}$

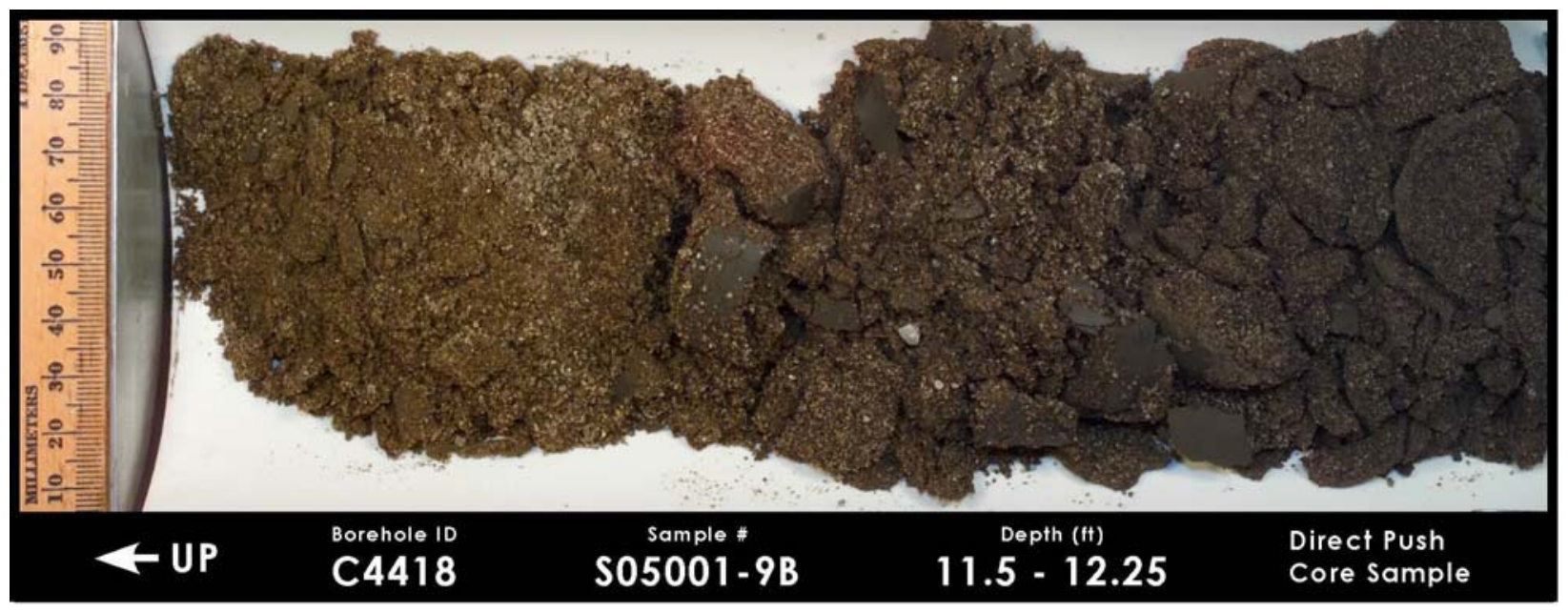

Figure A1.14. C4418 $11.5 \mathrm{ft}-12.25 \mathrm{ft}$

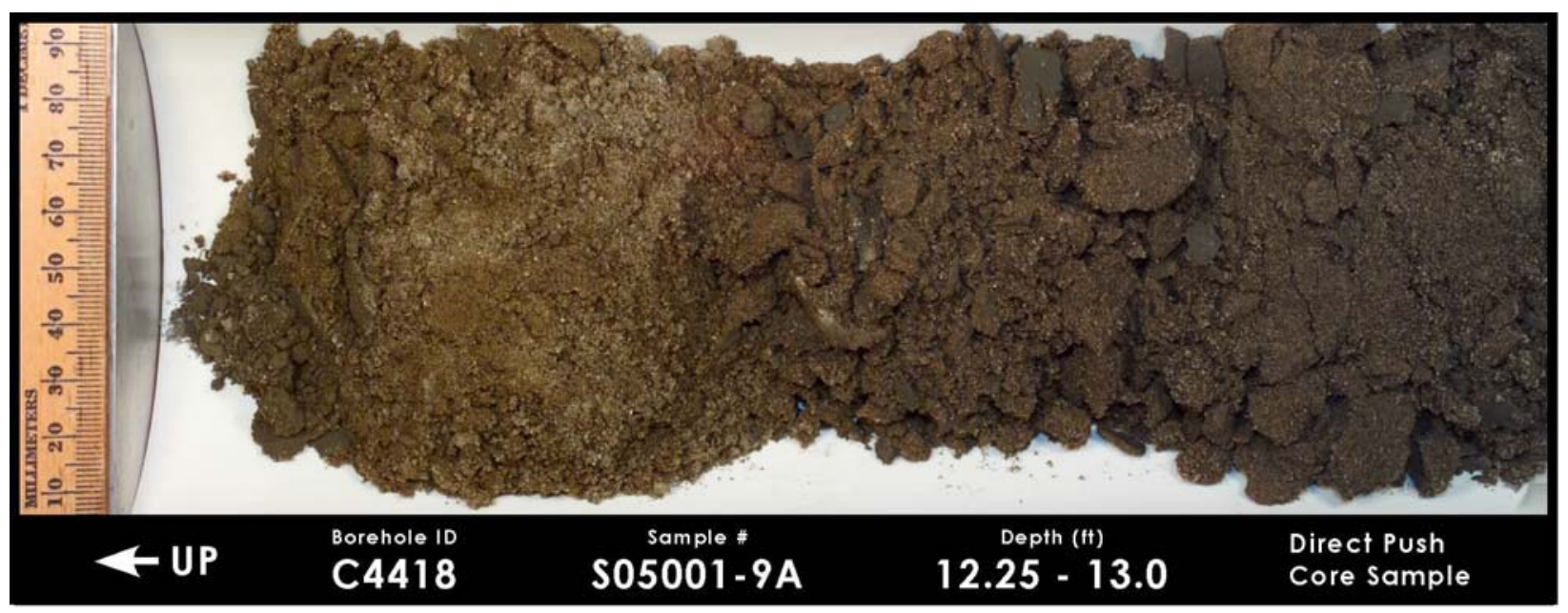

Figure A1.15. C4418 $12.25 \mathrm{ft}-13.0 \mathrm{ft}$ 


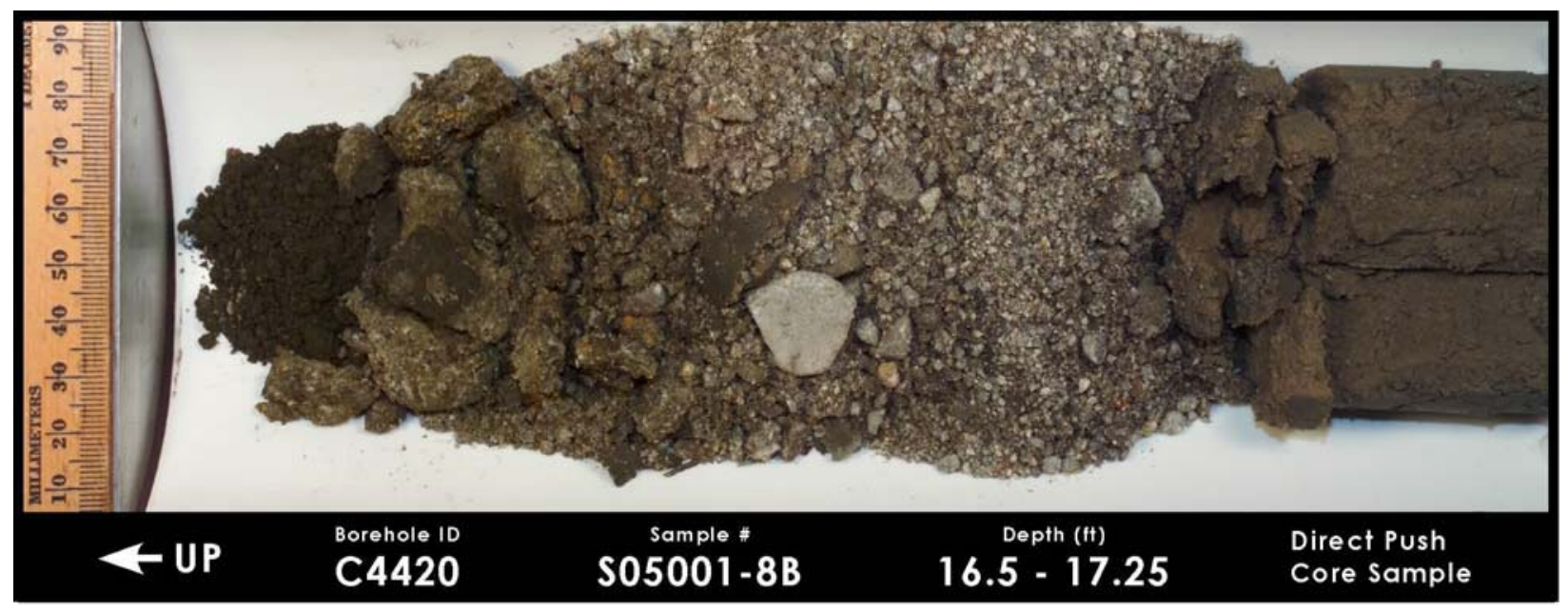

Figure A1.16. C4420 $16.5 \mathrm{ft}-17.25 \mathrm{ft}$

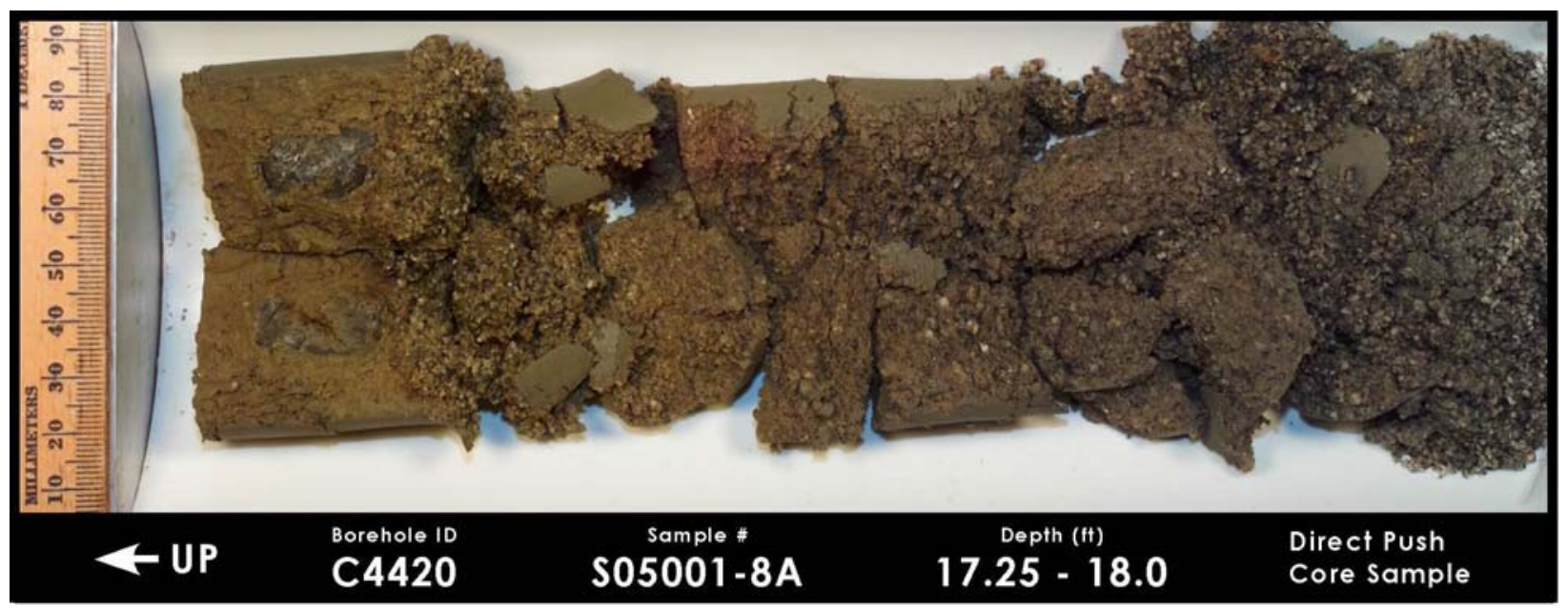

Figure A1.17. C4420 $17.25 \mathrm{ft}-18.0 \mathrm{ft}$

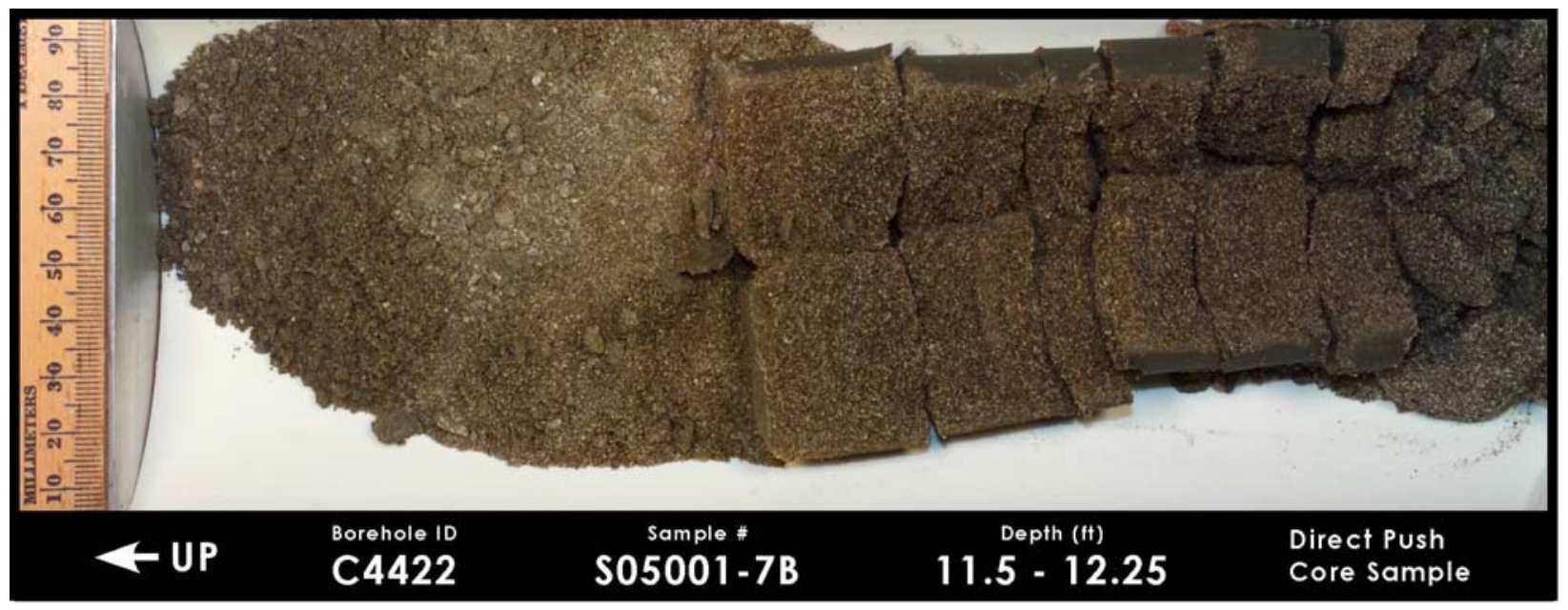

Figure A1.18. C4422 $11.5 \mathrm{ft}-12.25 \mathrm{ft}$ 


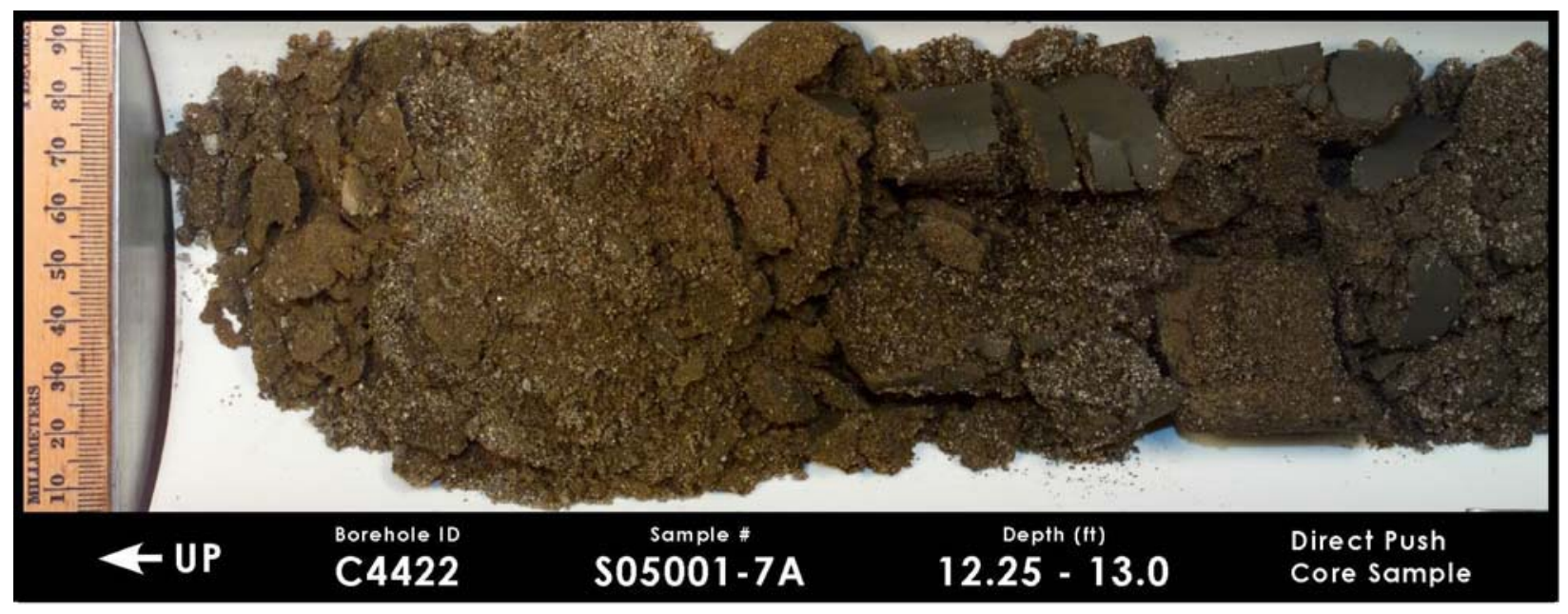

Figure A1.19. C4422 $12.25 \mathrm{ft}-13.0 \mathrm{ft}$

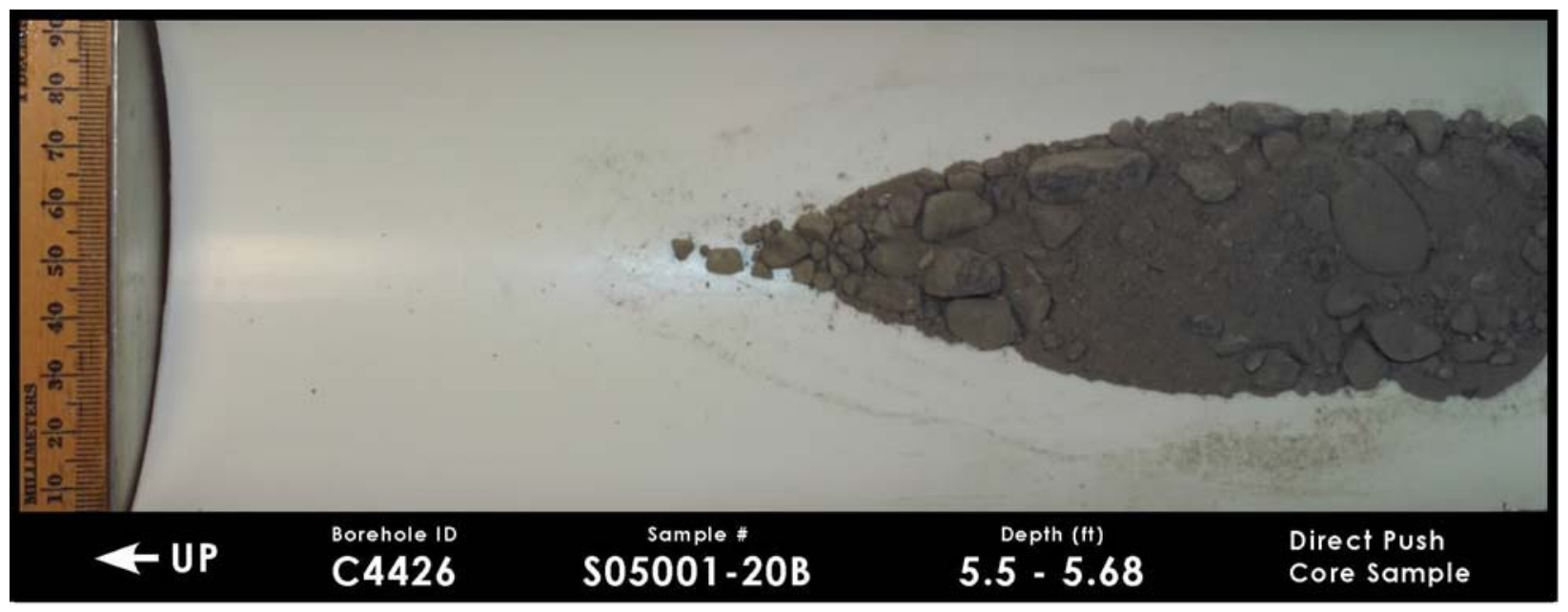

Figure A1.20. C4426 $5.5 \mathrm{ft}-5.68 \mathrm{ft}$

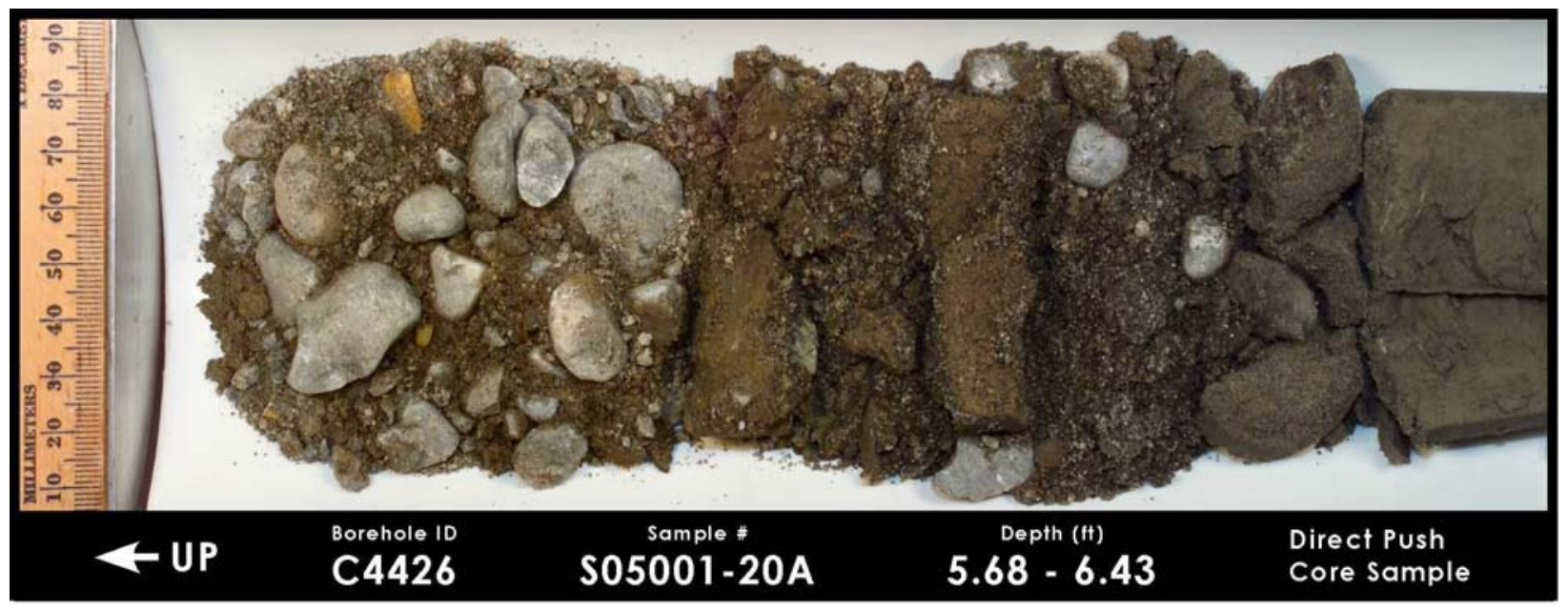

Figure A1.21. C4426 $5.68 \mathrm{ft}-6.43 \mathrm{ft}$ 


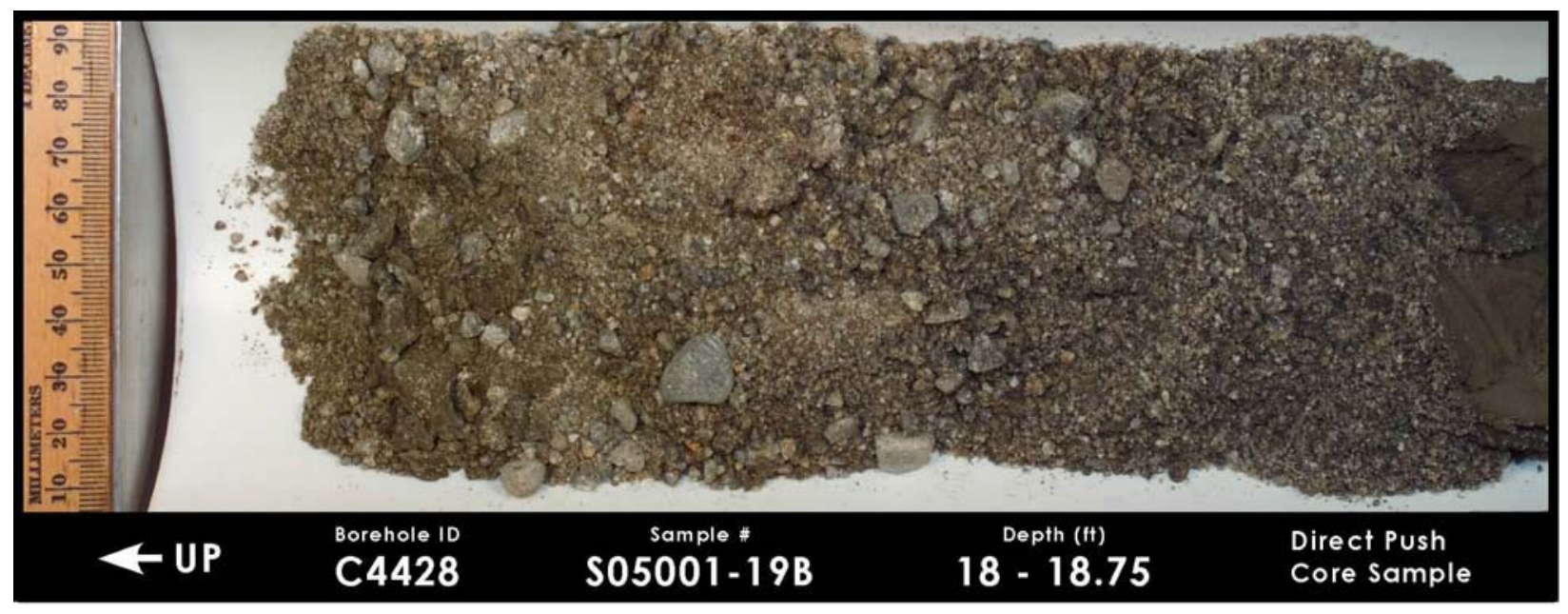

Figure A1.22. C4428 $18.0 \mathrm{ft}-18.75 \mathrm{ft}$

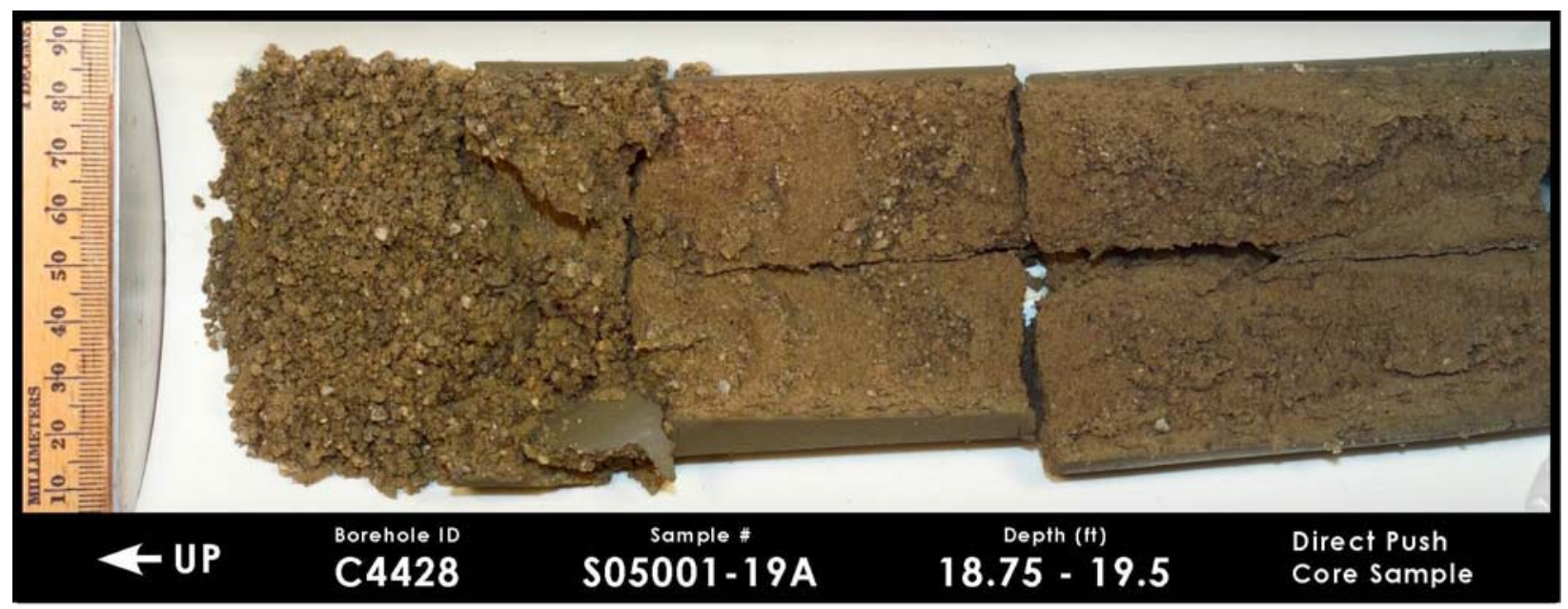

Figure A1.23. C4428 $18.75 \mathrm{ft}-19.5 \mathrm{ft}$

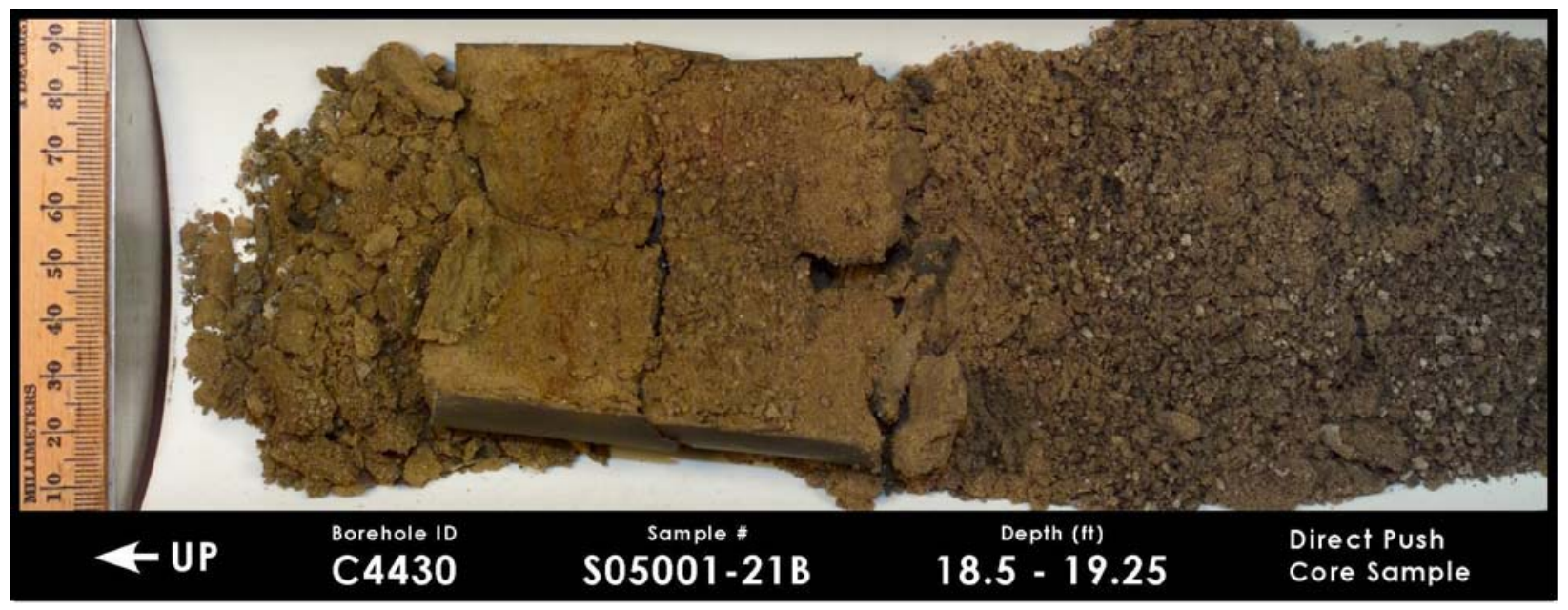

Figure A1.24. C4430 $18.5 \mathrm{ft}-19.25 \mathrm{ft}$ 


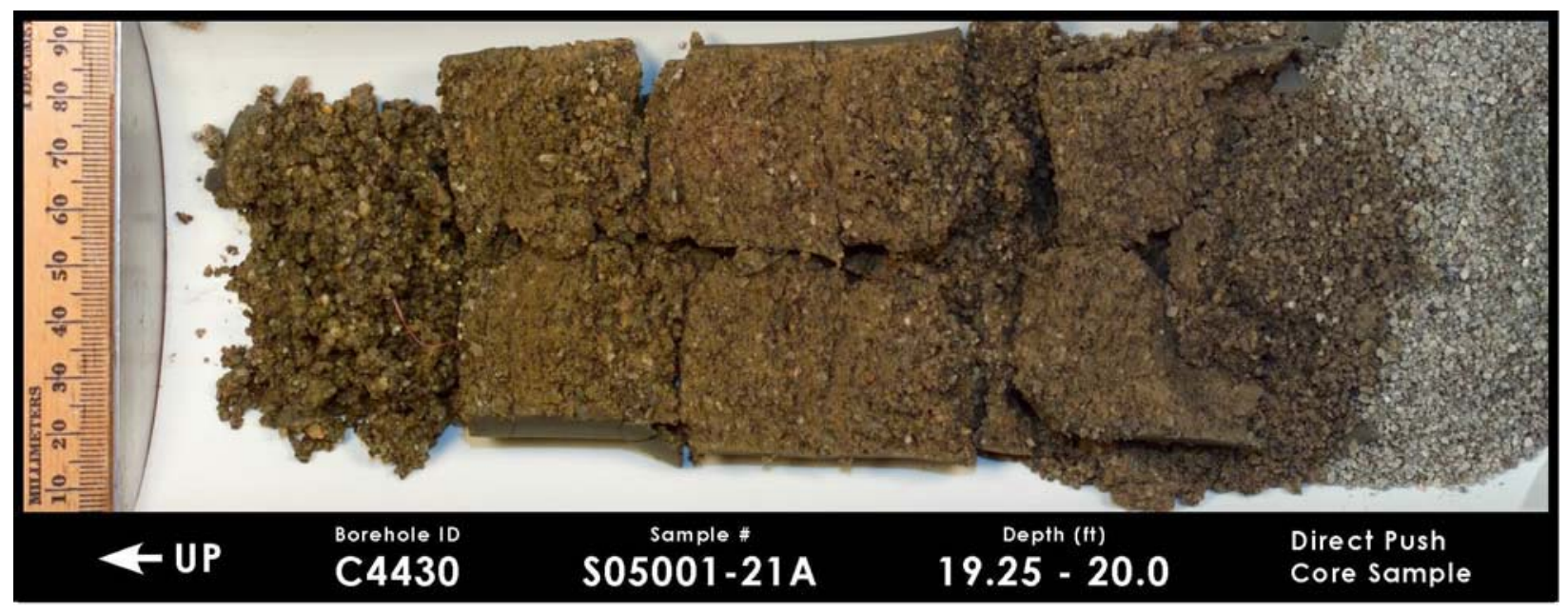

Figure A1.25. C4430 $19.25 \mathrm{ft}-20.0 \mathrm{ft}$

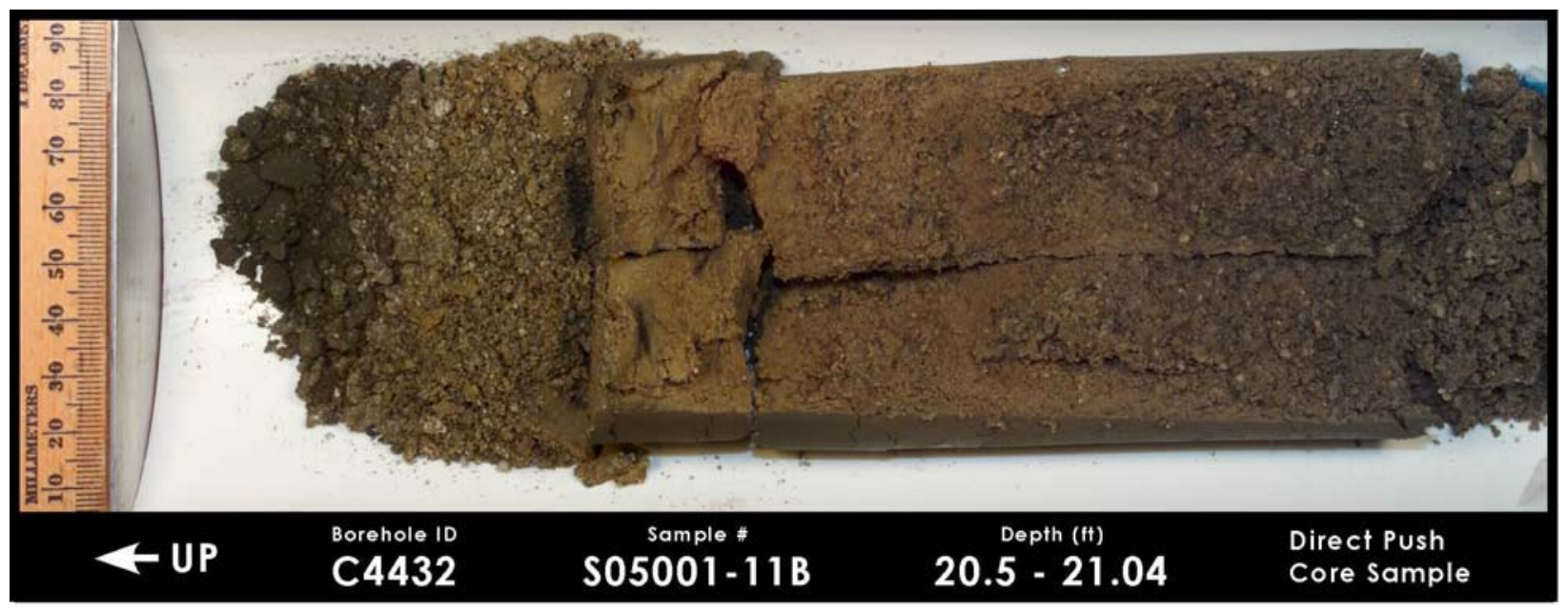

Figure A1.26. C4432 $20.5 \mathrm{ft}-21.04 \mathrm{ft}$

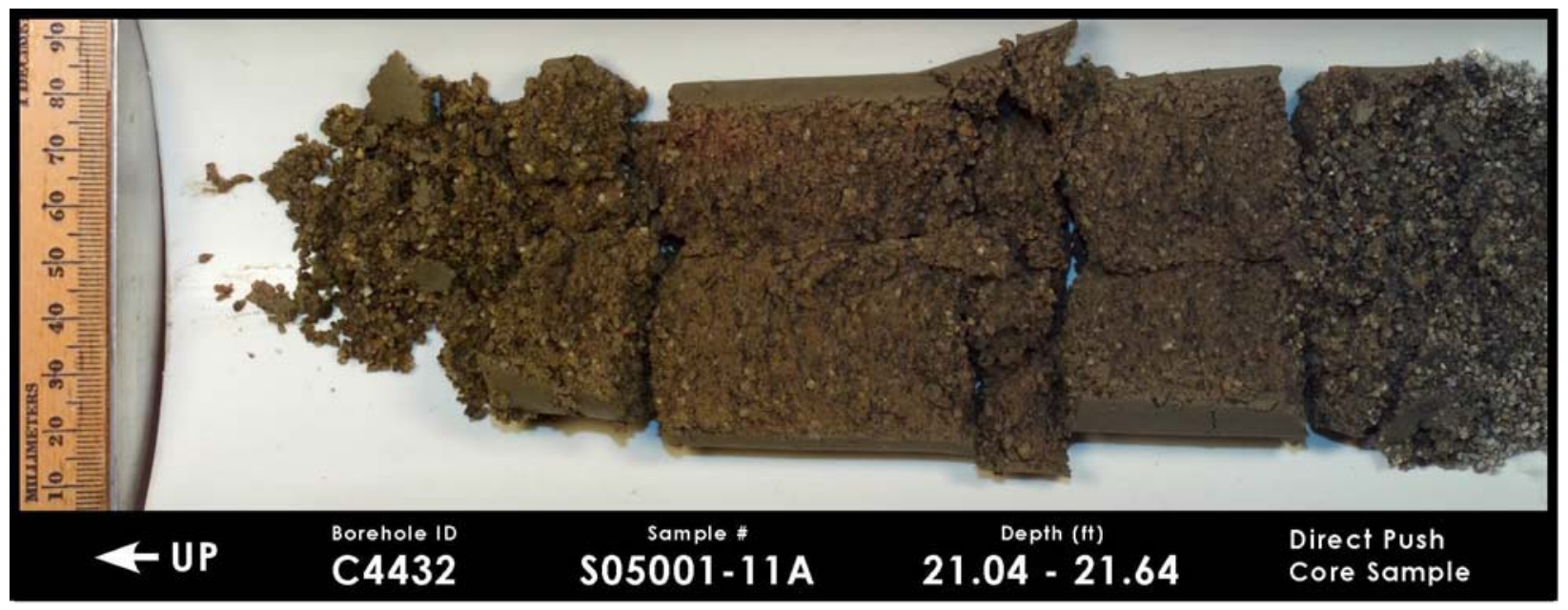

Figure A1.27. C4432 $21.04 \mathrm{ft}-21.64 \mathrm{ft}$ 


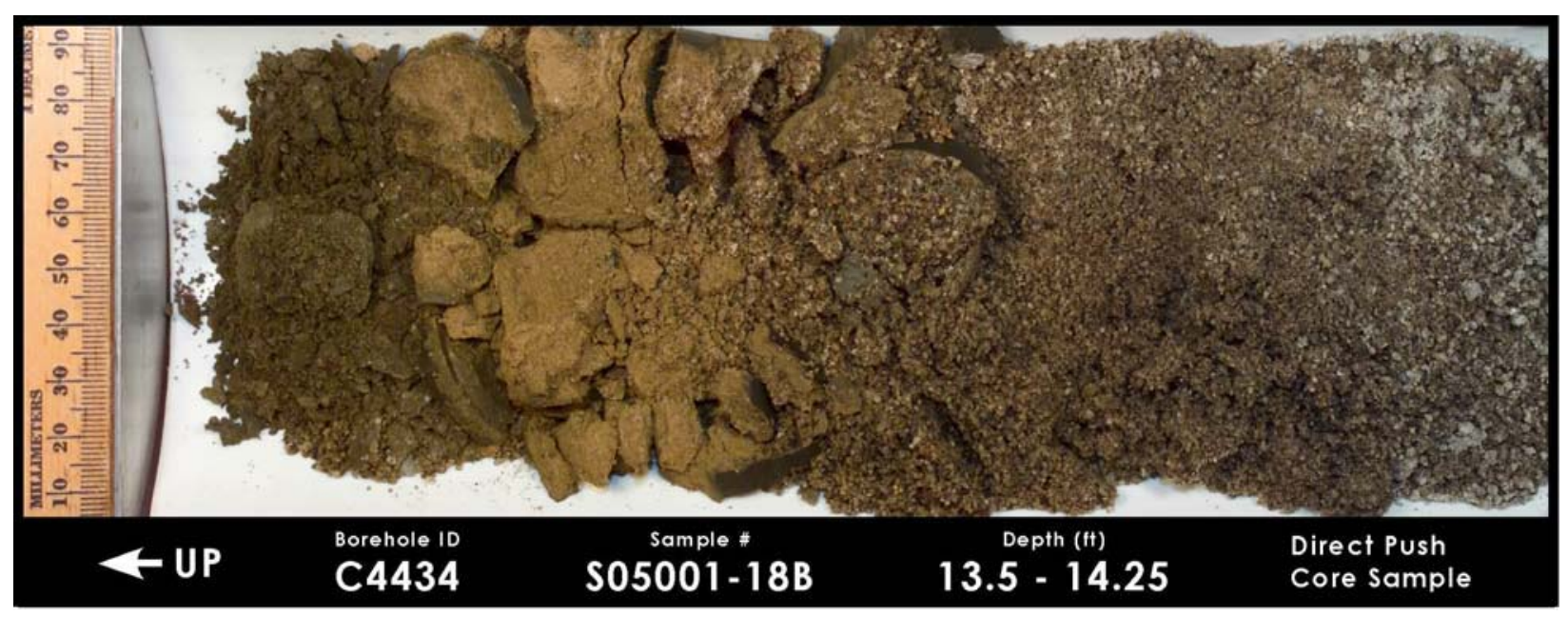

Figure A1.28. C4434 $13.5 \mathrm{ft}-14.25 \mathrm{ft}$

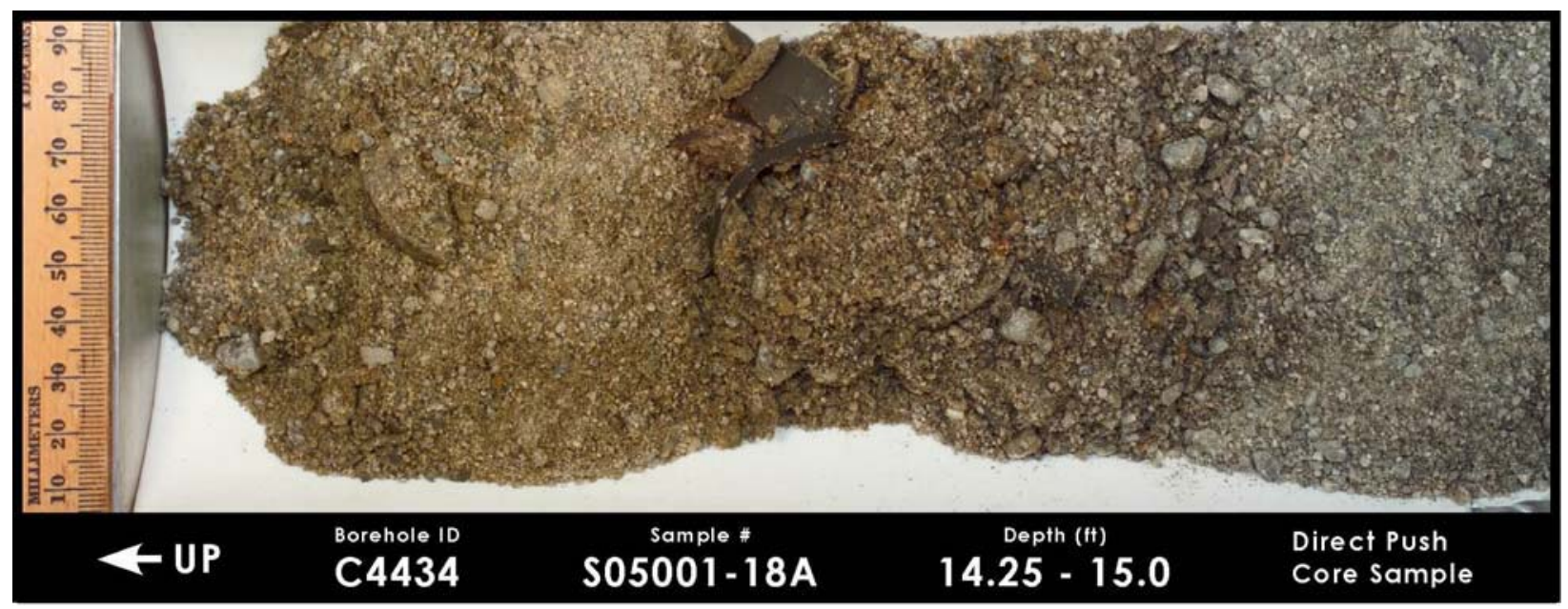

Figure A1.29. C4434 $14.25 \mathrm{ft}-15.0 \mathrm{ft}$

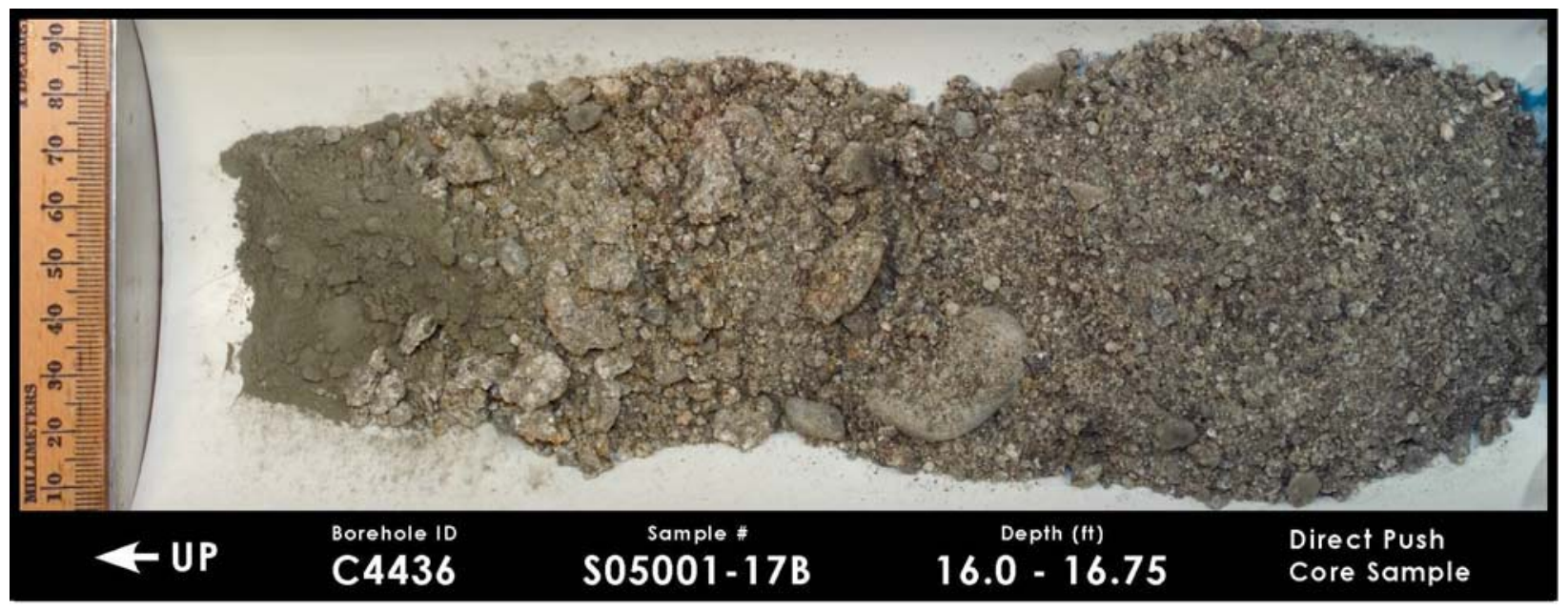

Figure A1.30. C4436 $16.0 \mathrm{ft}-16.75 \mathrm{ft}$ 


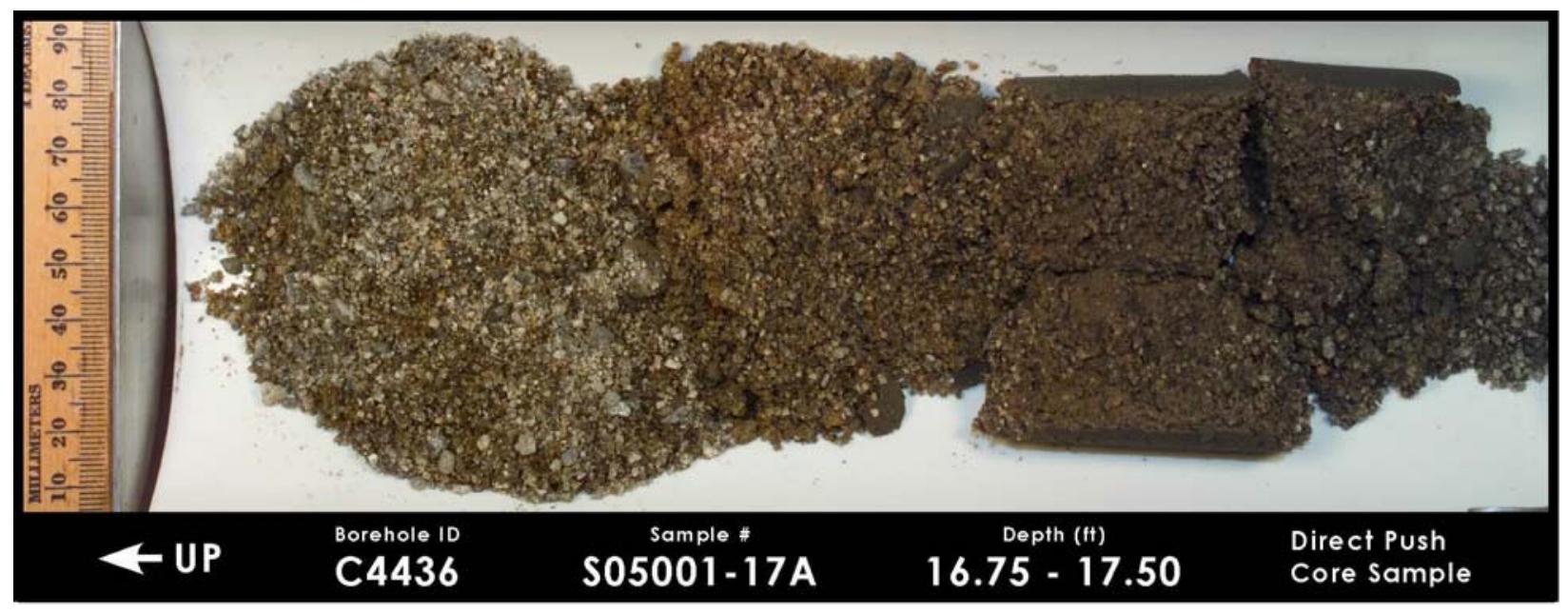

Figure A1.31. C4436 $16.75 \mathrm{ft}-17.5 \mathrm{ft}$

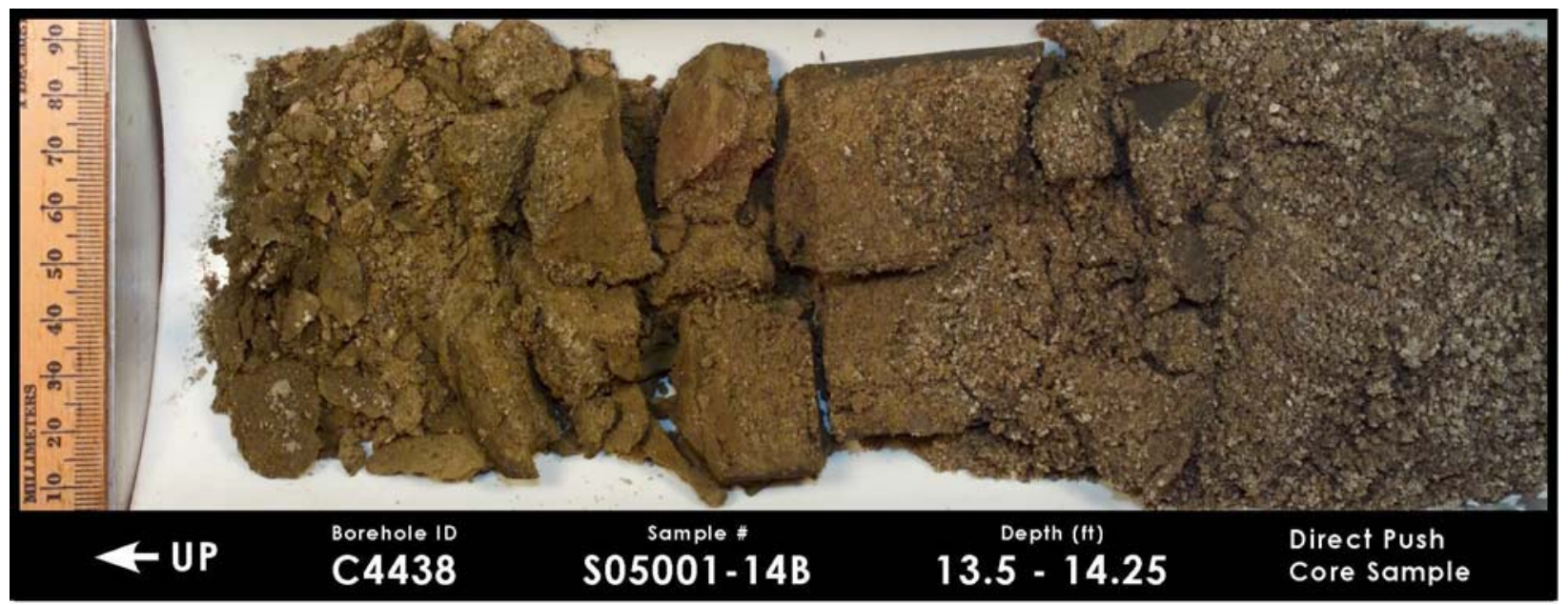

Figure A1.32. C4438 $13.5 \mathrm{ft}-14.25 \mathrm{ft}$

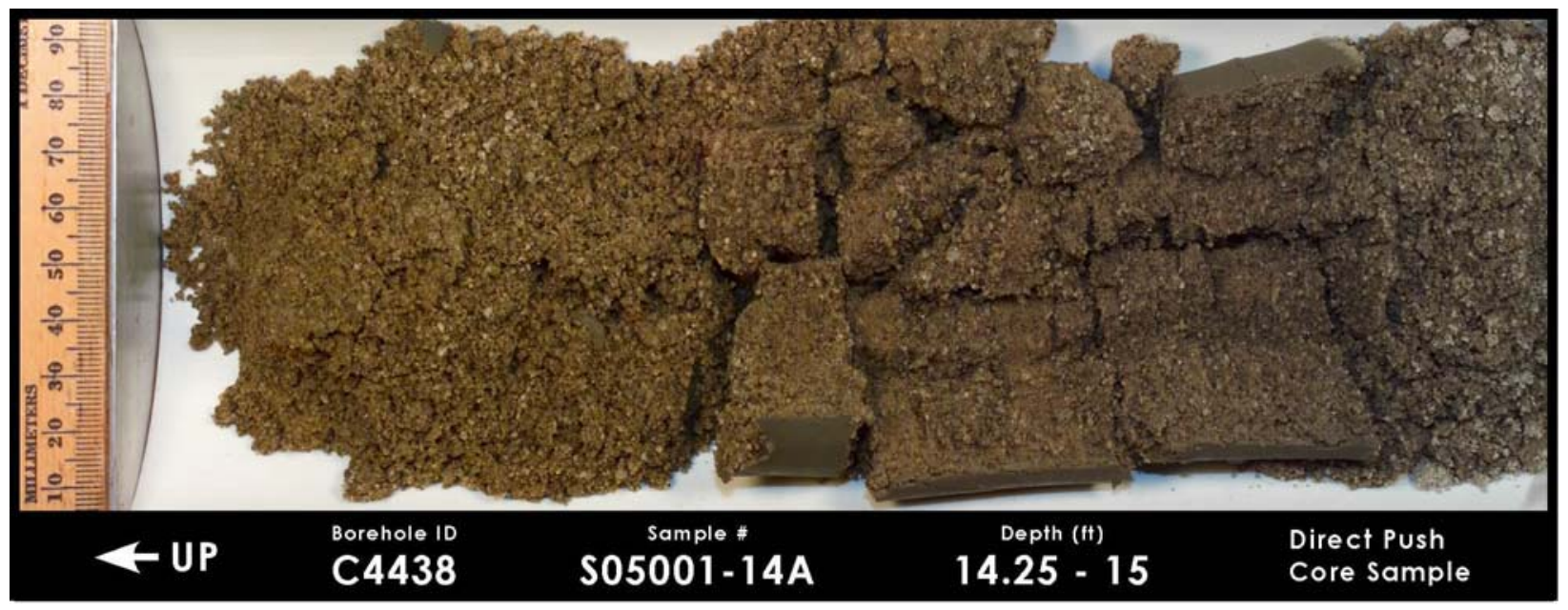

Figure A1.33. C4438 $14.25 \mathrm{ft}-15.0 \mathrm{ft}$ 


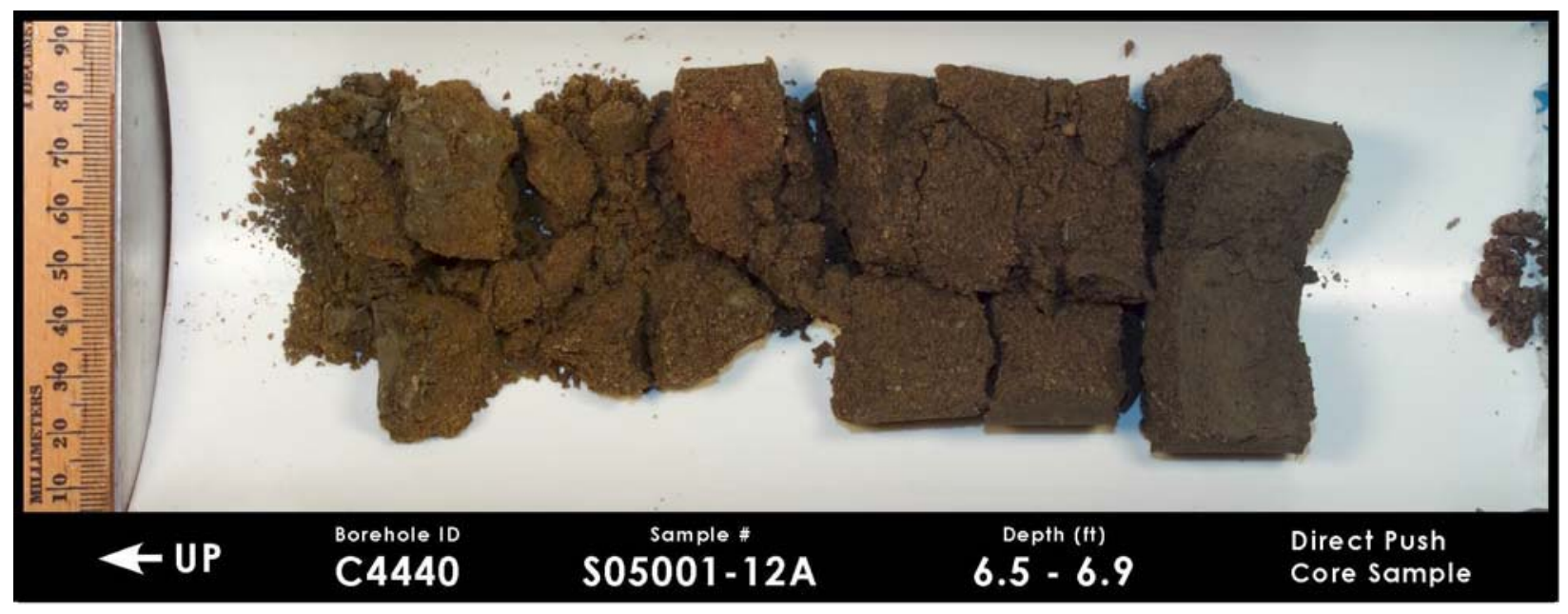

Figure A1.34. C4440 $6.5 \mathrm{ft}-6.9 \mathrm{ft}$

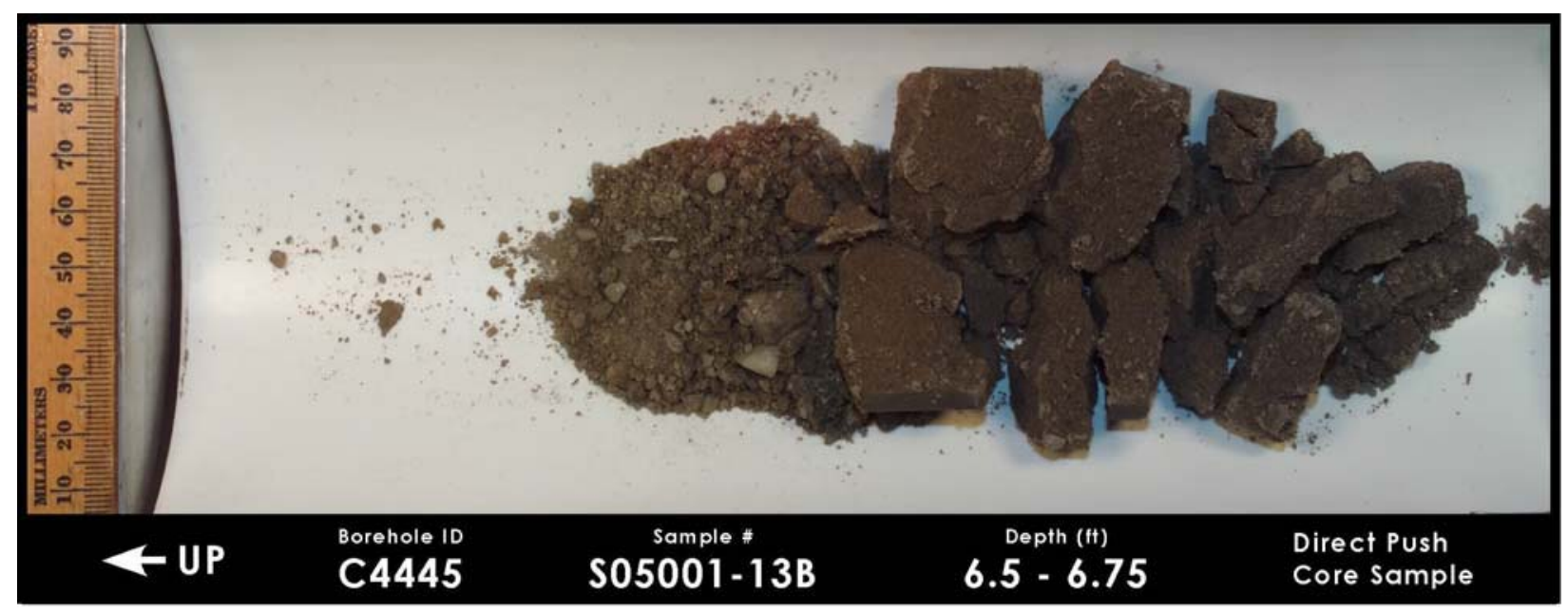

Figure A1.35. C4445 $6.5 \mathrm{ft}-6.75 \mathrm{ft}$

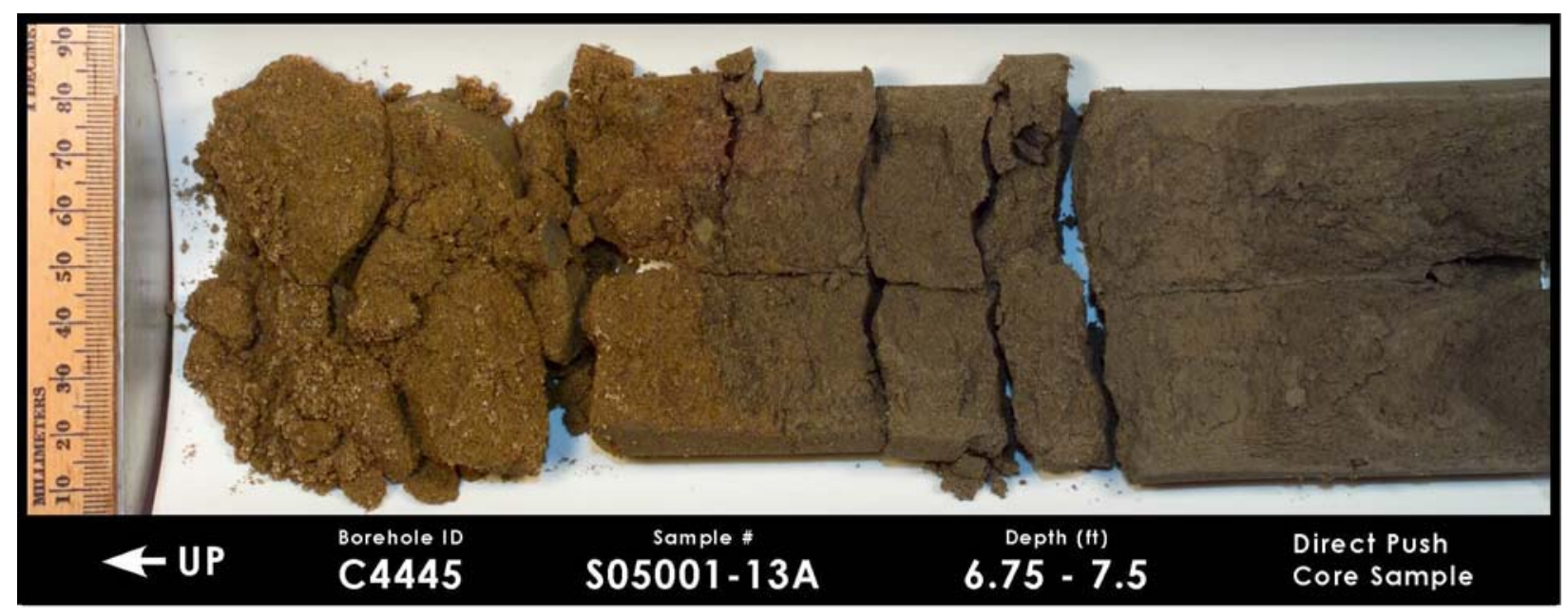

FigureA1.36. C4445 $6.75 \mathrm{ft}-7.5 \mathrm{ft}$ 


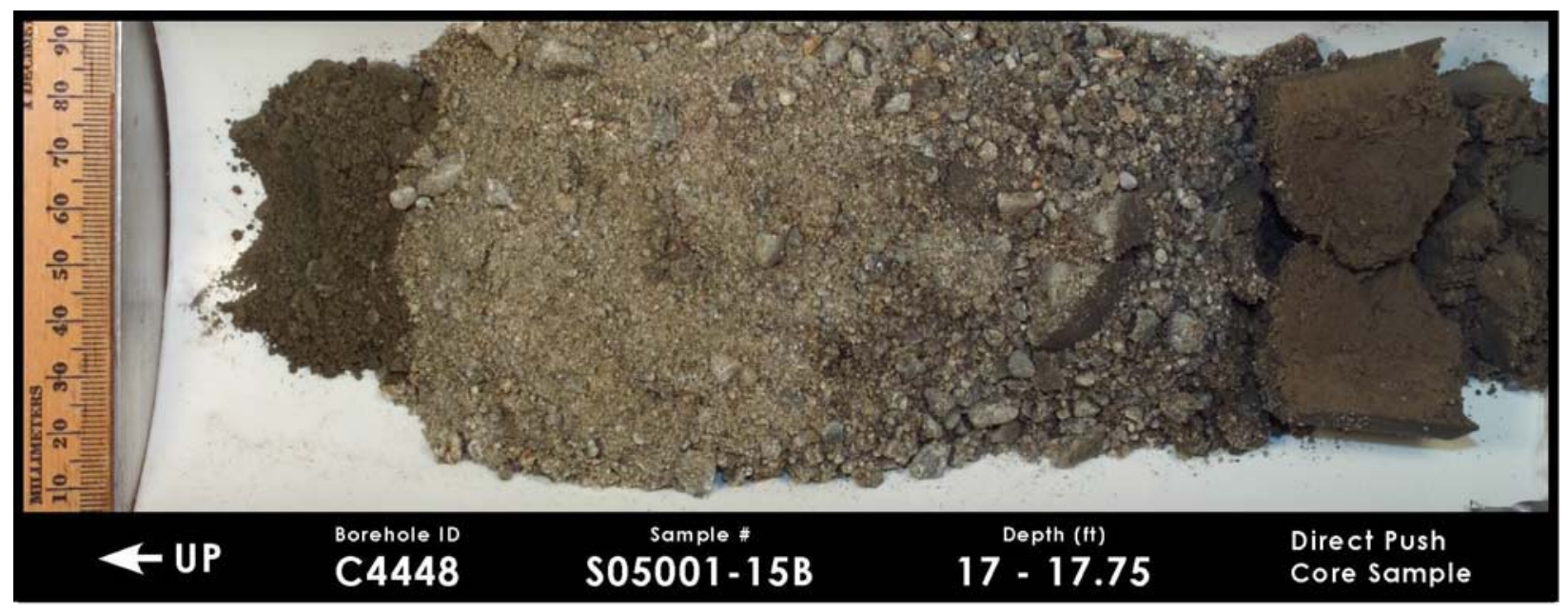

Figure A1.37. C4448 $17.0 \mathrm{ft}-17.75 \mathrm{ft}$

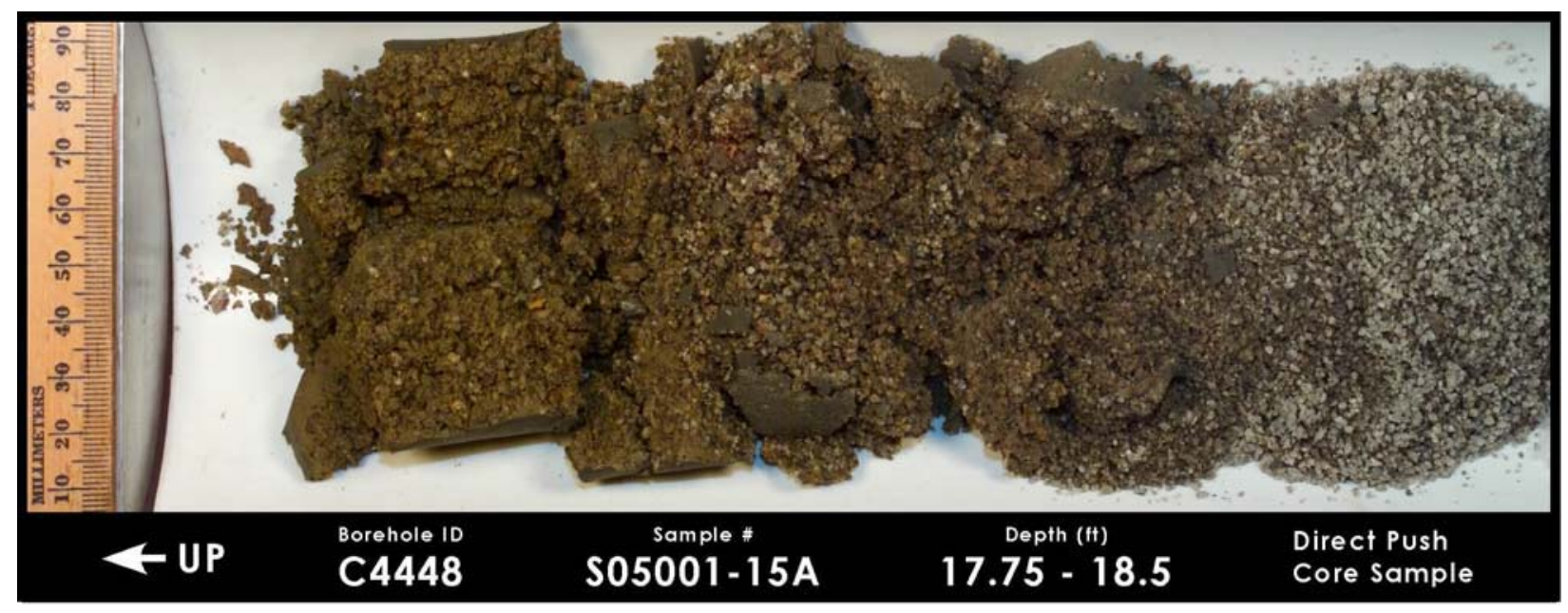

Figure A1.38. C4448 $17.75 \mathrm{ft}-18.5 \mathrm{ft}$ 
Appendix A2. Photographs of Samples from the C-152 Slant Probe Holes

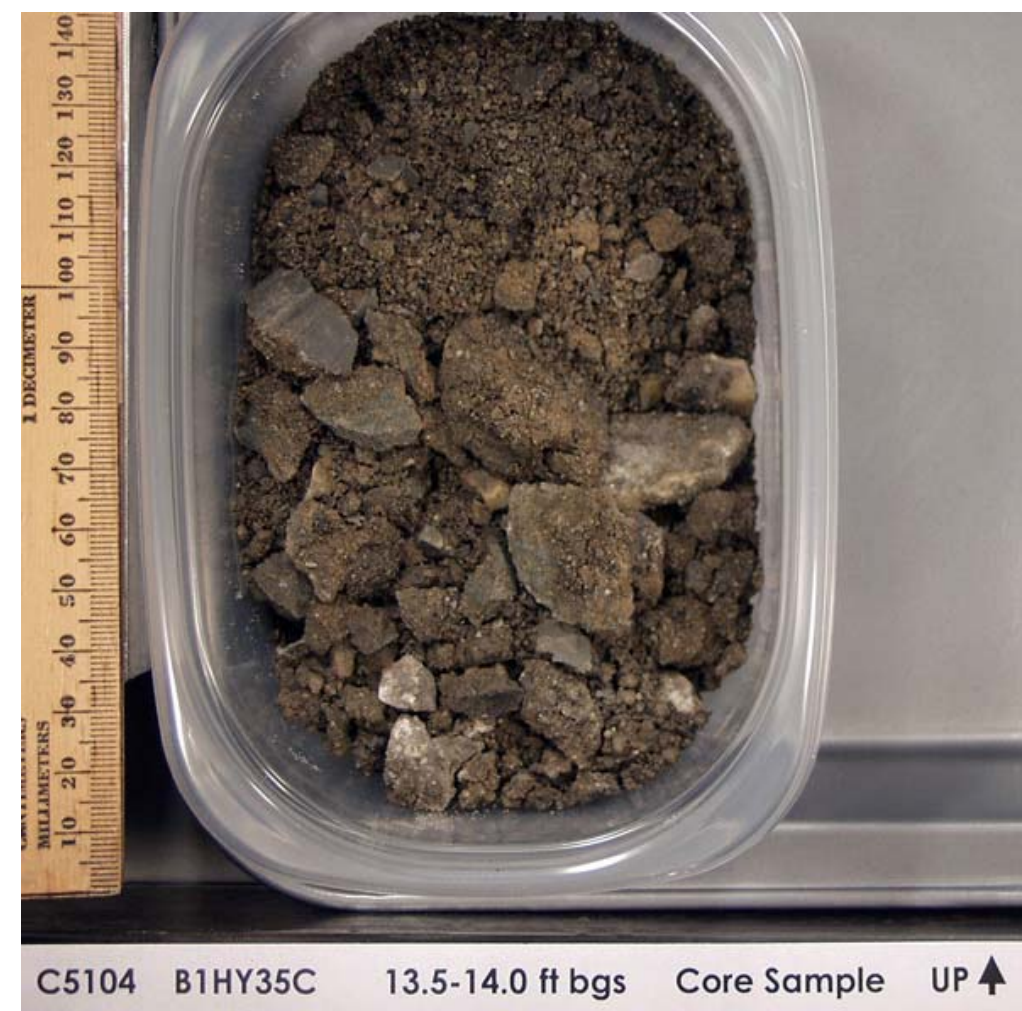

Figure A2.1. C5104 $13.5 \mathrm{ft}-14.0 \mathrm{ft}$

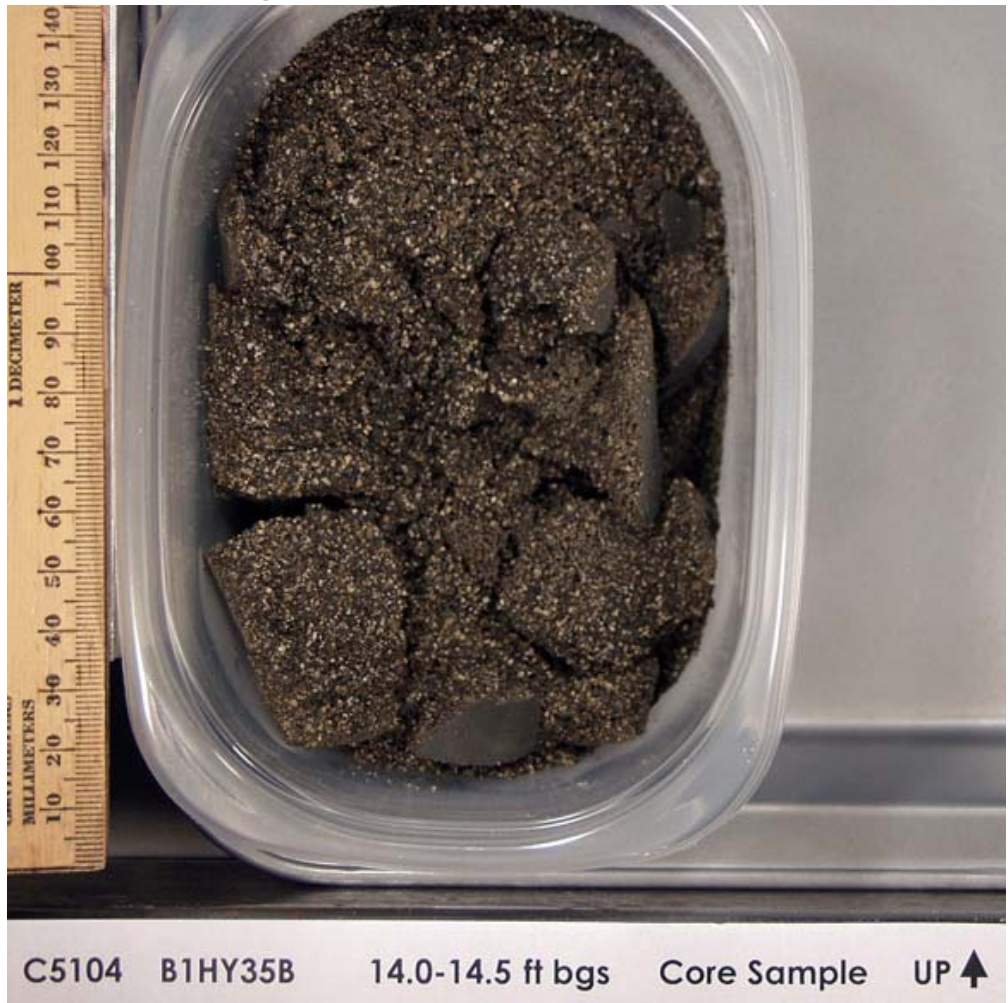

Figure A2.2. C5104 $14.0 \mathrm{ft}-14.5 \mathrm{ft}$ 


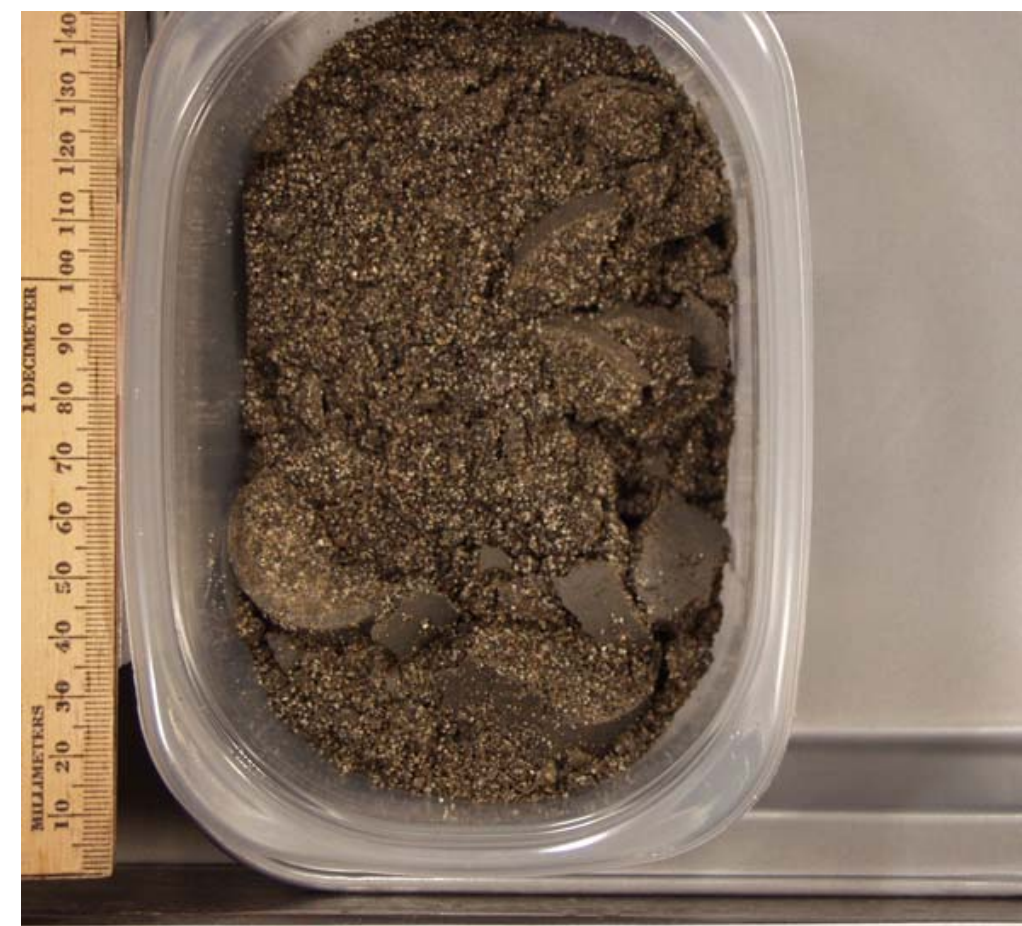

\section{C5104 B1нY35A $14.5-15.0 \mathrm{ft}$ bgs Core Sample UP $\mathbf{A}$}

Figure A2.3. C5104 $14.5 \mathrm{ft}-15.0 \mathrm{ft}$

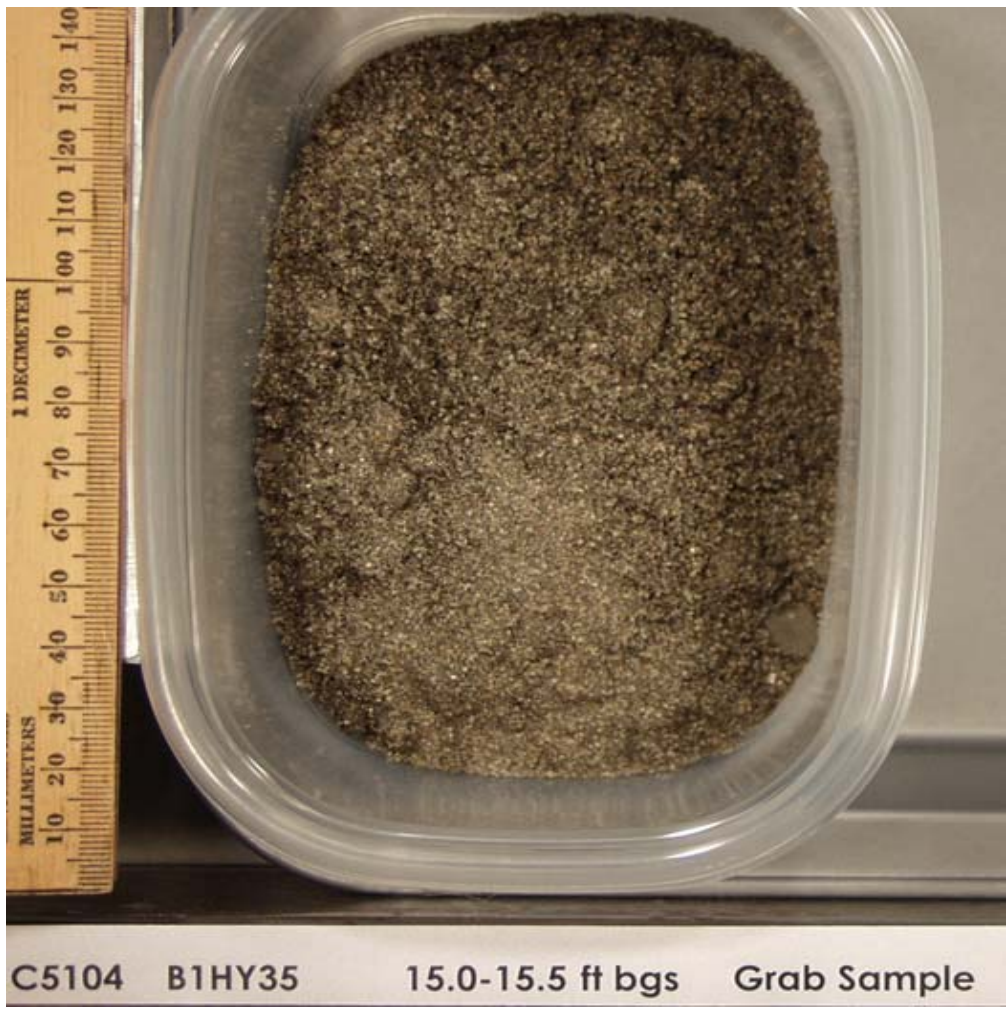

Figure A2.4. C5104 $15.0 \mathrm{ft}-15.5 \mathrm{ft}$ 


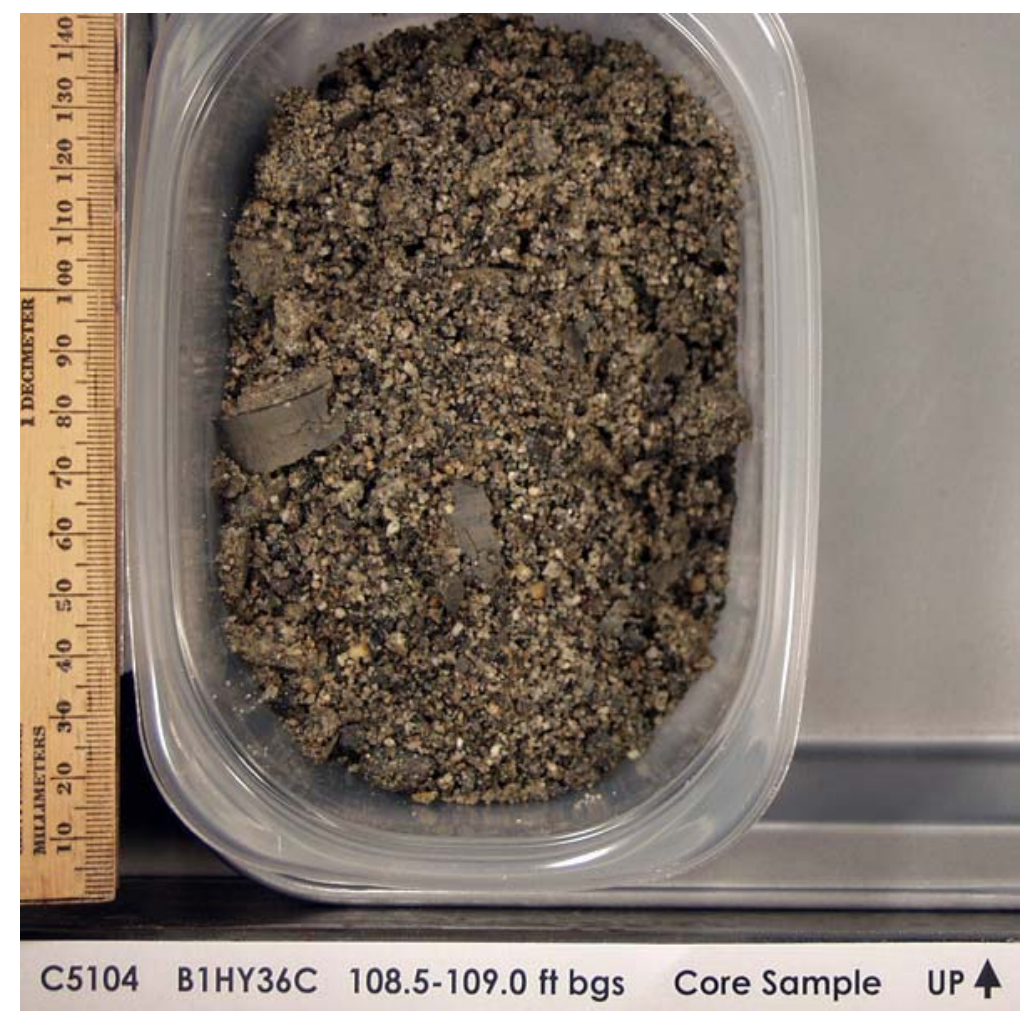

Figure A2.5. C5104 $108.5 \mathrm{ft}-109.0 \mathrm{ft}$

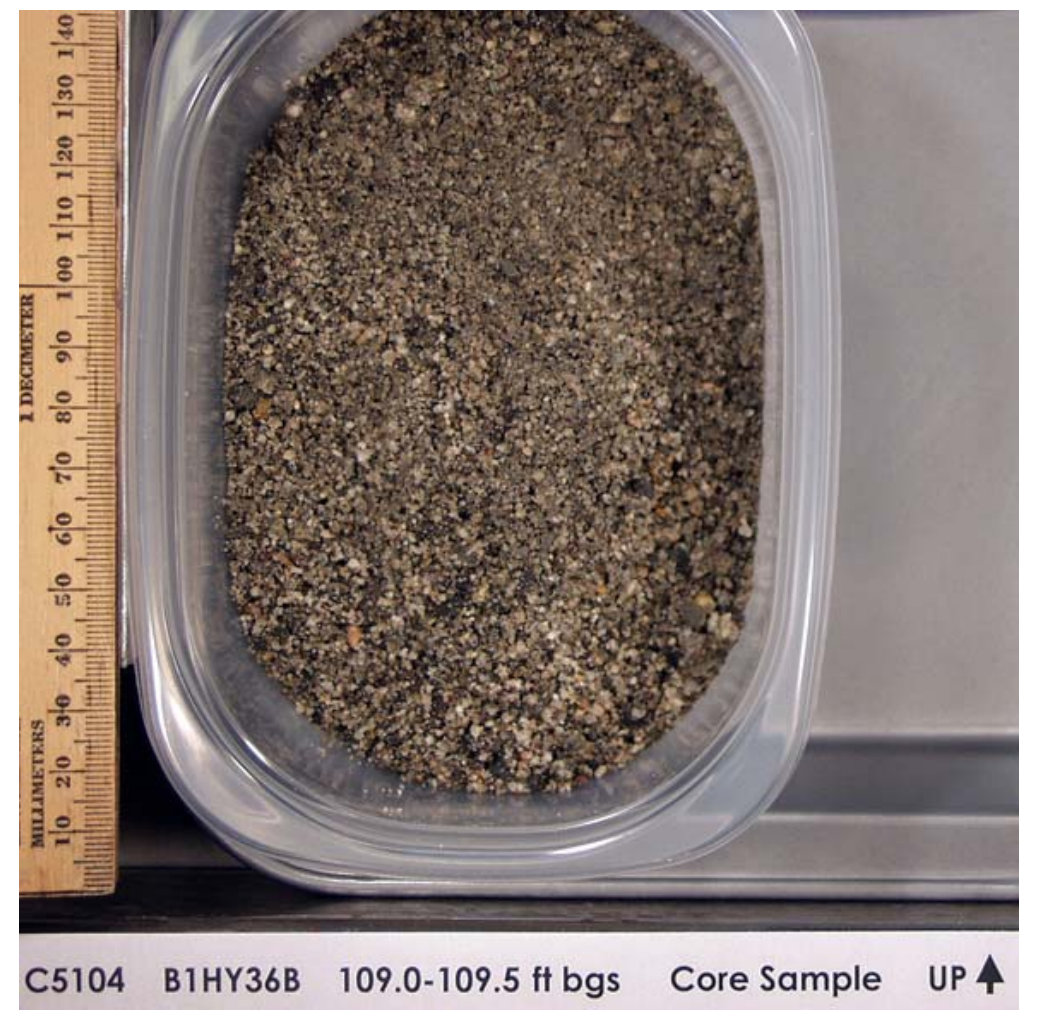

Figure A2.6. C5104 $109.0 \mathrm{ft}-109.5 \mathrm{ft}$ 


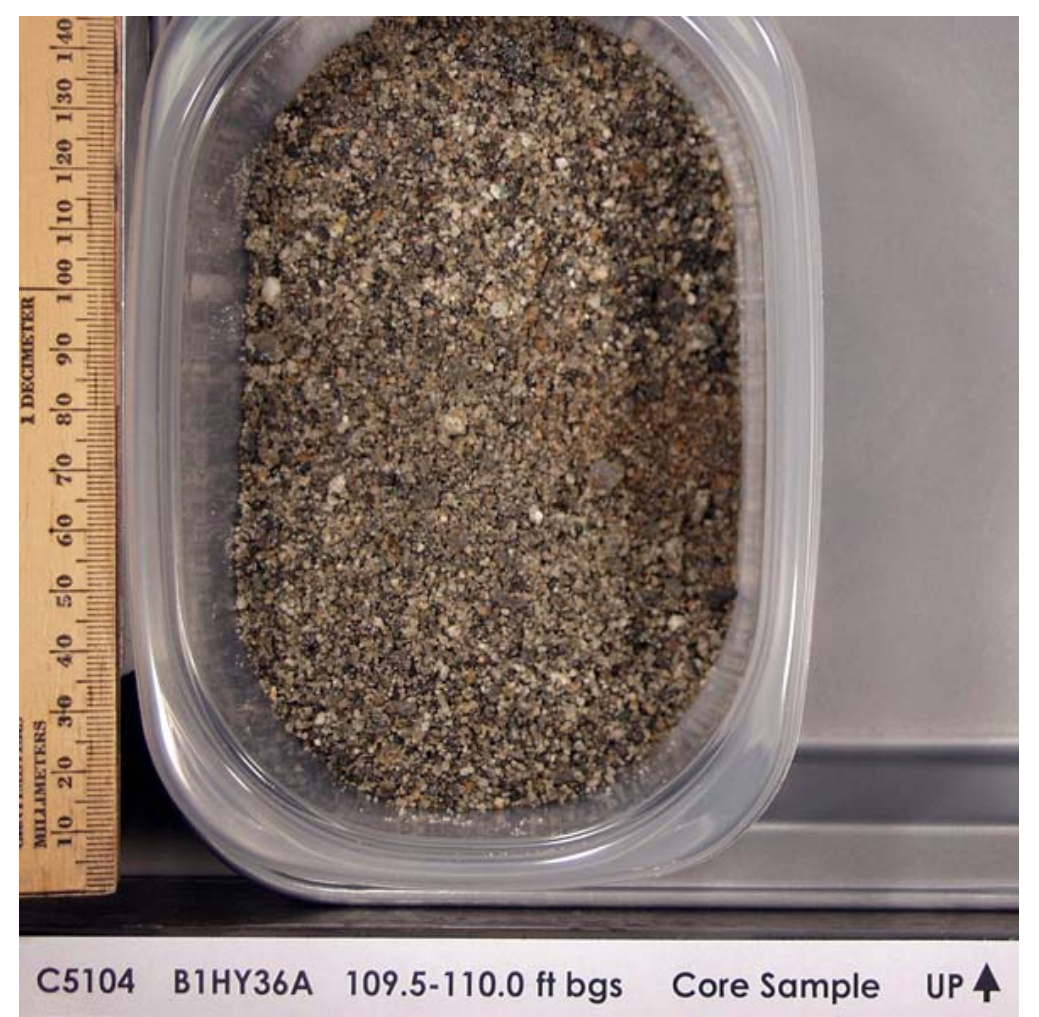

Figure A2.7. C5104 109.5 ft $-110.0 \mathrm{ft}$

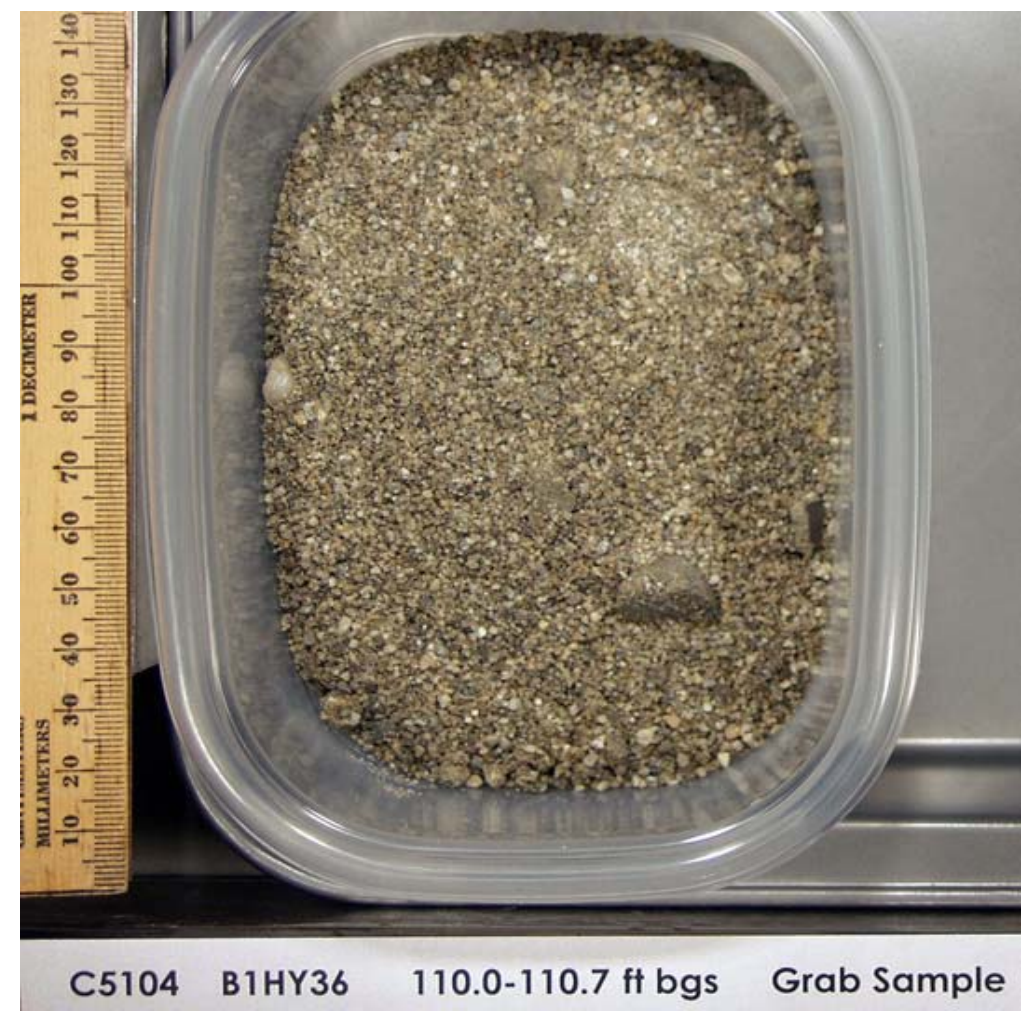

Figure A2.8. C5104 $110.0 \mathrm{ft}-110.7 \mathrm{ft}$ 


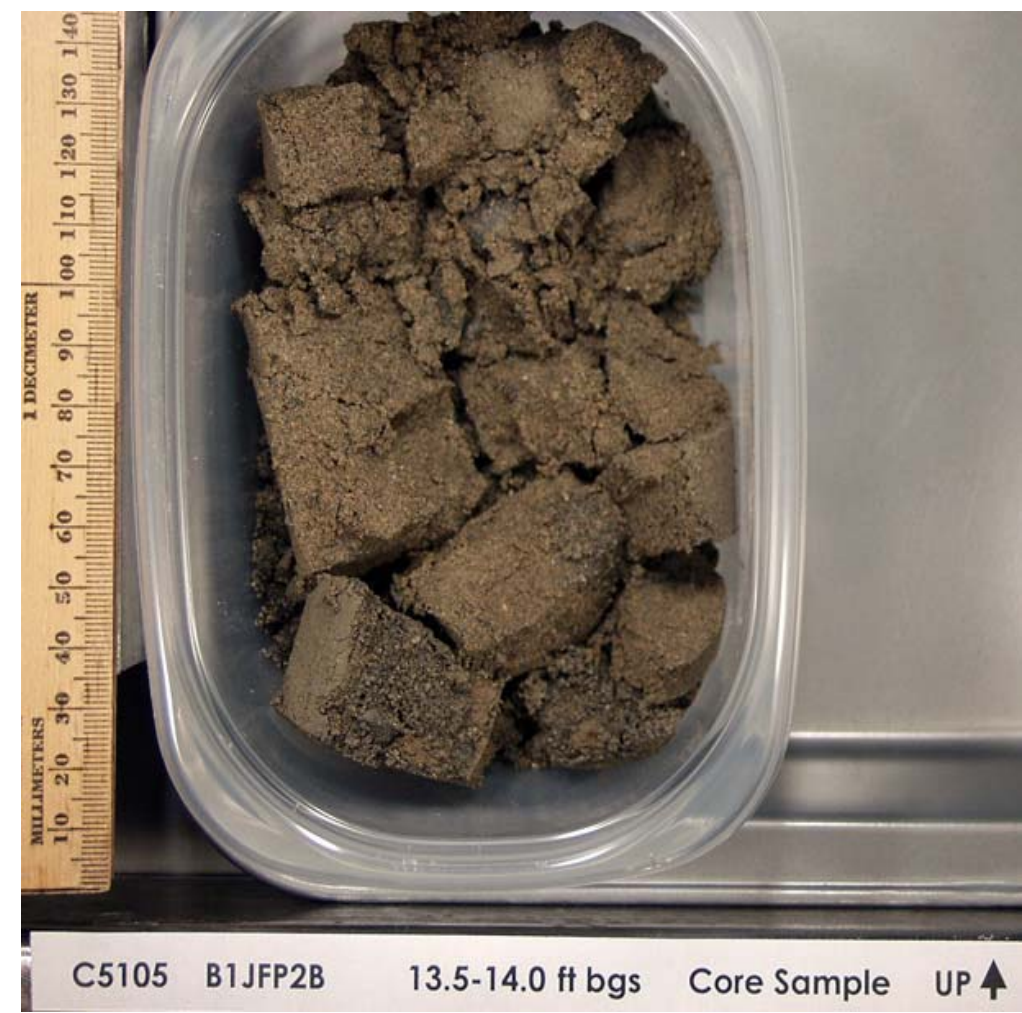

Figure A2.9. C5105 $13.5 \mathrm{ft}-14.0 \mathrm{ft}$

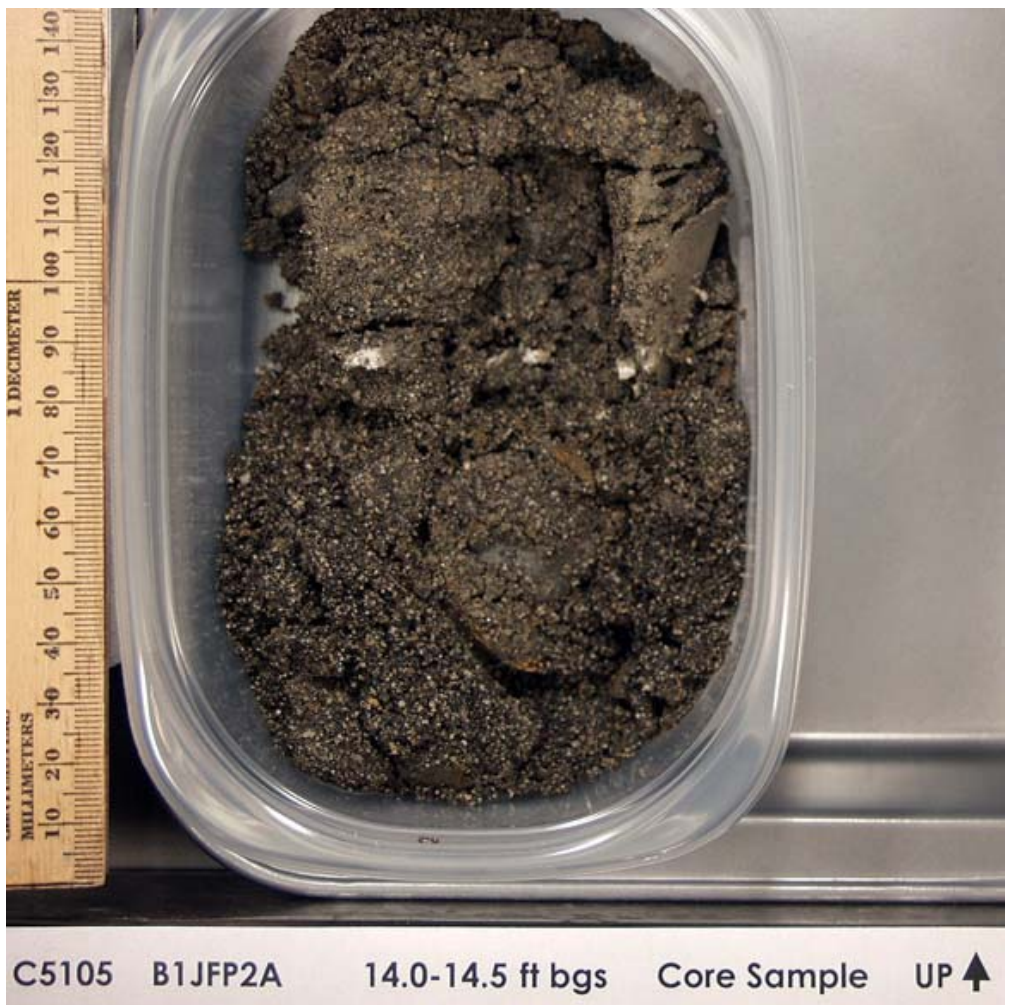

Figure A2.10. C5105 $14.0 \mathrm{ft}-14.5 \mathrm{ft}$ 


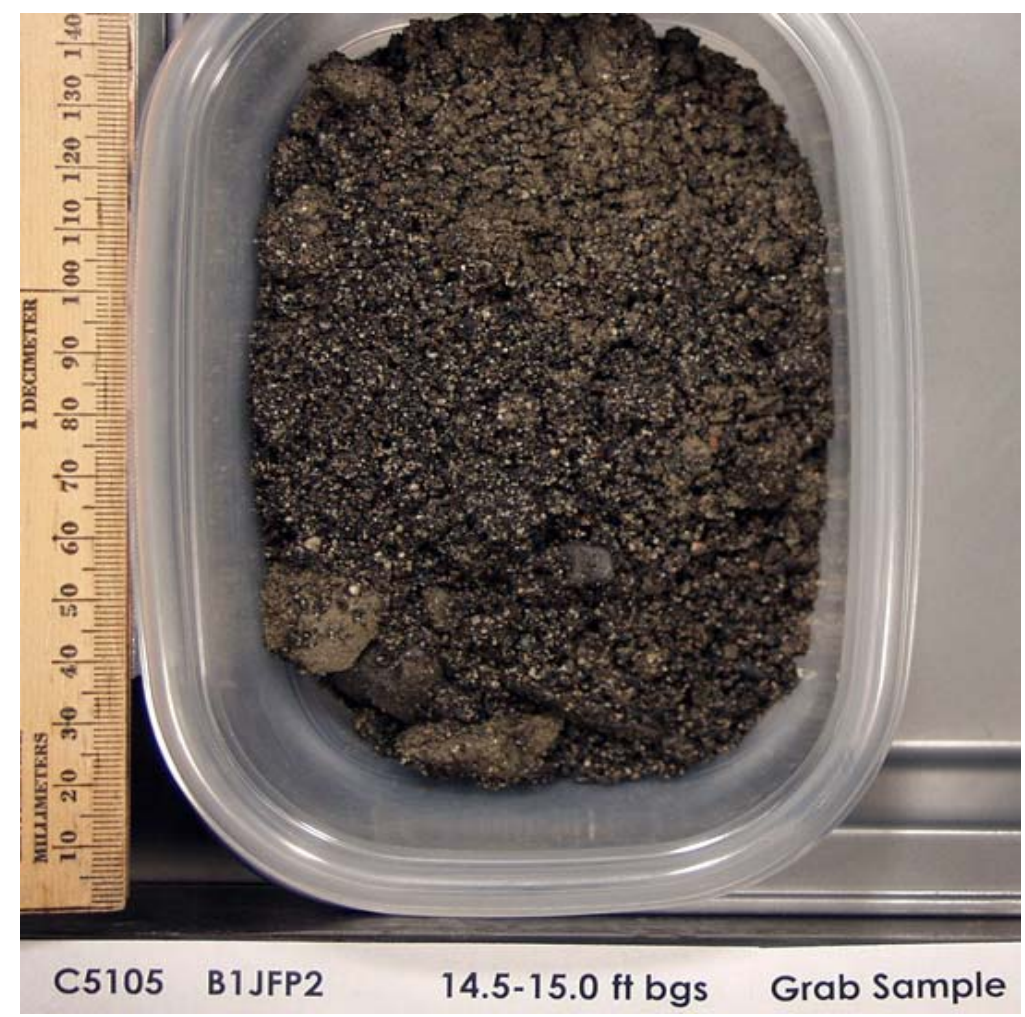

Figure A2.11. C5105 $14.5 \mathrm{ft}-15.0 \mathrm{ft}$

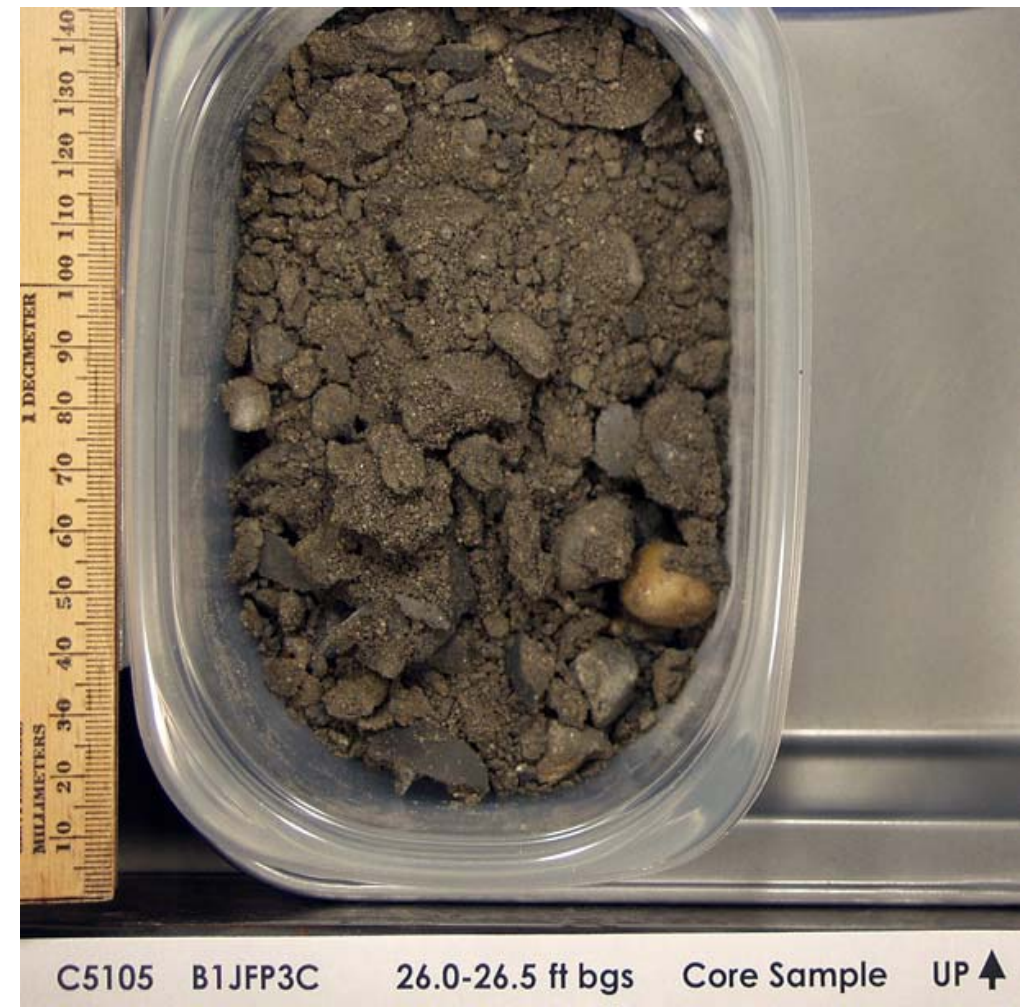

Figure A2.12. C5105 $26.0 \mathrm{ft}-26.5 \mathrm{ft}$ 


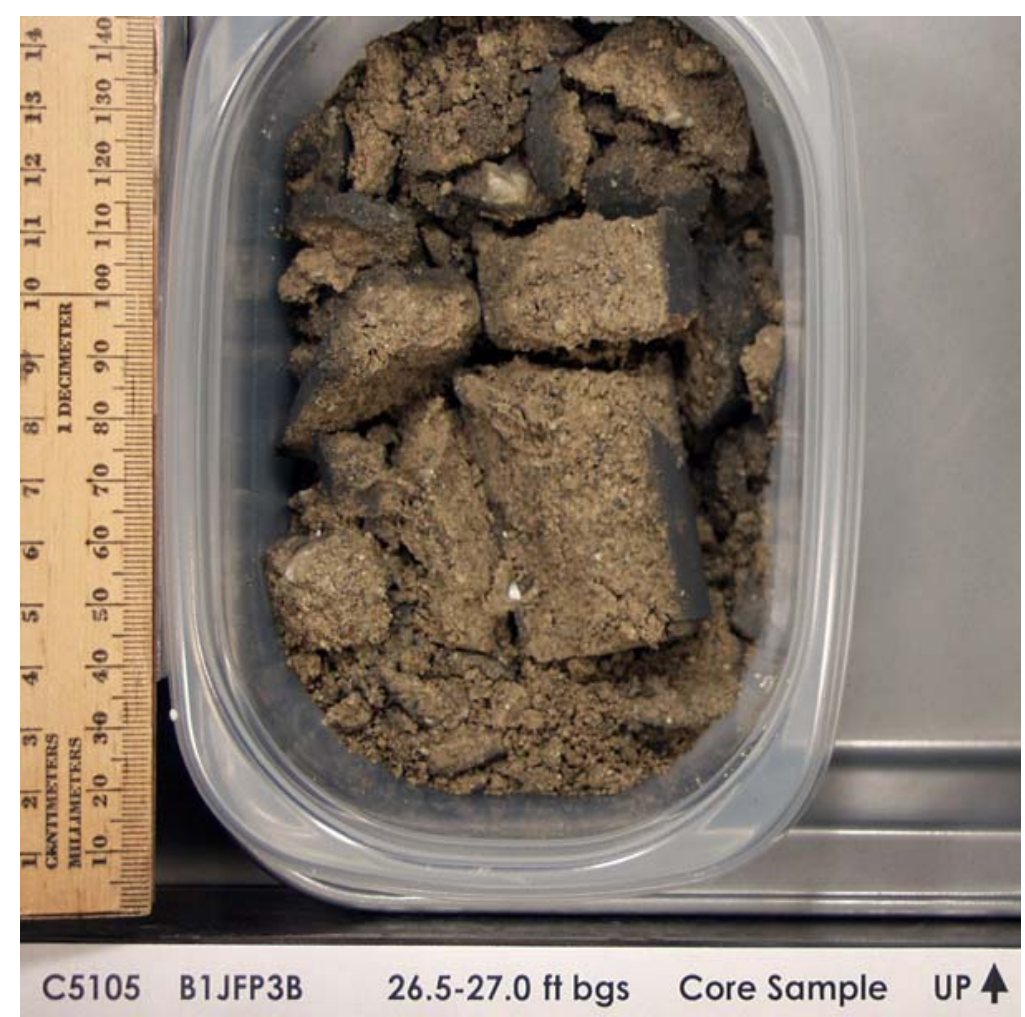

Figure A2.13. C5105 $26.5 \mathrm{ft}-27.0 \mathrm{ft}$

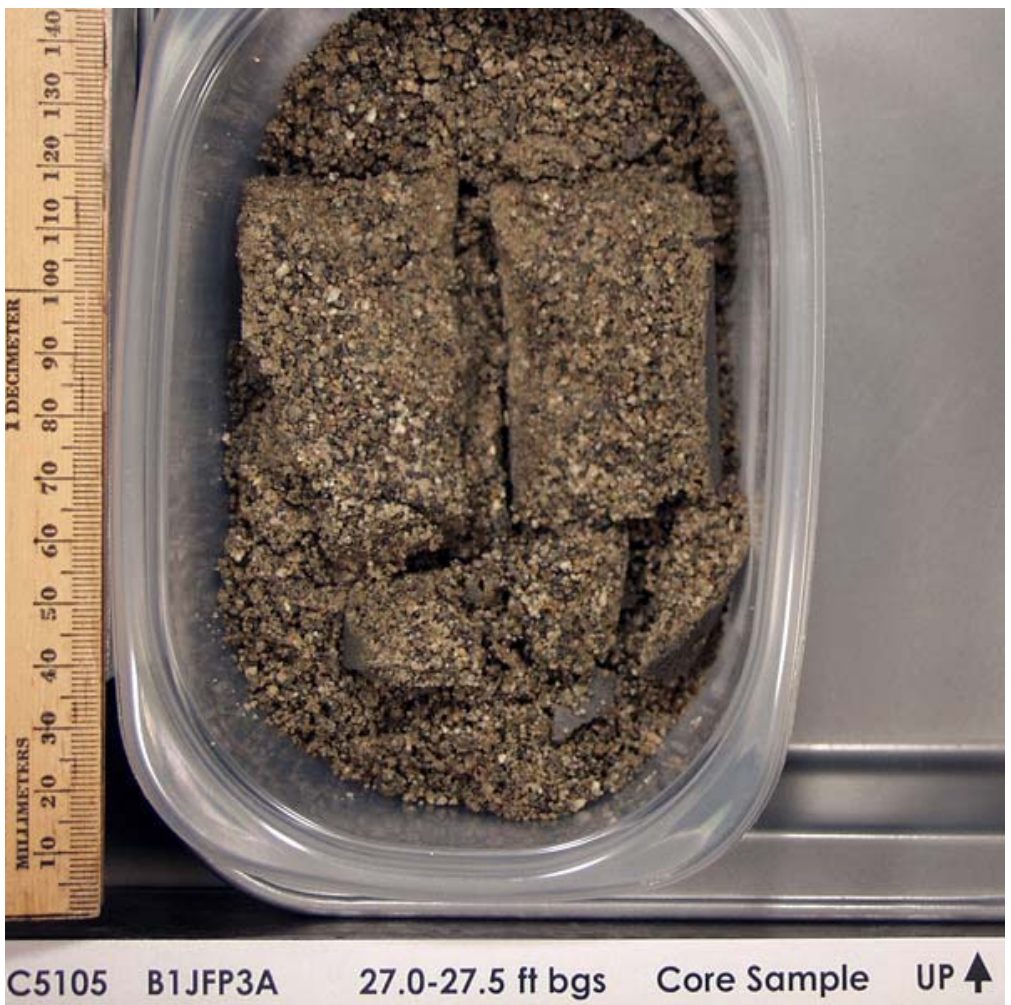

Figure A2.14. C5105 27.0 ft $-27.5 \mathrm{ft}$ 


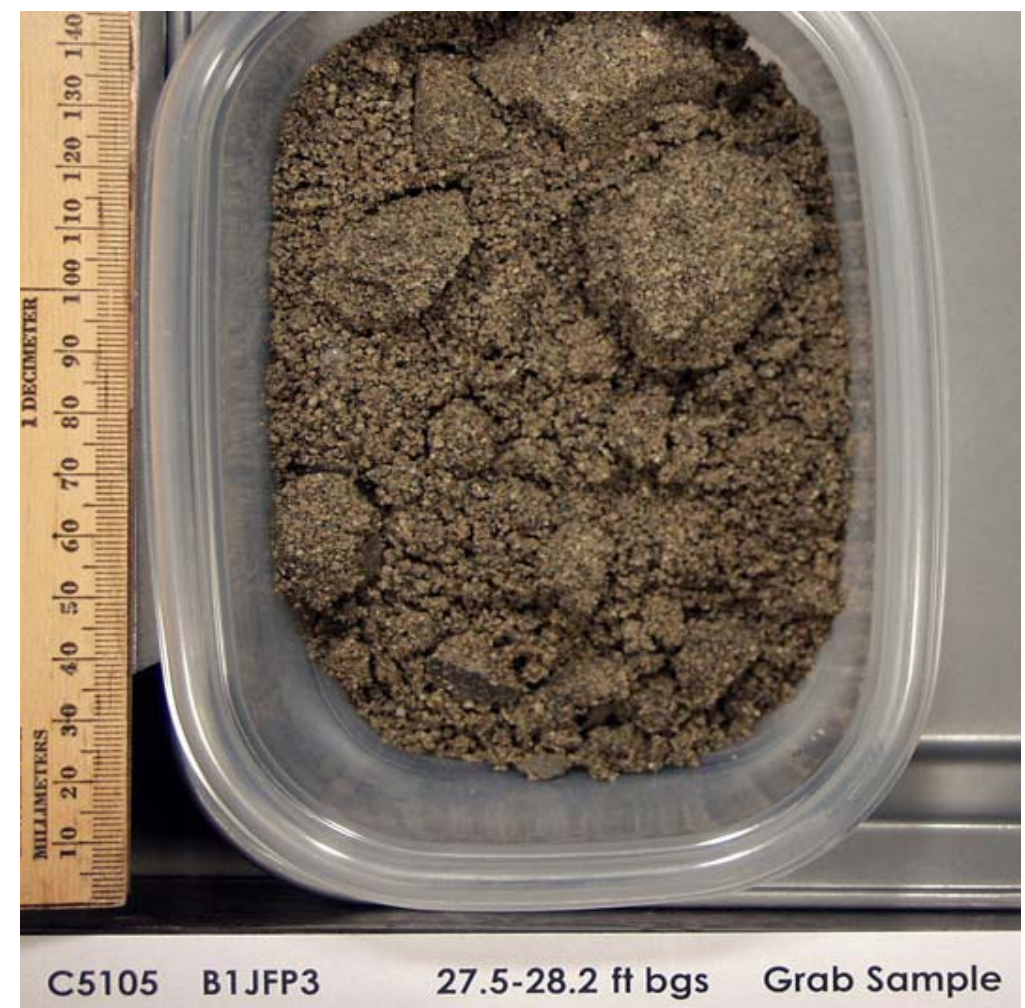

FigureA2.15. C5105 $27.5 \mathrm{ft}-28.2 \mathrm{ft}$

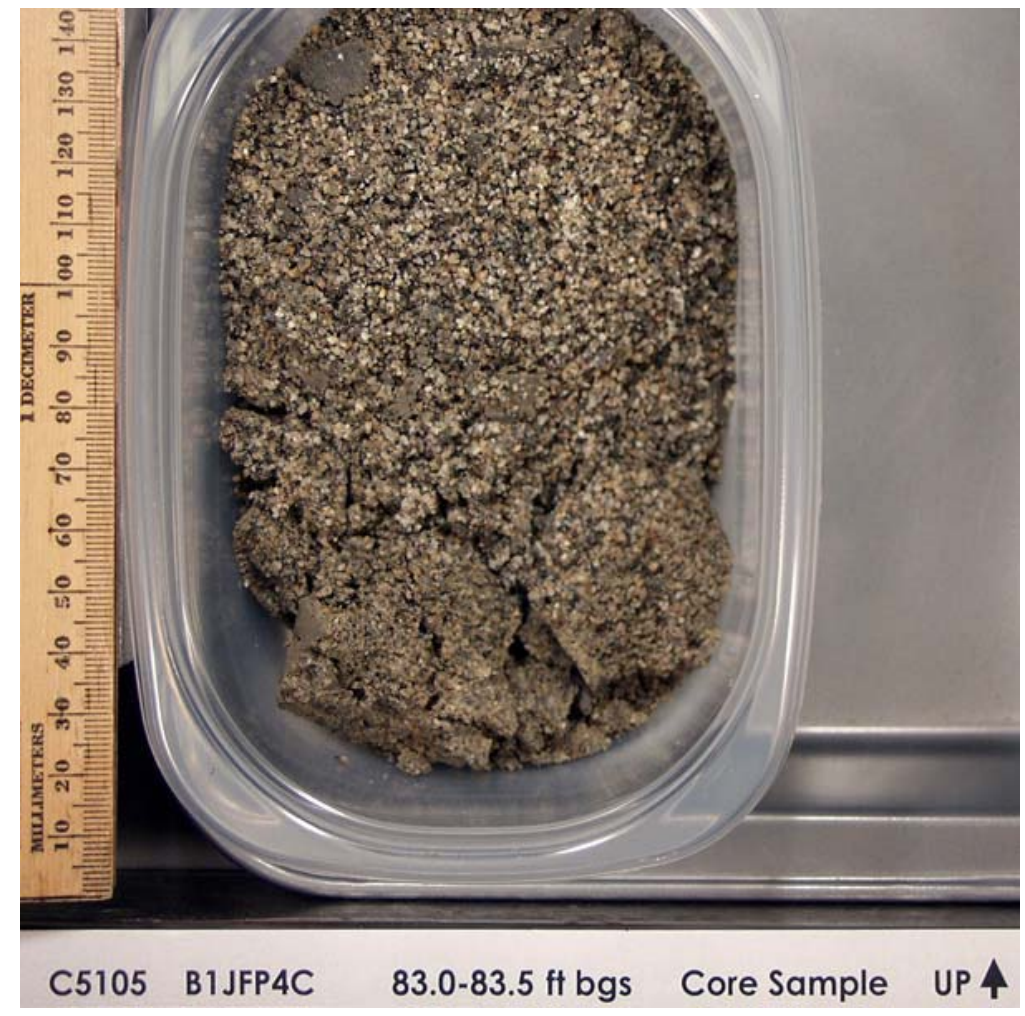

Figure A2.16. C5105 $83.0 \mathrm{ft}-83.5 \mathrm{ft}$ 


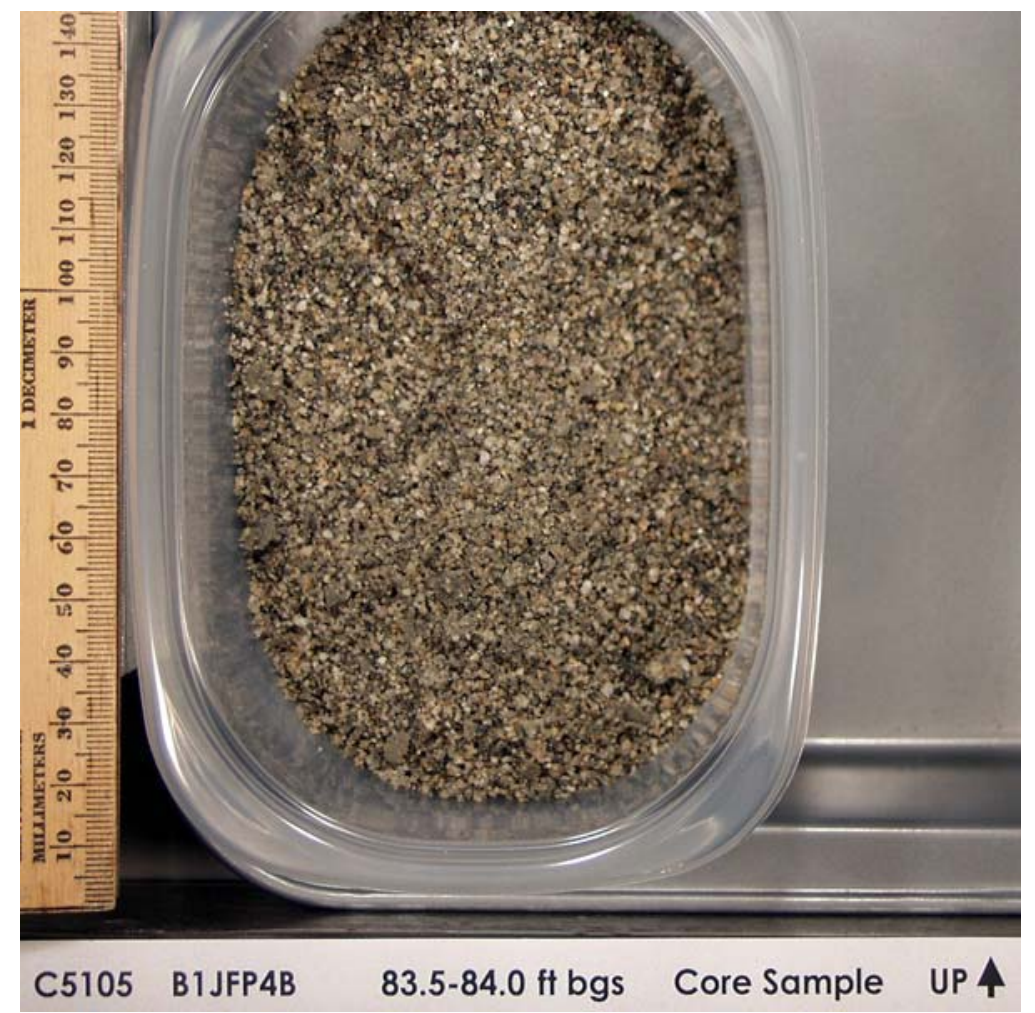

Figure A2.17. C5105 $83.5 \mathrm{ft}-84.0 \mathrm{ft}$

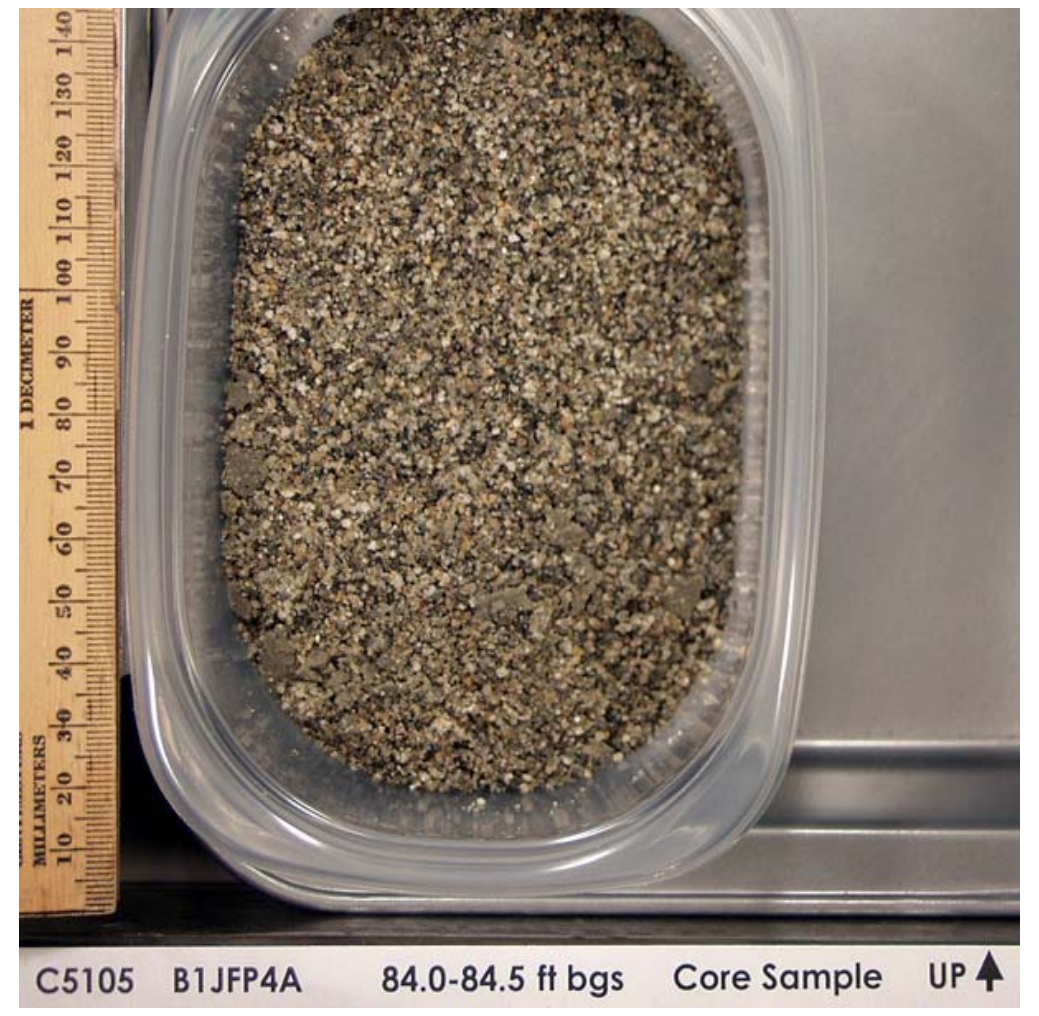

Figure A2.18. C510584.0 ft $-84.5 \mathrm{ft}$ 


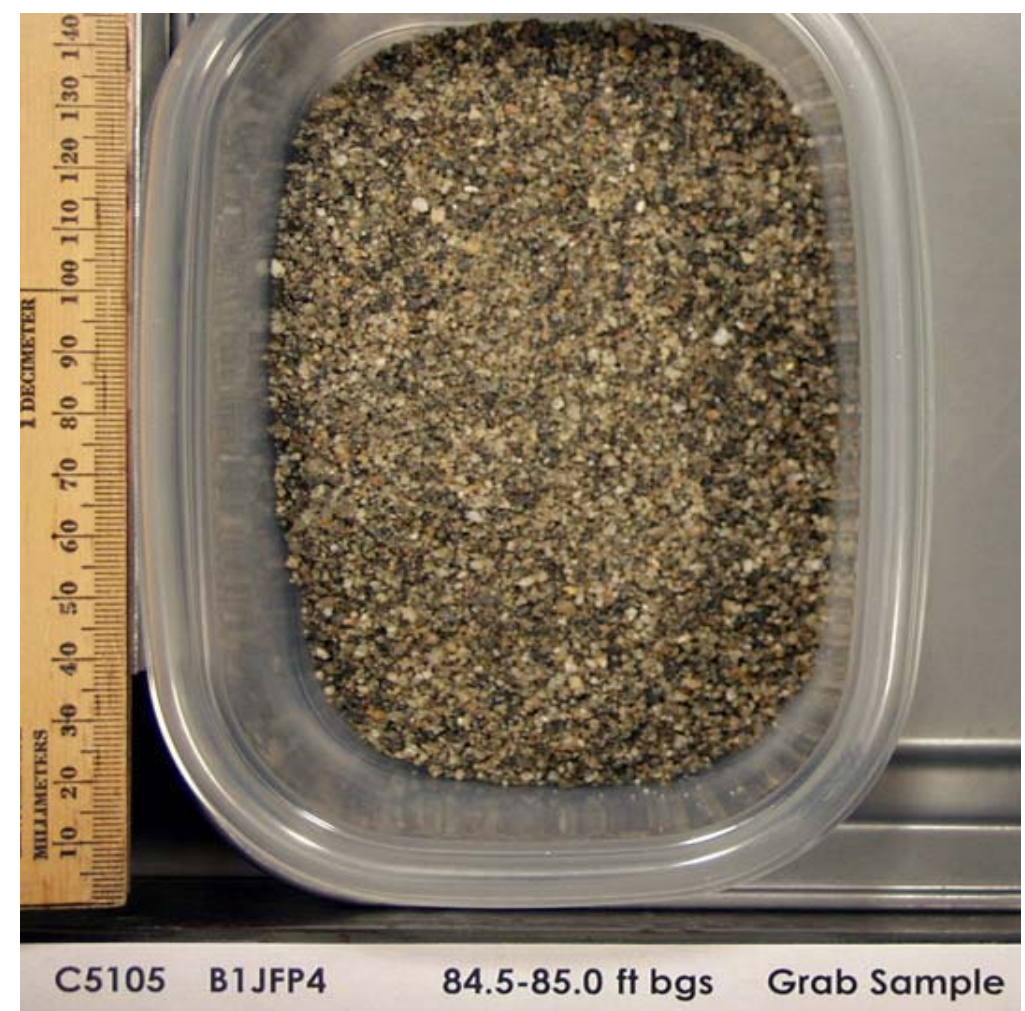

Figure A2.19. C5105 $84.5 \mathrm{ft}-85.0 \mathrm{ft}$

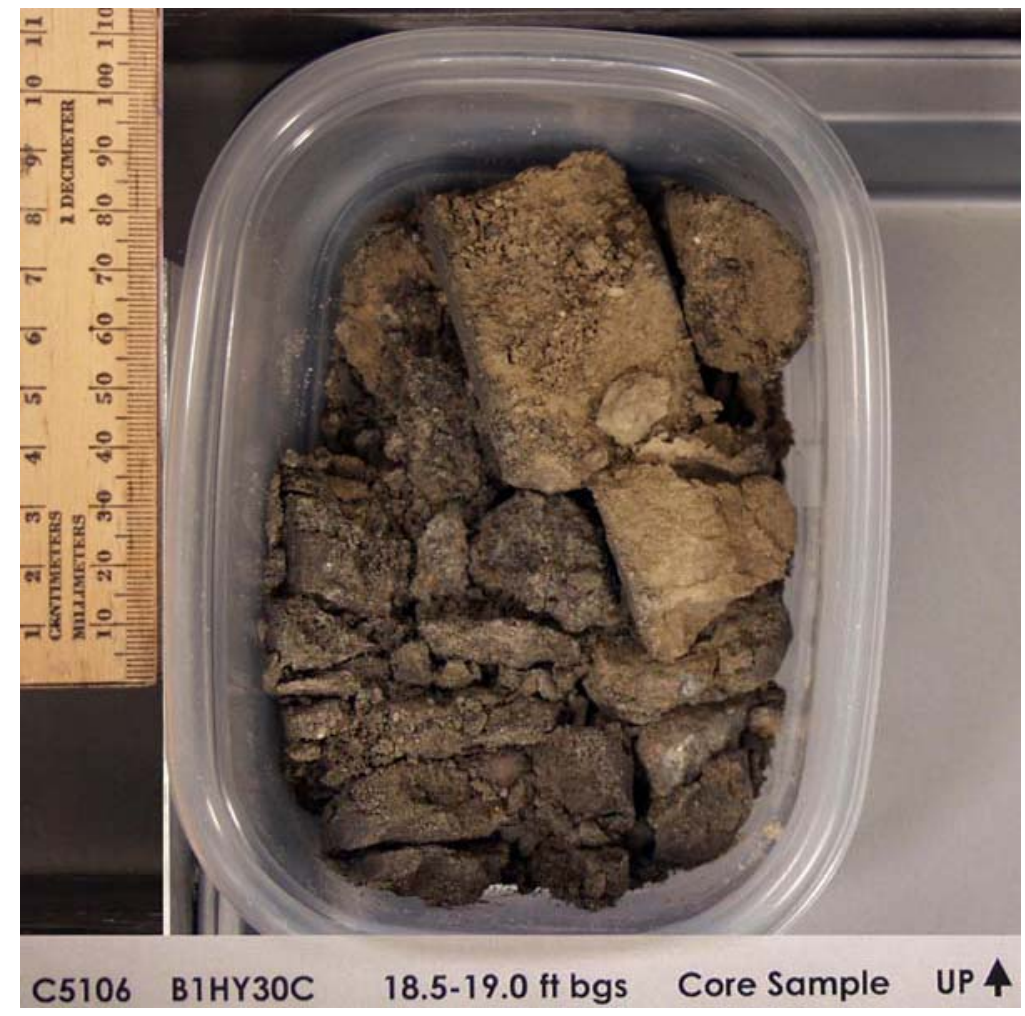

Figure A2.20. C5106 $18.5 \mathrm{ft}-19.0 \mathrm{ft}$ 


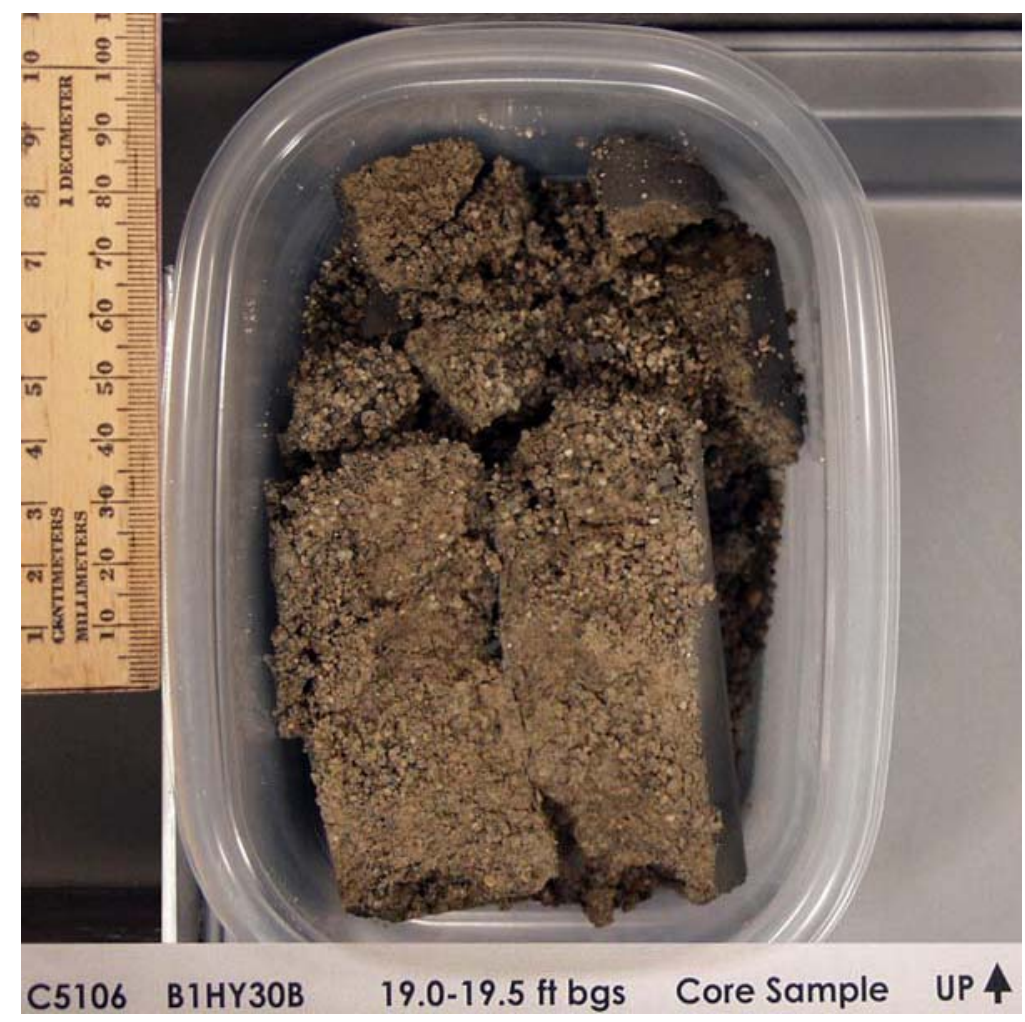

Figure A2.21. C5106 $19.0 \mathrm{ft}-19.5 \mathrm{ft}$

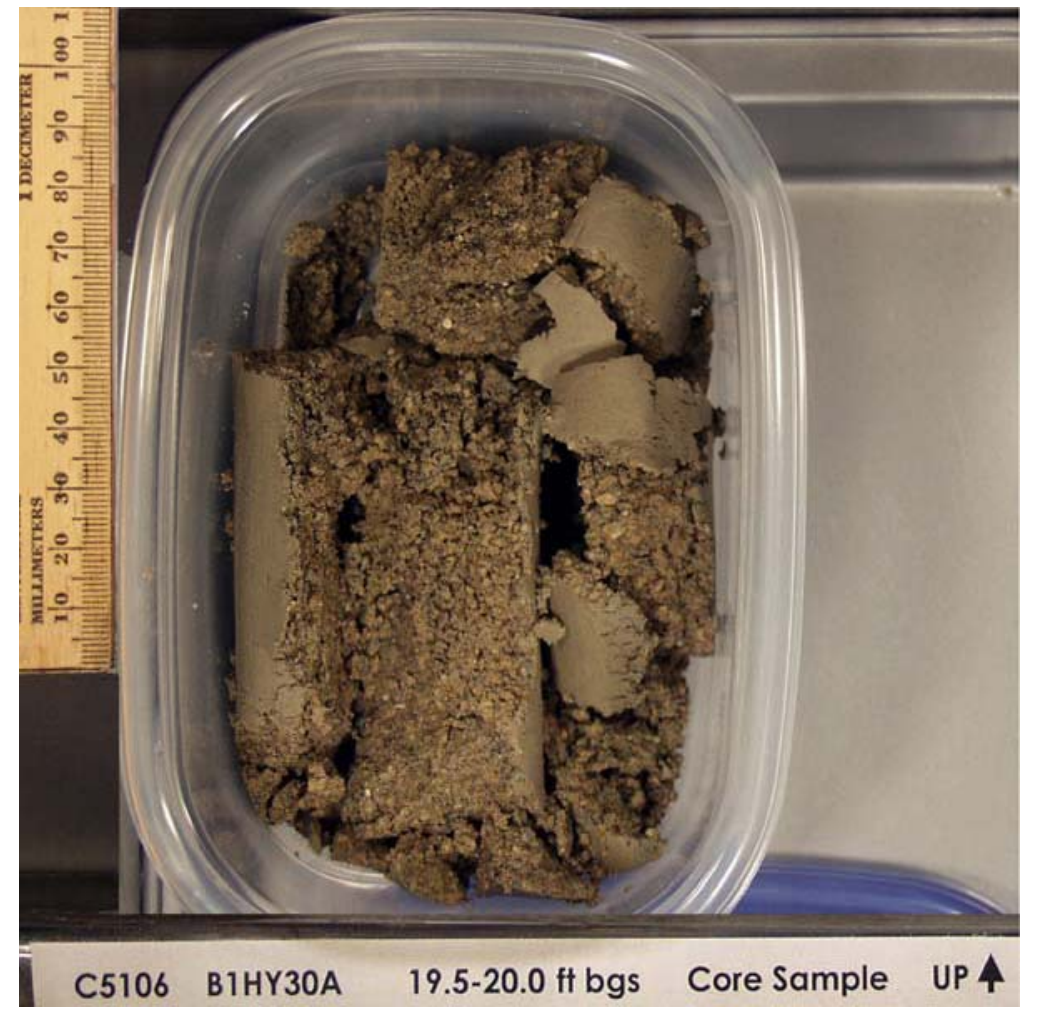

Figure A2.22. C5106 $19.5 \mathrm{ft}-20.0 \mathrm{ft}$ 


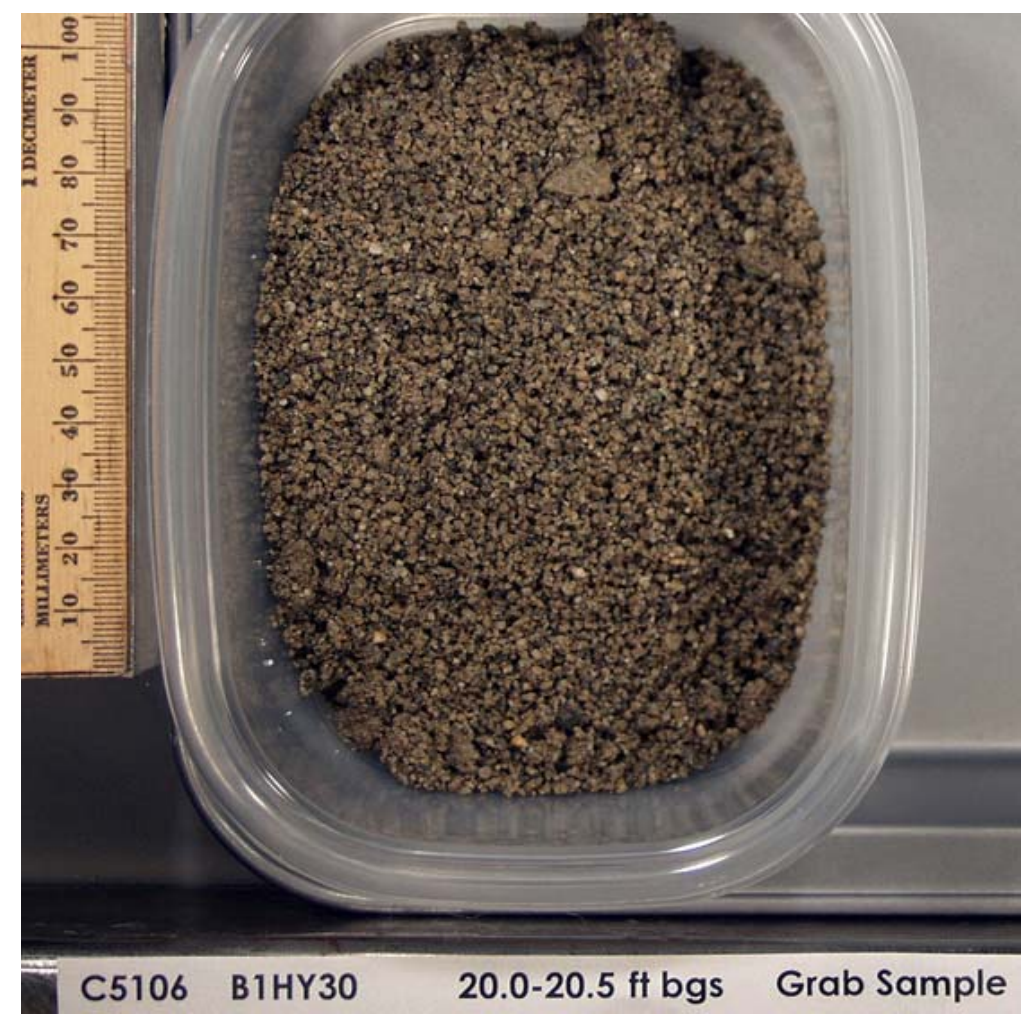

Figure A2.23. C5106 $20.0 \mathrm{ft}-20.5 \mathrm{ft}$

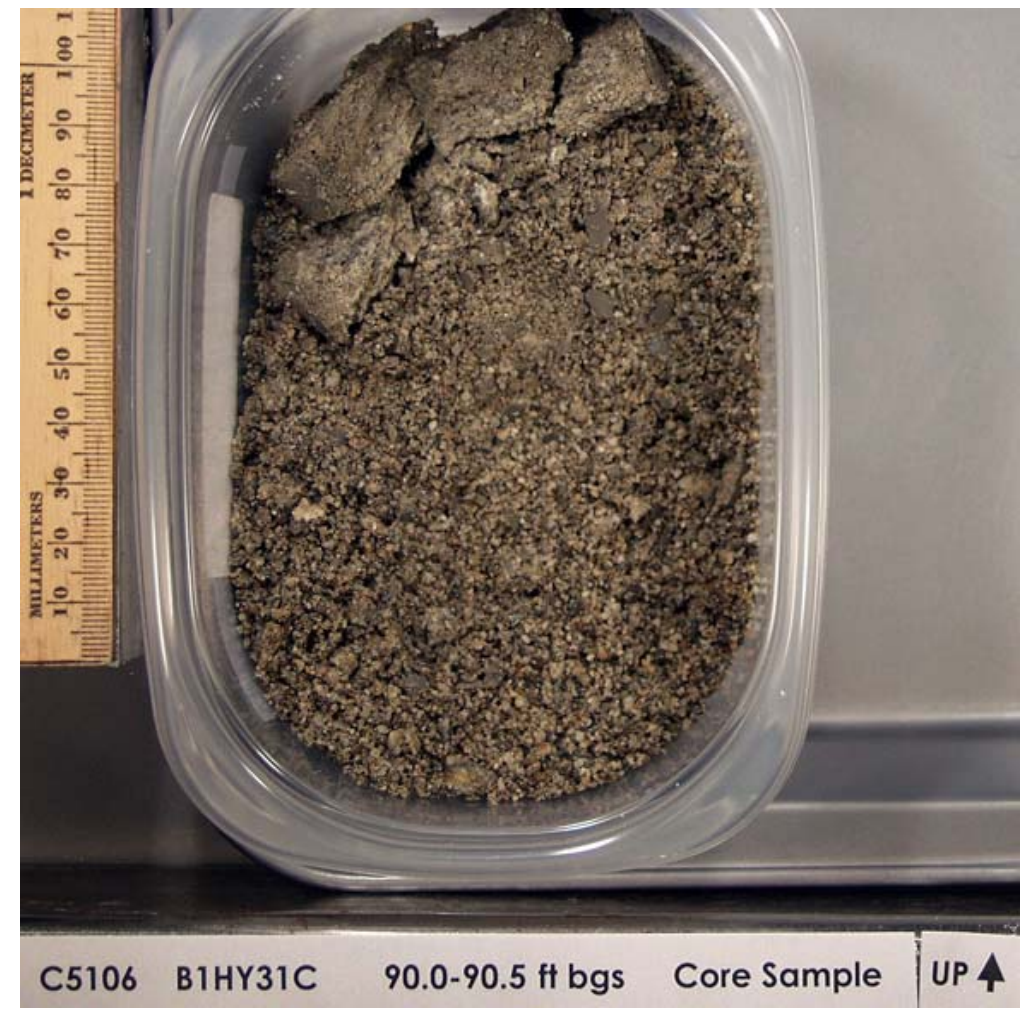

Figure A2.24. C5106 $90.0 \mathrm{ft}-90.5 \mathrm{ft}$ 


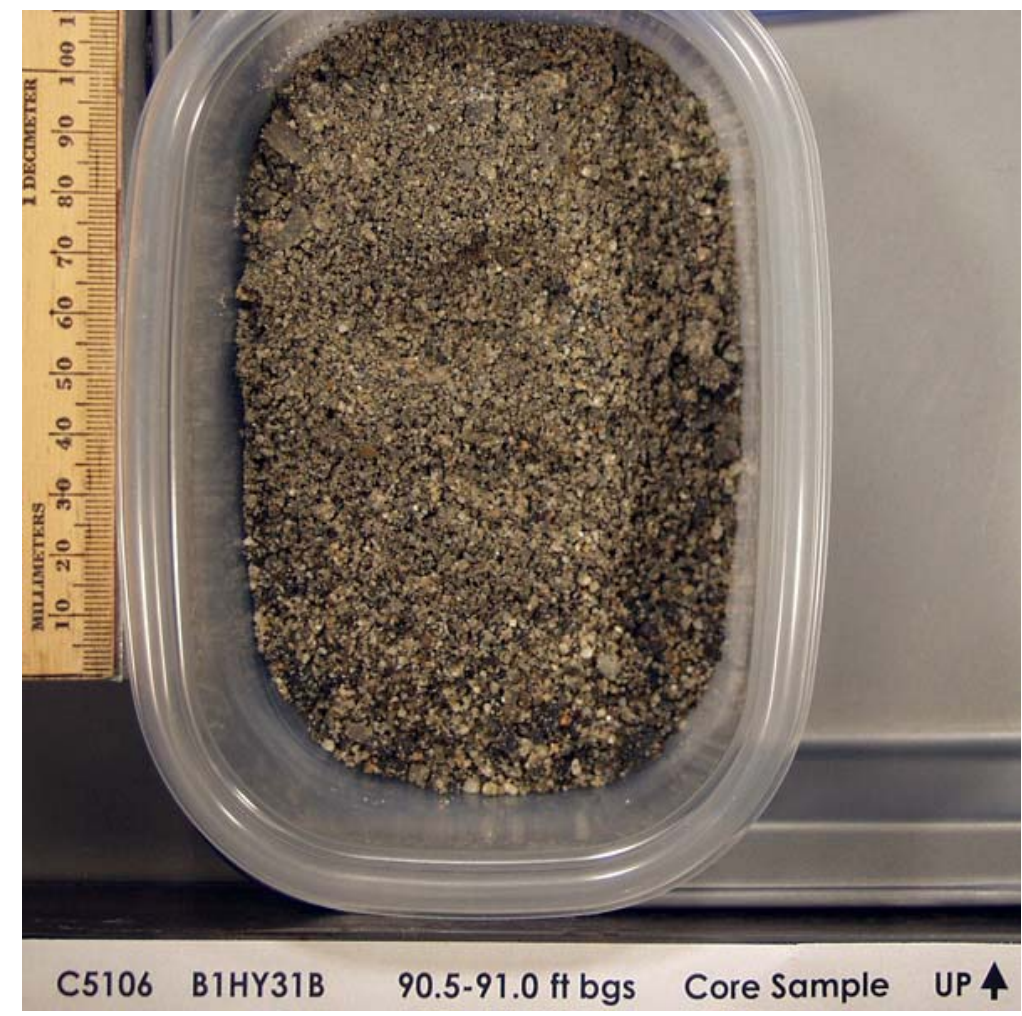

Figure A2.25. C5106 $90.5 \mathrm{ft}-91.0 \mathrm{ft}$

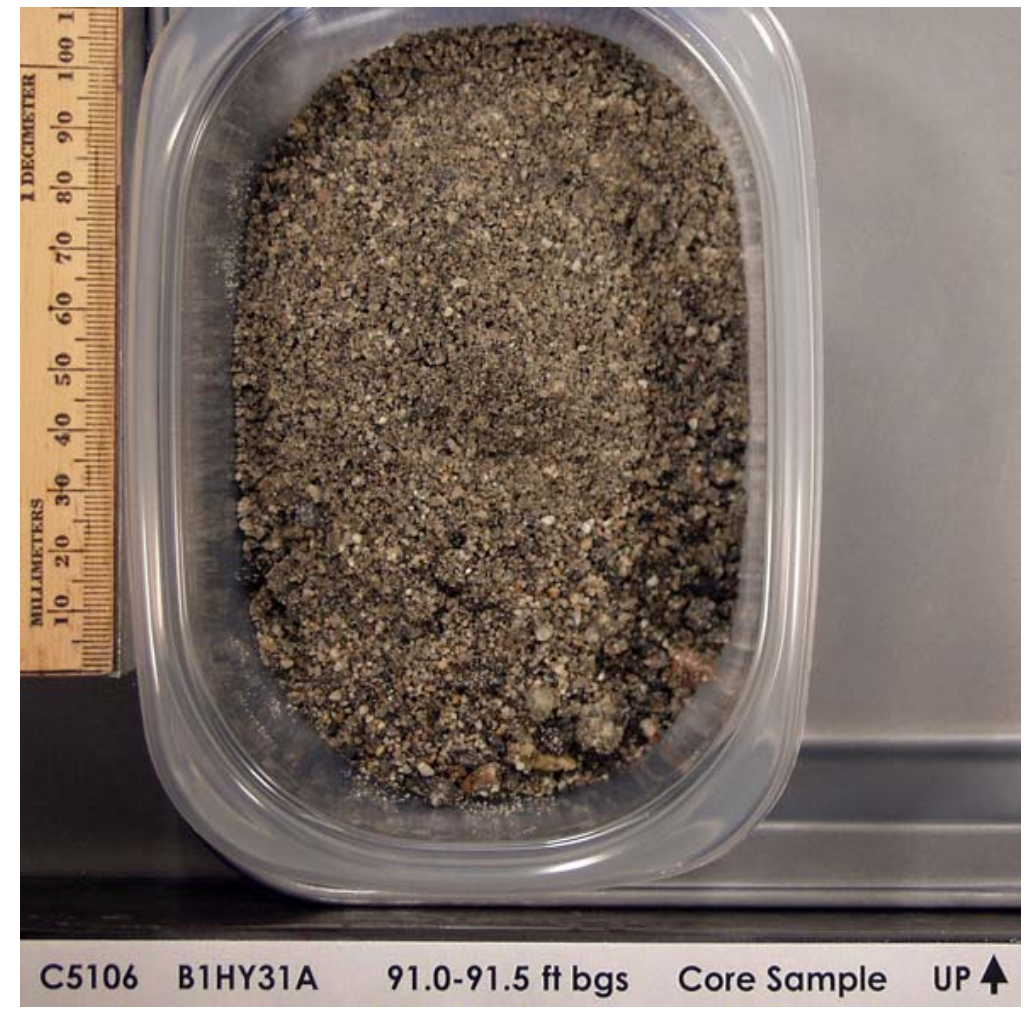

Figure A2.26. C5106 $91.0 \mathrm{ft}-91.5 \mathrm{ft}$ 


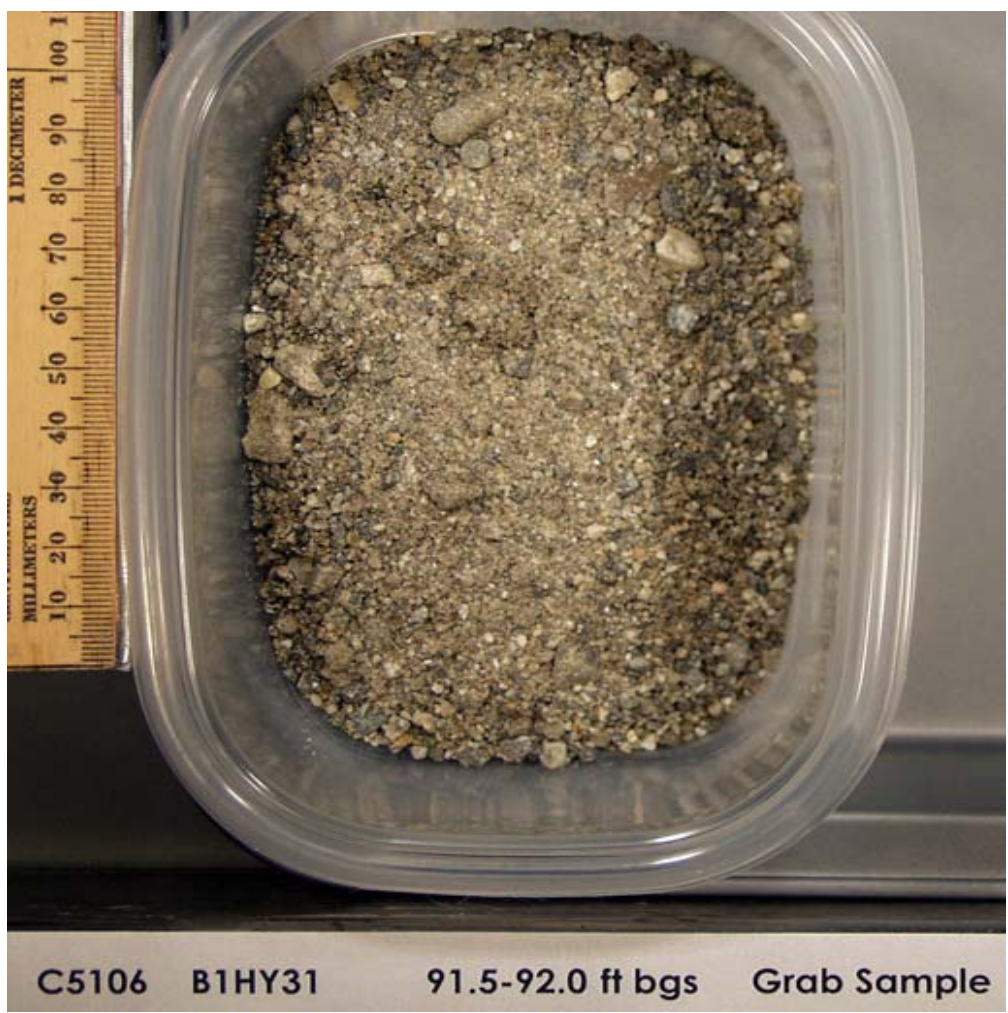

Figure A2.27. C5106 $91.5 \mathrm{ft}-92.0 \mathrm{ft}$

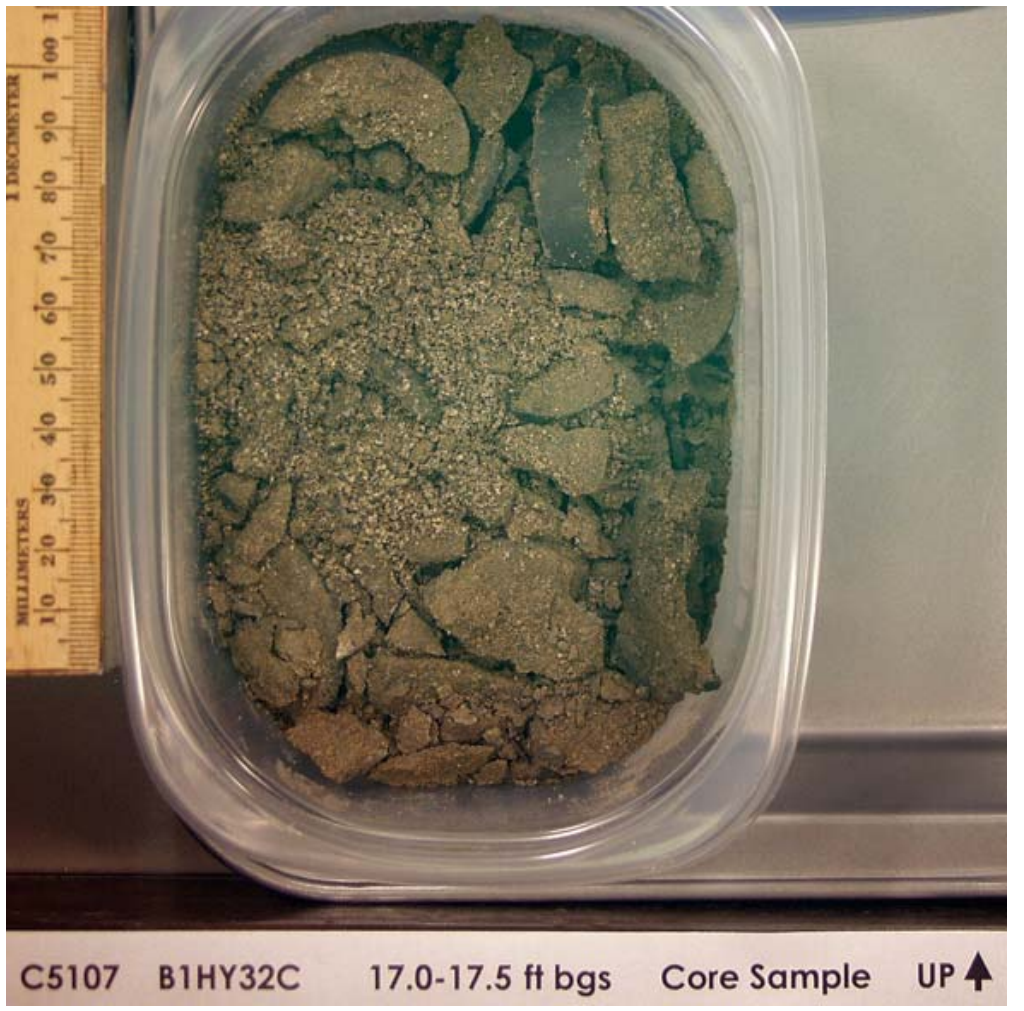

Figure A2.28. C5107 $17.0 \mathrm{ft}-17.5 \mathrm{ft}$ 


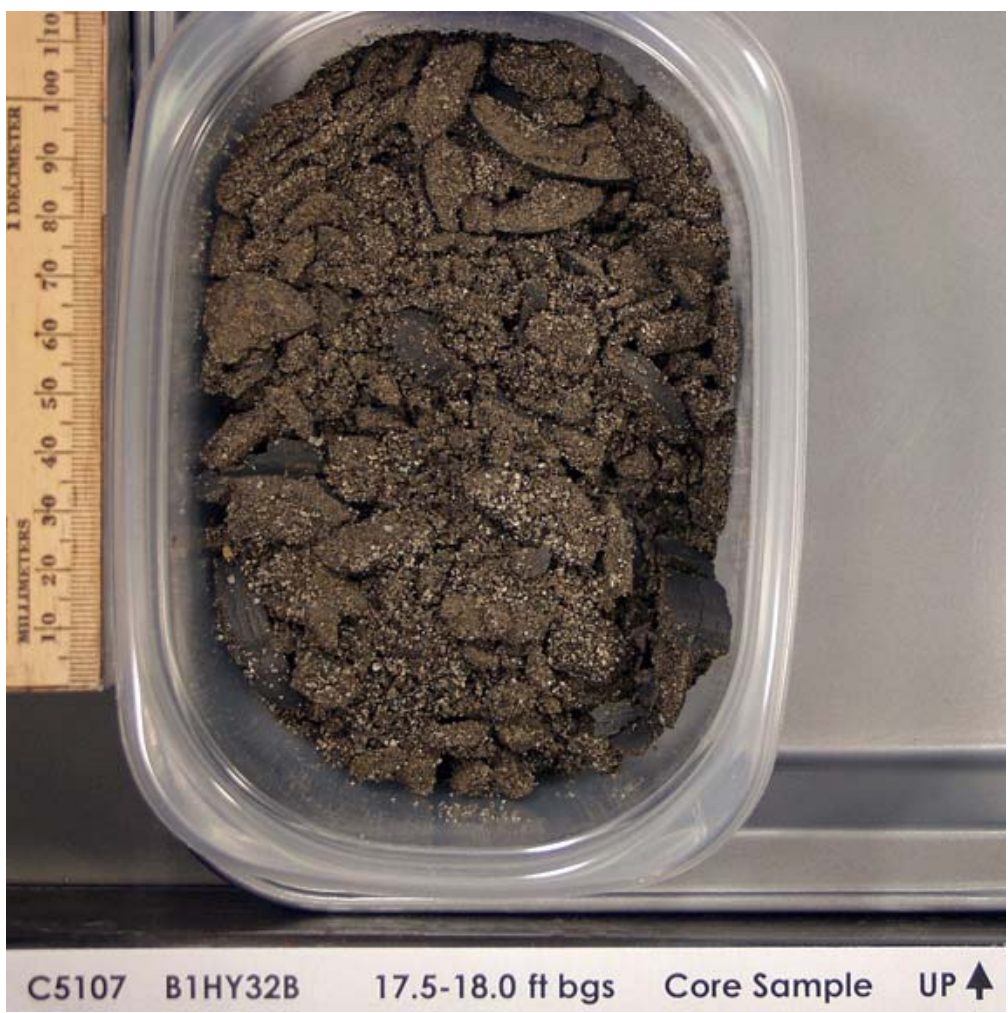

Figure A2.29. C5107 $17.5 \mathrm{ft}-18.0 \mathrm{ft}$

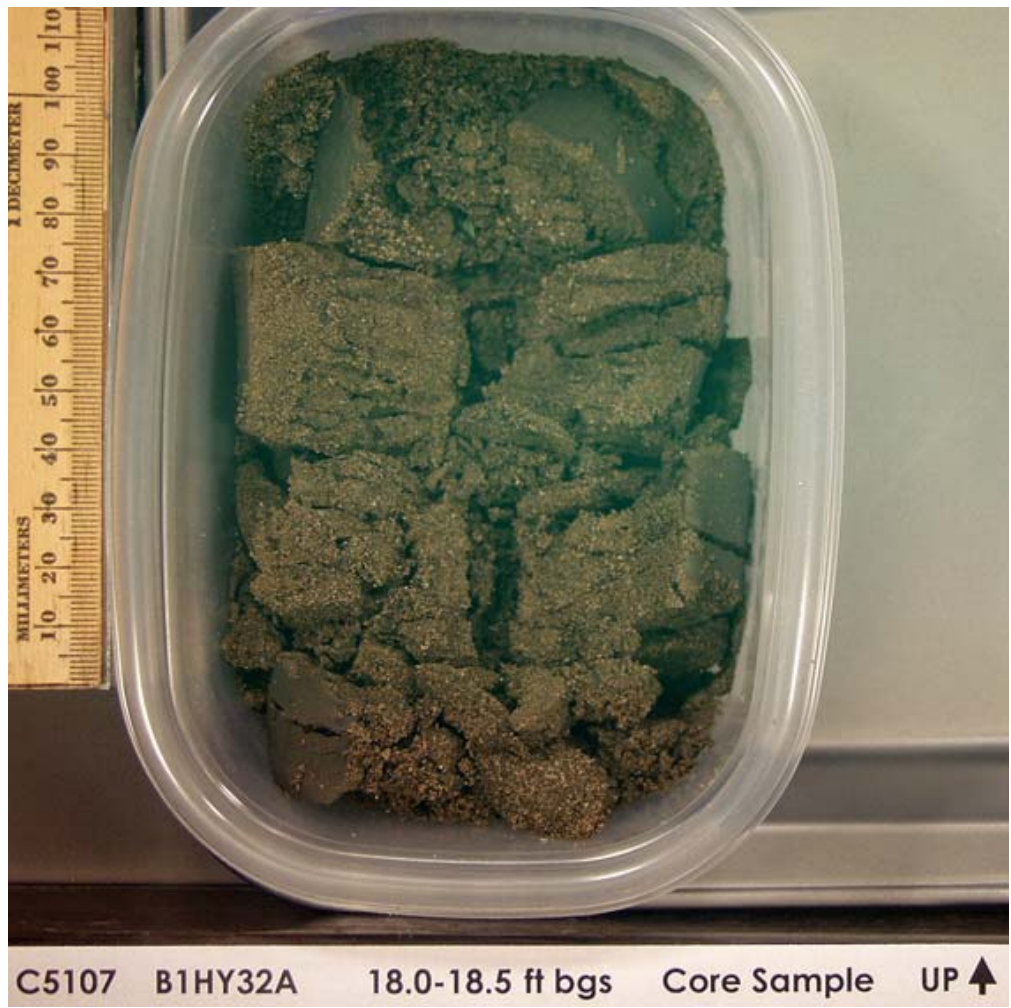

Figure A2.30. C5107 $18.0 \mathrm{ft}-18.5 \mathrm{ft}$ 


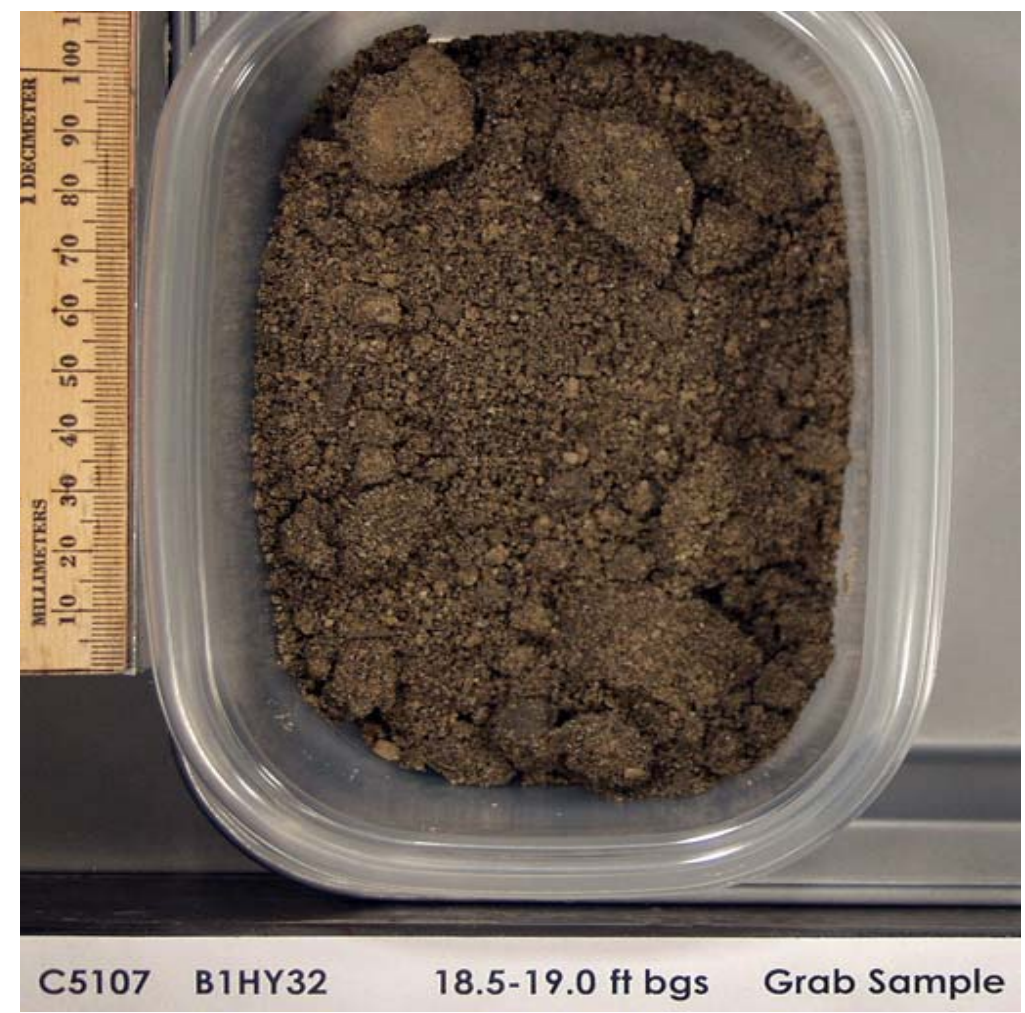

Figure A2.31. C5107 $18.5 \mathrm{ft}-19.0 \mathrm{ft}$

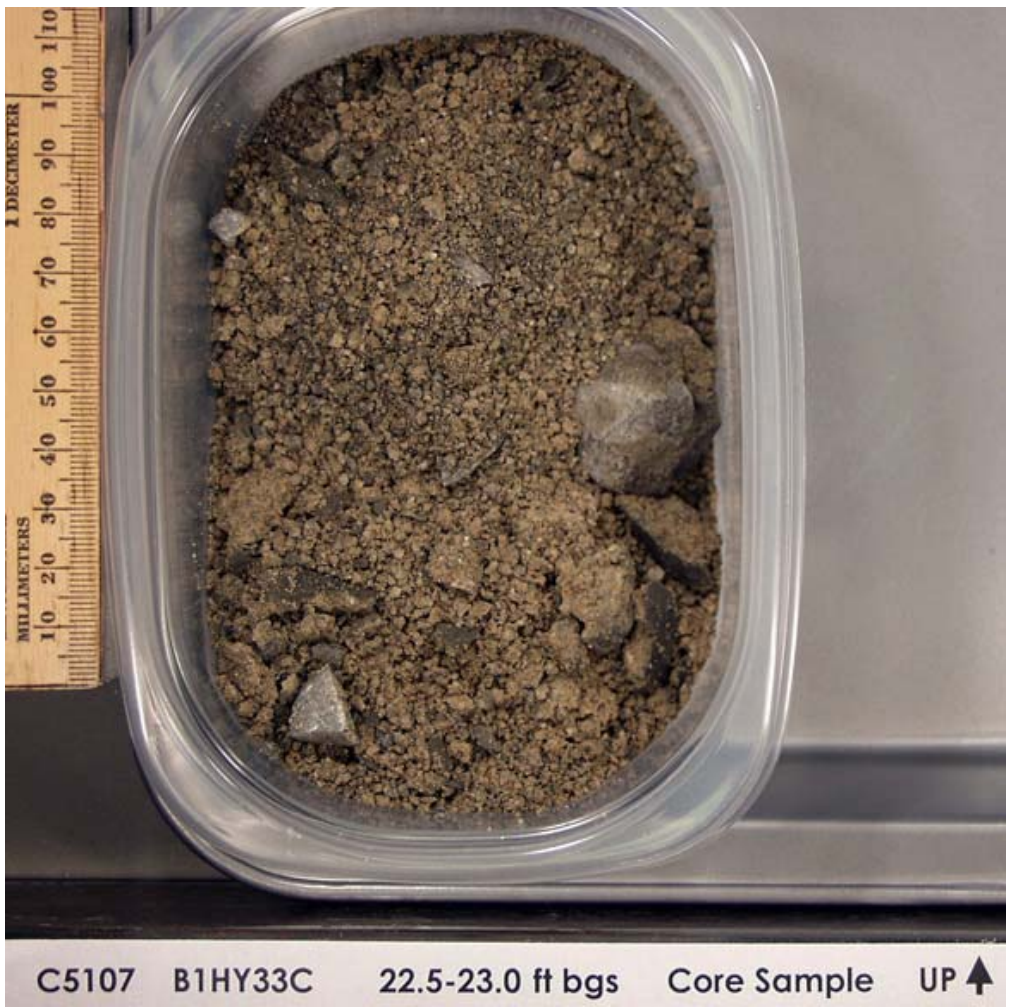

Figure A2.32. C5107 $22.5 \mathrm{ft}-23.0 \mathrm{ft}$ 


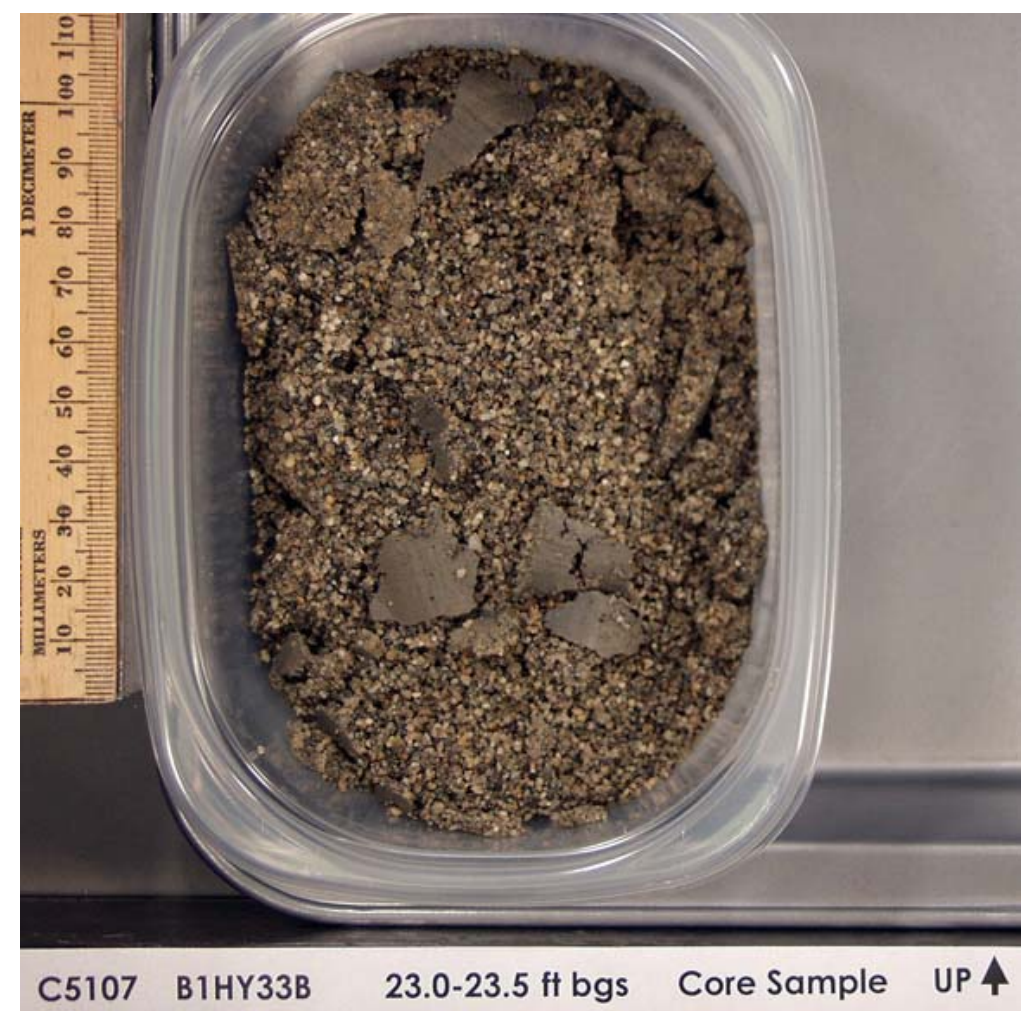

Figure A2.33. C5107 $23.0 \mathrm{ft}-23.5 \mathrm{ft}$

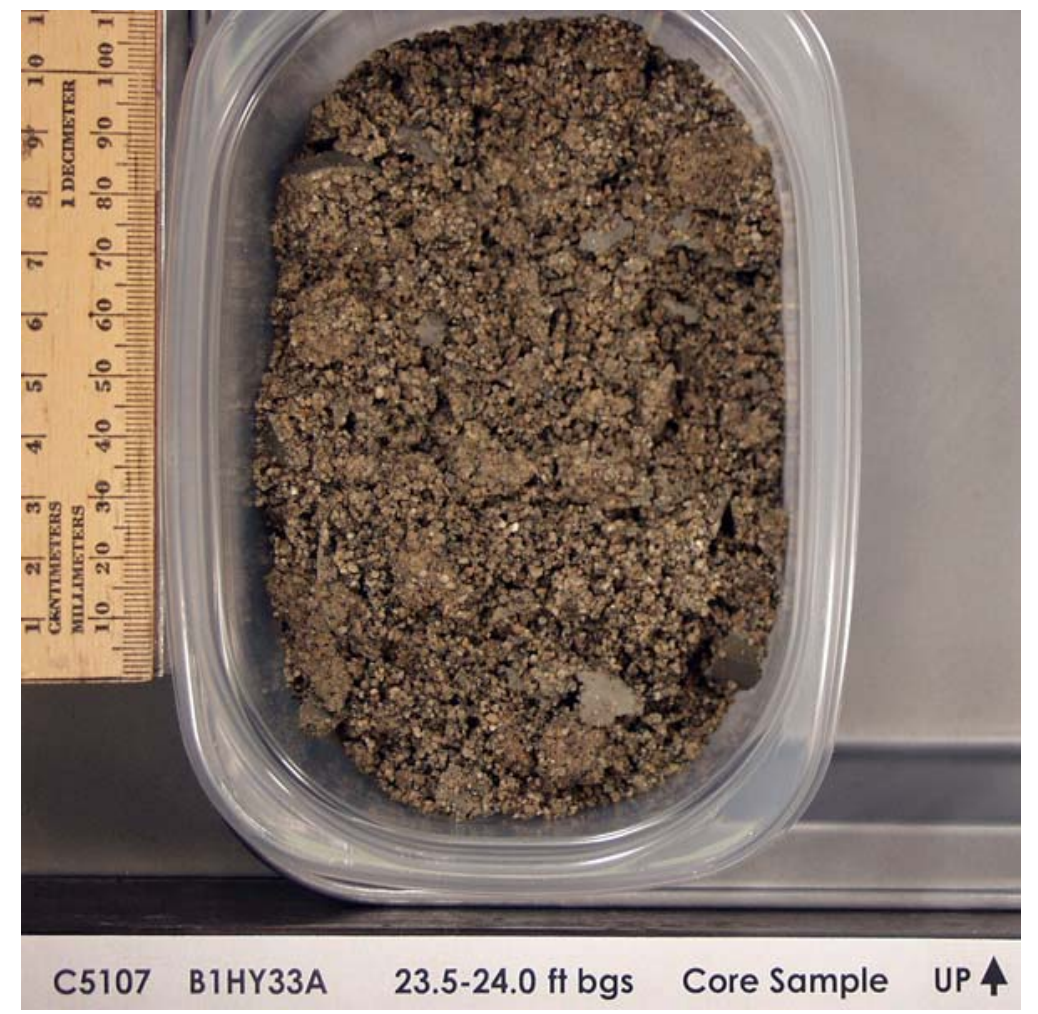

Figure A2.34. C5107 $23.5 \mathrm{ft}-24.0 \mathrm{ft}$ 


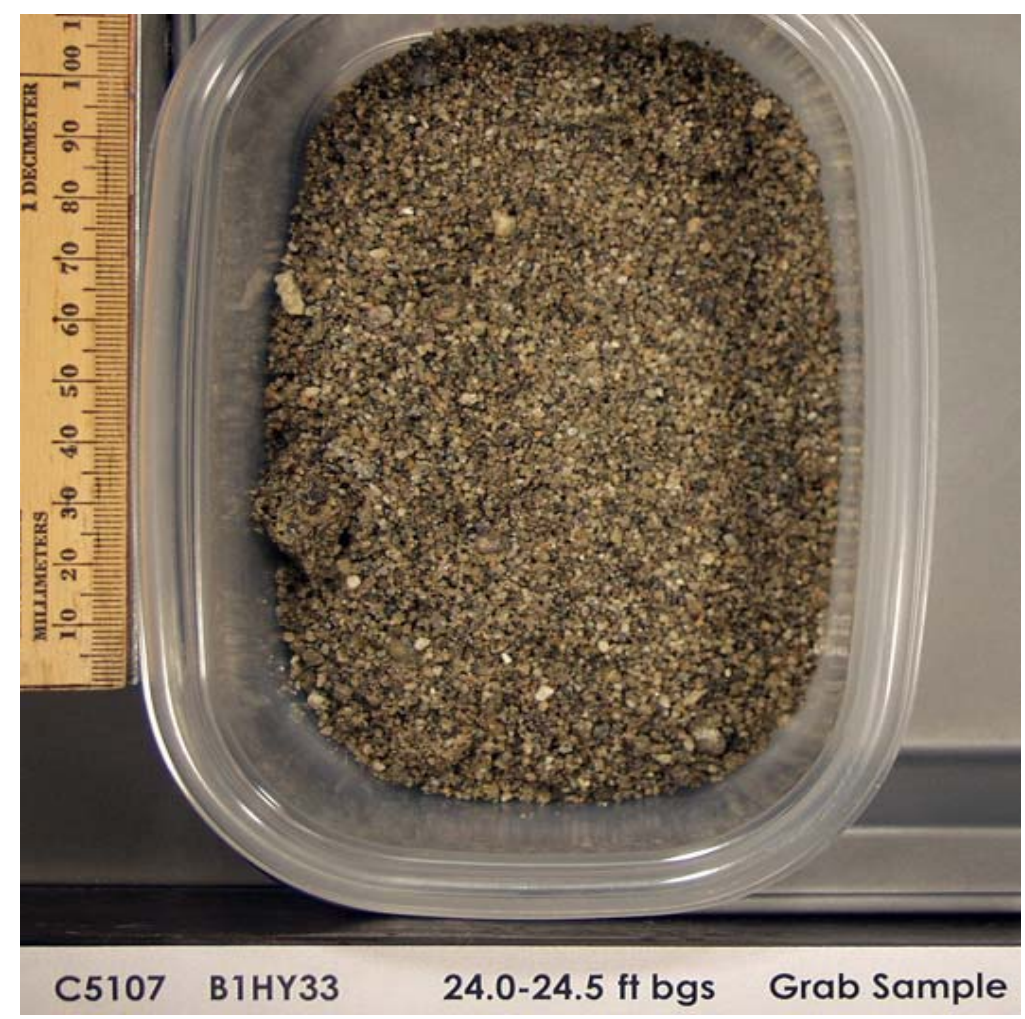

Figure A2.35. C5107 $24.0 \mathrm{ft}-24.5 \mathrm{ft}$

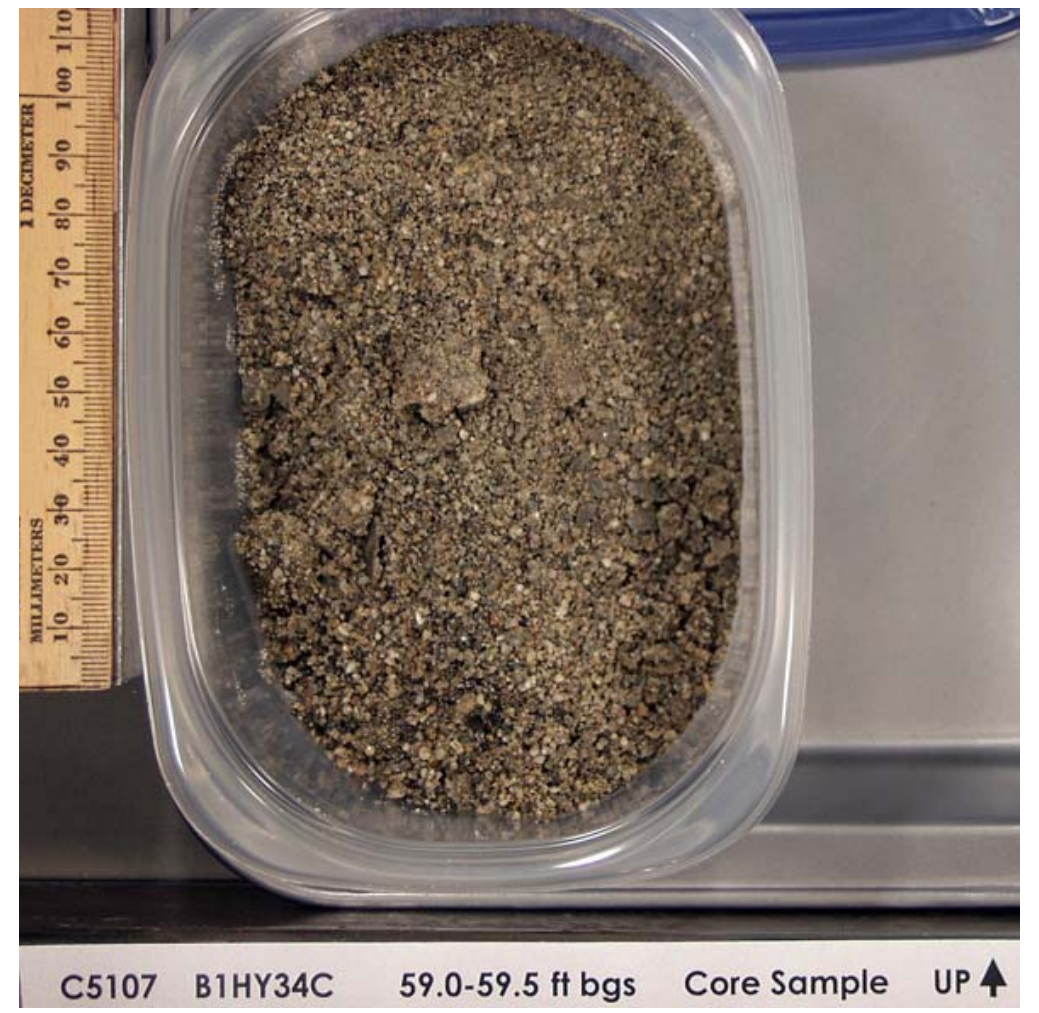

Figure A2.36. C5107 $59.0 \mathrm{ft}-59.5 \mathrm{ft}$ 


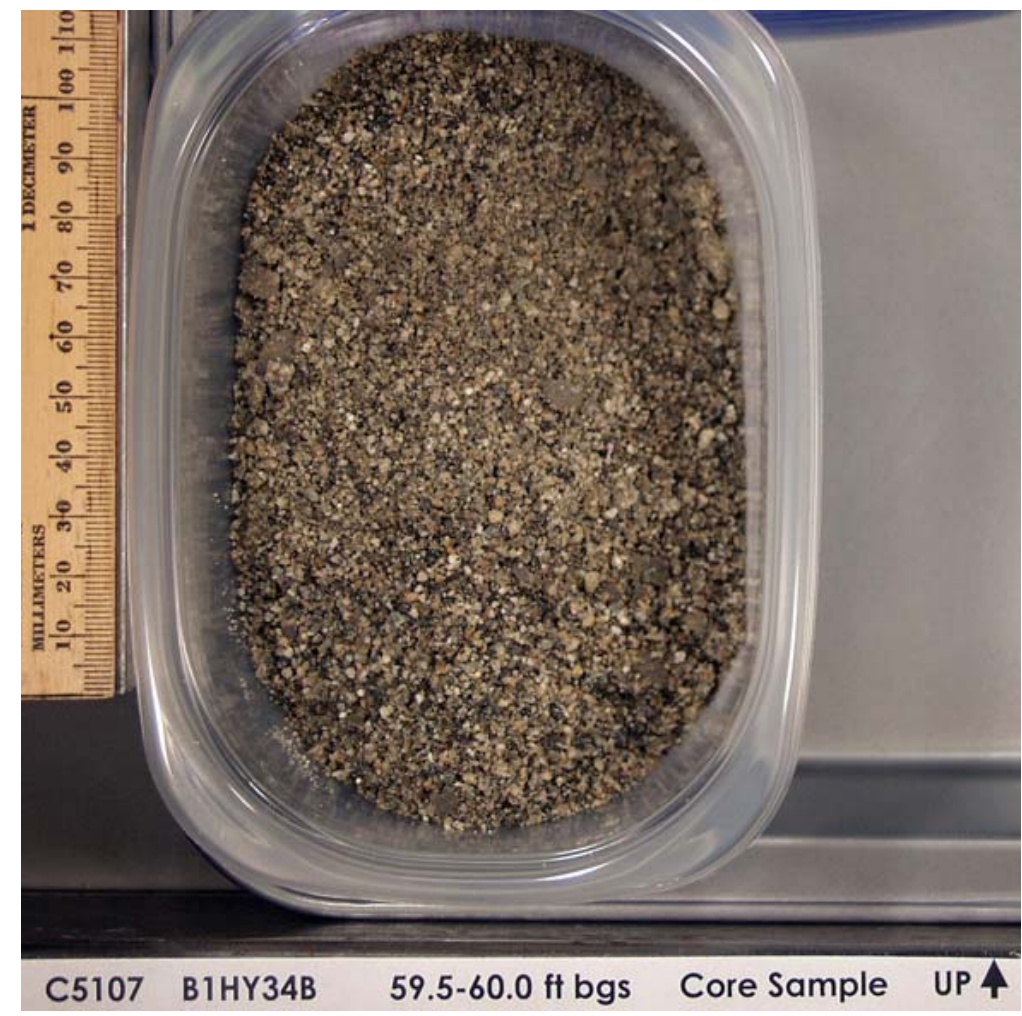

Figure A2.37. C5107 $59.5 \mathrm{ft}-60.0 \mathrm{ft}$

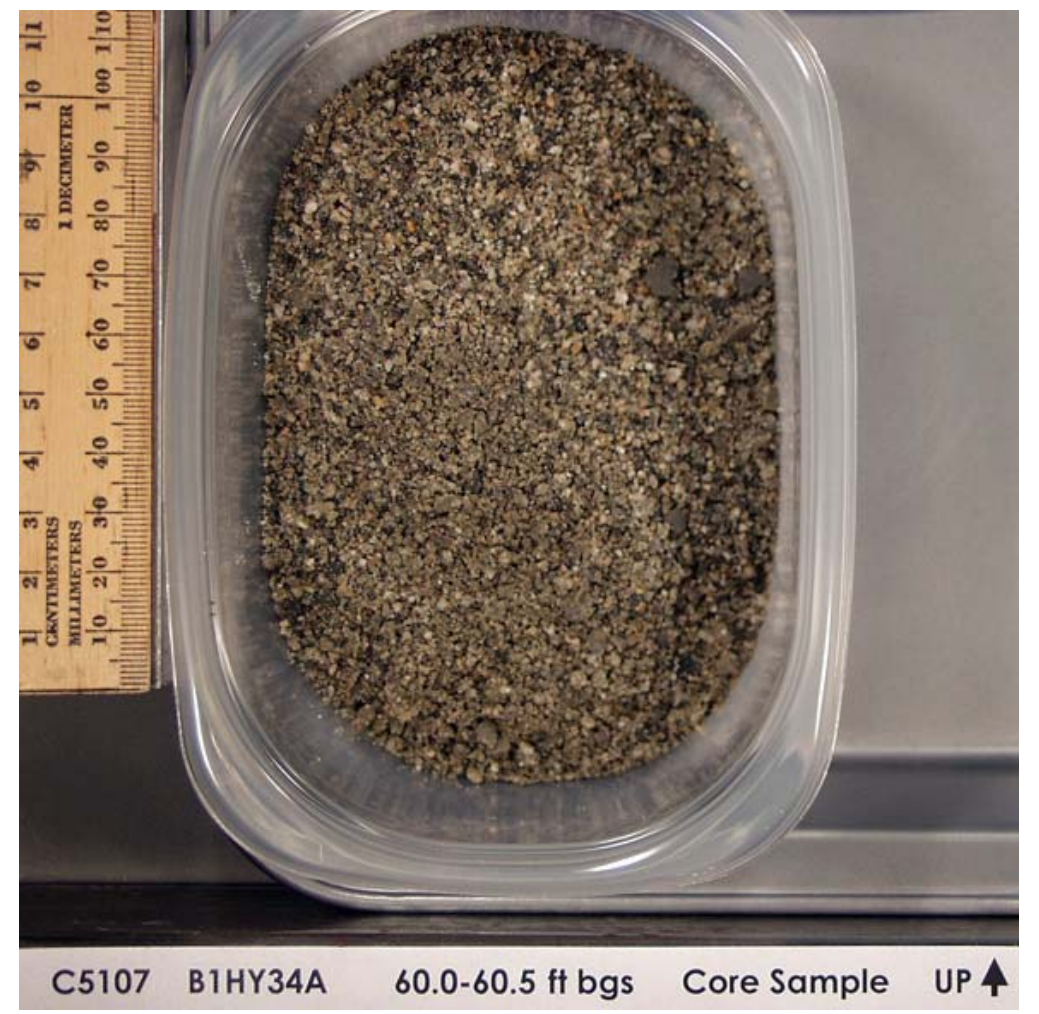

Figure A2.38. C5107 $60.0 \mathrm{ft}-60.5 \mathrm{ft}$ 


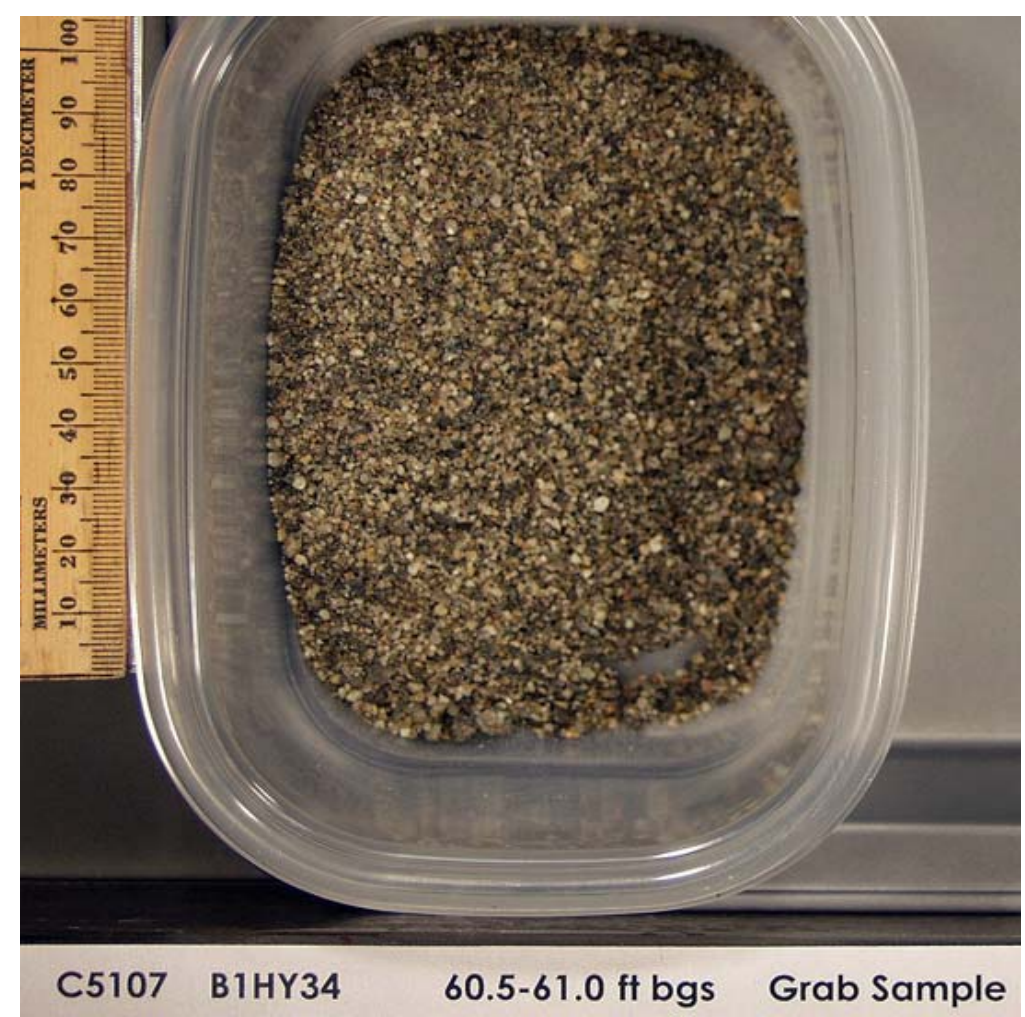

Figure A2.39. C5107 $60.5 \mathrm{ft}-61.0 \mathrm{ft}$

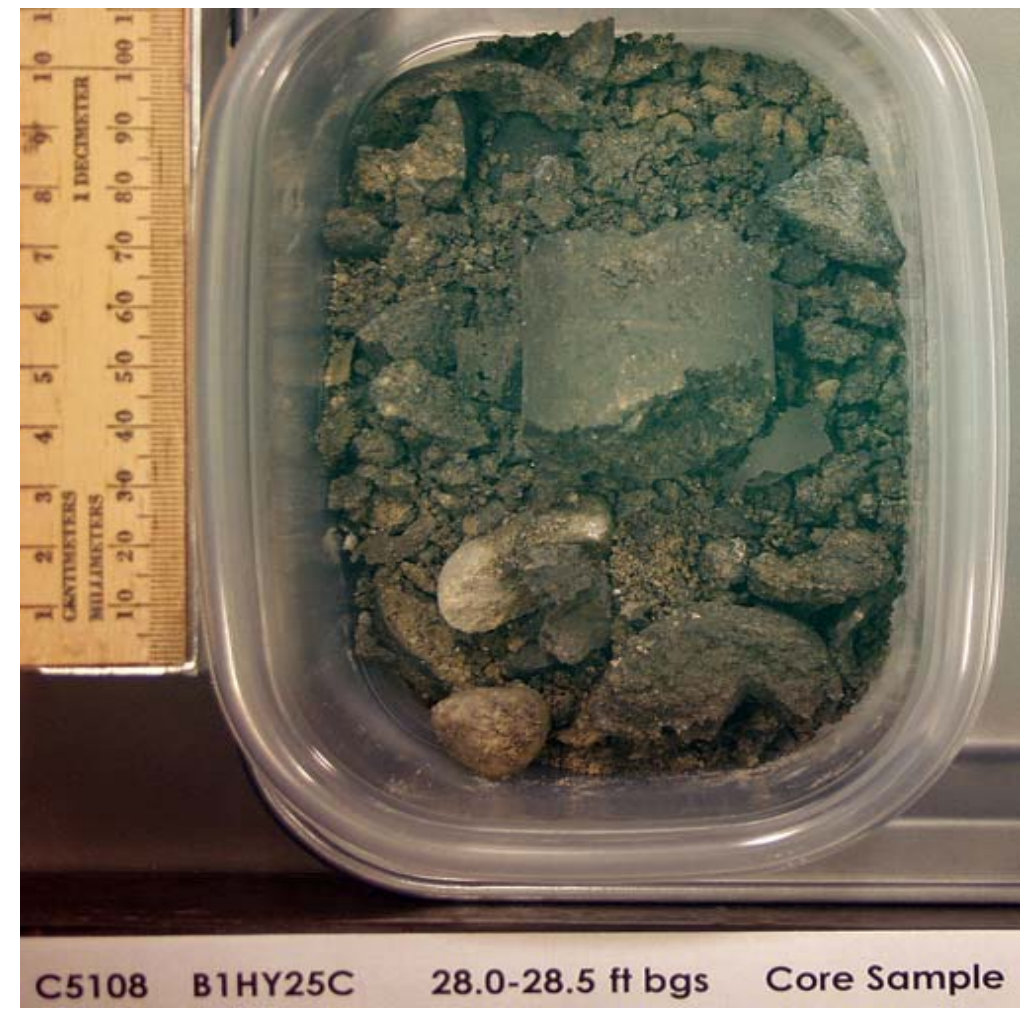

Figure A2.40. C5108 $28.0 \mathrm{ft}-28.5 \mathrm{ft}$ 


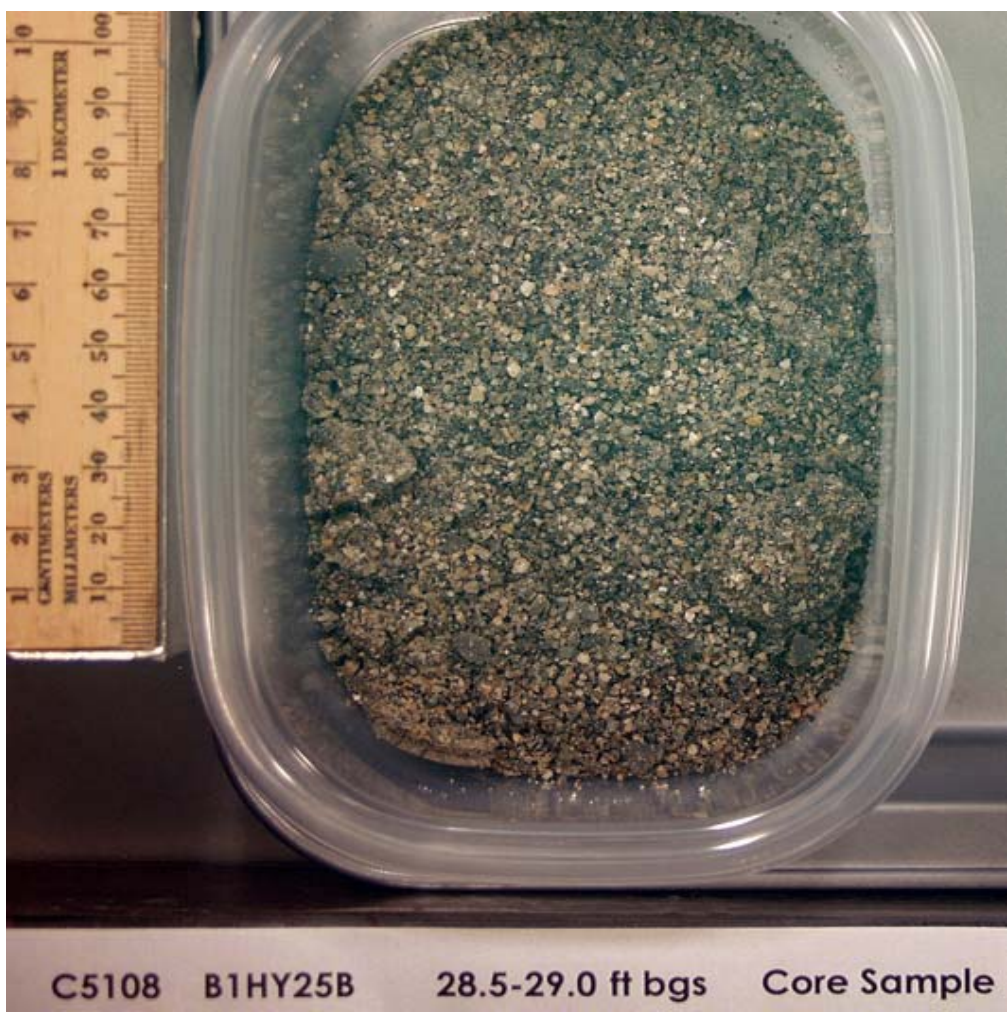

Figure A2.41. C5108 $28.5 \mathrm{ft}-29.0 \mathrm{ft}$

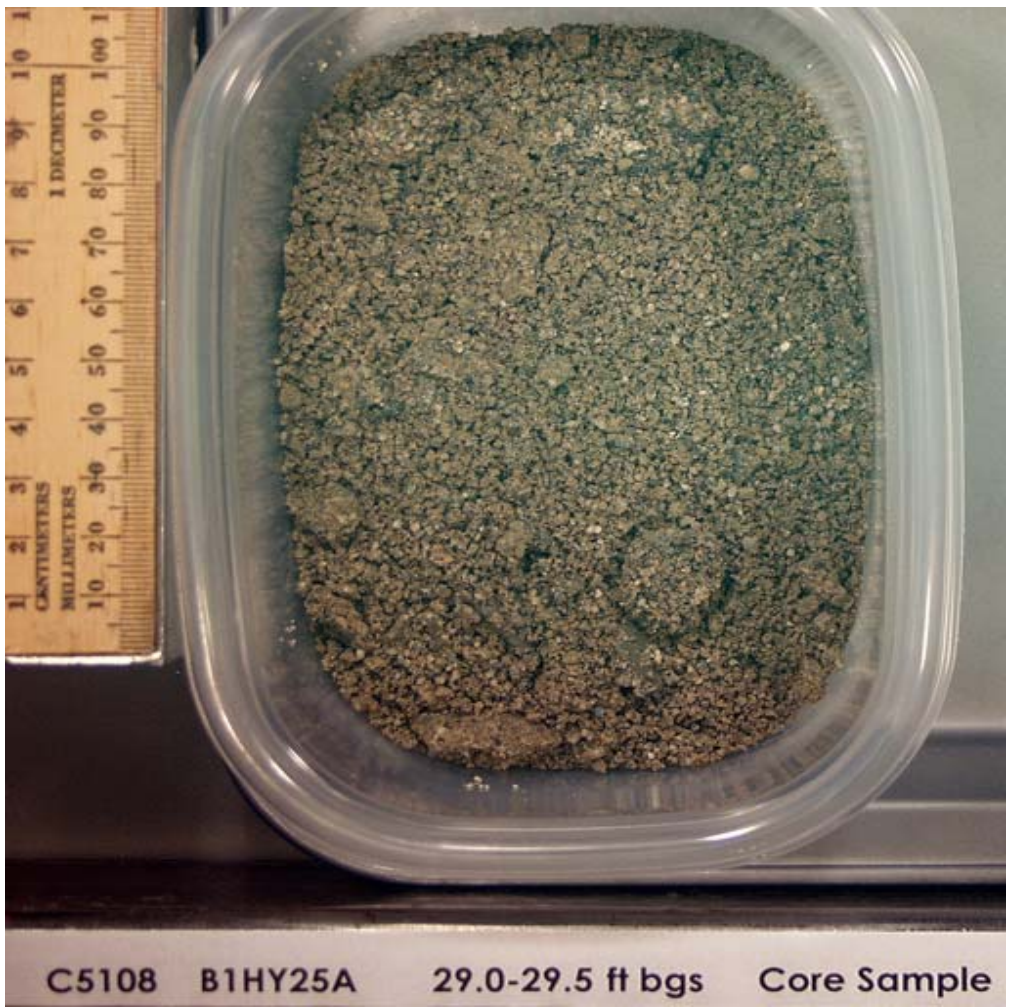

Figure A2.42. C5108 $29.0 \mathrm{ft}-29.5 \mathrm{ft}$ 


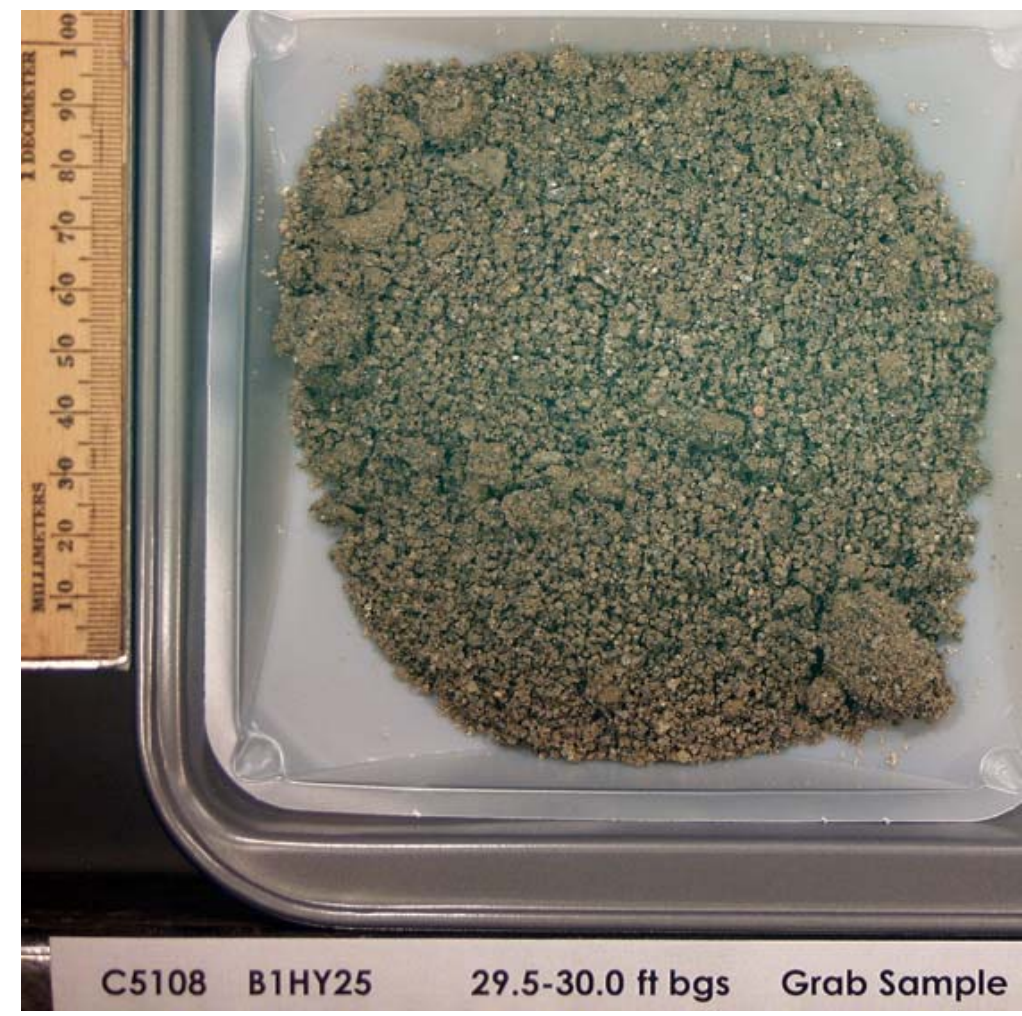

Figure A2.43. C5108 $29.5 \mathrm{ft}-30.0 \mathrm{ft}$

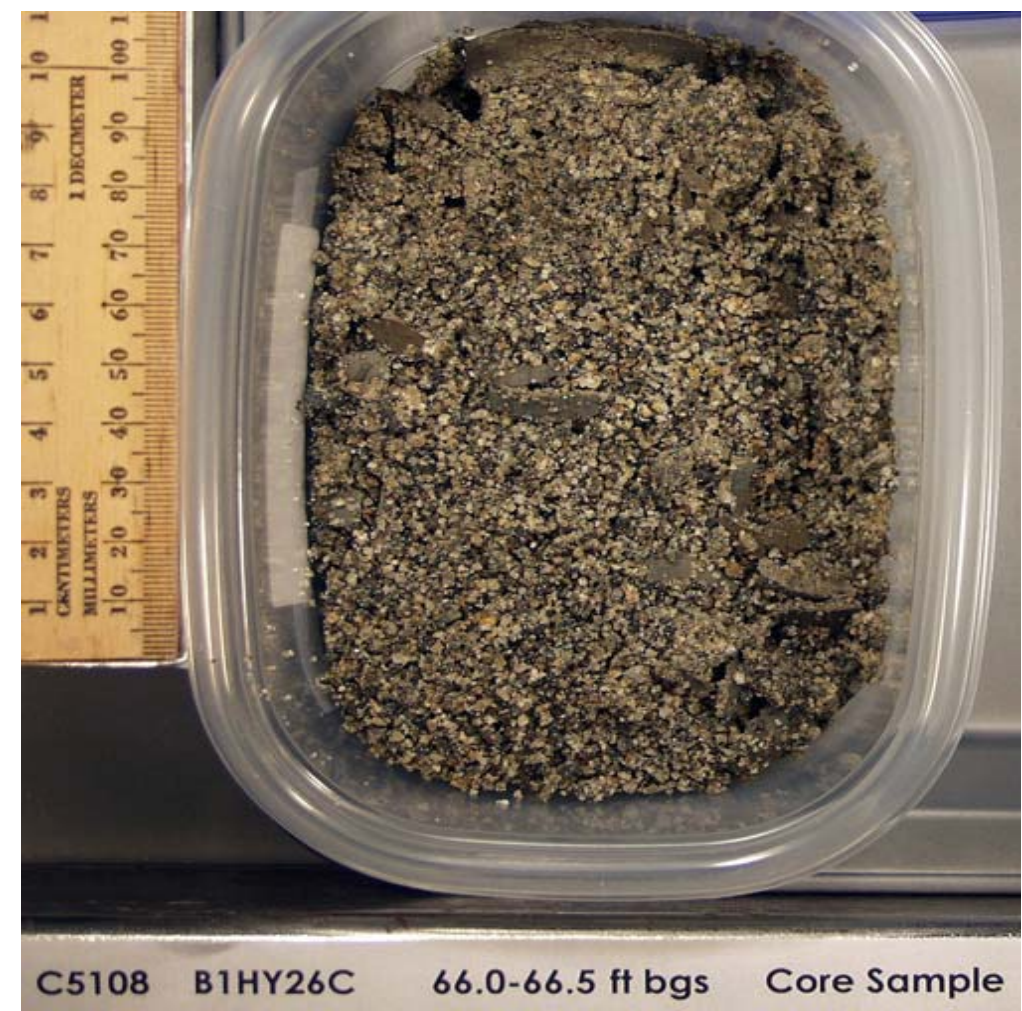

Figure A2.44. C5108 $66.0 \mathrm{ft}-66.5 \mathrm{ft}$ 


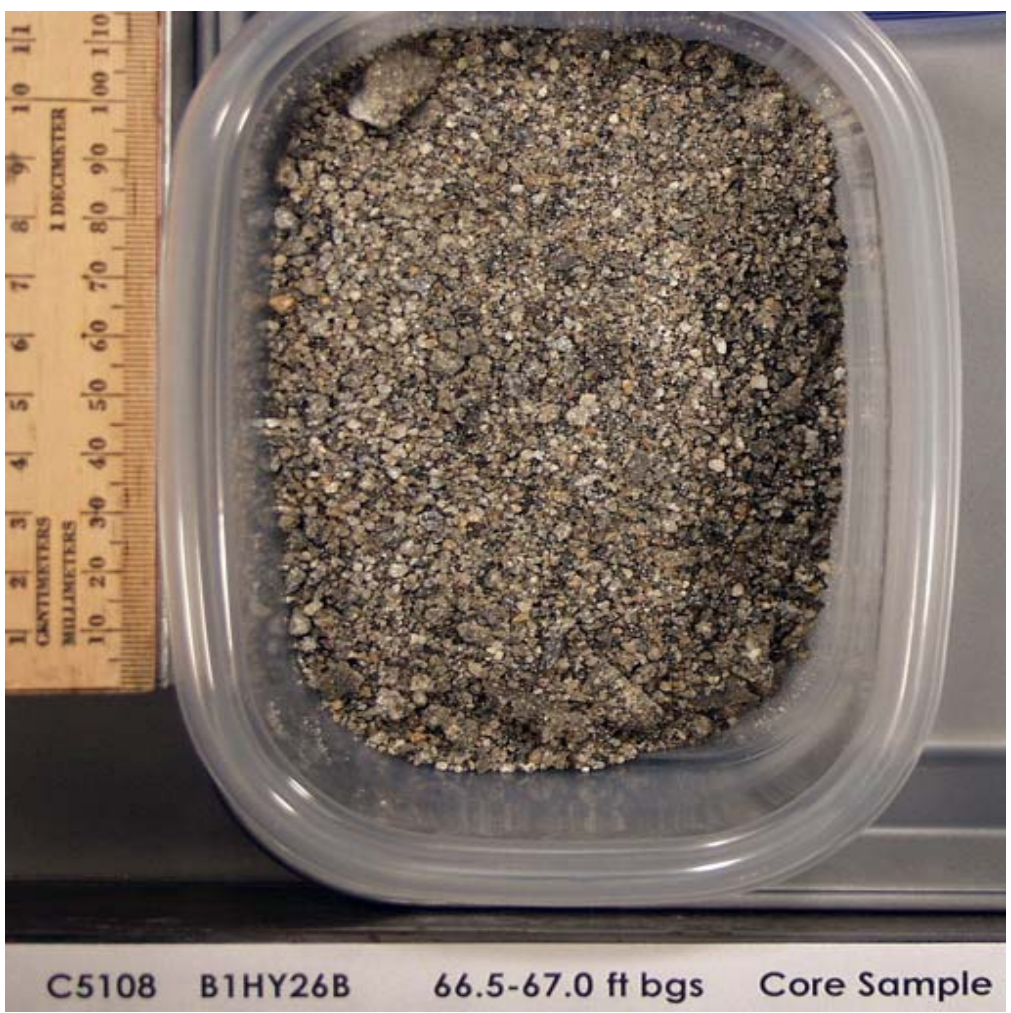

Figure A2.45. C5108 $66.5 \mathrm{ft}-67.0 \mathrm{ft}$

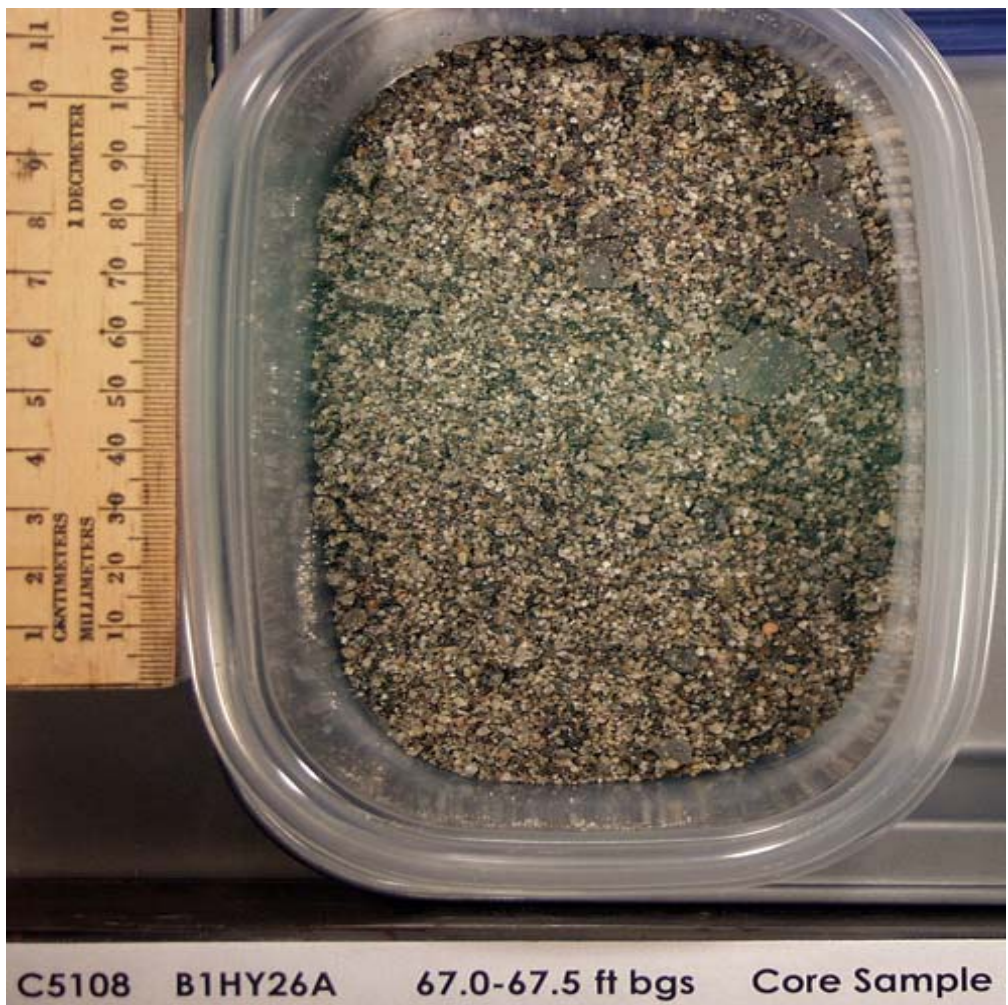

Figure A2.46. C5108 $67.0 \mathrm{ft}-67.5 \mathrm{ft}$ 


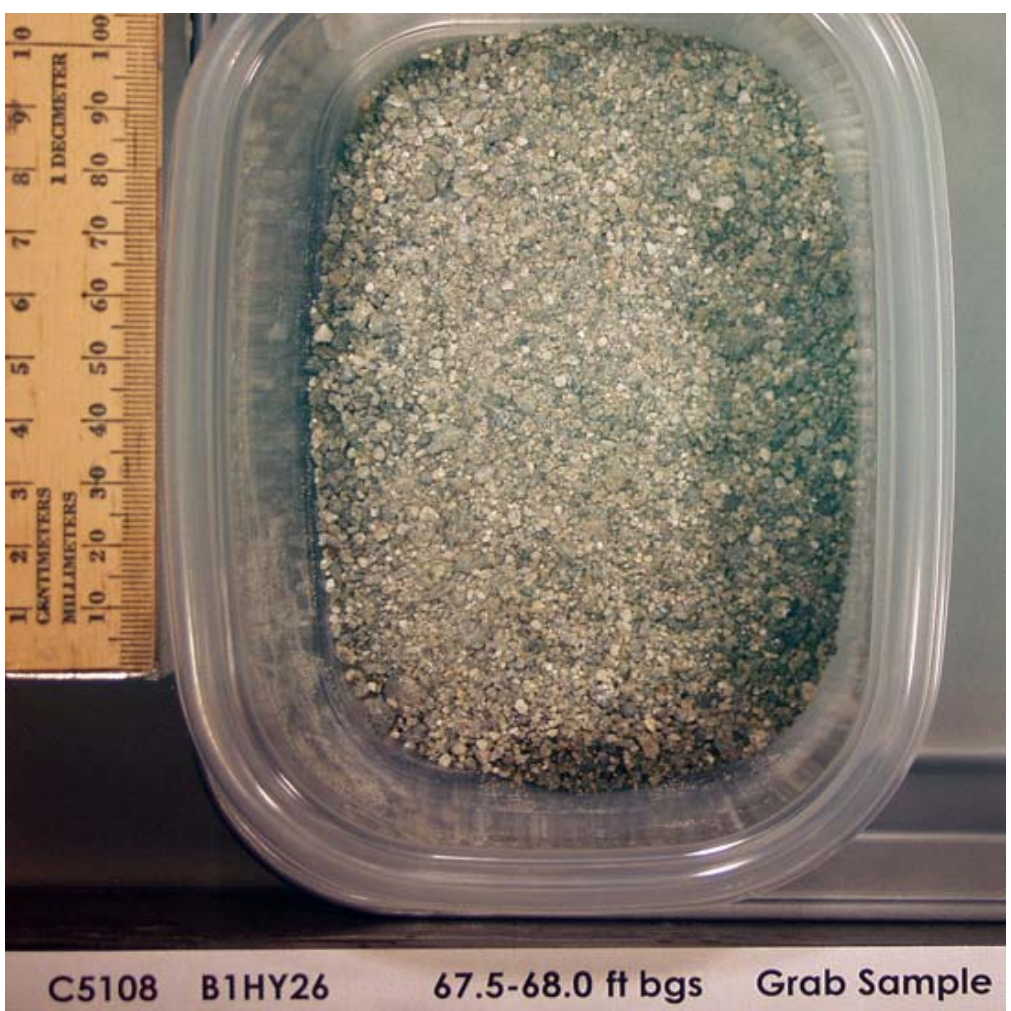

Figure A2.47. C5108 $67.5 \mathrm{ft}-68.0 \mathrm{ft}$

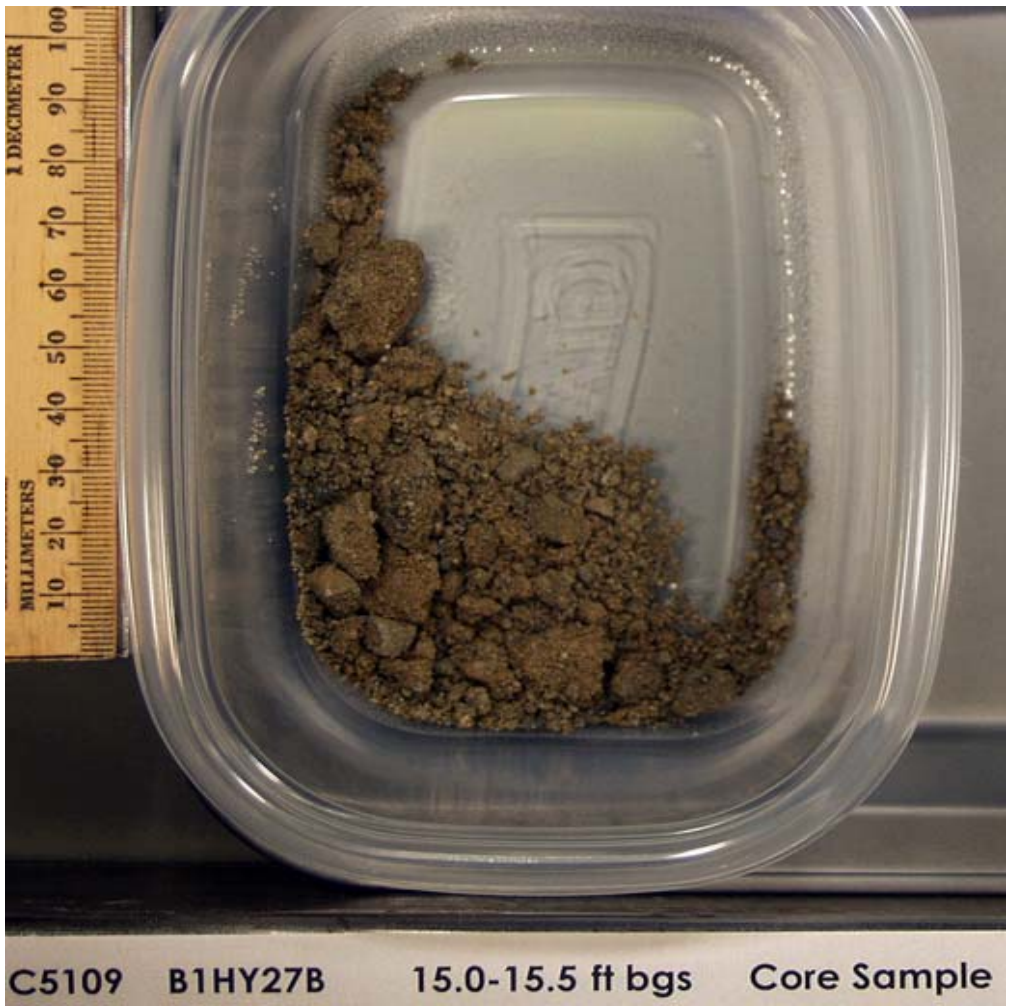

Figure A2.48. C5109 $15.0 \mathrm{ft}-15.5 \mathrm{ft}$ 


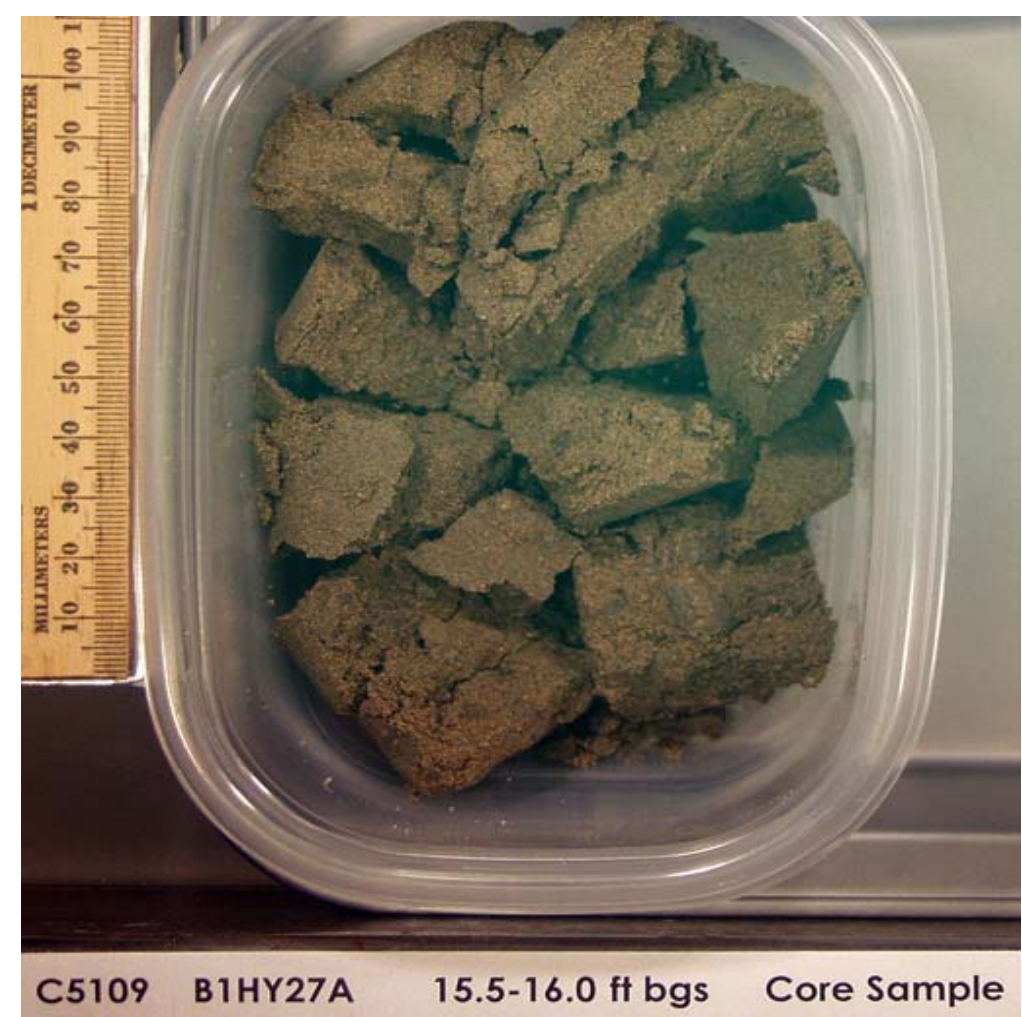

Figure A2.49. C5109 $15.5 \mathrm{ft}-16.0 \mathrm{ft}$

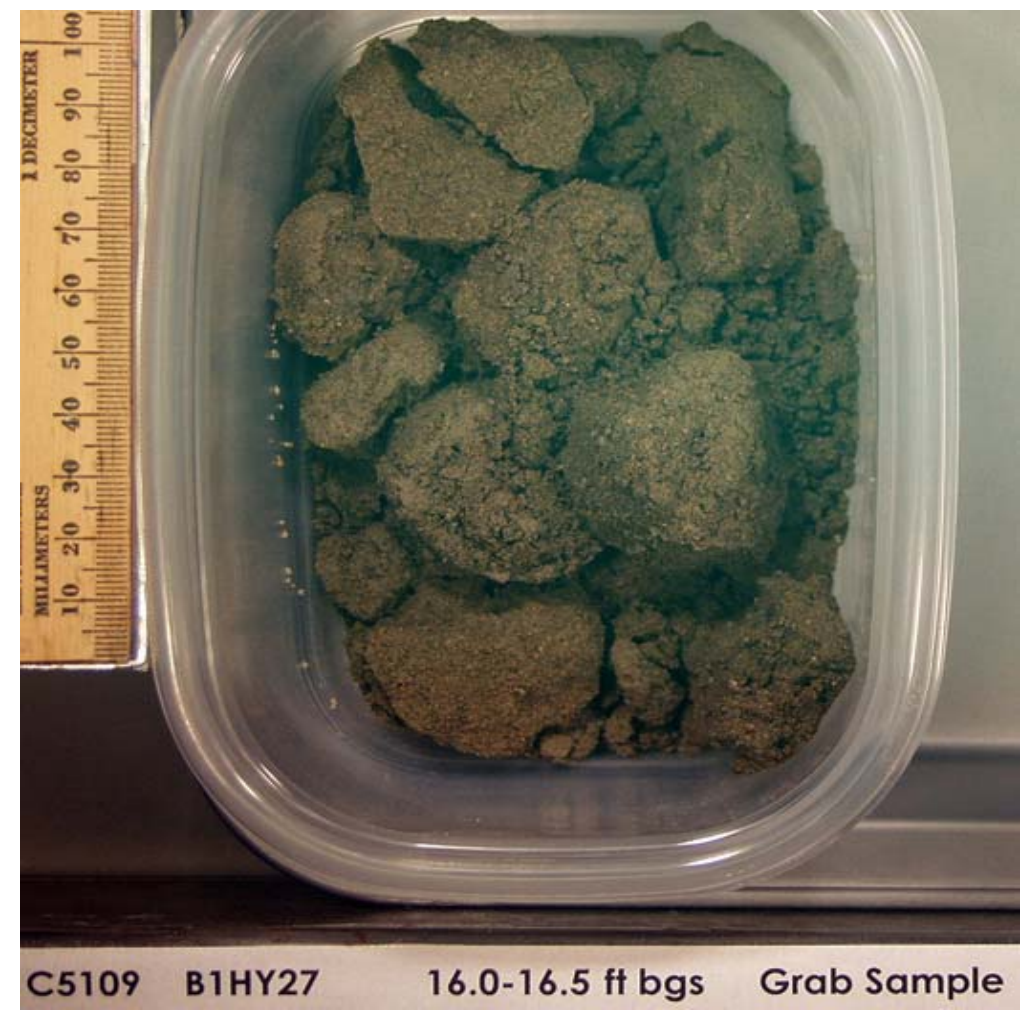

Figure A2.50. C5109 $16.0 \mathrm{ft}-16.5 \mathrm{ft}$ 


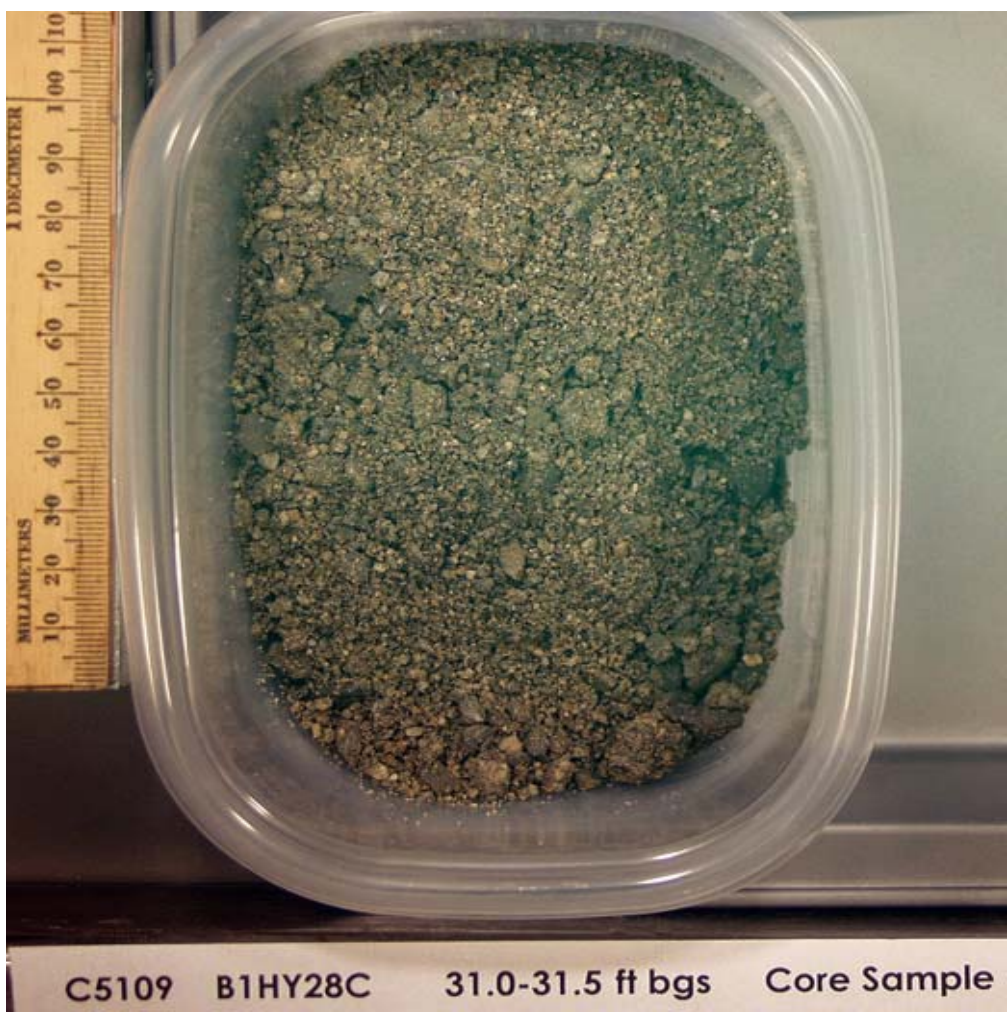

Figure A2.51. C5109 $31.0 \mathrm{ft}-31.5 \mathrm{ft}$

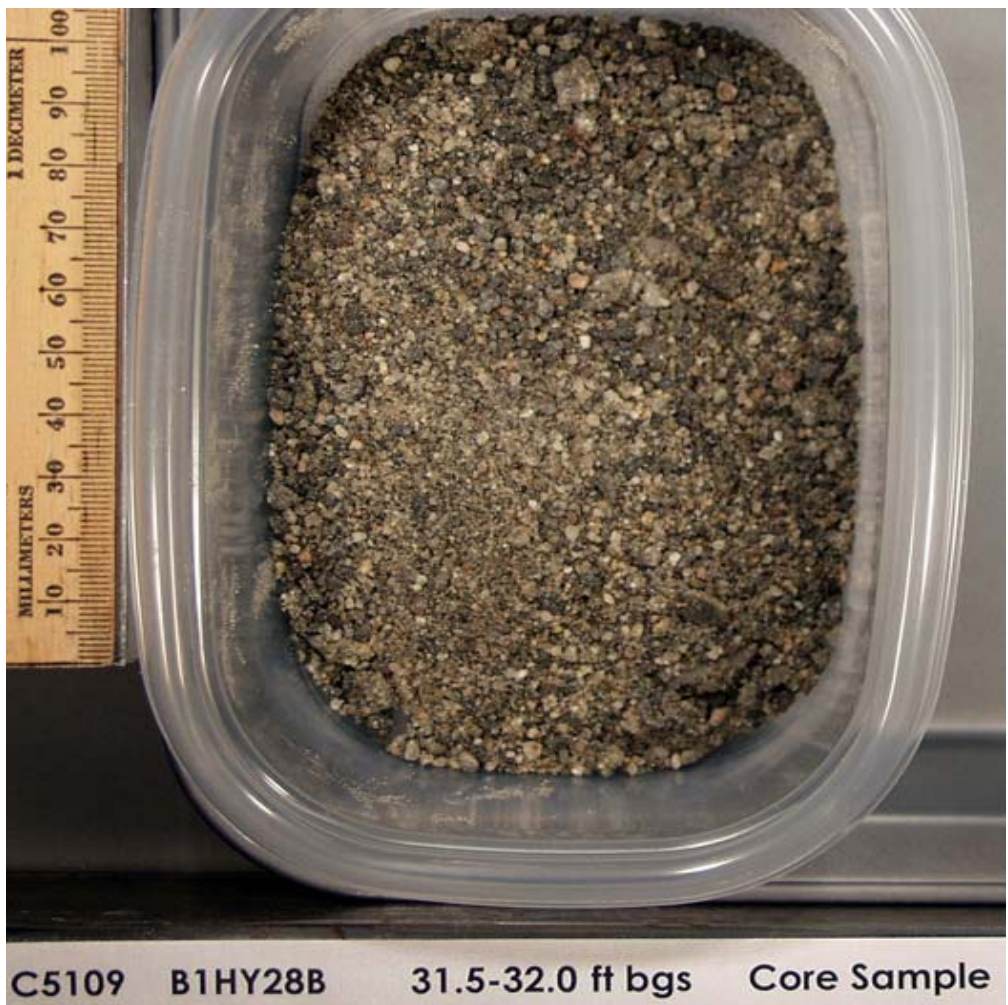

Figure A2.52. C5109 $31.5 \mathrm{ft}-32.0 \mathrm{ft}$ 


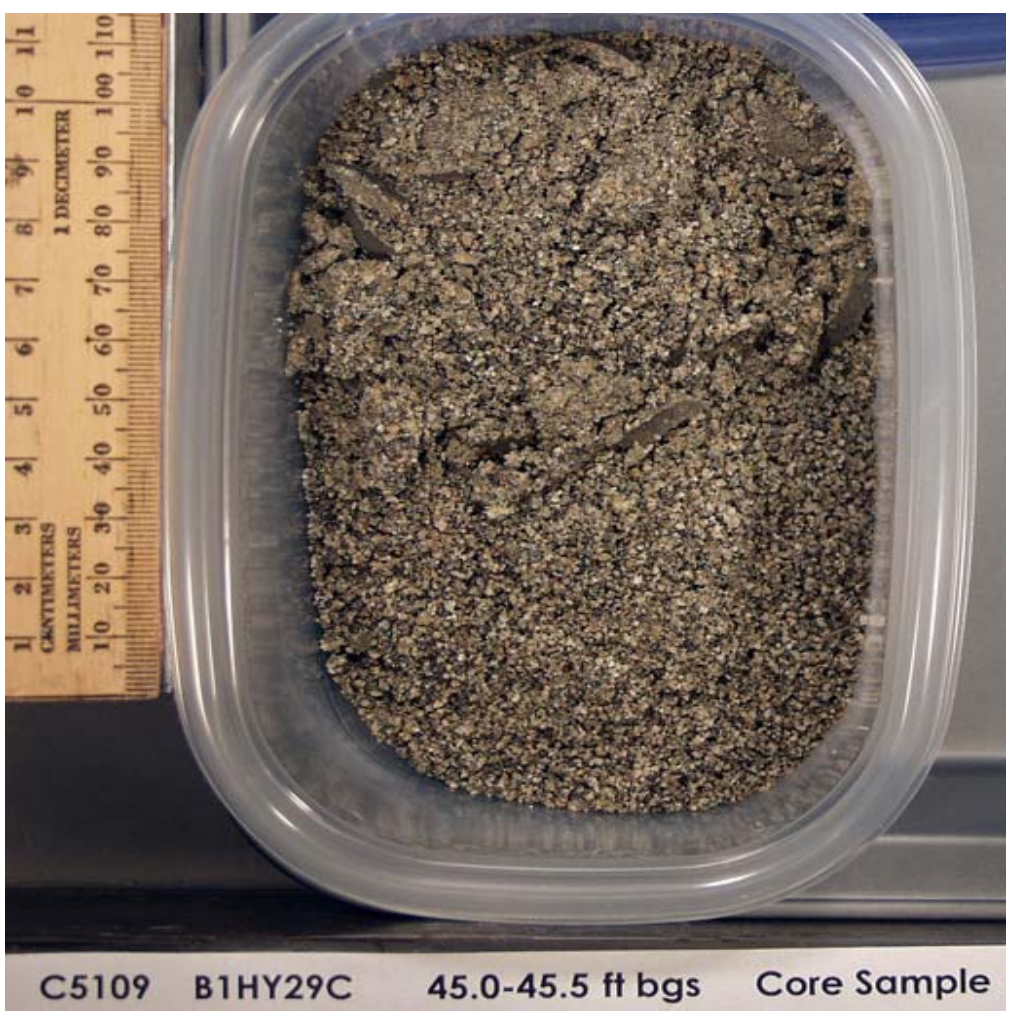

Figure A2.53. C5109 $45.0 \mathrm{ft}-45.5 \mathrm{ft}$

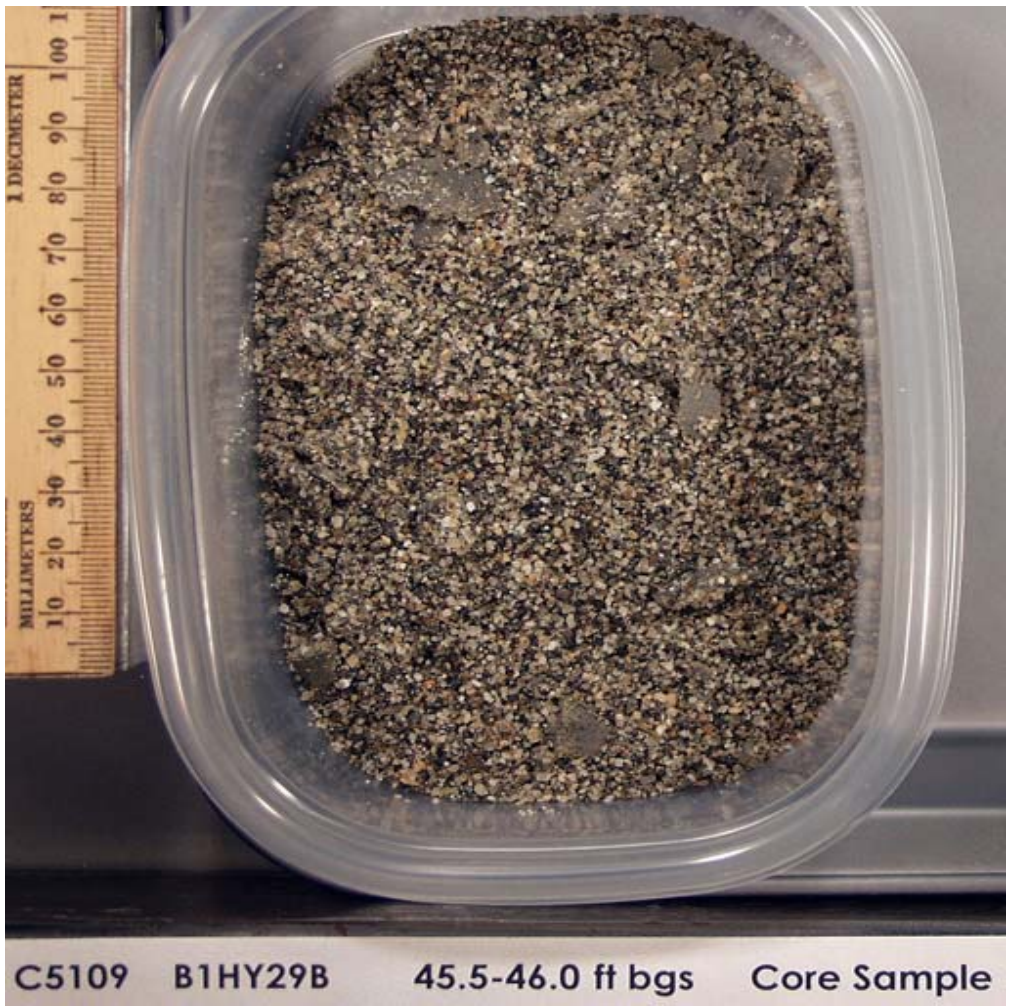

Figure A2.54. C5109 $45.5 \mathrm{ft}-46.0 \mathrm{ft}$ 


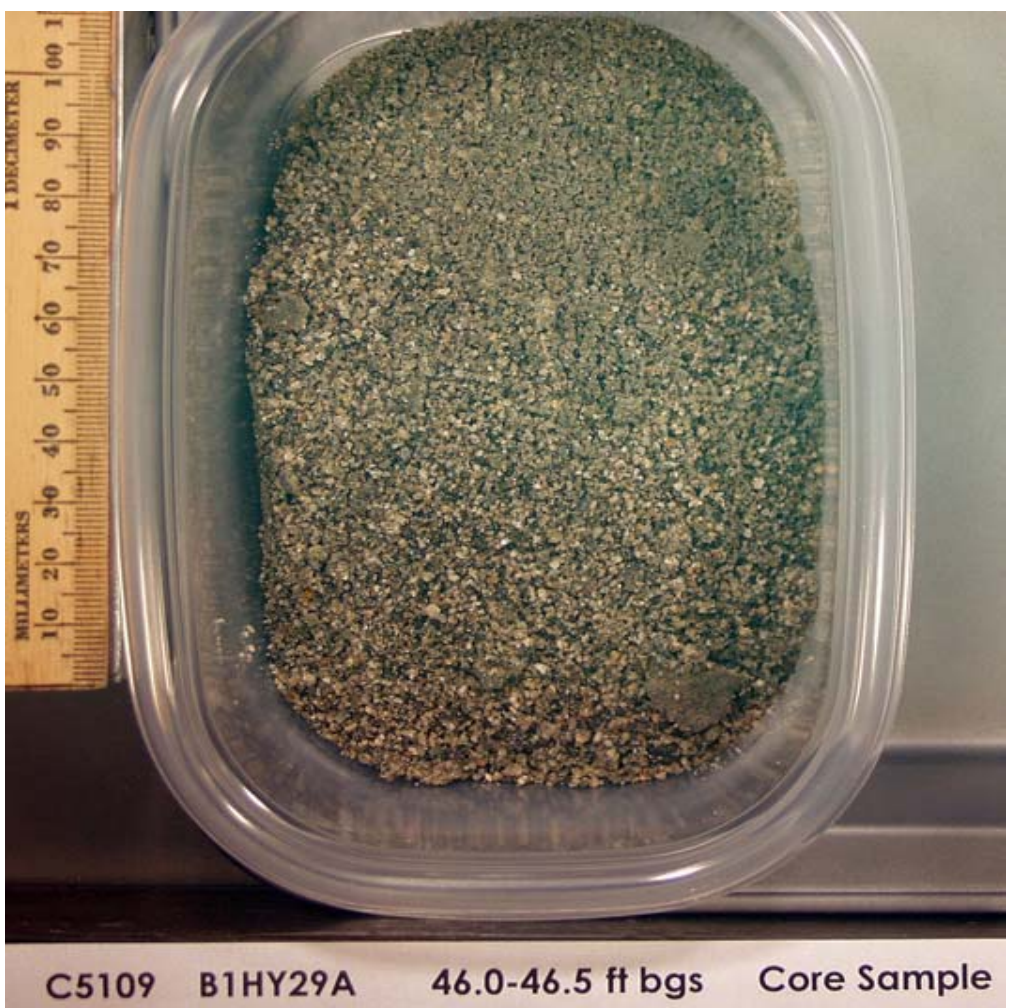

Figure A2.55. C5109 $46.0 \mathrm{ft}-46.5 \mathrm{ft}$

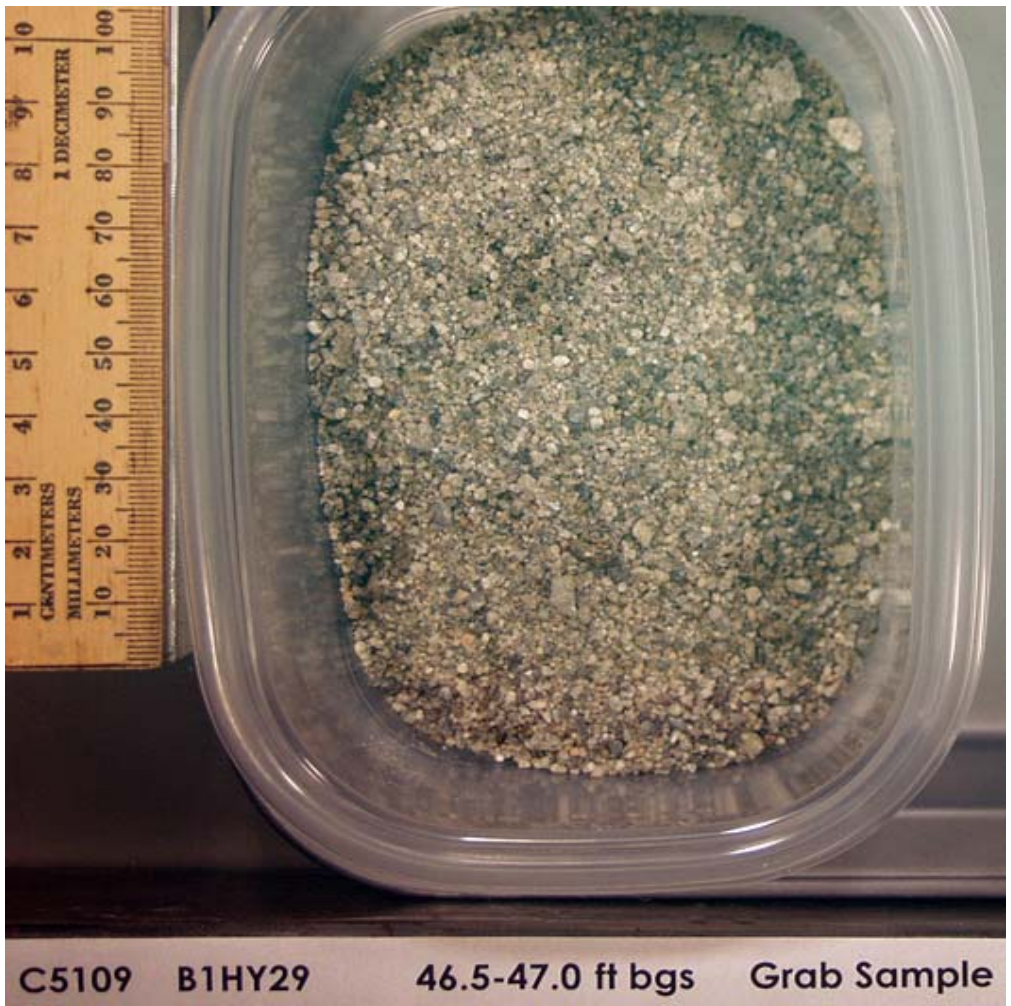

FigureA2.56. C5109 $46.5 \mathrm{ft}-47.0 \mathrm{ft}$ 


\section{Appendix B}

Geologic Description of C-152 Probe Hole Core Samples 


\section{Contents}

Appendix B1. Geologic Description of Samples from C-152 Vertical Probe Holes

B.1

Appendix B2. Geologic Description of Samples from the C-152 Slant Probe Holes

B. 21

\section{Figures}

\begin{tabular}{|c|c|}
\hline 31.1 & C4404 $20.0 \mathrm{ft}-21.5 \mathrm{ft} \ldots \ldots \ldots$ \\
\hline B1.2 & $\mathrm{C} 440612 \mathrm{ft}-12.7 \mathrm{ft} \ldots \ldots \ldots$ \\
\hline B1.3 & $\mathrm{C} 44088.5 \mathrm{ft}-11.0 \mathrm{ft} \ldots \ldots .$. \\
\hline 1.4 & $\mathrm{C} 441023 \mathrm{ft}-24.5 \mathrm{ft} \ldots \ldots$. \\
\hline B1.5 & $\mathrm{C} 441223.5 \mathrm{ft}-25.0 \mathrm{ft} .$. \\
\hline B1.6 & $\mathrm{C} 441413.5 \mathrm{ft}-15.0 \mathrm{ft} \ldots .$. \\
\hline B1.7 & $\mathrm{C} 441614.5 \mathrm{ft}-16.0 \mathrm{ft} \ldots .$. \\
\hline B1.8 & $\mathrm{C} 441811.5 \mathrm{ft}-13.0 \mathrm{ft} \ldots$. \\
\hline B1.9 & $\mathrm{C} 442016.5 \mathrm{ft}-18.0 \mathrm{ft} \ldots \ldots$. \\
\hline B1.10 & $\mathrm{C} 442211.5 \mathrm{ft}-13.0 \mathrm{ft} \ldots .$. \\
\hline B1.11 & $\mathrm{C} 44265.5 \mathrm{ft}-6.4 \mathrm{ft} \ldots \ldots$. \\
\hline B1.12 & $\mathrm{C} 442818.0 \mathrm{ft}-19.5 \mathrm{ft} \ldots$ \\
\hline B1.13 & $\mathrm{C} 443018.5 \mathrm{ft}-20.0 \mathrm{ft} \ldots \ldots$. \\
\hline B1.14 & $\mathrm{C} 443220.5 \mathrm{ft}-21.6 \mathrm{ft} \ldots$. \\
\hline B1.15 & $\mathrm{C} 443413.5 \mathrm{ft}-15.0 \mathrm{ft} \ldots$. \\
\hline B1.16 & $\mathrm{C} 443616.0 \mathrm{ft}-17.5 \mathrm{ft} \ldots \ldots \ldots \ldots \ldots$. \\
\hline B1.17 & $\mathrm{C} 443813.5 \mathrm{ft}-15.0 \mathrm{ft} \ldots$. \\
\hline B1.18 & $\mathrm{C} 44406.5 \mathrm{ft}-6.9 \mathrm{ft} \ldots \ldots \ldots \ldots$ \\
\hline B1.19 & 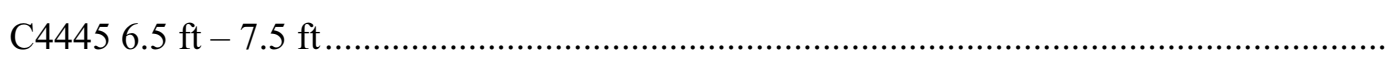 \\
\hline B1.20 & 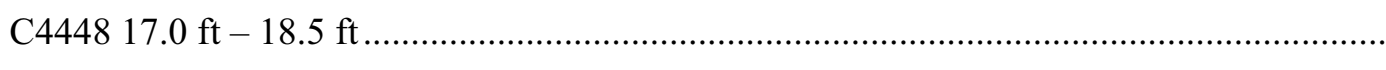 \\
\hline B2.1 & $\mathrm{C} 510413.5 \mathrm{ft}-15.5 \mathrm{ft}$ and $108.5 \mathrm{ft}-110.5 \mathrm{ft} \ldots \ldots \ldots \ldots \ldots \ldots$ \\
\hline B2.2 & C5105 $13.5 \mathrm{ft}-15.0 \mathrm{ft}, 26.0 \mathrm{ft}-28.0 \mathrm{ft}$, and $83.0 \mathrm{ft}-85.0 \mathrm{ft} \ldots \ldots \ldots \ldots . . . .$. \\
\hline B2.3 & 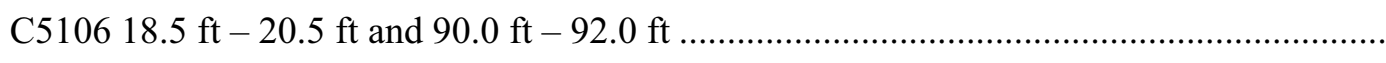 \\
\hline B2.4 & 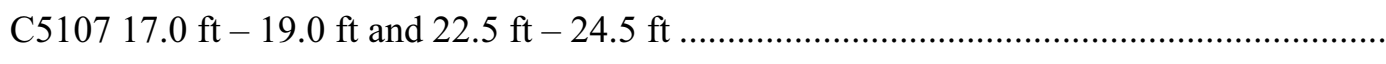 \\
\hline B2.5 & 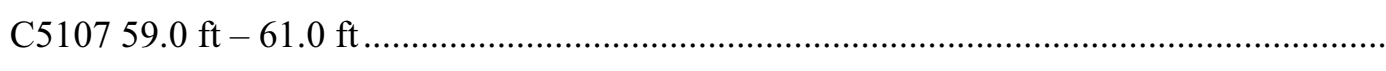 \\
\hline B2.6 & 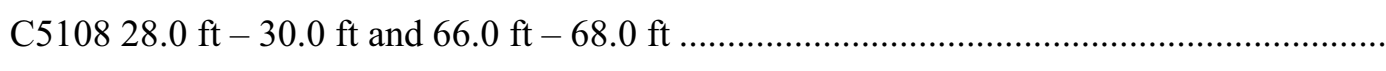 \\
\hline B2.7 & 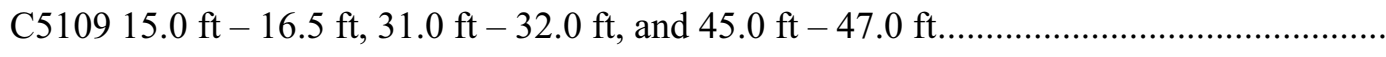 \\
\hline
\end{tabular}




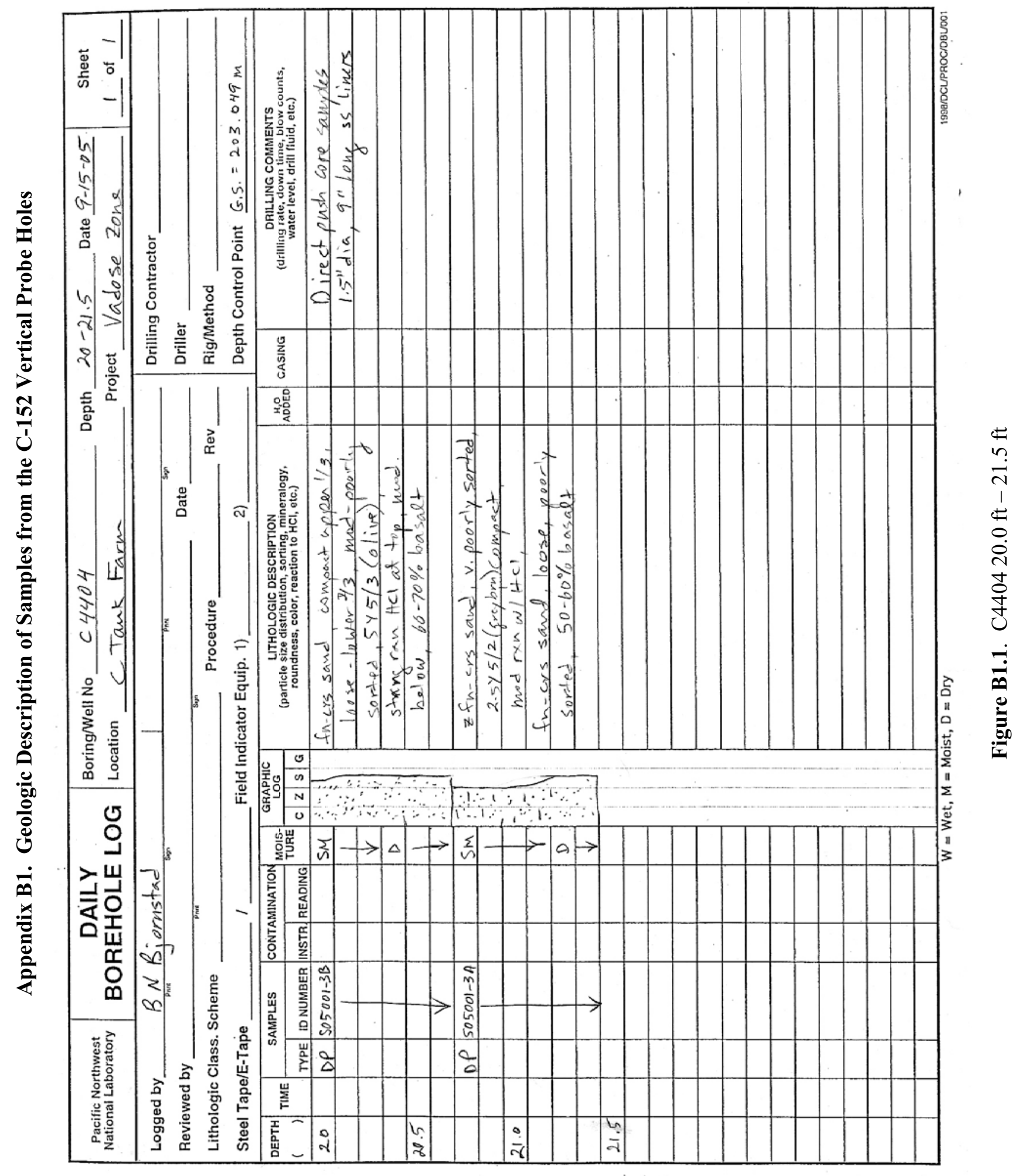

B. 1 


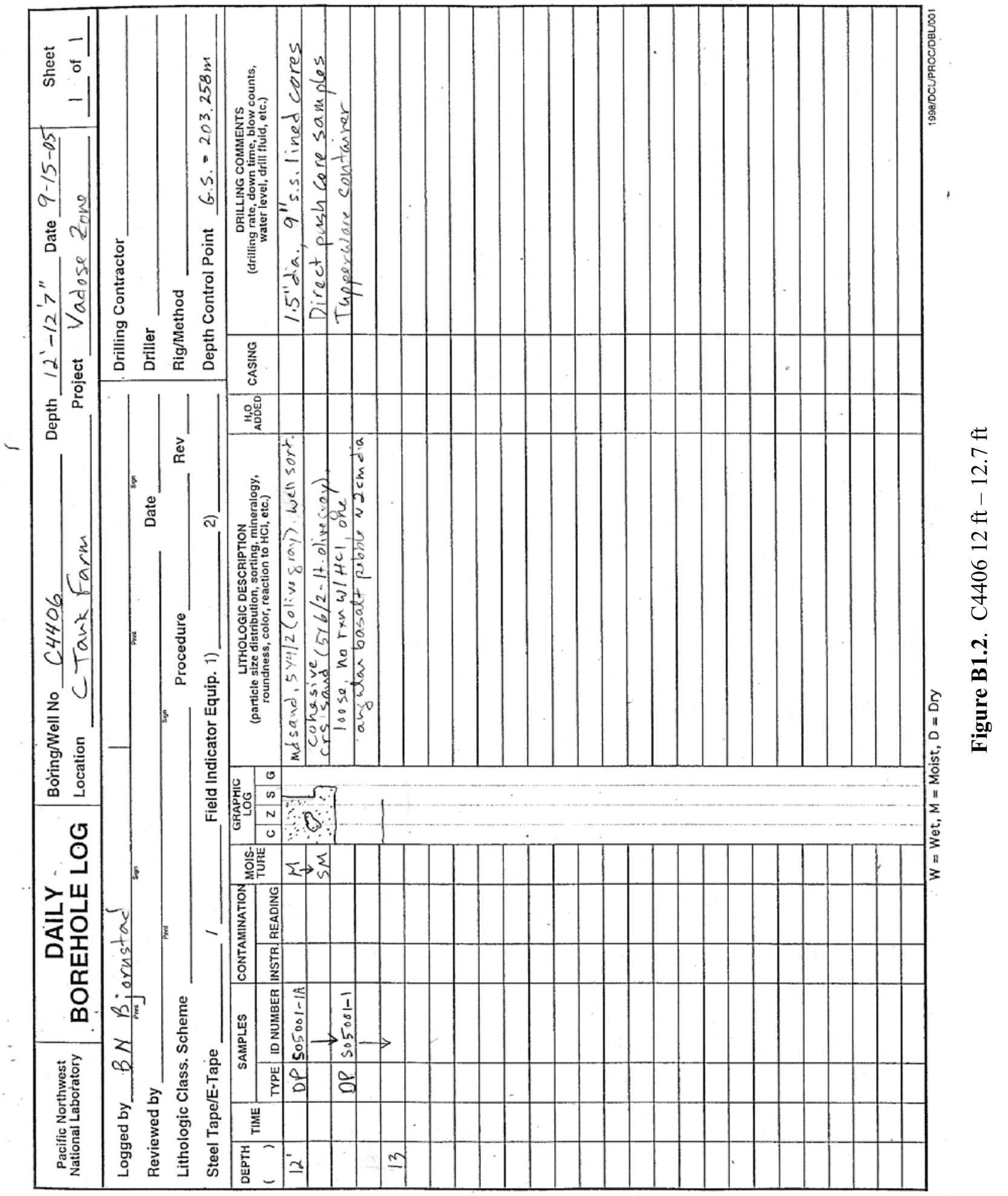




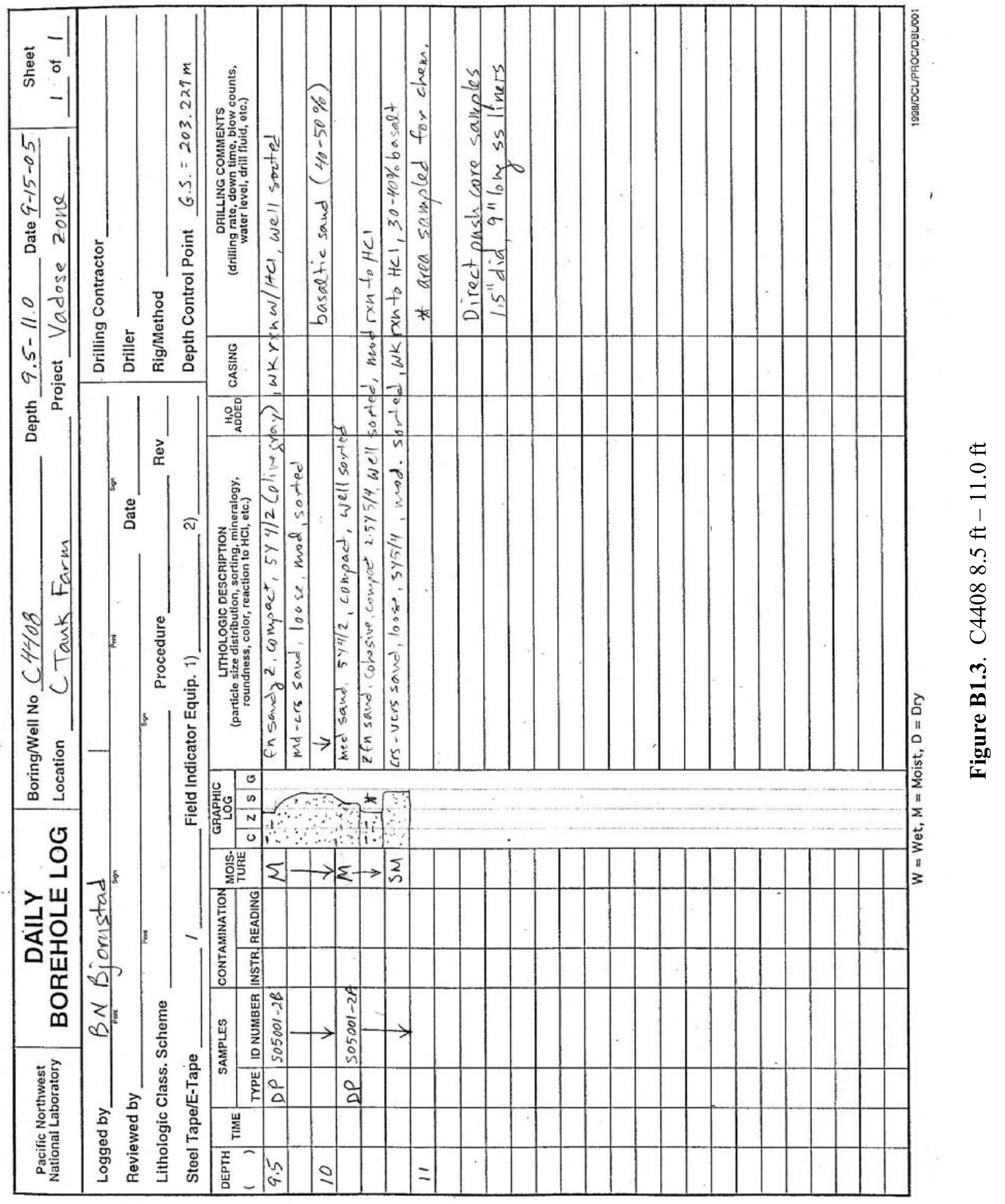




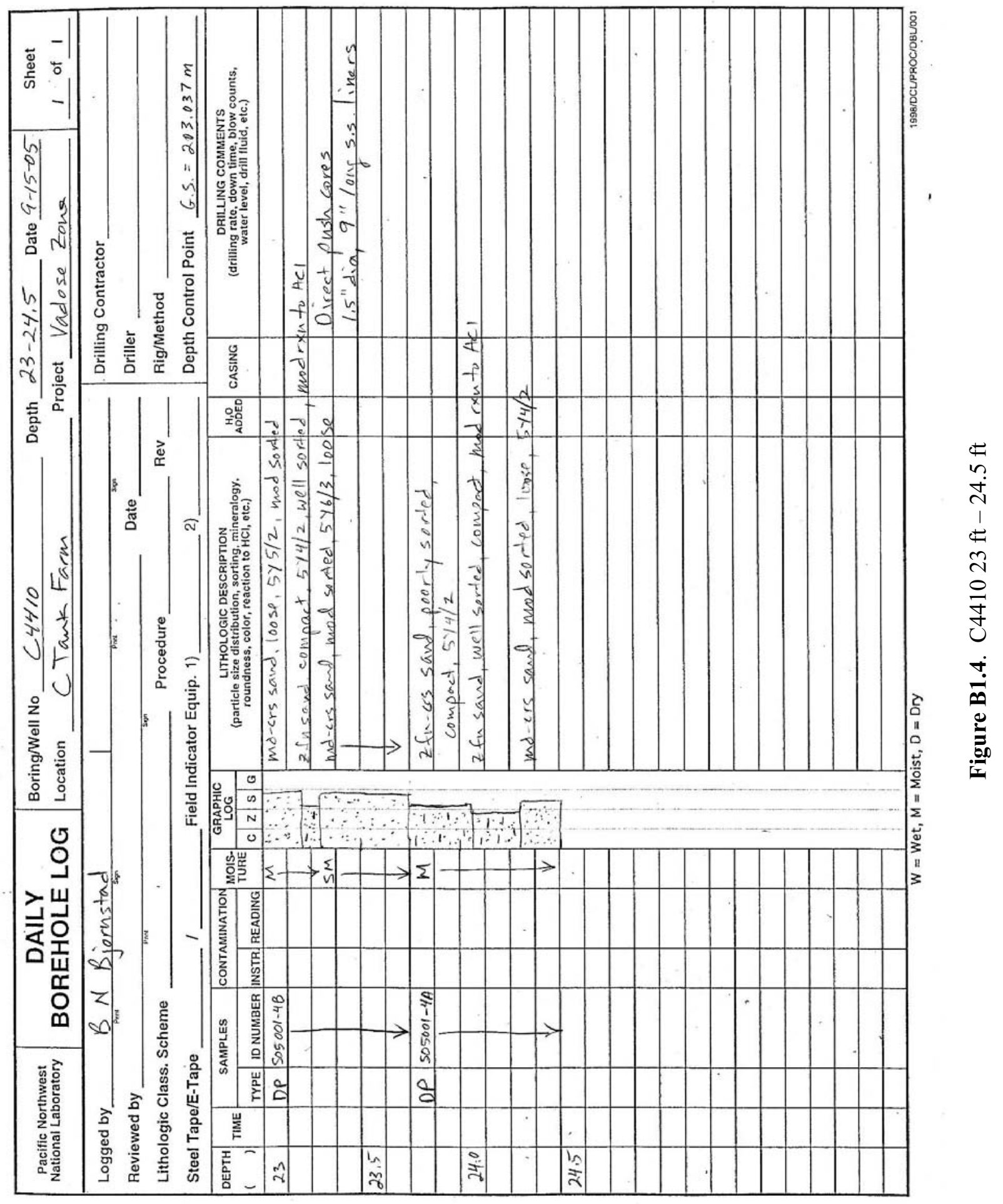




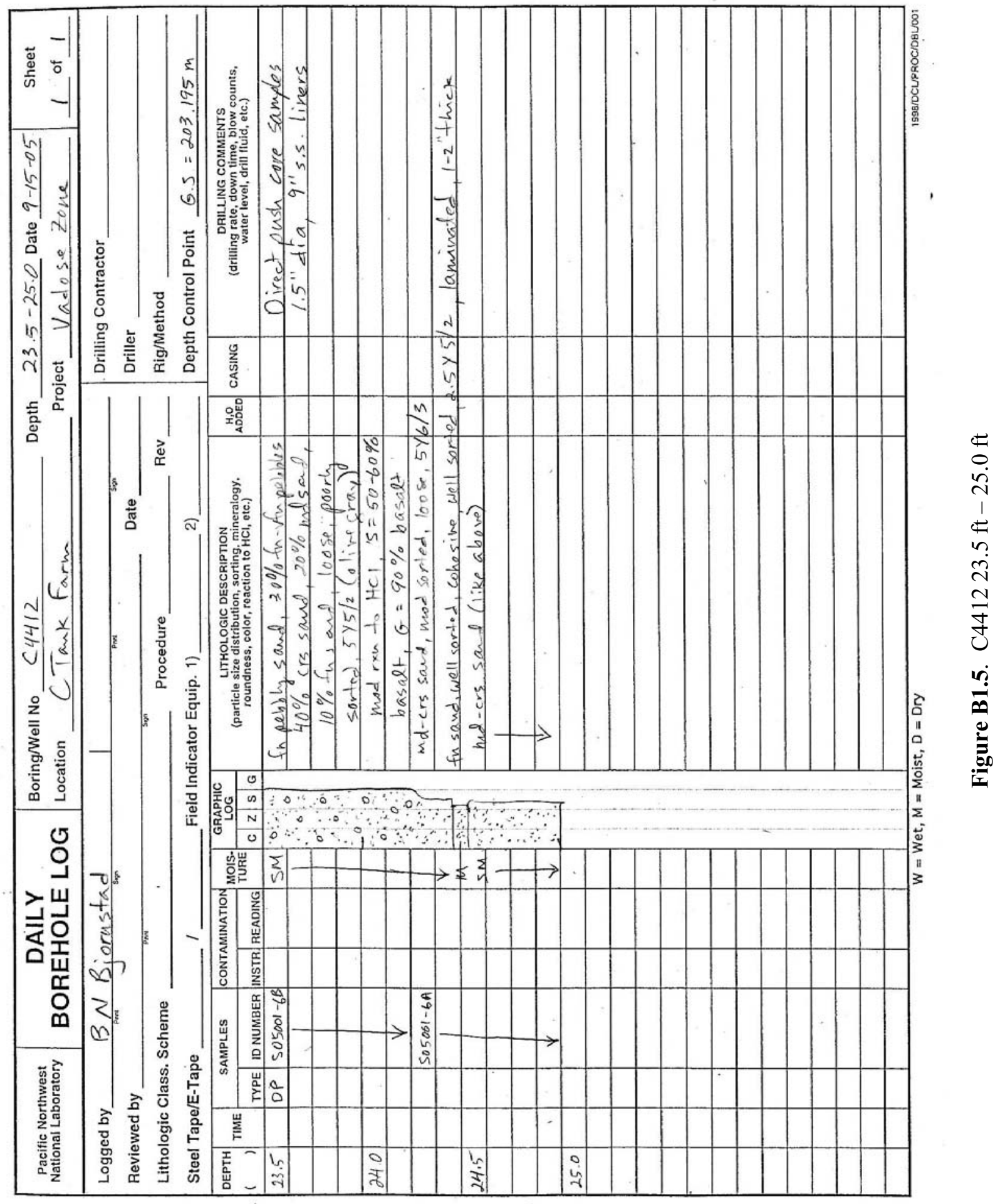




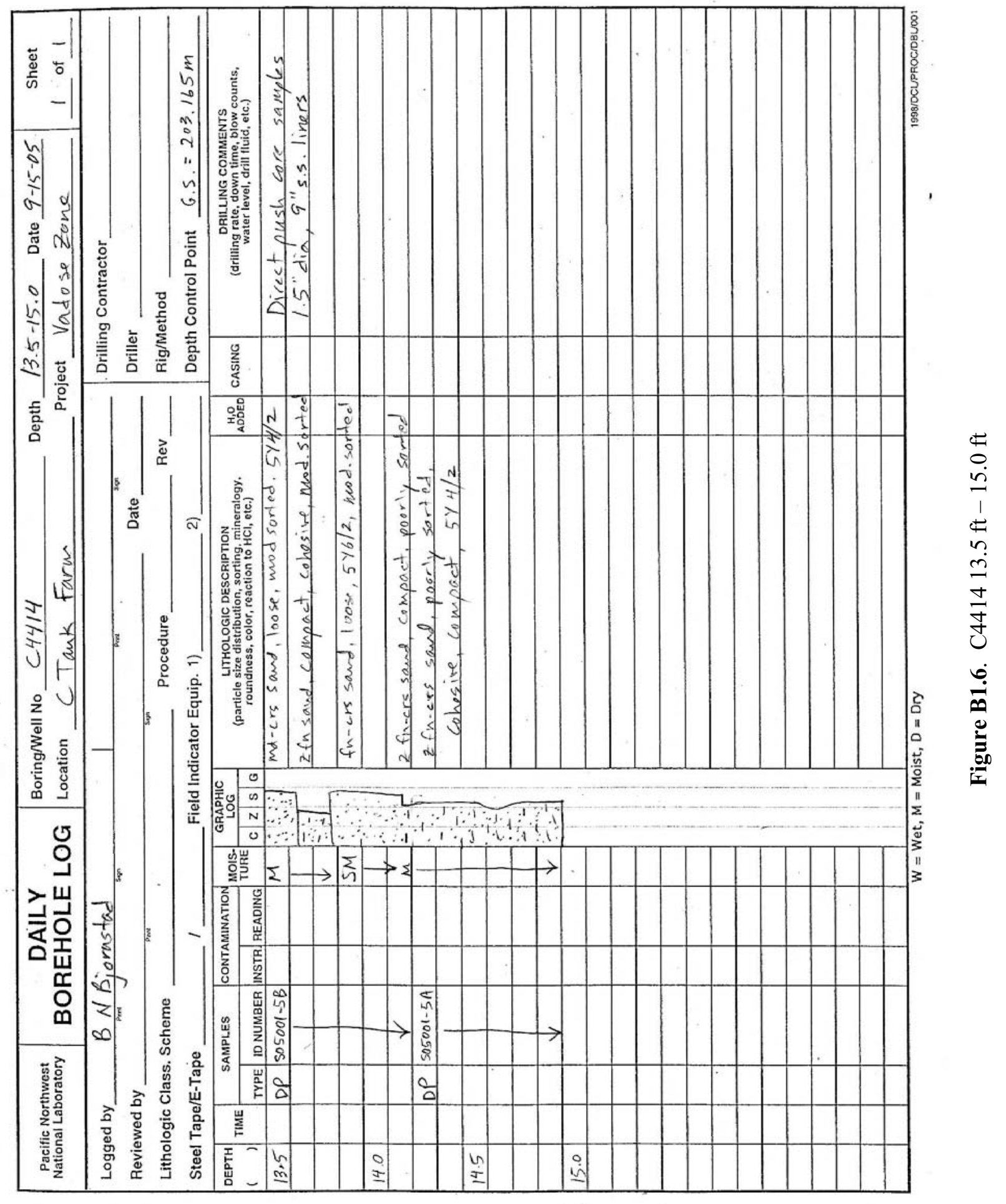




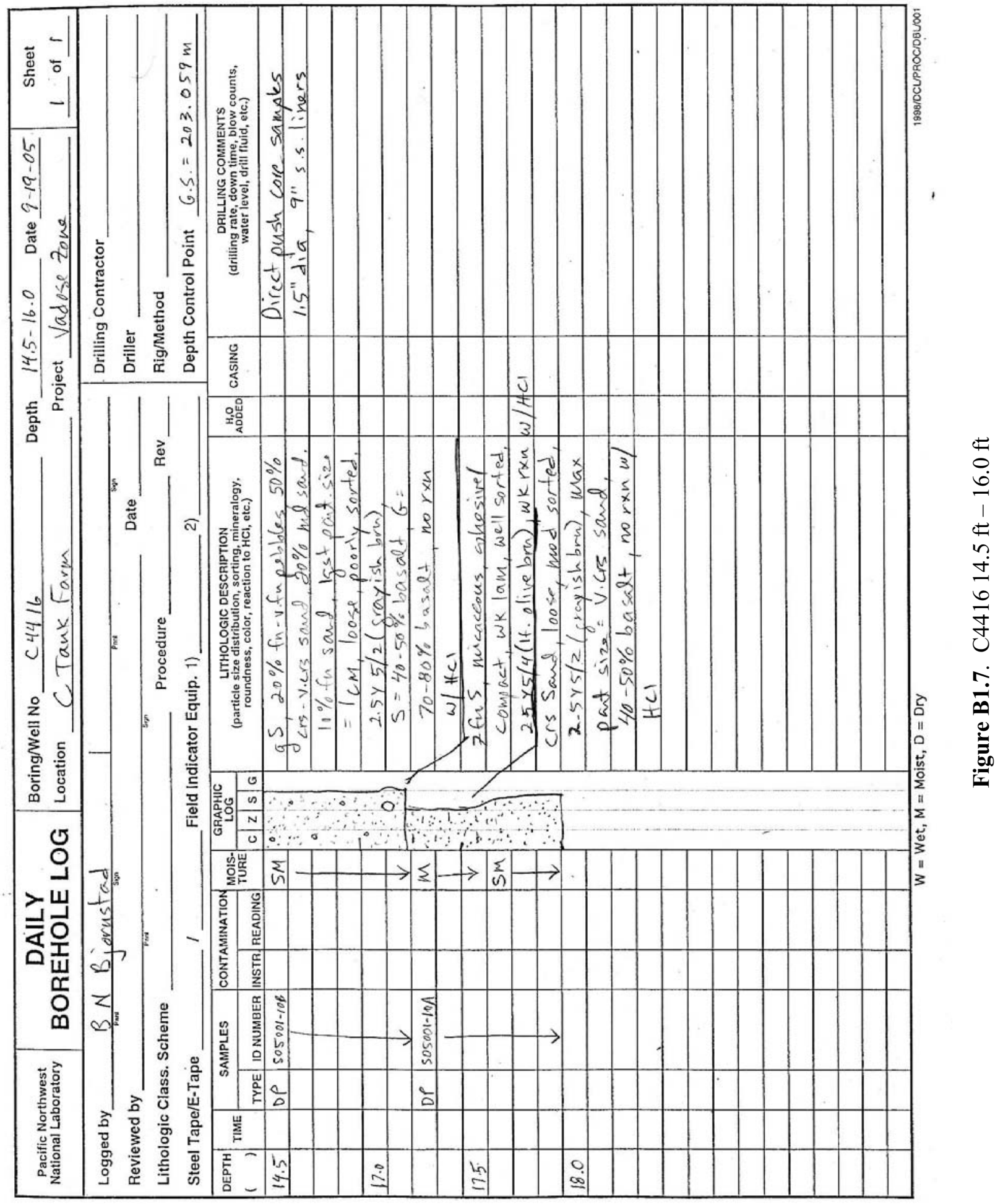

B. 7 


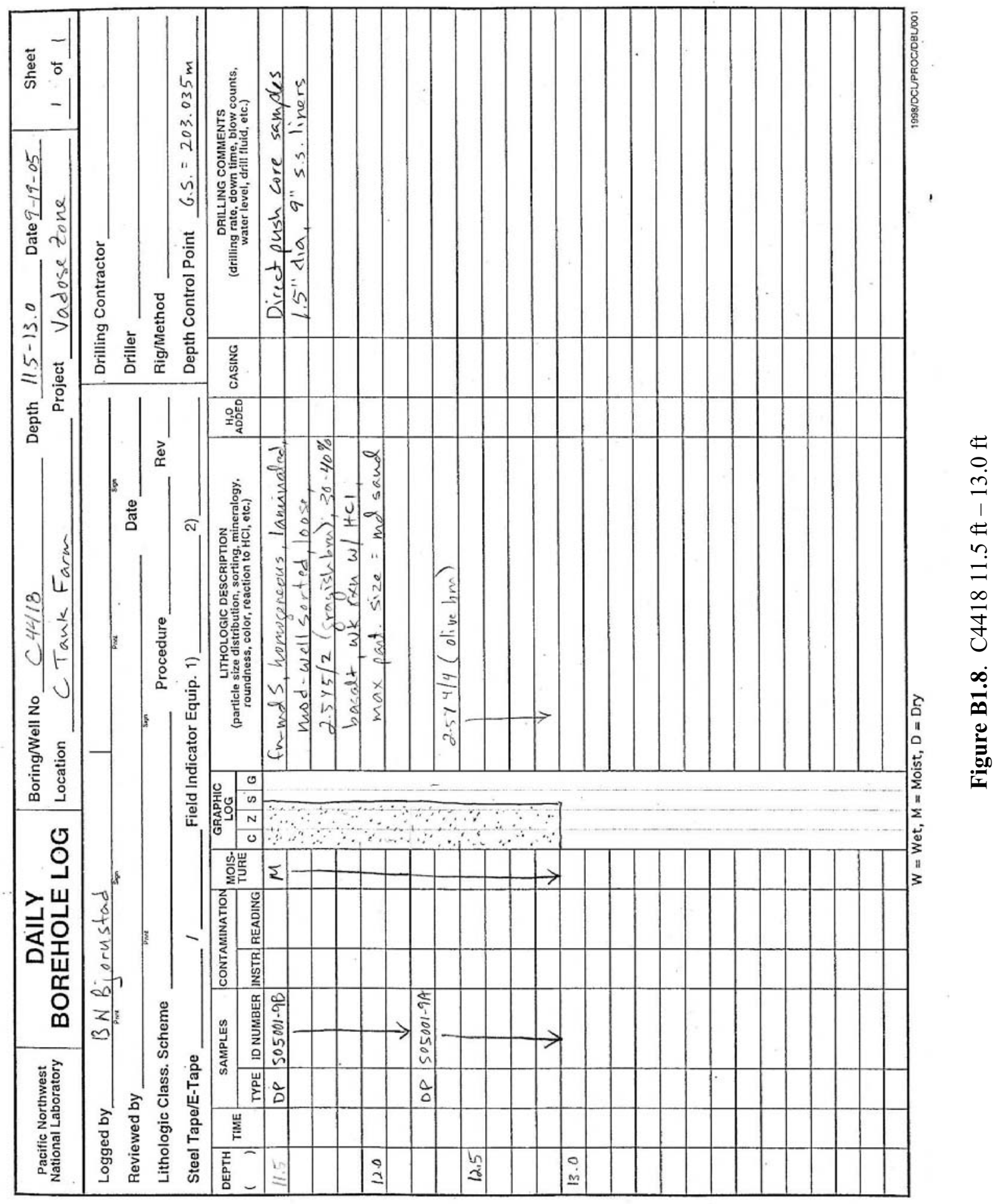




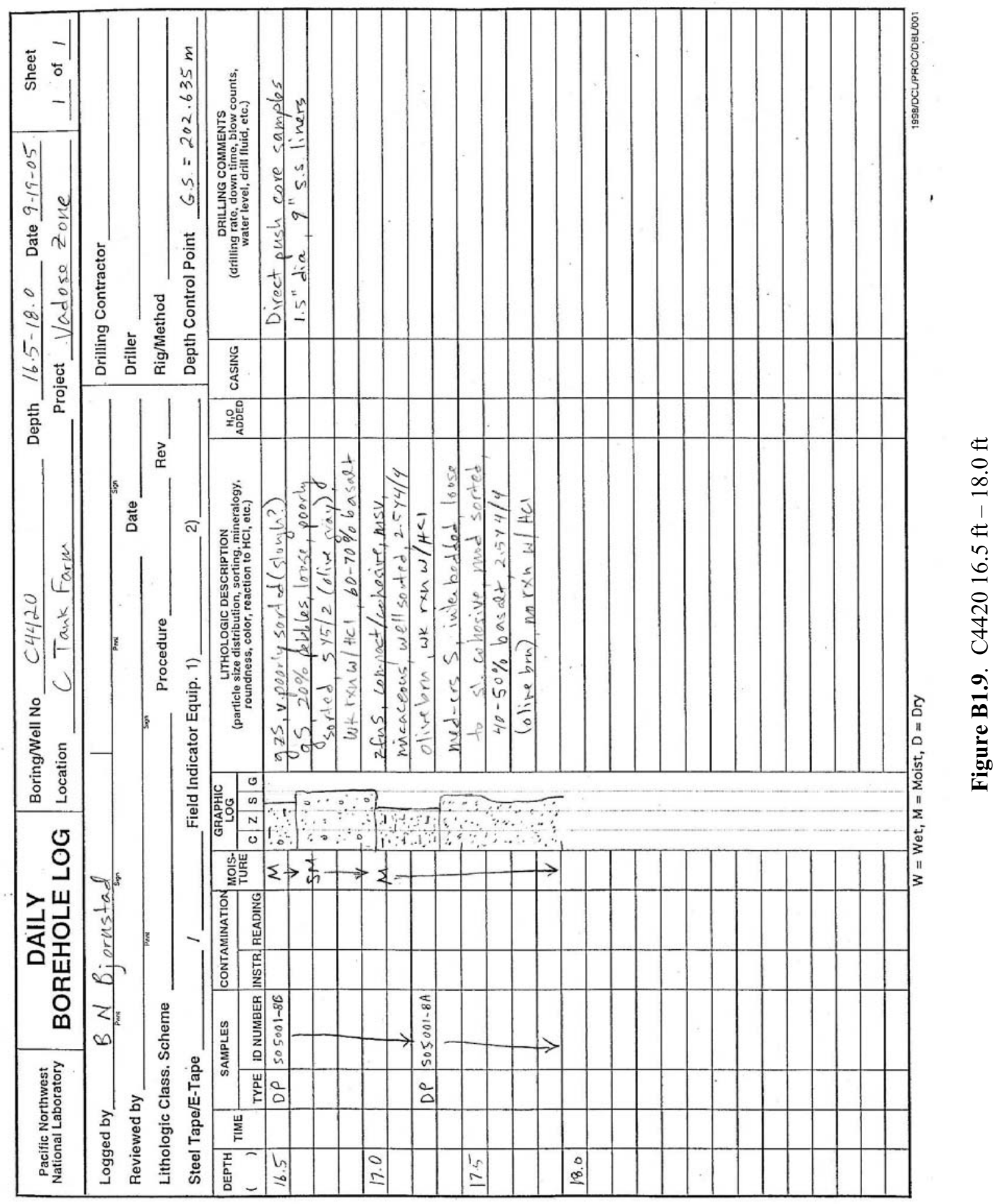




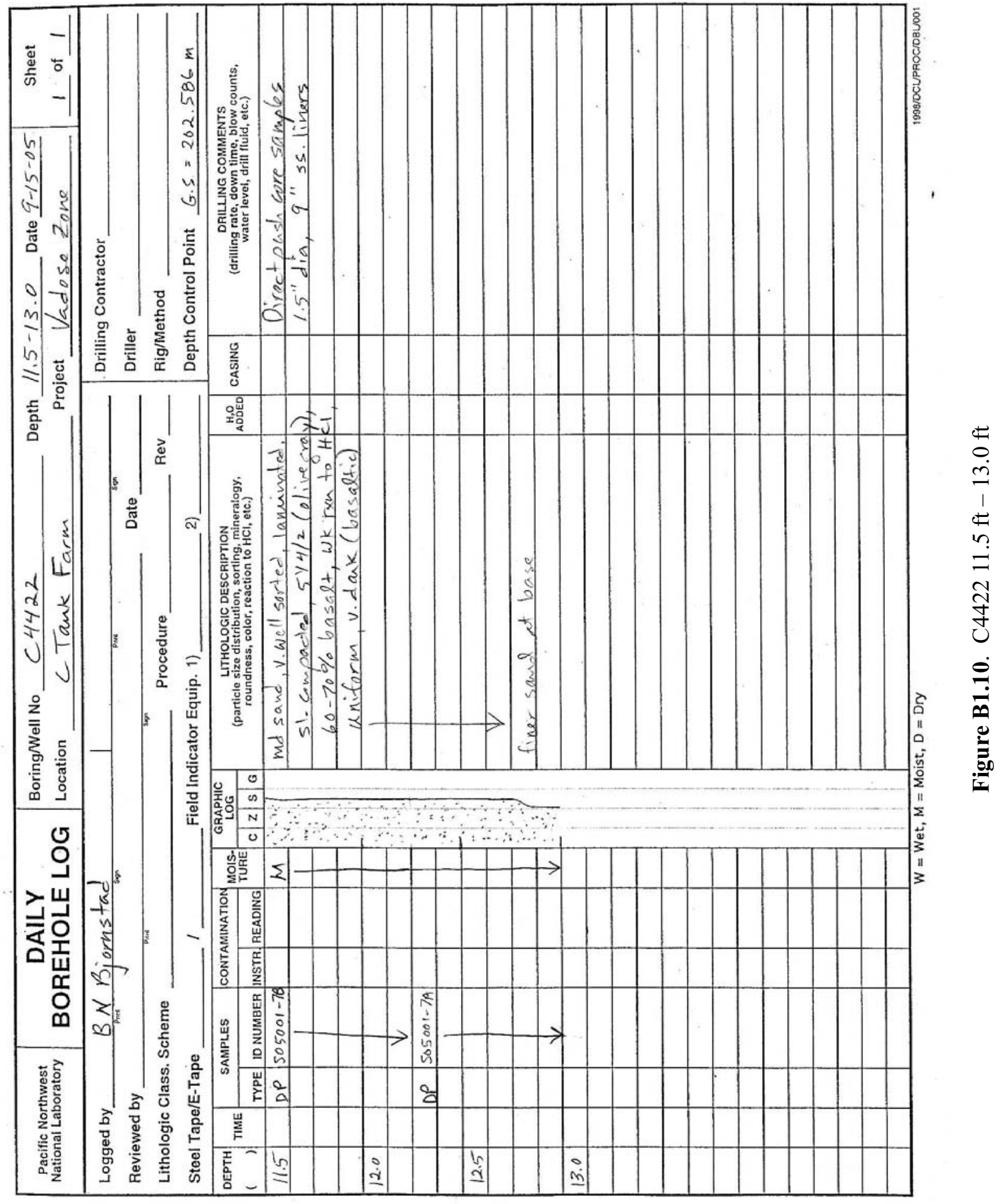

B. 10 


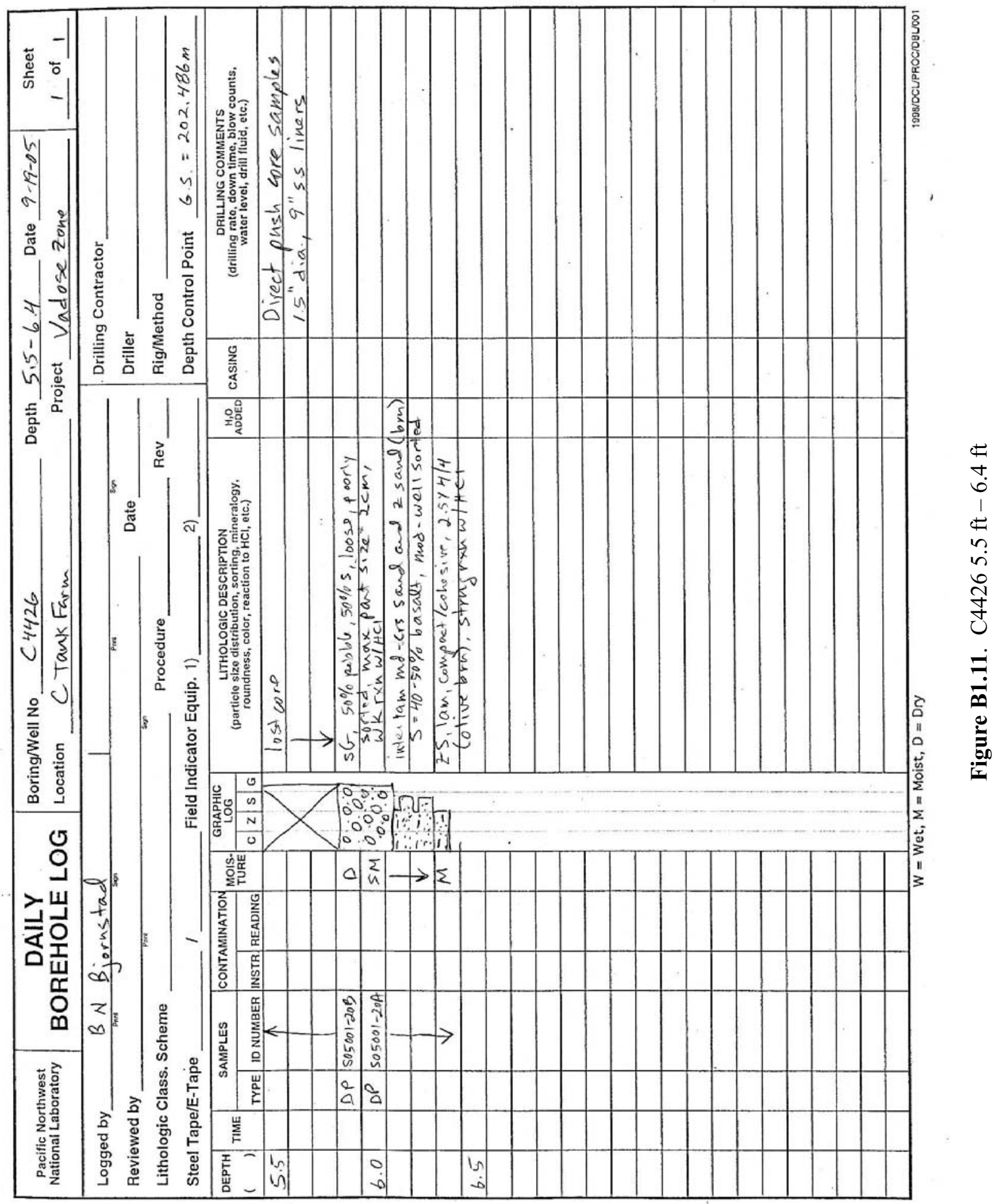




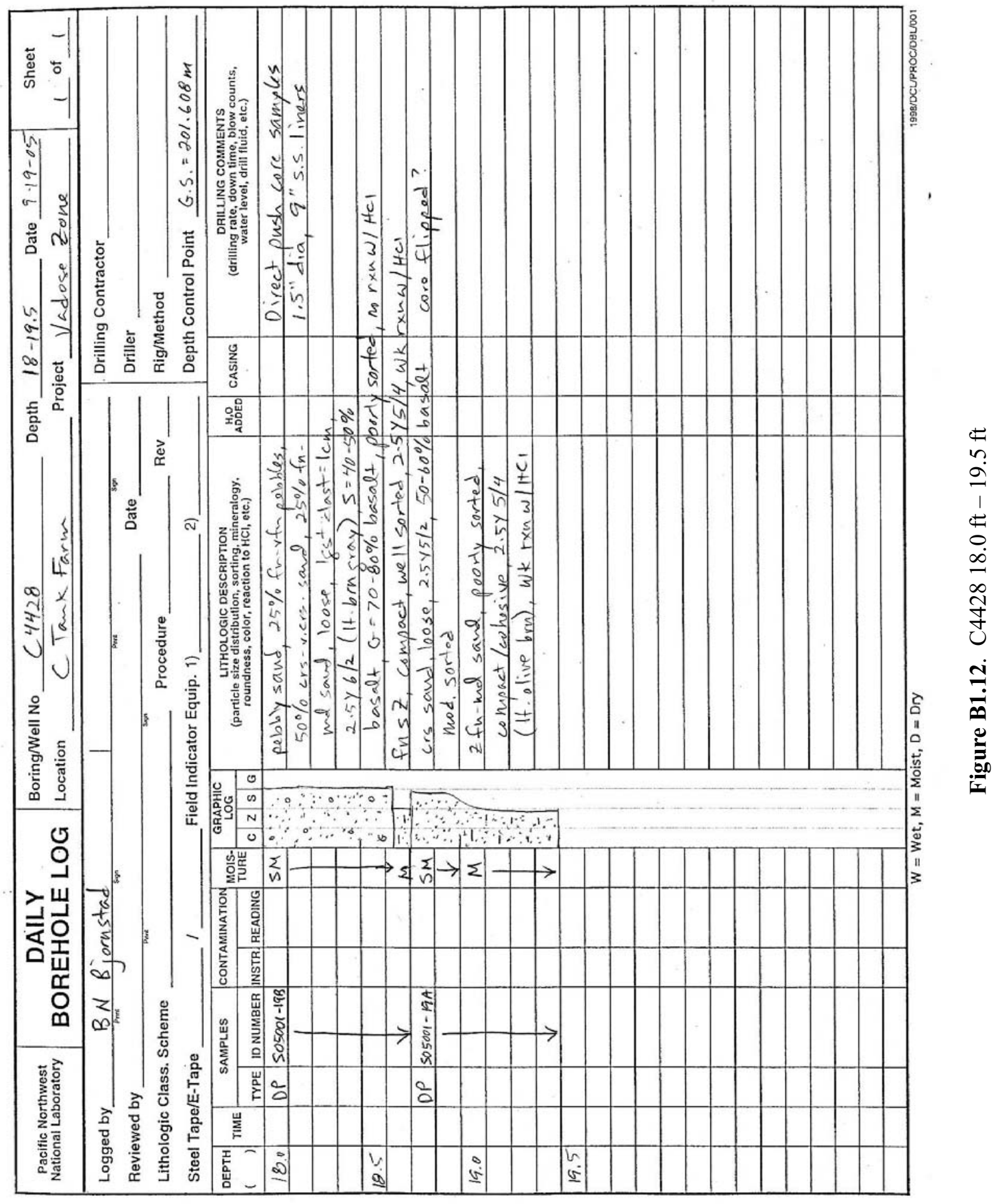




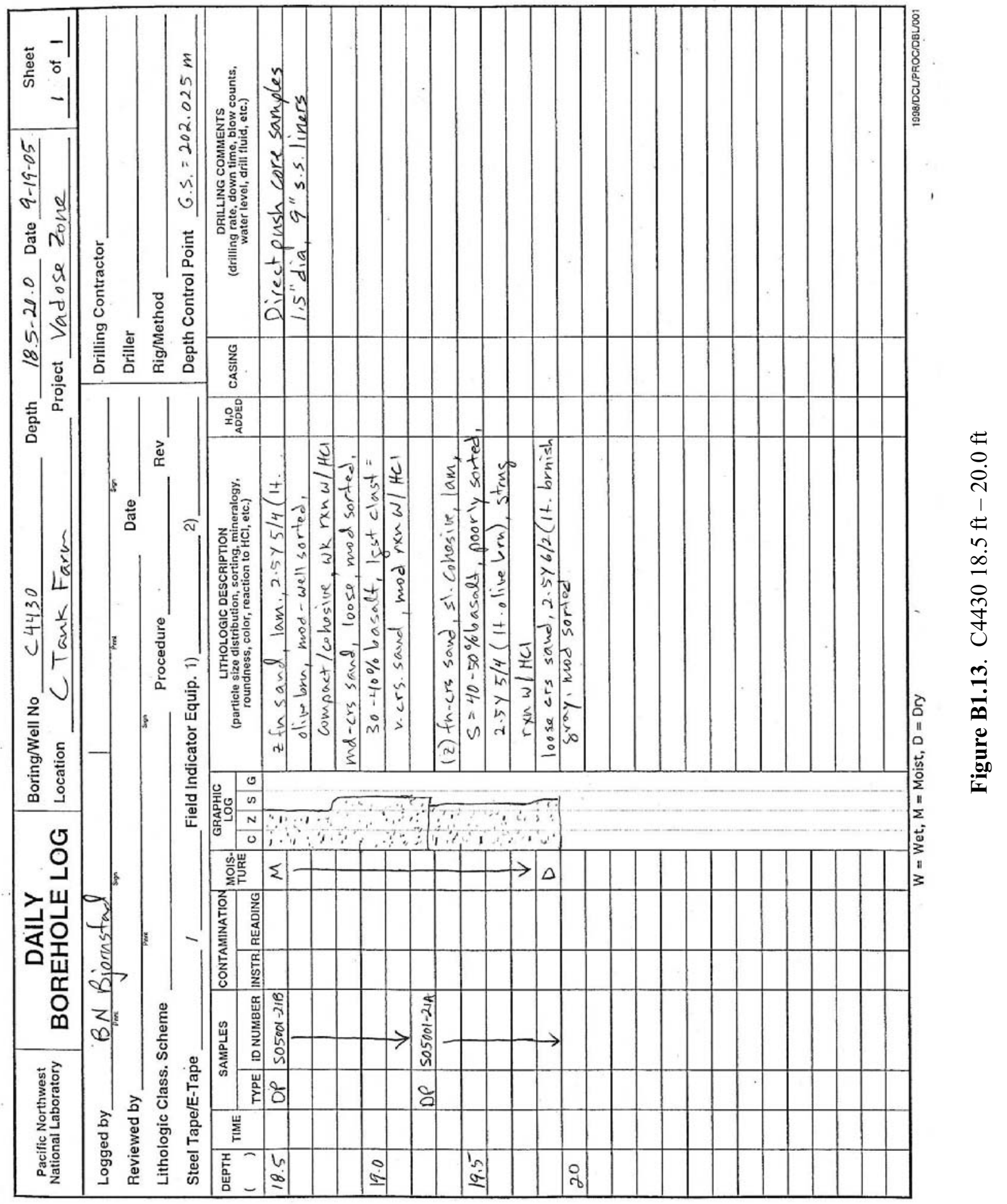

B. 13 


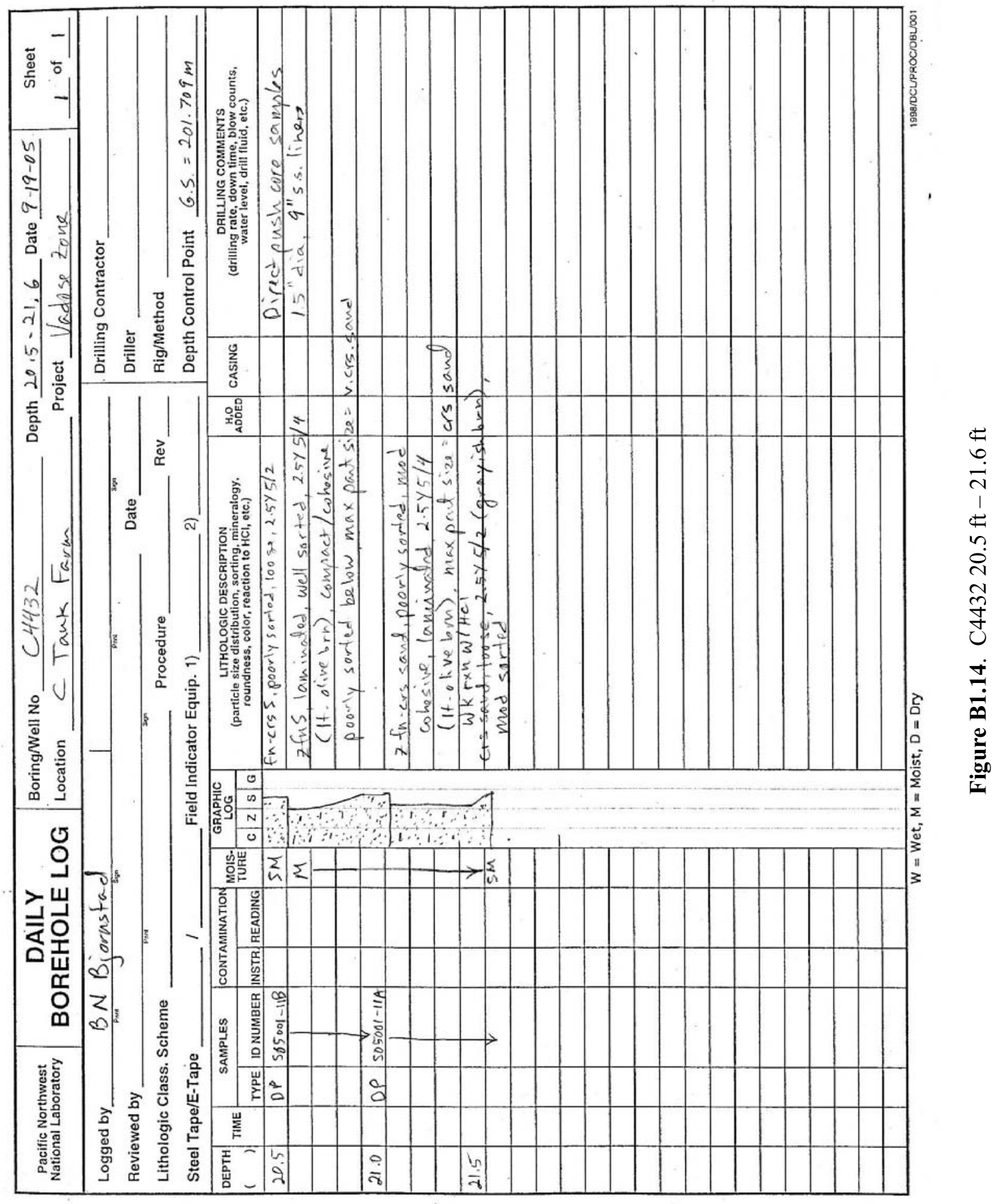




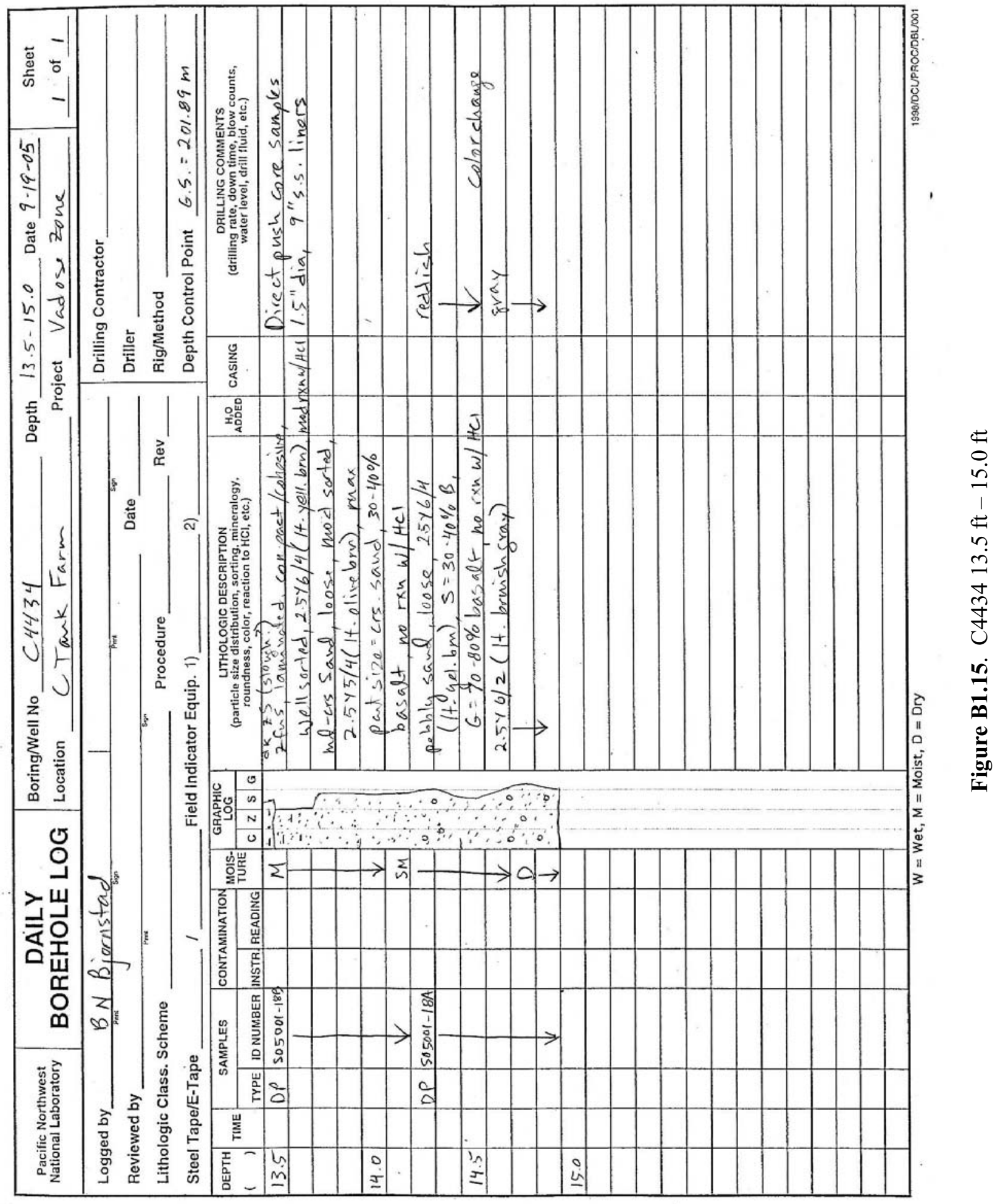

B. 15 


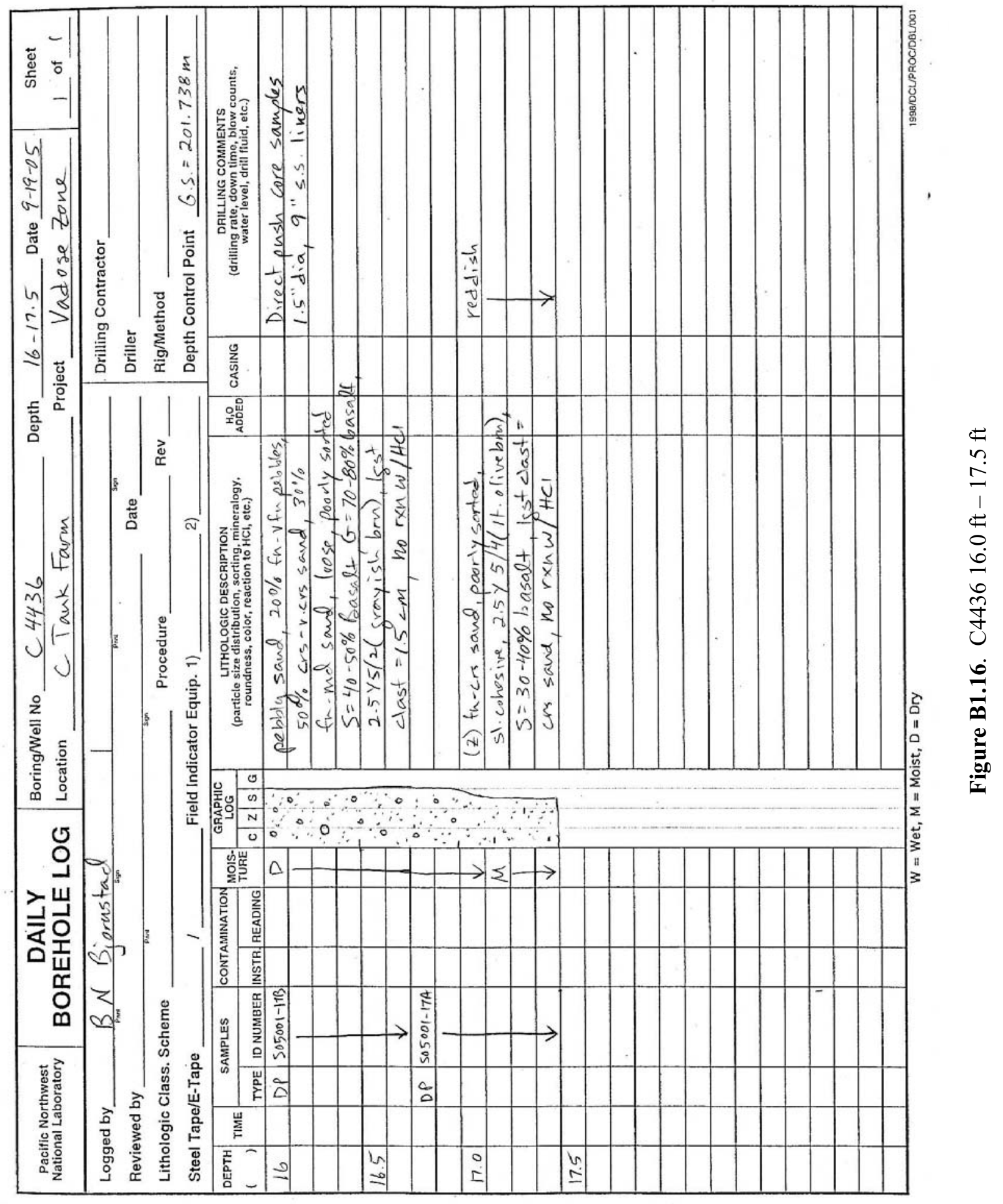




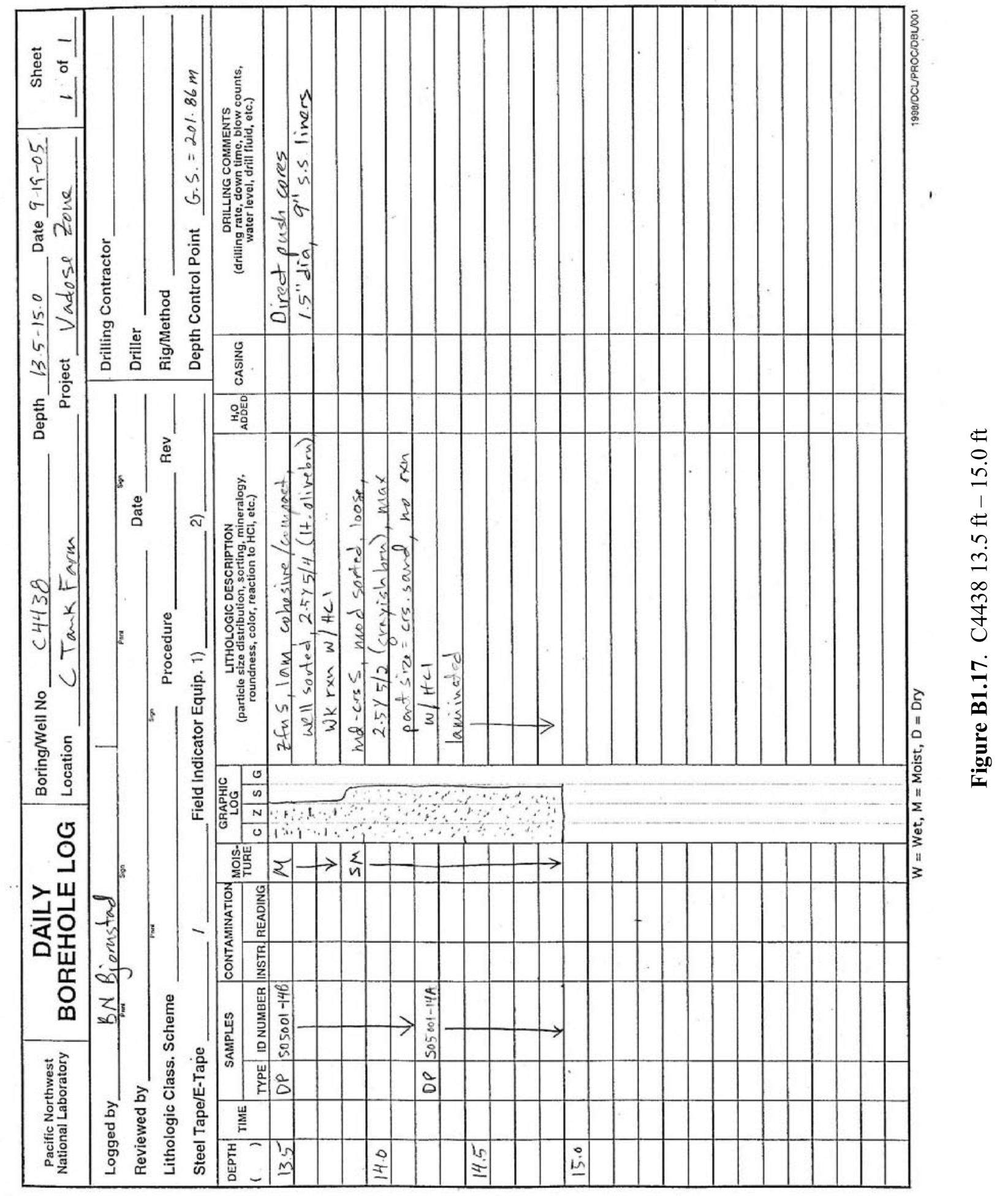




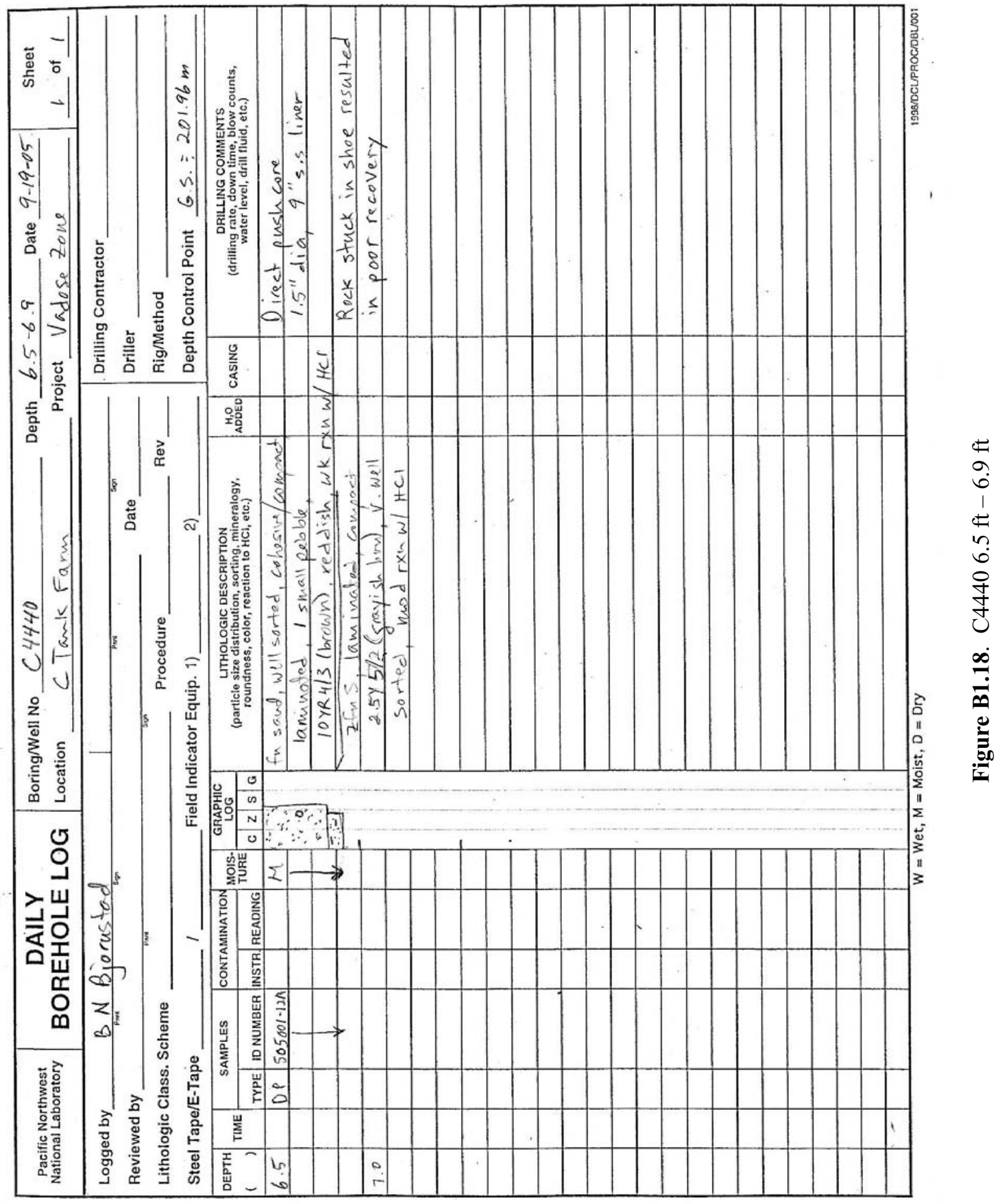




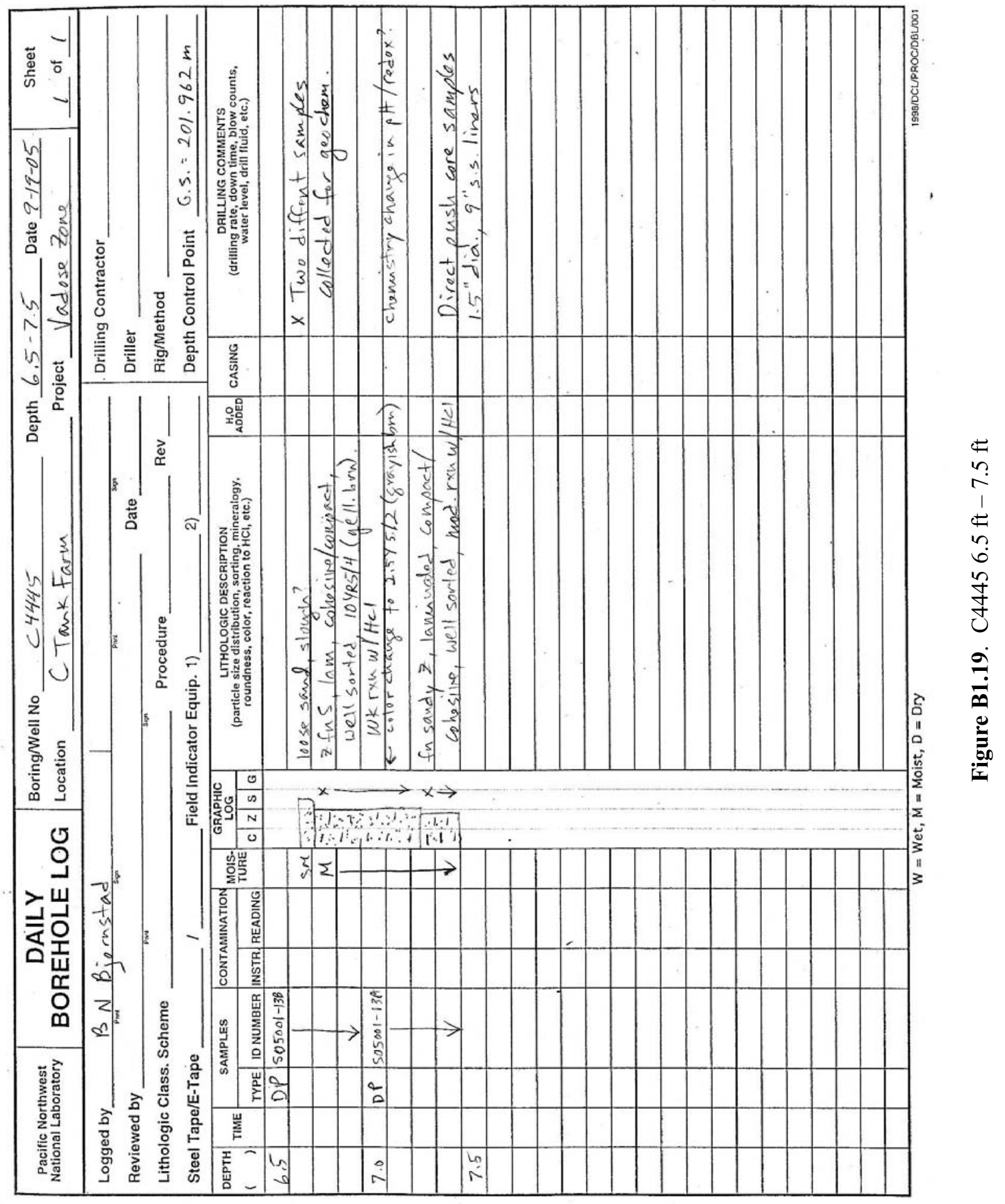




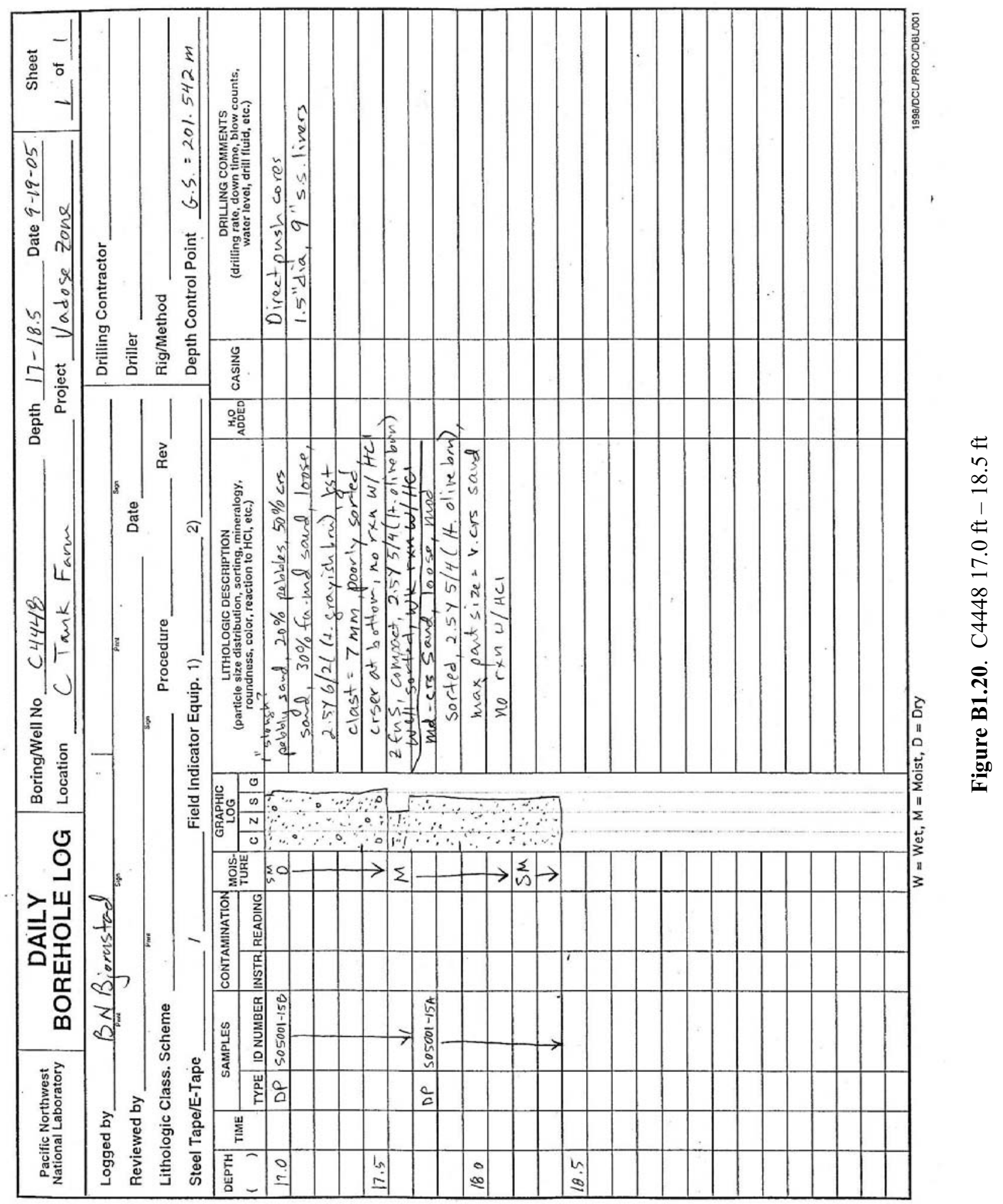




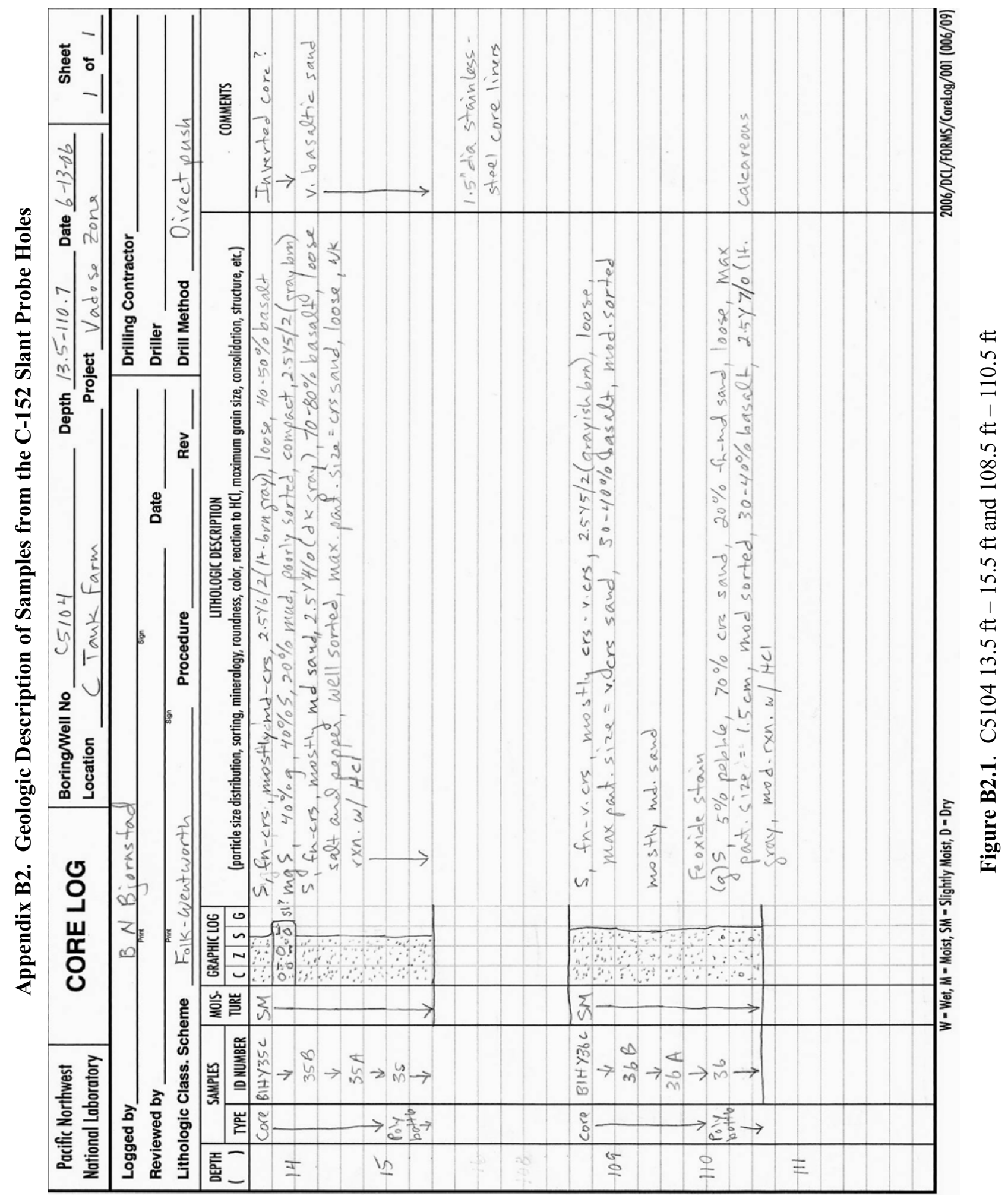




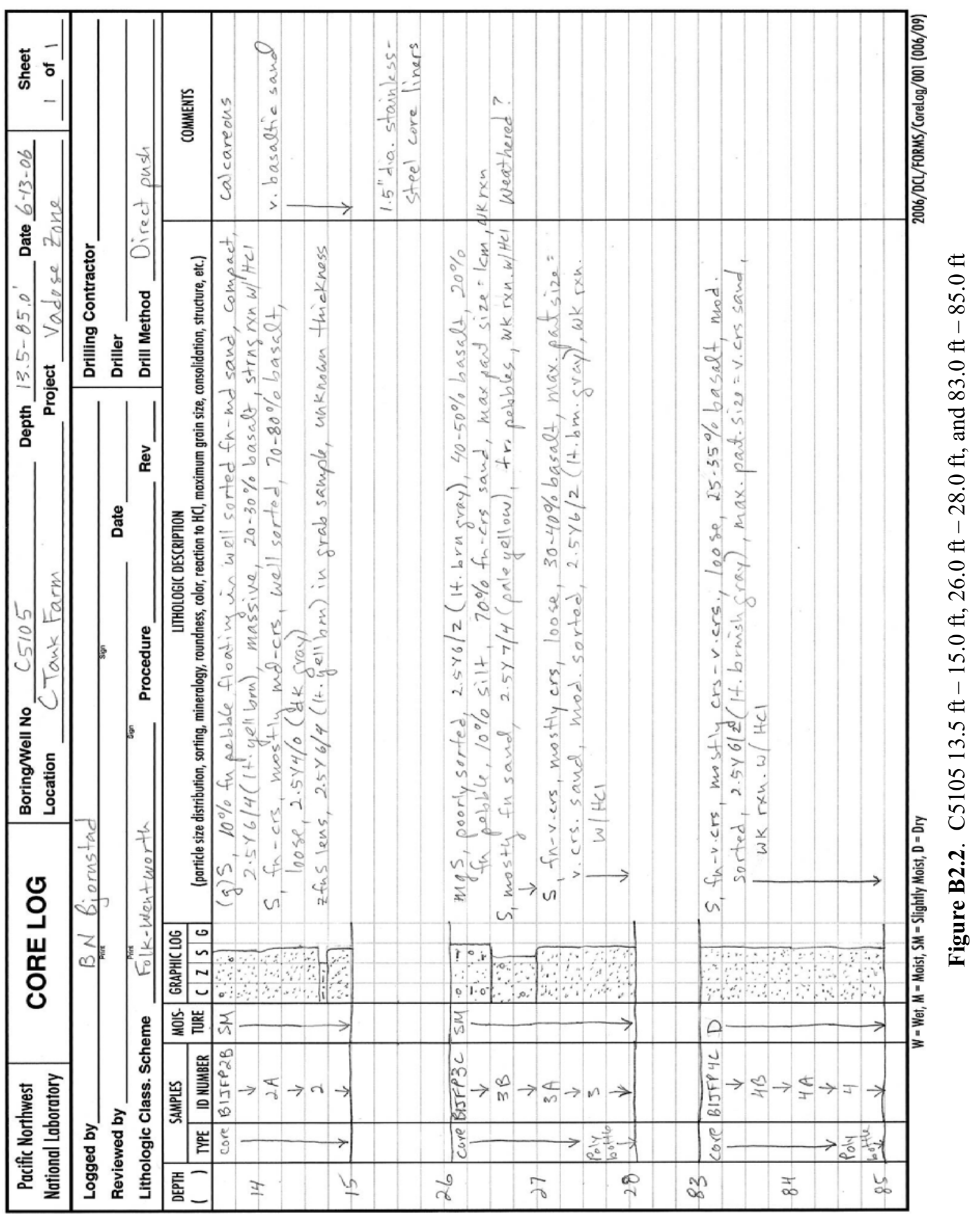




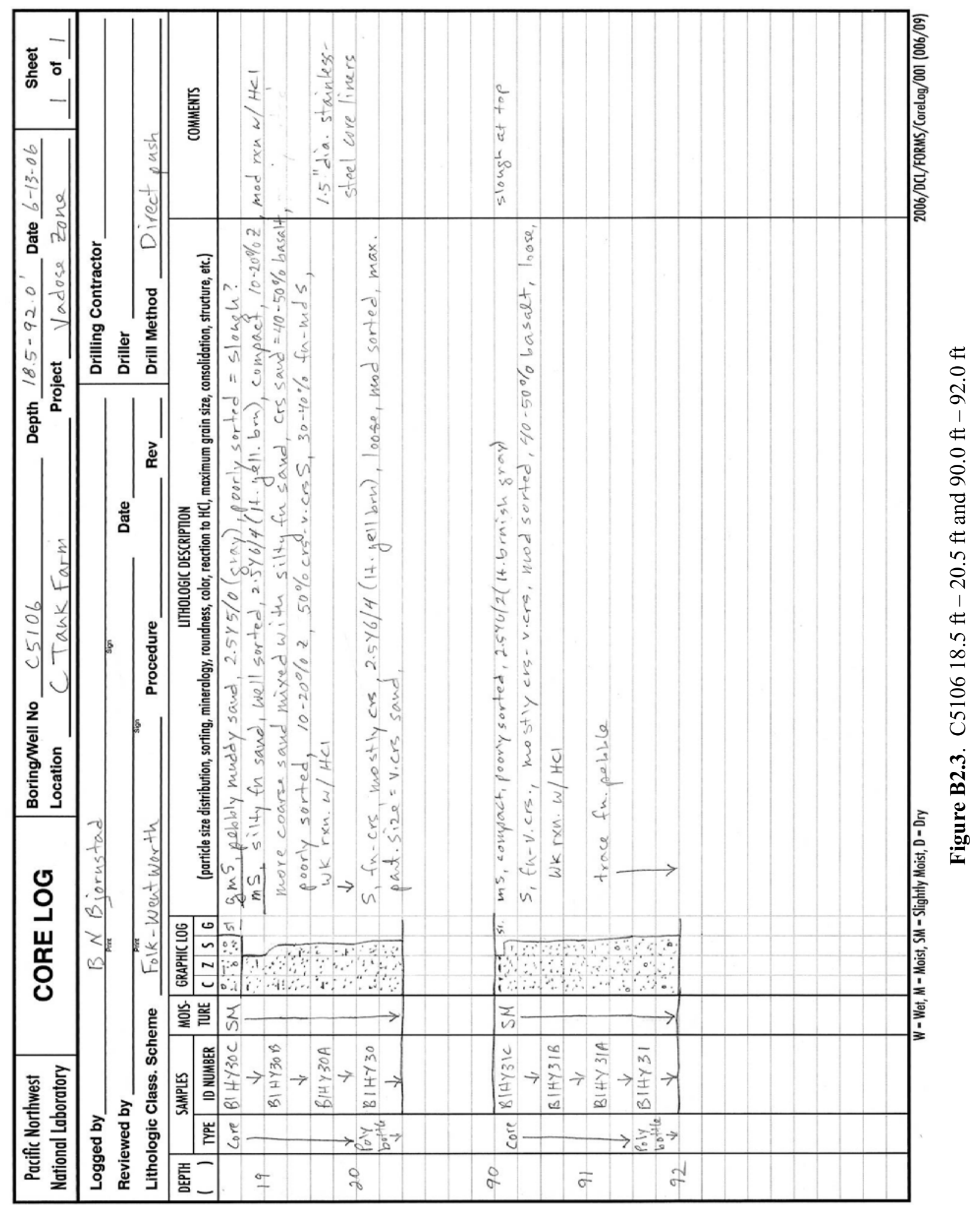




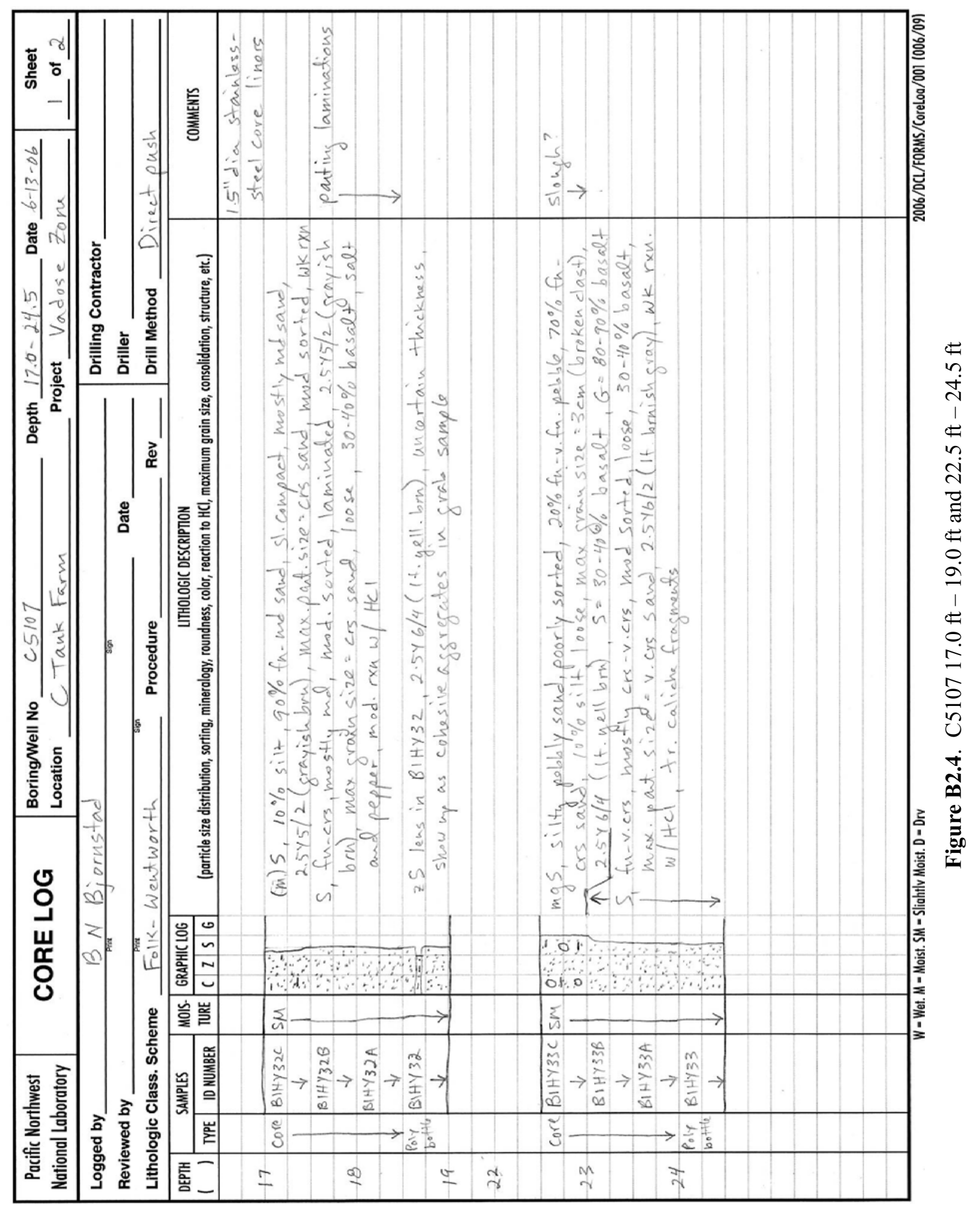




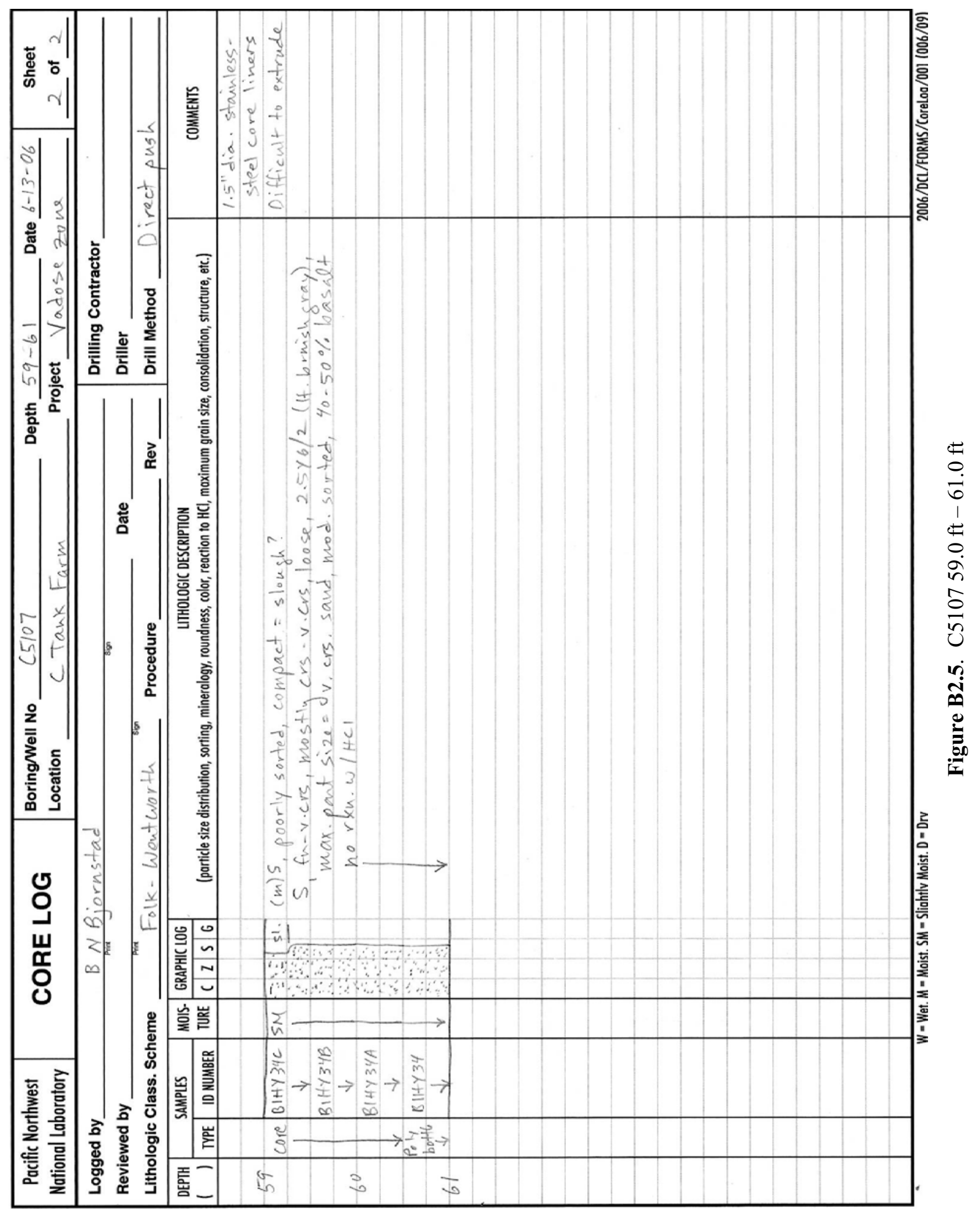




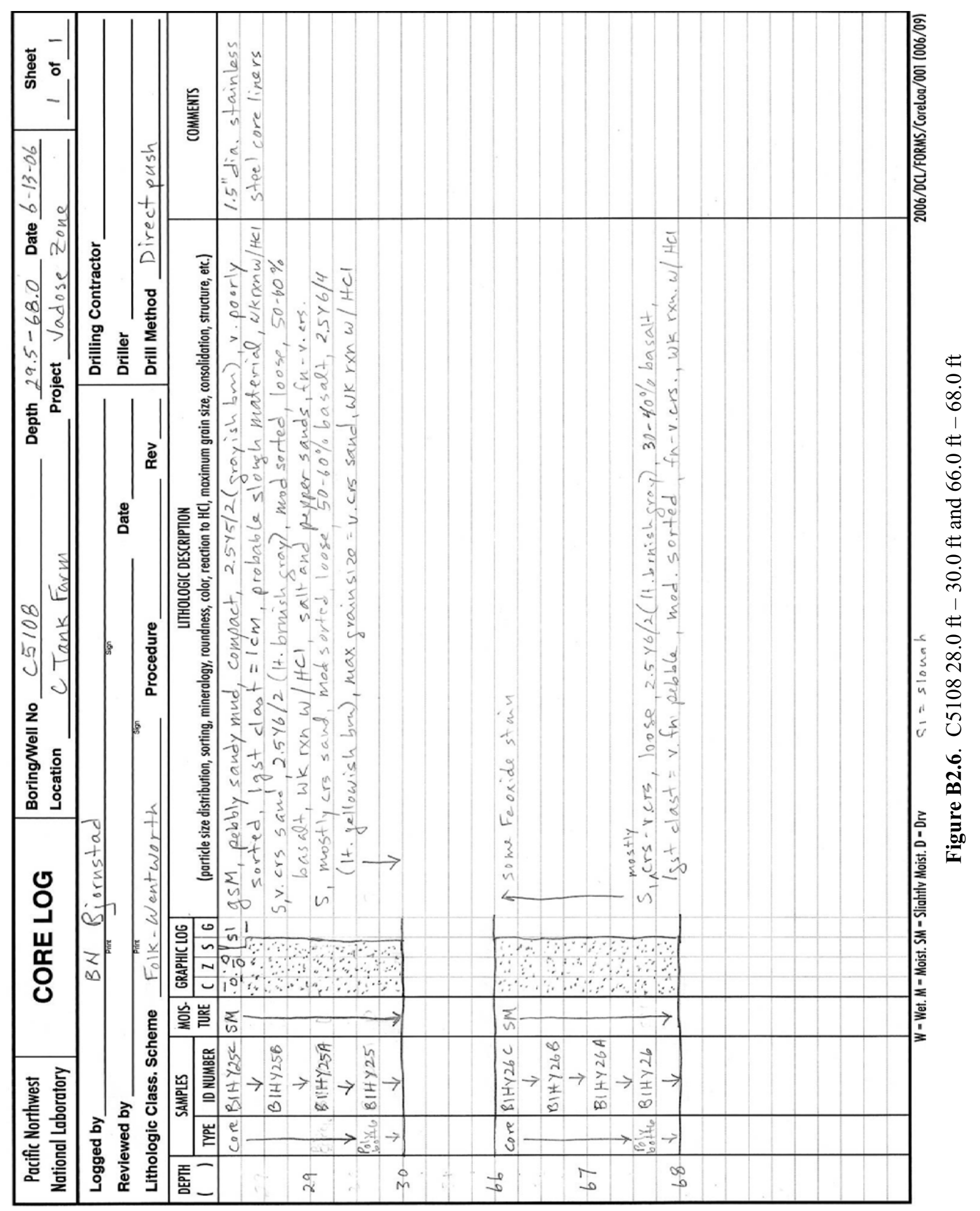




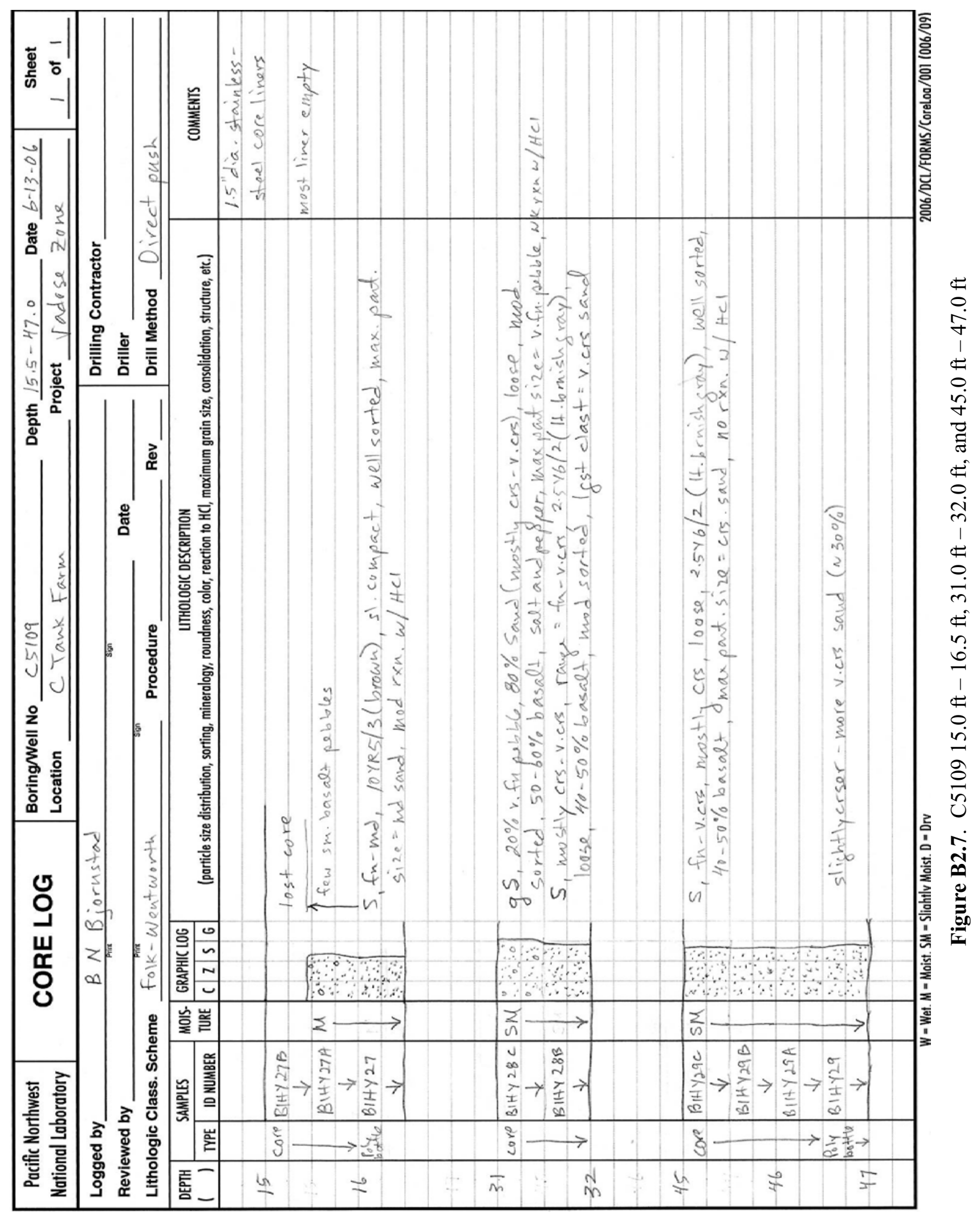




\section{Distribution}

No. of

Copies

\section{OFFSITE}

Dr. Harry Babad

2540 Cordoba Court

Richland, WA 99352-1609

Dirk A. Dunning

Oregon Office of Energy

625 Marion Street NE

Salem, OR 97301-3742

Dr. Daniel I. Kaplan

Westinghouse Savannah River Company

Building 774-43A, Room 215

Aiken, SC 29808

Phil Reed

U.S. Nuclear Regulatory Commission

Office of Nuclear Regulatory Research

Division of Systems Analysis and

Regulatory Effectiveness

Radiation Protection, Environmental

Risk, and Waste Management Branch

Mail Stop: T9-F31

Washington, DC 20555-0001

Tom Stoops, LPG

Oregon Office of Energy

Nuclear Safety Division

625 Marion Street NE

Salem, OR 97303

Mr. Ronald G. Wilhelm

Office of Radiation and Indoor Air

401 M Street, S.W.

Mail Code 6603J

Washington, DC 20460
No. of

Copies

W. Alexander Williams

U.S. Department of Energy

Office of Environmental Restoration

EM-33

19901 Germantown Road

Germantown, MD 20874-1290

\section{ONSITE}

8 DOE Richland Operations Office
B. L. Foley
A6-38
J. P. Hanson
R. D. Hildebrand
A5-13
K. A. Kapsi
J. G. Morse
K. M. Thompson
A6-38
A5-13
A6-38
A6-38
DOE Public Reading Room (2)
H2-53

3 DOE Office of River Protection
P. E. LaMont
H6-60
R. W. Lober
H6-60
S. A. Wiegman
H6-60

13 CH2M HILL Hanford Group, Inc.
R. Calmus
H6-05
M. P. Connelly
H6-03
J. G. Kristofzski
H6-03
F. M. Mann (5)
H6-03
W. J. McMahon
H6-03
D. A. Myers
H6-03
G. Parsons
T6-04
H. A. Sydnor
H6-03
D. J. Watson
H6-03

\section{Fluor Federal Services}

R. Khaleel

E6-17 
No. of

Copies

7 Fluor Hanford, Inc.

M. W. Benecke

E6-35

T. W. Fogwell

B. H. Ford

J. G. Hogan

L. C. Swanson

M. I. Wood

C. Wright

\section{S.M. Stoller}

R. G. McCain

B2-62

2 U.S. Environmental Protection Agency

N. Ceto

B5-01

D. A. Faulk

B5-01

6 Washington State Department of Ecology

S. Dahl-Crumpler

HO-57

J. A. Caggiano

HO-57

J.A. Hedges

HO-57

B. Rochette

HO-57

J. Yokel

HO-57

D. Goswami
No. of

Copies

41 Pacific Northwest National Laboratory

S. R. Baum

P7-22

B. N. Bjornstad

K6-81

C. A. Brandt

K9-04

T. M. Brouns

K9-69

C. F. Brown (10)

P7-22

K. J. Cantrell

K6-81

E. T. Clayton

P7-22

W. J. Deutsch

K6-81

P. E. Dresel

K6-96

K. N. Geiszler

P7-22

M. J. Fayer

K9-33

M. D. Freshley

K9-33

J. S. Fruchter

K6-96

D. G. Horton

K6-75

C. Iovin

P7-22

K. M. Krupka

K6-81

I. V. Kutnyakov

P7-22

D. C. Lanigan

K6-75

G. V. Last

K6-81

M. J. Lindberg

P7-22

W. J. Martin

K6-81

L. F. Morasch

K6-86

C. J. Murray

K6-81

K6-96

K6-75

P7-22

P7-22

P7-22

K6-75

K8-96

P8-55 